UNIVERSIDADE DE SÃO PAULO

FACULDADE DE FILOSOFIA, LETRAS E CIÊNCIAS HUMANAS

DEPARTAMENTO DE LETRAS MODERNAS

PROGRAMA DE PÓS-GRADUAÇÃO EM ESTUDOS LINGÜíSTICOS E LITERÁRIOS EM INGLÊS

\title{
A NOITE E AS VIDAS DE RENATOS AVELAR \\ CONSIDERAÇÕES SOBRE A TRADUÇÃO DO PRIMEIRO CAPÍTULO DE FINNEGANS WAKE DE JAMES JOYCE
}

Afonso Teixeira Filho

São Paulo

2008 
UNIVERSIDADE DE SÃO PAULO

FACULDADE DE FILOSOFIA, LETRAS E CIÊNCIAS HUMANAS

DEPARTAMENTO DE LETRAS MODERNAS

PROGRAMA DE PÓS-GRADUAÇÃO EM ESTUDOS LINGÜÍSTICOS E LITERÁRIOS EM INGLÊS

\section{A NOITE E AS VIDAS DE RENATOS AVELAR}

CONSIDERAÇÕES SOBRE A TRADUÇÃO DO PRIMEIRO CAPÍTULO DE FINNEGANS WAKE DE

JAMES JOYCE

Afonso Teixeira Filho

Tese apresentada ao Programa de PósGraduação em Estudos Lingüísticos e Literários em Inglês, do Departamento de Letras Modernas da Faculdade de Filosofia, Letras e Ciências Humanas da Universidade de São Paulo, para obtenção do título de Doutor em Letras.

Orientador: Prof. Dr. João Milton

São Paulo 
Ao meu devanceiro 
Llega el invierno. Espléndido dictado me dan las lentas hojas vestidas de silencio y amarillo.

Soy un libro de nieve, una espaciosa mano, una pradera, un círculo que espera, pertenezco a la tierra y a su invierno.

Creció el rumor del mundo en el follaje, ardió después el trigo constelado por flores rojas como quemaduras, luego llegó el otoño a establecer la escritura del vino: todo pasó, fue cielo pasajero la copa del estío, y se apagó la nube navegante.

Yo esperé en el balcón tan enlutado, como ayer con las yedras de mi infancia, que la tierra extendiera sus alas en mi amor deshabitado.

Yo supe que la rosa caería y el hueso del durazno transitorio volvería a dormir y a germinar: y me embriagué con la copa del aire hasta que todo el mar se hizo nocturno y el arrebol se convirtió en ceniza.

La tierra vive ahora tranquilizando su interrogatorio, extendida la piel de su silencio.

Yo vuelvo a ser ahora el taciturno que llegó de lejos envuelto en lluvia fría y en campanas: debo a la muerte pura de la tierra la voluntad de mis germinaciones.

Rubén Darío, "Jardin de invierno" 


\title{
RESUMO
}

Este trabalho discute as implicações do tempo na História, da História no romance e do romance nas vanguardas; trata da crise do romance no início do século XX e da ascensão das vanguardas; relaciona essa crise com a crise do racionalismo que resultará em obras de arte complexas como o livro Finnegans Wake de James Joyce, um livro considerado por muitos como ilegível e que não poderia ser traduzido. Este trabalho considera também que para se traduzir uma obra Finnegans Wake seria necessário, mais do que uma técnica, uma estética da tradução. Partindo de uma estética da tradução, elaboramos um critério específico para a tradução de Finnegans Wake, a qual apresentamos ao final deste trabalho, acompanhada de notas e de um glossário dos termos usados no original e na tradução.

Palavras-chave: James Joyce; Finnegans Wake; Tradução; Teoria do Romance; Estética.

\begin{abstract}
This thesis deals with the implications of time in History, History in the novel, and with the novel in the avant gardes. It also examines the crisis of the novel at the beginning of 20th century and the rise of the avant gardes, and relates this crisis to the crisis of rationalism that would result in complex works of art such as Finnegans Wake, believed by many to be unreadable and untranslatable. It then proposes that in order to translate Finnegans Wake a whole aesthetics of translation is necessary in order to express the complex workmanship involved in its creation. Bearing in mind this aesthetics of translation, the thesis then elaborates a specific criterion to translate Finnegans Wake, which is presented in the final section, followed by notes and a glossary of original and translated terms.
\end{abstract}

Keywords: James Joyce; Finnegans Wake; Translation; Theory of the Novel; Aesthetic. 


\section{Abreviaturas}

adj. adjetivo

afr. africânder

al. alemão

anag. anagrama

anglo-irl. anglo-irlândês

ant. antigo

ár. árabe

bul. búlgaro

cat. catalão

cf. conferir

chec. checo

chin. chinês

coloq. coloquial

coord. coordenador

corresp. corresponde

dial. dialeto

dim. diminutivo

din. dinamarquês

ed. editor

esc. escocês

esp. espanhol

esper. esperanto

ex. exemplo

fig. figura fin. finlandês

fr. francês

gal. galego

gír. gíria

gr. grego

gr. mod. grego moderno

hapleg. hápax

heb. hebraico

hind. hindustânico

hun. húngaro

indo-eur. indo-europeu

inf. informal

ing. inglês

ing. amer. inglês americano

interj. interjeição

irl. irlandês

it. italiano

jap. japonês

lat. latim

lat. vul. latim vulgar

lit. literalmente

LM Leitmotiv

ME Middle English

mir. mirandês 
mit. mitologia

mús. música

napol. napolitano

neer. neerlandês

neol. neologismo

nor. norueguês

$O E D$ Oxford English Dictionary

org. organizador

orig. original

onomat. onomatopéia

p. ex. por exemplo

paron. paronomásia

pol. polonês

port. português

pret. pretérito

pron. pronúncia

prov. provençal

provb. provérbio

PV palavra-valise ref. referência

reg. regionalismo

rel. relativo

reto-rom. reto-românico

rom. romeno

rus. russo

sânscr. sânscrito

séc. século

sin. sinônimo

subst. substantivo

sue. sueco

suf. dimin. sufixo diminutivo

topôn. topônimo

trad. tradução

troc. trocadilho

tur. turco

vb. verbo

* (palavra hipotética)

† (palavra arcaica, obsoleta) 


\section{Sumário}

\section{CRONOPÉIA}

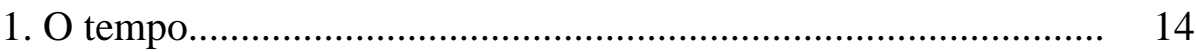

2. A História.............................................................................. 17

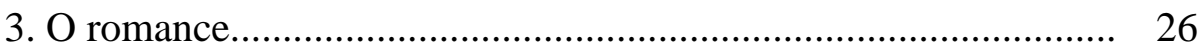

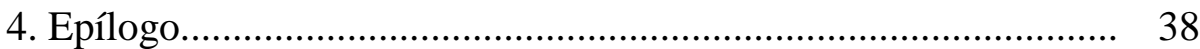

\section{HIPNOPÉIA}

1. Das vanguardas até Joyce...................................................... 45

2. Joyce e seus contemporâneos................................................. 47

3. Finnegans Wake ................................................................... $\quad 52$

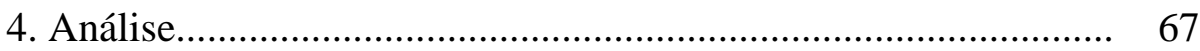

\section{TELEOPÉIA}

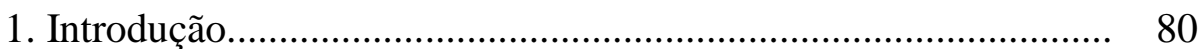

2. Análise exegética................................................................. 87

3. A crítica........................................................................... 93

4. Interpretação................................................................... 108

\section{GLOSSOPÉIA}

1. Tradução 127

1. 1. Finnegans Wake 128

1. 2. Renatos Avelar 159

2. Discrepâncias entre as edições................................................... 190

3. Glossário........................................................................... 201

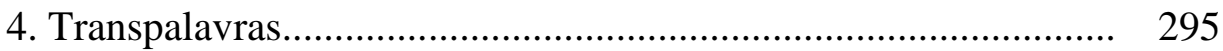

\section{REFERÊNCIAS}

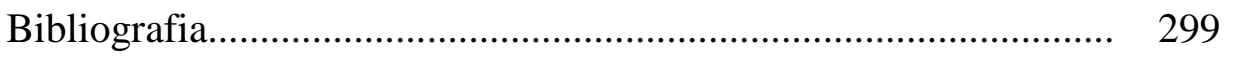


Discografia........................................................................ 313

Dissertações e teses................................................................... 313

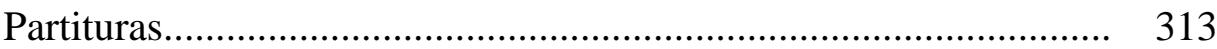

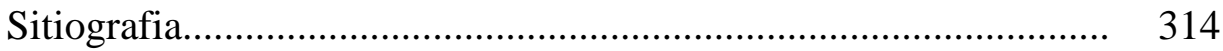

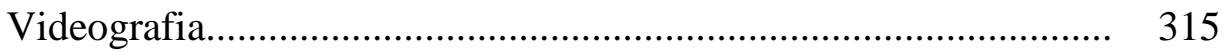

$\begin{array}{ll}\text { DISCO } & 316\end{array}$

ESTA TESE CONTÉM UM CD. 


\section{Antepalavras}

Discutiremos, nestas páginas, a última obra de grande porte do escritor irlandês James Joyce, Finnegans Wake, com o propósito de apresentar um critério de tradução para ele. Analisamos a fábula, a estrutura e a linguagem e procuramos reproduzi-las na tradução do primeiro capítulo do livro, acompanhada de notas e de um glossário de termos usados no original e na tradução.

Uma tese que apresente um princípio teórico para a tradução de uma obra específica e a aplicação desse princípio nessa mesma obra esgotaria seu escopo em si mesma, não tendo serventia além de suas páginas. Entretanto a obra de que trata é Finnegans Wake, obra que se encontra além do gênero. A escolha teve o objetivo de discutir a tradução, enquanto ofício, no limite de sua aplicação.

As teorias da tradução procuram estabelecer princípios determinantes, ou seja, dizem o que o tradutor deve ou pode fazer, baseadas naquilo que já foi feito ${ }^{1}$; melhor seria discutir o que fazer a partir de agora.

As novas técnicas de tradução eletrônica determinarão o fim do ofício de tradutor e intérprete. A sobrevivência deles dependerá de um grande esforço de adaptação. As traduções eletrônicas cuidarão de todo o aspecto semântico da transferência entre as línguas; até mesmo a métrica, as rimas e os aspectos fonéticos poderão ser reproduzidos com a ajuda de um programador.

Ao tradutor caberá lidar com aqueles aspectos que caracterizam a diferença entre a tradução e o original, aquilo que ele mesmo puder criar, puder inventar; caso contrário, terá de arrumar outro ofício. Não nos interessa aqui discutir o futuro da profissão, mas apresentar um método que está longe de se tornar obsoleto: o da tradução como arte, criação e transformação.

A tradução costuma ser uma processo de três etapas: análise, crítica e interpretação. De todas elas, a mais importante é a última, embora o tradutor esteja mais comprometido com a primeira.

\footnotetext{
${ }^{1}$ Maiakóvsqui, em um ensaio intitulado "Como escrever versos”, afirma: “os velhos manuais de versificação... são apenas a descrição dos métodos de escrita históricos, transformados em hábito. Seria correto denominar tais livros não “como escrever", e sim "como escreveram.” (SCHNAIDERMAN, 1971, p. 172-3)
} 
A análise é o entendimento do texto original em todos os seus aspectos: linguísticos, estilísticos, histórico, fônico, etc. É no aspecto lingüístico que o tradutor comete o maior número de desvios, quer sejam eles voluntários, quer decorrentes de distração ou ignorância. E é aqui também que ele será julgado com maior rigor.

A crítica é o espaço em que o original começa a se aproximar da tradução; é nele que as línguas se comunicam, pois no âmbito anterior, o da análise, elas ainda se estranhavam. É por meio da crítica que o tradutor determinará o critério, o estilo, a linguagem e os recursos a serem aplicados no texto traduzido.

A interpretação, por sua vez, é o âmbito do exercício propriamente dito da profissão. É nele que o tradutor se sai melhor (ou pior), e é nele que o uso da máquina será questionado, pois tudo o que ela fará, se for convenientemente programada, será compilar textos já traduzidos e arquivados num banco de dados para recortá-los e costurá-los na tradução, fazendo do texto definitivo uma quimera. O terreno da interpretação é o terreno da linguagem, da expressão e da comunicação de experiências estéticas e de vida que uma máquina não teve.

Para exemplificar será preciso ouvir uma música criada em formato "midi"” por exemplo. Por meio de um programa de computador, é acionado um mecanismo que "lê" e "interpreta” a música com uma perfeição e uma destreza que o músico nunca terá. Mas a beleza da interpretação musical não reside tanto na técnica, mas no esforço, no exercício da vontade e na imperfeição.

No esforço, na liberdade e na imperfeição, exercidos no reduzidíssimo espaço permitido a isso no texto original (no caso da tradução) ou na partitura (no caso da música), é que se encontra a interpretação.

Quando o intérprete transgride esse espaço, o intérprete se torna artista, passa a criar. O tradutor precisará ampliar o seu espaço para sobreviver.

Para traduzir uma obra, Finnegans Wake, que foi obrigada a ultrapassar as fronteiras do gênero e da própria literatura, será preciso ir além das fronteiras da análise da crítica e da interpretação e adentrar o terreno da criação.

\footnotetext{
${ }^{2}$ Abreviatura de "Musical Instrument Digital Interface". Tecnologia que permite, por exemplo, a um sintetizador tocar qualquer partitura. Ver Disco, faixas 14 e 15.
} 
Mas não se pode adentrar com facilidade o terreno da criação, levando um livro como Finnegans Wake debaixo do braço. O livro foi considerado, primeiro, ilegível; depois que foi lido, disseram que era intraduzível, apesar de já ter sido. O próprio Joyce, que criara uma obra para, segundo ele, ocupar os críticos por séculos, afirmava que não havia nada que não pudesse ser traduzido. Sua atitude como autor e como tradutor era de alguém das vanguardas.

O artista da vanguarda pensa sempre além do seu tempo. Assim deveria pensar também o tradutor.

Ao artista da vanguarda interessa romper com os padrões estéticos de sua época. $\mathrm{Na}$ era das vanguardas, começa-se a discutir a decadência do romance, por exemplo. Porque ao artista das vanguardas, interessa discutir o próprio meio: a sociedade (o mundo), a arte (a literatura), a expressão (o romance) e a linguagem (a realidade). Ele rompe com tudo. Vive o excêntrico, revolta-se contra o belo, transpõe as fronteiras lingüísticas; enfim, faz o que tem vontade de fazer. Mas com um propósito: ir além de uma sociedade que já não o comporta. Ele precisa transcender.

Finnegans Wake foi escrito transpondo todas estas barreiras: o tempo, o gênero, a língua e a realidade. Com isso, compromete a arte: Finnegans Wake não é mais romance; soltou-se das raízes do gênero que continuavam presas, irremediavelmente, ao tempo.

Tivemos de falar sobre isto, sobre o tempo, buscando nele as origens do romance. Chamamos a essa parte de nosso trabalho de Cronopéia (que significa fazer o tempo).

A genética do romance resulta no Finnegans Wake. Nele, o autor, rompendo com o tempo, rompe também com a realidade, adentrado o universo do sonhador. Chamamos a essa parte do trabalho de Hipnopéia (que significa fazer o sonho).

O sonho levou-nos à análise. Tratamos de entendê-lo. Foi preciso interpretá-lo. Valendo-nos da idéia de que tradução é interpretação, passamos a discutir a obra que encerra aquele sonho a partir das traduções dela. Mas nosso propósito era ir além, por isso chamamos a essa parte do trabalho de teleopéia (que significa realizar a transcendência).

Por fim, tratamos daquilo a que nos propusemos de início: traduzir; o que seria a concretização daquilo que tratamos no plano teórico. Foi, sobretudo, um exercício com a palavra, com a língua, e com as línguas; e chamamos a essa parte do trabalho de Glossopéia (que significa fazer a palavra). 
Essa tese está dividida em quatro partes. A primeira trata da gênese do romance até às vanguardas. A segunda vai das vanguardas até Finnegans Wake. A terceira discute a tradução como método interpretativo para a intelecção de Finnegans Wake, e propõe um critério para traduzi-lo. A quarta apresenta a tradução do primeiro capítulo do livro, acompanhada de um glossário de termos usados nela e no original.

Agradecemos a todos aqueles que nos ajudaram na realização desse trabalho: aos professores que nos ensinaram, aos amigos com quem debatemos e às pessoas com quem convivemos cotidianamente. Agradecemos também ao Conselho Nacional de Desenvolvimento Científico e Tecnológico (CNPq), pelo auxílio financeiro, e, especialmente, às seguintes pessoas: ao meu primeiro orientador, o Prof. Dr. Antônio Medina Rodrigues; ao Prof. Dr. John Milton, orientador desta tese; a Dirce Waltrick do Amarante, pelos livros, pela ajuda; aos meus filhos, Lívia e Júlio César, e a minha esposa, Maria Tereza. 


\section{Cronopéia}

O primeiro remedio [do amor] que diziamos, é o tempo. Tudo cura o tempo, tudo faz esquecer, tudo gasta, tudo digere, tudo acaba. Atrevese o tempo a columnas de marmore, quanto mais a corações de cêra? São as affeições como as vidas, que não ha mais certo sinal de haverem de durar pouco, que terem durado muito. São como as linhas, que partem do centro para a circumferencia, que quanto mais continuadas, tanto menos unidas. Por isso os antigos sabiamente pintaram o amor menino; porque não ha amor tão robusto que chegue a ser velho. ${ }^{3}$

Padre António Vieira, Sermão do mandato (1643)

\section{O TEMPO}

É comum considerar-se a história como uma ciência do tempo, dedicada ao estudo do passado da humanidade, como a definiu Herder ${ }^{4}$; ou ciência do homem no tempo, de acordo com Marc Bloch ${ }^{5}$; ou ciência da mudança perpétua das sociedades humanas, nas palavras de Lucien Febvre ${ }^{6}$.

Essas definições são, todas elas, práticas e suficientes, mas, antes de utilizá-las, devemos ter o cuidado de distinguir História e Tempo e determinar os seus vínculos.

A História ocorre fora do tempo. A ela pertencem o passado e o futuro; do passado tratam os cronistas; do futuro tratam os profetas. Aqueles relatando o que foi e estes relatando o que será. Ambos, de certa forma, trabalhavam com a adivinhação: a profecia utilizando-se dos áuspices, áugures, etc.; os cronistas selecionando fatos e interpretando-os. Se, por um lado, a profecia descreve o futuro pela observação, por exemplo, do vôo das aves, o trabalho

\footnotetext{
${ }^{3}$ VIEIRA, 1951, v. IV, p. 293.

${ }^{4}$ Johann Gottfried von Herder (1744 - 1803). Filósofo, poeta e crítico literário alemão associado ao Sturm und Drung.

${ }^{5}$ Marc Léopold Benjamin Bloch (1886 - 1944). Historiador francês.

${ }^{6}$ Lucien Febvre (1878-1956). Historiador francês da mesma escola que o anterior. Essa definição encontra-se no livro Combats pour l'histoire (1953).
} 
do cronista só começa a ser escrito depois que a ave pousa. Desse modo, o estudo do futuro precede o estudo do passado.

O presente não é, propriamente, objeto de estudo da História, porque não permite o distanciamento necessário para a consolidação dos fatos. A História é uma ciência que padece de hipermetropia.

O Tempo, no entanto, não se ocupa do passado, nem do presente, nem do futuro, porque nenhum dos três são categorias temporais, mas espaciais. Presente é aquilo que se encontra aqui; passado, aquilo que por aqui passou; futuro, aquilo que daqui partiu. Todos esses termos se referem a locais. São todos particípios ou formas nominais de verbos.

O termo "passado" deriva do particípio passado do verbo passo, passare (do latim vulgar), oriundo de passus, "afastamento das pernas"; passus, por sua vez, vem do verbo latino pandō, is, ěre, estender, afastar. "Presente" vem do substantivo latino praesens, presente (também o tempo verbal); o termo "presença", de praesentĭa, ae, referia-se, originariamente, à aparição dos deuses; o termo praesens opõe-se a absens, ausência; o prefixo prae- indica proximidade e o prefixo $a b$-, afastamento: sentido de proximidade e de distância, respectivamente. A palavra "pretérito" deriva do verbo latino praeterěo, is, ir além, deixar para trás, passar para trás, passar; praeterĭtus, a, um é o particípio desse verbo. "Futuro" é o particípio futuro latino do verbo sum, ser, estar (futūrum, $i$ ), significando "aquilo ou aquele que será", ou “o que há de ser".

Todos esses termos se referem ao espaço: presença, ausência, proximidade, afastamento. Mas as categorias temporais também carecem de uma terminologia precisa: “o tempo passa", "o relógio anda", “o tempo flui”, “as horas voam”, "não perca tempo!” Para se designar o tempo, usam-se metáforas espaciais. O tempo é algo muito abstrato para ser entendido pelo homem, que o marca contando os ciclos percorridos por uma engrenagem de relógio. O tempo só pode ser compreendido na comparação de uma mesma atividade sendo exercida por duas ou mais pessoas da mesma maneira. Toma-se um referencial como padrão. O padrão é o tempo.

Por esse motivo, Epicuro afirmava que o tempo "não pode existir por si mesmo" e não pode ser concebido "independentemente do movimento e do repouso das coisas" (De rerum natura). Mas antes mesmo de Epicuro, Zenão já questionava a existência do tempo. Para ele, o movimento (o qual depende do tempo e do espaço) era irreal, pois o espaço, sendo 
infinitamente divisível, exigiria, para que fosse percorrido em qualquer extensão, um tempo infinito. O raciocínio dele é que é irreal, embora irrefutável. É uma visão linear do tempo.

Heráclito, por sua vez, considerava o real movediço e contraditório. O ser, pertencente a esse real, apresentava multiplicidade e mobilidade: "É a mesma coisa ser vivo ou ser morto, desperto ou adormecido, jovem e velho; essas coisas se transformam umas nas outras e são de novo transformadas."7 Isso parece menos uma representação cíclica do tempo do que uma representação cíclica do ser, que combina com a forma do relógio de ponteiros: o disco do relógio, imóvel, é o tempo; os ponteiros, que se movem, é a vida.

Mais tarde, Platão, no Timeu, elabora a idéia de que o tempo é uma “imagem móvel da eternidade" (PlATO, 1987b, p. 450b) ${ }^{8}$ e não existe para as coisas eternas. Na eternidade, não existem dias e noites, nem meses e anos; essas coisas passaram a existir quando o céu foi criado, e o céu foi criado junto com o tempo.

Da observação do céu, surgiu a noção de tempo; é uma visão cíclica que leva em consideração o movimento aparente das estrelas, o ciclo solar e lunar (que resultam nas estações do ano, nas cheias dos rios e no movimento das marés), a rotação da terra (os dias e as noites), etc. O tempo estava a serviço da agricultura. Por essa razão, muitas culturas sedentárias confundem o tempo com o clima. ${ }^{9}$

A concepção cíclica do tempo predominou nas sociedades agrárias; mesmo entre povos que nunca tiveram contato entre si. Os hindus, os povos do Crescente Fértil, os Maias na América, etc. Essa concepção era, contudo, incompatível com o cristianismo, para o qual o tempo é apenas um caminho para a eternidade. Linear, portanto.

Com o avanço do racionalismo, na Idade Moderna, o tempo passou a ser concebido como algo absoluto, semelhantemente ao que pensava sobre ele Aristóteles. Como absoluto também se concebia o espaço. Para Newton, tempo e espaço eram absolutos, e a autoridade dele norteou a ciência entre os séculos XVII e o começo do XX, quando Einstein e outros

\footnotetext{
${ }^{7}$ Enciclopédia Mirador, v. 19, p. 10826b.

${ }^{8}$ Quando não estiver mencionado o nome do tradutor, em citações feitas do original, a tradução será nossa.

${ }^{9}$ Em diversas línguas, de famílias diferentes, a palavra "tempo" serve também para designar o "clima", como,

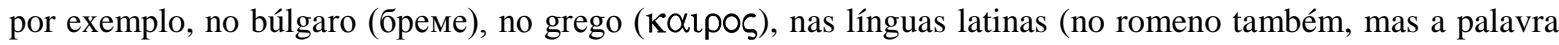
que designa as duas coisas é de origem eslava: vreme), no albanês (kohë), etc. No inglês, a palavra tide, que significa "maré", no inglês antigo significava "tempo". A relação entre o movimento das marés e a marcação do tempo deve-se, talvez, ao fato de a Inglaterra estar numa ilha.
} 
invalidaram a tese do tempo absoluto. Para Einstein ${ }^{10}$, o tempo é inseparável da consciência individual que o percebe. O tempo é apenas a sucessão das coisas.

A sucessão é, no entanto, para Bergson ${ }^{11}$, um tempo real, que "prolonga o antes no depois, impedindo-os de ser puros instantes, aparecendo e desaparecendo em um presente que renasceria sem cessar" ${ }^{\prime 12}$. O que permite, no entanto, o prolongamento do antes no depois, ou a fluidez do tempo, é a memória. A memória é a consciência do tempo. ${ }^{13}$

O homem tem consciência do tempo porque tem a capacidade de antecipar, porque a sua liberdade depende de um projeto existencial. São essas as idéias de Heidegger ${ }^{14}$ expressas em $O$ ser e o tempo. O prolongamento do antes no agora resulta no futuro, e o prolongamento do futuro no passado resulta no presente. Para que entendamos isso, devemos pensar no futuro não como um vir-a-ser, mas como um projeto para o ser. Portanto, a verdade do ser (o ser e seu projeto) se revela como tempo.

A literatura do século XIX podia ser explicada, no que diz respeito ao tempo, pelo racionalismo dos séculos XVII e XVIII; a do século XX, por sua vez, contempla as idéias de Bergson e Heidegger. O século XX foi dominado pelo irracionalismo nietzschiano sobre toda a atividade do espírito. A grande preocupação da literatura nesse período foi o tempo. Entretanto, em relação ao romance, houve também outra preocupação: a História.

\section{A HISTÓRIA}

A História está restrita ao âmbito de fatos selecionados que realmente aconteceram. Nem sempre foi assim, e nem sempre será. Antes do empirismo baconiano, ela lidava também com o que poderia ter acontecido, como relata Tucídides na História da guerra do

\footnotetext{
${ }^{10}$ Albert Einstein (1879 - 1955). Físico teórico alemão, formulador da lei do efeito fotoelétrico. Em 1913, publicou Entwurf einer Verallegemeinerten Relativitätstheorie und einer Theorie der Gravitation (Idéia global da teoria geral da relatividade e uma teoria da gravitação).

${ }^{11}$ Henri Bergson (1859 - 1941). Escritor e filósofo irracionalista francês. Essai sur les données inmédiates de la conscience (1889); Le Rire (1899); Matière et mémoire (1896); L'évolution créatrice (1907); L'Énergie spirituelle (1919); Les deux sources de la morale et de la religion (1932).

${ }^{12}$ Henri Bergson, Mélanges. Paris: PUF, 1972.

${ }^{13}$ Ver Coelho, J. G. "Ser del tiempo en Bergson", Interface - Comunic., Saúde, Educ., v. 8, n. 15, p. 233-46, mar/ago 2004.

${ }^{14}$ Martin Heidegger (1889 - 1976). Filósofo alemão. A Doutrina das Categorias e do Significado em Duns Escoto (1916); Ser e Tempo (1927); O que é a Metafísica? (1920); A Auto-afirmação da Universidade Alemã (1933); Hölderlin e a Essência da Poesia (1937); A Doutrina de Platão sobre a Verdade (1942); Da Essência da Verdade (1930); A Carta sobre o Humanismo (1949); Caminhos Interrompidos ou Caminhos de Floresta (1950); Introdução à Metafísica (1935); O que é isso - a Filosofia? ou O que é a Metafísica? (1956); Caminho Rumo à Linguagem ou A Caminho da Linguagem (1959); Nietzsche (1961); etc.
} 
Peloponeso. Mas ela deve lidar também com o que não aconteceu e com o que não poderia acontecer, com aquilo que chamamos de ficção, e que é estudado pela Literatura. Há uma parte da ficção, o relato, que deveria ser estudada pela História, da mesma forma que outras partes são estudadas por outras ciências: lingüística, psicologia, sociologia, etc. O relato é, em certa medida, sempre verdadeiro e, como tal, liga-se à História que é a ciência que trata dos fatos ou dos feitos e, conseqüentemente, da verdade. Pois "a verdade é o próprio fato", afirmava o filósofo napolitano Giambattista Vico na Italorum sapientia ${ }^{15}$.

O objeto de estudo da História não é, contudo, a verdade, pois a História é escrita pelas classes dominantes ${ }^{16}$, que selecionam como lhes convêm os fatos convenientes. Há tanta ficção na História quanto na Literatura.

Para os antigos, as narrativas históricas e literárias eram a mesma coisa. Para eles, não havia diferença entre a realidade e o mito. Os deuses viviam no mesmo mundo que os homens. Quando quiseram ver-se livres dos deuses, exilaram-nos no Olimpo ou no Céu. O mito foi-se distanciando da realidade e as narrativas históricas começaram a distanciar-se das literárias. Esse distanciamento fez surgir a História.

Durante muito tempo, apenas os povos conhecedores da escrita eram considerados históricos. O homem que vive ao lado do mito é o homem pré-histórico. A sua cultura é ágrafa e os relatos dele imprimem-se apenas na memória, no coração. O tempo do homem era a eternidade. $\mathrm{O}$ distanciamento dos mitos abreviou paulatinamente essa eternidade. Fez-se o céu e fez-se o tempo.

Tempo e História passaram a designar duas preocupações distintas para a Literatura. A História, que trata do passado, diz respeito à epopéia. O Tempo, que trata do que passa, diz respeito ao romance, que é considerado por muitos a epopéia dos tempos modernos, ou “epopéia de um mundo sem Deus” (LUKÁCS, s/d, p. 89) ${ }^{17}$.

\footnotetext{
15 "Verum ipsum facto". No primeiro capítulo da obra De antiquissima italorum sapientia ex lingua latinae originibus eruenda. Cf. nota 18.

${ }^{16}$ Tendências historiográficas contemporâneas, como a micro-história, que buscam diversos ângulos para a análise e interpretação do objeto de estudo, pensam livrar-se, por esse método, de uma historiografia oficial. Entre elas, há historiadores importantes como Eric Hobsbawm e Edward Thompson. Mas ninguém está totalmente livre da doutrinação. A direita neoliberal tem o monopólio dos meios de comunicação, e, portanto, o controle sobre a informação (mais de $95 \%$ da informação internacional é produzida por meia dúzia de agências de notícias, estado-unidenses e européias). Hoje, mais do que nunca, a História tem a chancela da classe dominante.

${ }^{17} \mathrm{Na}$ tradução inglesa, está "The novel is the epic of a world that has been abandoned by God" (LuKÁCs, 1971, p. 870; na tradução portuguesa, "O romance é a epopéia de um mundo sem deuses".
} 
O Tempo, ou a consciência que temos do tempo, deriva da História. Mas o romance, como veremos no capítulo seguinte, não deriva da epopéia. Até aqui, procuramos demonstrar em que diferem Tempo e História e encontramos uma relação genealógica entre eles, uma relação em que a História é mãe e o Tempo é filho. A conclusão é hegeliana.

Hegel entendia a História como a temporalidade humana, uma temporalidade dialética que se desdobrava em três momentos: identidade (tese), negatividade (antítese) e totalidade (síntese). A identidade diz respeito à natureza; a negatividade, ao trabalho; e a totalidade à História. Em outras palavras: o homem supera, por meio do trabalho, a natureza que o escraviza, e encontra a liberdade na História. A História é a síntese do Tempo.

Para Hegel, quando o Espírito encontra-se com a História, defronta-se com a liberdade, a qual ele viu personificada na figura de Napoleão Bonaparte.

Victor Hugo, ao relatar os momentos que antecederam a Batalha de Waterloo, usou estas palavras:

Esta figura [Napoleão] permaneceu por muito tempo na luz, livre de certa escuridade de lenda que se forma em volta da maior parte dos heróis, velando sempre por mais ou menos tempo a verdade; hoje, porém, faz-se o dia e a história.

O fulgor desta é impiedoso; tem isto de estranho e divino: que, apesar de ser luz, e exatamente porque o é, espalha sombra muitas vezes, onde se viam raios; um ataca o outro, as trevas do déspota lutam com o resplendor do capitão, mas ela faz justiça a ambos. Daí uma medida mais exata para a definitiva apreciação dos povos. Babilônia, violada, diminui Alexandre; Roma, manietada, diminui César; a morte de Jerusalém diminui Tito. A tirania segue o tirano. Desgraçado o homem que deixa atrás de si a sombra de sua forma. (HUGO, s/d, v. 2, p. 24)

Esses dois parágrafos revelam o que é a História: é o dia em que o herói deixa a penumbra da lenda para atrever-se ao tempo e à verdade, e transforma-se em luz e em sombra. Esses parágrafos revelam também o que é o tempo: luz sem fulgor que ofusca a verdade. A História sintetiza essa luz desmascarando-lhe o contraste. A verdade se revela e a revelação é a liberdade.

Ao negar a natureza, no caminho da libertação, o homem cria-se a si próprio. Embora devamos entender esse homem de que fala Hegel como o homem individualista do século XIX, nenhum homem, nem mesmo o homem moderno, goza por muito tempo da liberdade ao defrontar-se com ela. 
O homem não pode criar-se a si mesmo, porque é criatura de Deus. Além disso, não tem capacidade de entender senão o que criou. Portanto, não é capaz de entender a si próprio. A ele foi negada a liberdade. Mas se a ele é dado entender o que criou, pode entender a História, pois é o homem quem a faz. E por conhecê-la, a História é, portanto, ciência. A

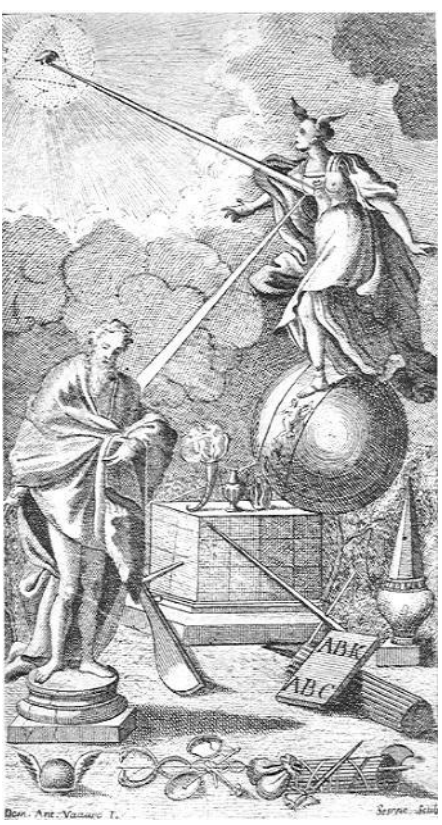
partir daqui se pôde elaborar uma filosofia da História. O trabalho coube a Vico, numa obra visionária: Princípios de uma ciência nova (figura ao lado).

Giambattista Vico ${ }^{18}$ é autor de uma concepção bastante singular da História, a um tempo pessimista e otimista. O pessimismo é, fundamentalmente, cristão. Imagina o homem como uma criatura degenerativa que, em vez de evoluir, se corrompe. Seu sentido histórico não é dominar a natureza, mas voltar a ela, ao paraíso perdido. Para o homem não é possível aperfeiçoar-se, pois foi criado à imagem de Deus, o ser perfeitíssimo. Ao deixar o Paraíso, o homem distancia-se cada vez mais de Deus e, conseqüentemente, da perfeição. Ou seja, regride.

Foi obrigado a deixar o Paraíso porque pecou; teve de trilhar, por meio do trabalho, seu caminho no mundo. O caminho é a História, e, pelo fato de a história humana ser a história do pecado, ela termina com a Redenção, com a volta ao Paraíso. Mas a Redenção é para poucos, e o homem terá, antes, de defrontar-se com o Juízo Final.

Como a esperança de salvação é pouca, será preciso procrastinar o julgamento, adiando indefinidamente o final da História.

A história nasceu uma só vez com a criação do homem, mas já renasceu muitas vezes e parece ir a caminho de um renascimento perpétuo, de uma perpétua destruição e reconstrução de si mesma. Por isso, a história assemelha-se a um processo jurídico interminável; não é, pois, por acaso, que Vico escolheu um termo exactíssimo: ricorso, recurso. O recurso é o que tem lugar quando se renova um expediente e se vai remetendo para datas cada vez mais incertas o definitivo juízo. [...] A história converte-se, assim, no expediente da espécie humana, na sua insistente e quase mecânica apelação ao supremo juiz e administrador. (MORA, s/d, p. 107, 8)

\footnotetext{
${ }^{18}$ Giambattista Vico (1668 - 1744). Filósofo, historiador e jurista italiano. De antiquissima italorum sapientia ex linguae latinae originibus eruenda (1710); Principi di una Scienza Nuova intorno alla natura delle nazioni (1725, 1730 e 1744); Vita di G. B. Vico scritta da se medesimo (1728); etc.
} 
A História assemelha-se, portanto, à águia de Prometeu. Da História o homem não escapa; daí, o pessimismo. Mas, por meio de recursos, consegue evitar o juízo final; por isso o otimismo.

Do primeiro pecado do homem ao primeiro castigo da humanidade, a História seguiu um curso linear. A partir das descendências dos filhos de Noé - os arianos (filhos de Jafé), os camitas, ou africanos (filhos de Cam), e os semitas (filhos de Sem) - surgiu o paganismo. Elas se dispersaram pelo mundo mantendo a mesma língua e os mesmos costumes. Quando pensaram em construir uma torre em Babel, que as levassem até às mesmas alturas que Deus, foram castigadas por ele com o desentendimento e passaram a falar línguas diferentes. A torre ruiu e seu desmoronamento assinala o primeiro cataclismo e o início da circularidade da História. Por essa queda, Deus foi, mais uma vez, o responsável indireto. A partir de então, os homens passaram a fazer a própria História. Não a fizeram, contudo, da maneira que queriam $^{19}$, como o comprovam as próprias circunstâncias do desenvolvimento da civilização. Se não fosse o descontrole, a dinâmica histórica estaria comprometida e os ciclos não se processariam.

A idéia de Vico de que a História passa por três idades distintas antes de recomeçar, foi tomada de Varrão ${ }^{20}$, escritor romano do período final da República, para quem os antigos egípcios haviam passado por três tempos ideais: o tempo obscuro (idade dos deuses, segundo Vico), o tempo fabuloso (idade dos heróis) e o tempo histórico (idade dos homens). Refletindo sobre a distribuição do homem nos tempos, Vico percebeu que a natureza dos povos "primeiro, é cruel; depois, severa; logo, benigna; em seguida, delicada; finalmente, dissoluta" (VICO, 2005, p. xvii).

Na Idade dos Deuses, há o predomínio da capacidade imaginativa do homem. Tudo é manifestação da vontade dos deuses. Nessa Idade, encontram-se as raízes do Direito. No entanto, os deuses não se comunicam diretamente com os homens: é preciso a intermediação (ou tradução) dos oráculos. Não cabe questionar a decisão dos deuses, apenas obedecê-la. É uma teocracia.

\footnotetext{
${ }^{19}$ A frase é de Marx. "Os homens fazem a sua própria história, mas não a fazem segundo a sua livre vontade, em circunstâncias escolhidas por eles próprios, mas nas circunstâncias imediatamente encontradas, dadas e transmitidas." (MARX; ENGELS, 1982, p. 417)

${ }^{20}$ Marco Terêncio Varrão (Marcus Terentius Varro, 116 a.C. - 27 a.C.). Toda sua obra se perdeu. A que trata das idades era a Rerum divinarum et humanarum. Santo Agostinho, que a deve ter lido, menciona a divisão da História no capítulo 5 do Livro VI da Cidade de Deus.
} 
A Idade dos Heróis é a idade dos semideuses, homens que atribuem a si próprios origem divina. Eles dominam sobre os homens comuns e lhes ditam as leis. Há, nessa idade, uma "razão de Estado" à qual todas as vontades estão sujeitas. É uma aristocracia.

Na Idade dos Homens, o predomínio não é da lei, mas da razão, à qual todas as coisas se sujeitam, inclusive as leis. A razão, por ser manifestação de um espírito livre, dá-se no reino da liberdade e da igualdade e exige, portanto, um governo na forma de república ou de uma monarquia fundamentada na igualdade de todos perante a lei. É uma democracia.

A História passa, invariavelmente, por essas três idades, as últimas evoluindo das primeiras. Ao final de um ciclo, que culmina com a Idade dos Homens, ou da Razão, sobrevém um cataclismo, ou ricorso, e a História entra novamente na Idade dos Deuses, reiniciando o ciclo. Os homens ouvem os trovões, relacionando-os com as vozes dos deuses e buscando refúgio nas cavernas. Finda a tempestade, buscam terras aráveis, perto dos rios, para iniciarem os plantios - e a cultura. Por causa disso, a Idade dos Deuses é também a idade dos rios. A cultura, com o tempo, passa a requerer um agrupamento humano mais organizado, e as cidades começam a ser organizadas. A Idade dos Heróis é também a das cidades.

Cabe sublinhar aqui que essas idades históricas não são exatamente períodos temporais, mas categorias racionais. História e tempo são coisas distintas. Se a Idade dos Deuses tem precedência sobre a dos Heróis, tal precedência é dialética e não, necessariamente, temporal.

Vico recorre à etimologia para investigar os movimentos da História. Ainda que elabore as mais abstrusas relações entre as palavras, tem o mérito de aliar à Filosofia a Filologia, ampliando o alcance da História como ciência.

Para a aplicação de seu método, ele toma, de início, alguns exemplos equivocados. Em primeiro lugar, faz da língua hebraica a mais antiga ${ }^{21}$ e procura derivar dela todas as outras, chegando mesmo a reproduzir nessas outras línguas etimologias próprias do hebraico. Por exemplo: na língua hebréia, a palavra adam (אדמ), que as primeiras versões da Bíblia interpretaram como nome próprio (Adão) ${ }^{22}$, mas que na realidade quer dizer simplesmente "homem", deriva do substantivo adamah (אדמה), "terra". Infere-se daí que o homem é um ser

\footnotetext{
${ }^{21}$ Até o século XIX acreditava-se nisso. A decifração dos cuneiformes (por Grotenfend e Rawlinson, a partir de 1800), a descoberta do indo-europeu (a partir das propostas de Sir William Jones, em 1786) e do subgrupo indo-ariano tiraram a primogenitura do hebraico.

${ }^{22} \mathrm{Na}$ Septuaginta, aparece $\alpha \delta \alpha \mu$ /adam/ em Gênesis III, 17 e $\alpha \nu \theta p o \pi \circ \sigma$ /antropos/ em Gênesis I, 26.
} 
da terra, ou, conforme o Gênesis, deriva do barro $^{23}$. Vico pretende que a origem do termo latino homō, ̌̌nis (homem) esteja em humus, $\bar{l}$ (solo, terra), seguindo o mesmo desenvolvimento do hebraico. A Idade dos Deuses era, para os gregos, a Idade de Ouro e, para os latinos, a Idade de Saturno, identificado como satus (particípio passado do verbo serō, is, ěre, "semear"), sendo, portanto, o deus das sementeiras. Vico procura estabelecer uma

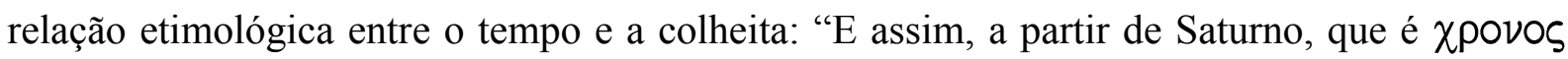

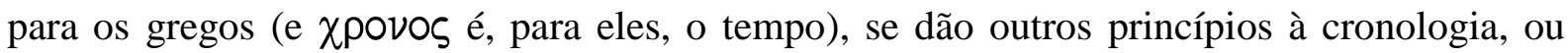
seja, à doutrina dos tempos" (VICO, 2005, p. 6). O princípio é mesmo verdadeiro, mas o exemplo que usa para estabelecê-lo é falso, porque o deus Cronos dos gregos nada tem que ver com o tempo:

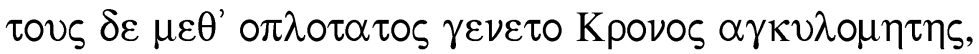

$\delta \varepsilon 1 \nu \circ \tau \alpha \tau \circ \varsigma \pi \alpha 1 \delta \omega \nu \cdot \theta \alpha \lambda \varepsilon \rho \circ \nu \delta^{\prime} \eta \chi \theta \eta \rho \varepsilon \tau о \kappa \eta \alpha$.

[E após com ótimas armas Crono de curvo pensar,

filho o mais terrível: detestou o florescente pai.] (HESíodo, 1995, tradução de Jaa Torrano, p. $112,3)$

Hesíodo utiliza apenas esta ortografia: Kpovos/cronos/. A palavra grega para tempo é

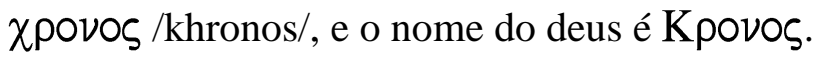

As imprecisões que Vico comete não chegam a comprometer seu sistema; paradoxalmente o enriquecem, porque instiga a imaginação - que desperta o espírito poético do homem primitivo na razão do homem moderno.

Para lermos a Ciência Nova, devemos dar livre trânsito à imaginação. A ciência da História, de Vico, tem um aspecto racional, que nos doutrina, e um aspecto poético, que nos encanta. Nela, misturam-se as linguagens das três eras: a mimética, com a qual os homens rogavam aos deuses; a poética, com que imitavam a música da natureza; e a racional, utilizada para articular os pensamentos.

As línguas evoluem, portanto, do sensível para o abstrato, do pouco articulado para o muito articulado, do sintético para o analítico. Todas as línguas naturais passam por essa evolução. Quanto mais primitivas forem, ou estiverem, mais próximas estarão das coisas

\footnotetext{
${ }^{23}$ Etimologicamente, os dois termos, "homem" e "terra" derivam de outra palavra, adom, "vermelho", com a mesma grafia de adam, mas que provavelmente tinha outra vocalização (nos textos bíblicos, estavam grafadas apenas as consoantes). No versículo em que o termo é considerado pela primeira vez como nome próprio nas traduções (Gênesis III, 17), aparece também a palavra "terra". É provável que o autor bíblico estivesse pensando mais no trocadilho do que em uma relação etimológica.
} 
sensíveis. E a escrita representará os objetos de maneira pictórica (hieróglifos), também por afinidade com as coisas sensíveis. Por esse motivo, ao compararmos duas línguas distintas, há maior probabilidade de semelhança lexical entre elas no conjunto daquelas palavras que entraram primeiro para a língua. Exemplo:

A palavra inglesa para "gado" é cattle. Entre o termo inglês e o português há certa semelhança fonética, mas nenhuma afinidade etimológica. No entanto, tomando-se a origem de um e de outro termo, encontramos um parentesco entre eles. O termo cattle vem do latim capitālis, "relativo à vida", o qual, por sua vez, deriva de caput, capútis, "cabeça". De capitālis, vem o termo capital, "principal”, comum em várias línguas. Capital, resultou em *catal, por síncope, e catel > cattle em inglês; em português, deu "cabedal”, riqueza, que na Idade Média era medida pela quantidade de cabeças de gado. A palavra "gado" vem do castelhano ganado, "ganho", que é a mesma coisa que cabedal.

Às vezes, a relação é anacrônica. Da palavra latina fenestra, nasceram a italiana finestra (igual no catalão), a francesa fenêtre e a romena fereastră; ou seja, desde o latim, esses termos têm o mesmo significado e designam as mesmas coisas. A palavra latina tem como ancestral a raiz indo-européia *pnes, sopro, vento, da qual veio a palavra grega pneuma, sopro, ar. Do grego, por meio do etrusco pnestra, surgiu na península itálica o termo fenestra. Há, portanto, em todas essas palavras, uma relação com vento, ar, pois a fenestra é o local por onde o ar entra na casa. A mesma relação aparece em inglês entre wind, vento, e window, janela. Em inglês, a origem da palavra remonta ao antigo teutônico, *windaz, que, por sua vez, remonta ao pré-teutônico *wentos, cognato com o latim ventus, do qual deriva a palavra espanhola ventana, janela. Em português, o termo latino resultou em fresta (freesta, no português antigo), abertura por onde passa o ar. O termo janela tem origem distinta: vem do latim vulgar janŭella, diminutivo de janŭa, entrada; de mesma origem é a palavra janeiro: entrada do ano. Como se vê, a atualidade de uma palavra de determinada língua tem afinidade com a forma antiga da palavra que em outra língua designa a mesma coisa.

À medida que a língua evolui, o grau de abstração aumenta; sua escrita torna-se mais rápida, mais cursiva, e mais irreconhecível; e a distância entre elas e as outras línguas também aumenta.

Há uma discussão sobre isso no Crátilo de Platão, em que se pretende verificar se a relação entre os nomes e as coisas que eles designam é natural ou não. A posição de Crátilo é a de que "cada coisa tem naturalmente um nome apropriado a ela"; Hermógenes, discípulo de Sócrates, afirma que o fator determinante das nomeações é social. Platão conclui que os 
nomes apresentam as duas coisas: convenção e natureza; a primeira releva a porção humana do nome; a segunda, sua parte divina.

John Locke, no Ensaio acerca do entendimento humano, retoma a questão.

Espírito, em seu sentido original, é sopro; Anjo, um mensageiro: e não duvido de que, se pudéssemos investigar até à origem, descobriríamos, em todas as línguas, que os nomes que designam as coisas que não percebemos por meio dos sentidos derivaram primordialmente das idéias sensíveis. (LOCKE, 1987, p. 252a)

A Etimologia pode apresentar incontáveis exemplos de palavras abstratas que derivam de palavras concretas, pois as palavras mais antigas são as mais concretas. No primórdio das línguas, nos primeiros agrupamentos humanos, na Idade dos Deuses, os homens desenvolveram as metáforas:

Como os primeiros motivos que fizeram o homem falar foram as paixões, suas primeiras expressões foram os tropos. A primeira a nascer foi a linguagem figurada e o sentido próprio foi encontrado por último. (...) A princípio se falou pela poesia, só muito tempo depois é que se tratou de raciocinar. (ROUSSEAU, 1999, p. 267)

Porque a metáfora é a substância da poesia.

Rousseau expressa um pensamento semelhante ao de Vico, e acrescenta que a poesia surgiu antes da prosa porque as paixões falaram antes da razão. As primeiras histórias, as primeiras leis eram entoadas e tudo no mundo era melódico. A razão afastou dos homens a música.

Não surpreende que no século do irracionalismo a música seja devolvida às palavras, o que comprometeu de vez a prosa do século XX. Quando o romance, em sua incessante luta pela sobrevivência - sobrevivência que só é possível para ele por meio de uma constante transformação - teve de incorporar a poesia e a música às suas páginas, feriu-se de morte. Ulysses, de James Joyce, é a reconciliação definitiva do romance com o mito. Aquele homem que provocara a "ira de Zeus", Odisseu ${ }^{24}$, reconciliava-se com o Olimpo. O caminho estava traçado, a porta para o novo gênero encontrava-se à frente e as chaves estavam dadas. O novo gênero apareceu em 1939 nas páginas de Finnegans Wake, de James Joyce, uma narrativa que tinha a fluidez do rio e a leveza do sonho, sensações que apenas a música era capaz de transmitir. James Joyce levou dezesseis anos para escrever um livro que continha todo o

\footnotetext{
24 "Homero explica a origem do nome de Ulysses em grego, Odysseos, pela frase Odyssáo Zeus, isto é, aquele contra o qual Zeus estava irado." (Francisco da Silveira Bueno, "A tentação da etimologia". In: Grande dicionário etimológico prosódico da língua portuguesa, v. I. São Paulo: Edição Saraiva, 1963.)
} 
conhecimento humano e todas as línguas do mundo. O resultado foi a literatura mais primitiva elaborada até então.

\section{O ROMANCE}

Conta-nos Ovídio que Cupido, o amor menino, tinha dois tipos de setas: a seta do amor e a seta da aversão. Querendo vingar-se de Febo, que fazia pouco da habilidade que o filho de Vênus tinha com o arco, este fere àquele com a seta do amor. E quando Febo se aproxima de uma ninfa do Peleio, Dafne, Cupido a atinge com a seta da aversão. Febo passa a persegui-la e ela lhe foge horrorizada. Vendo que o deus não a deixava em paz, roga ao pai para que a livre do tormento, e o pai a transforma num loureiro, livrando-a do amor (que havia de durar pouco) e, ao mesmo tempo, dotando-a da perenidade (que haveria de durar muito). $\mathrm{O}$ coração que era tênue (de cera) mudou em tronco, e a árvore foi consagrada à eternidade, pelo mesmo deus que não a podia amar.

O loureiro, a árvore consagrada a Apolo, aparece decapitada no título de um livro que parecia destinado à obscuridade, Les lauriers sont coupés, de Édouard Dujardin ${ }^{25}$. Em 1920, dois anos antes da publicação de Ulysses, James Joyce revelou a Valéry Larbaud que o monólogo interior, que então finalizava os últimos episódios, já havia sido utilizado por Dujardin em um romance escrito em plena fase simbolista, Les lauriers sont coupés. Bastou isso para que o livro de Dujardin ganhasse fama. O que Dujardin não suspeitava, ao escrever Os loureiros, era que estava desenvolvendo a técnica que iria ferir de morte um gênero prestes a ser decapitado como os loureiros do título.

A morte do romance foi anunciada há cem anos. O ensaio filosófico de György Lukács $^{26}$, A teoria do romance, foi o arauto dessa morte. Traçando a história do romance, desde a origem - a qual ele aponta em Dom Quixote -, Lukács vê os sinais históricos da deterioração desse gênero narrativo na mudança que estava ocorrendo, na época em que o ensaio foi escrito, na estrutura da sociedade burguesa.

\footnotetext{
${ }^{25}$ Édouard Dujardin $(1861-1949)$. Escritor francês. Inventor da técnica da torrente de consciência. Les Lauriers sont coupés (1888).

${ }^{26}$ Szegedi Lukács György Bernát (1885 - 1971). Filósofo húngaro, influenciado em etapas distintas da vida por Kant, Hegel e Marx. A teoria do romance (1916), História e consciência de classe (1923), O jovem Hegel (1938), A destruição da razão (1952)
} 
Por ser o romance arte burguesa desenvolvida nos primeiros momentos da Revolução Industrial, seria plausível pensar-se que, se a sociedade burguesa que o nutria entrasse em decadência, ele também entraria. E de fato entrou. Ocorre que Lukács pensava que a mudança que se estava processando no capitalismo da época, o qual havia superado a fase de livre concorrência e se tornava monopolista, anunciava uma mudança também nas formas estéticas, produto, por sua vez, de outras mudanças, como dos hábitos de consumo, de produção e da própria maneira de pensar.

Mais tarde, superando seu passado hegeliano, e vendo que o romance havia sobrevivido e que podia ser também uma forma de arte proletária, Lukács renega sua Teoria. Contudo, a prova de seu erro não foi o fato de o romance ter sobrevivido, porque, apesar disso, transformou-se, e essa transformação contempla a transformação do herói romanesco.

O herói dos romances é, como seu criador, alguém em busca de algo que não sabe o que é - uma ética determinada pelo próprio romance e que motiva a personagem - e que o mundo não lhe pode dar. Lukács denomina esse tipo de herói de personagem problemática ou demoníaca. Há entre ela e o mundo uma ruptura insuperável:

O fim da antiguidade é constatado pela morte da épica antiga, reforçado e marcado pela cisão entre a subjetividade e o sentido, que se traduz na necessidade de uma nova forma, o romance. Trata-se, agora, de marcar essa distância, essa nova situação transcendental, ou seja, perceber que se trata da transição de uma transcendência divina para outra secular, chamada por Lukács de "demoníaca", isto é, de entender o romance como "expressão simbólica" da impossibilidade da harmonia no mundo. (SILVA, 2006, p. 82)

Lucien Goldmann, ao tratar da sociologia do romance, observa que se a ruptura entre o herói do romance e o mundo fosse radical a narrativa poderia resultar em tragédia, e que, se a ruptura não houvesse, a narrativa redundaria em epopéia (GOLDMANN, 1967, p. 9). O romance, que procurou abandonar todos os modelos, possibilitando-lhe inúmeras mutações, não pode ser mesmo tragédia nem epopéia. O romance, como arte romântica, não imita, inventa; tem necessidade de criar, de ser original ${ }^{27}$. A personagem problemática é aquela que busca valores num mundo em que predominam os valores de troca: são homens que perderam uma totalidade - a integração entre o indivíduo e o mundo que havia nas epopéias - que ainda almejam, por isso não podem romper com o mundo totalmente; são seres sem alma imersos numa sociedade que produz para o mercado.

\footnotetext{
${ }^{27}$ Ian Watt, em Ascensão do romance, mostra que o termo "original" sofreu uma inversão de sentido no transcorrer do tempo. Primeiramente significava aquilo que é o mesmo desde a origem (WATT, 1996, p. 16).
} 
O homem moderno, o indivíduo, deveria encontrar a liberdade de seu espírito na História. A ascensão da burguesia prometeu essa liberdade ao homem. Posteriormente, o predomínio dos monopólios e do capitalismo financeiro viria a comprometer definitivamente a liberdade prometida e a acentuar a perda da individualidade e, conseqüentemente decretando o fim do liberalismo, das suas idéias e da sua arte: o romance, sobretudo.

Isso não aconteceu, o romance não acabou, mas a sobrevivência do gênero em nada compromete o trabalho de Lukács. A teoria do romance, mesmo assim, sustentar-se-ia. No entanto, o que a restringe é aquilo que ela tem de belo, de poético: a comparação sempre constante entre o romance e a epopéia.

Há um julgamento muito difuso de que o romance tem a sua origem na epopéia. Lukács toma de Hegel esse julgamento e o ostenta como axioma. Hegel considerava o romance como a epopéia de um mundo moderno prosaico (HEGEL, 1993, p. 598). Não objetamos que o mundo moderno seja prosaico, e aceitamos o romance como uma forma de epopéia, mas apenas numa extensão de sentido. Não podemos nos apressar a inferir que o romance, por apresentar características de épica - e essas características referem-se, acima de tudo, à narrativa -, dela derive. E se, por outro lado, concordamos com o fato de o mundo moderno ser prosaico, rejeitamos veementemente que ele continue a ser assim.

Um mundo prosaico é, antes de mais nada, um mundo destituído de memória, de glórias e de mitos. Um mundo sem Dafne nem Apolo. A memória é o material em que se imprime a epopéia: seu artífice é o século. O romance não se sujeita à memória nem aos séculos: sua indústria é o instante. $\mathrm{O}$ homem não deve sentir-se bem num mundo prosaico. $\mathrm{E}$ isso já se reflete nos romances que escreve. O incômodo que o mundo lhe causa é o tema principal dos romances do século XX. O mundo prosaico deve ser superado e um dos instrumentos de superação é a arte. Se o romance, como forma de arte, almeja essa superação, ele não pode ser visto como decadente. Mas há pouco dissemos que ele entrou em decadência.

A decadência pela qual passava o romance ao final do século XIX deveu-se a um esgotamento das formas prosaicas de representação. O romance buscou outras formas para outras expressões; por isso sobreviveu. Todavia, a sobrevivência do gênero depende do enfrentamento e da superação dos períodos de decadência. Mas é quando ele goza de saúde, quando se encontra em pleno vigor, que ele corre o risco da dissolução. É então que ele evolui. Atingindo a perfeição, ele supera - ou nega - a si mesmo e deixa de ser. E essa condição que ele atinge, na qual ele já não é ele mesmo, é o que torna obsoleto aquilo que ele 
era antes. Em outras palavras, o romance passa a ser decadente porque passou a existir uma forma narrativa superior.

Mas para se saber por que a narrativa chegou a esse estádio de deterioração, é necessário antes saber de onde ela veio e que caminhos tomou.

Muitas das teorizações sobre o romance tomam como postulado a idéia de que o romance é um gênero narrativo derivado da epopéia. Fundamentam-se elas, sobretudo, em Hegel, o qual, em sua Estética, chama o romance de "epopéia burguesa moderna" (HEGEL, 1993, p. 597). É provável, no entanto que a origem dessa caracterização esteja em Fielding.

Henry Fielding ${ }^{28}$ é considerado um dos precursores do romance, gênero que se

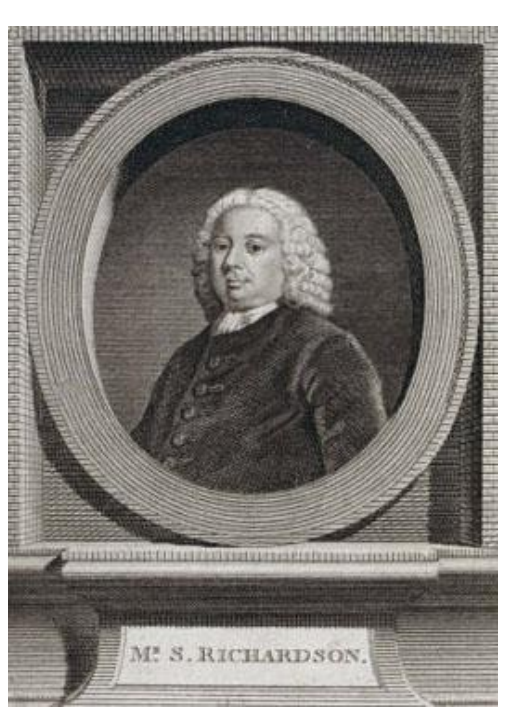
desenvolveu no início do século XVIII na Inglaterra e que teve como primogênito Pamela de Samuel Richardson (figura ao lado $)^{29}$. O primeiro romance de Fielding foi escrito na forma do romance epistolar de Richardson. Esse subgênero tinha o propósito de comover o leitor ao criar entre ele e o narrador uma espécie de solidariedade, porque parecia uma confidência. Mas Fielding não pretendia provocar lágrimas nem compaixão, como os outros autores, e sim a repulsão.

Shamela $(1741)^{30}$ mostrava que por trás do caráter gentil, humilde e casto de Pamela, a heroína de Richardson, havia uma mulher lasciva, mal-intencionada e manipuladora. Com isso, Fielding não pretendia apenas parodiar o romance de Richardson, mostrando-lhe as deficiências, mas ampliar as possibilidades da protagonista e do gênero também, além de denunciar a moralidade hipócrita de sua época. Em Jonathan Wild, faz de um famoso delinqüente, que havia sido condenado à forca, um herói nos moldes épicos. E em Tom Jones, desenvolve

\footnotetext{
${ }^{28}$ Henry Fielding $(1707$ - 1754). Romancista inglês, apontado como um dos fundadores do romance inglês, ao lado de Daniel Defoe e Samuel Richardson. An Apology for the Life of Mrs. Shamela Andrews (1741); The History of the Adventures of Joseph Andrews and his Friend, Mr. Abraham Abrams (1742); The Life and Death of Jonathan Wild, the Great (1743); The History of Tom Jones, a Foundling (1749); Amelia (1751).

${ }^{29}$ Samuel Richardson $(1689$ - 1761). Romancista inglês, apontado por muitos críticos como autor do primeiro romance moderno, Pamela. A forma utilizada por Richardson foi a do romance epistolar, que teve como precursor Montesquieu (Lettres persannes, 1721). O romance epistolar tornou-se um gênero bastante utilizado e teve em Rousseau (Julie ou la nouvelle Héloïse, 1761) e Goethe (Werther, 1774) dois grandes expoentes. Entre as obras de Richarson, destacam-se: Pamela: Or, Virtue Rewarded (1740), Clarissa: Or the History of a Young Lady (1748) and Sir Charles Grandison (1753).

${ }^{30}$ Fielding nunca assumiu a autoria desse livro e o publicou com o pseudônimo de Conny Keyber.
} 
aquilo que chamou de "epopéia cômica em prosa". É a partir daí que podemos inferir que o romance seria uma derivação da epopéia. E talvez fosse esse o ponto de partida de Hegel, que, ao buscar formas mais antigas, tenha encontrado no Dom Quixote ${ }^{31}$ um precursor.

Alguns autores, como Lukács, aceitam o primado do Quixote, e têm lá as suas razões. Outros deixam as raízes do romance na Idade Média. E outros ainda, na Antigüidade. Seja como for, o certo é que o romance tem diversas raízes, algumas híbridas. Mas as suas sementes não estão na epopéia.

Aristóteles, na Poética (II, 9), observa que a tragédia procura imitar os homens melhores do que são, e a comédia piores do que são (ARISTÓTELES, 1993, p. 23):

Um aleijado com um pé de pau, uma velha decrepita e trémula, um pobre remendado e enfermo, um cego e um frenetico, um insensato, no theatro fazem rir; e porque? Porque aquelles defeitos são suppostos e não verdadeiros; que se fôssem verdadeiros, seriam motivos de commiseração e não de riso. (VIEIRA, 1951, v. XV, p. 440)

o que faz de ambas, espécies de imitação, sendo a Tragédia, associada às desventuras da aristocracia - um gênero elevado -, e a comédia, associada às desventuras das classes mais baixas - um gênero baixo. E, por ser um gênero elevado, a tragédia teria origem na épica de Homero (aristocrática) e nos ditirambos, e a comédia nos cantos fálicos (populares). Logo, a origem do cômico associa-se ao popular e a do sério, ao aristocrático.

Durante a época da democracia ateniense, o teatro aperfeiçoou-se para um espetáculo direcionado para as massas populares. A tragédia era financiada pelos cidadãos ricos e o ingresso era gratuito; por causa disso, eram os cidadãos abastados que determinavam os destinos do teatro. Para que houvesse um teatro verdadeiramente popular, seria preciso que a sobrevivência desse teatro dependesse da venda de ingressos e não recebesse nenhuma subvenção do Estado (HAUSER, 1995, p. 85). O verdadeiro teatro popular eram os mimos.

[Esse teatro] oferecia ao público não dramas artisticamente à maneira trágico-heróica, com personagens nobres ou até sublimes, mas cenas naturalistas curtas, esquemáticas, com assuntos e personagens inspirados na vida cotidiana mais trivial. Aí estamos lidando, enfim, com uma arte que foi criada não meramente para o povo, mas, num certo sentido, também pelo povo. (HAUSER, 1995, p. 86)

\footnotetext{
${ }^{31}$ El ingenioso hidalgo Don Quixote de la Mancha (1604), de Miguel de Cervantes, que parodia os romances de cavalaria, é uma das influências do romance moderno inglês, como Robinson Crusoe, de Defoe e Joseph Andrews de Fielding. O próprio Fielding o reconhece e caracteriza Abraham Adams, personagem do Joseph Andrews, como um "padre quixotesco do século XVIII".
} 
A comédia só poderia desenvolver-se mesmo dentro de uma democracia ou de um regime popular, diferentemente da epopéia. A epopéia é a poesia da idade heróica (ou aristocrática), e a comédia, que, encerra dentro de si a semente do romance, é a poesia da idade dos homens (ou democrática).

Muita coisa aconteceu na literatura entre a época de Aristófanes e a Idade Média, quando surgiram os cantos de gesta e os romances de cavalaria. Entre uma época e outra, começou a desenvolver-se uma literatura em prosa, de feição narrativa, como o Satyricon de Petrônio $^{32}$, as Fábulas de Apuleio ${ }^{33}$ e os romances de Heliodoro ${ }^{34}$, Tácio $^{35}$, etc. ${ }^{36}$, que tinham origem na literatura cômica popular, representante dos gêneros inferiores.

A partir dos mimos, da poesia bucólica, da fábula, dos panfletos, dos diálogos socráticos e de Luciano $^{37}$ e da sátira menipéia ${ }^{38}$, a literatura cômica foi se desenvolvendo e, permeando toda a Idade Média, vai resultar naquilo que hoje chamamos de romance.

Apesar de o romance não ser essencialmente cômico no sentido de algo que provoca o riso, é-o no sentido de tratar-se de um gênero poeticamente inferior.

Com o advento do cristianismo e o domínio eclesiástico sobre o Ocidente, os "homens inferiores", os pobres, os humildes, passaram a identificar-se com o próprio Deus, que viera ao mundo na forma de um humilde e que, por amor dos humildes, foi sacrificado. A paixão de Cristo - cuja origem evoca os rituais dionisíacos ${ }^{39}$-, literatura eminentemente popular, não

${ }^{32}$ O nome de Gaius Petronius Arbiter (c. 27 - 66) é mencionado nos Anais de Tácito, e talvez seja ele o autor do Satyricon, obra que retrata a sociedade romana da época de Nero.

${ }^{33}$ Lucius Apuleius, filósofo platônico e retórico, nascido c. 124 e morto depois de 170, é o autor do Asno de ouro, a que deu o título de Metamorfoses.

${ }^{34}$ Heliodoro de Emesa, escritor grego do século III d. C. Seu romance Aethiopica, uma longa narrativa de aventuras envolvendo uma princesa da Etiópia e um príncipe da Tessália, contém várias características dos romances modernos.

${ }^{35}$ Achilles Tatius, autor alexandrino do século II d. C. Escreveu um romance de aventuras que gozou de grande sucesso até à Renascença, o Leucipo de Cleitofon.

${ }^{36}$ Vadim Koyinov. "El valor estético de la novela", in El destino de la novela. Buenos Aires: Editorial Orbelus, 1967. O autor menciona também Lucano; todavia de Lucano (Marcus Annaeus Lucanus) restou apenas o poema épico Pharsalia (Bellum civile) que narra a guerra entre César e Pompeu.

${ }^{37}$ Luciano de Samósata, nascido em 120 e morto depois de 180. Escritor grego, autor do Diálogo dos deuses e do Diálogo dos mortos

${ }^{38}$ Relativa a Menipo de Gandara (século III a. C.), filósofo cínico, participante do Diálogo dos mortos de Luciano. A sátira menipéia vem da obra de Marco Terêncio Varrão (116 - 27 a. C.), Satyrae Mennipeae, e influenciou Sêneca, por exemplo. Tem como características o fantástico, a paródia, a ironia e o grotesco.

${ }^{39}$ O sacrifício do bode, o bode expiatório, nos rituais dionisíacos, de provável origem babilônica. É conhecida a influência da literatura e da religião babilônica sobre os hebreus (que assimilaram, na época do cativeiro século V a. C. - muitas das lendas da região, como a narrativa do Dilúvio, por exemplo). No entanto, é mais provável que a similitude entre o bode expiatório e o "Agnus Dei, qui tollis peccata mundi" seja proveniente da Ásia Menor, região de propagação do cristianismo. Até mesmo no Islã há rituais parecidos, como a Eid ulAdha, ou Festa do Sacrifício, em que se comemora o sacrifício feito pelo profeta Ibraim (uma versão 
podia ser associada ao cômico, pois não se tratava mais dos sofrimentos de alguém inferior, mas de um ente sublime. O grotesco passou a ser sublime e, quando o sublime (o aristocrata) passou a ser grotesco, com a ascensão do burguês, o épico deixou de ter sentido. ${ }^{40}$

O único herói que podia ser aceito na Idade Média era o cavaleiro de cristo. Mesmo as localidades em que o cristianismo demorou em firmar-se e que desenvolveram uma épica pagã, como o Beowulf, o Nibelungenot e o ciclo arturiano, acabariam por ver sua literatura suplantada ou contaminada pelo cristianismo. É o que acontece com Tannhäuser ${ }^{41}$, que rejeita os apelos de Vênus, e com as lendas do Rei Artur, cujo misticismo do reino encantado de Avalão deforma-se numa Demanda do Santo Graal.

Na Idade Média, a literatura também se dividia entre baixa literatura e alta literatura; esta incluía tudo aquilo que era escrito em latim; aquela, a produção em língua vulgar ou romance. $\mathrm{O}$ nome do gênero deriva daí, ainda que nem toda a literatura vulgar fosse escrita em língua romance como, por exemplo, a de Wolfram von Eschenbach e Thomas Mallory ${ }^{42}$. Eles trataram dos mesmos temas do ciclo arturiano também desenvolvidos no Perceval, le Conte du Graal de Chrétien de Troyes ${ }^{43}$ e na Demanda do Santo Graal ${ }^{44}$, de origem portuguesa.

Inúmeras obras sobre o tema do Graal e do Rei Artur, que inclui o de Tristão e Isolda ${ }^{45}$, foram escritas durante a Idade Média, algumas em prosa, outras em verso. Esses

ligeiramente modificada do Gênesis, em que Abraão deveria imolar o filho Isaque para Deus; na versão muçulmana, o sacrifício é realizado, mas Deus substitui o corpo de Ismail pelo de um carneiro). A Festa do Sacrifício, que ocorre ao final do Haji (peregrinação a Meca), culmina com o sacrifício de um carneiro (mas pode ser o de um bode também).

${ }^{40} \mathrm{O}$ final do período barroco marca a decadência da poesia épica. O gênero foi mais prolífico do que nunca entre o Barroco e o período neoclássico. O Romantismo, interessado no original, quase não fez uso da forma épica tradicional. Contudo não é certo dizer que ela tivesse morrido e sido substituída pelo romance. Durante o renascimento europeu do século XIX, apareceram grandes poemas de feições épicas como o Pan Tadeusz (1834) de Adam Mickiewicz, numa Polônia prestes a desaparecer do mapa, o Mirèio (1859) de Frédéric Mistral, na Provença emancipacionista, e $O$ anel do nibelungo de Wagner. No século XX, há a grande Odisséia (1929 - 1938) de Kazantzakis, na Grécia, e A invenção de Orfeu (1952), de Jorge de Lima, no Brasil, por exemplo.

${ }^{41}$ As fontes diretas da ópera de Wagner, Tannhäuser und der Sängerkrieg auf der Wartburg (Tannhäuser e o torneio de cantores de Wartburg; o libreto foi escrito entre 1842 e 1843) foram o poema de Friedrich Heine, Elementargeister (1837), O torneio de cantores de E. T. A. Hoffman e O fiel Eckhart e Tannhäuser de Ludwig von Tieck (1799); as fontes secundárias são os Minnesänger do século XVI e o próprio Tannhäuser, um poeta medieval, de quem pouco se sabe.

${ }^{42}$ Autores de Parzival e Le Morthe D'Arthur, respectivamente, ligados ao ciclo do Graal. Von Eschenbach (c. 1170 - c. 1220) escreveu num dialeto germânico e Mallory (1405 - 1471) em inglês.

${ }^{43}$ Trovador francês do século XII. Von Eschenbach, no seu Parzival, desdenha o poema de Chrétien de Troyes.

${ }^{44} \mathrm{O}$ manuscrito encontra-se na Biblioteca Nacional de Viena e contém várias redações feitas entre os séculos XIII e XV em língua galego-portuguesa.

${ }^{45}$ Sobre Tristão e Isolda, ver René de Rugemont, $O$ amor $e$ o ocidente, que trata da origem e das diferentes versões desse romance. 
romances pouco tinham de realistas; era uma literatura fantástica que servia para excitar a imaginação. Quando o romance, no século XVIII, começou a tratar do cotidiano, das coisas "sérias" da vida, das coisas do coração, foi considerado um gênero novo; daí a denominação "novela" que recebe em alguns países.

E por tratar de coisas sérias que, em vez de excitar a imaginação, provocam a compaixão, essa literatura nova recupera o elemento catártico ${ }^{46}$ da tragédia. Leitor e personagem se identificam e a compaixão faz do protagonista um herói na imaginação do leitor.

Talvez Lukács tenha razão ao considerar o Dom Quixote o primeiro romance, pois o Quixote é a negação do herói medieval, do cavaleiro cuja existência não tem mais sentido no mundo moderno. O herói do mundo moderno pode ser um comerciante como Vasco da Gama ou Robinson Crusoe, heróis que perseguem a ascensão social - que a modernidade tornou possível - e, acima de tudo, o lucro.

Daniel Defoe ${ }^{47}$, autor do Robinson Crusoe, foi um dos primeiros jornalistas e talvez o maior de todos eles. Diferentemente do historiador e do cronista, o jornalista escreve sobre o imediato; e, para ele, só faz sentido escrever sobre os acontecimentos imediatos se eles puderem ser divulgados imediatamente. O que tornou isso possível foi a invenção da imprensa. $\mathrm{O}$ único grande gênero literário criado depois da imprensa foi o romance (BAKHTIN, 1993, p. 397), e o romance tem todas as características de uma grande reportagem.

A epopéia, como gênero narrativo da Idade Heróica, reproduziu-se em meio aos mitos, em ambiente em que a contagem do tempo nada significava. Na Idade Humana, contudo, tudo o que importa é o tempo. A vida moderna é obcecada pelo tempo; ele não apenas a controla, mas faz-se venerar por ela.

Depois que o Parlamento Britânico, símbolo máximo do Império, foi destruído por um incêndio, decidiu-se reformular sua arquitetura por completo. ${ }^{48} \mathrm{O}$ palácio de Westminster, que ainda abriga o Parlamento, é encimado por uma torre que contém um relógio de quatro faces,

\footnotetext{
${ }^{46}$ Ou seja, aquilo que purga as emoções, que "suscita o terror e a piedade" (ARISTÓTELES, 1993, p. 37).

${ }^{47}$ Daniel Defoe (1660-1731). Escritor e jornalista inglês é autor de grandes relatos em prosa, como os romances Robinson Crusoe (1719), Colonel Jack (1720), Captain Singleton (1720), Moll Flanders (1722) e Roxana: The Fortunate Mistress (1724). Talvez sua melhor obra seja A Journal of the Plague Year, que relata a peste que atingiu a cidade de Londres em 1665; alguns críticos têm essa obra como um romance histórico, outros como uma reportagem.

${ }^{48} \mathrm{O}$ incêndio ocorreu em 16 de outubro de 1834. Charles Barry foi o responsável pela planta atual das Casas do Parlamento, que começaram a ser construídas em 1840 e só ficaram prontas definitivamente em 1870.
} 
o mais famoso cartão-postal da cidade de Londres. Como as cruzes colocadas no alto dos templos católicos, o Big Ben ${ }^{49}$ representa a efígie do imperador do mundo: o tempo.

A classe social que predominava até então, e que construíra o Império era a burguesia mercantil. O incêndio do Parlamento assinalou um período de transição, em que o poder da indústria suplantou definitivamente o do comércio. A produção industrial é totalmente submissa ao tempo; precisa dele para controlar as etapas da produção, mas depende dele também, e, sobretudo, porque precisa evoluir constantemente, descobrindo novas técnicas, desenvolvendo novas idéias; a indústria sobreviverá apenas se estiver em constante mutação.

O mesmo vale para o romance, o gênero literário da burguesia.

Lukács, que em sua fase hegeliana havia profetizado a morte do romance, tinha em mente a decadência da burguesia industrial, suplantada pelo capitalismo financista. Da mesma forma que a burguesia comercial havia perdido poder para a industrial, esta perdia poder para a financeira, a qual, participante de grandes monopólios industriais, colocava em risco a livre concorrência e, de certa maneira, o próprio liberalismo, que não era apenas uma conquista econômica, mas também intelectual. Mais tarde, Lukács renegará a sua Teoria do romance ${ }^{50}$, mas já será um Lukács marxista e comprometido com as idéias do Realismo Socialista; no entanto, não poderia proceder de maneira diferente, porque o romance continuava a desenvolver-se na União Soviética e em outros Estados operários. Não era possível observar nesse gênero uma decadência e nem condicioná-lo mais ao desenvolvimento da classe burguesa. Era um gênero de resistência.

Outro crítico marxista, Mikhail Bakhtin, afirma, em 1941, que o romance é o único gênero literário que continua a evoluir e que vem predominando enquanto os gêneros velhos se desagregam e acabam perecendo:

O romance é o único gênero em evolução, por isso ele reflete mais profundamente, mais substancialmente, mais sensivelmente e mais rapidamente a evolução da própria realidade. Somente o que evolui pode compreender a evolução. O romance tornou-se o principal personagem do drama da evolução literária na era moderna precisamente porque, melhor que todos, é ele que expressa as tendências evolutivas do novo mundo, ele é, por isso, o único gênero nascido naquele mundo e em tudo semelhante a ele. (BAKHTIN, 1993, p. 398)

\footnotetext{
${ }^{49}$ Big Ben refere-se apenas ao sino de 13 toneladas que anuncia as horas, mas parece que hoje ninguém mais tem isso em conta.

${ }^{50}$ Publicada em 1916, um ano antes da Revolução Russa. Ver o prefácio de 1962 em que o autor renega as idéias expressas no livro.
} 
Entretanto só pode evoluir aquilo que não se completou. O romance evolui porque é imperfeito. Imperfeito como a sociedade que o produz. Mas a sua evolução é limitada: assim como o meio em que se encontra, o romance evolui apenas tecnicamente. A evolução de um e de outro não anuncia o aprimoramento. Portanto, a questão não é mais se o romance evolui ou não, subsistirá ou não, mas saber se sua evolução continua tendo um propósito. Nós sabemos que os primatas têm condições de evoluir, mas tal evolução seria capaz de engendrar algo superior ao homem?

Apesar de todo e qualquer processo evolutivo exigir que se processe uma mudança no meio antes que se processe a mutação no ser, Bakhtin, assim como Lukács, parece concentrar esse processo no ser:

1. O romance não deve ser "poético" no sentido pelo qual os outros gêneros literários se apresentam como tais ${ }^{51} ; 2$. O personagem do romance não deve ser "heróico", nem no sentido épico, nem no sentido trágico da palavra: ele deve reunir em si tanto os traços positivos, quanto os negativos, tanto os traços inferiores, quanto os elevados, tanto os cômicos, quanto os sérios; 3. O personagem deve ser apresentado não como algo acabado e imutável, mas como alguém que evolui, que se transforma, alguém que é educado pela vida; 4. O romance deve ser para o mundo contemporâneo aquilo que a epopéia foi para o mundo antigo (esta idéia, com toda a clareza, foi exposta por Blankenburg, e mais tarde retomada por Hegel). (BAKHTIN, 1993, p. 402-3)

Entendemos que o romance não pode ser poético porque a realidade que ele representa nada tem de poética. $\mathrm{O}$ mundo prosaico em que o romancista vive, e ao qual ele retrata, nega verossimilhança à poesia, que não é a linguagem das gentes. Entendemos também que o herói do romance não é épico, nem trágico; mas isso é dizer demais, porque não existem heróis de fato no romance. O sentido etimológico do termo "herói" é "chefe"; rigorosamente falando, heróis foram apenas os reis que lutaram na guerra de Tróia. O sentido que o termo recebeu posteriormente contribuiu para descaracterizá-lo. De qualquer forma, o caráter e as atitudes do herói não podiam ser questionados, uma vez que estavam sujeitos, caráter e atitudes, aos ditames do destino. O homem moderno, dotado de livre-arbítrio e, portanto, não sujeito ao destino, é questionado por todos, até por si mesmo; o que governa suas atitudes são a

\footnotetext{
${ }^{51}$ No entanto, alguns poemas narrativos se identificam mais com o romance do que com a épica. O Childe Harold's Pilgrimage de Byron e The Death of Islam, de Shelley. O romance prosístico era considerado leitura inferior e seu público eram as mulheres; o romance em versos, mais elevado, considerado de maior valor artístico, era lido pelos homens. Antes dos longos poemas de Byron, Púchkin escrevera Ievguêni Oniéguin, um longo poema narrativo, que agradou a homens (pelos motivos masculinos, como a honra e o duelo) e a mulheres (pelos sofrimentos de amor e pela força da jovem Tatiana, que soube superar com bravura suas desilusões). Acertadamente, Púchkin denominou seu poema de "Romance em versos".
} 
incerteza, o desencontro, a esperança e uma paixão ou racionalidade sem conseqüências certas. São essas as peculiaridades do herói romântico, o herói byroniano, o herói do nosso tempo ${ }^{52}$. Por isso Bakhtin ressalta que a personagem do romance deve ser apresentada como alguém que evolui: como algo inacabado.

No entanto, quando, dentro de sua enumeração, Bakhtin relaciona o romance com a epopéia, entendemos que, pelo menos nesse caso, ele não esteja estabelecendo uma relação genealógica, mas uma relação hierárquica que pretende colocar os dois gêneros em posição suprema relativamente aos gêneros coetâneos:

O confronto do romance com o epos (e a oposição deles) apresenta-se, por um lado, como um aspecto da crítica de outros gêneros literários (em particular do tipo mesmo da heroicização épica); por outro lado, tem por objetivo elevar a sua significação como gênero-mestre da nova literatura. (BAKHTIN, 1993, p. 403)

Por fim, acreditamos que haja um abismo entre o romance e a epopéia, um abismo que ocupa um espaço que nunca foi contíguo e nunca será. Não porque já não existam heróis; não porque o mundo moderno seja prosaico; mas porque já não existe mais o mito.

No mundo primitivo, o homem convivia com o mito ${ }^{53}$; os deuses faziam parte da vida do homem; o princípio (teogonia) e o passado estavam sempre presentes, e passado e presente eram uma coisa só. $\mathrm{O}$ mito era a própria história, e a história não era o relato do que passou, mas do que ficou. A história é a epopéia.

Quando a épica começa a distanciar-se da história e a história se torna um relato prosaico do que passou, surge um gênero novo, a historiografia, que é o estame que abriga o pólen que fará germinar as sementes do romance que se encontravam encapsuladas na comédia.

A historiografia é o único ponto de contato entre os dois gêneros, epopéia e romance. Por causa dela, o romance desenvolveu a falsa memória de que a epopéia fora sua geratriz. $\mathrm{O}$ romance não provém da epopéia, ele a objetiva. Procurou sempre imitá-la, inventando heróis, inventando histórias, inventando lendas e, ao mesmo tempo, afastando-se do mito. Por isso nunca logrou alcançar a épica. A grande pretensão do romance era chegar um dia a ser a epopéia do presente. Uma ambição impossível, já que epopéia do presente é um paradoxo.

\footnotetext{
${ }^{52}$ Um herói do nosso tempo é o título do romance do poeta russo Mikhail Liérmontov (1814 - 1841). Grigóri Petchorin, o herói do título, é um sujeito dotado dos traços mais contraditórios: sensível e cínico, arrogante e melancólico, impetuoso e compenetrado e que se mete em aventuras porque tem tédio da vida.

${ }^{53}$ Essa situação persiste em várias comunidades aborígines.
} 
Até hoje, o romance tem procurado representar no presente os reflexos de uma ação iniciada no passado; ou seja, representar um tempo incompleto, imperfeito; é algo que a epopéia não faz, porque ela representa um passado perfeito, acabado, em que todas as ações se concluíram. Goethe afirmava que "na épica, o passado deve ser conhecido"; o presente do romance é imperfeito porque é transitório; sem essa transitoriedade não existiria a surpresa: o feito heróico da epopéia opõe-se ao acontecimento surpreendente do romance; o notável se opõe à surpresa.

Enquanto o notável se perpetua, a surpresa só é mencionada uma vez, para logo mais ser esquecida. O que fica do acontecimento épico, guarda-o a memória. As coisas que se passam na epopéia fazem parte do convívio, enquanto as que se passam no romance fazem parte do conhecimento. E todas essas coisas são como as relações humanas em que existem as pessoas com quem convivemos e as pessoas que apenas conhecemos. Aquelas ficam, estas passam.

O homem moderno perdeu a capacidade de memória dos antigos. Precisa registrar por escrito tudo aquilo de que pode esquecer-se. O romance, o gênero literário supremo desse homem, que trata das coisas que não são notáveis, só pôde existir porque existiu a imprensa. E deve ser lido e esquecido para que o leitor se dedique a outros romances. Ao leitor não restará nada do circunstancial, apenas as marcas que a leitura lhe imprimir no coração. Ao fim e ao cabo, o que resta não é a prosa das circunstâncias, mas a poesia do coração, porque apenas a poesia nós guardamos de cor. ${ }^{54}$

Os primeiros romances burgueses eram obras de grande extensão e não podiam ser retidos na memória. No transcorrer dos anos, eles foram ficando menores, não por falta de memória, mas por falta de tempo ${ }^{55}$. As dificuldades modernas da vida foram abreviando o tempo do homem. Mas o romance nunca desviou o seu olhar do épico. É possível justificar-se um romance como Os miseráveis, de Victor Hugo, ainda no século XIX, ou Guerra e paz, de Tolstói, numa sociedade como a Rússia ainda agrária do final do mesmo século. Mas

\footnotetext{
54 "Um dos conflitos mais frequentemente tratado pelo romance, e que é o tema que mais lhe convém, é o que se trava entre a poesia do coração e a prosa das circunstâncias.” (HEGEL, 1993, p. 598)

${ }^{55}$ Há também um subgênero denominado roman-fleuve (romance-rio) que conta a história de várias gerações de uma mesma família, de um povo, ou diferentes etapas da vida de uma pessoa, em diversos volumes: Jean Christophe, de Romain Roland; Em busca do tempo perdido, de Proust; O tempo e o vento, de Érico Veríssimo. A principal característica desses romances é que entre as histórias, ou entre os volumes, haja um fluxo, e não sejam compostos apenas de episódios, como é o caso de séries como Sherlock Holmes. Tanto o roman-fleuve como os seriados tornaram-se gêneros dramáticos apropriados primeiro pelo rádio e depois pela televisão. O rádio, o cinema, a tevê e outros meios ocupam hoje a maior parte do terreno que o romance ocupava antes.
} 
certamente romances como os de Thomas Mann, apodados de épicos, e os de Proust não podiam mais ser concebidos para o ócio ou entretenimento de uma classe burguesa entediada. De fato, os grandes romances do século XX não foram escritos para as horas de folga. Não foram escritos para o preenchimento do vazio da vida, mas para denunciá-lo. Nesse sentido e em muitos outros - contrasta com o romance do século XIX, que retratava a miséria de se viver; o romance do século XX retratou a miséria de não se viver.

O romance, em sua busca sem fim pelo épico, defrontou-se no século XX com um problema que teria de resolver, mas não podia, para atingir o objeto de sua busca. A guerra, que sempre fora o palco de exibição do heroísmo, da honra, era agora o palco da covardia, da carnificina e tinha motivos e propósitos que não diziam respeito nem aos povos nem aos exércitos. O romance viu-se sem saída, e sua busca pelo épico seria, doravante, sem sentido. E, com isso, o próprio romance perdia a razão de ser.

Durante o século XIX, representaram-se com tristeza as misérias humanas; no século $\mathrm{XX}$, por meio do riso. Não porque antes fossem dignas de compaixão e depois, de escárnio. Mas porque no século XX, época de miséria espiritual extrema, de desprezo extremo pela vida, o riso é, antes que uma reação de alegria, manifestação de extremada tristeza. O riso é a lágrima de todas as coisas.

Sunt lacrymae rerum, et mentem mortalia tangunt. ${ }^{56}$

\section{EPÍLOGO}

Em 1965, um jornal italiano promoveu um debate entre alguns nomes importantes da literatura italiana para discutirem a crise do romance: Alberto Moravia ${ }^{57}$, Alberto Arbasino ${ }^{58}$, Pier Pasolini ${ }^{59}$, Edoardo Sanguineti ${ }^{60}$ e Francesco Leonetti ${ }^{61}$.

\footnotetext{
${ }^{56}$ Vírgilio, Eneida (I, 462). Quando vê, no palácio de Dido, os murais que retratavam as glórias passadas dos troianos, Enéias diz, chorando: "São lágrimas das coisas (lágrimas provocadas pelas coisas que vê), pois os que morreram (o destino dos que morreram) comovem o coração." Na tradução de Odorico Mendes: "Dói mágoa alheia, e remanesce o pranto" (verso 487 da tradução). (Virgílio, 2005, p. 45)

${ }^{57}$ Pseudônimo de Alberto Pincherli (1907 - 1990). Escritor e jornalista italiano. Um dos escritores de maior importância do século XX. Gli indifferenti (1929); Agostino (1944); La Romana (1947); La disubbidienza (1948); Il conformista (1951); La ciociara (1957); La noia (1960).

${ }^{58}$ Escritor e ensaísta italiano, nascido em 1930. Le piccole vacanze (1957); Fratelli d'Italia (1963); Super Eliogabalo (1969).

${ }^{59}$ Pier Paolo Pasolini (1922 - 1975). Escritor e cineasta italiano. Escreveu alguns romances: Ragazzi di vita (1955); Il sogno di una cosa (1962); Teorema (1968); Petrolio (post. 1992); poesia, peças de teatro e ensaios; é mais conhecido por sua filmografia.

${ }^{60}$ Escritor italiano, nascido em 1930. Fez parte do Grupo de 63. Foi tradutor (traduziu, entre outras coisas, as poesias de James Joyce), ensaísta, contista e romancista. Escreveu diversas peças de teatro e textos para
} 
A discussão acabou se desenvolvendo em torno de A teoria do romance de Lukács e das conclusões de Goldmann ${ }^{62}$ e Robbe-Grillet ${ }^{63}$ sobre essa obra.

Sanguineti, em um determinado ponto do debate, fala da crise, e demarca o período de tempo em que a vislumbrava:

[...] a crise nasceu em 1910 e não depois da Segunda Grande Guerra; não se deveu à derrubada do fascismo, mas à mudança nas estruturas do capitalismo europeu. É com Proust, Joyce, Kafka e Musil que o romance de fato entra em crise. [...] quando falo de crise, falo da crise das estruturas do romance burguês tal como o definiu Lukács. (KOYINOV et al., 1967, p. 52 e 57)

A crise do romance estaria ligada, de acordo com Lukács, à crise da própria personagem romanesca, a personagem problemática. Nesse ponto, Moravia procura distanciar-se um pouco de Sanguineti:

Podemos estar de acordo com Sanguineti em ver a crise do romance na personagem "problemática", que seria, pois, a personagem da sociedade burguesa do século XIX. Mas me parece que hoje o problema se desloca da personagem para o romancista. Vale dizer que já não existe mais uma personagem "problemática", mas um romancista "problemático". O romancista é, em última análise, o protagonista do próprio romance. Se Robbe-Grillet fosse sincero, colocaria a si mesmo no centro de seus romances, porque os problemas propostos em seus romances são seus próprios problemas. (KOYINOV et al., 1967, p. 40)

Moravia tocou num ponto importante, que parece ser o centro da crise, mas Arbasino vê esse ponto com mais profundidade:

Os franceses, na linha de Jean Starobinski, Georges Poulet, Jean Rousset e Jean-Pierre Richard, pensam, pelo contrário, que o romance deva criar, por meio de sua própria forma, suas próprias estruturas, que deva inventar a realidade, este mundo que não é capaz de refletir nem de expressar, como se dizia antigamente. (KOYINOV et al., 1967, p. 40)

Seu pensamento é mais profundo porque, rejeitando a realidade da crise, antevê uma solução. Mas essa solução, apresentada a ele pelos franceses que menciona, é um problema

música, mas tem maior importância como poeta. Romances: Capriccio italiano (1963); Il Giuoco dell'Oca (1967); Smorfie (1986); L'orologio astronomico (2002); Smorfie (2007).

${ }^{61}$ Escritor italiano nascido em 1924. Além de uma obra poética importante, escreveu os romances: Fumo, fuoco e dispetto (1956); Conoscenza per errore (1961); L'incompleto (1964); Il tappeto volante (1967); Irati e sereni (1974); Campo di battaglia (1981); Piedi in cerca di cibo (1995); I piccolissimi e la circe (1998).

${ }^{62}$ Lucien Goldmann (1913 - 1970). Filósofo e sociólogo marxista francês, nascido na Romênia.

${ }^{63}$ Alain Robbe-Grillet (nasc. em 1922). Escritor e diretor de cinema francês, expoente máximo do grupo do Nouveau Roman. Un Régicide (1949); Les Gommes (1953); Le Voyeur (1955); La Jalousie (1957); Dans le labyrinthe (1959); La Maison de rendez-vous (1965); Projet pour une révolution à New York (1970); Topologie d'une cité fantôme (1976); Souvenirs du Triangle d'Or (1978); Djinn (1981); La Reprise (2001). 
crônico que parece não ter remédio e que se encontra numa outra crise, a das vanguardas. Malcolm Bradbury ${ }^{64}$, em um ensaio sobre James Joyce, menciona um livro de Stephen Spender ${ }^{65}$, em que o autor estabelece uma diferenciação entre o moderno e o contemporâneo:

Os "contemporâneos" são [...] escritores que, de modo geral, aceitam os processos do mundo moderno, encaram com simpatia as forças transformadoras que o caracterizam e adotam em sua obra uma atitude de realismo, racionalismo e positivismo, Os "modernos" são escritores [...] que de modo geral têm uma visão diferente da época em que vivem - desconfiam de suas tendências históricas, questionam seu conceito de progresso, sentem-se deslocados de seu passado e possuem uma consciência acentuada da anarquia da vida e da cultura modernas. Assim, eles tendem a recolher-se à fortaleza da arte, tornando-a mais moderna ao construir novas ordens radicais: ordens fragmentárias e disjuntivas, que exprimem a vida e a consciência modernas. (BRADBURY, 1989, p. 140)

Os "modernos" que procuraram inventar a realidade e criar formas novas e estruturas novas, como disse Arbasino, faziam parte das vanguardas que começaram a se dispersar ao final da Segunda Guerra. Enquanto não se produzirem novas vanguardas, enquanto não surgirem escritores "modernos" atrelados a um movimento moderno, de contestação, portanto, o remédio de Arbasino não poderá ser aplicado. Ao tratarmos disso, veremos que a solução proposta por Arbasino e pelos franceses já havia sido tentada e aprofundou ainda mais a crise do romance.

Na continuação do debate, Pasolini, que pouco falou, parecia discordar de todos: "não é o romance tradicional que está em crise, o romance burguês, homólogo da sociedade burguesa, parece-me progredir de maneira triunfal. O que está em crise é uma forma de romance que procurou opor-se a essa." (KOYINOV et al., 1967, p. 49) E insistiu, quando percebeu que os debatedores não deram muita atenção para o que ele havia dito: "Vocês continuam falando de crise no romance burguês. Não percebem que..." (KoYINOV et al., 1967, p. 54) Mas Moravia o interrompeu: "Mas é que só existe romance burguês..." (KoYINOV et al., 1967, p. 54)

Também pensamos assim, mas o próprio Lukács rejeitou essa idéias no posfácio de 1962, o qual era ainda, aparentemente, desconhecido dos debatedores.

${ }^{64}$ Sir Malcolm Stanley Bradbury (1932 - 2000). Escritor e acadêmico inglês. The History Man (1975); Cuts (1987).

${ }^{65}$ Sir Stephen Harold Spender CBE, (1909 - 1995). Poeta, romancista e ensaísta inglês, cujos temas se concentravam na injustiça social e na luta de classes. 
Hoje em dia, ou pelo menos a partir da década de 1990, a crítica praticamente ignorou a existência de uma crise no seio do capitalismo, cujo sintoma era a adoção de medidas econômicas ortodoxas e a difusão de idéias neoliberais. Uma boa parte dessa crítica era formada na tradição marxista, e passou por uma reavaliação de conceitos que a deixou mais perdida do que estava em 1991. O grande sucesso da crítica do final do século XX foram o pós-modernismo e a análise desconstrucionista de Derrida ${ }^{66}$, por exemplo.

No entanto, o próprio Derrida deveu às vanguardas o seu método ${ }^{67}$. Confessa, no ensaio "Duas palavras por Joyce" ${ }^{\prime 68}$ que durante as leituras que fizera de Finnegans Wake teve a idéia da "desconstrução".

E Finnegans Wake nos mostra que durante as décadas de 1920 e 1930, tempo em que foi elaborado, o gênero romance estava superado. Talvez Leonetti estivesse pensando em Finnegans Wake quando questionou: "não nos veremos obrigados, num futuro muito próximo, a imaginar um romance, uma obra literária, que não será, ou que dificilmente será decifrável?” (KoYINOV et al., 1967, p. 43). Estranha-nos ele ter dito isso em 1965, sendo que Finnegans Wake, uma obra indecifrável já havia sido publicada em 1939 (e muitas outras antes dela ${ }^{69}$ ), uma data emblemática. No mesmo ano começa a Segunda Grande Guerra, corolário da crise do capitalismo e da sociedade burguesa.

Passada a Guerra, os Estados Unidos, que haviam se recuperado com ajuda das idéias de Keynes ${ }^{70}$, e que lucraram bastante com o conflito, ajudaram a Europa, semidestruída, a reviver. A década de 1950 foi um período de prosperidade para o capitalismo e, graças a ele, às artes também. Não houve, contudo, terreno para contestações, o destino da arte era o mercado de consumo. E como não houvesse terreno para contestações, não o haveria também para as vanguardas. Esse fenômeno, de acordo com Eric Hobsbawm ${ }^{71}$, decreta o fim das vanguardas. (HOBSBAWM, 1996, p. 508)

\footnotetext{
${ }^{66}$ Jacques Derrida (1930-2004). Filósofo francês. De la gramatologie (1967); L'écriture et la différence (1967); "Introdução" à Origem da Geometria de Edmund Husserl (1964).

${ }^{67}$ Derrida rejeita que se trate de um método. Melhor seria chamá-la de uma prática.

68 " [....] a cada vez que escrevo, e mesmo nas coisas da academia, um fantasma de Joyce está presente em minha abordagem. Há vinte anos, a Introductio à l'Origine de la Géométrie comparava, bem no meio do livro, as estratégias de Husserl e de Joyce." (NESTROVSKI (Org.), 1992, p. 23)

${ }^{69}$ Ver, por exemplo, o conto $\mathrm{Ka}$, de Velimir Khlébnikov.

${ }^{70}$ John Maynard Keynes, CB (1883 - 1946). Economista inglês que advogava o intervencionismo e o assistencialismo. The Economic Consequences of the Peace (1919); The General Theory of Employment, Interest, and Money (1936).

${ }^{71}$ Eric John Ernest Hobsbawm (1917 - 2007). Historiador inglês. The Age of Revolution : Europe 1789-1848 (1962); The Age of Capital, 1848-1875 (1975); The Invention of Tradition (1983; com Terence Ranger); The Age of Empire (1987); Age of Extremes : the short twentieth century, 1914-1991 (1994); etc.
} 
O ciclo de prosperidade iniciado na década de 1950 esgotou-se durante a de 1980. A União Soviética e os Estados operários do oriente da Europa, ilhados num mundo capitalista, não sobreviveram ao fim do ciclo. Os países capitalistas promoveram reestruturações no mundo inteiro e tiveram de recuar deixando Keynes de lado e adotando práticas neoliberais. A crise por que passam hoje não tem precedente: está chegando ao fim o modelo econômico de prosperidade que se apóia na sociedade de consumo; o consumo de bens e de energia terá de ser freado drasticamente para que o próprio planeta sobreviva.

Novas contestações estão surgindo e novas vanguardas surgirão. O ponto de partida para elas é a crítica ao pragmatismo econômico, pragmatismo que foi a bandeira neoliberal içada na década de 1980.

As antigas vanguardas, as do século $\mathrm{XX}$, começaram por questionar o Iluminismo. ${ }^{72} \mathrm{~A}$ arte do século XX caracterizou-se pelo irracionalismo. As vanguardas buscaram no misticismo esotérico, na Psicanálise e até mesmo na Física Quântica, alternativas para a ditadura da razão. O racionalismo reagiu com a teoria do Estado perfeitamente organizado, os fascismos, o liberalismo e o pragmatismo político.

As vanguardas atingiram o desenvolvimento pleno durante a trégua de vinte anos (1918-1939). O que aconteceu entre 1939 e 1945 colocou em xeque toda a evolução espiritual da humanidade. O golpe derradeiro, o xeque-mate, foi dado no Japão: a maior descoberta da ciência até então estava a serviço do genocídio. ${ }^{73}$

Se o homem contestava a razão porque não confiava mais nela, então já não pôde mais confiar nos sonhos, porque não havia o que sonhar; não podia se fiar no místico nem no espiritual porque se provou que o homem não tinha espírito, era fera; o que dizer então da ciência? O homem estava perdido. Assim se dispersaram as vanguardas.

As marcas deixadas por eles na cultura comprovaram que foi mesmo durante aquele período de vinte anos que a humanidade alcançou seu maior desenvolvimento espiritual. $\mathrm{O}$ espírito buscava decidido a sua liberdade. A hora havia chegado. Cumprir-se-ia o profetizado por Hegel. Mas ainda existia gente, como Churchill, Roosevelt, Stálin, Franco, Hitler e Mussolini, que tudo fez para que o capitalismo sobrevivesse. E veio a guerra. E o capitalismo sobreviveu. E, com ele, o romance.

\footnotetext{
${ }^{72}$ Ver o ensaio "O conceito de esclarecimento". In: T. Adorno e M. Horkheimer, Dialética do esclarecimento. Rio de Janeiro: J. Zahar, 2006. O “esclarecimento" que aparece nos títulos é o Iluminismo [Aufklärung].

${ }^{73}$ E hoje, os maiores avanços técnicos e científicos são subprodutos da indústria das armas.
} 
É, portanto, inútil discutir-se a decadência do romance ou prognosticar-lhe o fim sem discutir também a sociedade burguesa que o engendrou, na qual ele se apóia como medida de sobrevivência. Interessa-nos, contudo, e ainda mais, discutirmos se o romance, como gênero literário, está ultrapassado ou não.

Bakhtin argumenta que o romance sobrevive porque está em constante mutação. É a mesma fórmula de Arbasino. Sendo o romance um reflexo da sociedade burguesa, deveríamos esperar uma mudança também nessa sociedade. Acontece que as mudanças por que ela passa são aparentes, simples alternâncias de ciclos de prosperidades com ciclos de crise ${ }^{74}$, e isso não garante a ela, nem ao romance, perenidade.

Por outro lado, não é fato que o romance esteja em perpétua mutação. O romance sobrevive, assim como o capitalismo, porque é conservador. Modificações constantes levariam, necessariamente, à sua superação. Ou desnecessariamente, porque ele já estava superado.

Se compararmos os romances contemporâneos, ou escritos antes de 1965, ano do debate de que tratamos, com o Ulysses de James Joyce, teremos a impressão de que foram escritos antes do Ulysses ou de que, de alguma forma, o imitam.

Ulysses foi o último romance. Estava contaminado pela linguagem do devaneio, pelo mito, pela simbologia psicanalítica e mitológica, pela desestruturação do tempo e pelo lirismo. O solilóquio de quarenta páginas ${ }^{75}$ ao final do livro lembra-nos o estranho quadro musical de Francis Poulenc ${ }^{76}$ La voix humaine, em que durante aproximadamente uma hora, uma mulher canta seus devaneios ao lado de um telefone a espera de uma ligação. Embora haja o cenário, não há necessidade dele; há apenas um cantor; já não é ópera. O texto de Jean Cocteau faz experiências com o uso do tempo, desestruturando por completo a ação dramática. O mesmo acontece no Ulysses: no final de suas páginas, já predomina o lírico; ali já não há utilização de tempo; nada resta de romance: "a morte do romance consistiria em sua identificação com a poesia" (KOYINOV et al., 1967, p. 46), como disse Pasolini.

\footnotetext{
${ }^{74}$ Esses ciclos são conhecidos com Ciclos de Kondrátiev e duram de 25 a 40 anos. A alternância deles é analisada por Giovanni Arrighi em $O$ longo século $X X$.

${ }^{75}$ Edição de 1993, Oxford World's Classic.

${ }^{76}$ Francis Jean Marcel Poulenc (1899-1963). Compositor francês. Membro do grupo dos Seis. Autor de obra sinfônica, lírica e instrumental. Óperas: Les mamelles de Tirésias (1947); Dialogues des Carmélites (1957); La Voix Humaine (1959).
} 
E parece-nos que, naquele debate de 1965, a verdade estava com ele. A identificação apontada por ele ocorreu por completo em Finnegans Wake. O livro todo é um devaneio.

\section{Tristão e Isolda (de Edmund Blair-Leighton)}

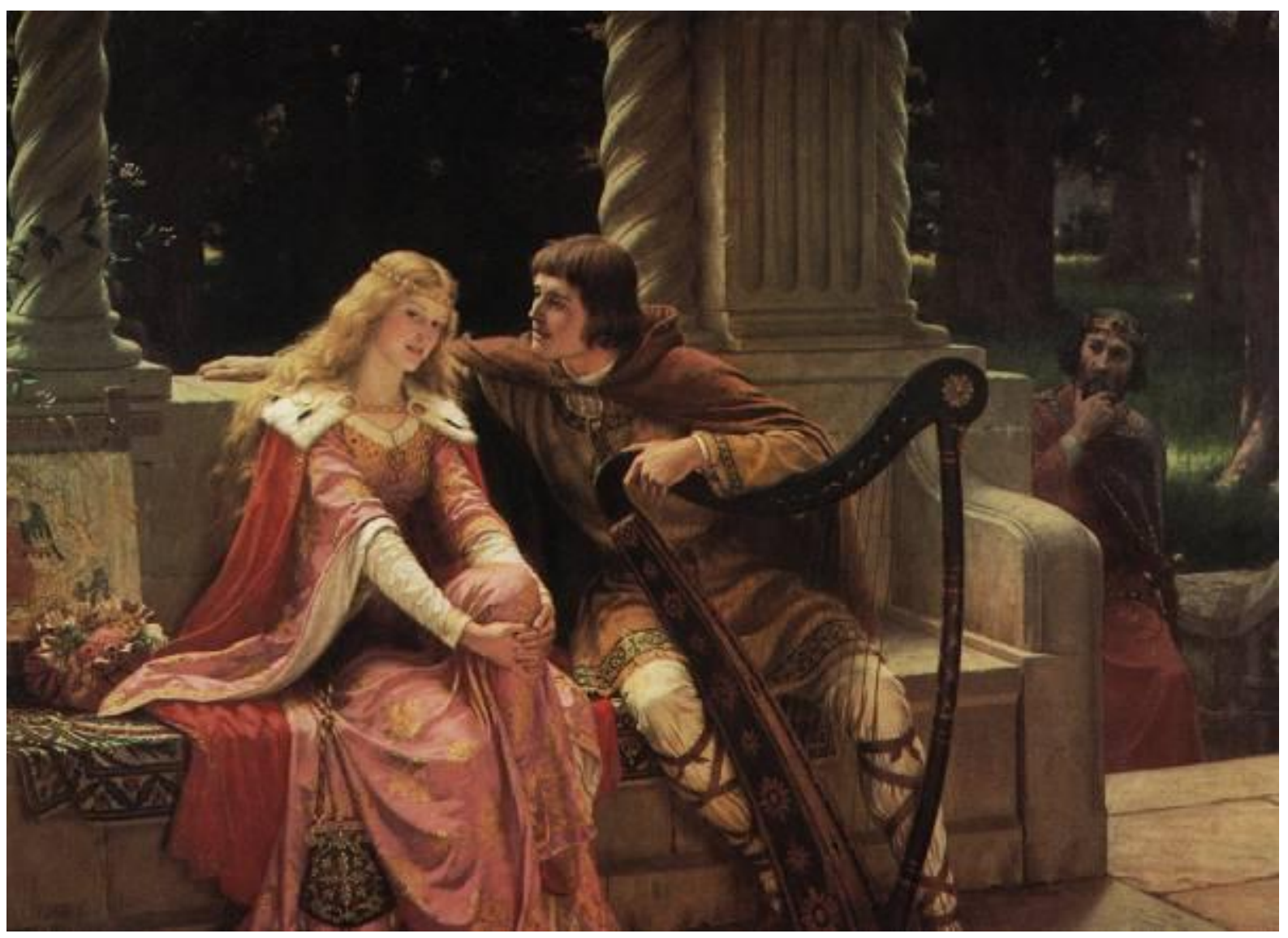




\section{Hipnopéia}

\section{DAS VANGUARDAS ATÉ JOYCE}

Entre os intelectuais que fizeram parte do círculo teosófico de Madame Blavatsky encontravam-se o compositor e pianista russo Alexandr Scriábin, o poeta irlandês W. B. Yeats, o pintor russo-germânico Wassily Kandinski e o pintor holandês Piet Mondrian. ${ }^{77}$

A obra de Scriábin ${ }^{78}$ é dividida, pelos críticos, em duas fases, uma romântica e outra voltada para o experimentalismo. Mas ele foi, acima de tudo, um representante dos movimentos simbolistas, nos quais germinaram artistas como Oscar Wilde, Yeats e Joyce. O experimentalismo de Scriábin está mais relacionado ao decadentismo do que às vanguardas. Scriábin, ao lado de Richard Wagner, Claude Debussy e Ígor Stravinski, com suas inovações tonais, são, de fato, os inventores da música moderna. ${ }^{79}$

Inspirado em concepções teosóficas da arte, Scriábin criou o acorde místico ${ }^{80}$, utilizado, por exemplo, na composição dos Dois prelúdios op. 67 [Disco, faixa 4]. Apesar da importância dessas composições para o desenvolvimento da música ocidental, as experiências de Scriábin foram ainda mais longe. Ele projetou uma grande peça musical, Prometeu ou Poema do fogo, opus 60, para piano, orquestra, coro e órgão. Para essa peça, ele inventou um instrumento, o teclado sinestésico, semelhante ao piano, mas com teclas coloridas que, em vez

${ }^{77}$ Elena Petrovna Gan $(1831$ - 1891). Fundadora da Sociedade Teosófica, em Nova York (1875). Influenciou diversos artistas, intelectuais, ativistas e políticos, entre eles, Gandhi, Hitler, Piet Mondrian, Borís Pasternak, Rudolf Steiner, Krishnamurti e o próprio James Joyce. Isis Unveiled (1877); The Secret Doctrine (1888); etc.

William Butler Yeats (1865 - 1939). Poeta e dramaturgo irlandês, considerado um dos maiores poetas do século XX. Ganhou o Prêmio Nobel de Literatura em 1923.

Wassily Kandinsky (1866 - 1944). Pintor, impressor e teórico da arte. Deve-se a ele, provavelmente, as primeiras obras abstratas de arte moderna.

Pieter Cornelis Mondriaan (1872 - 1944). Pintor modernista holandês. Participou do movimento artístico conhecido como Neoplasticismo e colaborou na revista De Stijl.

${ }^{78}$ Aleksandr Nikoláyevich Scriábin (1871 ou 1872 - 1915). Compositor e pianista russo.

${ }^{79}$ Na ópera Tristão e Isolda, Wagner levou ao extremo o desenvolvimento melódico, a ponto de que o ouvinte já não podia mais distinguir a tonalidade em que essa música era tocada; a consequiência disso será a desestruturação e superação do sistema tonal, que dominou a música desde a Renascença.

Achille-Claude Debussy (1862 - 1918). Compositor francês. Fez experiências com o sistema tonal, inventando uma escala de tons. Compôs uma ópera que obedece ao princípio wagneriano de melodia infinita: Pelléas et Melisande (com texto condensado de M. Maeterlinck).

Ígor Fiódorovich Stravinski (1882 - 1971). Compositor russo, bastante conhecido por suas suítes musicais: Pássaro de fogo, Petrúchca, A sagração da primavera. Fez experiências com a tonalidade, utilizando-se da harmonia das músicas sacras da Igreja Ortodoxa Russa, o que alguns críticos entenderam como politonalismo.

${ }^{80}$ Acorde de quartas: dó, fáł, sib, mi, lá, ré. 
de projetarem sons, projetavam cores. Foi uma tentativa de associar a música à visão, uma vez que era uma arte exclusivamente auditiva.

A mistura de sistemas de arte sempre existiu, mas foram sumamente importantes para o desenvolvimento da arte moderna. Kandinski, por exemplo, alega que sua pintura foi inspirada, no começo, pela audição da ópera Lohengrin de Wagner ${ }^{81}$, e, posteriormente pela filosofia de Madame Blavatsky; e Jackson Pollock, pintor estado-unidense, seguidor do Abstracionismo, pintava enquanto dançava.

A experiência de Scriábin tinha o mesmo caráter científico que o da harpa de sabores de des Esseintes ${ }^{82}$. Ainda que isso nos pareça estranho, experiências como essas eram levadas a sério. Muitos autores simbolistas, na França, imitavam des Esseintes, passeando com tartarugas amarradas à coleira, usando um cravo tingido de verde na lapela e levando a vida da maneira mais ociosa que pudessem.

Oscar Wilde ${ }^{83}$ buscou preservar a decadência em uma de suas personagens, Dorian Gray, uma figura estética, ideal de beleza, que nunca envelhecia. Todo o processo de deterioração física, que marca a decadência da vida e também o amadurecimento do indivíduo, era transferido para um retrato. A pintura, que representa a obra dos artistas, é, geralmente, o que sobra, o que garante a imortalidade a eles. Isso não importava para os pintores do retrato de Dorian Gray. O que eles queriam preservar era a decadência, um processo que já estava de fato preservado nas ruas da cidade de Dublim, onde nasceu Oscar Wilde.

Dublim, e a Irlanda como um todo, dominada pelos ingleses, vivia à sombra da Inglaterra, política e culturalmente. Os movimentos emancipacionistas, e até mesmo o

${ }^{81}$ Wilhelm Richard Wagner $(1813$ - 1883). Músico alemão. Óperas: Die Hochzeit (O matrimônio-1832; abandonada); Die Feen (As fadas-1833); Das Liebesverbot (A proibição de amar-1836); Rienzi (1837); Der fliegende Holländer ( $\mathrm{O}$ navio fantasma-1843); Tannhäuser (1845); Lohengrin (1848); Tristan und Isolde (Tristão e Isolda-1859); Die Meistersinger von Nürnberg (Os mestres cantores de Nurenberga-1867); Der Ring des Nibelungen (O anel do Nibelungo) [Das Rheingold (O ouro do Reno-1854); Die Walküre (A valquíria-1856); Siegfried (1871); e Götterdämmerung (O crepúsculo dos deuses-1874).]; Parsifal (1882).

${ }^{82}$ Personagem do livro de Joris-Karl Huysmans [Charles-Marie-Georges Huysmans (1848-1907], À rebours, obra tipicamente decadentista. Apesar de não sabermos se Scriábin teve conhecimento da obra de Huysmans, a relação com o decadentismo deve advir da leitura de Oblómov de Ivan Alexándrovitch Gontchárov (18121891), cuja personagem do título é muito semelhante a des Esseintes.

83 Oscar Fingal O'Flahertie Wills Wilde $(1854$ - 1900). Romancista, contista, poeta e dramaturgo irlandês. Poesia: The Sphinx (1894); The Ballad of Reading Gaol (1898). Teatro: Vera, or The Nihilists (1880); Salomé (em francês); Lady Windermere's Fan (1892); An Ideal Husband (1895); The Importance of Being Earnest (1895); Prosa: The Canterville Ghost (1887); The Happy Prince and Other Stories (1888); Lord Arthur Savile's Crime and Other Stories (1891); The Picture of Dorian Gray (1891); A House of Pomegranates (1891, contos); The Soul of Man under Socialism (1891); De Profundis (1905). 
progresso científico e cultural, acabavam detidos, aparentemente, pela paralisia da sociedade. Tal paralisia será representada em toda a obra de outro escritor irlandês: James Joyce.

\section{JOYCE E SEUS CONTEMPORÂNEOS}

James Augustine Aloysius Joyce (1882 - 1941) nasceu em Dublim, numa família católica. Apesar disso e da educação que recebeu nos colégios jesuítas em que estudou, logo passou a questionar a doutrina cristã e a desenvolver uma noção estética da realidade e interessar-se pela literatura e pela política. Admirava a obra do dramaturgo norueguês Henrik Ibsen $^{84}$ e a figura política de Charles Stewart Parnell ${ }^{85}$. Com pouco mais de vinte anos, foi estudar em Paris, voltando brevemente para a Irlanda para assistir a mãe que estava morrendo.

Nessa ocasião, Joyce conheceu Nora Barnacle, que seria sua companheira pelo resto da vida, e, no dia 16 de junho de 1904, tiveram o primeiro encontro. O romance mais importante de Joyce, Ulysses, tem como cenário esse dia. O dia 16 de junho tornou-se

\footnotetext{
${ }^{84}$ Henrik Johan Ibsen (1828 - 1906). Dramaturgo norueguês. Catiline (1850); Haermaendene paa Helgeland (Os viquingues de Helgeland-1857); Olaf Liljekrans (1857); Kongs-Emnerne (Pretendentes-1863); Brand (1865); Peer Gynt (1867); De unges Forbund (A liga da juventude-1869); Samfundets Støtter (Pilares da sociedade1877); Et Dukkehjem (Casa de bonecas-1879); Gengangere (Espectros-1881); En Folkefiende (O inimigo do povo-1882); Vildanden (O pato selvagem-1884); Rosmersholm (1886); Fruen fra Havet (A dama do mar1888); Hedda Gabler (1890); Bygmester Solness (Arquiteto Solness -1892); Når vi døde vaagner (Quando os mortos despertam ou Os mortos-vivos-1899); etc.

${ }^{85}$ Charles Stewart Parnell (1846 - 1891). Político irlandês. Foi eleito em 1875 para a Câmara dos Comuns como representante da Home Rule League por Meath e acabou se associando a Joseph Biggar e outros da ala mais radical do partido, e passou a adotar a política do obstrucionismo (impedindo o funcionamento da Câmara), para que a Câmara prestasse mais atenção aos problemas irlandeses. Isso lhe causou a oposição de um membro mais moderado do partido, e seu líder, Isaac Butt, a quem viria substituir em 1880, mantendo-se em tal posição por dez anos. Em 1882, mudou o nome do partido para Irish Parlamentary Party e obrigou-o a votar em bloco no Parlamento. Sob a liderança de Parnell, o partido foi se tornando cada vez mais oposicionista e com predominância de militantes católicos. Durante a década de 1880, Parnell lutou pela criação do Home Rule (governo autônomo) e recebeu o apoio de Gladstone, líder do Partido Liberal. A primeira Lei de Autonomia (Home Rule Bill), de 1886, não foi aprovada pela Câmara. O partido lutava também por uma lei de reforma agrária, ao lado de uma organização conhecida como Irish National Land League, da qual Parnell se tornou presidente em 1879. Em 1882, ele dissolveu a Land League e fundou National League, que passou a atuar por diversas demandas. Em março de 1887, Parnell foi acusado pelo jornal inglês The Times de ter patrocinado os crimes do Parque Phoenix, em que morreram o Lorde Frederick Cavendish, Secretário Geral para a Irlanda, e T. H. Burke, Sub-secretário Permanente para a Irlanda. O jornalista Richard Piggott, adversário da política de Parnell, forjou uma carta incriminando Parnell; a falsidade foi descoberta por causa de uma palavra que havia na carta e fora grafada de maneira incorreta. A carreira política de Parnell terminou por causa da ligação dele com uma mulher casada, Katharine (Katty) O'Shea, com quem teve três filhos. Apesar de ela ter-se divorciado do marido e casado legalmente com Parnell, o escândalo envolvendo o caso - porque uma sociedade católica não aceitava o divórcio - acabou resultando no afastamento de Parnell do partido. Ele recusou-se a renunciar, mas seus partidários começaram a abandoná-lo e deixar o partido. Numa reunião do partido, Parnell interpelou Gladstone perguntando-lhe "Quem é o chefe [master] do partido?" Um membro do partido, Tim Healey, respondeu com outra pergunta: "Quem é a amante [mistress] do partido?" Foi uma humilhação pública, provocada justamente por alguém a que tanto apoiara. Sobre esse fato, Joyce, ainda muito jovem, escreveu um poema, hoje desaparecido, intitulado "Et tu, Healy!" Parnell continuou lutando pela reabilitação política, mas a oposição dos católicos lhe foi muito grande. Morreu de um ataque do coração, nos braços da esposa, no dia 6 de outubro de 1891.
} 
posteriormente uma data comemorativa em que admiradores de Joyce do mundo todo se reúnem para reverenciá-lo.

Ao lado de Nora, Joyce (retrato abaixo) partiu para o continente, deixando a Irlanda, à

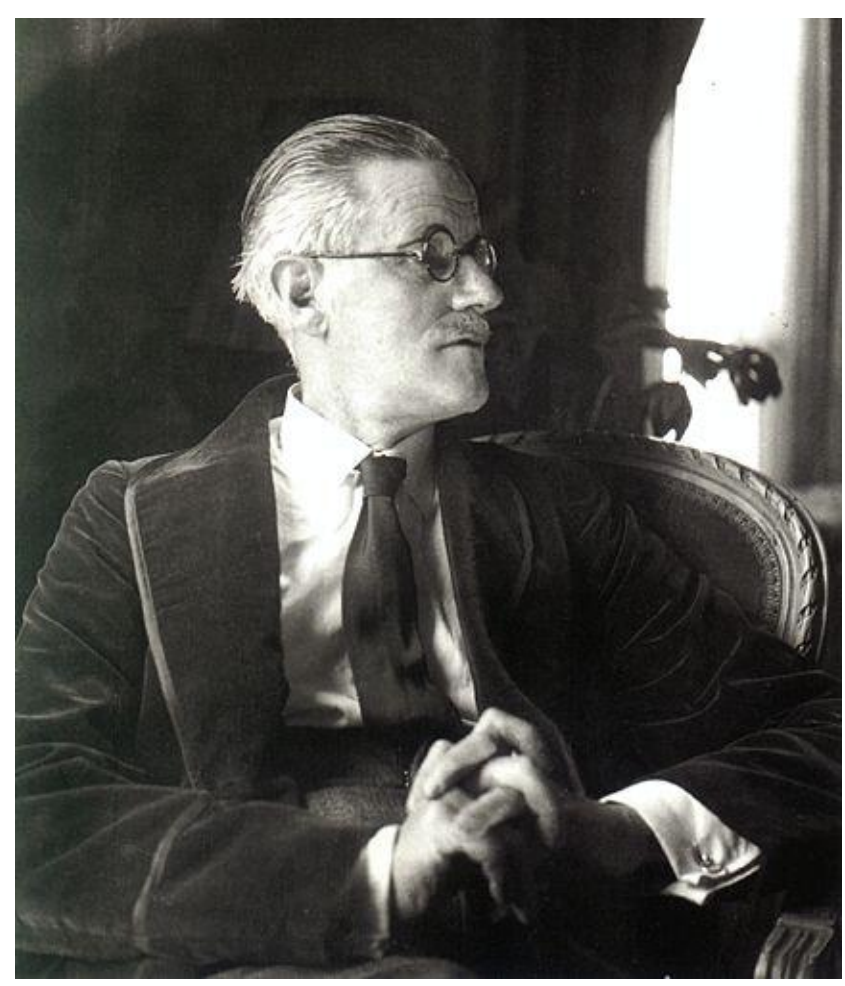
qual só voltaria por um breve período, em 1912, para montar uma sala de cinema em Dublim. Estabeleceram-se em Trieste, no Império Austro-Húngaro, e ali permaneceram até o começo da Primeira Grande Guerra. Partiram então para Zurique, e, em seguida para Paris, onde ficariam até o começo da Segunda Guerra. Voltaram então para Zurique, onde Joyce, pouco depois, viria a falecer por causa de um abscesso no intestino, provocado por uma úlcera.

A obra deixada por Joyce, apesar dos poucos títulos, é um dos maiores monumentos de toda a literatura mundial. ${ }^{86}$ A obra em prosa de Joyce evoluiu de uma escrita naturalista para outra de caráter personalíssimo, mas desde os primeiros momentos já apresentava sinais da modernidade, como se pode perceber já no primeiro conto de Dubliners, "The sisters": "O método de Joyce é de fato moderno. A estória apresentada por ele está incompleta na página. Exige a participação ativa do leitor para ser completada.” (NORRIS; FLINT, 2000, p. 75$)^{87}$ O livro foi publicado em 1914, mas já estava pronto em 1907, assim como estavam prontas, ou se desenvolvendo, algumas das vanguardas modernistas que iluminariam a primeira metade do século ${ }^{88}$. O fato é que a arte moderna já estava consolidada antes da

86 Stephen Hero: Escrita entre 1904 e 1906, parte da obra foi queimada; o que sobrou foi publicado postumamente, em 1944; Chamber Music: coletânea de poemas (1907); Dubliners: livro de contos naturalistas (1914); A Portrait of the Artist as a Young Man: romance naturalista, reelaboração de Stephen Hero (1916); Exiles: drama ibseniano (1918); Ulysses: romance composto durante sete anos, em que autor começa a fazer experiências com a linguagem e com o tempo (1922); Pomes Penyeach: pequeno livro de poemas (1927); Finnegans Wake: obra de gênero complexo, elaborada durante 16 anos (1939).

87 "Joyce's method is really modern. The story he presents is incomplete on the page. It requires the active participation of the reader for its fulfilment."

88 Cubismo (1907); Futurismo (1909); Cubo-Futurismo e Abstracionismo (1910); Construtivismo (1914); Suprematismo (1915); Dadá (1916); Neoplasticismo (1917). A Bauhauss (1919) e o Surrealismo (1924) surgiram depois da Guerra. 
Primeira Grande Guerra, o que enfraquece a idéia de historiadores como Eric Hobsbawm de atrasar o começo do século XX para 1914 (HoBSBAwM, 1996, p. ix).

A Europa era o centro político e cultural do mundo e Paris, a sua capital. Os artistas dirigiam-se para ela como o islamita para Meca. As vanguardas nasciam em Paris e dali eram exportadas para o mundo todo. Paris, por outro lado, absorvia também boa parte daquilo que era produzido em outros lugares. Basta-nos lembrar dos Ballets Russes de Diáguiliev ${ }^{89}$ que levaram a Paris músicos como Stravinski e dançarinos como Nijinski.

James Joyce mudou-se para Paris em 1920, por sugestão de Ezra Pound ${ }^{90}$. Ali, conheceu e conviveu com os maiores artistas do século: Ernest Hemingway, T. S. Eliot, Virginia Woolf, Samuel Beckett, Sierguiei Eisenstein, Eugène Jolas, Wyndham Lewis, Nabókov, etc. Todos eles, ou pelo menos a maior parte, leram Ulysses, romance que Joyce vinha escrevendo desde Trieste e que publicou em Paris em 1922, mesmo ano do The Waste Land de Eliot. Ambos eram complexos e difíceis.

O Ulysses afugentava muitos leitores. Nas pouco mais de setecentas páginas ${ }^{91}$ do romance, o leitor depara-se o tempo todo com formas estranhas: extensos parágrafos, diálogos no formato de um roteiro de teatro ou de cinema, incluindo as didascálias, notas musicais e um extenso solilóquio de mais de 40 páginas sem períodos nem pontuação, no final do livro. O livro foi escrito numa linguagem complexa, ilegível em algumas passagens, e está repleto de citações literárias e musicais. Só é possível lê-lo bem numa edição anotada. Posteriormente ficou demonstrado que esse romance seguia o roteiro da Odisséia de Homero. Cada capítulo do livro de Joyce corresponde a uma passagem daquele poema, e se refere também a um órgão do corpo, a uma arte específica, uma cor, um símbolo, etc.; e cada um desses capítulos foi desenvolvido seguindo uma técnica específica.

Entretanto, ele tem muito de simples. Obedece, com alguma amplitude, a lei renascentista das três unidades: um périplo (ação) pela cidade de Dublim (espaço), durante o dia 16 de junho de 1904 (tempo). Tudo se passa durante 18 horas, e a ação desse romance, iniciada abruptamente, é própria do conto. Ulysses tem muito da estrutura de um conto, e tinha sido planejado como tal. ${ }^{92} \mathrm{O}$ fato é que Joyce queria escrever mais do que um romance e

\footnotetext{
${ }^{89}$ Sergei Pavlovich Diaguilev (1872-1929). Empresário russo de dança.

${ }^{90}$ Ezra Weston Loomis Pound $(1885$ - 1972). Poeta, músico e crítico estado-unidense. Foi um dos maiores entusiastas das vanguardas, e impulsionar de movimentos como o Imagismo e o Vorticismo.

${ }^{91}$ Edição de 1993, Oxford World's Classic.

${ }^{92}$ Foi imaginado como um dos contos de Dubliners.
} 
planejara algo como o Gesamtkunstwerk (obra de arte total) ${ }^{93}$ de Wagner. Aplicou-o no Ulysses com certa modéstia, e no Finnegans Wake sem modéstia alguma.

Esse conceito não vingou na ópera, mas foi um sucesso no cinema, que podia incorporar todas as formas de arte, como foi feito, por exemplo, no filme Intolerância de D. W. Griffith ${ }^{94}$. O cinema era uma arte nova e foi muito explorado pelas vanguardas. O que era corriqueiro para ele, tornou-se uma aspiração para a Literatura, que pretendia ter o domínio técnico sobre outros sistemas da arte e escapar às limitações impostas pelo papel e pela letra. As vanguardas, desde o final do século XIX, buscavam obsessivamente essa liberdade. Inventaram linguagens, caligrafias, sistemas de escrita, subverteram gêneros - de maneira que já não se pudesse classificar uma obra literária - e subverteram também a própria arte, com o Dadá.

Walter Benjamin ${ }^{95}$ trata, num ensaio (BENJAMIN, 1992, p. 27), da decadência da narrativa, que começou a surgir com o aparecimento do romance. O ensaio vincula a arte de contar histórias à transmissão das experiências de vida. O romance, por seu caráter de reportagem, informativo, não transmite experiências, mas novidades. Não é obra de um artífice que queira, com paciência, imitar o lento processo da natureza; é obra de um profissional envolvido no tempo da produção.

A reflexão de Paul Valéry ${ }^{96}$ de que "o desaparecimento da idéia de eternidade coincidisse com a aversão crescente ao trabalho prolongado" (BENJAMIN, 1992, p. 39) revela uma profunda sensibilidade: a de entender a influência do tempo nos mecanismos de produção e na própria vida do homem. Mas com Joyce não era assim: ele não tinha aversão pelo trabalho prolongado e se preocupava bastante com a eternidade, a ponto de dizer que seus livros ocupariam os críticos por séculos.

E se a aversão a que se refere Valéry existisse, apareceria também no romance, marcada principalmente no tempo da narrativa. E existe, de fato. $\mathrm{O}$ tempo no romance transmite uma sensação de angústia, a sensação de que se caminha em vão; diferentemente do tempo da épica, que transmite a imensidade, o sentimento de que se sabe para onde caminha.

\footnotetext{
${ }^{93} \mathrm{O}$ conceito de obra de arte total foi utilizado por Wagner para a realização do ciclo do Anel em Bayreuth, para o qual ele teve de construir um teatro. Buscava unir a música a outras formas de artes, de maneira que tudo ficasse integrado à dinâmica dramática.

${ }^{94}$ David Llewelyn Wark Griffith (1875 - 1948). Diretor de cinema estado-unidense. O Nascimento de uma Nação (1915); Intolerância (1916); América (1924).

${ }^{95}$ Walter Bendix Schönflies Benjamin (1892 - 1940). Filósofo e crítico literário alemão, associado à Escola de Francoforte.

${ }^{96}$ Ambroise-Paul-Toussaint-Jules Valéry $(1871$ - 1945). Poeta e ensaísta francês.
} 
O que marca o tempo, em qualquer narrativa, é o enredo. Na Odisséia, Penélope passava o dia tecendo um tapete que desfazia ao entardecer. Fazer e desfazer a trama, ou o enredo, do tapete foi a forma encontrada por ela para que o tempo não passasse, e nunca chagasse o dia de dar sua resposta aos pretendentes. Isso, de certa forma, abreviava a chegada do marido, por quem esperaria por toda a eternidade, se fosse preciso, no leito de oliveiras.

Em relação aos gêneros narrativos, as vanguardas embaraçaram de tal maneira o novelo de $1 \tilde{a}^{97}$ que era quase impossível desenvolver com ele uma estrutura de grandes dimensões como o romance. ${ }^{98}$ E quando isso foi possível, depois de anos de trabalho, o resultado foi um desastre para o gênero ${ }^{99}$. O mais notável é que esse desastre tivesse sido obra de outra Penélope: uma Penélope infiel que, em vez de tecer um tapete no transcorrer do dia, limita-se a desembaraçar os fios do novelo numa noite de insônia.

Porque, para Marion Bloom, a Penélope do Ulysses de Joyce, não havia mesmo nada para ser tramado. Havia os fios, mas não havia a tela. A dimensão era psíquica. É estranho que a chamemos de dimensão, pois ela não apresenta medidas de espaço nem de tempo. Assemelha-se, portanto, àquilo que é o infinito, àquilo que é o nada, àquilo que é a eternidade. A eternidade é a dimensão da épica. Mas não é a dimensão do romance.

A épica relata acontecimentos transcendentais e o romance, acontecimentos pontuais. Nisso o romance assemelha-se à História, depois que ela se tornou um gênero à parte. Os gêneros narrativos em prosa são inspirados por Clio, e a épica por Calíope. Elas, como todas as outras musas são filhas da memória (HESíODO, 1995, p. 109). Walter Benjamin, no entanto, relaciona a épica à memória, e o romance, à recordação (BENJAMIN, 1992, p. 44).

O Ulysses, ao valer-se do épico, busca reaproximar da memória a recordação; reaproximação impossível, sobretudo em um texto em que os pensamentos são vagos. Mas dessa impossibilidade surge algo novo. A utilização da torrente de consciência ${ }^{100}$ é o que

\footnotetext{
97 Muitos dos contos de Katherine Mansfield [Kathleen Mansfield Beauchamp (1888-1923). Escritora neozelandesa], por exemplo, não têm enredo. E o enredo, em muitas das obras narrativas de Clarice Lispector, que se inspirava em Mansfield e em Joyce, tem importância secundária. Aqui se percebe que o lirismo procurava impor-se à narrativa, o que colocava os gêneros narrativos num beco sem saída: não havia como avançar; para sobreviver, tiveram de recuar.

${ }^{98}$ Por essa razão os movimentos mais radicais da vanguarda evitaram o romance. Há um romance surrealista escrito por André Breton, Nadja (1928), que além de ser curto, é bastante conservador se comparado ao que faziam os surrealistas.

${ }^{99}$ Ver final do capítulo anterior.

${ }^{100}$ Expressão cunhada por William James (1842 - 1910), psicólogo estado-unidense, no livro Principles of Psychology (1890). Designa a maneira pela qual processos que existem fora da consciência primária, como lembranças, pensamentos e sentimentos, surgem para nós. James chamou-a de "stream of thought, of consciousness, or of subjective life" (JAMES, 1897, p. 155). A expressão ganhou o terreno da Literatura e
} 
formalmente representa esse algo novo. Ela é a antítese da memória. Nada há de mais breve do que ela: nítido contraste com a vastidão da memória épica. Uma se dá no eterno, a outra no instante. Sendo antítese, requer uma síntese: algo que encerre dentro de si, a brevidade do instante e a perenidade do eterno: o sonho.

\section{FINNEGANS WAKE}

\subsection{Linguagem}

O sonho, com todas as suas implicações freudianas, é a dimensão da obra que James Joyce escreverá depois de Ulysses. Finnegans Wake já não é romance. Por tratar-se de uma narrativa que se despojou do tempo e se apegou à música como faz a poesia lírica, quase não apresenta linearidade, enredamento. Sobre isso, Walter Benjamin escreve:

[...] não existe nenhuma narrativa em que não se possa pôr a pergunta: e o que é que segue? $\mathrm{O}$ romance, pelo contrário, não admite que se dê o mais pequeno passo para além daquela fronteira demarcada pela palavra "Fim" na sua última página, altura em que convida o leitor a refletir sobre o sentido da vida que se pressente. (BENJAMIN, 1992, p. 44)

E não se pode acrescentar a palavra fim a Finnegans Wake. Nele, o fim está no próprio título, e é um fim que se repete, remetendo sempre ao recomeço. Não há nele, tampouco, uma reflexão sobre o sentido da vida, mas uma reflexão sobre o sentido da História.

[...] segundo Lukács, o romance é a única forma que engloba o tempo entre os elementos que a constituem. Na sua "Teoria do Romance" ele diz-nos que "o tempo só pode, pois, ser parte constitutiva quando perde a sua ligação com a pátria transcendental (...). Só no romance (...) o sentido da vida se separa da vida em si, separando assim o essencial do temporal; quase se pode dizer que toda a ação interna do romance não é senão a luta contra o poder do tempo" (BENJAMIN, 1992, p. 45).

A luta contra o poder do tempo ficou atrás. O tempo lutou contra Ulisses e Ulisses venceu $^{101}$ : na Odisséia e em Dublim. Já derrotado no final de Ulysses, o tempo já não conta em Finnegans Wake. Aqui, o sentido da vida não tem sentido, quer o consideremos apartado da vida ou dentro dela. A dimensão da obra é a dimensão épica, em que o tempo se dilata e é

acabou sendo utilizada indiscriminadamente para indicar uma técnica literária de reprodução de processos mentais. Harry Levin preferiu a expressão "monólogo interior" para designar essa técnica. O próprio inventor da técnica, Edouard Dujardin, chamou-a de torrente de consciência. Hoje se distinguem torrente de consciência e monólogo interior: no monólogo ainda persiste certo encadeamento lógico nos processos mentais; na torrente não pode haver encadeamento ["consciousness... does not appear to itself... as "chain"”] e a lógica se perde. Diz-se também "fluxo de consciência", mas essa tradução atenua o sentido do original.

${ }^{101}$ Ver o ensaio “A cicatriz de Ulisses” (AUERBACH, 1971). 
absorvido pela eternidade. E na eternidade a vida não tem sentido. Todavia, se aqui o tempo não importa, o mesmo não diremos da História. Finnegans Wake é uma reflexão sobre a História e não sobre a vida: porque a vida não tem importância para a História; a preocupação da História é com a existência; a existência pode ser eterna, a vida não.

O sonho, no livro, não é o sonho de um homem, é o sonho de uma raça, o sonho de um mito, o sonho de Finn MacCool (o irlandês, o pai da raça). Isso tudo representa a existência de uma raça oprimida por séculos de dominação inglesa, oprimida pela religião católica e, conseqüentemente, oprimida pela História. E para a Irlanda, assim como para Joyce, a História era um pesadelo do qual precisavam despertar. ${ }^{102}$

A necessidade de reagir à opressão da História era algo que incomodava Joyce, mas parecia não incomodar a Irlanda. Ali, parece que nada acontecia; por isso Joyce sempre retratou a imobilidade de seu povo usando a metáfora da paralisia, desde o primeiro conto de Dubliners até Finnegans Wake, obra em que a paralisia é representada com grande radicalismo e ironia. Ironia, no sentido de que a prosopopéia com que representa sua terra é um herói morto, um gigante acomodado a uma paisagem onde nascerá a cidade de Dublim. Radicalismo, no sentido de que o autor reduz o tempo da narrativa ao instante - pelo fato de o sonho ser um processo instantâneo que ocorre ao despertar ${ }^{103}$; o espaço, ao ínfimo; e a ação, ao nada, por se tratar de alguém que, imóvel no leito, sonha.

Estamos diante de uma narrativa quase destituída de tempo, de espaço e de ação. É quase uma obra lírica. Sua estrutura narrativa mal se sustenta e os fios de sua trama quase não se entrelaçam. Como no sonho, a linearidade é muito vaga, até mesmo desprezível. O livro não é projetado com linhas condutoras, mas com planos circulares sobrepostos, como discos numa vitrola automática. Seus planos narrativos são diversos: há o sonho, a vigília, o sonho dentro de um sonho, etc. E o sonho só pode ser compreendido se for interpretado.

A interpretação dos sonhos talvez tenha sido a obra que maior influxo exerceu sobre o pensamento do século XX. Publicada em 1900 por Sigmund Freud ${ }^{104}$, deu nova explicação

\footnotetext{
102 "History, Stephen said, is a nightmare from which I am trying to awake." [A História, disse Stephen, é um pesadelo do qual procuro despertar.] (JOYCE, 1993c, p. 34)

${ }^{103}$ Quando um estímulo externo perturba nosso sono - um barulho, por exemplo - começamos a sonhar. É uma forma de proteção do organismo para preservar o sono.

${ }^{104}$ Sigmund Freud (1856-1939). Médico austríaco, criador da Psicanálise. Obras principais: Estudos sobre a histeria (com Josef Breuer) (Studien über Hysterie, 1895); A interpretação dos sonhos (Die Traumdeutung, 1899 [1900]); Psicopatologia da vida cotidiana (Zur Psychopathologie des Alltagslebens, 1901); O chiste e sua relação com o inconsciente (Der Witz und seine Beziehung zum Unbewußten, 1905); Totem e tabu (Totem und Tabu, 1913); Sobre o narcisismo (Zur Einführung des Narzißmus, 1914); Além do princípio do prazer (Jenseits des Lustprinzips, 1920); O ego e o id (Das Ich und das Es, 1923); O futuro de uma ilusão (Die
} 
aos símbolos e livrou os sonhos da interpretação mística. Agiu na feição de vários movimentos estéticos e definiu marcadamente o Surrealismo, por exemplo. E os artistas, quer aceitassem ou não a influência dela, demonstraram que de uma maneira ou de outra ela deixava marcas naquilo que faziam.

É o caso de James Joyce, que sempre rejeitou a utilização estética da psicanálise: "Por que Jung é tão rude comigo? Ele nem sequer me conhece. As pessoas querem colocar-me para fora de uma igreja a que não pertenço. Não tenho nada que ver com psicanálise." ${ }^{105}$ Os amigos dele, no entanto, pensavam que ele fazia pouco caso da Psicanálise por ironia ou vaidade, e quando ele se convenceu de que os problemas mentais da filha eram de fato graves, levou-a para ser tratada por Jung, a quem se referia como charlatão.

Pode-se presumir, porém, da leitura da biografia de Joyce, que muitas das críticas que ele fazia eram fanfarrices, tinham mais o gosto da piada do que da verdade. Presume-se também que ele gostava de dar pistas falsas sobre como sua obra devia ser interpretada. Mas por trás das ironias de Joyce, encontra-se a decifração de sua esfinge. Certa vez, falava ele da Ciência Nova de Vico para um amigo, e dizia que sua imaginação crescia quando lia Vico, mas não quando lia Freud ou Jung (EllmanN, 1983, p. 693). Foi a resposta que deu quando o amigo lhe perguntou se acreditava na Scienza Nuova. "Eu não acredito em ciência alguma" (EllmanN, 1983, p. 693). A interpretação dessa anedota pode levar ao fim da esfinge. De fato, não se pode acreditar em ciência; ciência não é profissão de fé, não depende senão de provas. As ironias de Joyce não são gratuitas. Por isso, quando ele afirmou que Freud não lhe estimulava a imaginação, não o fez com qualquer palavra, mas com a palavra "imaginação". Ora, "imaginação" implica visão, capacidade que Joyce vinha perdendo, e que não predomina em Finnegans Wake, um livro feito mais para os ouvidos, do que para os olhos. Seja como for, há indícios mais do que suficientes em seu livro de que ali foi aplicada a teoria dos sonhos de Freud.

Freud fazia distinção entre sonho latente e sonho manifesto. O sonho latente é o sonho efetivamente sonhado, em que se conjugam as impressões sensoriais noturnas ${ }^{106}$, as

Zukunft einer Illusion, 1927); O mal-estar da civilização (Das Unbehagen in der Kultur, 1930); Moisés e o monoteísmo (Der Mann Moses und die monotheistische Religion, 1939).

105 "Why is Jung so rude to me? He doesn't even know me. People want to put me out of the church to which I don't belong. I have nothing to do with psychoanalysis." (ELLMANN, 1983, p. 628)

106 No primeiro capítulo de Finnegans Wake, o sonho da personagem é perturbado por um galho que bate várias vezes na janela. 
atribulações do dia e os impulsos do id. O sonho manifesto é a lembrança que fica ao despertar. Quando nos lembramos de um sonho, procuramos organizá-lo de diversas maneiras dentro da mente: fatos, personagens, idéias, tempo, etc., e quanto mais distantes estamos do momento do despertar, mais organizados eles se tornam e, conseqüentemente, mais racionalizados. A racionalização dos fatos sonhados empobrece o conteúdo do sonho. Não obstante, o sonho manifesto é complexo e precisa ser analisado para que se chegue ao sonho latente, ao esconderijo da alma.

Finnegans Wake relata um fato inocente que se transforma em culpa e é interpretado como um crime. Esse acontecimento, narrado no primeiro capítulo do livro, em que Humphrey Chimpden Earwick (HCE) surpreende no parque duas garotas urinando, transforma-se em culpa, porque desperta em HCE um desejo sexual, e em crime porque a sociedade em que vive tem por fundamento a repressão ao desejo. Esse simples desejo não seria nada de mais não fosse o fato de ocultar outro desejo, ainda que modesto, que a personagem nutria pela própria filha. A condenação é feita por ele mesmo no sonho, como forma de repressão. Uma vez interpretado o sonho, uma vez descoberto o medo, segue-se o alívio da culpa. E é o que acontece com o sonho de HCE. Sua mulher interpreta o sonho e inocenta o marido, apresentando o sonho manifesto dele, que no livro aparece como “mamafesta" (FW 104.03) ${ }^{107}$, termo que revela também um conteúdo edipiano.

Os desejos, que são o conteúdo latente do sonho, são elaborados no sonho basicamente por meio de dois processos: condensação e deslocamento. Lacan relacionou, mais tarde, esses processos com figuras literárias: para ele, a condensação equivale à metáfora e o deslocamento à metonímia. Por mais que Joyce procurasse negar, ou esconder, esses dois processos estão bastante claros em Finnegans Wake, se é que existe algo de claro nesse livro.

Freud, numa conferência, "A elaboração onírica" ${ }^{108}$, relata que, num sonho, um homem disse a uma mulher que a iria acompanhar, mas em vez de usar o verbo apropriado, begleiten, diz begleitdigen, que combinava blegeiten com beleidigen, insultar (formando uma palavra-valise $\left.{ }^{109}\right)$. Ora, diversos tipos de deformação verbal ocorrem em cada linha de Finnegans Wake: “violer d'amores" (FW 003.04), “penisolate war” (FW 003.06), por exemplo - ambas com conotações sexuais bastante acentuadas.

\footnotetext{
107 Todas as citações a Finnegans Wake são feitas, tradicionalmente, apondo-se a "FW" o número da página (com três algarismos), seguido de ponto e do número da linha (com dois algarismos).

${ }^{108}$ Freud, S. Edição eletrônica brasileira das obras psicológicas completas. Rio de Janeiro: Imago, s/d.

${ }^{109}$ Palavras formadas por partes de palavras diferentes. Por exemplo, "Bakerloo", estação de metrô em Londres situada entre as de Baker Street e Waterloo. A palavra toma o começo de Baker e o final de Waterloo.
} 
Um exemplo notável de condensação usado por Joyce é a mudança da palavra “incesto" em “inseto" (Earwick, Persse O'Reilly, etc.), conforme veremos mais adiante. Mas não são precisos mais exemplos ${ }^{110}$; para percebê-los basta observar a estruturação musical do livro em que se misturam dois ou mais discursos como nas vozes de um coro. Para isso, Joyce utiliza uma única palavra, composta ou simples, para se referir a vários elementos, condensando-os numa só palavra. As quatro vozes do coro são os quatro evangelistas que se fundem (condensam num só) e se deformam em Mamalujo (Mateus, Marcos, Lucas e João). Mamalujo também é uma deformação de outra deformação, "mamafesta”, pois o manifesto é a vida de Jesus interpretada (deformada), ou seja, o Evangelho.

O deslocamento, por sua vez,

Manifesta-se de duas maneiras: na primeira, um elemento latente é substituído, não por uma parte componente de si mesma, mas por alguma coisa mais remota, isto é, por uma alusão; e, na segunda, o acento psíquico é mudado de um elemento importante para outros sem importância, de forma que o sonho parece descentrado e estranho. (FREUD, "A elaboração onírica”)

No capítulo I de Finnegans Wake, o passeio pelo Parque Phoenix é descrito como um

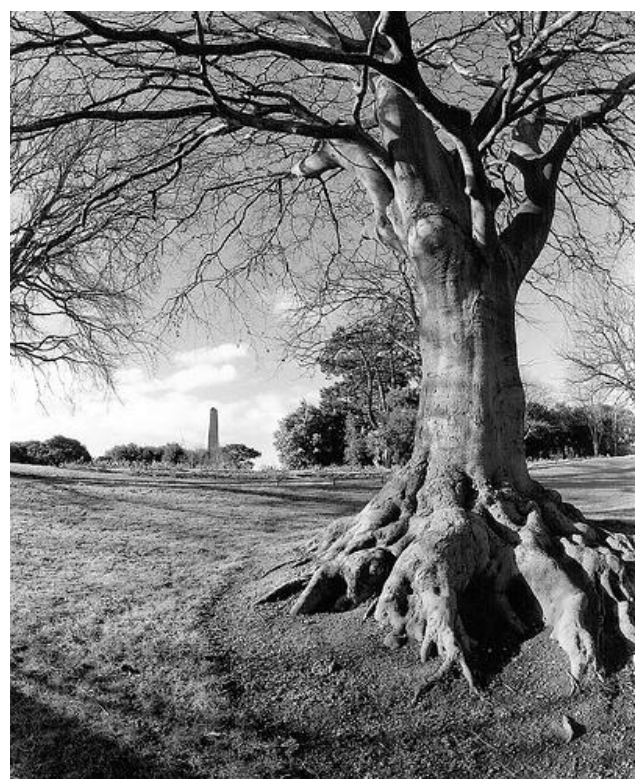
passeio por um museu no qual ocorre a batalha de Waterloo, entre Wellington e Napoleão. Esse deslocamento foi provocado pela visão do memorial de Wellington que há no Parque (ao lado: o Parque com o Memorial ao fundo). Isso denota outro deslocamento, do Memorial, que é uma coluna, para o museu. Numa interpretação psicanalítica muito simples, evidencia-se nesse caso uma substituição de um símbolo fálico por um símbolo uterino, que é um disfarce da impotência, o que explicaria a reação de HCE diante das moças no Parque, e, em última instância, o relacionamento dele com a esposa.

As palavras forjadas por Joyce para representar a linguagem dos sonhos em Finnegans Wake tiveram como matéria-prima, ou substrato, a língua inglesa. $\mathrm{O}$ autor fez uso de mais de

${ }^{110}$ No “Glossário", há uma relação bastante completa dessas palavras. 
sessenta línguas (MCHuGH, 1991, p. xiv-Xv), em seu livro, fundindo umas nas outras: "wielderfight" (o termo alemão wiederfechten, tornar a lutar, com o inglês fight, lutar [FW 006.03]); usando-as isoladamente no meio de um trocadilho com palavras de outra língua: “Gut aftermeal!” (do alemão, gut, bom, com a expressão inglesa "Good afternoon!” [FW 017.16]); deformando-as para que parecessem, por paronomásia, outra palavra ou expressão: "rutterdamrotter" (Götterdämmerung, título de uma ópera de Wagner [FW 017.15]), etc. Joyce usou diversos processos para a formação de palavras, como palavras-valise e hibridismos; para a formação de frases, como o trocadilho; enfim, moldou a língua de todas as formas que pôde para representar a linguagem da noite. De acordo com ele, essa linguagem, mais hermética, seria usada apenas de noite:

Eu coloquei a linguagem para dormir. [...] Ao escrever sobre a noite, eu de fato não podia, senti que não podia usar palavras em suas relações ordinárias. Usadas dessa forma, não expressam como as coisas são durante a noite nos diversos estádios - consciente, semiconsciente e inconsciente. [...] Quando amanhece, as coisas voltam a ficar, obviamente, mais claras... Darei de volta a elas a sua língua inglesa. Não a estou destruindo por completo. (ELLMANN, 1983, p. 546)

Mas enquanto a manhã não chega, Joyce aplica um terceiro processo de elaboração onírica mencionado por Freud, que transforma pensamentos em imagens visuais. Para isso, a linguagem tem de regredir de sua forma flexional para a monossilábica (ver, por exemplo, o diálogo de Mutt e Jute, no primeiro capítulo); de sua forma alfabética para a hieroglífica (os símbolos que aparecem no livro); de sua forma discursiva para a poética; e da descritiva para a metafórica. A deformação de pensamentos em imagens está relacionada com a linguagem primitiva em que os habitantes das cavernas reproduziam os sons da natureza e faziam desenhos de animais nas paredes das grutas. Joyce deformará ainda mais essas imagens, transformando-as em acrósticos. Podemos encontrar, ao longo do livro, centenas de frases de três palavras com as iniciais de HCE e ALP (abreviaturas de Humphry Chimpden Earwick e de Anna Livia Plurabelle): "Here Comes Everybody" (FW 032.18), "Haveth Childers Everywhere" (FW 535.34), "Hither, craching eastuards" (FW 017.25); "addle liddle phifie" (FW 004.28), etc., ou em palavras como “dalppling” (FW 007.02) em que existe a seqüência das letras ALP.

A marcação do texto com esses acrônimos funciona visualmente, mas é um recurso emprestado da música, sobretudo da música de Wagner, processo que os críticos 
denominaram Leitmotiv ou "motivo condutor"" para num texto pouco enredado.

Por fim, outro processo de elaboração onírica, segundo Freud, que encontra correspondência na evolução da linguagem, consiste na inversão de palavras que conservam sua significação anterior. Exemplo disso são os acrônimos ECH, EHC, etc., encontrados em Finnegans Wake. Um desses acrônimos, o mais inusitado que encontramos, relaciona HCE, em uma de suas variantes, EHC, bastante recorrente no livro, ao famoso tenor do início do século XX, Enrico (Henry) Caruso (EHC) (HodGART; BAUERLE, 1997, p. 98-9).

\subsection{Estrutura}

\subsubsection{Estruturação musical}

Há uma passagem curiosa, na vida de Caruso, sobre um passeio ao zoológico do Central Park, em Nova York. Uma mulher que observava os macacos acusou Caruso, que estava perto dela, de tê-la tocado nos quadris. Um policial chamado Caine, ou Kane, levou-o para o Distrito e abriu uma queixa-crime contra o cantor. Apesar de a moça não ter comparecido ao tribunal e das contradições em que caíram as testemunhas de acusação, Caruso foi condenado. A pena era mínima, uma multa de dez dólares e nada mais, o resultado do julgamento, porém, indignou vários artistas e intelectuais, inclusive o próprio Joyce que ironizou o fato dizendo que se os americanos tiveram tanto trabalho a ponto de usar três policiais para prender o pesado Caruso, por que não prenderam também o macaco do zoológico.

O episódio do Parque, em Finnegans Wake, certamente foi inspirado nesse acontecimento da vida de Caruso. Como Joyce atribui a culpa ao macaco, no caso do tenor, faz HCE assumir a culpa pelo homem e pelo macaco. HCE anda curvado, como um macaco, e a letra $\mathrm{C}$ de suas iniciais é Chimpden, palavra que contém chimp, chimpanzé.

Joyce, durante muitos anos de sua vida, alimentou o sonho de se tornar um cantor lírico. Herdara do pai o talento para a música. Do pai, herdou também a ironia, uma qualidade literária. Em Joyce, o talento literário sobrepujou o musical, mas o escritor aproveitou-se de

\footnotetext{
${ }^{111}$ Nas óperas de Wagner (e mesmo antes dele), são melodias que remetem a cenas ou personagens; no ciclo do Anel, por exemplo, há o conhecido Leitmotiv das valquírias: toda vez que ele toca, o ouvinte lembra-se das valquírias. É um procedimento muito comum hoje em dia no cinema.
} 
ambos em suas obras. Sobretudo em Finnegans Wake. Em Ulysses, havia o episódio das Sereias, que fora trabalhado musicalmente; no entanto, Finnegans Wake inteiro é musical. Há no livro mais de três mil alusões apenas à ópera, entre compositores, óperas, operetas, árias, etc. O maior número de alusões é a Wagner e, de suas composições, a obra mais mencionada é $O$ anel do nibelungo.

$O$ anel é um ciclo operístico formado por quatro óperas, uma espécie de roman-fleuve lírico. A primeira delas é “O ouro do Reno”, mencionada várias vezes no livro de Joyce, mas com importância destacada no início e no final. O fato de o livro terminar numa frase incompleta que se liga ao primeiro parágrafo do começo do livro tem sido explicado pelos críticos como reprodução dos ciclos propostos por Vico na Ciência nova, mas é também um elemento de estruturação musical.

Joyce procurava reproduzir uma estrutura musical em forma literária. É muito comum na música deixar o primeiro compasso incompleto para completá-lo com o último. Isso ocorre quando a música começa fora do tempo, ou seja, numa pausa. Esse processo chama-se anacruse e foi usado em Finnegans Wake.

É opinião quase unânime entre os críticos que Finnegans Wake possa ser lido a partir de qualquer ponto, de qualquer página, por ser um livro circular. Essa opinião é desnecessária, pois todo livro pode ser lido dessa maneira. Há outros motivos para isso, no caso de Finnegans Wake. Os primeiros esboços do livro revelam que a intenção do autor era começar no que veio a ser o segundo parágrafo na edição definitiva: "Sir Tristram, violer d'amores, fr'over the short sea, had passencore..." Logo na primeira linha, uma referência musical: viola d'amore, um instrumento medieval. Mas a razão de haver um parágrafo antes, acrescentado anos mais tarde, é, antes de mais nada, musical.

Há uma marcação musical, muito utilizada - quase não há partitura sem ela -, que serve para economizar tinta e papel. Quando se quer repetir uma frase, ou mesmo páginas inteiras, usa-se um sinal de repetição cuja grafia é um sinal de dois pontos, ou, se a repetição for longa, a frase Da capo, que significa, literalmente, a partir da cabeça, ou "a partir daqui". 
Essa marca também aparece no primeiro parágrafo do livro; não está escrita em italiano, e sim numa corruptela do dinamarquês hoved, cabeça: Howth. É uma indicação de que o livro deva ser lido a partir do parágrafo seguinte e terminar em "Howth Castle and Environs".

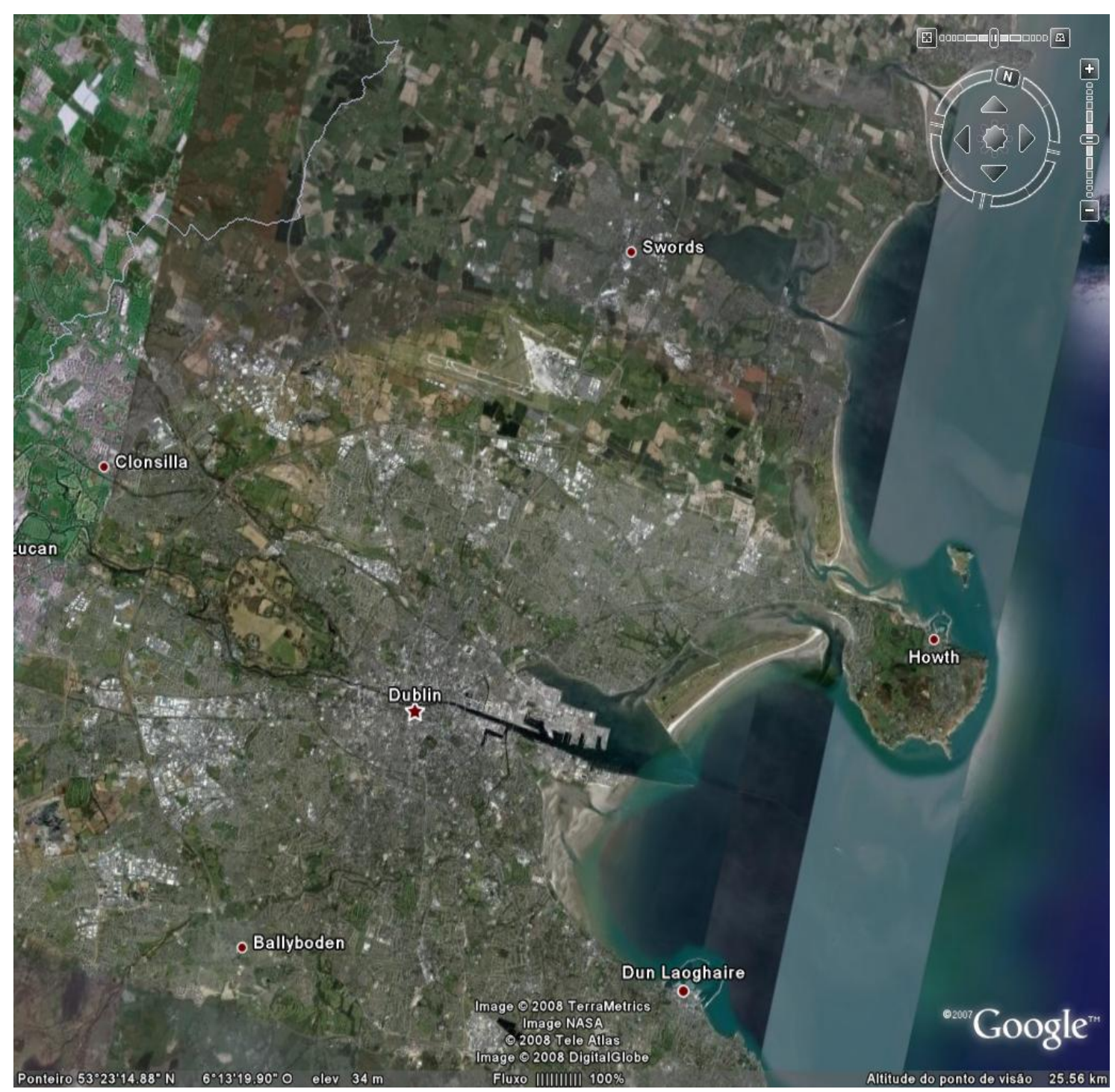

Dublim, vista por satélite: Cabeça (Howth) e corpo do gigante.

A abertura de "O ouro do Reno" procura imitar, com os violoncelos, o movimento das águas do rio. A primeira página de Finnegans Wake é uma alusão ao rio Liffey, e tem o ritmo e a sonoridade de suas águas, simulados pelas aliterações em S e TH e assonâncias em O. A página também funciona como abertura operística, resumindo os principais motivos e melodias da composição, que, no caso desse livro são: a coincidência dos contrários (Jhem ou 
Shen: fusão de Shem e Shaun; Esaú e Jacó; Stella e Vanessa; Adão e Eva; alfa e ômega), o trovão, o parque, a queda, a terra, o mar, e o acrônimo de HCE que funciona como um Leitmotiv. As palavras "riverrum" (FW 003.01), "stream" (003.07), "ringsome" ( $O$ anel, 003.14), “aquaface” (003.14), "livvy” (rio Liffey, 003.24), etc., referência todas elas ao rio e o ritmo de suas águas pode ser percebido no aumento e diminuição do tamanho das frases da página:

Sir Tristram, / violer d'amores, / fr'over the short sea, / had passencore rearrived from North Armorica on this side the scraggy isthmus of Europe Minor to wielderfight his penisolate war: / nor had topsawyer's rocks by the stream Oconee exaggerated themselse to Laurens County's gorgios while they went doublin their mumper all the time: / nor avoice from afire bellowsed mishe mishe to tauftauf thuartpeatrick not yet, / though venissoon after, / had a kidscad buttended a bland old isaac: / not yet, / though all's fair in vanessy, / were sosie sesthers wroth with twone nathandjoe.

Quando termina a abertura de $O$ ouro do Reno, ocorre a primeira intervenção vocal da ondina Woglinde:

$$
\begin{aligned}
& \text { Weia! Waga! } \\
& \text { Woge, du Welle, } \\
& \text { walle zur Wiege! } \\
& \text { Wagalaweia! }
\end{aligned}
$$

[Vaga, onda, balança como um berço! Vagalavaia!]

São onomatopéias que se combinam ao sentido das palavras que as acompanham. Nas últimas duas linhas do livro, há palavras com sonoridade semelhante e que reproduzem, por antonomásia, as palavras da ondina:

A way a lone a last a loved a long the

É como se o início do canto que interrompe a abertura viesse antes mesmo da abertura. Joyce completa, com a última frase do livro, o compasso que aparece inconcluso no começo.

Ao longo de todo o livro, encontramos alusões musicais. Os trocadilhos e as palavrasvalise, os jogos verbais mais empregados no livro, na maioria das vezes são artifícios para se dizer duas ou mais coisas ao mesmo tempo. É um recurso musical denominado polifonia.

Ao estudar o canto lírico, Joyce começou a entender a separação de vozes no coro e a polifonia. Como essas vozes são geralmente quatro (baixo, tenor, contralto e soprano), seria plausível suspeitar-se de que os discursos que se misturam em quase todo o Finnegans Wake, 
e que narram mais de uma história simultaneamente, fosse elaborado seguindo um processo de composição musical, uma composição polifônica. Isso ocorre em muitas passagens, como, por exemplo, no episódio de Nuvoletta (FW 157), conforme observação de B. F. Skinner ${ }^{112}$ :

Noutra conhecida passagem, através de uma notável série de trocadilhos e de misturas, Joyce conta duas histórias ao mesmo tempo: uma de Nuvoletta, uma menina que sobe a uns balaústres e cai; e outra, a de uma gota de chuva que se precipita de uma nuvem e cai num rio. (SKINNER, 1978, p. 369) ${ }^{113}$

Essa mistura confusa de línguas e de palavras pode ter ocorrido a Joyce quando viveu em Trieste, uma cidade multinacional em que se misturavam o dialeto triestino, o italiano, o esloveno, o alemão e as línguas e dialetos de todos os estrangeiros e marinheiros que para ali afluíam por causa do porto. Mas revela também uma preocupação com o arranjo coral:

Joyce tinha a mesma preocupação que Thomas Mann de como fazer a palavra falada funcionar como música. [...] As linhas seguintes, tiradas de [FW] 222.06, por exemplo, podem ser lidas, à primeira vista, como uma seqüência de dátilos:

'good for us áll for us áll us all áll’

As palavras precedentes, no entanto, um cânone coral, indicam que a leitura deveria ser feita como se se tratasse de uma série de stretti que se prolongam:

$1^{\text {a }}$ voz: good for us all

$2^{\mathrm{a}}$ voz: ......................good for us all

$3^{\mathrm{a}}$ voz: .................................good for us all

$4^{\text {a }}$ voz: ...........................................good for us all (HART, 1962, p. 177) $)^{114}$

Existe mesmo uma preocupação em fazer música com a palavra falada, e essa preocupação chega a ser exagerada, a ponto de Joyce ser comparado a músicos do final da Idade Média como Orlando di Lasso (1530 ou 1532 - 1594) e Josquin des Près (c. 1450 1521) (VIZIOLI, 1991, p. 93). O final da Idade Média, ou outono da Idade Média, na expressão de Huizinga, presenciou os maiores exageros da composição polifônica - faziam-se música para 36 vozes [Deo gratias de Joahannes Ockeghem (c. 1430 - 1495): Disco, faixa 1], 24 vozes [Qui habitat in adjutorio de Josquin des Près: Disco, faixa 2] e até 40 vozes [Spem in

\footnotetext{
${ }^{112}$ Burrhus Frederic Skinner (1904 -1990). Psicólogo estado-unidense, fundador do Behaviourismo. Walden Two (1948); Verbal Behavior (1957); etc.

${ }^{113}$ Mas aqui, imbricam-se, de fato, quatro histórias: a da nuvenzinha, a de dois rios (o Liffey e o Mississippi), a dos insetos (myriads, little life) e a das mulheres que foram dormir com os homens.

114 Joyce shared Thomas Mann's preoccupation with the problem of how to make the spoken word function like music. (...) The following line from 222.06, for example, reads at first like a series of dactyls: 'good for us áll for us áll us all áll' The preceding words, however, 'a chorale in canon', indicate that we are to read it as a series of telescoping stretti, thus: VOICE 1: good for us all...
} 
alium de Thomas Tallis (c. 1505 - 1585): Disco, faixa 3] -, exageros que adentraram a Renascença e acabaram provocando reformas na música. A título de exemplo, uma dessas reformas, ocorrida na década de $1570^{115}$, deu origem à ópera.

Finnegans Wake pode muito bem ser uma ópera, mas sua estruturação musical guarda pouca relação com o conteúdo. Outra moldura estrutural da obra - e que Joyce tirou de Giordano Bruno (a quem chama de Nolano ${ }^{116}$, no decorrer do livro), de Edgar Quinet ${ }^{117}$, mas, em maior medida, de Vico -, a histórica, está intrinsecamente ligada ao conteúdo.

\subsubsection{Estruturação cíclica}

A Scienza Nuova de Vico, obra de que tratamos no capítulo anterior, serviu para Joyce compor a estrutura de Finnegans Wake, da mesma forma que antes a Odisséia lhe servira para compor a estrutura do Ulysses. Da Scienza ele tirou também diversas idéias, mas a intenção dele não era reinterpretar a obra, como Ulysses também não fora uma reinterpretação da Odisséia.

Finnegans Wake divide-se em quatro partes. A primeira delas representa a Idade Divina, da maneira que é apresentada na Scienza Nuova; a segunda representa a Idade Heróica; a terceira, a Idade Humana; e a quarta, o ricorso, ou o cataclismo que porá fim à Idade Humana e levará a humanidade de volta para a Idade Divina. A primeira parte subdivide-se em oito capítulos: os quatro primeiros reproduzem os quatro estádios da História viquiana, e os quatro últimos os repetem; repetem-no também as partes seguintes do livro. Além disso, dentro de cada capítulo, existe uma divisão semelhante.

São os ciclos históricos da evolução humana reproduzidos no livro de Joyce. As pesquisas sobre a obra aceitam sem reservas o esquema relatado acima. Clive Hart (HART, 1962, p. 19), baseado nesse esquema e no apresentado por Gilbert sobre o Ulysses (GILBERT, 1952, p. 41), elaborou dois quadros sinópticos, que reproduzimos abaixo:

\footnotetext{
${ }^{115}$ Camerata fiorentina.

${ }^{116}$ Giordano Bruno (1548-1600). Padre, cosmólogo e filósofo italiano. Bruno, que nasceu em Nola (por isso Nolano), foi condenado à morte na fogueira pela Inquisição.

${ }^{117}$ Edgar Quinet (1803-1875). Historiador francês.
} 


\section{Quadro 1 - Ciclo três mais um}

\begin{tabular}{|l|l|l|l|l|l|}
\hline Parte & Fase da vida & Tempo & Metais & Direção & Evangelista \\
\hline Livro I & Nascimento & Passado & Ouro & Norte & Mateus \\
\hline Livro II & Casamento & Presente & Prata & Sul & Marcos \\
\hline Livro III & Morte & Futuro & Cobre & Leste & Lucas \\
\hline Livro IV & Ressurreição & Atemporal & Ferro & Oeste & João \\
\hline
\end{tabular}

\section{Quadro 2 - Ciclo quatro mais um}

\begin{tabular}{|l|l|l|l|l|l|l|l|l|}
\hline Parte & Elemento & Humor & Astro & Metal & Estação & Dir. & Evang. \\
\hline I (1-4) & Terra & Melancólico & Terra & Ouro & Primavera & Norte & Mateus \\
\hline I (5-8) & Água & Fleumático & Lua & Prata & Verão & Sul & Marcos \\
\hline II & Fogo & Sangüíneo & Vênus & Cobre & Outono & Leste & Lucas \\
\hline III & Ar & Colérico & Saturno & Ferro & Inverno & Oeste & João \\
\hline IV & Quintessência & Temperado & Sol & Fe/Au & Equinócio & Centro & Asno \\
\hline
\end{tabular}

Apesar dos trabalhos elaborados a esse respeito, nós devemos tomar esses esquemas como simples aproximações, ainda que neles tenham trabalhado os críticos mais experientes no assunto. Pois aqui não se trata de esquematizar um percurso pela cidade de Dublim, como em Ulysses, mas de esquematizar um sonho. O sonho só pode ser esquematizado em sua forma manifesta, mas Finnegans Wake, com sua aparente falta de ordem, procura representar muitas coisas do sonho latente, uma representação possível apenas numa obra de ficção. Os pedaços de sonho, ou pedaços de desejo, estão espalhados por toda a obra em forma de pistas; depende muito da interpretação, e um esquema como esses não ajudam muito.

Em todo caso, não é fácil identificar divisões no livro, e uma observação atenta nos leva a concluir que, se elas existem, estão dispersas, como nos sonhos. Podemos dar um exemplo. O ricorso, de acordo com Vico, representa a voz dos deuses e marca a volta dos homens às cavernas. Joyce elaborou dez palavras de cem letras cada uma, que são onomatopéias do trovão. Se houvesse rigor na divisão do livro em capítulos históricos, as palavras-trovão seriam 4 (uma em cada parte do livro, no momento do ricorso), 5 (se dividirmos a parte I, que tem oito capítulos, em duas partes de quatro) ou 17 (uma para cada 
um dos capítulos do livro). Mas são dez. E estão distribuídas de maneira muito irregular ao longo do livro:

\section{Quadro 3 - Palavras-trovão}

\begin{tabular}{|c|c|c|c|c|c|c|c|c|c|c|}
\hline Parte & I & & & & & II & & & III & \\
\hline Capítulo & 1 & & 2 & 3 & 5 & 9 & 11 & & 13 & \\
\hline Página & 3 & 23 & 44 & 90 & 113 & 257 & 314 & 332 & 414 & 424 \\
\hline
\end{tabular}

Joyce construiu Finnegans Wake seguindo a divisão histórica formulada por Vico porque queria nesse livro narrar a história de sua raça. Fez essa narração em forma de sonho porque via a História como um pesadelo, mas não seguiu apenas Vico: modificou as concepções viquianas, em parte conforme a interpretação de Quinet, e em parte acompanhando uma formulação mais mística da História feita por Yeats no livro A Vision (HART, 1962, p. 49 $9^{118}$ ) e por Madame Blavatski em Isis Unveiled. A diferença entre todas essas concepções, diagramadas no livro de Hart, não parecem muito significativas porque são quase impossíveis de serem visualizadas num livro feito, fundamentalmente, para ser ouvido, e porque os sonhos não se organizam segundo esquemas geométricos. Geometrizar essa obra é o caminho para interpretá-la de maneira errônea. Mas, em que medida, a estruturação histórica se presta para narrar o sonho?

Já dissemos que, para Joyce, a História era um pesadelo; e o fato de que não conseguia despertar desse pesadelo, como se dele não houvesse fuga, combina com o esquema fechado de Yeats, no qual a História percorre caminhos que levam sempre aos mesmos lugares. É algo semelhante a uma sensação recorrente no sonho em que se corre desesperadamente sem se sair do lugar. Por outro lado, o esquema de Vico não era completamente circular: sua forma assemelha-se mais a uma espiral, em que o recomeço implica certa evolução. Um esquema mais apropriado para Finnegans Wake seria o de planos circulares sobrepostos em que um plano teria ligação com outro, mesmo que esses planos sejam descontínuos entre si, ou seja, que entre dois planos que se comunicam haja um ou mais planos intermediários. Esse esquema seria mais apropriado não porque necessitemos de esquemas, mas porque reproduz a dinâmica do sonho, que é descontínua.

${ }^{118}$ O gráfico está na p. 95 do livro de Hart. 
Página do Livro de Kells

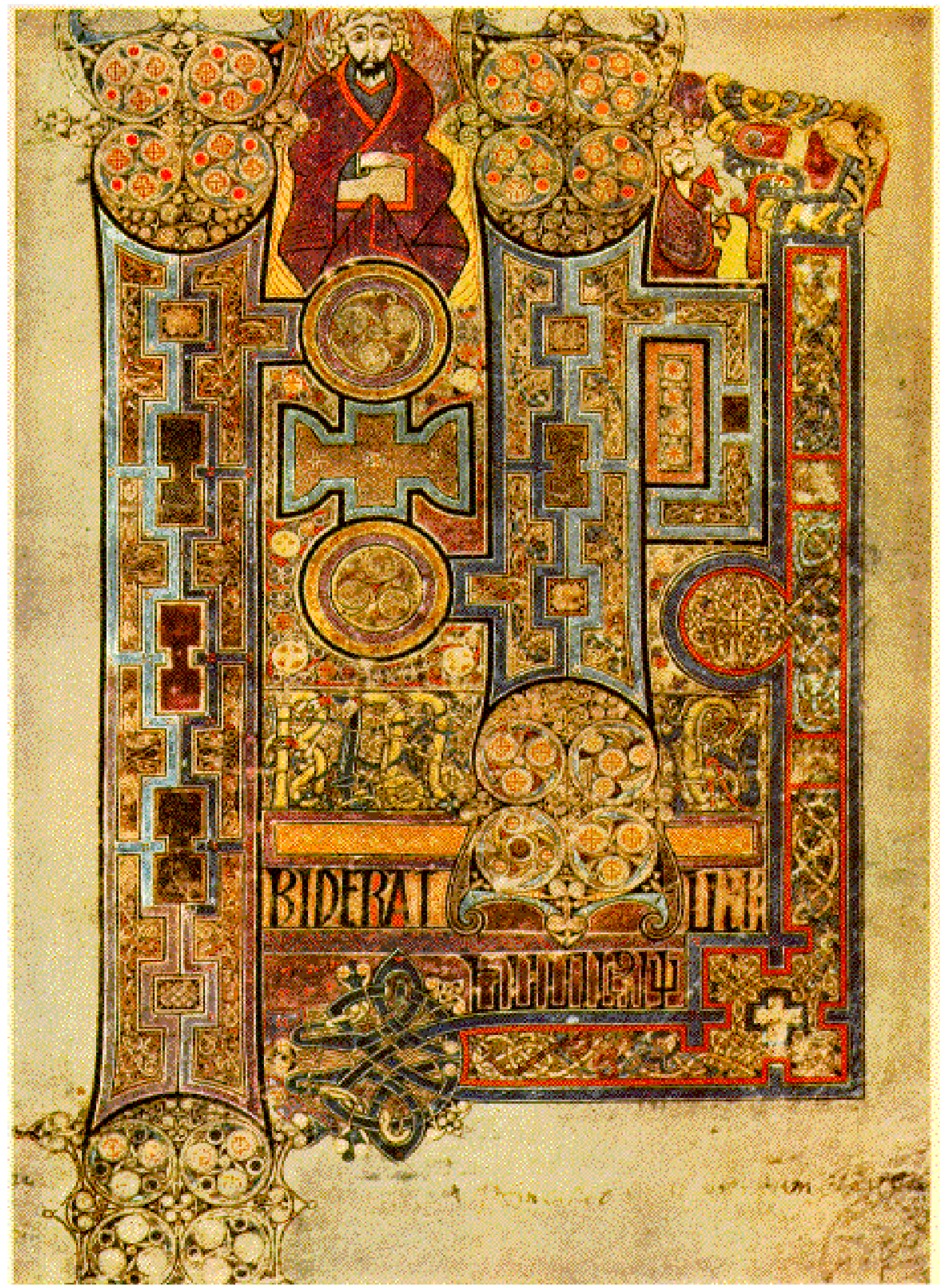




\section{ANÁLISE}

\subsection{Aspectos gerais}

Como quase não existe linearidade em Finnegans Wake, não é possível fazer uma sinopse do livro sem o descaracterizarmos por completo dando a ele uma linearidade que não tem.

É o que fazem seus exegetas. E vamos tentar fazer o mesmo em seguida, porque nos interessam alguns de seus episódios. No entanto, advertimos que os episódios são estruturas, e descrevê-los é o mesmo que descrever a moldura de um quadro em vez da pintura. Porque Finnegans Wake é acentuadamente musical, e, portanto, lírico, e na poesia, o episódico, o fabular, é secundário. O livro contém um lirismo que se percebe logo na linguagem, que é quase um idioleto. É uma linguagem hermética como o sonho e que, como o sonho, precisa ser interpretada. E é justamente essa linguagem poética, usada, como na poesia lírica, para descrever estados da alma, que nega a Finnegans Wake a qualificação de romance.

Os exegetas do livro procuraram explicá-lo de diversas maneiras. Uns, palavra por palavra, como Roland McHugh (Annotations to Finnegans Wake $)^{119}$; outros, por meio da paráfrase, como W. Y. Tindall (A Reader's Guide to Finnegans Wake) e Campbell e Robinson (A Skeleton Key to Finnegans Wake); e outros ainda, investigando frases, trocadilhos, símbolos $^{120}$, personagens ${ }^{121}$, fazendo interpretações ${ }^{122}$, etc. A forma mais completa de interpretação, contudo, é a tradução e trataremos dela, especificamente, no capítulo seguinte. Por enquanto, ficaremos nos aspectos secundários.

Finnegan ${ }^{123}$ é um pedreiro que costuma beber (uísque), pela manhã, para suportar as misérias da vida e da profissão. Um dia, ao pintar uma parede, cai da escada, quebra a cabeça e morre. Durante o velório, doze amigos (apóstolos ${ }^{124}$ ) de Finnegan bebem, embriagam-se, e acabam derramando uísque (termo derivado do antigo gaélico, uisce beatha, água da vida) sobre o morto, que, ungido pela água da vida, volta a viver para participar da bebedeira. ${ }^{125}$

\footnotetext{
${ }^{119}$ E os glossários. Ver a relação deles no início do "glossário" à nossa tradução.

${ }^{120}$ Roland McHugh. The Sigla of Finnegans Wake, 1976.

${ }^{121}$ Adaline Glasheen. Third Census of Finnegans Wake, 1977.

${ }^{122}$ Cf. C. Hart. Structure and Motif in Finnegans Wake, 1962; e John Bishop. Joyce's Book of the Dark, 1986.

${ }^{123}$ Personagem de vaudeville. Ver "Glossário", nota 4.

${ }^{124}$ Do grego $\alpha \pi \circ \sigma \tau 0 \lambda \circ \varsigma$, mensageiro, delegado.

125 Esse pequeno enredo, retirado por Joyce de uma canção de vaudeville (ver "Glossário", nota 4), serviu também de base para a novela de Jorge Amado, A morte e a morte de Quincas Berro d'Água. A personagem de Jorge Amado recebe essa alcunha porque grita "É água!" quando lhe dão água para beber dizendo ser cachaça. A palavra irlandesa uisce (pron. /uíche/), de onde vem "uísque” quer dizer, simplesmente, "água".
} 
Depois, os amigos o convencem a voltar para o caixão, como um cordeiro de sacrifício, e anunciam a vinda de outro homem para tomar-lhe o lugar. Finnegan, o Messias ${ }^{126}$ (porque fora ungido) consente em ser sacrificado para renascer. Dizem-lhe os amigos: "Mister Finn, you're going to be fined again." ( $F W 05.12)$

Esse outro homem é Humphrey Chimpden Earwick, que será mencionado ao longo da narrativa pelas letras iniciais de seu nome. HCE é um taverneiro em Chapelizod (pron. /tchapelízad/), vilarejo que fica na extremidade sul do Parque Phoenix ${ }^{127}$ (onde renasce o Messias), em Dublim. No entanto, HCE, não é uma personagem física, é a manifestação onírica de outra personagem, provavelmente alguém de apelido Porter ${ }^{128}$, cujo nome se refere a um tipo de cerveja ${ }^{129}$, homem de meia-idade que já não sente mais atração física pela mulher e passa a desenvolver um desejo velado pela filha que está entrando na puberdade.

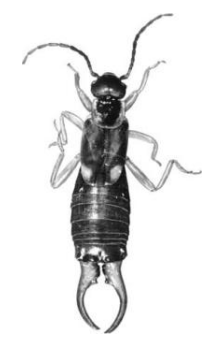

Como esse sentimento é tabu, sobretudo para um irlandês católico, Porter o manifestará apenas no sonho, e de uma forma também velada. Nele, a palavratabu, "incesto", se transformará em "inseto", num lapso de linguagem, mas deformada no nome de Earwick, que, por sua vez, é a deformação de earwig, tesourinha ${ }^{130}$, ou lacrainha (figura ao lado), cujo nome em inglês, e também seu nome científico, deve-se a uma crença antiga de que esses insetos penetram nos ouvidos das pessoas quando elas dormem. A palavra earwig também significa contar ou insinuar algo ao

\footnotetext{
${ }^{126}$ A palavra "messias" vem do hebraico e quer dizer "ungido" (משיה pron. /machiakh/). Aparece, pela primeira vez na Bíblia em Levítico IV, 3: "se o sacerdote que recebeu a unção, é quem pecou, fazendo pecar o povo; oferecerá ao Senhor pelo pecado um novilho, que não tenha mancha”. É o cordeiro de Deus que tira os pecados do mundo. O termo foi utilizado no Novo Testamento em João I, 41: "Temos achado o Messias (que quer dizer o Cristo)". Cristo é a palavra grega, Xpı $\sigma \tau \varsigma$, para "ungido". [Todas as traduções da Bíblia são do Padre António Pereira de Figueiredo, exceto em algumas passagens do glossário em que indicamos outro tradutor.]

${ }^{127}$ Ave mítica que, no deserto da Arábia, renascia das próprias cinzas. Esse mito está relacionado ao da ave egípcia bennu, mencionada por Heródoto. A palavra é de origem grega, фolvı $\chi$, palavra homógrafa à que significa fenício (vermelho), talvez por causa da coloração da plumagem da ave. Em português, a pronúncia correta é /fênis/ e pode ser grafada "fênice".

${ }^{128}$ A crítica não chegou a um consenso sobre isso. Não se sabe quem sonha em Finnegans Wake. O primeiro a procurar uma identificação foi Edmund Wilson, que se refere a Porter como o sonhador. Campbell e Robinson concordam com ele. Parece que o primeiro a discordar foi Ruth von Phul, que acredita tratar-se de um sonho de Jerry, filho de Porter. Clive Hart, em seu Structure demonstra a inconsistência das idéias de Phul (cf. HART, 1962, p. 80). Hart afirma também que Porter não é o sonhador, mas apenas uma forma de encarnação de HCE (HART, 1962, p. 83). No entanto, John Bishop, em sua introdução à edição de 1999 de $F W$, ainda se refere a Porter como o sonhador. A posição mais consistente parece ser a de Hart, não no que se refere a Porter, mas à afirmação de haver um narrador em $F W$ que seria quem tudo sonha, porque o livro, sendo escrito todo numa linguagem de sonho, evidenciaria a presença de um narrador-sonhador; contudo, dentro desse sonho do narrador, o principal sonhador seria, para Hart, HCE. É plausível que haja mesmo um narrador-sonhador, e ele seria Finn MacColl. O próprio Joyce falou de sua obra como um sonho de Finn MacCool, ou seja, da Irlanda.

${ }^{129}$ A cerveja é uma espécie de patrimônio cultural da Irlanda. A cervejaria Guinness (Arthur Guinness Son \& Co. Ltd), por exemplo, é mencionada ao longo de todo o Finnegans Wake. Porter é uma cerveja da família Ale (cerveja de alta-fermentação), feita com malte torrado e de cor escura.

${ }^{130}$ Inseto dermáptero: Forficula aricularis Linnaeus.
} 
ouvido de alguém, como se estivesse contando um segredo. E esse segredo é uma das características do livro: não é apenas o sentimento incestuoso, mas também a própria estrutura do livro, do sonho, que se apresenta sempre de maneira velada, necessitando de interpretação.

O pecado do incesto oculta-se no sonho por condensação, um processo que ocorre também no ato falho, ou lapso de linguagem, e que consiste numa sobreposição de conteúdos, como a formação de palavras-valise ou o uso de trocadilhos na literatura ou nos chistes, a polifonia ou sobreposição de acordes na música, alguns recursos da pintura cubista, etc. Joyce incorpora tudo isso a sua obra, não apenas para descrever o sonho do ponto de vista do sonhador, mas também para descrever os processos da História.

Vico acreditava que a História era criação do homem, mas que Deus criara o tempo junto com o mundo. A História humana só começaria, pois, no momento em que o homem fosse expulso do Paraíso, pois então teria ele de criar as condições para a própria existência, o trabalho, os instrumentos com os quais mudaria o mundo; enfim, a própria história. Como o homem tinha sido expulso do Paraíso por causa do pecado, pode-se inferir que o pecado terá como conseqüência a História. O pecado é o fruto da árvore do conhecimento; as sementes desse fruto fizeram germinar a História. Mas, para Joyce, Deus é quem pecou primeiro, pois foi o responsável pela criação do homem. Assim, o pecado é a própria criação, e Deus, não o homem, seria responsável pela presença do pecado na História ${ }^{131}$. O homem, por sua vez, por ser temente a Deus, procuraria ocultar os pecados de Deus (ou do pai, do primeiro chefe de tribo) por meio da sublimação ou, num sentido mais amplo, por meio da cultura. Por causa disso, a História tornou-se uma farsa, ou algo que só poderia ser interpretado por meio de uma revelação; ou seja, por meio da retirada do véu. É por essa razão que a História humana, em Finnegans Wake é contada num sonho; por que ali ela se apresenta em sua forma latente, tal como ela foi, tal como ela se processou. Finnegans Wake é essa História do pecado, representada por meio de um sonho latente, quer dizer, tal como foi sonhado.

O pecado, como a História, tem de ser oculto para não tirar a majestade totêmica de Deus. Não apenas oculto como também diminuído. O pecado de Porter, o incesto, faz com que ele, pecador, ao dormir se transforme num inseto, uma criatura insignificante, HCE. Mas a partir daí, porque a História tem de continuar, o pecado tende a se transformar, crescer, e

\footnotetext{
${ }^{131}$ O pecado é uma transgressão religiosa, moral ou legal presente em diversas culturas ao longo da História. Para os hebreus, o pecado era a transgressão da lei (Torá). Os missionários cristãos, ao entrarem em contato com povos que não entendiam o conceito de pecado, transgrediram um fundamento jurídico, pois, para ensinar a esses povos o sentido do termo, tiveram de introduzir o pecado em suas culturas.
} 
torna-se cada vez mais difícil de ser ocultado. E será num gesto acidental, provocado pelo sentimento de culpa, que o pecado de HCE se revelará a todos.

Uma noite, HCE surpreendeu duas moças no Parque Phoenix, em Dublim; elas talvez estivessem urinando, de acordo com uma das versões do fato. Três soldados, que por ali passavam, viram HCE a observar as moças sem entenderem muito bem o que se passava. Logo, uma história começou a se difundir pela cidade, que especulava sobre o que haveria de fato ocorrido naquela noite. Durante outro passeio pelo Parque, HCE tornou a encontrar um dos soldados que o surpreendera antes; o soldado apenas lhe pergunta as horas, mas HCE, pensado que se tratava de um interrogatório, ficou perturbado e começou a gritar que nada havia acontecido e que tudo era mentira. Isso bastou para que fosse incriminado. Levado a julgamento, é condenado a uma prisão submersa, onde o corpo dele permanece inerte.

Uma carta, escrita pela esposa, Anna Livia Plurabelle, ALP, poderá inocentar HCE, mas a carta se perde e será, mais tarde, encontrada num monte de esterco por uma galinha, ou pela arrumadeira ${ }^{132}$. Um dos filhos do casal, Shem (o próprio Joyce ${ }^{133}$ ), atuando como escriba, copia a carta; mas o outro irmão, Shaun ${ }^{134}$, a publica como se tivesse sido ele mesmo o autor.

Tudo isso ocorre na primeira parte do livro. As partes seguintes concentram uma espécie de disputa entre Shem e Shaun e, durante todo o transcorrer do livro, a pena de HCE continua a ser cumprida e julgada. Ela cessa apenas nos momentos de vigília, no contato com o trabalho cotidiano (sublimação), para reaparecer em outro sonho e transbordar para o sonho de outros. O pecado de HCE, que é o pecado de toda a humanidade, passa de um sonho para outro, pois o pecado (peccō) de Adão (ou de Deus) passou de um homem para outro, contaminando toda a humanidade, até que veio o cordeiro $(p e c u)^{135}$ de Deus para tirar o

${ }^{132} \mathrm{O}$ nome da galinha é Biddy, palavra que tem três diferentes sentidos: galinha, arrumadeira e mulher alcoviteira.

${ }^{133}$ Shem: forma irlandesa de James; relaciona-se ao apóstolo Tiago, autor de um evangelho, considerado apócrifo pela Igreja. Tiago deriva do grego Iacobos, suplantador (uma indicação de que Shem seria o substituto de HCE), que, por sua vez, vem do heb. Iacob; passou para o latim como Iacomus; daí as formas modernas: it. Giacomo; fr. Jacques; ing. James; esp. Iago. Da localidade de Santiago (San Iago), deriva o nome port. Tiago (interpretado como São Tiago, em vez de Santo Iago, como deveria ser).

${ }^{134}$ Shaun: forma irlandesa de John; relaciona-se com o apóstolo João, tradicionalmente considerado também autor do Apocalipse ou Revelations [Livro das Revelações], em inglês.

${ }^{135}$ Não existe relação etimológica entre peccō, āre (tropeçar, pecar) e pecu, gado (do qual derivam termos como pecúnia, pecúlio, pecuária, todos relacionados com dinheiro), mas as duas palavras formam um trocadilho entre si. No original bíblico, há também um trocadilho (etimológico, contudo): o cordeiro (mencionado em

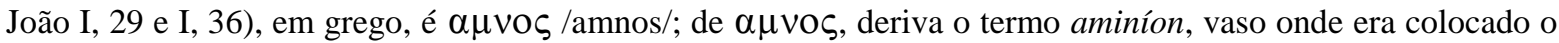
sangue dos animais imolados (refere-se hoje à placenta). O evangelista escolheu bem o termo cordeiro, pois reforça as relações entre o cordeiro, o sacrifício e a taça de vinho (sangue) da última ceia. 
pecado do mundo. Surge então a necessidade do batismo (imersão), momento em que o pecado original é retirado do homem.

\subsection{Peccata mundi}

A Bíblia representa o pecado de maneira concreta: pela queda. Em latim, o verbo pecar - peccō, peccare - significa dar um passo em falso, tropeçar; ${ }^{136}$ cair, portanto. A primeira queda que ocorre em Finnegans Wake é a queda de Finn MacColl (ou Finn Mac Cumhaill), que já aparece caído no primeiro parágrafo do livro (pelo menos é o que se pode inferir). O gigante, cujo corpo morto forma o relevo da cidade de Dublim, é o pai de Óssian (ou Óisin), o bardo que cantou a saga do clã dos fiannas, uma raça de guerreiros irlandeses que participaram das guerras de Fingal. As sagas cantadas por Óssian, e atribuídas a MacPherson ${ }^{137}$, tornaram-se um dos maiores monumentos do romantismo por todo o mundo $^{138}$, a ponto de o valor de Óssian ser comparado ao de Homero. Esse pormenor é importantíssimo para se entender o propósito de Finnegans Wake, a outra epopéia de Finn. Finn foi o pai de uma raça de guerreiros e também de poetas. A próxima luta dessa raça seria travada no papel. Foi o que Joyce propôs ao final de seu primeiro romance, A Portrait of the Artist as a Young Man:

Saio a procurar pela milionésima vez a realidade da experiência e a forjar na frágua da minha alma a consciência ainda não engendrada de minha raça. [...] Meu pai, antigo artífice, amparame e ajuda-me agora e sempre. ${ }^{139}$

O que impede essa raça de crescer, de se desenvolver, é a religião, o catolicismo, imposto aos pagãos da Irlanda e mencionado na primeira página de Finnegans Wake, em que Santa Brígida, diz, ao ser convertida: "mishe, mishe" (FW 003.09). O batismo de Santa Brígida representa a introdução do pecado na ilha, contraditoriamente ilustrado pelo batismo. O pecado, todavia, não se revelava por meio da palavra; a palavra era aquilo que estava

\footnotetext{
${ }^{136}$ Em hebraico, também tem sentido concreto. Na Bíblia, a palavra pecado, que aparece pela primeira vez em Gênesis IV, 7, é חטאה (/khata'/), desviar-se, perder-se.

${ }^{137}$ James Macpherson (1736-1796). Poeta e lingüista escocês. Traduziu antigos poemas gaélicos, atribuídos a Óssian. O crítico Samuel Johnson questionou a autenticidade dos poemas, declarando que eram falsificações feitas pelo próprio MacPherson. Hoje, acredita-se que pelo menos uma parte desses poemas seja original.

${ }^{138}$ Goethe traduziu trechos inteiros das baladas de Óssian no Werther. Hegel elogia os poemas na Estética e diz que seria impossível que se tratasse de falsificações. Óssian era admirado até no Brasil, por exemplo, por Álvares de Azevedo.

${ }^{139}$ I go to encounter for the millionth time the reality of experience and to forge in the smithy of my soul the uncreated conscience of my race. [...] Old father, old artificer, stand me now and ever in good stead (JOYCE, 1996, p. 288).
} 
escrito na Bíblia. Era preciso interpretar a palavra para que o pecado se mostrasse. Mas interpretar a Bíblia também era proibido, e era crime grave, punido com a morte na fogueira, morte essa que tinha o sentido de expiação, de sacrifício ${ }^{140}$. A Bíblia não podia ser lida pelo povo, que não sabia ler, e nem entendida, pois a única versão autorizada pela Igreja era a Vulgata, a tradução latina organizada por São Jerônimo no século IV. A religião não era difundida pela palavra, mas pela doutrina interpretada. Além disso, no decorrer da Idade Média, a leitura tornava-se mais complexa ainda, por causa das elaborações caligráficas que acabavam resultando em escritas cada vez mais elaboradas como a do Livro de Columba, ou Livro de Kells.

O Livro de Kells tem uma escritura tão intrincada que o exercício de lê-lo é um verdadeiro trabalho de interpretação. Trata-se de uma compilação dos Quatro Evangelhos, com comentários e notas introdutórias, elaborada por monges celtas na Idade Média e que se encontra hoje no Trinity College, em Dublim. É uma obra-prima de iluminuras e - a despeito do trocadilho - também de obscurantismo.

A escrita de Finnegans Wake também se baseia no Livro de Kells. E, como ele, pretende ocultar o pecado, a História e a palavra; mas, ao mesmo tempo revelando-os na forma em que se encontram, herméticos. Joyce escolhe, em vez do latim, um idioma por ele inventado, no qual se misturam as palavras do inglês entre si e palavras de línguas diferentes umas com as outras. O propósito dele é reproduzir a linguagem do sonho em seus aspectos latente e manifesto. Para isso fez uso de neologismos, trocadilhos, hibridismos e diversas formas de criação de palavra e jogos verbais.

A queda do homem relaciona-se a um problema antropológico que está na origem das tribos e dos clãs, e foi estudado por Freud e relatado no livro Totem e tabu. O chefe da primeira linhagem era senhor absoluto de todas as mulheres da tribo, inclusive das próprias filhas. Ao tomar todas as mulheres para si, acabou recebendo a oposição dos filhos, os varões da tribo. Era uma oposição tímida, velada, pois eles não tinham força nem poder para suplantar o pai. Resolvem então se unir para enfrentá-lo e o matam e esquartejam. Por se tratar de uma desobediência, de um crime, a morte do pai se transforma também num pecado, e os filhos, para expiar esse pecado, elevam o pai morto à condição de Deus, criando para ele um totem, cuja base representa o fundador da tribo ou do clã. Morto o pai e consagrado, os

\footnotetext{
${ }^{140} \mathrm{O}$ ato de sacrificar algo para Deus por meio do fogo é expressado, na Bíblia, pelo mesmo verbo traduzido como pecar. O tipo de sacrifício pelo fogo chamava-se holocausto.
} 
filhos terão de lutar pelo posto do chefe, promovendo uma luta fratricida, em que o vencedor, enquanto estiver vivo, ocupará o lugar do pai no trono da tribo e, quando morto, será colocado junto ao pai no totem da tribo. A culpa acabou sendo sublimada e atenuada pela religião, transformou-se em religião. Religião é, portanto, culpa; a religião é a concretização do pecado.

Este é o fulcro mais importante do livro de Joyce: a luta dos irmãos para tomar o lugar do pai. É a luta dos filhos de Adão, dos filhos de Noé, dos filhos de Isaque: Esaú e Jacó. É também a luta de James (Shem) Joyce contra seu irmão John (Shaun) Stanislau Joyce pela bênção do pai. Entre irmãos e entre pais e filhos (Parnell e Healy, César e Brutus), estabelecem-se os conflitos que percorrem as páginas do livro, que percorrem os sonhos, que percorrem a História. E a História é, em última análise, produto do conflito entre a ordem e a anarquia, entre o desejo e a subilmação, entre o prazer e o pecado. Totem e tabu são indiscutivelmente elementos de formação de Finnegans Wake:

“As mais antigas e importantes proibições ligadas aos tabus são as duas leis básicas do totemismo: não matar o animal totêmico e evitar relações sexuais com os membros do clã totêmico do sexo oposto. Estes devem ser, então, os mais antigos e poderosos dos desejos humanos" (FREUD, Totem e tabu) ${ }^{141}$

O pecado de HCE, que equivale ao poder, será transmitido aos filhos. A carta, a boa nova, que inocentaria HCE, foi escrita por Shem, o escriba, como é identificado no livro, e roubada por Shaun, o carteiro, ou apóstolo, que a recompõe e imprime no próprio corpo, deturpando-a ou tornando-a ininteligível.

A mensagem que o evangelho (a boa nova) transmite teria sido deturpada pelos apóstolos, ou mensageiros, para favorecer a doutrinação eclesiástica. Os evangelhos e toda a literatura neotestamentária serviram de pretexto para a fundação da Igreja, que teve em Pedro sua pedra fundamental. O trocadilho de Pedro com pedra ${ }^{142}$ é mencionado na abertura de Finnegans Wake. Mas há também um indício de que a boa nova, assim como o Finnegans Wake, era para ser ouvida e não lida, pois o nome de Pedro era Simão ${ }^{143}$, que, em hebraico, significa “ouvido, escutado". E toda a palavra de Deus seria ouvida, doravante, pelo fiel,

\footnotetext{
${ }^{141}$ S. Freud, Edição eletrônica brasileira das obras psicológicas completas.

${ }^{142}$ Ver "Glossário", 003.10.

143 שמען (/chimon/).
} 
dentro da igreja. A mensagem escrita no corpo de Shaun é a mensagem dos apóstolos, do Livro de Kells e da Igreja.

A mensagem evangélica não é, contudo, positiva: "Desperta tu que dormes, e levantate dentre os mortos." ${ }^{144}$ Ao lermos, pensamos que se trata de uma mensagem de vida. Não é. Toda a fé cristã tem como fundamento a morte. E como fim, a ressurreição na cidade de Deus, a Nova Jerusalém, que não é o mundo dos vivos, e sim dos reencarnados. A mensagem é clara: abdicar de tudo desta vida, e, acima de tudo, do prazer, como forma de preparação para a vida eterna, que é uma incógnita.

A fé na reencarnação é comum em diversas religiões, mas foi mais forte entre os egípcios do que em qualquer outra religião antiga, provavelmente. Para o egípcio, o homem era composto de quatro elementos: o $\mathrm{Ka}$, réplica imaterial do corpo; o $\mathrm{Ba}$ (Bai), a alma propriamente dita; o Khu, a chispa do fogo divino; e o corpo. O corpo era a habitação do Ka e

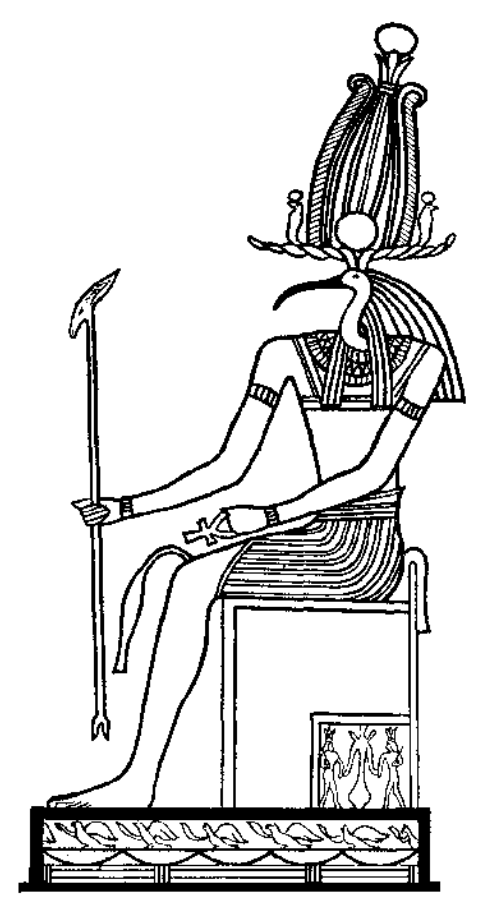
tinha de ser preservado, por isso davam os egípcios tanta importância ao embalsamamento ou à representação de uma efígie do corpo. O Ka permanecia vivo na múmia ou nos retratos no interior dos túmulos, que encerravam também disposições escritas para a preservação do Ka. Parte desses escritos compõe o Livro dos mortos, ou Reu nu pert em Hru (Capítulos do sair da luz).

Catalogado e traduzido por um egiptólogo ${ }^{145}$ do Museu Britânico, o Livro dos mortos, apareceu em forma de livro em 1909, chamando a atenção de muitos intelectuais e místicos da época. Esse livro foi uma das principais fontes de Finnegans Wake, cujos personagens assumem, em algumas passagens, características ou atributos próprios de entidades egípcias como é o caso do próprio HCE (Osíris) e de Shaun (Tote; figura acima).

O sepultamento de HCE num túmulo submerso é uma alusão ao destino de Osíris. Osíris era o deus mais adorado em todas as terras do Egito. Por inveja, seu irmão, Sete, preparou-lhe um ardil e aprisionou-o num cofre que, depois, lançou às águas do mar, ou do Nilo. Ísis, irmã e esposa de Osíris, resgata o corpo morto do marido e o esconde. Mas Sete o encontra e o desmembra, espalhando os pedaços por todo o Egito. Isís dedica-se depois a

\footnotetext{
${ }^{144}$ Efésios, V, 14.

${ }^{145}$ Sir Ernest Alfred Thompson Wallis Budge (1857-1934). Filólogo, orientalista e egiptólogo inglês.
} 
buscar os restos do marido e consegue recuperar todas as partes com exceção do pênis, que é representado em Finnegans Wake pelo Memorial de Wellington. Ela junta os pedaços que pôde reunir, recompõe o corpo de Osíris e o embalsama. Essa é a explicação mitológica da origem do processo de embalsamento. Osíris reinará no reino dos mortos onde caberá a ele julgar os que para ali vão, pesando-lhes os corações numa balança que determinará o destino das almas deles.

Por outro lado, os irmãos Shem e Shaun são representações do deus Tote. Tote é associado, pelos gregos da época helenística, ao deus grego Hermes, o mensageiro de Deus; nessa condição, ele é Shaun, descrito em Finnegans Wake como o postalista. Mas Tote é também Hermes Trismegisto, responsável pela literatura hermética (relativa a Hermes) e, portanto, o próprio Joyce, ou Shem (autor de Finnegans Wake). Entre seus diversos atributos, Tote tinha também, para os egípcios, o da criação da escrita, a separação das línguas e a invenção de palavras e, portanto, é representado no Finnegans Wake, por Shem, o escriba. ${ }^{146}$

No Apocalipse (XXII, 13), Jesus diz, repetindo as palavras de Kṛ̣ṇa no Bhagavad Gìtā: "Eu sou o Alfa e o ômega; o primeiro, e o último, princípio e fim.",147

No que diz respeito ao tempo, a História não tem princípio nem fim, como o Finnegans Wake, por que é cíclica. Mas se a História foi criada pelo homem, o homem é o princípio e o fim da História. E se suas sementes estão no pecado, como parece indicar o Finnegans Wake, então o princípio gerador, o fruto, da História é a mulher, o primeiro a pecar. Ela é o Alfa. E se, por outro lado, a História reproduz sempre a luta de irmãos pelo lugar do pai, então o fim da História, ou a finalidade, é sempre o pai, ou o homem. O homem é o Ômega.

No Finnegans Wake, Anna Livia Plurabelle, o rio, é o início, e HCE, a terra, é o fim. ALP é o alfa, representado pela disposição de palavras no início do capítulo VIII, que trata de Anna Livia, e pelas três primeiras letras que forma a palavra Alpha, ALP, latinizada. A personagem de $\mathrm{HCE}$, é muitas vezes representada por hieróglifos que representam três primeiras letras da palavra Ômega em caracteres gregos: $\omega \mu \varepsilon \gamma \alpha$ (com a letra inicial minúscula); se deixarmos essas letras mais retas, teremos: Ш $\mathrm{m} \mathrm{E}$ (OME). Essas letras retas,

\footnotetext{
${ }^{146}$ Ver A. Glasheen, Third Sensus of Finnegans Wake, 1977, p. 281-2

${ }^{147}$ No Bhagavad Gìtā (X, 20), Kṛ̣ṇa diz: "Eu sou o princípio, o meio e o fím de todas as coisas."
} 
três das quatro posições da letra E, são símbolos que representam HCE (sua queda, sua ascensão, seu avanço, seu regresso) ao longo do livro e dos manuscritos. ${ }^{148}$

Finnegans Wake é um livro de um escritor quase cego, escrito ao longo de uma enfermidade nos olhos que se agravava cada vez mais e que o obrigou a diversas cirurgias oculares. O livro todo é trabalhado no aspecto sonoro, muito mais do que no visual, e seria mais bem apreciado - ou compreendido - se fosse recitado em vez de lido. Quando lhe disseram que a linguagem do livro era obscura, Joyce respondeu:

Confesso que não entendo alguns de meus críticos [...] Eles dizem que ele [Work in Progress $]^{149}$ é obscuro. [...] a ação de minha nova obra ocorre à noite. É natural que as coisas não sejam claras à noite, não é? [...] O mundo da noite não pode ser representado na linguagem do dia. [...] É simples. Se alguém não entende uma passagem, tudo o que tem de fazer é lê-la em voz alta. ${ }^{150}$

A degradação visual do autor não justifica a linguagem empregada no livro. Essa linguagem já fora esboçada em Ulysses, e Finnegans Wake foi escrito com ela desde os primeiros esboços, em 1922, época em que os problemas oculares de Joyce não estavam tão graves. O fato de terem-se agravado apenas serviu para que essa linguagem fosse mais convincente em algumas passagens. Ela teria de ser obscura como a noite, e velada como o sonho. Mas que espécie de sonho?

O Antigo Testamento afirma explicitamente que a visão de Deus era terrível; todo aquele que visse a face de Deus morreria. No entanto, Deus aparecia para os profetas; aparecia em sonhos e, mesmo assim, não mostrava sua figura. O que os profetas viam nos sonhos eram imagens de "pessoas, animais, objetos, processos, como os que ocorrem na vida e na natureza, algumas vezes com figuras mitológicas ou celestiais, mas nunca Deus em pessoa." ${ }^{151}$ Contudo, o que predominava não eram as imagens. "Nas visões, o aspecto auditivo predomina sobre o elemento visual. É uma revelação por palavras em vez de por

\footnotetext{
${ }^{148}$ Joyce fazia anotações nos manuscritos com diversas cores e utilizando símbolos para que ficasse mais visível para ele, cujos problemas nos olhos se agravavam.

${ }^{149}$ Título provisório de Finnegans Wake.

150 "I confess I can't understand some of my critics [...] They say it's obscure. [...] the action of my new work takes place at night. It's natural things should not be so clear at night, isn't it now? [...] The night world can't be represented in the language of the day. [...] It is all so simple. If anyone doesn't understand a passage, all he need do is read it aloud." (ELLMANN, 1983, p. 590)

${ }^{151}$ VanGemeren (Ed.), Novo Dicionário Internacional de Teologia e Exegese do Antigo Testamento. No prelo. Verbete: 8011 - ראה ("Ver").
} 
figuras." $152 \mathrm{O}$ mesmo se pode dizer de Finnegans Wake. É um sonho em que o elemento auditivo predomina sobre o visual. Não é um sonho qualquer, a simbologia psicológica - e os processos de elaboração onírica - é secundária em relação ao fato de Finnegans Wake ser um sonho profético.

Se as lições de Escolástica, que teve nos colégios jesuítas por que passou, inspiraram James Joyce para a criação do conceito de epifania na literatura, conceito esse que é, na verdade, um elemento estético, e que aparece em toda obra do autor até o Ulysses, em Finnegans Wake esse conceito será substituído pelo de teofania que é a manifestação de Javé a seus profetas, predominantemente em sonhos e por meio de palavras e não de imagens.

A profecia era uma forma de se narrar a História. Pretendia contar a História do futuro, das coisas que ainda não haviam sido. Mas na maioria das vezes a profecia era feita sobre coisas já passadas e narradas como se ditas antes dos acontecimentos previstos por ela, uma farsa semelhante à dos oráculos de Apolo. A profecia percorre, portanto, diversas direções no tempo, abrangendo toda a História: é a manifestação de Deus na História. Não apenas de Javé, mas de qualquer deus, em qualquer cultura. Podemos observar o mesmo em Homero, por exemplo. Não foi à toa que James Joyce decalcou seu livro numa obra filosófica que tratava justamente da História. Ao escrever um livro cuja linguagem simula a linguagem dos sonhos - a voz de Deus a seu profeta - e apresenta uma Filosofia da História, teve de lidar com duas outras questões: o tempo, que precisava ser suprimido, para que a História corresse em várias direções; e o mito, que precisou ressurgir, para que a História corresse de volta àquela época em que o passado era toda a eternidade: o tempo mítico.

\section{3. Conclusão}

A enorme dificuldade que a leitura e a intelecção do texto de Finnegans Wake apresentam, e o fato de que rompe com o gênero e com as estruturas narrativas tradicionais, de maneira radical, podem nos dar a idéia de que se tratava de algo inédito, de um texto escrito por um revolucionário, um louco ou por alguém que não tinha mais o que inventar.

Ezra Pound pensava que Finnegans Wake não tinha valor estético e era uma brincadeira exagerada e desnecessária com as palavras. Era obra de alguém que não tinha mais o que inventar.

${ }^{152}$ VANGEMEREN (Ed.), Verbete: 8011 - ראה (“Ver”). 
O psicólogo Jacques $\operatorname{Lacan}^{153}$ acreditava que Joyce era um psicótico e que Finnegans Wake fosse uma obra desprovida de significado. Há uma obra de Lacan, "Seminário 23" 154, em que Joyce é analisado como paciente. As conclusões do texto, em linhas gerais, são de que Joyce sofria de um surto psicótico quando escreveu Finnegans Wake e, como a alma do psicótico é impenetrável, o livro de Joyce também seria, não produzindo, portanto, significados que pudessem ser interpretados. E, como não produz significado, como não pode ser interpretada, não pode ser traduzida.

Se colocarmos estes dois adversários de Joyce, Pound e Lacan, um contra o outro, talvez possamos responder se a obra em questão pode ou não pode ser traduzida. Pound advogava que a tradução deveria observar três aspectos do texto original e procurar transpôlos para a língua a que o texto seria traduzido. São eles: melopéia, fanopéia e logopéia. A melopéia diz respeito à carga melódica das palavras ou do texto exercida sobre o significado; a fanopéia é o aspecto imagético do texto; e a logopéia, a maneira própria como as palavras são empregadas (Pound, 1976, p. 37-8). A questão é: em qual desses aspectos o livro de Joyce não produz significado?

Quando Lacan fala de significado e tradução, entende tradução como a mera transposição semântica de uma língua (ou código) para outra. É o ofício do tradutor juramentado. Mas, e os outros aspectos? São intraduzíveis? Não reforçam eles o significado do texto? Se nos fiarmos nas palavras de Lacan teremos de esquecer as de Pound e ignorar o debate histórico em torno da tradução, aceitando como vencedor desse debate os apologistas da tradução semântica. Isso significaria ignorar também um aspecto fundamental para a Literatura: a maneira pela qual as culturas influenciam umas às outras e são enriquecidas por essa influência. Foi justamente porque os tradutores não se ativeram meramente aos aspectos elementares das línguas e da tradução que a cultura, as línguas e as literaturas evoluíram.

Nesse sentido, faz sentido trabalhar-se com um texto como Finnegans Wake. É o que discutiremos no capítulo seguinte. Traduzir Finnegans Wake não é apenas um trabalho lingüístico, mas um propósito.

\footnotetext{
${ }^{153}$ Jacques-Marie Émile Lacan (1901 -1981). Psicólogo francês.

${ }^{154}$ Lacan, Edição eletrônica. Cf. HARARI, 2003 e ESTEVES, 1999.
} 
Papiro de Ani, cujo coração está sendo pesado por Osíris.

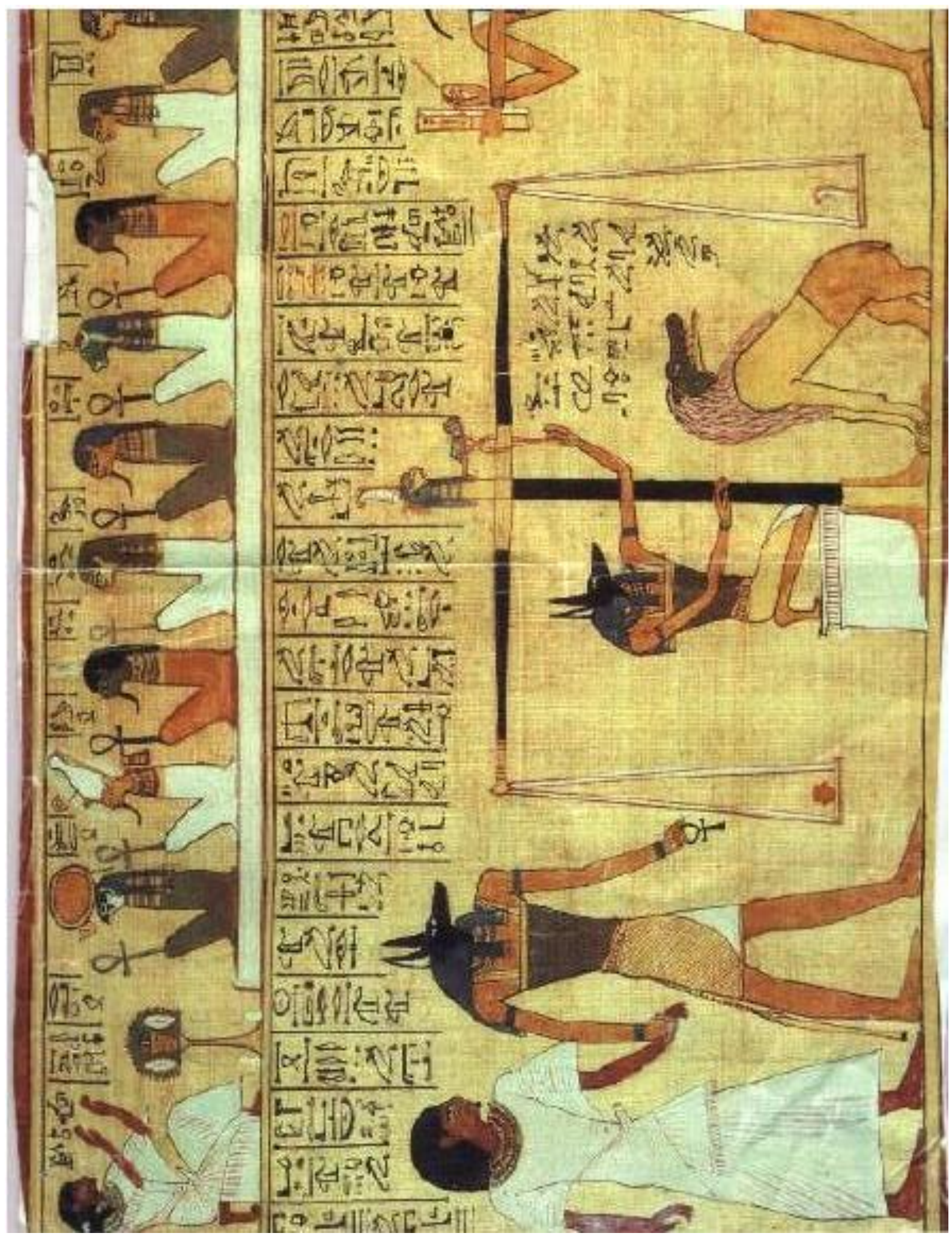




\section{Teleopéia}

\section{INTRODUÇÃO}

O desenvolvimento da idéia, de tempos em tempos, exige que toda a obra do espírito seja negada. Há duas explicações: uns falam de saturação, outros falam de envelhecimento. Os primeiros dão o exemplo de uma doutrina que se firma e só pode ser dobrada pela força de outra mais vigorosa cuja vitalidade foi adquirida à custa da primeira; os últimos afirmam que uma doutrina caduca porque o seu tempo passou e só resta a ela retirar-se de cena e dar lugar a uma substituta. As duas explicações assemelham-se muito, mas são radicalmente distintas. Apenas uma delas leva em conta a evolução: a primeira. Negar as obras que o Espírito empreendeu no passado não significa rechaçá-lo, mas identificar suas contradições, adquiridas em sua luta por ser livre, para poder superar a si mesmo. A ciência só avança nesse sentido. E é esse sentido que vem sendo negado a ela.

Um dos ramos da atividade intelectual humana, da ciência portanto, que atingiu esse limite foi a tradução. Da mesma forma que a pintura viu-se no desígnio de abandonar o retrato quando foi inventada a fotografia, a tradução está prestes a abandonar o seu desígnio por causa das novas técnicas que, apesar de serem ainda rudimentares, substituirão inexoravelmente o homem nesse ofício. Para que ela sobreviva terá de evoluir.

A evolução já está contida na gênese. Os organismos sabem de antemão que terão de evoluir, só não sabem quando. O momento certo para isso é aquele em que as contradições começam a surgir; no entanto esse também é o momento de maior reação a ela.

A teoria da tradução nesta época procura acima de tudo retratar o ofício. A maior parte dos ensaios críticos trata de temas como a fidelidade da tradução, a ética do tradutor, normas de tradução, o que pode ou não ser traduzido, como traduzir, etc. Esses temas são descritivos, nada dizem a respeito do futuro; antes, constatam uma situação que é, a mais das vezes, humilhante para o próprio tradutor, que tem de aceitar a tradução como um ofício servil, sujeitando-se a uma indústria que tem suas próprias normas a respeito da técnica e até mesmo da própria língua, instrumento do ofício. Para essa indústria, que procura de certa forma ser proprietária até mesmo da língua escrita, o que importa não é o tradutor, mas a propriedade de direitos sobre a tradução. 
A tradução tornou-se um trabalho, não apenas subalterno, mas de alienação: o tradutor, diferentemente do autor, não sabe o que vai acontecer a sua obra. Sabe porém o que vai, mais cedo ou mais tarde, acontecer ao seu ofício. Para o tradutor só resta uma saída: evoluir.

Já é hora de os teóricos pensarem nisso e começar a evoluir também. Até agora eles se limitaram a descrever a atividade do tradutor e viram nele o produto de uma sociedade civil produzindo para uma sociedade civil. O tradutor, como o teórico de sua atividade, deverá deixar de considerar a sociedade civil para enxergar a sociedade humana. ${ }^{155}$ A tese é de $\operatorname{Marx}^{156}$ (MARX, 1982, v. 1, p. 3.). O tradutor deve, desde já, deixar de ser um intérprete dos pensamentos do autor; já não interessa interpretá-los, mas superá-los.

Um importante teórico da tradução, Friedrich Schleiermacher (1768-1834) afirmou que para o tradutor não havia senão duas possibilidades: levar o autor até o leitor (tornar o texto fluente na língua para a qual foi traduzida) ou levar o leitor até o autor (manter o que o texto tem de estranho ao universo da língua para a qual se o traduz). Essa retórica, que influenciou toda a teoria depois dele até hoje, estava mal orientada desde o princípio. Melhor seria perguntar aonde o texto pode levar o leitor.

Quem menciona os métodos de traduzir de Schleiermacher é o filósofo espanhol Ortega y Gasset (ORTEGA Y GASSET, 1947, p. 448), que acredita, como o outro, que só existe tradução quando se obriga o leitor "a se mover dentro dos hábitos lingüísticos do autor". Nesse movimento, a tradução deverá renunciar a um propósito estético em nome do exótico, da clareza, do científico. Ou seja, deverá deixar de dizer muitas coisas: "Um ser que não fosse capaz de renunciar a dizer muitas coisas, seria incapaz de falar" (ORTEGA Y GASSET, 1947, p. 444).

Mas não estamos nós diante de uma renúncia quando falamos de tradução, e sim diante da necessidade de falar. Se a tradução se dá em nome da clareza, para que se descortine um mundo que a diferença lingüística toldava, será preciso também mostrar-lhe a forma.

Talvez tenha sido o poeta inglês John Dryden (1631-1700) a classificar pela primeira vez as espécies de tradução: metáfrase, paráfrase e imitação. A metáfrase é o tipo ideal de que

\footnotetext{
${ }^{155}$ Venuti defende também uma participação do tradutor na sociedade. Ver VENUTI, 2002, cap. 1 e 7.

${ }^{156}$ Karl Heinrich Marx (1818 - 1883). Filósofo e economista alemão. Manifesto do Partido Comunista (1848); O capital (1867); etc.
} 
nos fala Ortega y Gasset. É um pouco diferente da tradução literal, pois permite ao tradutor arranjar as palavras de acordo com a sintaxe da língua para a qual traduz. O que Dryden chama de paráfrase ("tradução com latitude" ou uma tradução na qual se acompanha o texto original permitindo-se, quando muito, ampliações, mas nunca alterações) é aquilo que a maioria das pessoas entende hoje em dia por tradução. E, por último, há a imitação, na qual o tradutor aproveita do original apenas a idéia.

Essas espécies se assemelham às propostas pelo escritor russo Vladímir Nabókov (1899-1977). No prefácio de sua tradução do Ievguêni Oniéguin de Púchkin, Nabókov chama a tradução de parafrásica quando o tradutor procura reproduzir os aspectos formais, estilísticos do original; de lexical, a mera versão do sentido básico das palavras (que é o que fazem hoje em dia os programas de tradução); e de literal a tradução que "verte, tanto quanto as possibilidades associativas e sintáticas da outra língua o permitem, o significado contextual exato do original” (Pushkin, 1964, p. viii). Para ele, apenas esta última espécie é de fato tradução.

Não são significativas as diferenças entre uma e outra classificação, e a maioria dos classificadores dividem o gênero em três, prestando um tributo a Dryden.

Algo que intriga o pesquisador da teoria da tradução é essa divisão tríplice: por que o número três? É certo que se trata de uma simplificação e que poderia ser elaborada de outro modo. Talvez fosse mais abrangente uma divisão que contemplasse também a paródia e que diferenciasse a tradução semântica da literal, como fazem alguns.

A tradução precisa ser sistematizada, precisa ser explicada porque é uma atividade da sociedade civil e, portanto, sujeita às leis e à interpretação jurídica. O plágio, que é outra forma de tradução, é considerado uma atividade ilícita a não ser que a obra plagiada já se encontre em domínio público, ou que o autor permita, com o consentimento da sociedade, que seja plagiada; mas nesses casos não recebe mais o nome de plágio e sim de adaptação.

Num certo sentido, tudo o que o homem cria é tradução. E tudo o que dissermos o será. Por que, então, o cuidado em querer definir o sentido da tradução, desvinculando-o de conceitos como paródia, paráfrase, plágio, etc.? A classificação é uma atividade que tem origem no comércio, no inventário jurídico ou comercial, e definir a tradução é tomá-la como mercadoria ou como algo inseparável de uma atividade mercantil. Essa taxonomia impõe ao ofício limites. Não se pode, contudo, impor limites à arte além dos limites que lhe são 
inerentes, seus limites físicos ${ }^{157}$. E se considerarmos a tradução como arte, a ela não caberá atribuir limites além dos limites físicos que a suportam desde a origem, vale dizer a obra à qual ela está vinculada. Fora desses limites, não há mais fronteira. Fronteira que é também um conceito caro às sociedades mercantis.

A arte da tradução, alijada de suas fronteiras, poderia ser explicada - e não definida, porque definição impõe fins, limites, fronteiras - de acordo com a sua prática. E, em vez de dizermos que a tradução não poderia adentrar o terreno da imitação ou da paródia, por exemplo, diríamos que determinadas traduções apegam-se mais ao sentido (como geralmente acontece com a tradução da prosa), mais à paráfrase e à paródia (a tradução poética), mais ao gestual e ao fático (a interpretação oral), mais ao conceito (a científica) e mais à metáfora (a analítica ou psicanalítica). A primeira interpreta os sentidos; a segunda, o belo; a terceira, o corpo; a quarta, o intelecto e a quinta, a alma.

Não coube a nossa explicação no limite das três categorias (como as de Dryden, de J. W. Goethe [1749-1832] e Ezra Pound [1885-1972]). Essa divisão parece ter origem na dialética (como a própria doutrina trinitária), e o barroco, contemporâneo de Dryden, adota a dialética como forma.

Outro barroco, o filósofo Giambattista Vico, explica a evolução da linguagem humana de maneira filogenética, ou evolutiva, e ontogênese produto da história individual. $\mathrm{Na}$ primeira idade do mundo, Divina, predominava a linguagem mimética, gestual, própria também da criança; na segunda, Heróica, a linguagem analógica, expressa por meio da poesia, própria do jovem. A última, Humana, é a idade da expressão racional, representada pela prosa e estrita ao indivíduo maduro. A linguagem prosaica, por ser racional, é a mais fácil de ser traduzida; a linguagem poética é a mais difícil, porque não se detém no âmbito da razão; e a linguagem mimética não precisa ser traduzida: é a primeira expressão do homem, do que viveu antes da torre de Babel, do homem da língua pura de Benjamin, a Ursprache. ${ }^{158}$

Não se sabe, no entanto, se houve uma língua pura, se houve uma língua única anterior a Babel. Só há um lugar em que as línguas são iguais: no reino das idéias, antes da formação das palavras. Esse reino situa-se na mente do que pensa; cabe ao tradutor verter-lhe os pensamentos antes de terem virado palavras. A ciência que cuida disso é a exegese.

\footnotetext{
${ }^{157} \mathrm{Na}$ Estética, Hegel define quais sejam esses limites: na pintura, o quadro, ou local sobre o que se pinta; na música, o tempo de propagação do som; na arquitetura, a lei da gravidade; etc. (HEGEL, 1993, parte III).

${ }^{158}$ Walter Benjamin, “The Task of the Translator”. Ver também, MiLton, 1993, p. 130.
} 


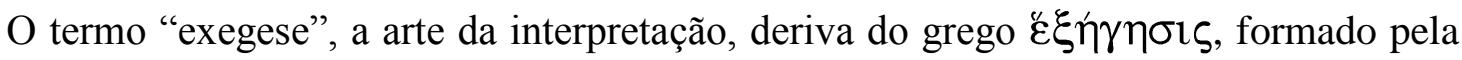

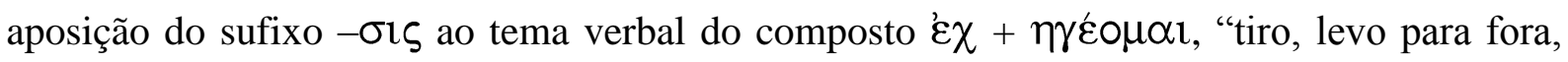
extraio". A exegese é, portanto, "a extração dos pensamentos que assistiam ao escritor ao redigir determinado documento" (CHAMBERLAIN, 1989, p. 25). A arte da interpretação toma o texto de cinco formas consecutivas: lexicamente, sintaticamente, contextualmente, historicamente e analogicamente.

Para o tradutor da prosa, verter o léxico é o trabalho mais elementar, respaldado no vocabulário adquirido por ele no aprendizado da língua. As traduções eletrônicas ou literais traduzem quase que apenas o léxico. O tradutor da prosa tem de dominar os arranjos sintáticos da língua da qual traduz da mesma forma que deveria dominar-lhe o léxico, mas não é sempre que tem de recorrer ao contexto para entender a frase e muito raramente tem de se preocupar com o contexto histórico da criação da obra, da mudança de sentido do vocábulo, de uma expressão, ou mesmo de uma sentença. Todavia é curioso que a interpretação analógica do texto seja algo que o tradutor de prosa quase nunca tenha de fazer (um dos motivos para isso é que, quando ela é necessária, esse trabalho já se encontra pronto, obra de outrem), mas que, por outro lado, é bem possível de ser feito por uma máquina de tradução, por exemplo, na utilização de arquivos de frases, ou corpora literários.

Para o tradutor da linguagem poética, o conhecimento lexical tem de ser mais profundo; recorre ele não apenas ao vocabulário, mas à sinonímia, à etimologia, aos dicionários analógicos e de regionalismos, e deve, mais do que qualquer outra espécie de tradutor, desconfiar do que sabe.

Quanto mais aplicado for o tradutor nas cinco formas de interpretação, melhor será o resultado daquilo que traduz.

A exegese resolve, porém, apenas parte do problema, pois sendo ela bem aplicada pode ajudar o analista a decifrar ou desvelar muito daquilo que o primeiro olhar não enxergou; mas ela não é capaz de trazer de volta tudo o que o tempo apagou.

Os tradutores de Homero, como Dryden, Chapman, Hobbes, Odorico Mendes, quase nada sabiam do mundo que os aedos cantaram na Ilíada e na Odisséia. Tudo o que a arqueologia desenterrou foram cacos. Até hoje pouco sabemos do que pensava ou como vivia aquela gente, o que sentia, como se comportava ou como se relacionava. Foi uma sociedade que se perdeu no tempo. Quando os poemas homéricos foram registrados por escrito, a sociedade que os compusera também não existia mais e os poemas, já desgastados pela 
transmissão oral ocorrida ao longo de séculos, foram sendo modificados à medida que mudavam vocabulário e costumes. Mesmo reunindo todo trabalho exegético que a humanidade já produziu sobre esses poemas não conseguiríamos juntar todos os cacos. Tampouco seremos capazes de adentrar os pensamentos de seu autor, pois não sabemos o que pensava o homem de então; mas ora sabemos que Homero não foi um homem só e mais difícil ser-nos-ia a tarefa de adentrar os pensamentos de toda uma extirpe de aedos que não se restringiu a uma só época e lugar.

T. S. Eliot falou-nos sobre isso:

Necessitamos de uma digestão capaz de assimilar Homero. (...) Necessitamos de um olho capaz de ver o passado... tão cheio de vida que deverá parecer tão presente para nós como o próprio presente (CAMPOS, 2004, p. 36).

Nenhum olhar é capaz de enxergar o passado; muito menos de ver a vida onde só existem cinzas. A questão não é o presente, nem o passado, mas a transcendência. O texto deverá parecer para nós transcendente, para que eternize o passado. A tradução é a prova viva de que o passado vive e revive.

A etimologia é a ciência que indica ao homem o caminho da verdade, da compreensão. Vico sustentava que "toda teoria deve começar pelo ponto onde a matéria em questão começou a tomar forma pela primeira vez" (VICO, 1979, p. xviii). Por essa razão, ele vincula sempre a Filosofia à Filologia. E esta última, por meio da procura da palavra em seu momento histórico, é o alicerce da verdade. O próprio termo o indica: $\varepsilon \tau v \mu \circ \varsigma_{\text {(verdadeiro). }}$

Essa verdade não se encontra no passado ou na origem, mas na História; quer dizer: no mito (ou na palavra). A procura da verdade pode ser um intento vão. Nietzsche afirmava que a verdade - e a própria História - não é a "coisa em-si", algo determinado a priori (uma concepção kantiana), mas que a verdade é criada pelo próprio homem.

Se a verdade é criada pelo próprio homem, então é possível ao homem conhecer a verdade. Vico dizia que ao homem só é dado conhecer aquilo que ele mesmo cria. O homem não é capaz de compreender a natureza pois ela foi criada por Deus; da mesma forma não pode o homem conhecer a si mesmo; mas ele é capaz de conhecer a História pois é ele quem a faz.

Mas aquilo que Nietzsche chama de verdade são as falsidades estabelecidas na busca do poder. $\mathrm{O}$ homem estabelece as verdades que lhe convêm. Contudo a genealogia das 
verdades encontra-se nas metáforas: “Acreditamos saber algo das coisas mesmas... e no entanto não possuímos nada mais do que metáforas das coisas, que de nenhum modo correspondem às entidades de origem" (NIETZSCHE, 1999, p. 56).

E as metáforas perderam o vínculo com as entidades de origem. Na Idade Divina, os homens viviam em comunhão com a natureza e criaram essas metáforas para descrever a realidade imediata, realidade que permanece nos povos primitivos de sempre, que revive nas crianças e que transcende na poesia. Não se pode afirmar que a verdade se encontre na origem. Esteve lá um dia, mas perdeu-se no tempo. Por isso só pode ser encontrada, por meio da etimologia, na História.

Para a elaboração de uma teoria da tradução, será preciso levar em conta esse momento transcendental em que as línguas coincidem, o momento da Ursprache. A etimologia conduz o tradutor até esse momento. É ela também quem conduz o tradutor ao entendimento da arte dele.

A palavra "tradução" tem origem no termo latino traductio, onis [passagem (de um estado a outro), curso (de tempo)], e o verbo "traduzir" (a ação) em traduco, is, ere [fazer passar (de um lado ou estado ao outro), conduzir para o outro lado, atravessar]. Outro verbo latino que indica passagem é o verbo depoente transgredior, eris, $i$ (passar além, passar por cima, transpor, superar). Os dois indicam um movimento de passagem, de travessia; o segundo deles acabou formando o adjetivo transgressor, oris, com o significado de transgressor, pecador, sentido que passou ao português. Transgredir significa transpor os limites, desobedecer normas, insurgir-se. A palavra traduzir tem para o alemão o mesmo sentido que transgredir tem para o latim: übersetzen. É o que o tradutor deve fazer se não quiser que sua arte se limite a um mero ofício comercial. O tradutor deve passar além.

Como a tradução só tem sentido na prática, de nada adianta impor-lhe regras e limites. As regras e os limites detêm as idéias no tempo e no espaço. Traduzir não é apenas levar um texto de uma língua para outra, de um tempo para outro, de um pensamento para outro. Traduzir é levar além: traduzir é transgredir.

Cabe dizer aqui umas palavras de encerramento sobre tradução. Ezra Pound tinha uma idéia bastante progressista a respeito da tradução, vendo-a como um instrumento da crítica, 
um instrumento pedagógico ${ }^{159}$ para a formação de poetas, de leitores e dos estudantes de literatura. Quanto a nós outros, não podemos aceitar essa idéia sem submetê-la a crítica.

Só haverá sentido em se falar em educação se o objetivo do aprendizado for o de educar para a revolta. Tudo o que o aluno aprende na escola é o como as coisas são. O sentido do conhecimento não é o de saber como as coisas são, mas como elas podem ser; o sentido último e objetivo do saber é o de mudar as coisas. Toda a educação se frustra diante do futuro.

Da mesma forma, a tradução não pode simplesmente se limitar à explicação do texto, mas alcançar a sua superação estética.

\section{A ANÁLISE EXEGÉTICA}

Num ensaio denominado "Duas palavras para Joyce” (NESTROVSKI (Org.), 1992, p. 17-39), o filósofo francês Jacques Derrida dedica pouco mais de vinte páginas para tratar de apenas duas palavras: "He War".

Essas palavras aparecem ao final do primeiro capítulo da segunda parte do Finnegans Wake (FW 258.12) num contexto que trata da Torre de Babel e da dispersão das línguas.

Parece exagero gastar tantas páginas com tão poucas palavras. Mas tudo é assim no último livro de Joyce. Poderíamos escrever ensaios ainda mais vastos sobre uma única palavra, mas fiquemos nessas duas.

"He War" é uma expressão que conota confusão. A pessoa que a disse, pretendia dizer, provavelmente, "he was", expressão existente na língua inglesa. No entanto, "He war" seria perfeitamente aceitável num registro dialetal:

1865 - Mut. Fr. xii, Warn't I troubled? $(O E D)^{160}$

ou primitivo:

c1340 Ibid. (Trin.) 388 BoPe were [v.r. war, ware, was] made sonne and mone. (OED)

Sabemos que o substantivo "war" era pronunciado nos primórdios da língua da mesma maneira que se pronuncia hoje o termo "were":

\footnotetext{
${ }^{159}$ No ensaio "Da tradução como criação e como crítica", o autor, Haroldo de Campos, fala "da impossibilidade do ensino da literatura, em especial da poesia... sem que se coloque o problema da... crítica via tradução.” De fato é uma postura avançada tomar-se a Tradução como um instrumento para o ensino de Literatura, para a formação de poetas e de críticos. O problema é o momento histórico e a sociedade em que o ensino se dá. Para que a sociedade de hoje educa os poetas de amanhã?

${ }^{160}$ Oxford English Dictionary (versão eletrônica). As citações se referem ao verbete "be". Os grifos são nossos.
} 
1154 O.E. Chron. (Laud MS.) an. 1140, per efter wæx suythe micel uuerre betuyx Pe king \& Randolf eorl of Cæstre. $(O E D)$

Derrida não leva em consideração essas variações lingüísticas e se apressa em afirmar que existe na expressão um trocadilho entre uma palavra da língua inglesa, war ("guerra"), e outra do alemão, que pode ser war (o mesmo que o inglês was) ou wahr ("verdadeiro"). Não há mais como sabermos exatamente o que Joyce pensou ${ }^{161}$ quando esteve escrevendo essa expressão. Podemos apenas inferir. Derrida poderia estar com a razão; mas também não temos como saber.

A análise hermenêutica dessa obra de Joyce produz no transcorrer do tempo mais e mais possibilidades. Onde uns analistas viram uma coisa, outros viram outra. $\mathrm{O}$ número de possibilidades aumenta conforme aumentam os estudos. Roland McHugh (MCHUGH, 1991, p. 258), por exemplo, observa apenas que a expressão completa, "And He war", pode estar parodiando a expressão dinamarquesa "og han var" (“e ele foi”). Todavia, é importante ressaltar que esse fenômeno ocorre com toda e qualquer obra literária e não apenas com o Finnegans Wake. Não é necessária a polêmica, termo que aliás traduz perfeitamente aquilo que Derrida interpretou. ${ }^{162}$

Apesar de os povos germânicos terem sido na Antigüidade povos guerreiros, não havia uma palavra apropriada para designar "guerra" em suas línguas. O termo que produziu nas românicas a palavra "guerra" é provavelmente o teutônico werra, que os povos românicos preferiam usar para não expressar a confusão existente na língua latina entre os termos bellum, $i$ ("guerra") e bellus, a, um ("belo"). E a palavra que melhor traduz werra é "confusão", que em hebraico é bavel que ficou sendo o nome do topônimo Babel.

Babel é palavra que aparece apenas duas vezes na Bíblia (Gênesis X, 10 e XI, 9): na primeira delas, em uma enumeração de cidades, e, na segunda, na referência à torre que os homens construíram para aproximar-se dos céus. Deus confundiu-lhes as línguas para que não se entendessem mais e se dispersassem pela terra: "E por essa razão é que lhe foi posto o

\footnotetext{
${ }^{161}$ O recurso que alguns críticos denominam "palimpsesto", descobrir o que se encontra por trás do texto, é fácil de ser pesquisado em Finnegans Wake, pois os manuscritos foram conservados e encontram-se no acervo da Universidade de Buffalo, NY. David Hayman consultou os manuscritos de Buffalo e publicou um livro, A First-Draft Version of Finnegans Wake, contendo as discrepâncias entre a versão final e os manuscritos. Apesar de o livro conter muitos erros, é útil. Não há nele a frase analisada aqui, o que nos faz acreditar que Joyce não a mudou. Se ele a tivesse modificado, teríamos mais de uma versão dela, o que nos permitiria inferir o processo de elaboração. Seria uma maneira de saber o que o autor tinha em mente na hora da composição. O uso dessa técnica do palimpsesto é de enorme utilidade para a pesquisa exegética e, neste caso, podemos tomar o significado do termo "exegese" ao pé da letra.

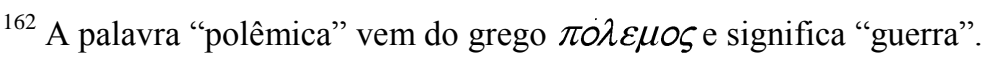


nome de Babel, porque nela é que sucedeu a confusão de todas as línguas do mundo. E dali os espalhou o Senhor por todas as regiões.”

Há duas palavras no versículo às quais devemos nos ater: "Babel” e "Senhor".

O Livro de Gênesis foi escrito provavelmente durante o cativeiro dos hebreus na Babilônia, que é o nome grego de Babel ${ }^{163}$. Durante essa época, Nabucodonosor II esteve construindo uma torre gigantesca sobre as ruínas de outra muito mais antiga já mencionada por Hamurábi. É provável que essa edificação e o fato de a cidade ser ponto de confluência de caravanas vindas do Oriente e do Ocidente e, portanto, de se falarem ali diversas línguas, tenham influenciado a narrativa do autor javista ${ }^{164}$. O que é pouco provável é que o trocadilho que aparece na Bíblia seja verdadeiro. Babel ou não quer dizer confusão, ou não era o nome da cidade. É certo que a palavra hebraica bavel significa "confusão", mas o trocadilho, que provavelmente inspirou toda a redação da passagem bíblica, é falso. Sobre a origem do topônimo, o Professor Sayce $(O E D)$ o faz derivar do assírio bāb-ilu (portão de Deus) ou bābili (portão dos Deuses). Apenas a coincidência entre o verdadeiro nome do local e o termo hebraico bavel é que fez da cidade um lugar de confusão.

No capítulo da Bíblia que trata da dispersão dos povos, descendentes de Noé, Deus é chamado de יהוה (yhwh). Esse nome não pode ser pronunciado. Como a Bíblia só grafasse as consoantes, não foi possível recuperar a pronúncia dos termos da língua. Nesse nome há duas semiconsoantes (iod e vav: normalmente transliteradas por y e w, respectivamente) e uma consoante que aparece duas vezes (he: normalmente transliterada pela letra $h$ ). Tentou-se por meio do acréscimo de vogais ${ }^{165}$ dar uma pronúncia a esse nome (que não deveria ser pronunciado). Primeiro adotou-se Jeová, e hoje se adota Javé ou Iavé. Mas a intenção do autor bíblico talvez fosse apenas a de grafar algo que não pudesse ser pronunciado. ${ }^{166}$

\footnotetext{
${ }^{163}$ A tradução da Bíblia feita pelos judeus de Alexandria, conhecida como Tradução dos Setenta, ou Septuaginta, não utiliza o termo $\beta \alpha \beta \nu \lambda \omega v$ no segundo caso, e preferiram Babel por causa da dificuldade de verter o trocadilho.

${ }^{164}$ No Pentateuco, Deus é chamado sobretudo por estes nomes: Elohim [plural (majestático) de Eloá (Senhor)], Javé (nome impronunciável, trocadilho com a expressão hebraica que significa "Eu sou" ou "Eu serei") e Adonai (nome derivado de dûn, “julgar"). Alguns filólogos defendem, por meio da análise de estilo, que cada um desses nomes foi usado por um autor diferente; seriam portanto três os autores do Pentateuco: o eloinista, o adonaísta e o javista.

${ }^{165}$ O hebraico era, até o começo da Idade Média, grafado sem as vogais. Os sinais vocálicos foram introduzidos pelos massoretas entre os séculos V (quando iniciaram o registro escrito da tradição religiosa oral) e o final do IX (quando terminaram a sistematização das vogais e dos acentos da língua usada na Bíblia).

${ }^{166}$ A interpretação de que o nome de Deus não deveria ser pronunciado é, contudo, tardia e se deve aos judeus da época do segundo Templo.
} 
Quando Moisés pediu ao Senhor que se identificasse, Deus disse apenas "Eu sou" (היה ${ }^{167}$, talvez a afirmação que mais se aproxime do termo impronunciável. Mas em hebraico, a expressão היה pode ser traduzida também por "eu serei”. E quando Joyce disse "he war" pode ter buscado jogar com os tempos verbais.

Derrida afirma que não seria apropriado traduzir-se a expressão "he war" no sistema de uma única língua. Pois Finnegans Wake é uma obra que "fala várias línguas ao mesmo tempo... as parasita" (NESTROVSKI (Org.), 1992, p. 27), e a passagem em que a expressão aparece "reflete, em estado de extrema concentração, toda a aventura babélica do livro" (NESTROVSKI (Org.), 1992, p. 30).

Como as línguas se dispersaram e os povos deixaram de se entender, foi necessário inventar um sistema paralingüístico que colocasse de novo esses povos em entendimento. Esse sistema é a tradução. Que não significa apenas a passagem de uma língua para outra, mas a decodificação de um sistema e a recomposição do código em outro sistema. É por causa desse processo de decodificação e recomposição que Derrida precisou de vinte páginas para traduzir apenas duas palavras: "É preciso traduzir... Sim mas para isso é preciso mais do que duas palavras" (NESTROVSKI (ORG.), 1992, p. 33).

Mas no processo de recomposição do termo, como faríamos nós outros para traduzir "he war" e reter todos os sentidos que pudemos observar até agora?

O mais simples seria traduzir-se a expressão por "ele guerra", mas nesse caso perderse-ia o verbo, a ação. "Ele era", o significado básico da expressão, nos faz perder todos os significados secundários.

O tradutor francês do Finnegans Wake, Philippe Lavergne, usou algo equivalente a "e assim foi”, mas a sua tradução é anterior ao ensaio de Derrida. O tradutor brasileiro, Donaldo Schüler, que leu o ensaio de Derrida ${ }^{168}$, verteu para "E El YaHWeHrra" (JOYCE, 2002a, p. 90). O problema da primeira é a falta da confusão, do trocadilho; o da segunda, é a falta do sentido básico da expressão ${ }^{169}$. Podemos dizer que o primeiro parafraseou e o segundo parodiou. O que pretendemos é traduzir, ou seja produzir algo que contenha paráfrase, paródia e metáfrase, ou então algo que reproduza a maior parte dos elementos estéticos que a expressão contém (quer tenha sido ou não a intenção do autor produzi-los).

\footnotetext{
${ }^{167}$ Êxodo III, 14.

${ }^{168}$ O livro, do qual o ensaio faz parte, consta da "Bibliografia" da tradução de Schüler (v. 5, p. 538).

${ }^{169}$ Existe, contudo, a possibilidade de lermos "-eHrra" como "era" ou como "será" (/errá/).
} 
Depois de decodificado, o termo aparece em português desta forma:

"E ele havera."

O primeiro processo adotado por nós na tradução do livro é a interpretação etimológica das palavras. Sabemos que o livro está estruturado sobre a Nova Ciência de Vico, e um dos processos de alcance da verdade propostos por ele é a filologia (etimologia), ou desvelo das palavras. Por outro lado, a Filosofia da História proposta por ele, da sucessão cíclica das eras, não se resume apenas em sucessão mas em concomitância. As eras estão presentes todas elas em cada momento da vida. Em outros termos: a ontogenia reflete a filogenia. A filogenia nos revela que em algum momento da história alguns povos de língua inglesa disseram "Bobe were made sonne and mone"; a ontogenia, que em algum momento da vida, quando a criança está aprendendo a recitar os verbos, por analogia pode pronunciar, em vez de "houvera", "havera". Nesse sentido reconstruímos a expressão com o uso da ontogenia. $^{170}$

A segunda vogal do pronome "ele" é pronunciada na maior parte do território da língua como /i/. Se lermos a expressão em voz alta (como Joyce sugeriu que se fizesse com seu livro) ${ }^{171}$, ouviremos o eco do nome de Iavé: /eliavéra/ e de Eli (“Deus" em hebraico), palavra dita por Jesus ${ }^{172}$ ao morrer, repetindo o Salmo 22.

O termo "havera" reproduz também, filogeneticamente, wer, "confusão", termo embrião do nosso "guerra".

E a expressão "E Ele havera" pode ser também interpretada como "E Eli há vera" ou "Deus é fiel”, pois a palavra russa bepa /viéra/ significa “fé".

Como "havera" não é forma padrão, e seria quase sempre irreconhecível no registro escrito, alguns poderão ler "haverá", o que daria à expressão a mesma ambigüidade que ela tem no hebraico: presente e futuro, na Bíblia; pretérito no inglês do Finnegans Wake; e pretérito e futuro no português, na tradução.

O texto de Joyce pode ser analisado da seguinte maneira (aproveitando as explicações de Derrida e aquilo que observamos posteriormente): E Deus, sendo (ou afirmando-se),

\footnotetext{
${ }^{170}$ Encontramos, porém, no século XIII o registro da forma "havera" (grafada "auera"). O documento que contém o termo é o FG3 (Foros de Garvão do Alentejo), 18v (L014), so séc. XIII (1280?). "d(e)lles obliga todo q(ua)nto q(ue) a e Auera Ad(e)ante q(ue) o teña e q(ue) o d(e)sfruyte".

171 "If anyone doens’t understand a passage, all he need do is read it aloud" [Se alguém não entende uma passagem, basta ler em voz alta]. ELLMANN, 1983, p. 591.

${ }^{172}$ Eli, Eli, lamma sabachthani (em aramaico;"Deus meu, Deus meu, por que me desamparaste?"). Mateus XXVII, 46.
} 
decretou a confusão (ou a guerra), dispersando os povos (ou adquirindo um exército de fiéis). A conjunção denota a confusão presente no momento da dispersão das línguas e presente também no mundo dos sonhos (já que a obra é, em grande parte, escrita numa linguagem que procura exprimir estilisticamente os sonhos).

O texto traduzido, por sua vez, poderá ser interpretado assim: E Deus, eterno, fez (a confusão, a guerra) e devemos confiar naquilo que fez (embora parecesse estranho). O texto traduzido incorporou de forma anagramática o nome de Iavé, ainda que não fosse necessário, pois já estaria implícito em "Ele era” presente também no anagrama. No entanto, é possível que Joyce tenha tentado incorporar a "He war" a expressão hebraica "hayah" (eu sou), as palavras confusas que Iavé disse a Moisés. O que ficou de mais na tradução foi a referência a Jesus. Mas nas discussões teológicas cristãs sobre o significado do tetragrama que seria o verdadeiro nome de Deus (impronunciável), afirma-se que o verdadeiro nome de Deus é Jesus Cristo.

Uma análise hermenêutica como a feita por Derrida pode levar o crítico a suspeitar de que o analista sofra de paranóia; que uma obra como Finnegans Wake não pode ser interpretada de maneira segura, que palavras e sentenças do livro sempre proporcionarão significados novos no decorrer de novas análises. Em resposta ao crítico, perguntamos: desse ponto de vista, que obra é diferente de Finnegans Wake?

Não há análise que esgote a obra literária, ou a obra de arte. O artista não é interlocutor do analista. O propósito da arte não é a análise; a análise serve apenas de subsídio para a crítica e para a interpretação.

O crítico procura enxergar as contradições da obra de arte. Se é um profissional, as contradições apontadas por ele servirão para determinar o valor (de mercado) do artista e da obra. Mas essa não é a função social do crítico. Todo produto do Espírito é consequiência de suas contradições. O valor da arte, por ser ela um produto do Espírito, não está senão nessas contradições. Ao identificá-las, o crítico cumpre seu único papel social, o de revelar ao intérprete os mecanismos da arte (e, nesse sentido, o crítico é um educador).

Acima do crítico e do analista está o intérprete, aquele que retira a obra de arte de sua condição abstrata. Por exemplo, a música que não saiu da partitura é uma arte muda, abstrata. Só o intérprete pode tirar sons de um pedaço de papel. 
Tudo o que o artista fala é para si mesmo e para o intérprete. $\mathrm{O}$ artista não se preocupa nem com a crítica nem com o público.

Quando James Joyce escreveu o Finnegans Wake em uma linguagem extremamente pessoal, numa espécie de idioleto, estava preocupado com o leitor ou consigo mesmo? E quando ele disse que seu livro, o Ulysses, ocuparia o crítico por séculos, estava demonstrando uma preocupação para com o crítico ou desdenhando dele?

Pouco importa se os críticos não chegam a um acordo ao interpretarem um livro, pois isso só demonstra a riqueza, ou o valor, que o próprio livro tem.

Quanto a nós, nosso papel como críticos é o de revelar contradições; e como intérprete, de reproduzi-las. O meio para a reprodução das contradições é a tradução. Tradutor e intérprete são uma coisa só.

\section{A CRÍTICA}

Se James Joyce escreveu seus dois últimos romances em uma linguagem muito pessoal, uma espécie de idioleto, como dissemos anteriormente, que linguagem usaríamos nós para traduzi-lo?

Esse problema é crucial. A decisão de qual linguagem usar é tomada pelo tradutor, respaldado ou não num determinado critério. Nas traduções que mostraremos a seguir, alguns tradutores não se preocuparam com critérios; e os que se preocuparam adotaram uma destas duas filosofias: tornar o texto mais simples na tradução (simplificando a arquitetura do original) ou procurar reproduzir os jogos verbais e sintáticos do livro. Os tradutores do primeiro grupo devem ter imaginado que uma tradução só se justificaria se fosse feita na língua deles, e acabaram privilegiando a interpretação. Outros, provavelmente por saberem que a língua de Finnegans Wake não era o inglês, mas uma língua decalcada nele, tentaram resolver os problemas da tradução no âmbito da análise.

Há uma tradução italiana, feita por Luigi Schenoni ${ }^{173}$, que resolve o problema da análise e da interpretação. Percebe-se que nela existe um estilo e que para ela foi adotado um critério. Seu ponto fraco é a sonoridade. Tem-se dado muita importância, no estudo do Finnegans Wake, ao significado das palavras, e era com isso que os dois gêneros estavam preocupados, apesar de adotarem posições aparentemente tão opostas. A prioridade, de acordo

${ }^{173}$ Tradução dos quatro primeiros capítulos (JOYCE, 1999a). 
com o que vimos no capítulo anterior, está mais no som do que no sentido. Finnegans Wake é música, quase explicitamente uma ópera.

\section{1 . O critério}

Selecionamos uma passagem da obra para, por meio da crítica às suas traduções, definirmos o método que utilizaremos na nossa. O trecho é o final do capítulo VIII, escolhido não por acaso, mas porque é a parte do livro mais traduzida, a que resultou em mais ensaios e, além de ter sido a primeira célula do livro, contou com duas traduções feitas pelo próprio autor. Uma delas, a italiana, foi a última obra de Joyce.

Analisamos alguns aspectos de três traduções brasileiras, duas para o castelhano, uma para o italiano e duas para o francês. Essa análise visa apenas a determinar algumas diferenças entre as traduções feitas por Joyce e as feitas por outros autores. No capítulo 4, procedemos a uma análise mais profunda.

O texto original foi publicado em 1924, quinze anos antes da publicação do livro completo, e trata de duas mulheres que estão lavando roupa num rio; cada uma delas se encontra em uma das margens e falam de "uma tal de Ana Lívia". Essa passagem do livro é conhecida como "Anna Livia Plurabelle". Anna Livia ${ }^{174}$ é um outro nome do rio Liffey que atravessa a cidade de Dublim.

Original:

\section{$\mathrm{O}$}

tell me all about

Anna Livia! I want to hear all

about Anna Livia. Well, you know Anna Livia? Yes, of course, we all know Anna Livia. Tell me all. Tell me now. You'll die when you hear. Well, you know, when the old cheb went futt and did what you know. Yes, I know, go on. Wash quit and don't be dabbling. Tuck up your sleeves and loosen your talktapes. And don't butt me - hike! — when you bend. Or whatever it was they threed to make out

\footnotetext{
${ }^{174}$ Nos antigos mapas de Dublim, o rio Liffey se chamava Anna Liffey. O autor mudou Liffey para Livia aproveitando o sentido da palavra dinamarquesa Liv que quer dizer "vida". Assim, Ana Lívia seria o rio da vida, ou água da vida. Da expressão "uisce beatha" (água da vida), tirou-se o termo gaélico uisce, que é a bebida da vida, o uísque (que os irlandeses grafam Whiskey). Joyce inspirou-se também em Livia Schmitz, esposa do escritor italiano Italo Svevo (Ettore Schmitz, 1867 - 1928), cujos cabelos longos, ruivos e ondulados lembravam as águas do Liffey (vermelhas por causa das indústrias de corante de roupa que esvaziavam seus esgotos no rio).
} 
he thried to two in the Fiendish park. He's an awful old reppe. Look at the shirt of him ! Look at the dirt of it! He has all my water black on me. And it steeping and stuping since this time last wik.

\title{
a. Tradução brasileira de Donaldo Schüler:
}

\section{$\mathrm{O}$}

Conta-me tudo sobre

Ana Lívia! Quero ouvir tudo

sobre Ana Lívia. Bem, conheces Ana Lívia? Açai, claro, todos conhecemos Ana Lívia. Conta-me tudo. Conta-me agora. É de morrer o que escutarás. Bem, sabes, quando o velho velhaco fez fiasco e fez o que fez. Sim, sei, adiante. Lava Limpo e deixa de fazer onda. Arregaça as mangas e abre o bico. Nada de abaeter em mim - ai! - quando te abayas. O que é que Tefé que tresandaram a descobrir o que ele doisdou de fazer no Fuscoix Parque. Trata-se de piolhento pilontra. Olha pra esta tamisa que é dele! Repara a sujeira. Ele preteou todágua Acala em minho. E bota e bate já lá vão dias sete de danúbio a tejo. ${ }^{175}$

\section{b. Tradução brasileira de Augusto de Campos:}

\section{$\mathrm{Ah}$}

\author{
fala-me de
}

\section{Ana Lívia! Quero ouvir tudo}

sôbre Ana Lívia. Bem, você conhece Anna Lívia? Mas claro, todo mundo, Fala-me tudo. Quero ouvir já. É de matar. Ora, você sabe, quando aquêle malandro fez baque e fez o que você sabe. Sim, eu sei, e daí? Lave com calma e não saalpique a gente. Levante as mangas e solte a língua. E pare — ai! — de bater em mim quando se abaixa anágua. Ou que diabo foi que trentaram duescobrir que êle tresandou fazendo no parque de Duêndix. O grande canalha! A camisa sua, veja! A lama que ela deixa! Tôda a água está preta. É molhar e malhar a setemana inteira. ${ }^{176}$

c. Tradução brasileira de Dirce Waltrick do Amarante

\section{$\mathrm{O}$}

Me conta tudo sobre

Anna Livia! Eu quero saber tudo

\footnotetext{
${ }^{175}$ Finnegans Wake / Finnicius Revém v. 3, p. 196.

${ }^{176}$ Campos; Campos, 1971, p. 54.
} 
sobre Anna Livia. Bem, conheces Anna Livia? Sim, é claro, todo mundo conhece Anna Livia. Me conta tudo. Vais cair dura quando ouvires. Bem, sabes, quando o velho folgado falhou e fez o que sabes. Sim, sei, anda logo. Lava aí e não me enroles. Arregaça as mangas e solta a língua. E não me batas - ei! - quando te abaixas. Seja lá o que quer que tenha sido eles tentaram doiscifrar o que ele trestou fazer no parque Fiendish. É um gradessíssimo velhaco. Olha a camisa dele! Olha que suja está! Ele deixou em mim toda minh'água escura. E estão embebidas, emergidas toduma semana. ${ }^{177}$

\section{d. Tradução ao espanhol por Francisco García Tortosa:}

$\mathrm{O}$

dímelo to de

\section{Anna Livia! Quiero oirlo to}

de Anna Livia. Bueno, conoces a Anna Livia? Si, claro, tol mundo conoce a Anna Livia. Cuéntamelo to. Cuéntamelo ya. Te vas a morir cuando te enteres. Bueno, ya sabes lo del viejo calandrajo ganforro que hizo lo que sabes. Si, ya lo sé, sigue. Lava listo y no despatrickes. Súbete las mangas y desmarra tu farfulla. Y no me empures - soo!- cuando te encorves. O lo que tresaran soltar que intrestó doser en et Parque Findio. Es un viejo carona asqueroso. Mira qué camisa! Mira qué sucia! Me tiene tol agua ciénegra. Y en sopapa y en emplasta desde el vikingo pasao astahora. ${ }^{178}$

e. Tradução espanhola de Víctor Pozanco:

$$
\begin{gathered}
\text { ¡OH }, \\
\text { cuéntamelo todo } \\
\text { Anna Livia! Quicro saberlo Lode }
\end{gathered}
$$

de Anna Livia. Porque sabéis quién es Anna Livia, ¿no? Claro que sí; todos sabemos quién es Anna Livia. Cuéntamelo todo; ahora mismo. Te va a dar algo cuando lo oigas. Ya sabes, cuando el viejo anduvo riorriendo, se mojó e hizo lo que hizo. Sí, ya lo sé, sigue. Que hay mucha ropa sucia que lavar; y no salpiques. Remángate y larga. Y no embistas — soo! - al agacharte. Fuese lo que fuese lo que intentasen descubrir que les hiciera a aquellas dos en Phoenix Park, es un tipo de cuidado. ¡Fijate en su camisa! ¡La de mierda que tiene! Como si me echase encima todo el albañal de Dublin. Como si se hubiese pasado toda la semana arrastrándose por el lecho del río. ${ }^{179}$

\section{f. Tradução francesa de Philippe Lavergne}

\footnotetext{
177 AMARANTE, 2001 p. 210.

178 JOYCE, 1992a (Trad. Francisco García Tortosa), p. 139.

${ }^{179}$ JoYCE, 1993 b (Trad. Víctor Pozanco), p. 85.
} 
Tellus, dis-moi tout sur

Anna Livia! Je veux tout savoir d'Anna Livia! Mais connais-tu Anna Livia? Oui, bien sûr, nous connaissons tous, Anna Livia. Dis-moi tout. Dismoi maintenant, c'est a mourir lorsque tu l'entendras. Non tu sais lorsque le vieux, et crac, fit ce que tu sais. Oui je sais, continue. Lave tranquillement et n'éclabousse pas partout . Relève tes manches et mets ton disque en route. Et me cogne pas - hein! - lorsque tu te baisses. Ou quoi que ce fût que l'on essaya de découvrir qu'il ait bien Pu faire a Fiendish Park. Il a une affreuse vieille reputation. Regarde sa chemise! Regarde-moi cette saleté! Il me salit mon eau tout plein de sa noirceur. Et ça trempe et ça étoupe depuis maintemnant une semaine. ${ }^{180}$

g. Tradução francesa de Samuel Beckett, Eugène Jolas, Paul Léon, Alfred Perron, Ivan Goll, Adienne Mounier e Philippe Soupault. ${ }^{181}$

Et ça trempe et sa traîne toute une sommamaine! Il m'a noirci toute mon eau. C'est un beau saalaud! Vois sa chemise à lui! Voi-moi cette saleté. l'Inphernix. Ou quelque fut le tréfleuve que le triplepatte qu'on dit qu'il trouva dans le parc de Et ne me cogne pas avec ta caboche, hein! Retrousse tes manches et délie ton battant. Oui, je sais, et après, après? Lave tranquillement ton linge et ne patauge pas tant. Alors, tu sais, quand le vieux gaillarda fit krach et fit ce que tu sais. Dis-moi tout, dis-moi vite. C'est à en crever! Eh bien! tu connais Anna Livie? Bien sûr tout le monde connaît Anna Livie. O, dis-moi tout d'Anna Livie! Je veux tout savoir d'Anna Livie!

h. Tradução italiana de Ettore Settanni, Nino Frank e James Joyce:

Raccontami di Anna Livia. Tutto sapere vo' di Anna Livia. Beh, conosci Anna Livia? Altro che, conosciamo tutte Anna Livia! Dimmi tutto, e presto presto. Roba da chiodi! Beh, sai quando il messercalzone andò in rovuma e fe' ciò che fe'? Si, lo so, e po' appresso? Lava pulito e non sbrodolare! Rimboccamaniche e scioglilinguagnolo. Ma la zucca per te se mai ti pieghi. O cosa mai fece bifronte o triforo in quell'infenice di porco nastro? Oibo', quel lughero malandrone! Che sudiciume di camiciaccia! Guarda un po', tutta l'acqua ne ho sporca. Bagno di qua, bagno di là, otto giorni di bucato. $^{182}$

\footnotetext{
${ }^{180}$ JOYCE, 1982 (Trad. Philpe Lavergne), p. 303.

${ }^{181}$ Esta tradução foi feita durante as reuniões semanais mantidas por Joyce e outros intelectuais que viviam em Paris. A tradução foi coordenada por Joyce que nela colaborou.

${ }^{182}$ Publicado em duas partes: 15.2.1940 (com o título de "Anna Livia Plurabella"); 15.12 .1940 ("I fiumi scorrono") na revista Prospettive de Roma.
} 


\section{1. 1. Linguagem}

Essa passagem não é muito complexa, e a reproduzimos aqui por ter sido a única cuja tradução contou com a ajuda do próprio autor ${ }^{183}$. Como se pode ver, não há muitos jogos verbais nela e as traduções, cuidando de resolver os problemas semânticos, deram conta da tarefa.

As dificuldades semânticas do texto são as seguintes: 1. O (fr. eau, água): não precisa ser traduzido; 2. cheb (Cheb ou Eger, cidade da Boêmia, atravessada pelo Ohre): manter o som da palavra (ou usar o nome de outra cidade banhada por rio, se a localização do topônimo original for irrelevante no texto) e, ao mesmo tempo o sentido de chap, camarada, sujeito; 3 . went (rio inglês, em Yorkshire): combinar o nome do rio com o sentido e o tempo do verbo; 4. went futt (go phut, desaparecer): é também uma referência ao rio Futa (Guiné) e lembra-nos o calão fuck, foda, foder; 5. hike: pare! (diz-se para o cavalo parar); 6. threed: tried + three; 7. thried (inglês hibérnico: tried, com forte aspiração do h): tem o mesmo sentido que 6, mas ressalta o som de tried em vez do som de three; 8. to two (to do): manter o duplo sentido; 9. Fiendish (diabólico): refere-se ao Parque Phoenix; 10. reppe (rep, tecido para estofamento, pessoa depravada): manter o duplo sentido e a referência ao nome do rio (Répce, Hungria); 11. water black (água suja): manter a referência ao nome do rio (Blackwater, Irlanda) e à cidade de Dublim, cujo nome deriva de dubh linn, brejo preto; 12. steeping (esfregar a roupa no tanque ou na água): é também nome de rio (Steeping, em Gibraltar); 13. stuping (corruptela de stopping, barragem, parar): nome de rio (al. Stolpe; pol. Słupia); 14. wik (palavra dialetal: riacho): significa também week, semana.

Como pudemos perceber, a principal dificuldade que o tradutor tinha pela frente era tentar reproduzir os nomes de rios. A maior parte deles não se preocupou com isso, no fragmento; e os que se preocuparam, deslocaram o trocadilho para outra palavra e mudaram os nomes dos rios. Esse critério parece-nos bastante adequado, pois o próprio Joyce recorreu a ele. As outras dificuldades semânticas foram resolvidas, na maior parte das traduções, por deslocamento ou pela invenção de uma dificuldade diferente.

O que se pode concluir desses exemplos é que os textos diferem bastante entre si e, curiosamente, os que mais diferem do original são justamente os textos em que o próprio autor do original trabalhou.

183 James Joyce colaborou também na tradução da mesma passagem para o francês. 
Esse distanciamento em relação ao texto original ocorre mais acentuadamente em outras passagens da obra. No fragmento acima, os trocadilhos são poucos, existem ali poucas aglutinações de palavras e misturas de línguas e, mesmo assim, as disparidades entre as traduções dele são muitas. Contudo, há outra espécie de disparidade com que o tradutor tem de se preocupar: a disparidade entre seu texto e a estrutura da língua para a qual o texto será traduzido.

Muitas tentativas de tradução de trechos do livro apresentavam marcas estruturais próprias da língua inglesa. Todavia, os processos lingüísticos de formação de palavras diferem em muitos casos de uma língua para outra.

As línguas germânicas suportam com mais naturalidade do que as latinas a aglutinação de palavras. Além disso, a língua inglesa, mais do que as germânicas suporta que essa aglutinação seja feita com termos estrangeiros entre si, porque o inglês tem quase metade de seu léxico constituído por palavras de origem latina. O inglês é uma língua híbrida por natureza. Uma das idéias de Joyce para traduzir o fragmento para o italiano era a concepção de hibridismo dentro da própria língua. A língua italiana, por causa dos muitos dialetos, é uma língua estrangeira dentro de si mesma.

A tradução da seguinte passagem (que parece uma quimera lingüística),

“... Annona, gebroren arrostokrat Nivea, dochter of Sense and Art, with Sparks' pirryphlickathims funkling her fan...” (FW 199.34-36)

que contém uma palavra latina (Annona: deusa romana do trigo), duas alemãs (geboren: "nascido"; e funkeln: "faísca"; [funkling é também deformação de fucking, foder]), uma holandesa (dochter: "filha") e nomes de rios [Aroostook (Maine, EU), Nive (França), Ebro (Espanha), Sense (Suíça), Arta (província onde fica o rio Arakhtos; ou o Golfo de Arta), Pyriphlegethon (Flegetone, rio de fogo do Hades) e Fan (Gabão); fan remete ao inglês fanny, xoxota;] de várias partes do mundo, ficou assim:

“... Annona genata arusticratica Nivea, laureolata in Senso e Arte, il ventaglio costellati di filigettanti..."

com os elementos estrangeiros completamente diluídos na fluidez da língua italiana e desprezando os nomes de alguns rios, pois para Joyce importava mais o aspecto sonoro do que o significado. 
As traduções ${ }^{184}$ :

“Annona, gebrotada areostokroática Nivia, poetiga de senso y d'Arte, con pyrtiliplosolios de chispas chispesteando su soplillo...” (Tortosa, p. 145)

"Annona, aristocratiquement née Nivia Docteur és-Sens et Art, avec son éventail tout étincelant du pyrraphlox des Parques...” (Lavergne, p. 309)

"Annona, de nascimento aristocrata, Nívia, filha de engenho e arte, a lampear o ventoso leque piriflox da Parca...” (Schüler, v. 3, p. 263)

"Annona née aroostucratiquement Nivia, tokteur è Raison et Art, son éventail ruisselant de perlicoluminifichets téclatants..." (BECKETT et al. $)^{185}$

Percebe-se que a tradução francesa de Lavergne e a brasileira adotaram critérios diferentes para traduzir essa passagem. A francesa, que era facilitadora, torna o texto tão difícil quanto está no original; a brasileira a traduz de maneira explicativa. A tradução de Tortosa pareceu, em toda a sua extensão, tão difícil quanto o original.

Diferentemente do pretendido pela tradução italiana, a francesa, realizada muito antes, procurou manter a mesma técnica de deformação utilizada no original.

$\mathrm{Na}$ tradução italiana, Joyce preocupou-se com a italianização, e em vez de usar idiomas das mais diversas partes, usou dialetos (veneziano, triestino, toscano), arcaísmos literários retirados da literatura e da ópera italiana. E para representar a linguagem das mulheres no rio ele faz com que "os diferentes estratos (altos, baixos) se encontrem de algum modo liberados de hierarquia e afastados de seu lugar de origem" (NESTROVSKI (ORG.), 1992, p. 416-7). Joyce procura compensar certa deficiência da língua italiana para os jogos de palavras fazendo com que a invenção de palavras seja dirigida pelo som (NESTROVSKI (ORG.), 1992, p. 417-8).

\section{1. 2. O método de Joyce}

"Ask Lictor Hackett or Lector Reade of Garda Growley or the Boy with the Billyclub. How elster is he a called at all? Qu'appelle? Huges Caput Earlyfouler."

"Chiedi a Manganelli, o al Randelloni, o al Mazzaferrata, o al Fracco la Frombola. Che saarebbe il suo superanome? Hugo Capeto l'Eccellatore."

\footnotetext{
${ }^{184}$ Nem todos os tradutores verteram esta passagem.

185 “Anna Livia Plurabelle”. In: Nouvelle revue français, 36, maio de 1931. p. 645-6)
} 
"Demande à Lictor Huckett ou à Lector Noiret ou à Gardar de Norval ou au Boy dit Browning. Comment le préenomme-t-on encore? Hughes Caput Earlyfowler.”

Percebemos nessa passagem que a tradução francesa se mantém mais atrelada ao sistema do original, diferentemente da italiana que procura até mesmo modificar os nomes próprios para que tenham sonoridade italiana. Alguns topônimos são eliminados dos trocadilhos: "elster" que faz trocadilho com Ulster (a região nordeste da ilha); e outros acrescentados: como Saara em saarebbe. As palavras que, no original, estavam em francês $(q u \text { ' appelle })^{186}$ viraram trocadilho em italiano (superanome), mostrando que um recurso criativo (a utilização de termos e expressões estrangeiros) podia ser substituído por outro (trocadilho). Há também uma série de alusões sexuais deformadas em nomes de personagens de comédia popular.

"And letting on hoon var daft about the warbly sangs from over holmen: High hellskirt saw ladies hensmoker lilyhung pigger: and soay and soan and so firth and so forth in a tone sonora and Oom Bothar below like Bheri-Bheri in his sandy cloak, so umvolosy, as deaf as a yawn, the stult!"

"Et de faire comme si Hon adourait follement les chansons gozillantes d'au delà de l'armor: "Ya elle square sot ladys insmoking lill et un piqué" et soaytera et soantera et Yangtsé de sweet, dans un "tone sonora", pendant que Oom Bothar reste en bas dans son manteau de sable tout embirassé et sourd comme un pô, le stupe!"

"Facendo finta di sposimare pei cantilanti d'oltramore: Io l'Oscar solletico, smoccogli lì un picchetto; e così e colà più ne hai più ne metti con toce sonora, e zio Zibeppe in cappa di sabbia, sì umvoloso e sodomurto, el belb'!"

Nesse caso, a tradução francesa faz uso, como acontece com o original, de expressões e palavras estrangeiras (no exemplo, inglesas). Na tradução italiana, o rio Iang-Tsé vira "zio Zibeppe", comprovando que o autor dava maior atenção ao aspecto fônico no caso dessa tradução.

Os pormenores da tradução de "Anna Livia Plurabelle” para o italiano aparecem no ensaio de Jacqueline Risset, “Joyce pour Joyce”, publicado na revista Tel Quel v. 55 (1973). É ela quem demonstra os recursos utilizados nessa tradução. Na conclusão de seu estudo, ela explica de onde Joyce tirou essas idéias: Ao tratar a língua como um grande dialeto, ele não

\footnotetext{
${ }^{186}$ Pode ser também o plural italiano de capela: cappelle; e um nome de rio "Qu'Appelle" (Saskatchewan, Canadá).
} 
distinguia mais uma da outra. Foi o mesmo processo empregado por Dante na Commedia. O próprio Joyce o disse:

Que pai Dante me perdoe, mas eu parti desta técnica de deformação para atingir uma harmonia que vence nossa inteligência, como a música. Você já parou junto a um rio que corre? Seria capaz de dar valores musicais e notas exatas a esse fluxo que lhe enche os ouvidos e o adormece de felicidade? (NESTROVSKI (Org.), 1992, p. 420) ${ }^{187}$

Da mesma forma que Dante usou os dialetos para criar uma língua maior, Joyce usou as línguas para criar uma linguagem maior, ou, uma língua verdadeira, como disse Walter Benjamin: "o que dá conteúdo a seu trabalho [do tradutor] é o grande motivo da integração de várias línguas para formar uma língua verdadeira” (NESTROVSKI (Org.), 1992, p. 420).

A língua verdadeira é aquela que se situa entre a da obra e a do tradutor. É a língua de um autor intermediário, o qual, no caso de Joyce, era Dante.

A tradução italiana de que Joyce participou é a única que conhecemos que se preocupa com a invenção de uma linguagem própria, e acabou sendo o método escolhido por nós para a tradução do primeiro capítulo do livro, como se verá. ${ }^{188}$

Não será possível seguir à risca o método empregado por Joyce na versão italiana, pois o critério adotado para se traduzir um fragmento pode não ser suficiente para se traduzir a obra por inteiro. Para manter as modificações feitas ao texto pela tradução italiana seria preciso reformular o livro todo: renomear as personagens, modificar cenários, situações, enfim reestruturar toda a obra, deslocando a ação de Dublim para algum lugar na Itália. ${ }^{189}$

\section{1.3. O paradigma}

O idioleto que buscamos para traduzir o Finnegans Wake será forjado a partir da língua intermediária, "falada" por um autor intermediário. O problema a seguir será encontrar esse autor.

\footnotetext{
${ }^{187}$ A citação é de uma conversa de Joyce com Ettore Settani publicada num opúsculo dele chamado James Joyce (Veneza, 1955).

${ }^{188}$ Há uma tradução inédita (intraduction) para o francês, por Halphé Michel, que se utiliza de uma linguagem própria, inventada para ela (linguagem "qu' ouac"). Ver http://arvemchelp.ifrance.com/.

${ }^{189}$ Foi o que fez Donaldo Schüler ao deslocar muitos topônimos e referenciais para o Brasil. Por exemplo, ao fazer com que o rio Liffey atravessasse a Freguesia do Ó e passasse pela Bahia antes de suas águas atingirem o promontório de Howth em Dublim; ou substituindo, por exemplo, Sterne e Swift por Machado de Assis e Eça de Queirós, respectivamente (ver JoYCE, 2004, p. 92). Joyce, por sua vez, dizia que o rio Liffey desaguava no Grande Canale de Trieste.
} 
Dante pode ser considerado o criador da língua italiana ao agregar ao limitado dialeto toscano outros dialetos para a invenção de uma língua literária que pudesse usar para a composição da Commedia. Mas na França, na Espanha e em Portugal isso não ocorreu, pois suas línguas nasceram de um decreto real que escolheu um determinado dialeto para ser a língua oficial.

A solução do problema poderia ser encontrada nos grandes mestres do período de formação da língua ou da nacionalidade, a época de Gil Vicente (1465?-1537?), Sá de Miranda (1481-1558) e Camões (1524/-1580), época também da primeira gramática da língua ${ }^{190}$. Poderia ser encontrada também nos grandes mestres da língua como o Padre Vieira (1608-1697), António Feliciano de Castilho (1800-1875), Alexandre Herculano (1810-1877) e Camilo Castelo Branco (1825-1890). Ou então nos mestres modernos como Euclides da Cunha (1866-1909), Coelho Neto (1864-1934), Humberto de Campos (1886-1934), José Geraldo Vieira (1897-1977) e Guimarães Rosa (1908-1967).

Há uma tendência na crítica contemporânea de querer vincular a obra de Joyce com a de Guimarães Rosa, por terem sido ambos inventores de palavras. ${ }^{191}$

No entanto o vínculo é muito sutil. Guimarães Rosa inventou uma linguagem para o sertanejo, uma linguagem que lhe possibilitou criar um narrador intermediário, posicionado entre o leitor e a personagem; e Joyce inventou uma linguagem para os sonhos. A linguagem de Guimarães Rosa não quer, como a de Joyce, provocar confusão. Nela não ouvimos em nenhum momento discursos concomitantes como no canto de um coro; uma história é contada de cada vez. Em Joyce as línguas se misturam porque as histórias se misturam, as eras se misturam, as personagens se misturam, os sonhos se misturam. Em Guimarães Rosa as línguas se misturam para criar uma sonoridade, um tom local; misturam-se para acentuar e não para confundir.

Se compararmos o narrador de Grande Sertão com o de Finnegans Wake perceberemos uma grande diferença. O narrador sertanejo é sempre o mesmo, sua língua é sempre a mesma e a língua das personagens é a dele. Em Finnegans Wake tudo é diferente: não é um narrador só; a linguagem varia de narrador para narrador, varia no mesmo narrador

\footnotetext{
${ }^{190}$ Gramática da Lingoagem Portugueza (1536), de Fernão de Oliveira (1507-1581).

${ }^{191}$ Augusto de Campos, no ensaio "Um lance de 'dês' do Grande Sertão", estabelece uma série de comparações entre Finnegans Wake e Grande Sertão-Veredas, retomando o que havia escrito antes em "O lance de dados do Finnegans Wake" (este último resume as comparações entre Joyce e Mallarmé feitas por David Hayman no livro Joyce et Mallarmé). O fato é que nenhum dos dois ensaios nos convenceram. As comparações nos pareceram muito vagas. No segundo, sequer conseguimos ser persuadidos de que houvesse alguma semelhança entre Joyce e Mallarmé.
} 
de um momento para o outro; às vezes há mais de um narrador, contando histórias diferentes ao mesmo tempo em línguas iguais ou diferentes. Guimarães Rosa está interessado no dialeto; James Joyce, no idioleto.

Otto Maria Carpeaux, escrevendo sobre Ulysses (CARPEAUX, 1999), um romance que causou escândalo na época de sua publicação por causa da ousadia de sua linguagem, disse não conhecer nenhum escritor em lugar algum, em tempo algum, que se utilizasse de uma linguagem tão pessoal como a que James Joyce usou em Ulysses. O único exemplo que se aproximava era o Baldus de Teófilo Folengo ${ }^{192}$ :

Phantasia mihi plus quam phantastica venit

historiam Baldi grassis cantare Camoenis.

Altisonam cuius phamam, nomenque gaiardum

terra tremat, baratrumque metu sibi cagat adossum.

Sed prius altorium vestrum chiamare bisognat,

o macaroneam Musae quae funditis artem.

Folengo escreveu o poema numa linguagem que mistura o latim com o italiano, a "lingua macheronica" ${ }^{193}$. Era uma língua usada por outros poetas satíricos da época, mas Folengo fez dela uma língua pessoal, com uma sintaxe e um vocabulário próprio e coerente, obediente à métrica latina e demonstrando um conhecimento perfeito da prosódia, do léxico e do estilo poético, diferentemente dos outros que faziam dela um meio de expressão da desordem.

O exemplo de Carpeaux parece tornar vão o intento de procurar algum escritor cuja linguagem se assemelhe à de Joyce, ainda mais à do Joyce do Finnegans Wake. Tampouco adiantaria procurar a semelhança num autor posterior a ele, pois da árvore genealógica da literatura estamos atrás de raízes e não de frutos.

O escritor francês François-René Chateaubriand (1768-1848) esteve diante de um problema semelhante ao nosso, que foi apontado por Antoine Berman no ensaio “Chateaubrind traducteur de Milton" (BERMAN, 1985, p. 109-25). Quando Chateaubriand estava traduzindo o Paraíso perdido, percebeu que as passagens da Bíblia citadas por Milton

\footnotetext{
${ }^{192}$ Escritor italiano que viveu entre 1491 e 1543. Pertenceu à ordem de São Bento e escreveu um poema épico para criticar a aristocracia. Esse poema, Baldus, apesar de ter influenciado Rabelais e Cervantes, não é mais lido, justamente por causa de sua linguagem.

${ }^{193}$ António José da Silva, o Judeu (1705 - 1739) usa essa linguagem (latim macarrônico) nas falas de Sósia na peça Júpiter e Alcmena (1736). No Brasil, o escritor Juó Bananere (Alexandre Marcondes Machado) escreveu um poema inteiro em italiano macarrônico: La divina increnca (1915).
} 
eram todas extraídas da Versão Autorizada ${ }^{194}$, a qual não tinha correspondente em francês. Para traduzir essas passagens, ele não pôde recorrer à Bíblia protestante, quer pela falta de traduções, quer pela distância que ainda havia entre a Igreja Anglicana e a Protestante ${ }^{195}$ na época. Como Chateaubriand estivesse se orientando pela teoria latina de tradução, fez uso da Vulgata, de certa forma latinizando o inglês: "traduziu Milton em uma língua cristã francesa que seria a de uma versão autorizada inexistente” (BERMAN, 1985, p. 114). É um método semelhante ao usado por Goethe no West-Öesterlicher Divan. ${ }^{196}$ A latinização do inglês buscava aproximar da França o universo de Milton, criando um espaço intermediário no qual o tradutor pudesse desenvolver o seu estilo. A justificativa inicial de Chateaubriand era esta: como Milton viveu num período revolucionário, a era de Cromwell, em que as idéias acompanhavam as atitudes, o tradutor de Milton devia ter a mesma coerência e produzir um texto (a atitude) bastante próximo do original (a idéia). Parece-nos que ele atingiu seu intento, apesar de ter agido como os tradutores franceses da época de Molière que expurgavam do texto tudo o que consideravam de mau gosto. A concepção de literalidade de Chateaubriand, de acordo com aquilo que ele soube mostrar, significa mais fidelidade à idéia do que à letra.

O espaço ocupado pelo autor intermediário é um terreno muito exíguo que existe entre a obra e sua tradução. Quanto menor for esse espaço, maior será a fidelidade. É um espaço que pode ser ocupado por um autor ${ }^{197}$, uma língua ${ }^{198}$ ou uma cultura ${ }^{199}$.

Dada a dificuldade de se encontrar um paradigma para o Joyce de Finnegans Wake, e o inusitado do fato de ter ele próprio escolhido Dante como paradigma italiano, como resolver a questão do autor intermediário no universo da língua portuguesa? A investigação mostrou que esse paradigma não era uma língua, nem uma cultura, mas um tradutor: Manuel de Odorico Mendes. ${ }^{200}$

\footnotetext{
${ }^{194}$ King James Version, versão para o inglês dos textos sagrados patrocinada pelo rei Tiago I da Inglaterra, em 1611, e realizada por uma comissão de 47 tradutores.

${ }^{195}$ Os protestantes francófonos utilizavam a versão da Vulgata feita por Olivétan, sobrinho de Calvino. Coube a Louis Segond a primeira tradução protestante feita diretamente dos textos originais. Essa versão apareceu apenas em 1880.

${ }^{196}$ Traduções feitas por Goethe do Divã do poeta persa Hafiz. No prefácio, Goethe define sua teoria de tradução e descreve um processo em que ocorre uma perfeita correspondência entre o original e a tradução; um processo no qual as línguas se afetam umas às outras.

${ }^{197}$ Dante, no caso de Joyce.

198 No mesmo livro, Le tours de Babel, Berman dedica um ensaio à tradução da Eneida feita por Pierre Klossowski, na qual o tradutor, por ter estudado as versões dos textos clássicos feita por Voss, usou o alemão como língua intermediária, semelhantemente ao que fez Chateaubriand ao usar o latim.

${ }^{199}$ O sistema de Goethe.

${ }^{200}$ Manoel Odorico Mendes (1799 - 1864). Poeta e tradutor maranhense. Traduziu os poemas de Homero e de Virgílio para o português.
} 
Odorico Mendes, apesar de ter sido também poeta, é como tradutor de Homero e de Virgílio que o aproveitaremos. Os estudos do Professor Antonio Medina Rodrigues ${ }^{201}$ atestam o grande valor estético das traduções de Odorico, refutando as críticas de Sílvio Romero e Antonio Candido.

Silvio Romero, ao falar das traduções de Odorico, diz que a tradução "deve revelar-se na leitura como trabalho autônomo e independente, como se fora produto original e assim primitivamente escrito. É o que não se nota nas traduções de Odorico." Mas é justamente isto o que são as traduções de Odorico: trabalho autônomo, independente e original. Diz também o crítico que Odorico "inventou termos, (...) jungiu arcaísmos e neologismos, latinizou e grecificou" (Homero, 2000, tradução de Odorico Mendes, p. 34), mas são essas as marcas da tradução criativa.

Antonio Candido, ao afirmar que o espírito dos "árcades rotinizados" atinge com “Odorico Mendes tradutor de Homero um ápice de tolice” (CANDIDO, 1969, v. II, p. 74), talvez usasse expressão semelhante para se referir ao Joyce autor do Finnegans Wake. Da Ilíada do maranhense, diz estar "alastrada de vocábulos e expressões que tocam as raias do bestialógico" (CANDIDO, 1969, v. I, p. 202). Tolice e bestialidade não parecem substantivos apropriados para designar o trabalho de alguém capaz de traduzir do grego e do latim. Uma expressão bastante usada por Candido na Formação, ao se referir àqueles poetas e tradutores muito inventivos, é "Mau gosto", título do capítulo em que Antonio Candido trata dos neologismos. Ele começa a falar deles desta maneira:

Outras ocorrências do mau gosto são os neologismos em que se fundem substantivo e adjetivo, sujeito e complementos. Com dificuldade de transpor ao português os versos densos e sintéticos do grego, José Bonifácio foi levado a recomendar esse processo, na "Advertência” à tradução das Olímpicas (...): “(...) ser-nos-ia preciso enriquecer primeiro a língua com muitos vocábulos novos, principalmente compostos..." (CANDIDO, 1969, v. I, p. 202)

Pouco mais adiante, Candido menciona vários desses vocábulos: Auricomada, Roxicomada, Boquirubra, Bracirósea, Olhinegra, Olhiamorosa, Argentipede, Tranciloira, Docirisonha (José Bonifácio), Puerpera Diva, septemfluo, pulcros celicultores, Padre Cristífero, aquícola, Romípetas, lucífugas, ignícolas, celícolas ou célites (Francisco de São Carlos) (CANDIDO, 1969, v. I, p. 202).

${ }^{201}$ Sua Dissertação de Mestrado (1977) e as introduções à Odisséia (2000) e à Eneida (2005). 
Seja de mau gosto ou não, o neologismo foi um dos processos de criação de palavras utilizado por Joyce e dele faremos uso. No entanto, foi um recurso pouco usado por Odorico Mendes, e quase sempre para traduzir os epítetos dos deuses e da natureza. Não é o principal recurso de suas traduções.

O maior mérito delas foi reproduzir a síntese da língua grega em português, usando o verso decassilábico. Fez exatamente o contrário do que o acusa Antonio Candido de ter feito. Não teve nenhuma dificuldade em "transpor ao português os versos densos e sintéticos do grego", como fez José Bonifácio e, "melhor fez Odorico Mendes”.

Como ele atingiu essa síntese é algo que Romero e Candido ignoravam. Antonio Candido chegou a esbarrar numa resposta ao dizer que Odorico refugiou-se "no pedantismo arqueológico das traduções de Homero e Virgílio". Mas a preocupação do crítico estava no "pedantismo" e não no "arqueológico", o que fez com que ele se desviasse da resposta. A arqueologia das palavras em Odorico Mendes não é uma ciência de coisas mortas, de palavras enterradas, de expressões perdidas, de verbos abandonados; Odorico Mendes usa a língua num âmbito temporal maior, e o local de pesquisa dele não é outro senão o glossário. Muito mais do que inventar palavras, ele se preocupava em encontrar palavras; muito mais do que palavras mortas, vocábulos vivos. O propósito da tradução é ampliar o alcance da língua; não apenas adicionando termos ao léxico, mas também ampliando o alcance desse léxico. A língua portuguesa, graças a seu enorme vocabulário, podia ser tão sintética e densa quanto a grega, tudo o que Odorico Mendes teve de fazer foi escolher palavras para isso.

Com Joyce foi diferente. Ele inventou palavras porque não queria estar preso ao arcabouço da língua inglesa. James Joyce usou, para compor o seu Finnegans Wake, 63924 palavras diferentes (HART, 1962, p. 13), quase cinco vezes mais palavras do que o número de vocábulos distintos que há a Bíblia; no entanto, tendo-se em conta que a maioria delas foi inventada por ele, as palavras do inglês (a língua à qual não queria estar preso) que ele usou representam pouco menos de cinco por cento do léxico da língua. Como se pode falar em prisão quando se conhece tão pouco o espaço? Quanto ao arcabouço, que era a estrutura da língua, ele tinha razão: de fato a estrutura da língua inglesa é muito mais limitada do que a de qualquer outra língua européia. Mas são poucas as experiências sintáticas feitas no livro com a utilização de outra língua, a maioria delas consistiu em aplicar ao inglês a capacidade de aglutinar palavras que tem a língua alemã ${ }^{202}$, uma capacidade que o inglês também possui,

\footnotetext{
${ }^{202}$ Há uma preferência pelo uso de palavras germânicas em Finnegans Wake, pois são mais próximas do inglês, que também é uma língua germânica, do que são das línguas latinas. Há, contudo, outro motivo para isso. A
} 
apenas em menor grau. A grande novidade do livro resulta da invenção de palavras. E nesse ponto a língua não representava nenhuma prisão.

\section{INTERPRETAÇÃO}

O método de Odorico Mendes é bastante apropriado para se traduzir o Finnegans Wake. As mais de quatrocentas mil palavras do vocabulário da língua portuguesa devem dar conta de formar outras 63924 para a tradução de Finnegans Wake. Será possível produzir um texto com a sonoridade da língua portuguesa, como fez Joyce ao traduzir para o italiano. Será possível criar neologismos, palavras-portmanteaux, fazer trocadilhos, enfim, utilizar a mesma criatividade de Joyce no português.

Contudo, menos do que ele, preocupar-nos-emos com estar presos ao arcabouço da língua: a sintaxe do português, apesar de ser menos flexível que a do inglês, é muito mais rica e o vocabulário não é muito menor. Será preciso, no entanto, tomar cuidado com as aglutinações, um processo estranho à nossa língua. Nas traduções que analisamos, percebemos que muitos tradutores tiveram dificuldade em lidar com termos aglutinados e, mais do que isso, com os trocadilhos que, ao serem desdobrados foram traduzidos por termos aglutinados: na tradução brasileira de Donaldo Schüler encontramos, na mesma página, um exemplo das duas coisas. Primeiro, a palavra inicial do livro, riverrun, é composta pela junção de dois termos river e run (embora não seja tão simples assim) ${ }^{203}$; Schüler usou três termos para montá-la: "rolarrioanna" (rola + rio + ana) ${ }^{204}$. Segundo: o termo mumper (uma palavra só) foi traduzido por "mamypapypares" (três palavras). Embora exista uma explicação para isso $^{205}$, esses exemplos servem para ilustrar o problema que as aglutinações representam para o tradutor.

Não há necessidade de se incorporar as aglutinações ao texto traduzido ${ }^{206}$, pode-se desdobrá-las ou usar um termo do próprio léxico que contenha os termos aglutinados; o

personagem central HCE é de origem escandinava e quando uma palavra escandinava aparece no texto pode estar aludindo a ele ou à invasão da Irlanda pelos povos escandinavos.

203 A composição do termo está explicada no início da tradução.

${ }^{204} \mathrm{Na}$ segunda edição, está "rolarriuanna" (Joyce, 2004, p.31).

${ }^{205}$ Em "rolarrioanna", o tradutor antecipou a relação que há entre a personagem Anna Livia e o rio, relação que vai sendo estabelecida ao longo da narrativa. Em "mamypapypares", procura traduzir o desdobramento do termo mumpers em mom ("mamãe" em inglês) e père ("pai" em francês); apesar de mumper ser uma gíria que significa "mendingo", ela faz trocadilho com number ("número"), deve ser por isso que o tradutor acrescentou "par" ao final da palavra.

${ }^{206}$ No livro Deus e o diabo no Fausto de Goethe, o autor, Haroldo de Campos, mostra seu método de tradução que consiste, entre outras coisas, em aproximar o idioma da tradução do idioma traduzido. Diz ele, sobre uma 
mesmo pode ser feito com termos simples que podem ser desdobrados. O exemplo seguinte revela três aspectos de nosso método: a pesquisa etimológica, a pesquisa lexical e o aportuguesamento do texto com relação às aglutinações.

A passagem "doublin their mumper all the time" (FW 003.08-9) pode ser lida como "doubling their number all the time". Mumper é uma gíria que significa "mendigo", "pedinte"; doublin é um trocadilho entre doubling e Dublin; além disso, o morfema "mum" de mumper pode se referir a "Mum", uma marca de cerveja (CAMPBELL; RoBINSON, 1976, p. 32), ou a mom, hipocorístico de mother (mãe); e o morfema "per" pode ser a palavra père (pai) do francês. Traduzimos assim:

"dublicavam a gorjeta abeternamente"

Aí estão contidos os componentes Dublin, doubling, mumper, Mum, mom, père. "Dublicavam" é um trocadilho óbvio entre "Dublim" e "duplicar"; "gorjeta" é uma referência ao significado etimológico do termo, diminutivo de "gorja" (garganta), de origem francesa, gorge, que vem do latim vulgar gurga, que por sua vez descende do latim clássico gurges, itis. Gorjeta é um termo que surgiu por volta do século XVIII ${ }^{207}$ e tem o sentido original de "bebida que se oferecia a quem prestou algum serviço"208, ou, "pequena gratificação em dinheiro"209 para, como dizemos hoje, "molhar a goela". A palavra gorjeta aparece na tradução para contemplar a acepção de "pedinte" (gratificação) e de bebida (cerveja, Mum). Para incorporar os termos "mãe" e "pai", usamos a técnica do deslocamento que consiste em transferir o trocadilho para um termo próximo: em "abeternamente", semelhante a "all the time”, usamos os termos (ab/av/) e אב (em) que em hebraico significam respectivamente "pai" e "mãe".

Traduzindo dessa maneira, evitamos a aglutinação, aportuguesamos o topônimo, deixamos a frase com o aspecto da língua portuguesa e traduzimos tudo que pudemos identificar por meio da análise.

Por outro lado, não é preciso evitar sempre as aglutinações. O propósito é a obtenção de um texto decalcado nos aspectos fônicos da língua portuguesa que tem seus meios próprios de formação de palavra e que pode incorporar outras línguas. Um exemplo disso é a forma

passagem de sua tradução do Fausto: "ao invés de aportuguesar o alemão, germanizo o português, deliberadamente, para o fim de alargar-lhe as virtualidades criativas". O autor refere-se aos termos "flamirrompe", "rubibochechudos", "pescocicurtos", etc., usados por ele.

207 1791, segundo o Dicionário Houaiss.

${ }^{208}$ Dicionário Houaiss.

${ }^{209}$ Dicionário Houaiss. 
como foram aportuguesados os topônimos e os nomes das personagens da Bíblia na tradução para o português: Nabucadne'tstsar (Nabucodonosor); Belcha'tstsar (Belsazar ou Baltazar); Bachan (Basã); em que a chiante quase sempre vira S; “-an” vira "-am” ou "-ão"; a vogal dobrada quase sempre vira simples; etc.

O texto pretendido por nós recusa o conceito de fidelidade por ser este muito vago. Chateaubriand pretendeu uma fidelidade e encontrou outra. Pretendeu uma fidelidade à letra e obteve uma fidelidade ao sentido geral; recusou a fidelidade poética para encontrá-la no final. Não jogaremos segundo as mesmas regras do autor, porque as regras de nossa língua são outras. Almejamos o mesmo fim por meios diversos. O fim para nós é o além. E nisto seremos fiéis ao autor.

o trabalho de tradução não consiste, neste caso, em uma pesquisa de hipotéticos equivalentes do texto "original" (isto é: dado, definitivo), mas em uma elaboração ulterior, que representa, com relação ao texto visto verdadeiramente como work in progress, uma espécie de prolongamento, uma nova etapa, uma diferenciação mais acentuada da matéria verbal em atividade. (NESTROVSKI (Org.), 1992, p. 411) ${ }^{210}$

\section{1. Análise}

Of the first was he to bare arms and a name: Wassaily Boos-laeugh of Riesengeborg. His crest of huroldry, in vert with ancillars, troublant, argent, a hegoak, poursuivant, horrid, horned. His scutschum fessed, with archers strung, helio, of the second. Hootch is for husbandman handling his hoe. Hohohoho, Mister Finn, you're going to be Mister Finnagain! Comeday morm and, O, you're vine! Sendday's eve and, ah, you're vinegar! Hahahaha, Mister Funn, you're going to be fined again! (JOYCE, 1976b, p. 5)

Essa passagem do livro menciona as armas de Finnegan; uma referência à heráldica de Vico. Como o romance mistura várias personagens, transformando figuras históricas umas nas outras, nessa passagem Finnegan é um gigante russo-alemão, Wassaily Booslaeugh de Riesengeborg e, além disso, o mesmo Finnegan que está sendo velado.

É o preciso momento em que ele ressuscita para participar da festa de seu próprio velório e beber com os amigos; é a passagem de que fala a canção Finnegan's Wake: "lots of fun at Finnegan's Wake". São muitos os Finnegans que despertam (Finnegans Wake) na

${ }^{210}$ Work in Progress era o nome provisório do Finnegans Wake. 
vigília de um só (Finnegan’s Wake) por causa do uísque (a água da vida). E aqui também se revela um dos critérios de composição da obra, o trocadilho (trocadilho até no título).

Sabemos, pela canção, que Tim Finnegan ${ }^{211}$ era um pedreiro que caiu da escada e quebrou a cabeça, como Humpty Dumpty. No velório, a água da vida, lhe cai na cabeça e ele ressuscita para participar da bebedeira. Mas se ele volta à vida e se torna Finn de novo (Finnagain), um dia voltará a morrer (Finned), a apodrecer, da mesma forma que o vinho se transforma em vinagre. É uma reprodução do esquema cíclico da História elaborado por Vico.

A expressão que aparece no início do parágrafo, "of the first was he to bore arms", é uma paródia de Hamlet ("was the first that ever bore arms"), Ato V, cena 1, na qual dois campônios $^{212}$, encarregados de abrir a cova na qual será sepultada Ofélia, discutem se ela, por ter tirado a própria vida afogando-se, merecia ou não um enterro cristão. Nela os coveiros falam sobre a água que tira a vida; na paródia de Joyce, sobre a água que proporciona a vida. Os coveiros falam também da profissão daqueles que têm armas, fazendo um trocadilho com braços (arms em inglês significa "armas" e também "braços"), um trocadilho que mostra o poder do trabalho. Adão, despojado do Paraíso, teve de viver à custa dos braços, suas únicas armas. Os camponeses concluem que o coveiro é melhor construtor do que o pedreiro (profissão de Finnegan) porque constrói moradas eternas. O primeiro a ter armas (ou braços) foi Adão ("the first that ever bore arms"), o primeiro coveiro da História. Shakespeare faz, nessa passagem, vários jogos de palavra (assim como Joyce em todo o Finnegans Wake): entre a água e a terra, entre a vida e a morte, entre o que ergue e o que cava, entre o trabalho (que constrói) e a guerra (que destrói), entre o braço e a arma. Quando Hamlet entra em cena, irrita-se com o fato de um dos coveiros estar cantando. Todos cantam no velório de Finnegan, aquele que para se erguer na vida ("to rise in the world", diz a canção), carregava sua ferramenta ("he carried a hod") e que ao morrer será destinado à terra, mas a água o fará reerguer-se.

Finnegan, na passagem citada, é identificado com Adão. O nome de Adão (ver nota 23, na p.23) relaciona etimologicamente a palavra homem com a palavra terra: Adão é

\footnotetext{
211 "Tim Finnegan lived in Walkin Street, / A Gentleman Irish mighty odd. / He has a tongue both rich and sweet, / An' to rise in the world he carried a hod (...) / One morning Tim was rather full, / His head felt heavy which made him shake, / He fell from the ladder and broke his skull, / So they carried him home his corpse to wake..."

${ }^{212}$ Shakespeare escreve clowne, cujo sentido é de "homem simples, rústico", mas também de "palhaço" (sentido este derivado do anterior). Ele usa o termo em suas obras geralmente com o sentido de "serviçal da corte". Mas, nesta cena, ele caracteriza o clowne de maneira bufa, como personagens da commedia dell'arte: um deles diz "It must be se offendendo", usando uma expressão italiana.
} 
homem que, mais tarde, quando for expulso do Paraíso, deverá retirar o seu sustento da terra. É o homem que veio do pó e que ao pó retornará. Adão é todos os homens e o primeiro homem. Esse homem é como o bêbado ingênuo que morre ao tentar subir na vida. Tim Finnegan tem a ambição de subir na vida ("to rise in the world, he carried a hod") e essa ambição é um desafio aos deuses; ou a Deus que responde a ela (a construção da torre de Babel) com a dispersão das línguas (dispersas também ao longo de todo o romance). Mas o desafio do homem já era anterior à torre de Babel. Ao comer o fruto da árvore da sabedoria, o homem (Adão) está desafiando Deus. Esse homem deixa o Paraíso para viver da terra; para trabalhar e ser explorado; e encontrar alento apenas na bebida, a qual he revela uma dimensão da existência que, apesar de fantasiosa, é confortante e que, no livro, se torna real. Essa dimensão será reproduzida, ao longo do livro, na linguagem. A linguagem do bêbado, semiconsciente, a linguagem da plena consciência (que é a linguagem da manhã) e a do sonho (da noite) articulada pelo dono da taverna - o substituto de Finnegan - que viverá a dupla existência do sonho e da vigília (wake) e confundirá o leitor que não saberá mais quando se está no plano do desperto, quando se está no plano do sono.

Toda essa passagem do romance foi forjada a partir daquela cena de Hamlet e da canção Finnegan's Wake (com apóstrofo). E apenas nessas poucas linhas, o autor resume todo o ciclo viquiano das eras da História.

Adão, como primeiro homem de armas, caminha do Paraíso para a Idade Heróica. O herói aqui é Wassaily Booslaeugh, ou Vassili Buslaiev, herói do ciclo de baladas de Novgorod. O nome Wassaily é um trocadilho com Vassili e wassail, "bebedeira".

Riesengeborg é uma forma de transformar o topônimo Riesengebirge ${ }^{213}$ em um nome nórdico ${ }^{214}$. Booslaeugh, por sua vez, é uma tentativa de transformar um nome russo ${ }^{215} \mathrm{em}$ um

\footnotetext{
213 "Serra dos gigantes" em alemão. Trata-se da serra dos montes Sudetos na Polônia (Karkonosze).

${ }^{214}$ Borg significa "castelo" em sueco. É uma alusão ao castelo de Howth em Dublim, uma fortaleza edificada para evitar invasões vindas do mar. Quando Sir Almeric Tristram, duque normando, conquistou a Irlanda em 1177, fez do local posto de vigia. O Castelo é de 1564 e foi edificado sobre um cemitério pré-histórico. Há um mito que explica a formação geológica da cidade de Dublim como se ela fosse o corpo de um gigante caído, Finn MacCool, o vigia da terra (ver figura na p. 60). A cabeça do gigante é o promontório de Howth, onde fica o castelo. Howth deriva do termo dinamarquês hoved, que significa "cabeça"; os pés do gigante estão do outro lado da cidade, no Parque Phoenix. Finn MacCool, a terra, é Tim Finnegan que se transformará em HCE, dono de uma taverna num dos extremos do Pareque. Essa alusão ao gigante remonta ao primeiro parágrafo do livro.

215 A mulher de HCE, Ana Lívia, é de origem russa. Ela representa o rio Liffey, que atravessa Dublim. Essa passagem, além de se referir à metamorfose do homem em terra, refere-se também à metamorfose da mulher em rio. A terra, símbolo feminino na maioria das mitologias, não o é na irlandesa; e o rio, que em todos os lugares tem sempre um nome masculino, apenas na Irlanda tem nome de mulher.
} 
nome irlandês. E a menção aos gigantes, contida no topônimo, faz referência a Dublim, cuja paisagem assemelha-se a um gigante deitado.

A passagem seguinte fala da heráldica, do brasão forjado de elementos irlandeses (o verde da Irlanda, que se inverte [“in vert"]) e nórdicos (a prata), representando a conquista da ilha. Mas nisso há também uma outra história, que começa a ser contada, e que se descortinará mais tarde, que é a queda do protagonista, HCE, que sofre a humilhação de ter sido acusado de molestar (ou de se exibir a) duas garotas que passeavam no Parque Phoenix em Dublim, parque em cuja extremidade sul fica a taberna do protagonista. Vários símbolos fálicos aparecem aqui: o arco tenso, o bode, o chifre (que também representa a traição); e símbolos da proteção: o escudo, o Sol e o segundo (cavalariço), o que significa que houve uma agressão de um lado e uma defesa do outro. São duas coisas ao mesmo tempo: o estupro (a invasão) e a defesa da terra.

No final a terra se elevará novamente; será trazida de volta à vida para morrer depois. HCE é a personagem do romance que se identifica com a terra. Ele é casado com ALP (Ana Lívia) que é o rio (o rio Liffey que corta Dublim, passando ao lado do gigante). Juntos eles formam a História (porque darão frutos), reproduzem o começo das civilizações que se agregavam em torno dos rios $(+)$ para cultivar a terra $(ð)$.

Só depois de feita uma análise exaustiva do texto é que o tradutor pode passar à tradução. Todavia, entre a análise e a tradução, está a crítica, da qual trataremos em seguida. Antes, para encerrar o capítulo da análise, fornecemos um pequeno glossário das palavras exóticas encontradas nessa passagem:

\section{GLOSSÁRIO}

\begin{tabular}{|l|l|l|l|}
\hline PALAVRA & SIGNIFICADO & PALAVRA & SIGNIFICADO \\
\hline arms (tr.) & arse (bunda) & argent (1.) & prata \\
\hline Wassaily (tr.) & Basílio e bebedeira & hegoak (tr.) & he-goat (bode) ${ }^{216}$ \\
\hline buslai (r.) (tr.) & bêbado e & Poursuivant (fr.) & perseguidor \\
\hline
\end{tabular}

\footnotetext{
${ }^{216}$ São possíveis outras duas interpretações: 1. hedgehog (ouriço); 2. hedge-school, uma escola improvisada e clandestina onde os católicos se instruíam na Irlanda, uma vez que do século XVII ao XIX era proibido dar educação aos católicos na Irlanda. Pode ser também "groat", moeda antiga, pois algumas delas mostravam a efígie da harpa de Brian Boru; essa harpa compõe o brasão atual do país.
} 


\begin{tabular}{|c|c|c|c|}
\hline & booze (bebida) & horrid, horned (tr.' & horrid horn (estúpido) \\
\hline laoch (irl.) & guerreiro & scutschum & $\begin{array}{l}\text { escutcheon (brasão); } \\
\text { scrotum (escroto) }\end{array}$ \\
\hline Riesen (al.) & gigantes & fessed (fr.) & $\begin{array}{l}\text { fesse (bunda); } \\
\text { feces (defecou) }\end{array}$ \\
\hline \multirow[t]{2}{*}{ Geborgen } & seguro (hol.); Salve! (al.) & helio & Sol \\
\hline & borg (s.) (castelo) & second & cavalariço \\
\hline \multirow[t]{2}{*}{ Huroldry (tr.) } & heraldry (heráldica) e & hootch & bebida, uísque \\
\hline & Hure (al.) (puta) & Comeday morn & $\begin{array}{l}\text { comedy; Monday morn; } \\
\text { come (gozar) }\end{array}$ \\
\hline vert (fr.) & verde & vine & wine, fine \\
\hline ancilla (1.) & criada & Sendday's eve & Sunday eve; send away \\
\hline troublant (fr.) & distraído & & \\
\hline
\end{tabular}

\section{2. Crítica}

Como já dissemos, o método da análise crítica parte das contradições que a obra encerra, contradições essas que podem ser observadas na crítica que dela surgiu e nas traduções que dela foram feitas. Mostraremos nas linhas seguintes esse procedimento em mais pormenores.

\subsubsection{Traduções:}

Tradução para o castelhano, por Víctor Pozanco:

De los primeros fue en descubrir sus armas y su nombre: Wassaily Booslaeugh de Riesengeborg. Con su heráldica cresta de macho cabrío, plata sobre verde campo, horrible e cornudo poursuivant. Su escudo de armas con frangle, tenso arco y Sol figurado e su padrino. Y ahora a brindar, que a cuartillo toca quien llena el celemín. Ajajá, Mister Finn, ¡vais a 
emular a Mister Finn McCumbal! ¡Tan de mañana y como una cuba! Avinagrado os darán las tantas y más multas que maltas pagaréis al fin. (JOYCE, 1993b, p. 18)

\section{Tradução para o italiano, por Luigi Schenoni:}

Dei primi lui fu a nudare armi ed un nome: Wassaily Booslaeugh di Riesengeborg. La sua insegna hurealdica, in verde con ancillarie, troublant, argento, un caprione, poursuivant, coriaceo, cornuto. Il suo blesone fasciato, con arceri in tiro, celioh, del secondo. Cicchettoni è un contadino che coltiva cavoli. Ohohohoh, Mister Finn, stai per diventare Mister Finnagain! Viendì mattì, e, Oh, sei vite! Vamenica sera e, ah, sei vinagro! Ahahahah, Mister Funn, stai per essere funminato ancora! (JOYCE, 1999a, p. 5bis)

Tradução para o francês, por Philippe Lavergne:

Il fut parm les premiers à se découvrir d'armes et de nom: Georges Grosbœuf de Grandgousier. Cimier d'héraldique, à l'en vert sur ancillaires, trouble, argent, bouc de chêne, poursuivant, horrible, cornu. Écusson de fasce, avec cordes d'arches, hélion, d'autre part. Chaque verre appartient à chacun qui manie le foin. Hohohoho, Maître Finn encore! Le vendredi matin, vous voilà en vin! Dimanchoir et vous voilà encore vinaigre! Hahahaha, Maître Finn, vous aurez encore à Financer! (JOYCE, 1982, p. 23)

Tradução para o português, por Donaldo Schüler:

Dos primeiros foi ele a portar armas e que nome: Aquoso Pinguço Serragigante! Seu elmo de putáltica, em verde, ostentava servulgatas, sexitantes; argênteo, um bode, persecutante, hórrido, cornudo. Trazia couraça de banda, ornada com arqueiros; hélio, d'outra parte. Empino um copo à saúde do adão que no serviço topo. Hohohoho, Mister Finn, o senhor será Mister Refinnado! Com'é dia de segunda e, oh! eres vino! Finnda a dominga e, ah!, és vinagre! Hahahaha, Mister Funnéreo, o senhor será afunndado! (JOYCE, 1999c, p. 35)

\section{GLOSSÁRIO DAS TRADUÇÕES}

\begin{tabular}{|c|c|c|c|c|}
\hline ORIGINAL & CASTELHANO & ITALIANO & FRANCÊS & PORTUGUÊS \\
\hline Wassaily Boosla & Wassaily Boosla $\epsilon$ & Wassaily Boosla & Georges Grosbœı & Aquoso Pinguço \\
\hline Riesengeborg & Riesengeborg & Riesengeborg & Grandgousier & Serragigante \\
\hline huroldry & heráldica & hurealdica & héraldique & putáltica \\
\hline vert & verde & verde & Não traduziu & verde \\
\hline
\end{tabular}




\begin{tabular}{|c|c|c|c|c|}
\hline ancillars & - & ancillarie & ancillaires & servulgatas \\
\hline troublant & troublant & trouble & troublant & sexitantes \\
\hline argent & plata & argento & argent & argênteo \\
\hline hegoak & macho cabrío & caprione & bouc de chêne & bode \\
\hline poursuivant & poursuivant & poursuivant & poursuivant & persecutante \\
\hline scutschum & escudo & blesone & Écousson & couraça \\
\hline fessed & flangle & fasciato & de fasce & de banda \\
\hline helio & Sol & celioh & hélion & hélio \\
\hline Hootch & cuartillo & - & verre & empino um copo \\
\hline Finnagain & Finn McCumbal & Finnagain & Finn encore & Refinnado \\
\hline Comeday & - & Viendì & vendedri & segunda \\
\hline morm & de mañana & mattì & matin & dia de \\
\hline vine & cuba & vite & vin & vino \\
\hline Sendday & Sendday & Vamenica & Dimanchoir & dominga \\
\hline
\end{tabular}

A tradução para o castelhano segue um critério semelhante ao da francesa, procurando não complicar demais as coisas para o leitor. Prefere desdobrar algumas palavrasportmanteaux, eliminar trocadilhos, mas recorre ao procedimento de ignorar palavras do contexto. Por exemplo, o trecho "in vert with ancillars, troublant, argent, a hegoak" é traduzido por "macho cabrío, plata sobre verde campo", ignorando os termos troublant e ancillars. Ignorou também o trocadilho "in vert", que pode ser invert (inverter). Na sentença seguinte — "Su escudo... padrino.” —, o tradutor consegue verter todos os significados básicos ${ }^{217}$, decompondo "scutschum fessed" em "escudo de armas con frangle" (escudo de armas com esquarteladura), e sem usar nenhum trocadilho.

No próximo período, "Hootch is for husbandman handling his hoe", o tradutor adapta o que está escrito para algo que parece um ditado popular: em vez de "A aguardente é para

${ }^{217}$ Como ele mesmo diz no prefácio, limitou-se a traduzir apenas o discurso principal. 
um camponês que usa a enxada", ele escreve "uma garrafa cai bem para quem enche um celemim [medida de volume]", fazendo um trocadilho ao utilizar duas medidas. Cuartillo é um quarto de galão, a mesma coisa que "garrafa" (750 ml aproximadamente). Ele não se preocupa com o efeito sonoro da frase, deixando de lado as aliterações que ocorrem no original.

O maior problema das traduções é esta passagem: "Mister Finn... vinegar!". Quando o autor diz “O, you're fine!”, ele mostra ao leitor que alguém está dizendo, com a voz pastosa de um bêbado, "you're fine". O tradutor espanhol deixa esse pormenor de lado; o italiano troca o vinho pela uva (o que parece uma boa solução); o francês faz trocadilho entre enfin e en vin, mas muda um pouco o sentido da frase. Da tradução brasileira falaremos depois.

O tradutor espanhol desvia a posição e o sentido do trocadilho para criar outro em outro lugar: McCumbal com "una cuba". Despreza o trocadilho entre "Mister Funn" e "be fined again”, essencial para a intelecção da obra, e recolhe uma personagem, Finn McCumbal, que é Finn MaCool, o gigante cujo corpo forma a paisagem da cidade de Dublim, e a coloca aqui. $\mathrm{O}$ vinagre, que deveria combinar com o vinho, passa a combinar com o malte; como entre esses dois não dá para formar um trocadilho, o recurso utilizado foi combinar as maltas com as multas. Parece haver mais um trocadilho no final do parágrafo: a frase "que maltas pagaréis" pode ser lida como "que mal te las pagaréis".

A tradução italiana é a que se aproxima mais do método proposto pelo próprio Joyce e o tradutor apresenta soluções coerentes com o método. O trocadilho entre bare (de Joyce) e bore (de Shakespeare) virou nudare. Nesse primeiro período, o que o autor quer dizer é que Adão foi o primeiro homem a mostrar (e não a portar como em Shakespeare) as armas; ou seja, a mostrar sua nudez, seu falo. O trocadilho é feito com o termo seguinte: "a nudare armi" é arenare (encalhar) que, em sentido figurado é estagnar, desistir, depor; e nudare é "despir". Outra característica dessa tradução italiana é aproveitar as palavras-portmanteaux formadas a partir de duas línguas diferentes. Foi o que Schenoni fez ao traduzir o termo hurealdica; ele manteve o termo usado por Joyce, Hure, "puta" em alemão e o combina com araldica, "heráldica". Blesone é um termo cunhado a partir de blasone, "brasão"; blesone é um neologismo, um aumentativo de bleso, que em português é "bleso", "gago"218. Celioh é um jogo de palavras: é, ao mesmo tempo anagrama de Helio e a junção da expressão "ce li hó",

${ }^{218}$ O parágrafo anterior começou com estas palavras: "Bygmester Finnegans, of the Stuttering Hand...". Stuttering quer dizer "gago". 
"eu tenho", "tenho à mão". O termo Cicchettone representa a alcunha do bêbado: cicchetto significa tanto "cálice" quanto "reprimenda"; o duplo sentido dessa palavra fez da alcunha algo muito preciso. Cavoli (plural de cavolo) também tem vários sentidos: é a "couve" e tem o sentido figurado de "morrer", o que também está de acordo com o contexto, pois se refere ao coveiro (couveiro?) que aparece no Hamlet, que cultiva a morte (contadino traduz perfeitamente o termo inglês clown).

A próxima passagem o tradutor não resolve: não traduz nem "Mister Finn", nem "Mister Finnagain", mas se sai muito bem na seguinte. Encontra uma boa solução para Comeday e Sendday ("come day" ["some day"] e "send away" [Sunday]): Vinedì ("vem dia") e Vamenica (va e Domenica); em português existe a expressão "mais dia, menos dia" que traduz bem esse jogo de palavras. "Sei vite" soluciona o jogo verbal que há entre o erro do bêbado que disse vine em vez de fine (o tradutor fez o mesmo com o termo blesone) e o trocadilho entre wine e Wein, "vinho" em inglês e alemão, respectivamente. Vinagro parece um neologismo e ao mesmo tempo um arcaísmo, o mesmo que seria vine em inglês. Mas o autor não quer uma mistura entre o moderno e o arcaico, mas entre o irlandês e o nórdico, pois está representando nessa passagem a conquista da Irlanda pelos nórdicos e a substituição do irlandês Finnegan pelo nórdico HCE que os convidados anunciam. ${ }^{219}$

Finalmente, a tradução não resolve como transpor "Mister Funn" e deixa como estava; mas soluciona o trocadilho com fined, traduzindo-o termo por funminato (o que é bastante adequado ao contexto do livro se pensarmos que as idades de Vico terminam com um grande cataclismo anunciado por um trovão; "fulminar" significa, ao mesmo tempo, "matar" e "virar fumaça", "ser atingido por um raio").

Da tradução francesa (1982), encontraremos pouco que dizer depois de termos analisado a espanhola (1993), que parece tributária da outra que foi a pioneira; muitas das soluções utilizadas pelos outros tradutores são soluções descobertas pelo tradutor francês ${ }^{220}$. Assim, seremos breves nos comentários.

Découvrir: Philippe Lavergne fez aqui algo muito semelhante ao italiano, e a frase "se descobrir das armas" encerra em si mesma os dois significados (o de “despir" e o de "depor").

\footnotetext{
${ }^{219}$ No norueguês, no dinamarquês e no sueco, a palavra vinho é a mesma: vin. O termo vine, do texto, pode ser interpretado como um termo escandinavo; nesse caso, teria de ser pronunciado /vin'/ como entre os escandinavos.

${ }^{220}$ A tradução dos quatro primeiros capítulos do livro para o italiano, feita por Luigi Schenoni, saiu também em 1982.
} 
Wassaily Booslaeugh of Riesengeborg se transforma em Georges Grosbœuf de Grandgousier. Grandgousier é uma personagem de canção infantil, um apreciador da comida, da carne (boeuf). O termo cimier, utilizado em seguida está relacionado com o Senhor Grandgousier da canção infantil, pois significa a "cimeira de um capacete" e o "lombo ou a costela do boi”.

"Bouc de chêne": o tradutor francês foi o único que prestou atenção ao termo hegoak, forjado por Joyce. Hegoak é feito de "he goat" ("bode") e oak ("carvalho", ou chêne).

O mais significativo desse parágrafo é como Philippe Lavergne recria Finnagain (trocadilho entre "Finn again" [Finn de novo] e Finnegan). Ele desdobra o termo em dois, de maneira explicativa: "Finn encore" [Finn de novo]. Isso é significativo pois revela o critério desse tradutor, ou seja, desdobrar as palavras que foram fundidas pelo autor em uma só. Certamente Lavergne fez isso por saber que a língua francesa, pela sua própria morfologia, não comporta muito adequadamente as aglutinações. Já dimanchoir revela o procedimento oposto, pois é a aglutinação de Dimanche com choir (domingo e sucumbir).

A última sentença do parágrafo é traduzida, de certa forma, ao pé da letra. Apesar disso, o tradutor conseguiu manter os dois sentidos dela e deixá-la tão natural quanto o autor havia deixado.

A tradução brasileira não parece apresentar problemas de análise. O principal problema dela pareceu-nos o texto resultante em si. "Aquoso Pinguço Serragigante" contém o mesmo problema que o da tradução de Lavergne: o desaparecimento do herói russo. Mas por que escrever "Serragigante" em vez de "Serra Gigante"?

Putáltica resolve o trocadilho, mas deixa os dois termos numa língua só. Servulgatas, traduzindo ancillars, pode ser uma tentativa de acentuar ainda mais a vulgaridade dos paramentos do Aquoso Pinguço (que remete a Finnegan mas não a Vassili, embora nos lembre Quincas Berro d’Água), com “-vulgata” aludindo ao termo latino ancilla, ae, criada, e remetendo à Bíblia de São Jerônimo.

O termo cunhado por Joyce, scutschum (escutcheon, "brasão") parece ser a fusão de scutcheon e Scotus, o nome latino do filósofo medieval inglês Duns $\operatorname{Scot}^{221}$. Essa interpretação é plausível uma vez que a filosofia de Scot era ensinada nos colégios jesuítas onde Joyce teve seus primeiros estudos. Além do mais, a filosofia formulada por esse filósofo se opunha ao conceito tomista de universalidade. Para ele, o real não era totalmente universal,

${ }^{221}$ John Duns Scotus (c. 1266 - 1308). Filósofo e teólogo medieval inglês (nascido talvez na Irlanda). 
nem individual, uma vez que a universalidade se decompunha nos indivíduos e o real podia ser evidenciado nas idéias gerais. A experiência por que passam os protagonistas do Finnegans Wake, na qual o sonho (uma experiência individual) de um prossegue no sonho de outro (tornando essa experiência individual algo universal) parece ter relação com as idéias de Scot. O tradutor usa "couraça" em vez de "brasão" (mas nas notas ele fala de brasão), sem dúvida, como sinônimo de escudo, o principal componente do brasão.

A frase "Hélio d'outra parte", ao traduzir "helio, of the second", deixa de lado a figura do cavalariço. Se parafrasearmos essa passagem, teremos: "Seu brasão continha uma linha intermediária que separava dois lados: no primeiro, havia arqueiros com os arcos tencionados e, no segundo, o Sol". Este termo, "segundo", que traduz second, é, além de "cavalariço", a "segunda cor em importância", um termo da heráldica.

Nesse período, o tradutor usa "saúde" para hootch e "adão" para traduzir husbandman, o que parece uma boa solução devido à origem do termo em hebraico (adam = homem). Esse homem que ele vê trabalhando, ou com o qual "no serviço topo" (mudando o discurso para a primeira pessoa) é o Finnegan que quer subir na vida, como diz a canção: o tradutor faz o trocadilho entre o verbo "topar" e o substantivo "topo" (a parte superior).

Finnagain virou "Refinnado". Existe aqui uma inversão de sentido (perfeitamente compatível com o livro). O autor diz que Finnegan voltou à vida, e não que voltou à morte. Em seguida, o tradutor escreve "Com'é dia de segunda" ("como é segunda-feira"), utilizandose da mesma forja que Joyce. Joyce mistura "come day" com comedy; e o tradutor mistura "como é dia" com "comédia".

No trecho em que escreve "eres vino", o tradutor rejeita, no entanto, o sentido de "you're fine" (o senhor está bem). Ele deve ter raciocinado que vine, lido à inglesa, tem o som de Wein, vinho em alemão; como o inglês é uma língua relativamente próxima ao alemão, o tradutor imaginou substituir essa relação de proximidade pela que há entre o português e o castelhano. Assim, "vinho" virou vino. E se lermos "eres vino" como "era ex-vino", teremos o vinagre. No original se diz mais ou menos o seguinte: "quando chega o dia, tens o vinho; quando chega a noite, estás ávido pelo vinho" ("when come (sic) the day, your wine; when ends the day, you are eager for wine [wine eager]"). Mas isso não é tudo; há aí também uma

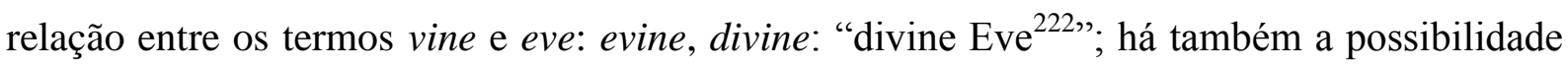
de se ler "you're vine" como "you revine", "you revive".

${ }^{222}$ Eve חוה :ociarbeh me "ida tem o significado de "v (Eva) /hawah/ virou "Eva" em grego. 
Para encerrar, o Mister Funn, o "Senhor Engraçadinho", se transforma no "Mister Funnéreo"; e o "to be fined again" vira "será afunndado" (irá para a cova). Literalmente, o que o autor quis dizer é que o Senhor Finn voltava a ser Finnegan (Finn again), e que o engraçado (fun) era que ele voltaria (again) a morrer, mais dia, menos dia. O termo "Refinnado" interpreta corretamente o outro sentido de Finnagain: fin (fim em francês) e again: morrer de novo. Contudo, talvez fosse melhor atenuar o sentido fúnebre de Finnagain para que o nome mantivesse o sentido de "ser Finn de novo" e fizesse o trocadilho com o "fined again" do final da passagem.

\section{3. Interpretação}

O parágrafo transcrito em 4.1 é o que explica o título da obra. Finnegan é uma personagem que entra no romance na segunda página e o deixa na terceira. Parece que a presença dele é apenas para dar nome ao livro. O parágrafo serve de síntese, como no início das epopéias, em que o poeta expunha o argumento. Há nele considerações a respeito da História, da evolução, do ciclo da vida, da morte e da ressurreição. Tudo isso é contado por meio de uma parábola, na qual a heráldica e a bebida se confundem, como se confundissem também o elevado e o baixo, o nobre e o camponês.

Os elementos criadores da vida são a água (sangue) e o fogo (alma), elementos que se combinam para formar o espírito. Água e fogo é a água ardente, aguardente, bebida, que em inglês é spirit. E o som do spirit é ouvido em toda a passagem, como se fosse o rio da vida. Portanto, as menções veladas à bebida (o espírito) e ao sexo (a carne) devem transparecer no texto traduzido. Isso é o mais importante.

Ao traduzirmos o trecho ${ }^{223}$ tivemos em mente todas essas considerações. Ao lado delas estavam os problemas estéticos do original que envolviam não apenas a arquitetura verbal do autor, mas sobretudo a sonoridade do texto.

Procuramos causar a impressão de que a língua portuguesa não foi afetada pelos jogos de palavras e pela força do termo estrangeiro. Nunca deixamos que os processos de criação de palavras parecessem estranhos ao nosso idioma. Por exemplo: huroldry foi vertido para "veneráldica", termo formado pela justaposição de venere, forma italiana de Vênus e "heráldica". O resultado foi um termo que parece com "venerada" e que tem uma terminação

\footnotetext{
${ }^{223} \mathrm{O}$ trecho que será apresentado em seguida foi remodelado posteriormente e difere, portanto, do que está na parte IV, capítulo I deste trabalho ("Tradução").
} 
própria da língua. A palavra francesa poursuivant, que está em francês no original, foi por nós aportuguesada.

Nesse ponto parece haver uma contradição, pois se no original está em francês, por que não deixar como estava? Por que desobedecer o esquema arquitetado pelo próprio autor? É que não seguimos o Joyce autor, mas o Joyce tradutor. Além disso, há outro ponto a considerar. O francês é uma língua bem diferente do inglês, apesar de ter exportado para esta língua boa parte do vocabulário. Sendo assim, por que não manter esse distanciamento?

O inglês talvez seja hoje a língua que conte com o maior glossário entre todas as línguas do mundo; ele foi, e continua sendo, afetado por todos os lados pelas mais diversas línguas; recebeu influências as mais distintas e acabou se tornando uma língua multinacional. Além disso, o inglês é hoje quase uma koiné em muitas regiões do mundo. E por ser uma das línguas mais faladas possui, ao mesmo tempo, riqueza vocabular e pobreza gramatical. Isso a torna mais maleável. O português não é tão permeável assim a vocábulos estrangeiros; os estrangeirismos demoram para serem incorporados; precisam de um tempo de adaptação e, muitas vezes, são abandonados antes mesmos de serem absorvidos; e quando o termo é absorvido já possui as características da língua que o absorveu.

Por outro lado, sabemos que Joyce utilizou-se de mais de sessenta línguas ${ }^{224}$ no Finnegans Wake; que essas línguas se misturam formando palavras sem identidade nacional alguma, como jpysian (egípcio e cigano), kisstivanes (cristãos e beijos em vão), etc.; e que essa mistura toda tem que ver com a dispersão das línguas provocada pela torre de Babel.

Muito bem, esse critério foi elaborado pelo autor, e vamos adaptá-lo. É preciso seguir processos consagrados, como o da adaptação de nomes estrangeiros feita por causa da tradução da Bíblia que transforma Av'raham em Abraão, Adam em Adão, mas mantém Babel.

Nesses exemplos perceberemos de que forma a língua é permeável: Babel é o nome da cidade em hebraico e Babylon em grego; por causa dos dois Testamentos, um escrito em hebraico e outro em grego, temos dois termos para uma única cidade: Babel e Babilônia; no Antigo Testamento existe um livro chamado Josué; Josué é a forma aportuguesada de Ióchua; mas a forma de Ióchua no grego coiné era Iesu que aportuguesamos para Jesus.

${ }^{224}$ Roland McHugh enumera 53 língua e 9 dialetos (McHuch, 1991, p. xiv e xv). 
Ao adotar esse procedimento, faremos o leitor perceber que língua orienta os processos de formação de palavra. Muitas traduções de trechos do Finnegans Wake revelam que os tradutores acabaram se orientando pela morfologia da língua inglesa.

Contudo, há ainda um critério para ser julgado. Percebemos, pela análise da tradução francesa, que se buscou, em muitas passagens, desdobrar as aglutinações para acomodar o texto à língua francesa. Essa justificativa é verdadeira apenas em parte. As traduções francesas revelam uma preocupação por parte dos tradutores de explicar coisas que o texto apenas sugere. Não adotamos esse procedimento e desdobramos as aglutinações quando as palavras, segregadas umas das outras, atendiam melhor à musicalidade do texto. Nossa maior preocupação foi com o ritmo, as aliterações, as assonâncias, enfim, com o som.

Por fim, cabe sublinhar que tanto a tradução que mostraremos abaixo como a que será mostrada no capítulo seguinte fizeram uso de palavras, na maior parte, oriundas de línguas latinas; de vocábulos que, apesar de pertencerem a línguas mais remotas, apresentam grande vocalização; e de palavras de pouca vocalização que foram deformadas para parecerem mais próximas ao português.

\section{4. Tradução}

Foi dele a primásia de despor as armas e ter nome. Chamou-se Vasílio Beblaievo Adamastor. Levava um penhacho em sua veneráldica em verte com turvantes ancilárias, argentinas; um cabralho pursuivante, hórrido, córnico. Seu escuto faixado por frecheiros tesos no lado primeiro e hélio na segunda. Cachaça é pro mixanga que mexe na enxada. Orrorrô, Seo Finn, Zegunda comédia zedo e o sor tá novinho em folha! E vin agradecer o tropeço de dormingo! Arrarrá, Seo Finnório, desse jeito o sior volta a definnhar.

Depois de feita a análise e a crítica, a tradução parece explicar-se por si própria. Restanos algumas considerações. O que nelas faltar constará do glossário anexado abaixo.

O primeiro homem se revela na primeira linha e esse revelar-se tem duplo sentido: o de aparecer e o de mostrar (despor [despir + depor] o falo enorme, escrito de maneira velada [ter nome: ernome (enorme)]). A primásia é a primeira amásia, que foi Eva, a quem ele fodeu (foi dele); o primeiro a ter amásia foi Adão, mencionado pouco depois na metamorfose do gigante que se transformou em montanha, como o gigante Adamastor (em cujo nome está contido o nome de Adão) do Canto V de Os Lusíadas, que é a prosopopéia do Cabo da Boa Esperança. Por ele substituímos a Serra dos Gigantes. 
Adão se transforma num herói de brasão e passa a formar uma casta. Sua última metamorfose antes do fim (Finn) será Finnegan em cujo velório (wake) começará a povoar o mundo com seus descendentes, os Finnegans que sairão do estado de torpor em que se encontram, em que se encontra a Irlanda. Os Finnegans se erguem (Finnegans wake) para povoar o mundo. "Finnegan's wake" e "Finnegans wake" é trocadilho que dá nome ao livro.

O brasão, ou as armas (o copo e a bebida) de Vasílio (o copo, a vasília) Beblaievo (a bebida) aparecem quando a metamorfose se completa, quando a montanha se transforma em armas, quando a Idade Divina termina e começa a Idade Heróica. A palavra penhacho é, ao mesmo tempo, o penhasco e o penacho que encima o escudo. Mas é também o membro viril do bode (he-goat), o cabralho, rijo como carvalho, que contrai doença venérea por que se diverte (em verte) com as criadas (ancilárias). A doença que o afeta é de formato córnico e, por isso, tem de fazer um curativo (enfaixar) no escroto (escuto). $\mathrm{O}$ arco teso que aparece no escudo pode ser o arco de Apolo (o Sol) ou de Eros; de qualquer forma, representa a chama (do sol ou do amor) e a rigidez do membro excitado.

Dessa geração de bêbados depravados, ou de reprodutores, nasce Finnegan. Dele surgirá HCE que, entre outras coisas, significa Haveth Childers Everywhere, aquele que por onde anda deixa um filho. Do membro decepado de Cronos surge a vida no mar. Do membro ardente que mija (mixanga) vem a água da vida, que é também o esperma (que do membro de Cronos gerou Afrodite no mar) daquele que se masturba (mexe na enxada).

A água da vida faz Finnegan renascer. Ele se eleva de seu ataúde para participar da festa da própria vigília. Um amigo embriagado lhe diz: "Zegunda começa zedo" (segunda começa cedo) e o sor (senhor e azedo) tá novinho (no vinho) em folha, com folha de vinha, semelhante a da figueira com que Adão se vestiu ao perceber que estava nu. O jardim das delícias, o Éden, para Finnegan é onde o vinho é farto. E assim como Adão que pecou (tropeçou), Finnegan também perderá o paraíso, pois desrespeitou o domingo, e o dia do Senhor, que em inglês é o dia do Sol (Sunday) ou de Hélio, é também o dia do pecado (Sinday), um feriado pagão. O crime de Finnegan é o crime da raça, pois o Sol faz parte do escudo dela.

Finnegan terá de voltar a definhar. A morte dele é a ressurreição de sua raça. No Parque Phoenix em Dublim, numa modesta taverna, rebrotará das cinzas. HCE será seu nome. Para sua taverna todos irão (Here Comes Everybody) para beber a água da vida. 
GLOSSÁRIO DA TRADUÇÃO

\begin{tabular}{|l|l|l|l|}
\hline TERMOS & SIGNIFICADO & PALAVRA & S S GNIFICADO \\
\hline foi dele (tr.) & fodeu & veneráldica & heráldica, Vênus e \\
\hline primásia (tr.) & primasia e amásia & cabrálio (tr.) & cabrão, caralho e carvalho \\
\hline despor (tr.) & despir e depor & escuto (pp) & Scuts, escudo e escroto \\
\hline ter nome (anagr.) & er nome = enorme & cupido \\
\hline laoch (irl.) & guerreiro & frecheiro & (duplo sentido) \\
\hline Chamou & chama & tesos (tr.) & dia e cavalariço \\
\hline Vasílio (tr.) & Vassili e vasília & segunda & começa \\
\hline Beblaievo (pp) & Belaiev e beber & comédia & senhor e azedo \\
\hline Adamastor (tr.) & Adão e & sor (tr.) & no vinho \\
\hline penhacho (tr.) & penha e penacho & tropeço & vinagre \\
\hline
\end{tabular}

\section{4. 1. Transgressão}

A idéia de transgressão que adotamos aqui como sinônimo de tradução não tem apenas o sentido etimológico de passar além como em alemão. Pois o nosso intuito não é mostrar que existe algo além da tradução no relacionamento dos textos, mas que a tradução pode ir além do escopo ao qual está limitada hoje em dia. Por isso definimos tradução como transgressão. Mas a idéia de transgressão tem aqui também o sentido de insurreição, de recusa em se enquadrar àquilo que é hoje o ofício do tradutor; de aceitar a tradução como uma arte subalterna à do romancista, do poeta, enfim, do criador; de aceitá-la como uma obra meramente de recriação.

A tradução é para nós: primeiro: um método interpretativo; segundo: uma forma de criação; terceiro: uma forma de transformação; e quarto: transcendência.

O exemplo que demos acima, extraído da página 5 de Finnegans Wake, serve para demonstrar, mais do que um critério e um método, um objetivo. A leitura da tradução mostra 
um texto bastante independente do original, mas mostra também o quanto ela se apega a ele. E, mais do que isso, revela um texto que, feito à imagem e semelhança de outro, o complementa. Para rejeitá-lo em seguida. E assim o transcende, sem rejeitar-lhe o valor, sem rejeitar-lhe a grandeza, como fez Dafne com Apolo, mas rejeitando-lhe o tempo e o espaço, como fez Joyce com o romance. 


\section{Glossopéia}

\section{TRADUÇÃO}

\section{Texto original: Finnegans Wake, capítulo 1 - p. 128}

\section{Tradução: Renatos Avelas, capítulo 1 - p. 159}

\section{Página de Finnegans Wake com correções do autor}

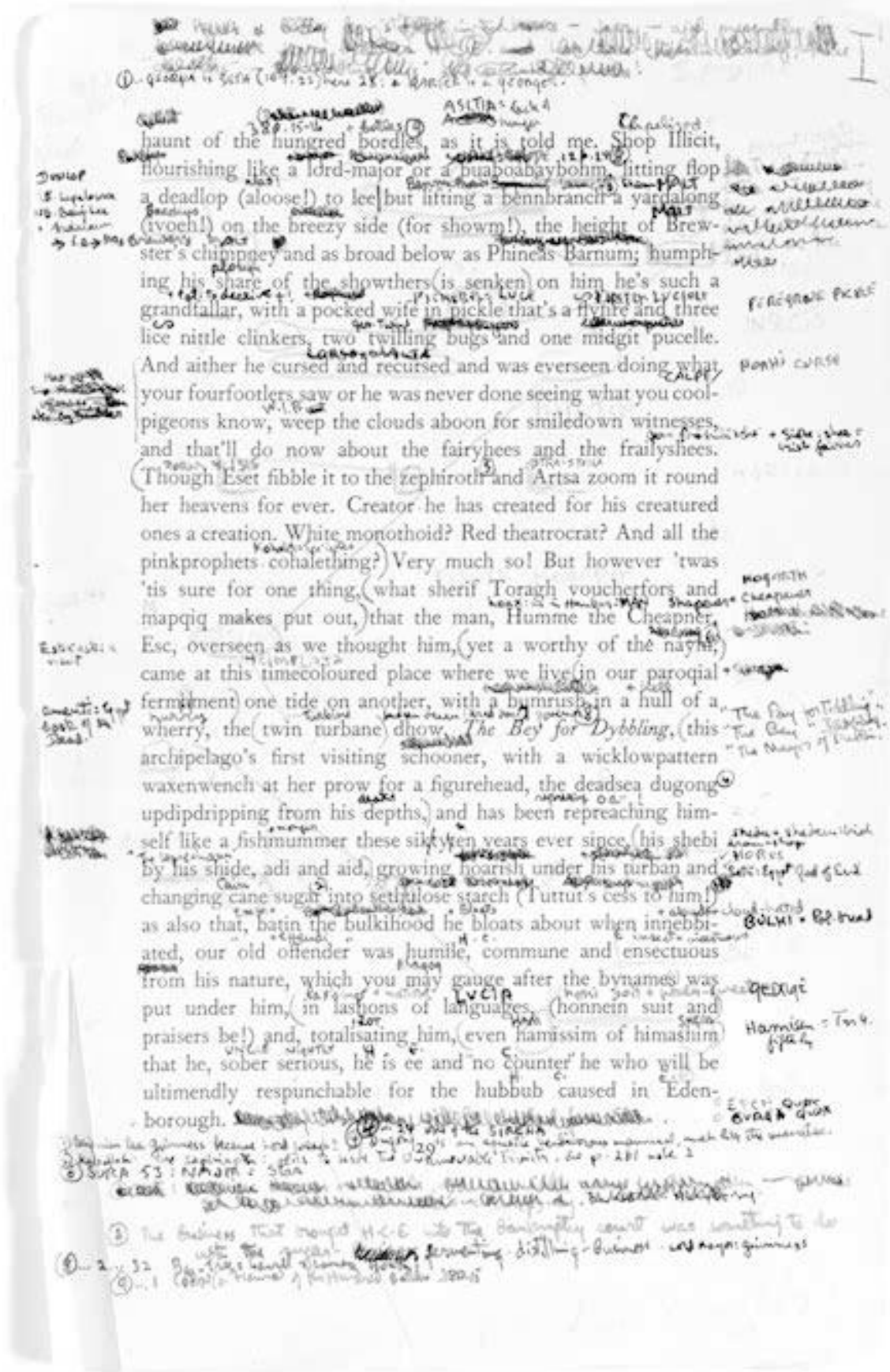




\section{P. 3}

riverrun, past Eve and Adam's, from swerve of shore to bend $\quad \underline{1}$

of bay, brings us by a commodius vicus of recirculation back to $\underline{2}$

Howth Castle and Environs. $\underline{3}$

Sir Tristram, violer d'amores, fr'over the short sea, had passen- $\quad \underline{4}$

core rearrived from North Armorica on this side the scraggy $\underline{5}$

isthmus of Europe Minor to wielderfight his penisolate war: nor $\underline{6}$

had topsawyer's rocks by the stream Oconee exaggerated themselse $\quad \underline{7}$

to Laurens County's gorgios while they went doublin their mumper $\underline{8}$

all the time: nor avoice from afire bellowsed mishe mishe to $\underline{9}$

tauftauf thuartpeatrick: not yet, though venissoon after, had a $\quad \underline{10}$

kidscad buttended a bland old isaac: not yet, though all's fair in $\quad \underline{11}$

vanessy, were sosie sesthers wroth with twone nathandjoe. Rot a $\underline{12}$

peck of pa's malt had Jhem or Shen brewed by arclight and rory $\quad \underline{13}$

end to the regginbrow was to be seen ringsome on the aquaface.

The fall (bababadalgharaghtakamminarronnkonnbronntonner- $\quad \underline{15}$

ronntuonnthunntrovarrhounawnskawntoohoohoordenenthur- $\quad \underline{16}$

nuk!) of a once wallstrait oldparr is retaled early in bed and later $\quad \underline{17}$

on life down through all christian minstrelsy. The great fall of the $\underline{18}$

offwall entailed at such short notice the pftjschute of Finnegan, $\quad \underline{19}$

erse solid man, that the humptyhillhead of humself prumptly sends $\quad \underline{20}$

an unquiring one well to the west in quest of his tumptytumtoes: $\underline{21}$

and their upturnpikepointandplace is at the knock out in the park $\underline{22}$

where oranges have been laid to rust upon the green since dev- $\underline{23}$

linsfirst loved livvy. $\quad \underline{24}$

\section{p.}

What clashes here of wills gen wonts, oystrygods gaggin fishy- $\quad \underline{1}$

gods! Brékkek Kékkek Kékkek Kékkek! Kóax Kóax Kóax! Ualu $\underline{2}$

Ualu Ualu! Quaouauh! Where the Baddelaries partisans are still $\underline{3}$

out to mathmaster Malachus Micgranes and the Verdons cata- $\underline{4}$

pelting the camibalistics out of the Whoyteboyce of Hoodie $\underline{5}$

Head. Assiegates and boomeringstroms. Sod's brood, be me fear! $\underline{6}$ 
Sanglorians, save! Arms apeal with larms, appalling. Killykill- $\quad \underline{7}$

killy: a toll, a toll. What chance cuddleys, what cashels aired $\underline{8}$

and ventilated! What bidimetoloves sinduced by what tegotetab- $\underline{9}$

solvers! What true feeling for their's hayair with what strawng $\quad \underline{10}$

voice of false jiccup! O here here how hoth sprowled met the $\underline{11}$

duskt the father of fornicationists but, (O my shining stars and $\quad \underline{12}$

body!) how hath fanespanned most high heaven the skysign of $\underline{13}$

soft advertisement! But was iz? Iseut? Ere were sewers? The oaks $\quad \underline{14}$

of ald now they lie in peat yet elms leap where askes lay. Phall if $\quad \underline{15}$

you but will, rise you must: and none so soon either shall the $\underline{16}$

pharce for the nunce come to a setdown secular phoenish.

Bygmester Finnegan, of the Stuttering Hand, freemen's mau- $\quad \underline{18}$

rer, lived in the broadest way immarginable in his rushlit toofar- $\quad \underline{19}$

back for messuages before joshuan judges had given us numbers $\quad \underline{20}$

or Helviticus committed deuteronomy (one yeastyday he sternely $\underline{21}$

struxk his tete in a tub for to watsch the future of his fates but ere $\underline{22}$

he swiftly stook it out again, by the might of moses, the very wat- $\underline{23}$

er was eviparated and all the guenneses had met their exodus so $\underline{24}$

that ought to show you what a pentschanjeuchy chap he was!) $\underline{25}$

and during mighty odd years this man of hod, cement and edi- $\underline{26}$

fices in Toper's Thorp piled buildung supra buildung pon the $\underline{27}$

banks for the livers by the Soangso. He addle liddle phifie Annie $\underline{28}$

ugged the little craythur. Wither hayre in honds tuck up your part $\underline{29}$

inher. Oftwhile balbulous, mithre ahead, with goodly trowel in $\underline{30}$

grasp and ivoroiled overalls which he habitacularly fondseed, like $\underline{31}$

Haroun Childeric Eggeberth he would caligulate by multiplicab- $\underline{32}$

les the alltitude and malltitude until he seesaw by neatlight of the $\underline{33}$

liquor wheretwin 'twas born, his roundhead staple of other days $\quad \underline{34}$

to rise in undress maisonry upstanded (joygrantit!), a waalworth $\quad \underline{35}$

of a skyerscape of most eyeful hoyth entowerly, erigenating from $\underline{36}$

\section{P. 5}

next to nothing and celescalating the himals and all, hierarchitec- 
titiptitoploftical, with a burning bush abob off its baubletop and

with larrons o'toolers clittering up and tombles a'buckets clotter$\underline{3}$

ing down.

Of the first was he to bare arms and a name: Wassaily Boos-

laeugh of Riesengeborg. His crest of huroldry, in vert with

ancillars, troublant, argent, a hegoak, poursuivant, horrid, horned.

His scutschum fessed, with archers strung, helio, of the second.

Hootch is for husbandman handling his hoe. Hohohoho, Mister

Finn, you're going to be Mister Finnagain! Comeday morm and,

O, you're vine! Sendday's eve and, ah, you're vinegar! Hahahaha,

Mister Funn, you're going to be fined again!

What then agentlike brought about that tragoady thundersday

this municipal sin business? Our cubehouse still rocks as earwitness

to the thunder of his arafatas but we hear also through successive

ages that shebby choruysh of unkalified muzzlenimiissilehims that

would blackguardise the whitestone ever hurtleturtled out of

heaven. Stay us wherefore in our search for tighteousness, O Sus-

tainer, what time we rise and when we take up to toothmick and

before we lump down upown our leatherbed and in the night and

at the fading of the stars ! For a nod to the nabir is better than wink

to the wabsanti. Otherways wesways like that provost scoffing

bedoueen the jebel and the jpysian sea. Cropherb the crunch-

bracken shall decide. Then we'll know if the feast is a flyday. She

has a gift of seek on site and she allcasually ansars helpers, the

dreamydeary. Heed! Heed ! It may half been a missfired brick, as

some say, or it mought have been due to a collupsus of his back

promises, as others looked at it. (There extand by now one thou-

sand and one stories, all told, of the same). But so sore did abe

ite ivvy's holired abbles, (what with the wallhall's horrors of rolls-

rights, carhacks, stonengens, kisstvanes, tramtrees, fargobawlers,

autokinotons, hippohobbilies, streetfleets, tournintaxes, mega-

phoggs, circuses and wardsmoats and basilikerks and aeropagods 
the mecklenburk bitch bite at his ear and the merlinburrow bur-

\section{p. 6}

blightblack workingstacks at twelvepins a dozen and the noobi-

busses sleighding along Safetyfirst Street and the derryjellybies

snooping around Tell-No-Tailors' Corner and the fumes and the

hopes and the strupithump of his ville's indigenous romekeepers,

homesweepers, domecreepers, thurum and thurum in fancymud

murumd and all the uproor from all the aufroofs, a roof for may

and a reef for hugh butt under his bridge suits tony) wan warn-

ing Phill filt tippling full. His howd feeled heavy, his hoddit did

shake. (There was a wall of course in erection) Dimb! He stot-

tered from the latter. Damb! he was dud. Dumb! Mastabatoom,

mastabadtomm, when a mon merries his lute is all long. For

whole the world to see.

Shize? I should shee! Macool, Macool, orra whyi deed ye diie?

of a trying thirstay mournin? Sobs they sighdid at Fillagain's

chrissormiss wake, all the hoolivans of the nation, prostrated in

their consternation and their duodisimally profusive plethora of

ululation. There was plumbs and grumes and cheriffs and citherers

and raiders and cinemen too. And the all gianed in with the shout-

most shoviality. Agog and magog and the round of them agrog.

To the continuation of that celebration until Hanandhunigan's

extermination! Some in kinkin corass, more, kankan keening.

Belling him up and filling him down. He's stiff but he's steady is

Priam Olim ! 'Twas he was the dacent gaylabouring youth. Sharpen

his pillowscone, tap up his bier! E'erawhere in this whorl would ye

hear sich a din again? With their deepbrow fundigs and the dusty

fidelios. They laid him brawdawn alanglast bed. With a bockalips

of finisky fore his feet. And a barrowload of guenesis hoer his head. 
Hurrah, there is but young gleve for the owl globe wheels in $\underline{29}$

view which is tautaulogically the same thing. Well, Him a being $\underline{30}$

so on the flounder of his bulk like an overgrown babeling, let wee $\underline{31}$

peep, see, at Hom, well, see peegee ought he ought, platterplate. II $\underline{32}$

Hum ! From Shopalist to Bailywick or from ashtun to baronoath $\quad \underline{33}$

or from Buythebanks to Roundthehead or from the foot of the $\underline{34}$

bill to ireglint's eye he calmly extensolies. And all the way (a $\underline{35}$

horn!) from fiord to fjell his baywinds' oboboes shall wail him $\underline{36}$

\section{P. 7}

rockbound (hoahoahoah!) in swimswamswum and all the livvy- $\quad \underline{1}$

long night, the delldale dalppling night, the night of bluerybells, $\underline{2}$

her flittaflute in tricky trochees (O carina! O carina!) wake him. $\underline{3}$

With her issavan essavans and her patterjackmartins about all $\underline{4}$

them inns and ouses. Tilling a teel of a tum, telling a toll of a tea- $\underline{5}$

ry turty Taubling. Grace before Glutton. For what we are, gifs $\underline{6}$

à gross if we are, about to believe. So pool the begg and pass the $\underline{7}$

kish for crawsake. Omen. So sigh us. Grampupus is fallen down $\underline{8}$

but grinny sprids the boord. Whase on the joint of a desh? Fin- $\underline{9}$

foefom the Fush. Whase be his baken head? A loaf of Singpan- $\quad \underline{10}$

try's Kennedy bread. And whase hitched to the hop in his tayle?

A glass of Danu U'Dunnell's foamous olde Dobbelin ayle. But, $\quad \underline{12}$

lo, as you would quaffoff his fraudstuff and sink teeth through $\quad \underline{13}$

that pyth of a flowerwhite bodey behold of him as behemoth for $\underline{14}$

he is noewhemoe. Finiche! Only a fadograph of a yestern scene.

Almost rubicund Salmosalar, ancient fromout the ages of the Ag- $\underline{16}$

apemonides, he is smolten in our mist, woebecanned and packt $\quad \underline{17}$

away. So that meal's dead off for summan, schlook, schlice and $\quad \underline{18}$

goodridhirring. $\underline{19}$

Yet may we not see still the brontoichthyan form outlined a- $\underline{20}$

slumbered, even in our own nighttime by the sedge of the trout- $\underline{21}$

ling stream that Bronto loved and Brunto has a lean on. Hic cubat $\underline{22}$

edilis. Apud libertinam parvulam. Whatif she be in flags or flitters, $\underline{23}$ 
reekierags or sundyechosies, with a mint of mines or beggar a

pinnyweight. Arrah, sure, we all love little Anny Ruiny, or, we $\underline{25}$

mean to say, lovelittle Anna Rayiny, when unda her brella, mid $\quad \underline{26}$

piddle med puddle, she ninnygoes nannygoes nancing by. Yoh! $\underline{27}$

Brontolone slaaps, yoh snoores. Upon Benn Heather, in Seeple $\underline{28}$

Isout too. The cranic head on him, caster of his reasons, peer yu- $\quad \underline{29}$

thner in yondmist. Whooth? His clay feet, swarded in verdigrass, $\quad \underline{30}$

stick up starck where he last fellonem, by the mund of the maga- $\underline{31}$

zine wall, where our maggy seen all, with her sisterin shawl. $\quad \underline{32}$

While over against this belles' alliance beyind Ill Sixty, ollol- $\quad \underline{33}$

lowed ill! bagsides of the fort, bom, tarabom, tarabom, lurk the $\underline{34}$

ombushes, the site of the lyffing-in-wait of the upjock and hock- $\underline{35}$

ums. Hence when the clouds roll by, jamey, a proudseye view is $\quad \underline{36}$

\section{p. 8}

enjoyable of our mounding's mass, now Wallinstone national $\quad \underline{1}$

museum, with, in some greenish distance, the charmful water- $\underline{2}$

loose country and the two quitewhite villagettes who hear show $\underline{3}$

of themselves so gigglesomes minxt the follyages, the prettilees! $\underline{4}$

Penetrators are permitted into the museomound free. Welsh and $\underline{5}$

the Paddy Patkinses, one shelenk! Redismembers invalids of old $\underline{6}$

guard find poussepousse pousseypram to sate the sort of their butt. $\underline{7}$

For her passkey supply to the janitrix, the mistress Kathe. Tip. $\underline{8}$

This the way to the museyroom. Mind your hats goan in! $\underline{9}$

Now yiz are in the Willingdone Museyroom. This is a Prooshi- $\quad \underline{10}$

ous gunn. This is a ffrinch. Tip. This is the flag of the Prooshi-

ous, the Cap and Soracer. This is the bullet that byng the flag of $\underline{12}$

the Prooshious. This is the ffrinch that fire on the Bull that bang $\underline{13}$

the flag of the Prooshious. Saloos the Crossgunn! Up with your

pike and fork! Tip. (Bullsfoot! Fine!) This is the triplewon hat of $\underline{15}$

Lipoleum. Tip. Lipoleumhat. This is the Willingdone on his $\underline{16}$

same white harse, the Cokenhape. This is the big Sraughter Wil- $\quad \underline{17}$

lingdone, grand and magentic in his goldtin spurs and his ironed $\underline{18}$ 
dux and his quarterbrass woodyshoes and his magnate's gharters

and his bangkok's best and goliar's goloshes and his pullupon-

easyan wartrews. This is his big wide harse. Tip. This is the three

lipoleum boyne grouching down in the living detch. This is an

inimyskilling inglis, this is a scotcher grey, this is a davy, stoop-

ing. This is the bog lipoleum mordering the lipoleum beg. A

Gallawghurs argaumunt. This is the petty lipoleum boy that

was nayther bag nor bug. Assaye, assaye! Touchole Fitz Tuo-

mush. Dirty MacDyke. And Hairy O'Hurry. All of them

arminus-varminus. This is Delian alps. This is Mont Tivel,

this is Mont Tipsey, this is the Grand Mons Injun. This is the

crimealine of the alps hooping to sheltershock the three lipoleums.

This is the jinnies with their legahorns feinting to read in their

handmade's book of stralegy while making their war undisides

the Willingdone. The jinnies is a cooin her hand and the jinnies is

a ravin her hair and the Willingdone git the band up. This is big

Willingdone mormorial tallowscoop Wounderworker obscides

on the flanks of the jinnies. Sexcaliber hrosspower. Tip. This

\section{P. 9}

is me Belchum sneaking his phillippy out of his most Awful

Grimmest Sunshat Cromwelly. Looted. This is the jinnies' hast-

ings dispatch for to irrigate the Willingdone. Dispatch in thin

red lines cross the shortfront of me Belchum. Yaw, yaw, yaw!

Leaper Orthor. Fear siecken! Fieldgaze thy tiny frow. Hugact-

ing. Nap. That was the tictacs of the jinnies for to fontannoy the

Willingdone. Shee, shee, shee! The jinnies is jillous agincourting

all the lipoleums. And the lipoleums is gonn boycottoncrezy onto

the one Willingdone. And the Willingdone git the band up. This

is bode Belchum, bonnet to busby, breaking his secred word with a

ball up his ear to the Willingdone. This is the Willingdone's hur-

old dispitchback. Dispitch desployed on the regions rare of me 
Damn fairy ann, Voutre. Willingdone. That was the first joke of $\quad \underline{14}$

Willingdone, tic for tac. Hee, hee, hee! This is me Belchum in $\quad \underline{15}$

his twelvemile cowchooks, weet, tweet and stampforth foremost, $\quad \underline{16}$

footing the camp for the jinnies. Drink a sip, drankasup, for he's $\quad \underline{17}$

as sooner buy a guinness than he'd stale store stout. This is Roo- $\underline{18}$

shious balls. This is a ttrinch. This is mistletropes. This is Canon $\underline{19}$

Futter with the popynose. After his hundred days' indulgence. $\underline{20}$

This is the blessed. Tarra's widdars! This is jinnies in the bonny $\underline{21}$

bawn blooches. This is lipoleums in the rowdy howses. This is the $\underline{22}$

Willingdone, by the splinters of Cork, order fire. Tonnerre! $\underline{23}$

(Bullsear! Play!) This is camelry, this is floodens, this is the $\underline{24}$

solphereens in action, this is their mobbily, this is panickburns.

Almeidagad! Arthiz too loose! This is Willingdone cry. Brum! $\underline{26}$

Brum! Cumbrum! This is jinnies cry. Underwetter! Goat $\underline{27}$

strip Finnlambs! This is jinnies rinning away to their ouster- $\underline{28}$

lists dowan a bunkersheels. With a nip nippy nip and a trip trip- $\underline{29}$

py trip so airy. For their heart's right there. Tip. This is me Bel-

chum's tinkyou tankyou silvoor plate for citchin the crapes in $\underline{31}$

the cool of his canister. Poor the pay! This is the bissmark of the $\underline{32}$

marathon merry of the jinnies they left behind them. This is the $\underline{33}$

Willingdone branlish his same marmorial tallowscoop Sophy- $\underline{34}$

Key-Po for his royal divorsion on the rinnaway jinnies. Gam-

bariste della porca! Dalaveras fimmieras! This is the pettiest $\underline{36}$

\section{p. 10}

of the lipoleums, Toffeethief, that spy on the Willingdone from $\quad \underline{1}$

his big white harse, the Capeinhope. Stonewall Willingdone $\underline{2}$

is an old maxy montrumeny. Lipoleums is nice hung bushel- $\underline{3}$

lors. This is hiena hinnessy laughing alout at the Willing- $\underline{4}$

done. This is lipsyg dooley krieging the funk from the hinnessy. $\underline{5}$

This is the hinndoo Shimar Shin between the dooley boy and the $\underline{6}$

hinnessy. Tip. This is the wixy old Willingdone picket up the $\underline{7}$

half of the threefoiled hat of lipoleums fromoud of the bluddle $\underline{8}$ 
filth. This is the hinndoo waxing ranjymad for a bombshoob.

This is the Willingdone hanking the half of the hat of lipoleums

up the tail on the buckside of his big white harse. Tip. That was

the last joke of Willingdone. Hit, hit, hit! This is the same white

harse of the Willingdone, Culpenhelp, waggling his tailoscrupp

with the half of a hat of lipoleums to insoult on the hinndoo see-

boy. Hney, hney, hney! (Bullsrag! Foul!) This is the seeboy,

madrashattaras, upjump and pumpim, cry to the Willingdone:

Ap Pukkaru! Pukka Yurap! This is the Willingdone, bornstable

ghentleman, tinders his maxbotch to the cursigan Shimar Shin.

Basucker youstead! This is the dooforhim seeboy blow the whole

of the half of the hat of lipoleums off of the top of the tail on the

back of his big wide harse. Tip (Bullseye! Game!) How Copen-

hagen ended. This way the museyroom. Mind your boots goan

out.

Phew!

What a warm time we were in there but how keling is here the

airabouts! We nowhere she lives but you mussna tell annaone for

the lamp of Jig-a-Lanthern! It's a candlelittle houthse of a month

and one windies. Downadown, High Downadown. And num-

mered quaintlymine. And such reasonable weather too ! The wa-

grant wind's awalt'zaround the piltdowns and on every blasted

knollyrock (if you can spot fifty I spy four more) there's that

gnarlybird ygathering, a runalittle, doalittle, preealittle, pouralittle,

wipealittle, kicksalittle, severalittle, eatalittle, whinealittle, kenalittle,

helfalittle, pelfalittle gnarlybird. A verytableland of bleakbardfields!

Under his seven wrothschields lies one, Lumproar. His glav toside

him. Skud ontorsed. Our pigeons pair are flewn for northcliffs.

\section{p. 11}

The three of crows have flapped it southenly, kraaking of de

baccle to the kvarters of that sky whence triboos answer; Wail, 
Thon's flash with his Nixy girls or when Thon's blowing toom- $\underline{4}$

cracks down the gaels of Thon. No nubo no! Neblas on you liv! $\underline{5}$

Her would be too moochy afreet. Of Burymeleg and Bindme- $\underline{6}$

rollingeyes and all the deed in the woe. Fe fo fom! She jist does $\underline{7}$

hopes till byes will be byes. Here, and it goes on to appear now, $\underline{8}$

she comes, a peacefugle, a parody's bird, a peri potmother, $\quad \underline{9}$

a pringlpik in the ilandiskippy, with peewee and powwows $\quad \underline{10}$

in beggybaggy on her bickybacky and a flick flask fleckflinging $\quad \underline{11}$

its pixylighting pacts' huemeramybows, picking here, pecking $\quad \underline{12}$

there, pussypussy plunderpussy. But it's the armitides toonigh, $\quad \underline{13}$

militopucos, and toomourn we wish for a muddy kissmans to the $\underline{14}$

minutia workers and there's to be a gorgeups truce for happinest

childher everwere. Come nebo me and suso sing the day we $\underline{16}$

sallybright. She's burrowed the coacher's headlight the better to $\quad \underline{17}$

pry (who goes cute goes siocur and shoos aroun) and all spoiled $\underline{18}$

goods go into her nabsack: curtrages and rattlin buttins, nappy $\quad \underline{19}$

spattees and flasks of all nations, clavicures and scampulars, maps, $\quad \underline{20}$

keys and woodpiles of haypennies and moonled brooches with $\underline{21}$

bloodstaned breeks in em, boaston nightgarters and masses of $\underline{22}$

shoesets and nickelly nacks and foder allmicheal and a lugly parson $\underline{23}$

of cates and howitzer muchears and midgers and maggets, ills and $\underline{24}$

ells with loffs of toffs and pleures of bells and the last sigh that $\quad \underline{25}$

come fro the hart (bucklied!) and the fairest sin the sunsaw $\underline{26}$

(that's cearc!). With Kiss. Kiss Criss. Cross Criss. Kiss Cross. 27

Undo lives 'end. Slain. $\quad \underline{28}$

How bootifull and how truetowife of her, when strengly fore- $\underline{29}$

bidden, to steal our historic presents from the past postpropheti- $\quad \underline{30}$

cals so as to will make us all lordy heirs and ladymaidesses of a $\underline{31}$

pretty nice kettle of fruit. She is livving in our midst of debt and $\underline{32}$

laffing through all plores for us (her birth is uncontrollable), with $\underline{33}$

a naperon for her mask and her sabboes kickin arias (so sair! so

solly!) if yous ask me and I saack you. Hou! Hou! Gricks may $\underline{35}$

rise and Troysirs fall (there being two sights for ever a picture) $\underline{36}$ 
for in the byways of high improvidence that's what makes life- $\quad \underline{1}$

work leaving and the world's a cell for citters to cit in. Let young $\underline{2}$

wimman run away with the story and let young min talk smooth $\underline{3}$

behind the butteler's back. She knows her knight's duty while $\quad \underline{4}$

Luntum sleeps. Did ye save any tin? says he. Did I what? with $\underline{5}$

a grin says she. And we all like a marriedann because she is mer- $\underline{6}$

cenary. Though the length of the land lies under liquidation $\quad \underline{7}$

(floote!) and there's nare a hairbrow nor an eyebush on this glau- $\quad \underline{8}$

brous phace of Herrschuft Whatarwelter she'll loan a vesta and $\underline{9}$

hire some peat and sarch the shores her cockles to heat and she'll $\quad \underline{10}$

do all a turfwoman can to piff the business on. Paff. To puff the $\underline{11}$

blaziness on. Poffpoff. And even if Humpty shell fall frumpty $\quad \underline{12}$

times as awkward again in the beardsboosoloom of all our grand $\underline{13}$

remonstrancers there'll be iggs for the brekkers come to mourn- $\quad \underline{14}$

him, sunny side up with care. So true is it that therewhere's a

turnover the tay is wet too and when you think you ketch sight $\underline{16}$

of a hind make sure but you're cocked by a hin. $\quad \underline{17}$

Then as she is on her behaviourite job of quainance bandy, $\quad \underline{18}$

fruting for firstlings and taking her tithe, we may take our review $\underline{19}$

of the two mounds to see nothing of the himples here as at else-

where, by sixes and sevens, like so many heegills and collines, $\quad \underline{21}$

sitton aroont, scentbreeched and somepotreek, in their swisha- $\underline{22}$

wish satins and their taffetaffe tights, playing Wharton's Folly, $\quad \underline{23}$

at a treepurty on the planko in the purk. Stand up, mickos! $\underline{24}$

Make strake for minnas! By order, Nicholas Proud. We may see $\underline{25}$

and hear nothing if we choose of the shortlegged bergins off

Corkhill or the bergamoors of Arbourhill or the bergagambols $\quad \underline{27}$

of Summerhill or the bergincellies of Miseryhill or the country- $\underline{28}$

bossed bergones of Constitutionhill though every crowd has its $\underline{29}$

several tones and every trade has its clever mechanics and each $\underline{30}$

harmonical has a point of its own, Olaf's on the rise and Ivor's $\underline{31}$ 
on the lift and Sitric's place's between them. But all they are all

there scraping along to sneeze out a likelihood that will solve

and salve life's robulous rebus, hopping round his middle like

kippers on a griddle, $\mathrm{O}$, as he lays dormont from the macroborg

of Holdhard to the microbirg of Pied de Poudre. Behove this

\section{p. 13}

sound of Irish sense. Really? Here English might be seen.

Royally? One sovereign punned to petery pence. Regally? The

silence speaks the scene. Fake!

So This Is Dyoublong?

Hush! Caution ! Echoland !

How charmingly exquisite! It reminds you of the outwashed

innkempt house. Used they? (I am sure that tiring chabelshovel-

ler with the mujikal chocolat box, Miry Mitchel, is listening) I

say, the remains of the outworn gravemure where used to be

blurried the Ptollmens of the Incabus. Used we? (He is only pre-

tendant to be stugging at the jubalee harp from a second existed

lishener, Fiery Farrelly.) It is well known. Lokk for himself and

see the old butte new. Dbln. W. K. O. O. Hear? By the mauso-

lime wall. Fimfim fimfim. With a grand funferall. Fumfum fum-

fum. 'Tis optophone which ontophanes. List! Wheatstone's

magic lyer. They will be tuggling foriver. They will be lichening

for allof. They will be pretumbling forover. The harpsdischord

shall be theirs for ollaves.

Four things therefore, saith our herodotary Mammon Lujius

in his grand old historiorum, wrote near Boriorum, bluest book

in baile's annals, $\mathrm{ft}$. in Dyffinarsky ne'er sall fail til heathersmoke

and cloudweed Eire's ile sall pall. And here now they are, the fear

of um. T. Totities! Unum. (Adar.) A bulbenboss surmounted up-

on an alderman. Ay, ay! Duum. (Nizam.) A shoe on a puir old 
a'bride, to be desarted. Adear, adear! Quodlibus. (Marchessvan.) A $\underline{27}$

penn no weightier nor a polepost. And so. And all. (Succoth.) $\underline{28}$

So, how idlers' wind turning pages on pages, as innocens with $\underline{29}$

anaclete play popeye antipop, the leaves of the living in the boke $\underline{30}$

of the deeds, annals of themselves timing the cycles of events

grand and national, bring fassilwise to pass how. $\underline{32}$

1132 A.D. Men like to ants or emmets wondern upon a groot $\underline{33}$

hwide Whallfisk which lay in a Runnel. Blubby wares upat Ub- $\underline{34}$

lanium.

566 A.D. On Baalfire's night of this year after deluge a crone that $\underline{36}$

\section{p. 14}

hadde a wickered Kish for to hale dead tunes from the bog look- $\quad \underline{1}$

it under the blay of her Kish as she ran for to sothisfeige her cow- $\underline{2}$

rieosity and be me sawl but she found hersell sackvulle of swart $\underline{3}$

goody quickenshoon ant small illigant brogues, so rich in sweat. $\quad \underline{4}$

Blurry works at Hurdlesford. $\underline{5}$

(Silent.) $\underline{6}$

566 A.D. At this time it fell out that a brazenlockt damsel grieved $\underline{7}$

(sobralasolas!) because that Puppette her minion was ravisht of her $\underline{8}$

by the ogre Puropeus Pious. Bloody wars in Ballyaughacleeagh- $\underline{9}$

bally. $\quad \underline{10}$

1132. A.D. Two sons at an hour were born until a goodman $\underline{11}$

and his hag. These sons called themselves Caddy and Primas.

Primas was a santryman and drilled all decent people. Caddy $\underline{13}$

went to Winehouse and wrote o peace a farce. Blotty words for $\quad \underline{14}$

Dublin.

Somewhere, parently, in the ginnandgo gap between antedilu- $\underline{16}$

vious and annadominant the copyist must have fled with his $\quad \underline{17}$

scroll. The billy flood rose or an elk charged him or the sultrup $\underline{18}$

worldwright from the excelsissimost empyrean (bolt, in sum)

earthspake or the Dannamen gallous banged pan the bliddy du- $\underline{20}$ 
ran. A scribicide then and there is led off under old's code with

some fine covered by six marks or ninepins in metalmen for the

sake of his labour's dross while it will be only now and again in

our rear of o'er era, as an upshoot of military and civil engage-

ments, that a gynecure was let on to the scuffold for taking that

same fine sum covertly by meddlement with the drawers of his

neighbour's safe.

Now after all that farfatch'd and peragrine or dingnant or clere

lift we our ears, eyes of the darkness, from the tome of Liber Li-

vidus and, (toh!), how paisibly eirenical, all dimmering dunes

and gloamering glades, selfstretches afore us our fredeland's plain!

Lean neath stone pine the pastor lies with his crook; young pric-

ket by pricket's sister nibbleth on returned viridities; amaid her

rocking grasses the herb trinity shams lowliness; skyup is of ever-

and Hairyman the cornflowers have been staying at Ballymun,

\section{p. 15}

the duskrose has choosed out Goatstown's hedges, twolips have

pressed togatherthem by sweet Rush, townland of twinedlights,

the whitethorn and the redthorn have fairygeyed the mayvalleys

of Knockmaroon, and, though for rings round them, during a

chiliad of perihelygangs, the Formoreans have brittled the too-

ath of the Danes and the Oxman has been pestered by the Fire-

bugs and the Joynts have thrown up jerrybuilding to the Kevan-

ses and Little on the Green is childsfather to the City (Year!

Year! And laughtears!), these paxsealing buttonholes have quad-

rilled across the centuries and whiff now whafft to us, fresh and

made-of-all-smiles as, on the eve of Killallwho.

The babbelers with their thangas vain have been (confusium

hold them!) they were and went; thigging thugs were and hou-

hnhymn songtoms were and comely norgels were and pollyfool 
blond has sought of the brune: Elsekiss thou may, mean Kerry $\underline{16}$

piggy?: and the duncledames have countered with the hellish fel- $\quad \underline{17}$

lows: Who ails tongue coddeau, aspace of dumbillsilly? And they $\underline{18}$

fell upong one another: and themselves they have fallen. And $\underline{19}$

still nowanights and by nights of yore do all bold floras of the $\underline{20}$

field to their shyfaun lovers say only: Cull me ere I wilt to thee!: $\underline{21}$

and, but a little later: Pluck me whilst I blush! Well may they $\underline{22}$

wilt, marry, and profusedly blush, be troth! For that saying is as $\underline{23}$

old as the howitts. Lave a whale a while in a whillbarrow (isn't $\underline{24}$

it the truath I'm tallin ye?) to have fins and flippers that shimmy $\underline{25}$

and shake. Tim Timmycan timped hir, tampting Tam. Fleppety! $\underline{26}$

Flippety! Fleapow! $\quad \underline{27}$

Hop! $\underline{28}$

In the name of Anem this carl on the kopje in pelted thongs a $\underline{29}$

parth a lone who the joebiggar be he? Forshapen his pigmaid $\quad \underline{30}$

hoagshead, shroonk his plodsfoot. He hath locktoes, this short- $\quad \underline{31}$

shins, and, Obeold that's pectoral, his mammamuscles most $\underline{32}$

mousterious. It is slaking nuncheon out of some thing's brain $\underline{33}$

pan. Me seemeth a dragon man. He is almonthst on the kiep $\underline{34}$

fief by here, is Comestipple Sacksoun, be it junipery or febrew-

ery, marracks or alebrill or the ramping riots of pouriose and $\underline{36}$

\section{p. 16}

froriose. What a quhare soort of a mahan. It is evident the mich- $\quad \underline{1}$

indaddy. Lets we overstep his fire defences and these kraals of $\underline{2}$

slitsucked marrogbones. (Cave!) He can prapsposterus the pil- $\underline{3}$

lory way to Hirculos pillar. Come on, fool porterfull, hosiered $\underline{4}$

women blown monk sewer? Scuse us, chorley guy! You toller- $\quad \underline{5}$

day donsk? N. You tolkatiff scowegian? Nn. You spigotty an- $\underline{6}$

glease? Nnn. You phonio saxo? Nnnn. Clear all so! 'Tis a Jute. $\quad \underline{7}$

Let us swop hats and excheck a few strong verbs weak oach ea- $\underline{8}$

ther yapyazzard abast the blooty creeks. $\underline{9}$

Jute._- Yutah! $\quad \underline{10}$ 
Mutt.— Mukk's pleasurad. $\quad \underline{11}$

Jute.— Are you jeff?

Mutt.— Somehards. $\quad \underline{13}$

Jute.— But you are not jeffmute?

Mutt.— Noho. Only an utterer.

Jute._- Whoa? Whoat is the mutter with you? $\underline{16}$

Mutt._ I became a stun a stummer. $\quad \underline{17}$

Jute._ What a hauhauhauhaudibble thing, to be cause! How, $\underline{18}$ Mutt? $\underline{19}$

Mutt.— Aput the buttle, surd.

Jute._- Whose poddle? Wherein? $\underline{21}$

Mutt._ The Inns of Dungtarf where Used awe to be he. $\underline{22}$

Jute.- You that side your voise are almost inedible to me. $\underline{23}$

Become a bitskin more wiseable, as if I were $\underline{24}$

you. $\quad \underline{25}$

Mutt._ Has? Has at? Hasatency? Urp, Boohooru! Booru $\underline{26}$

Usurp! I trumple from rath in mine mines when I

rimimirim! $\underline{28}$

Jute._ One eyegonblack. Bisons is bisons. Let me fore all $\underline{29}$

your hasitancy cross your qualm with trink gilt. Here

have sylvan coyne, a piece of oak. Ghinees hies good $\underline{31}$

for you. $\quad \underline{32}$

Mutt._ Louee, louee! How wooden I not know it, the intel- $\underline{33}$

lible greytcloak of Cedric Silkyshag! Cead mealy

faulty rices for one dabblin bar. Old grilsy growlsy!

He was poached on in that eggtentical spot. Here $\underline{36}$

\section{p. 17}

where the liveries, Monomark. There where the mis- $\underline{1}$

sers moony, Minnikin passe. $\underline{2}$

Jute.- Simply because as Taciturn pretells, our wrongstory- $\underline{3}$

shortener, he dumptied the wholeborrow of rubba- $\underline{4}$

ges on to soil here. 
Mutt._ Just how a puddinstone inat the brookcells by a $\underline{6}$ riverpool.

Jute._ Load Allmarshy! Wid wad for a norse like? $\underline{8}$

Mutt.— Somular with a bull on a clompturf. Rooks roarum $\quad \underline{9}$ rex roome! I could snore to him of the spumy horn, $\quad \underline{10}$

with his woolseley side in, by the neck I am sutton $\underline{11}$

on, did Brian d' of Linn. $\quad \underline{12}$

Jute._ Boildoyle and rawhoney on me when I can beuraly $\underline{13}$

forsstand a weird from sturk to finnic in such a pat- $\quad \underline{14}$

what as your rutterdamrotter. Onheard of and um- $\quad \underline{15}$

scene! Gut aftermeal! See you doomed. $\quad \underline{16}$

Mutt._ Quite agreem. Bussave a sec. Walk a dun blink $\underline{17}$

roundward this albutisle and you skull see how olde $\quad \underline{18}$

ye plaine of my Elters, hunfree and ours, where wone $\quad \underline{19}$

to wail whimbrel to peewee o'er the saltings, where $\underline{20}$

wilby citie by law of isthmon, where by a droit of $\underline{21}$

signory, icefloe was from his Inn the Byggning to $\underline{22}$

whose Finishthere Punct. Let erehim ruhmuhrmuhr. $\underline{23}$

Mearmerge two races, swete and brack. Morthering $\underline{24}$

rue. Hither, craching eastuards, they are in surgence: $\underline{25}$

hence, cool at ebb, they requiesce. Countlessness of $\underline{26}$

livestories have netherfallen by this plage, flick as $\quad \underline{27}$

flowflakes, litters from aloft, like a waast wizzard all of $\underline{28}$

whirlworlds. Now are all tombed to the mound, isges $\underline{29}$

to isges, erde from erde. Pride, O pride, thy prize! $\quad \underline{30}$

Jute.— 'Stench! $\underline{31}$

Mutt._ Fiatfuit! Hereinunder lyethey. Llarge by the smal an' $\underline{32}$

everynight life olso th'estrange, babylone the great- $\quad \underline{33}$

grandhotelled with tit tit tittlehouse, alp on earwig, $\quad \underline{34}$

drukn on ild, likeas equal to anequal in this sound $\underline{35}$

seemetery which iz leebez luv. $\underline{36}$ 
Jute.— 'Zmorde!

Mutt._ Meldundleize! By the fearse wave behoughted. Des- $\quad \underline{2}$

pond's sung. And thanacestross mound have swollup $\underline{3}$

them all. This ourth of years is not save brickdust $\underline{4}$

and being humus the same roturns. He who runes $\quad \underline{5}$

may rede it on all fours. O'c'stle, n'wc'stle, tr'c'stle, $\quad \underline{6}$

crumbling! Sell me sooth the fare for Humblin! Hum- $\quad \underline{7}$

blady Fair. But speak it allsosiftly, moulder! Be in $\underline{8}$

your whisht! $\underline{9}$

Jute._- Whysht? $\underline{10}$

Mutt._ The gyant Forficules with Amni the fay. $\quad \underline{11}$

Jute.- Howe? $\underline{12}$

Mutt.— Here is viceking's graab. $\quad \underline{13}$

Jute. - Hwaad! $\quad \underline{14}$

Mutt.— Ore you astoneaged, jute you? $\quad \underline{15}$

Jute._- Oye am thonthorstrok, thing mud. $\quad \underline{16}$

(Stoop) if you are abcedminded, to this claybook, what curios $\quad \underline{17}$

of signs (please stoop), in this allaphbed! Can you rede (since $\underline{18}$

We and Thou had it out already) its world? It is the same told $\underline{19}$

of all. Many. Miscegenations on miscegenations. Tieckle. They $\underline{20}$

lived und laughed ant loved end left. Forsin. Thy thingdome is $\underline{21}$

given to the Meades and Porsons. The meandertale, aloss and $\underline{22}$

again, of our old Heidenburgh in the days when Head-in-Clouds $\underline{23}$

walked the earth. In the ignorance that implies impression that $\underline{24}$

knits knowledge that finds the nameform that whets the wits that $\underline{25}$

convey contacts that sweeten sensation that drives desire that $\underline{26}$

adheres to attachment that dogs death that bitches birth that en- $\underline{27}$

tails the ensuance of existentiality. But with a rush out of his $\underline{28}$

navel reaching the reredos of Ramasbatham. A terricolous vively- $\underline{29}$

onview this; queer and it continues to be quaky. A hatch, a celt, $\quad \underline{30}$

an earshare the pourquose of which was to cassay the earthcrust at $\underline{31}$

all of hours, furrowards, bagawards, like yoxen at the turnpaht.

Here say figurines billycoose arming and mounting. Mounting and $\underline{33}$ 
arming bellicose figurines see here. Futhorc, this liffle effingee is for

a firefing called a flintforfall. Face at the eased! O I fay! Face at the

waist! Ho, you fie! Upwap and dump em, 'Tace to «ace! When a

\section{p. 19}

part so ptee does duty for the holos we soon grow to use of an

allforabit. Here (please to stoop) are selveran cued peteet peas of

quite a pecuniar interest inaslittle as they are the pellets that make

the tomtummy's pay roll. Right rank ragnar rocks and with these

rox orangotangos rangled rough and rightgorong. Wisha, wisha,

whydidtha? Thik is for thorn that's thuck in its thoil like thum-

fool's thraitor thrust for vengeance. What a mnice old mness it

all mnakes! A middenhide hoard of objects! Olives, beets, kim-

mells, dollies, alfrids, beatties, cormacks and daltons. Owlets' eegs

(O stoop to please!) are here, creakish from age and all now

quite epsilene, and oldwolldy wobblewers, haudworth a wipe o

grass. Sss! See the snake wurrums everyside! Our durlbin is

sworming in sneaks. They came to our island from triangular

Toucheaterre beyond the wet prairie rared up in the midst of the

cargon of prohibitive pomefructs but along landed Paddy Wip-

pingham and the his garbagecans cotched the creeps of them

pricker than our whosethere outofman could quick up her whats-

thats. Somedivide and sumthelot but the tally turns round the

same balifuson. Racketeers and bottloggers.

Axe on thwacks on thracks, axenwise. One by one place one

be three dittoh and one before. Two nursus one make a plaus-

ible free and idim behind. Starting off with a big boaboa and three-

legged calvers and ivargraine jadesses with a message in their

mouths. And a hundreadfilled unleavenweight of liberorumqueue

to con an we can till allhorrors eve. What a meanderthalltale to

unfurl and with what an end in view of squattor and anntisquattor

and postproneauntisquattor! To say too us to be every tim, nick 
sons, when usses not to be, every sue, siss and sally of us, dugters

of Nan! Accusative ahnsire! Damadam to infinities

True there was in nillohs dieybos as yet no lumpend papeer

in the waste, and mightmountain Penn still groaned for the micies

to let flee. All was of ancientry. You gave me a boot (signs on

it!) and I ate the wind. I quizzed you a quid (with for what?) and

\section{p. 20}

under the ban of our infrarational senses fore the last milch-

camel, the heartvein throbbing between his eyebrowns, has still to

moor before the tomb of his cousin charmian where his date is

tethered by the palm that's hers. But the horn, the drinking, the

day of dread are not now. A bone, a pebble, a ramskin; chip them,

chap them, cut them up allways; leave them to terracook in the

muttheringpot: and Gutenmorg with his cromagnom charter,

tintingfast and great primer must once for omniboss step rub-

rickredd out of the wordpress else is there no virtue more in al-

cohoran. For that (the rapt one warns) is what papyr is meed

of, made of, hides and hints and misses in prints. Till ye finally

(though not yet endlike) meet with the acquaintance of Mister

Typus, Mistress Tope and all the little typtopies. Fillstup. So you

need hardly spell me how every word will be bound over to carry

three score and ten toptypsical readings throughout the book of

Doublends Jined (may his forehead be darkened with mud who

would sunder!) till Daleth, mahomahouma, who oped it closeth

thereof the. Dor.

Cry not yet! There's many a smile to Nondum, with sytty

maids per man, sir, and the park's so dark by kindlelight. But

look what you have in your handself! The movibles are scrawl-

ing in motions, marching, all of them ago, in pitpat and zingzang 
a thyme and two's behind their lettice leap and three's among the

strubbely beds. And the chicks picked their teeths and the domb-

key he begay began. You can ask your ass if he believes it. And

so cuddy me only wallops have heels. That one of a wife with

folty barnets. For then was the age when hoops ran high. Of a

noarch and a chopwife; of a pomme full grave and a fammy of

levity; or of golden youths that wanted gelding; or of what the

mischievmiss made a man do. Malmarriedad he was reverso-

gassed by the frisque of her frasques and her prytty pyrrhique.

Maye faye, she's la gaye this snaky woman! From that trippiery

toe expectungpelick! Veil, volantine, valentine eyes. She's the

very besch Winnie blows Nay on good. Flou inn, flow ann.

Hohore! So it's sure it was her not we! But lay it easy, gentle

\section{p. 21}

mien, we are in rearing of a norewhig. So weenybeeny-

veenyteeny. Comsy see! Het wis if ee newt. Lissom! lissom!

I am doing it. Hark, the corne entreats! And the larpnotes

prittle.

It was of a night, late, lang time agone, in an auldstane eld,

when Adam was delvin and his madameen spinning watersilts,

when mulk mountynotty man was everybully and the first leal

ribberrobber that ever had her ainway everybuddy to his love-

saking eyes and everybilly lived alove with everybiddy else, and

Jarl van Hoother had his burnt head high up in his lamphouse,

laying cold hands on himself. And his two little jiminies, cousins

of ourn, Tristopher and Hilary, were kickaheeling their dummy

on the oil cloth flure of his homerigh, castle and earthenhouse.

And, be dermot, who come to the keep of his inn only the niece-

of-his-in-law, the prankquean. And the prankquean pulled a rosy

one and made her wit foreninst the dour. And she lit up and fire-

land was ablaze. And spoke she to the dour in her petty perusi- 
pease? And that was how the skirtmisshes began. But the dour $\underline{19}$

handworded her grace in dootch nossow: Shut! So her grace $\underline{20}$

o'malice kidsnapped up the jiminy Tristopher and into the shan- $\underline{21}$

dy westerness she rain, rain, rain. And Jarl van Hoother war- $\quad \underline{22}$

lessed after her with soft dovesgall: Stop deef stop come back to $\underline{23}$

my earin stop. But she swaradid to him: Unlikelihud. And there $\underline{24}$

was a brannewail that same sabboath night of falling angles some- $\quad \underline{25}$

where in Erio. And the prankquean went for her forty years' $\underline{26}$

walk in Tourlemonde and she washed the blessings of the love- $\underline{27}$

spots off the jiminy with soap sulliver suddles and she had her $\underline{28}$

four owlers masters for to tauch him his tickles and she convor- $\quad \underline{29}$

ted him to the onesure allgood and he became a luderman. So then $\underline{30}$

she started to rain and to rain and, be redtom, she was back again $\underline{31}$

at Jarl van Hoother's in a brace of samers and the jiminy with $\underline{32}$

her in her pinafrond, lace at night, at another time. And where $\underline{33}$

did she come but to the bar of his bristolry. And Jarl von Hoo- $\underline{34}$

ther had his baretholobruised heels drowned in his cellarmalt,

shaking warm hands with himself and the jimminy Hilary and $\underline{36}$

\section{p. 22}

the dummy in their first infancy were below on the tearsheet, $\quad \underline{1}$

wringing and coughing, like brodar and histher. And the prank- $\underline{2}$

quean nipped a paly one and lit up again and redcocks flew flack- $\underline{3}$

ering from the hillcombs. And she made her witter before the $\underline{4}$

wicked, saying: Mark the Twy, why do I am alook alike two poss $\underline{5}$

of porterpease? And: Shut! says the wicked, handwording her $\underline{6}$

madesty. So her madesty 'a forethought' set down a jiminy and $\underline{7}$

took up a jiminy and all the lilipath ways to Woeman's Land she $\underline{8}$

rain, rain, rain. And Jarl von Hoother bleethered atter her with $\quad \underline{9}$

a loud finegale: Stop domb stop come back with my earring stop. $\quad \underline{10}$

But the prankquean swaradid: Am liking it. And there was a wild $\underline{11}$

old grannewwail that laurency night of starshootings somewhere $\quad \underline{12}$

in Erio. And the prankquean went for her forty years' walk in $\underline{13}$ 
Turnlemeem and she punched the curses of cromcruwell with $\quad \underline{14}$

the nail of a top into the jiminy and she had her four larksical $\underline{15}$

monitrix to touch him his tears and she provorted him to the $\underline{16}$

onecertain allsecure and he became a tristian. So then she started $\quad \underline{17}$

raining, raining, and in a pair of changers, be dom ter, she was $\quad \underline{18}$

back again at Jarl von Hoother's and the Larryhill with her under $\quad \underline{19}$

her abromette. And why would she halt at all if not by the ward $\underline{20}$

of his mansionhome of another nice lace for the third charm? $\underline{21}$

And Jarl von Hoother had his hurricane hips up to his pantry- $\underline{22}$

box, ruminating in his holdfour stomachs (Dare! O dare!), ant $\underline{23}$

the jiminy Toughertrees and the dummy were belove on the $\underline{24}$

watercloth, kissing and spitting, and roguing and poghuing, like $\underline{25}$

knavepaltry and naivebride and in their second infancy. And the $\underline{26}$

prankquean picked a blank and lit out and the valleys lay twink- $\quad \underline{27}$

ling. And she made her wittest in front of the arkway of trihump, $\underline{28}$

asking: Mark the Tris, why do I am alook alike three poss of por- $\underline{29}$

ter pease? But that was how the skirtmishes endupped. For like $\underline{30}$

the campbells acoming with a fork lance of-lightning, Jarl von $\underline{31}$

Hoother Boanerges himself, the old terror of the dames, came $\underline{32}$

hip hop handihap out through the pikeopened arkway of his $\underline{33}$

three shuttoned castles, in his broadginger hat and his civic chol- $\quad \underline{34}$

lar and his allabuff hemmed and his bullbraggin soxangloves $\underline{35}$

and his ladbroke breeks and his cattegut bandolair and his fur- $\underline{36}$

\section{p. 23}

framed panuncular cumbottes like a rudd yellan gruebleen or-

angeman in his violet indigonation, to the whole longth of the

strongth of his bowman's bill. And he clopped his rude hand to

his eacy hitch and he ordurd and his thick spch spck for her to

shut up shop, dappy. And the duppy shot the shutter clup (Per-

kodhuskurunbarggruauyagokgorlayorgromgremmitghundhurth-

rumathunaradidillifaititillibumullunukkunun!) And they all drank 
girls under shurts. And that was the first peace of illiterative

porthery in all the flamend floody flatuous world. How kirssy the

tiler made a sweet unclose to the Narwhealian captol. Saw fore

shalt thou sea. Betoun ye and be. The prankquean was to hold

her dummyship and the jimminies was to keep the peacewave

and van Hoother was to git the wind up. Thus the hearsomeness

of the burger felicitates the whole of the polis.

O foenix culprit! Ex nickylow malo comes mickelmassed bo-

num. Hill, rill, ones in company, billeted, less be proud of. Breast

high and bestride! Only for that these will not breathe upon

Norronesen or Irenean the secrest of their soorcelossness. Quar-

ry silex, Homfrie Noanswa! Undy gentian festyknees, Livia No-

answa? Wolkencap is on him, frowned; audiurient, he would

evesdrip, were it mous at hand, were it dinn of bottles in the far

ear. Murk, his vales are darkling. With lipth she lithpeth to him

all to time of thuch on thuch and thow on thow. She he she ho

she ha to la. Hairfluke, if he could bad twig her! Impalpabunt,

he abhears. The soundwaves are his buffeteers; they trompe him

with their trompes; the wave of roary and the wave of hooshed

and the wave of hawhawhawrd and the wave of neverheedthem-

horseluggarsandlisteltomine. Landloughed by his neaghboormis-

tress and perpetrified in his offsprung, sabes and suckers, the

moaning pipers could tell him to his faceback, the louthly one

whose loab we are devorers of, how butt for his hold halibutt, or

her to her pudor puff, the lipalip one whose libe we drink at, how

biff for her tiddywink of a windfall, our breed and washer givers,

there would not be a holey spier on the town nor a vestal flout-

\section{p. 24}

to play cash cash in Novo Nilbud by swamplight nor a' toole o'

tall o' toll and noddy hint to the convaynience. 
all belonging to him and he sweated his crew beneath his auspice

for the living and he urned his dread, that dragon volant, and he

made louse for us and delivered us to boll weevils amain, that

mighty liberator, Unfru-Chikda-Uru-Wukru and begad he did,

our ancestor most worshipful, till he thought of a better one in

his windower's house with that blushmantle upon him from ears-

end to earsend. And would again could whispring grassies wake

him and may again when the fiery bird disembers. And will

again if so be sooth by elder to his youngers shall be said. Have

you whines for my wedding, did you bring bride and bedding,

will you whoop for my deading is a? Wake? Usgueadbaugham!

Anam muck an dhoul ! Did ye drink me doornail?

Now be aisy, good Mr Finnimore, sir. And take your laysure

like a god on pension and don't be walking abroad. Sure you'd

only lose yourself in Healiopolis now the way your roads in

Kapelavaster are that winding there after the calvary, the North

Umbrian and the Fivs Barrow and Waddlings Raid and the

Bower Moore and wet your feet maybe with the foggy dew's

abroad. Meeting some sick old bankrupt or the Cottericks' donkey

with his shoe hanging, clankatachankata, or a slut snoring with an

impure infant on a bench. 'Twould turn you against life, so

'twould. And the weather's that mean too. To part from Devlin

is hard as Nugent knew, to leave the clean tanglesome one lushier

than its neighbour enfranchisable fields but let your ghost have

no grievance. You're better off, sir, where you are, primesigned

in the full of your dress, bloodeagle waistcoat and all, remember-

ing your shapes and sizes on the pillow of your babycurls under

your sycamore by the keld water where the Tory's clay will scare

the varmints and have all you want, pouch, gloves, flask, bricket,

kerchief, ring and amberulla, the whole treasure of the pyre, in the

land of souls with Homin and Broin Baroke and pole ole Lonan 


\section{p. 25}

you presents, won't we, fenians? And il isn't our spittle we'll stint

you of, is it, druids? Not shabbty little imagettes, pennydirts and

dodgemyeyes you buy in the soottee stores. But offerings of the

field. Mieliodories, that Doctor Faherty, the madison man,

taught to gooden you. Poppypap's a passport out. And honey is

the holiest thing ever was, hive, comb and earwax, the food for

glory, (mind you keep the pot or your nectar cup may yield too

light !) and some goat's milk, sir, like the maid used to bring you.

Your fame is spreading like Basilico's ointment since the Fintan

Lalors piped you overborder and there's whole households be-

yond the Bothnians and they calling names after you. The men-

here's always talking of you sitting around on the pig's cheeks

under the sacred rooftree, over the bowls of memory where every

hollow holds a hallow, with a pledge till the drengs, in the Salmon

House. And admiring to our supershillelagh where the palmsweat

on high is the mark of your manument. All the toethpicks ever

Eirenesians chewed on are chips chepped from that battery

block. If you were bowed and soild and letdown itself from the

oner of the load it was that paddyplanters might pack up plenty and

when you were undone in every point fore the laps of goddesses

you showed our labourlasses how to free was easy. The game old

Gunne, they do be saying, (skull !) that was a planter for you, a

spicer of them all. Begog but he was, the G.O.G! He's dudd-

andgunne now and we're apter finding the sores of his sedeq

but peace to his great limbs, the buddhoch, with the last league

long rest of him, while the millioncandled eye of Tuskar sweeps

the Moylean Main! There was never a warlord in Great Erinnes

and Brettland, no, nor in all Pike County like you, they say. No,

nor a king nor an ardking, bung king, sung king or hung king.

That you could fell an elmstree twelve urchins couldn't ring

round and hoist high the stone that Liam failed. Who but a Mac- 
funeral to compass our cause? If you was hogglebully itself and

most frifty like you was taken waters still what all where was

your like to lay the cable or who was the batter could better

Your Grace? Mick Mac Magnus MacCawley can take you off to

\section{p. 26}

the pure perfection and Leatherbags Reynolds tries your shuffle

and cut. But as Hopkins and Hopkins puts it, you were the pale

eggynaggy and a kis to tilly up. We calls him the journeyall

Buggaloffs since he went Jerusalemfaring in Arssia Manor. You

had a gamier cock than Pete, Jake or Martin and your archgoose

of geese stubbled for All Angels' Day. So may the priest of seven

worms and scalding tayboil, Papa Vestray, come never anear you

as your hair grows wheater beside the Liffey that's in Heaven!

Hep, hep, hurrah there! Hero! Seven times thereto we salute

you! The whole bag of kits, falconplumes and jackboots incloted,

is where you flung them that time. Your heart is in the system

of the Shewolf and your crested head is in the tropic of Copri-

capron. Your feet are in the cloister of Virgo. Your olala is in the

region of sahuls. And that's ashore as you were born. Your shuck

tick's swell. And that there texas is tow linen. The loamsome

roam to Laffayette is ended. Drop in your tracks, babe! Be not

unrested! The headboddylwatcher of the chempel of Isid,

Totumcalmum, saith: I know thee, metherjar, I know thee, sal-

vation boat. For we have performed upon thee, thou abrama-

nation, who comest ever without being invoked, whose coming

is unknown, all the things which the company of the precentors

and of the grammarians of Christpatrick's ordered concerning

thee in the matter of the work of thy tombing. Howe of the ship-

men, steep wall!

Everything's going on the same or so it appeals to all of us,

in the old holmsted here. Coughings all over the sanctuary, bad 
for lunch and dinnerchime. As popular as when Belly the First $\underline{28}$

was keng and his members met in the Diet of Man. The same $\underline{29}$

shop slop in the window. Jacob's lettercrackers and Dr Tipple's $\underline{30}$

Vi-Cocoa and the Eswuards' desippated soup beside Mother Sea-

gull's syrup. Meat took a drop when Reilly-Parsons failed. Coal's $\underline{32}$

short but we've plenty of bog in the yard. And barley's up again, $\quad \underline{33}$

begrained to it. The lads is attending school nessans regular, sir, $\quad \underline{34}$

spelling beesknees with hathatansy and turning out tables by $\underline{35}$

mudapplication. Allfor the books and never pegging smashers $\underline{36}$

\section{p. 27}

after Tom Bowe Glassarse or Timmy the Tosser. 'Tisraely the 1

truth! No isn't it, roman pathoricks? You were the doublejoynted $\underline{2}$

janitor the morning they were delivered and you'll be a grandfer $\underline{3}$

yet entirely when the ritehand seizes what the lovearm knows. $\underline{4}$

Kevin's just a doat with his cherub cheek, chalking oghres on $\underline{5}$

walls, and his little lamp and schoolbelt and bag of knicks, playing $\underline{6}$

postman's knock round the diggings and if the seep were milk $\quad \underline{7}$

you could lieve his olde by his ide but, laus sake, the devil does $\underline{8}$

be in that knirps of a Jerry sometimes, the tarandtan plaidboy, $\quad \underline{9}$

making encostive inkum out of the last of his lavings and writing $\quad \underline{10}$

a blue streak over his bourseday shirt. Hetty Jane's a child of $\quad \underline{11}$

Mary. She'll be coming (for they're sure to choose her) in her $\underline{12}$

white of gold with a tourch of ivy to rekindle the flame on Felix $\underline{13}$

Day. But Essie Shanahan has let down her skirts. You remember $\quad \underline{14}$

Essie in our Luna's Convent? They called her Holly Merry her $\quad \underline{15}$

lips were so ruddyberry and Pia de Purebelle when the redminers $\underline{16}$

riots was on about her. Were I a clerk designate to the Williams- $\quad \underline{17}$

woodsmenufactors I'd poster those pouters on every jamb in the $\underline{18}$

town. She's making her rep at Lanner's twicenightly. With the $\underline{19}$

tabarine tamtammers of the whirligigmagees. Beats that cachucha $\underline{20}$

flat. 'Twould dilate your heart to go. $\underline{21}$

Aisy now, you decent man, with your knees and lie quiet and $\underline{22}$ 
repose your honour's lordship! Hold him here, Ezekiel Irons, and

may God strengthen you! It's our warm spirits, boys, he's spoor-

ing. Dimitrius O'Flagonan, cork that cure for the Clancartys ! You

swamped enough since Portobello to float the Pomeroy. Fetch

neahere, Pat Koy! And fetch nouyou, Pam Yates! Be nayther

angst of Wramawitch! Here's lumbos. Where misties swaddlum,

where misches lodge none, where mystries pour kind on, $\mathrm{O}$

sleepy! So be yet!

I've an eye on queer Behan and old Kate and the butter, trust me.

She'll do no jugglywuggly with her war souvenir postcards to

help to build me murial, tippers! I'll trip your traps! Assure a

sure there! And we put on your clock again, sir, for you. Did or

didn't we, sharestutterers? So you won't be up a stump entirely.

Nor shed your remnants. The sternwheel's crawling strong. I

\section{p. 28}

seen your missus in the hall. Like the queenoveire. Arrah, it's

herself that's fine, too, don't be talking! Shirksends? You storyan

Harry chap longa me Harry chap storyan grass woman plelthy

good trout. Shakeshands. Dibble a hayfork's wrong with her only

her lex's salig. Boald Tib does be yawning and smirking cat's

hours on the Pollockses' woolly round tabouretcushion watch-

ing her sewing a dream together, the tailor's daughter, stitch to

her last. Or while waiting for winter to fire the enchantement,

decoying more nesters to fall down the flue. It's allavalonche that

blows nopussy food. If you only were there to explain the mean-

ing, best of men, and talk to her nice of guldenselver. The lips

would moisten once again. As when you drove with her to Fin-

drinny Fair. What with reins here and ribbons there all your

hands were employed so she never knew was she on land or at

sea or swooped through the blue like Airwinger's bride. She

was flirtsome then and she's fluttersome yet. She can second a 
a concertina and pairs passing when she's had her forty winks

for supper after kanekannan and abbely dimpling and is in her

merlin chair assotted, reading her Evening World. To see is

it smarts, full lengths or swaggers. News, news, all the news.

Death, a leopard, kills fellah in Fez. Angry scenes at Stormount.

Stilla Star with her lucky in goingaways. Opportunity fair with

the China floods and we hear these rosy rumours. Ding Tams he

noise about all same Harry chap. She's seeking her way, a chickle

a chuckle, in and out of their serial story, Les Loves of Selskar

et Pervenche, freely adapted to The Novvergin's Viv. There'll

be bluebells blowing in salty sepulchres the night she signs her

final tear. Zee End. But that's a world of ways away. Till track

laws time. No silver ash or switches for that one! While flattering

candles flare. Anna Stacey's how are you! Worther waist in the

noblest, says Adams and Sons, the wouldpay actionneers. Her

hair's as brown as ever it was. And wivvy and wavy. Repose you

now! Finn no more!

For, be that samesake sibsubstitute of a hooky salmon, there's

already a big rody ram lad at random on the premises of his

\section{p. 29}

haunt of the hungred bordles, as it is told me. Shop Illicit,

flourishing like a lordmajor or a buaboabaybohm, litting flop

a deadlop (aloose!) to lee but lifting a bennbranch a yardalong

(Ivoeh!) the breezy side (for showm!), the height of Brew-

ster's chimpney and as broad below as Phineas Barnum; humph-

ing his share of the showthers is senken on him he's such a

grandfallar, with a pocked wife in pickle that's a flyfire and three

lice nittle clinkers, two twilling bugs and one midgit pucelle.

And aither he cursed and recursed and was everseen doing what

your fourfootlers saw or he was never done seeing what you cool-

pigeons know, weep the clouds aboon for smiledown witnesses, 
Though Eset fibble it to the zephiroth and Artsa zoom it round

her heavens for ever. Creator he has created for his creatured

ones a creation. White monothoid? Red theatrocrat? And all the

pinkprophets cohalething? Very much so! But however 'twas

'tis sure for one thing, what sherif Toragh voucherfors and

Mapqiq makes put out, that the man, Humme the Cheapner,

Esc, overseen as we thought him, yet a worthy of the naym,

came at this timecoloured place where we live in our paroqial

fermament one tide on another, with a bumrush in a hull of a

wherry, the twin turbane dhow, The Bey for Dybbling, this

archipelago's first visiting schooner, with a wicklowpattern

waxenwench at her prow for a figurehead, the deadsea dugong

updipdripping from his depths, and has been repreaching him-

self like a fishmummer these siktyten years ever since, his shebi

by his shide, adi and aid, growing hoarish under his turban and

changing cane sugar into sethulose starch (Tuttut's cess to him!)

as also that, batin the bulkihood he bloats about when innebbi-

ated, our old offender was humile, commune and ensectuous

from his nature, which you may gauge after the bynames was

put under him, in lashons of languages, (honnein suit and

praisers be!) and, totalisating him, even hamissim of himashim

that he, sober serious, he is ee and no counter he who will be 


\section{p. 3}

fluminente, eventando o riocurso adante, do desrumo da fraga $\quad \underline{1}$

até à orla da angra, reavida por um vicomodado recirculoso, devoluta- $\quad \underline{2}$

se para a colina de Howth, o Castelo e o Entorno. $\underline{3}$

Seo Tristão, violamor, de marilanda alenavara, inda se não $\underline{4}$

havia arrevultado a passo ancora da Armórica do Norte, no magristmo $\quad \underline{5}$

da Eiropa Menor, aonde isolou-se forâneo ao quersoneso afuleimar-se $\quad \underline{6}$

em penoso prélio: nem tão sóia as fragas d'alta serra despenhar pelo regato Oconina $\quad \underline{7}$

amealhando-se ao gargalho do concelho laurenciano ao passo que dublicavam a $\quad \underline{8}$

gorjeta abeternamente: nem a chamejada voz a taufolegar mexe mexe a $\quad \underline{9}$

crendospadre espetrufara inda não, embora evanesceu assim que o embuste não $\quad \underline{10}$

baldou discordeirar um velho isaque, suave cego: inda não, embora esteleja sinfeira $\quad \underline{11}$

a vanidade, as rútilas sestrelas lirigavam com o janota doizum. Depois de levedar $\quad \underline{12}$

um barril do velho malte do pai, Joanim ou Jocem fermentaram-no no arquilume e $\quad \underline{13}$

no cabo rórido para que o regialto aparecesse anelhures no renho d'áqua. $\quad \underline{14}$

O derrumbe (itukóvitiohochjetlhinganwadichjeqavbo- $\quad \underline{15}$

tlhtaghjepitlhwadichqunchenmohterajechalñanderuetewapto- $\quad \underline{16}$

kwazawre) do mural estrito outrora esparramou-se em velhas trovas $\quad \underline{17}$

do berço à tumba por toda a menestréria crístina. A enorme queda do $\quad \underline{18}$

muro acarretou nota mirim aluzindo à cadência de Avelar $\quad \underline{19}$

galego firme que na cupinlheira se acostou $\quad \underline{20}$

galevando incontinenti a murada pra esticar as canelheiras: $\quad \underline{21}$

e o prélio barral delas aponta ao nó do parque onde $\quad \underline{22}$

arâncias deitam-se a putrefar na relva em que o dublinás $\quad \underline{23}$

sobre a lívida aliviou-se. $\quad \underline{24}$

\section{p. 4}

Com se lhutan ací enguenos talantes: ostrogagos arpelejando piscigodos! $\quad \underline{1}$

Bré qué qué quéch! Coach Coach Coach! Uálu $\quad \underline{2}$

Uálu! Uálu! Quauau! Onde baudelários partisões açodam $\quad \underline{3}$

o maltemástrico Malactius Micgranus e os Verdungos catapelam $\quad \underline{4}$

os canibalarísticos pra longe dos ornalbos de Testalta. $\quad \underline{5}$

Aríetes e mestromantes. Meu bum Deus, coitado de mim! $\quad \underline{6}$ 
Sanglorianos, ave! Braços pedem brados, aterrador. Mutámata:

atolátribu, atolátribu. Quanta sorte, seres, quantos castros dareados

arados! Quanta madamante pecaminhada por esgotos absolventes!

Quanta abensão pêlo braço lusco que arremeda estronha

palhavra ao atrampaiado já comprometido! Eis então como o estatelado encontrou o

encardido pai dos fornicadores e (Ó minhas estelas brilhantes, meu

corpo!) como foi purifraldado ceuberano o sinal celeste de

suave advertência. Mas que sucede? Sisoldou? E as irmanantes? Os carvelhos

de alto desturfam em paz, e onde cinis havia os olmos sonem. Se caizeres calar,

falo para subires: e ninguém tão cedo deveria assim mesmo a

fuarça das inimongináveis apressetar para finéxios seculares.

Renatos, grão-mestre obreiro, tartamano de Alvanel, que mexia a

massa na areia, morava na mais ampla via soidisante numa lústica longedícula

aos messianjos semota suso juízos josuéticos numerar-nos

ou Helvítico, que do pecado deu ter o nome (outro dia consternado,

jogou a cabeça com tudo na bacia para augurar o fático futuro, mas antes

que ele a retirasse de lá com suifciente celeridade, devido ao podor mosasco,

a própria água seviparou-se e todos os guinerosos convivas rumaram exsuldados

só para mostrar que judeito torajoso ele era!)

e durante anos já venidos, com seu cocho e cimento, esse homem

construiu edifícios na Aldeia Alterna, edefecado ensina destercas supra a falda

o agraço que escorrio ruanguerruando pela flúvia ourela. Esposou Analice,

pícola sirigaita e apavorou a linda e pequena criatuba. Cingiu-a pelos laços cenos

de brancas flores fraleditas. Semprora balbo, mitreu a testa,

com diva trolha pega e a bata ebúrnea com que habitacularmente sementava, como

Harum Criaderico Egberso caligulou por multiplicabos

a altituda e a maltituda até vervir à puraluz do

licor, onde a gema nasceu, a testova redonda, sina doutrora

de levantar-se em camisa malsão acima (garantiago!), uma aranha-céu rendeira

\section{p. 5}

de nada e celescalando o mimelaiaí, hierarquiteticeterotal, 
com uma sarçardente no alto da torrefação e

com ladrêncio gazúler surrupiateiramente a tomar a bel que $\underline{3}$

tinhabaixo.

Foi dele a primásia de despor as armas e ter nome. Chamou-se Vasílio

Beblaievo Adamastor. Levava um penhacho em sua veneráldica

em verte com turvantes ancilárias, argentinas; um cabralho pursuivante,

hórrido, córnico. Seu escuto faixado por frecheiros tesos no lado primeiro e

hélio na segunda. Cachaça é pro mixanga que mexe na enxada. Orrorrô,

Seo Rei, logo serás Reinatos. Zegunda comédia zedo e o sor tá

novinho em folha! E vinagradecer o tropeço de dormingo! Arrarrá,

Seo Finatos, desse jeito o sior volta a refinar.

Que espécie de agentil provocou naquele tragódio dia dos quintos

esse negócio de pecado municipal? Nossa caabana inda rola como

otestemunha do trovão de nosso fedor, mas ouvimos também por meio

de sucessivas eras fatos que se sabá como coreis de descalificadas

que deveriam preteger a pedralva persempre expulsa do

céu. Fazei com que fiquemos ontes no caminho da justeza, ó Protetor,

na hora que nos levantamos, que palitamos os dentes, que

nos ajoelhamos ao pé do catre e ao cair da noite e

ao apagar das estrelas! É melhor um nabir que me carregue do que

um ausanto que me derrube. De ostra maneira taríamos como o morro

em médio a boca do maregito. Colherva, a papiroca,

é quem decide. Então saberemos se sexta-feira vou em festa. Ela

tem como dom medrar e o de alcançar para seus caros aljudantes os

sítios e os sonhos. Olha! Olha! Talvez seja um tijolo mal cozido,

dizem uns, ou bode ter sido por causa de uma quoda de sua promessa trazeira,

como viram outros. (Deve perfazer agora mil e uma

estórias conhecidas e parecidas.) Tanto duvidara que mala

abelcanhava aservinhas que abraçara (que valha lá velhas vias de pavimentos,

róis ruídos, carnacos estongeantes, túmultus tranvias, fargobólios,

autoquinotões, hipomóveis, urbondes, viravórios, megafumos,

circundos e castros e sinameias e aeropagodes 
mequelemburque e o empuçado e a maranha e o merlão depressa

\section{p. 6}

mulejada amenaçagora coruscante na Garvaia a dúzia baça ônis

núbia rastrenando ao longo da Setantuna e o indo, emburgos,

coscuvilhando na esquina da Nessundire e o fumo e o

progresso e o estrépito de seus indigenos citadinos sem roma,

sem broma, sem doma, malho e malha não fácia muralha

e rumores de revoltelhas, rufos amaios e

calhas arrifas sob a balaustrada ponte avogar) que umalva

ébria devino e dessonhar. Tropéu na escalada golova, pesava a

capota (Havia um muro em vistosa ereção). Tam! Tombou

do tartamuro. Tom! Tá coa cabeça quebrada. Tum! Mastamora,

mastatumba, celibata até laúde. Pra

todo o mundo sambalelê.

Vêla? Devera eu ver! Macul, Macul, aimè, per què tu moríres?

se de uma provação numa triste albaxova? Soluçospiros recopados na avelada

natarena, todos os ruviões da nação prostrados pela

tristeza e pela profusa pletora duodizimal de plangente

algaravia. Tudo havia, prunas e passas, cerejas e cítaras

e corinta e canela também. E todos mostravam que juventude

esbanjavam. Gogue e Magogue e todos em volta, grogues.

Para a continuação daquela celebração até à hora da

expiação! Havia uns que coravam e outros que cancarpiam.

Inchavam-no e esvaziavam-no. Está duro, mas firme

com Priamolim! É que era ele um jovem dessente de uma giornada. Desbastam-lhe

a lápide, entornam a tampa do féretro! Em que canto chão

ouvirias sons tão aultos? De profundo pesar, adestam

fidélios. Trouxeram-no e depuseram-no no catre, engalanado

de finuísque nos pés, e de revelada guênesis na cabeceira. 
Viva! Não há senão a jovialidade estuante das engrenagens do estrígeo globo

que é tautologicamente o mesmo assunto. Bem, sendo ele $\quad \underline{30}$

um ser tão plano de volume como crescida babelina, deixa-o $\quad \underline{31}$

mijorar, olha, em Cas, bem, olha a tampestampa da saifa vuitanta vuit. 되 $\underline{32}$

Hum! De Chapelizado até Bailiado ou de sóterra a baronalta $\quad \underline{33}$

ou de Bancabanca a Rodatesta ou do sopé do socalco até ao olho de $\quad \underline{34}$

Oculira, ele che arrimara adágio. E por todo o passo $\quad \underline{35}$

(clarim!) do fiorde ao combro, as boaltas brisas saupesavam-no $\quad \underline{36}$

\section{p. 7}

ao pedredor (cuacuacuá!) no aceno suave do cisne e toda a longa $\quad \underline{1}$

e lívida noite, a desvailada pálpita noite, a noite de umbelas arandelas, $\quad \underline{2}$

a aflitaflauta dela em tromposos troqueus (Carina, ó Carina!) presto o desperta. $\quad \underline{3}$

Com as caterinatércias e os patrijecamartes e todo $\quad \underline{4}$

aquele disqüisque. Talha tuna, tila pia, conta tina $\quad \underline{5}$

paga torta tuga trema. Graça ante Gula. Por o que somos, graça $\quad \underline{6}$

a grossa se somos, por o crer. Então salta do leito e prega $\quad \underline{7}$

a chave mordieu. Omem. Assir veja! Avui demachou-se a ir $\quad \underline{8}$

mas avoro espalhafatou-se. Quem é aqueste enextremado? $\quad \underline{9}$

Egoagoúgo Fosco. De quem é aquesta cabaça? Quinédia clebassou? $\quad \underline{10}$

um pedaço de Simpão. Quem calcou arriba a coda? $\quad \underline{11}$

Um copo de Dano ou Duno famosta, cervícia dobelina. Sed, $\quad \underline{12}$

eia, mentre enxugas a despensa e afundas odontos naquesta $\quad \underline{13}$

reserva de um corpão de florfarinha contempla-o beemótico pois $\quad \underline{14}$

ele é nictótico, não é? Finato! Mera etereografia de uma cena de pasquelão. $\quad \underline{15}$

O quase rubente Salmossalar, primevo dos antanhos dos $\quad \underline{16}$

agapemônidas, alevinou-se entre nós, enlutado e $\quad \underline{17}$

despachado. Aquela ceva está finita para púmblios avaros avessos $\quad \underline{18}$

arengos. $\quad \underline{19}$

Apesar de invisível a forma assonífera do bosquejado ictobrôntico, $\quad \underline{20}$

mesmo em nostra vita noctâmbula pela caniçura do ribeiro $\quad \underline{21}$

trutuante que Bronto amava e em que repoisava Brunto. Hic cubat $\quad \underline{22}$

edilis. Apud libertinam parvulam. E se ela estiver em andrajos e andejos, $\quad \underline{23}$ 
enfarosos farrapos ou assúnticos, na bufunfa ou na $\quad \underline{24}$

pindura. Arrá, certíssimo, todos adoramos a Aninha Runinha, ou, $\quad \underline{25}$

quem sabe, a lovelita Ana Rúnia, que, sob a plúrica $\quad \underline{26}$

umbela, ela nança ninando nuvelas. Tue! $\quad \underline{27}$

Brontolone indormisca, tue ressonas. Su Benn Testóite, $\quad \underline{28}$

enebetudizou. A crânica cabeça sobre ele, funda das rezões, chapa jovem $\quad \underline{29}$

em marabruma. Tuesta? Seus surdos pés de barro, arrevaldos em verdigrasso, $\quad \underline{30}$

disparestram gomas onde dantes cambaram, pelo imundo jornaleiro, $\quad \underline{31}$

onde nosso prestímano tudo vê, com o véu que suorela avui. $\quad \underline{32}$

Enquanto contra esta bella aliança alentria Sessenta ei, perpermite $\quad \underline{33}$

ai! culatra do forte, bom, tarabom, tarabom, espreite no $\underline{34}$

embosque, o sítio do lifespera do arribaldo e ribarranco.

Então quando as nuvens avançam, jaça, apreza-se uma altivista de $\quad \underline{36}$

\section{p. 8}

nosso argílico monte, hoje museu nacional Uelítico, $\quad \underline{1}$

com, a certa verdistância, o atraente campo não vai ter $\quad \underline{2}$

luz e as duas branquíticas vilãs que se mostram, aqui, tão $\quad \underline{3}$

gracejeitas enimijo à folhera, as pulcrinhas! $\quad \underline{4}$

Permitem-se penetras no montuseu aberto. Entrem o gálico galês $\quad \underline{5}$

e gaélico galante, unadomina! Desmembrora os invalidos da velha $\underline{6}$

guarda encontram o puxapuxa coxacoxe para aberbarem a boga. $\quad \underline{7}$

Pois sua gázua provê a ganitriz, mestressa Tércia. Troc. $\underline{8}$

Este é o meio para o salamuseu. Agarra o gorro e entra! $\underline{9}$

Estás aora no salamuseu do Uelintarioso. É uma arma prussiosa. $\quad \underline{10}$

É um francho. Troc. É a bundeira do prussioso, $\quad \underline{11}$

do Capo e do Feixicro. Eis a bala que bingou a bundeira do $\quad \underline{12}$

prussioso. Este é o francho que furou na bala o mosco que bingou $\quad \underline{13}$

a bundeira do prussioso. Salusta o fogo congresso! Levanta tua

baioneta e teu forcado! Troc. (Bosta! Afina!) É o sombreiro de três picas de $\quad \underline{15}$

Lipoleão. Troc. Chapelipóleo. Este é o Uelintarioso na $\underline{16}$

cavalgadura branca de sempre, o Coprinhapo. É o massacrasso $\quad \underline{17}$

Uelintarioso, grão e magêntico com suas esporas aureolatas e su férreo $\quad \underline{18}$ 
ducasno e sus aquartebraços tamancos e sus magnantes ligardos

e sus vestes bangóticas e galochas goliardas e su pulopenásia

rutra luta. Este é su enorme cavalgadura blancha. Troc. É a boina

de três picas reclamando desmortos gruchivos. Este é

enemicanglés, aqueste escogris, aquestroutos daníferos, capítulo.

Este é o palustro lipoleão mordercando o parvo lipoleão.

Um argomento gavirauto. Este é o catraio do lipoleão que

não era lustro nem parvo. Assaiam, assaiam! Tuchou dois é demais.

Charco MacDyke e Harry O'Surto. Todos eles

armínimos e vermínimos. Aquestes são os alpes Délios. Aqueste, o montível;

estoutro o monte Tipsey, aquel o grão monjúlio. Aqueste é o

crimelinho dos alpes cerceando a resguarda dos tripoleões.

Aquestas são as fiandas com suas livórnias fingindo ler em seus

livros manufraturados de estragédia enquanto planeam a guerra para o

o Uelintarioso indefileirado. A fianda arrulhalva a mão e a fianda

renegrava o lustro pêlo e o Uelintarioso armava a barraca. Aqueste

Uelintarioso marmorial taloscópico, um carpintudo obscida

sopra o flanco das fiandeiras. Sexalibrudo de seis conúbios. Troc. Aquest

\section{p. 9}

é meu Belcro infiltrando suas filírias no seu mais Artreiro

Dignésio Chapelissol Cromélico. Sacado. É a fianda crastinindo

despachos para irrigar o Uelintarioso. Despachado

em finas cranaias linhas a frente de mortalha do meu Belcro. Iá, iá, iá!

Líbido Ortor! Firmo consiquimos! Fidegena dana claudesfrauda. Censuramente.

Bona. Esses foram os tiquetáticos das fiandas para fontanezar o

Uelintarioso. Xixixi! As fiandas infiamadas reagem cortesmente

a todos os lipoleões. E os lipoleões deixam boicoitado

o Uelintarioso. E o Uelintarioso levanta o bando. Aqueste é o

trápago Belcro, boina a barrete, quebrando sua cripta palavra com uma

bala no ouvido para Uelintarioso. É o despacho decrépito do Uelintarioso

Despacho despeso nos fundilhos da reta guarda de meu

Belcro. Salamangra! Aiaiai! Cricas fiandas. Frodam-se! 
Dela hilariana, Vultro. Uelintarioso. Foi o primeiro remuque de $\quad \underline{14}$

Uelintão, taques por tiques! É o meu Belcro calçando $\quad \underline{15}$

suas galochas de setéguas, reto, tirado e forte estampido afrenta, $\quad \underline{16}$

refugando o campo pelas fiandas. Toma um trago, trastomado, pois ele $\quad \underline{17}$

logo pedirá guinés para que se veja alto, escuro e desgolo. $\quad \underline{18}$

Bólides russos. Aquesta é uma presúria. Aquestos, missuntropos. Aqueste $\quad \underline{19}$

é Canobuxo com o paternaso. Passados cem dias de indulgência. $\quad \underline{20}$

Aqueste é o abenchagado. Taras víduas. Aquesta é a fianda no boníbano $\underline{21}$

blúcher. Aqueste é o lipoleão no casalo vago. E aqueste é o $\underline{22}$

Uelintarioso, pelas córquicas esquírolas, mandafogo. Corisca! $\quad \underline{23}$

(Alvalhaço! Joga fora!) Aquesta é a camelaria, aquestes os flundeiros, aquestes $\quad \underline{24}$

solferinos em ácio, aquestes, seus termóbilos, aquestes os panicábrios. $\quad \underline{25}$

Vagalmeideus! Arteus tu, Luso? Aquest é o grito do Uelintarioso. Brum! $\underline{26}$

Brão! Cambrão! Aqueste é o grito da fianda. Votroada! Deus $\quad \underline{27}$

esquartraga a Fingraterra. Aquesta é a fianda desfrenando-se de seus austerlíticos $\underline{28}$

burseguidores. Com tragos e tropéis e aerótragos e $\quad \underline{29}$

aerótrocos. Pois seus cuouros correm lá. Troc. Aqueste é-me o $\quad \underline{30}$

agráito e argêncio plauto para canastrar as vides $\quad \underline{31}$

em aprilinos sudários. Pilha a Pátria a malta! Aquesta é a bismarta da $\quad \underline{32}$

álacre mariatona das fiandas deixada pra trás. Aqueste é o $\quad \underline{33}$

Uelintarioso a molejar seu próprio taloscópio mastorial, o $\quad \underline{34}$

Sofia-Paula, para sua real divorsão com as desfrenadas fiandas. $\quad \underline{35}$

Gambarista della Porra! Fimerato de Molherino! Desvaleras $\quad \underline{36}$

\section{p. 10}

os lipoleônicos, Alarife, que espreitafa o Uelintarioso de $\quad \underline{1}$

sua alva cavalgadura, o Capengança. Estontenaz Uelintarioso $\quad \underline{2}$

é um prístino sumontrumano. Lipoleões são benices em $\quad \underline{3}$

forcados. Aquesta é Inês Iena rindo-se desbragadamente daquel $\quad \underline{4}$

Uelintarioso. Aqueste é o lápis índigo d'olho a refregar das reginésias. $\quad \underline{5}$

Aquest está indo Chamar Sim entre o moçolho e as $\underline{6}$

reginésias. Troc. Aquest é o prístino cerúmano Uelintarioso a folgar-se $\quad \underline{7}$

em meio à trifólia barretina do lipóleo retirada da hematômica $\quad \underline{8}$ 
espurcícia. Aquest é o ceríndio a ensebar o rajairado por ua bomburina.

Aquest é o Uelintarioso arrancando a meada da lipólica barretina

até o rabo pendente da anca de sua biancona cavalgadura. Troc. Fora

o último remuque de Uelintão. Cap, cap, cap! A mateixa cavalvadura

do Uelintarioso, Culpenhado, baloiçando a torsicódia

com a boinaveia do lipóleo para insoldar sobre o catracipaio

indólio. Rinch, rinch, rinch! (Xingney! Asco!) Aquest é o catracipaio

madracheiro, atrepai-os, grita ao Uelintarioso:

Atrepucaro! Apucarasse! Aquest é o Uelintarioso, presepense

gantil-homem, pavila o espórcoro ao acorsado Chamar Sim.

Basofe afrente! Aquest é o durfaio catracípico que atroou o esconso

da boinaveia do lipóleo que beija a rabuja sobre o

o arnês de su alva cavalgadura. Troc. (Namusca! Taca!) Copenhacabou.

Por aqui o salamuseu. Tomai vustra sávata per que

salgais.

Foi!

Que hora cálida passamos ali! Em que medúsea airagem

nos matemos! Nus savemos dovela pero tendes dizer analguém pois

o lume alboborece! É ua casóita candelária de um mensardo

e ua ventana. D'ablegar, Alt'ablegar. Em conta

de vinde os novos. E um tempo leniente também! O vento

vagrante espreita em torno às pitinvalas e acolimadas

a cada golpe (se qüenta espias, mais quatroscopio) estão

implumes recolhinas, runitas, dolonitas, presditas, quartzitas,

acintitas, cessitas, sevaritas, anoirexita, noviditas, adessitas,

metonsitas e ducitas desovitas. Um verodíplano ao debar dos pastos pretos.

Sob os sete glavos ruxios, um repoisa, o Imperabulho. Seu gládio

ao lado. O escudo atirado. Nossos columbinos fluaram aos nórtios enclives.

\section{p. 11}

Três dos corvos volaram sulbtamente, corvejando al

caidia dos quatro ventos donde as tripos contestam; Vai, 
Thon corisca-se com suas noitinfas ou quando Thon atroa $\quad \underline{4}$

apocabuns nas galezitas de Thon. Não. Anuba! Nébulas sôbolas lívias! $\quad \underline{5}$

Ela ficaria murcha e aflita. De Gambalima a Capemérida $\quad \underline{6}$

e todos os feitos nefandos. Fia-te, foto e fado! Ela gesta a $\underline{7}$

esperança de que as águas passem. Cá, e continua parecendo avui, $\quad \underline{8}$

ela vem, proacífica, parodávia, diva perimui, $\quad \underline{9}$

uma picada na pailhagem, com galispo e prestímanos $\quad \underline{10}$

na mochila em sua cangespádua e um frasco frísio, flagício flagelo, $\quad \underline{11}$

corusconfuso pacto dos criptarcos, picando aqui, bicando $\quad \underline{12}$

acolá, gatochota varramarte. Mes son las notas armitidas, $\quad \underline{13}$

militopax, e demalutosos anelamos um argílico tiósculo para os $\quad \underline{14}$

jornaleiros e haverá daver erebela trégua para as hilarenidas $\quad \underline{15}$

crias eventuais. Aproxineba a mim e sussalmodia em que $\quad \underline{16}$

nós celestrugimos. Ela tomou o luzeiro do carro para alcovitar $\quad \underline{17}$

melhor (quem baila à bala e vasta a vista) e todo bem $\quad \underline{18}$

espoliado mete no alforje: curtuchos e butins enfrechados $\quad \underline{19}$

frascos e borrifos de todas as nações, clavicuros e escampulários, mapas $\quad \underline{20}$

chaves e lenhossos de ledos vinténs e alfileiros selenuares com $\quad \underline{21}$

bombáceas hematíticas nelas, notígatos bostampidos e massas $\quad \underline{22}$

súticas e nicúpedas e pédicas almíscaras e lugros sacergentes $\quad \underline{23}$

de catos e oviços moucanos e enamos e magias, ilhos e $\underline{24}$

elhas com promíscaras e pleuras campanas e a ultima vísio que $\quad \underline{25}$

vai de cervo em corva (cervolídio!) e a mais justa apostavia o aocaso

(que cerco!). Cos quis. Quis Cris. Cruz Cris. Quis Cruz. 27

No fim da figa. Essa sina. $\quad \underline{28}$

Que botina molhetina vi dela, quando fortemente prossebido, $\quad \underline{29}$

a roubar nossa presente história do antanho posprofetérico $\quad \underline{30}$

de forma a fazer-nos senhorios e moçoirias daquela $\quad \underline{31}$

pândega assuada. Ela está livivendo em meio a nós deflúvia $\quad \underline{32}$

gaia entre pronóbios apulpos (seu nascimirto Ana arqui-a), com $\quad \underline{33}$

uma bata para sua persona e sua sabina a catelárias (tristares! $\quad \underline{34}$

probritas!) se tu mas preguntas e to pregunto. Ao! Ao! Grigos podem

erguer-se e ílios caírem (dois pontos para duas vistas) $\quad \underline{36}$ 


\section{p. 12}

pois é nas sendas da diva improvidência que a vida

vale ser divida e a gaia é cela onde os citados se sentam. Deixai

as hímanas donzelas divagarem a estória e os rapacitos sussurrarem

botocudos pelas costas. Ele sabe do dever de seu senhor mentre

londrana dorma. Tens algum trocado? diz ele. Tenho o quê? folga

a outra. E todos adoramos a esponsana por ser ela

mercenária. Tot i que a covadura da terra esteja em liqüidação

(flutamerda!) e não sobram sobrolhos nem ciliares nesta

praça glabra de Raimundo Valtério e ela tomará uma vesta e

e afretará sarças e turfas à preamariscada para cozer e

fará tudo que uma damazona faz pra às coisas não pifar. Ufa. Afasta

a fleumaça. Fífia. E mesmo Cumpim cascairá miríadas

vezes para desaver-se de novo no florigácio de nossas grãs

remonstrações, e habrá ivos para os bricos manharem-se,

solácios acimados com cuidado. Tão vero isso é que houvavia

uma revolteia pronta, e quando crês que te dessumiste

em abundamento, avém-te de não galear-te toda.

Ales hores em quiel astá incomodata darcadas bizarrias,

desfrutando dos primos fruitos e tomando-lhe o óbulo, revisamos

os dous cômoros e nada vemos dos senhos vistos algures,

pelos séquistos e sétidos, como tandos combros e colinas

sitos envoltos, brégidas e putrícias, em suisávidos

cetins e tafetáficas ceroilas, figurando o Devaneio de Gartão,

no tripúrio plânico do esparco. Erguei-vos, mijel!

Folgai em bimbas! A pedido do Cujo Nicola. Nada veremos

e oiremos se escolhermos entre os bergomontes cercanos às

Corquinas e os bergamouros de Arvouquir ou as bergâmbolas

de Monte Esteio ou as bergoncelas de Montavaro ou os bergões

contrabases do Morro da Constituição malgrado toda populecha tenha

vário tom e toda troca tenha sábios mecanismos e cada 
no sinistreu e Sitrico no entremeio. Mas todos 1s sam

acolá tirando raspas para cheirar a possibilidade de que solverão

e salvarão lá o robuloso rébulo da vida, fiando-se no meio como

fumo na panela, Ó, mentre ele está dormente do macroburgo

de Capoforte ao microburgo de Caçafecho. Desfrutai

\section{p. 13}

deste som de hibérnio sentimento. Realmente? Aqui o português poderá ser visto. $\quad \underline{1}$

Realístico? Um soberano trocadito por óbulos pétreos. Regiamente? O $\underline{2}$

silêncio narra a cena. Ficto! $\quad \underline{3}$

Então esta é Clubim? $\quad \underline{4}$

So This Is Dyoublong? $\quad \underline{5}$

Harto! Cuidado! Ecolanda! $\quad \underline{6}$

Harto cortês encantador! Isso te memora a aluviada $\quad \underline{7}$

gravidura usada para se borrar na manchuria desse $\quad \underline{8}$

despendário moradio. Foram? (Tenho por certo que o esfaldado $\quad \underline{9}$

capelento com o realejo de chocolate, Miguel de Barros, está ouuindo) $\quad \underline{10}$

Digo, os restolhos da puída morentalha cá usados no $\quad \underline{11}$

fenecimento dos íncabos Ptolomões. Fomos? (Ele apenas tem $\quad \underline{12}$

a pretensão de ferir a harpa do jubileu desde um segundo ouvinte $\quad \underline{13}$

esvaído, Feérico Farinello.) Fato notório. Busca loquelizar-se e

acha o novo o velho bútico. Debele. Sonara. O' Yes? Cerca do muro $\underline{15}$

mausolimo. Afanado féretro finito. Afinada fanfarra. Finato defunto. $\quad \underline{16}$

Aquesté o optofone que ontofana. Listania, tu! A sortilira $\quad \underline{17}$

do Vigarostão. Pugnarão per sempre. Ouuirão $\quad \underline{18}$

per tot. Torvarão doravante. A desaspineta $\quad \underline{19}$

será deles per tot i sempre.

Quatro coisas per tant, disse nosso herodotário Júlio Mamôneda $\underline{21}$

em seu famoso historiório, escrito cerca de Boriório, o livro mais triste que $\quad \underline{22}$

há nos celestes anais bailestreiros, cabidal de Divinarca, nunca crestada $\quad \underline{23}$

nem alhanada ínsula, hibérnica e pertinaz. E ora hoje estão, o temor

de uno tal de Tote atado! Unum. (Adar.) Um bulbócio superno

sobre um vetusto. Ai, ai! Duum. (Nizam.) Um calçono abateu a puída 
ondina. Ah, oh! Triom. (Tamuz.) Uma donzela baia, nôvia

noiva, a ser despojada. Adera, adera! Quodlibus. (Amarsemvão.) Uma $\quad \underline{28}$

pena não menos pesa nem a posta. Dum modo ou doutro. (Sucote.)

Pois, assim como os ventos passageiros viram páginas e páginas, inocêncios $\quad \underline{30}$

anacléticos folgam abugalhados antípopas, as lívidas folhas livram-se $\quad \underline{31}$

dos mortos, desfeitos anais apróprios temporando ciclos de eventos $\quad \underline{32}$

grãos e nacionais, fósseis feitos pascompassados.

1132 d. C. Homens eqüipolentes a fórmicas atas levigatam alvacetácias

grunas recônditas e que corrunam por um veio. Caudais sangüíneos sobem oblânios.

566 d. C. Este ano, anuíte em falobálica, pastos delúvios, um encronado que $\underline{36}$

\section{14}

tenya un cisto salgário para salutar pálidas turvas do palude $\quad \underline{1}$

sob a fataça de beije, mentre dessoterrava-se para açular $\quad \underline{2}$

a vacuriosidade dess' alma, mas com a taleiga prena de $\quad \underline{3}$

boas pragatas e miúdas caligas, tão sudourudas.

Balacladas em Vauparaísso. $\quad \underline{5}$

(Tácito!) $\quad \underline{6}$

566 a. C. Nessora aquiesceu-se de que era ua ruiva donzela a sofrer $\quad \underline{7}$

(sobolosrios!) perquè a monyica que petinha fora violada $\quad \underline{8}$

de suas gambas pelo ogro prepurópio. Cruévias guerras em balaclivadi- $\quad \underline{9}$

bala. $\quad \underline{10}$

1132. a. C. Dois filhos tautócronos nasceram de um alvergueiro $\underline{11}$

e sua canorça. Esses filhos denominaram-se Cássio e Prínio. $\quad \underline{12}$

Prínio era sentil e traladava a bonagente. Cássio $\underline{13}$

foi a Vini Culá e escreveu Guerra e Farsa. Bellas palras para

Dublim.

Algure, perece, no gineforo entre antedulúvios $\quad \underline{16}$

e anadominantes, o escriba teve de abanda-se com seu $\quad \underline{17}$

purgaminho. O boneflúvio esbordou-se como havia ou alçando-se guindou, ou $\quad \underline{18}$

satrapiou

o logomundo do excelso empireador (trom, em suma) $\quad \underline{19}$

ciclossísmico, ou os danados gáleos pancrassaram a puerta gala. $\quad \underline{20}$ 
Um escribicida alesores comunhecou-se em códigos priscos com $\quad \underline{21}$

cincoimados por seis marcas de nove pências em androssíderos pelo $\quad \underline{22}$

androcídeo do escrimentor mentre el será o solo crônico em $\quad \underline{23}$

nostre era passa, consectário de derivas milico-civilistas, $\quad \underline{24}$

que unha ginesura foi deixada no patíbulo por haver tomado $\quad \underline{25}$

persè boa soma em esconso ao intromedar-se com os cobicistas da $\quad \underline{26}$

mulher aliena. $\quad \underline{27}$

Dopo aquela farfalha e peragrino indignante ou clério $\underline{28}$

librou-nos ouvidos, olhos calígenos, do tomo de Liber Lividus $\quad \underline{29}$

e, (tó!), que dulcilidade eirênica crepusculândunas toas $\quad \underline{30}$

e umbrando clareiras, sestendendo davante nosaltres nostra forra devanceira! $\quad \underline{31}$

Sesgo sob seixos peniscos repoisa o báculo pegureiro; jovem $\quad \underline{32}$

madoca a corcear-se à níbula sorela ou volver-se viridente; avestou-a $\quad \underline{33}$

grassando inolente a baixeza de trifolíceas petrindades; celeste sempre $\quad \underline{34}$

cinza. Así, tamén, por asnos a fio. Dêsdelas fainas Héberas $\quad \underline{35}$

e Heremônias, as florigômias vicejavam em Balimuna, $\quad \underline{36}$

\section{p. 15}

a agalancéia desabrocha nas sebes de Caprília, dulipas

acerbam-se jungindo-as à russa rosa, duplúscula urbelândia, $\quad \underline{2}$

a alvaguda e a rubraguda desfaldaram os molivares $\underline{3}$

de Nocamara, e, apesar dos anéis que as envolvem, durante uma $\quad \underline{4}$

quiliada de súcias periélias, os formorianos britaram os tuatas $\quad \underline{5}$

dedânios e os oxímanos foram acossados pelos pirobólguios $\quad \underline{6}$

e os jutões expurgaram os taperários para a Celesquévia $\quad \underline{7}$

e o zilionito é o filho devanceiro da Cidade (Roma! $\quad \underline{8}$

Roma! E rizomas!), esses sinetes pásculos $\underline{9}$

quadrilharam pelos sexos afora e sopra agora e assopra-nos, viçosos $\quad \underline{10}$

amarridentes como, sobre as evésperas de Quilacídeo. $\quad \underline{11}$

Os babeleiros e suas telangas motas foram (confusi-os!)

eles vieram e se foram; tigando tudo estavam e relinchinos $\quad \underline{13}$

sintomissas foram e venintes norsos foram e polifulanceiras $\quad \underline{14}$

núbias. Homens criam, clérigos murmuravam, a $\quad \underline{15}$ 
bionda suspirava a bruna: Elóscula domiga, meu Caro $\quad \underline{16}$

eqüino? e as ducadamas arrostaram-se com relichos $\quad \underline{17}$

infernados: Cadê o tongador, espaço de imbecil? E eles

caíram um sôlobos altres: e eles mesmo se quedaram. E $\quad \underline{19}$

ainda hoje em véspera e por vesperais dantanho todas as gordas floras do $\quad \underline{20}$

campo dizem a seus pávidos faunos: Manda-me ter contigo! $\quad \underline{21}$

mas, pocodopo: Rega-me para que eu cora! Bem definham elhos, $\quad \underline{22}$

acasalam e profusamente rubros, totemos! Pois aquele dito é tão $\quad \underline{23}$

prisco quanto os clivos. Canta enquanto acalanta um cantil (não $\quad \underline{24}$

é a plena verdade o que vis conto?) para ter barbafinas e nadadeiras que tremeluzem $\quad \underline{25}$

e baloiçam. Tímpanos e tampas, latas Renatas tantas. Badanas! $\underline{26}$

Badanos! Banidos! $\quad \underline{27}$

Opa! $\quad \underline{28}$

Em nome de Anemo, mujica sobre o monte em lápidas corrijas uma $\underline{29}$

partalona, que joãozão será? Remutada sua suinama $\quad \underline{30}$

encestada, apertou o pé zado. Ele teve artelhose, essa $\quad \underline{31}$

artrofia, e, Olhalá, é o peitoral, seu mamúsculo mais $\quad \underline{32}$

monteirioso. Está matando a sede pândega na calva de $\quad \underline{33}$

algo. Pareceu-me um andragão. Ele está quasentre no feudetido

por aqui, é Bebestível Sacossônico, seja junipérico ou ser febreérico, $\quad \underline{35}$

marracos ou alebrilos ou os violentos alúvios do pluvioso e $\quad \underline{36}$

\section{p. 16}

frorioso. Que estranho surto de homarro. É evidente o babuímigo. $\quad \underline{1}$

Ultrapassemos sus piroquádrigos barrais e aquestes cucrais de $\quad \underline{2}$

medulossugadores. (Cava!) Ele pode preposterar o sendeiro $\quad \underline{3}$

pilomar até aos Pilares Hircúleos. Como vos portai-vos, hojudia $\underline{4}$

a donas, biondo ser? Cios plau, laurador! Danota lento, $\quad \underline{5}$

assueto? N. Tu doctíloquo escovegiano? Nã. Tu anglo $\quad \underline{6}$

espigótico? Nan. Tu saxo fônias? Nana. Escleróptico! Aquestum juto.

Troquemos as umbelas e cambiemos turpilóquios palatais $\quad \underline{8}$

e quais jazuais abasta ablutórios arroios. $\quad \underline{9}$

Juto: - Otá! 
Muto: - Muco plazeiro.

Juto: - Tu és jurdo?

Muto: - Um mouco.

Juto: - Mas não és jurdomuto?

Muto: - Nono. Um fafalador nomás.

Juto: - Quaim? Qualé o amuo contigo?

Muto: - Tornei-me um tátaro, um estucho.

Juto: - Que coisa perpereperopercepetiva, per cauço! É

Muto: - Depende da botelha, douvidas?

Juto: - Que podelha? Pe care?

Muto: - Nos estaus de tarfugo dove deviastar.

Juto: - Esse gesto de tua voz é quase indigesto permigo.

Ficou mouco mais conspícuo, como se fora

tu.

Muto: - Tá? Tátaro? Tartamudo? Urso. Boruru! Buru

Ursupa! Açarçalho de minhas ravinas quando eu mi rimino!

Juto: - Um oliocêntrico. Oglum paizon apason. Diapasin anton ton existância cruzinância propriapina com guilda. Aqui tens cobragentas, moedinas. Guinéus tifanobénicos.

Muto: - Luí, luízes! Não notei o que denota, a inefável

\section{p. 17}

adove os livrários, Monomarca. Havia lá os missioneiros

selenos, pequenicos manecos.

Juto: - Simplesmente porque como Taciturno prequer, nosso 
Muto: - Assim como um remontalho num bruxuleante regato $\underline{6}$ celebrejo. $\quad \underline{7}$

Juto: - Todo Paludoso! Que bulha eu norso? $\underline{8}$

Muto: - Romulhante a um boi numa clonturfa. Róricas rocas $\quad \underline{9}$ regirrômicas! Pudera ressonhar com ele no escumado corno, $\quad \underline{10}$ com seu uelintário lanolado, pelo colo me assunto $\quad \underline{11}$ sobre Briamolim. $\quad \underline{12}$

Juto: - Bandoleias e rameiras em mim quando mal me posso $\quad \underline{13}$ quedar do coméxico a filanda em tal camino $\quad \underline{14}$ pela rota da merunga. Inveredas e avercenas! $\quad \underline{15}$ Boa sobreceia! Anhangá manhã. $\quad \underline{16}$

Muto: - Anuo. Um bocadito! Caxorroloqueia 17 à roda dessa penilha e escularás como longevas as $\quad \underline{18}$ plainuras de meseltros, enricursos, onde vive $\quad \underline{19}$ plangente um pássaro a piar sobre a campina, onde $\underline{20}$ salgarão povoados pelas legimoras, onde por régula $\underline{21}$ senhoria, a glasa veio de seu Estau de Beresite ao $\quad \underline{22}$ qual Aponta Ali Ponto. Deixemo-lo ali ao rumurmúrio. $\underline{23}$ Margemerge duas cepas, branuegos e danegros. Mortendrando $\underline{24}$ via. Haciacá, confrangendo estuários, eles estão em surgência: $\underline{25}$ adonque, hipocalidermos, eles rescansam. Eviternas $\underline{26}$ biostórias nunca findam nessas plagas, tênues $\quad \underline{27}$ flocos de leves, lixívias do alto, como nemágicas dossos $\underline{28}$ giramundos. Agora estamos tumados ao monturo, assins assins, após após, a terra herda. Tesura, qual o teu preço, tesura?

Juto: - Smiert! $\underline{31}$

Muto: - Lucifez! Acabaixo restam. Letárgicos em $\underline{32}$ notívaga vida oslienada, babilônia a grã- $\quad \underline{33}$ prostitestária com mansueta mansarda, alpenrícula pensonha com píreas que igualam inequações neste sonoro almocave - lívido libertório. 
Juto: - śmierć!

Muto: - Umildelasso! Pela ferça sorpresou-se. Cântico $\underline{2}$

despondado. E o outeiro tanancestroz sorveram-nos $\underline{3}$

todos. Essa tera noastra não está totalmente saibra $\underline{4}$

e ser humanoso o mesmo redundoso. Para que reia $\underline{5}$

aquele que o verbarruna aquatro. O'Castro, neocastro, trocastro, $\underline{6}$

desmorona! Dime o vero valor da pobridade! Húmil $\underline{7}$

Flora. Mas dímelo argilosamente, sem mofar! $\quad \underline{8}$

Canastrão! $\underline{9}$

Juto: - Canaquem?

Muto: - As ciclópeas forfículas e amnifadas. $\quad \underline{11}$

Juto: - Rouquê?

Muto: - Eis a campa do vi que um rei. $\quad \underline{13}$

Juto:-Qui!

Muto: - Ora estás atônito, juteu? $\quad \underline{15}$

Juto: - Oie sou torvão, timônteo. $\quad \underline{16}$

(Calhe) se estás abecedéreo, para aqueste livrestígio, cioso $\quad \underline{17}$

de sinais (calhe prego), neste escatralphobético! Podes ouvisar (des $\quad \underline{18}$

que nosaltrestu já nos entendremos) este muto? É a mesma andrômina

de sempre. Molto mene. Hemisções depois de hemisções. Teco. Eles $\underline{20}$

vieram, viveram, amaram-se e voaram. Pois sim. Teu temódomo está $\quad \underline{21}$

dado aos Meadros e Pérsidas. O meandro e tal, logo e $\underline{22}$

logo, de nosso Findoburgo na época em que houve Capalhuna $\quad \underline{23}$

de encaminhar-se sobre a terra. Na inscícia que carreia o assomo que $\underline{24}$

enleia o saber que descobre o nômeno que aguça a acuidade que $\quad \underline{25}$

convolha contatos que endulçam as sensações que dirige o desejo que $\underline{26}$

adere ao apego que fareja a morte que despoja o nascimento que $\quad \underline{27}$

gratula o acaecimento da existencialidade. Mas com a azáfama de sua $\underline{28}$

onfalogradura a exornar-lhe o batarama. Um terrículo biobliovista $\quad \underline{29}$

oviu; estúrdio e trêmulo-contínuo. Um hebético, um celta, $\quad \underline{30}$

um eurículo aos patamutos que devia confranger a erinacórea em $\quad \underline{31}$

horapronóbia, embarga e agita, volpeliça no polaio. $\quad \underline{32}$

Boatam cá figurnos belicóseos armontando. Montandármios $\quad \underline{33}$ 
cosibelos figurnos cabotando. Futarco, aquesta lífula efíngea é para $\quad \underline{34}$

uma pirofinha chamada de triscafora. Miraoleste vos toca! É fada! $\quad \underline{35}$

Miroeste já podeis. Sustai fôo! Levoltai-vos e varejai-os, 'Tace a [

\section{P. 19}

parte tão petica afaenando para o burácolo a que alforabitar logo nos $\quad \underline{1}$

assentaremos. Acì (chusma prego) há selvárias erlívias de $\quad \underline{2}$

de rasgo deveras pecuniar na mesura em que são projéteis que fazem $\quad \underline{3}$

o livro-termo de totumulo. Régula orla ráguna lora e conaquestas

canastras larangotangas altercou acerbo desacertango. Decerto, decerto, $\quad \underline{5}$

perquetuda? Tesco é para tornar este estreno na encalistrada como $\underline{6}$

treslúcido traidor apalavrado de despique. Que ingresia alvitroz $\quad \underline{7}$

é mnessa? Um monturo acúmulo de coisas! Alivas, béteis, gimbas $\quad \underline{8}$

dalas, alfridos, beatas, comarcas e daltôneos. Ó meu letes $\quad \underline{9}$

(Oh paraqüiço!) aqui, a grecorrear queijando-se do tempo $\quad \underline{10}$

epselino, e velhociladoras, indecente limpada de marrabatrás; $\quad \underline{11}$

Sss! Segue a serpe e na caça ofícia! Nossa durblin é $\quad \underline{12}$

serpéia insinuosa. Eles vieram a nossa ísola partindo da trinácrea $\quad \underline{13}$

Trelanterra além da úmida pradaria encabritada no meio do $\quad \underline{14}$

pesadiso de interditas taronjas mas avante aportou Herpetro $\quad \underline{15}$

Espatria e seus ascoros vérgios a rastrear-lhes a $\quad \underline{16}$

chafurda antes quenhoça extirpe viraga pudesse otomar suas $\quad \underline{17}$

quioças. Divisar e sumar as sortes mas os todos terminam sempre na $\quad \underline{18}$

mesma chaça. Achacantes e candongas.

Acho que o diacho trincha igreixo. Um porã ponhum $\underline{20}$

pratrez préter uno antequão. Dois amenozuns redundam $\quad \underline{21}$

crível tresandar e mateixo arrere. Começando com uma enorme sucuri e $\quad \underline{22}$

tripódios ovisários e igrânias araliácias jadem com um recado na $\quad \underline{23}$

boca. E um centofólio em undeznível de fabulatório $\quad \underline{24}$

decornancido podemos horróridos deverar. Que história sinocavernosa para $\quad \underline{25}$

se abrir e tendo um feicho em vista escático, antiscático $\quad \underline{26}$

e proparoscatológico! A dicernos que fôramos todos timos, nicas e $\quad \underline{27}$

larifos, filhos da sudra, filhos, filhotes e, certamente, lealevinos, $\quad \underline{28}$ 
quando noi nu suntem, cada suntana echita issesta de noi, ficas

de Nã! Soluçana acusativa! Damadâmicas infinitudes!

Vero que havia em nilos diébolos ora não ai lumpapiro

na lichiera, e a montíssima Pena ainda ruge pelos fugentes

bugios. Tudo era ancestral. Deste-me a caliga (bote o teu

sinete!) e eu sorvi o vento. Eu quis a ti qüídido (qüiproquó?) mas

foste para os quódices. Todavia o termo, o pensamento, foi e será

\section{p. 20}

sob a praga de nossos sentidos infrarracionais pois o derradeiro

camelácteo, a vena que turbava os sobrolhos seus, quedava

moiro diante da tumba de sua primorosa dona onde o recontro foi

tamarrado à palma de que era senhora. Mas o corno, a bebida, $\mathrm{o}$

dia da fúria inda não arrivaram. Um osso, um seixo, um percaminho; eiva-os,

ceifa-os, sega-os enfim; deixa que a terra cote na

muteolaria: e Gutemórgio com suas teses cromanhosas,

corroborrou os capitulares que duma vez por todos haveriam de passar

aos rolos além da geoprensa não há virtude mais no alcoolrão.

Por isso (lemanta e admolesta) eis a essência papirista,

ascência, recônditos e pistas erratas. Até que tu, por fim,

(em boa hora não ao cabo) te atremas ao Senhor

Cúmio, à Senhora Címia e a todos os sumitos. Ponta. A donque

não hajas de deletrar-me como feitio de cada parábola abarrega

setuadas sumíticas leituras por tôdolo livro de

Dublímane Fimórdio (que a cabeça se lave na lama daquele

que aparte!) até a hora daletéria, maomanaventura, o que axaura

Não chores todavia! Há muito joio até Nondres, com septuas $\quad \underline{19}$

ginas por homem, sô, e o parque tão tetro pelas parvas lucernas. Mas

olha as dadimanas que tens! As prendas se eespalham

em bulícios, abalando-se, todas passando, em peonas e contornos, 
aveia, outro atrás da lentilha e uma terceiro entre os alfofres

de frutilhas. E as franguinhas picaram os dentes e os equasinos $\quad \underline{25}$

burros rebunaram. Podes indagar teu ásnus se ele o abona. E $\quad \underline{26}$

acuda-me apenas se cervedes calcovidos. Aquela senhora com $\quad \underline{27}$

seus quarentinhas. Pois foi na época das barretinas. De um $\quad \underline{28}$

noarca e uma cobaia; de uma pomerança e uma intemperança $\quad \underline{29}$

leviana; ou de jovens doiros que safaram oiros; ou de seja lá que $\quad \underline{30}$

engenículas o homem cavilou. Malmariado, ele retro- $\quad \underline{31}$

asfixiou-se pela fervilha dos frascos e da pirra pierrice dela. $\quad \underline{32}$

Minha alfaia, uma gaia aquesta ginofídica! Daquele tripieiro $\quad \underline{33}$

artéio, esperam pouco! Vélicos, volatinos, olhos columbinos. Ela é o

próprio balde d'água Fina. Flutasca, flumana. $\quad \underline{35}$

Escróia! Por certo foi ela, não fomos! Mas rumorejem, $\quad \underline{36}$

\section{p. 21}

briosos, somos trasouvidos por um nuerículo. Tão pequeinho $\quad \underline{1}$

picolotirro. Vinividi! Fuera como si supiera. Oigan! Oigan! $\quad \underline{2}$

Fá-lá-ei. Ascolta, um hábil corno exorta! E as anacruses da lira $\quad \underline{3}$

proseiam.

Foi numa noute, tarde, fai moito tempo, desde o tempo $\quad \underline{5}$

em que Adão devaneava e madama desfiava sedáquas tábidas, $\quad \underline{6}$

em que imberbes comorinos aduavam e às lídimas primevas $\quad \underline{7}$

alarifas a serem totalmente desbravadas pelos olhos $\quad \underline{8}$

amávidos, e toda gente viveu solamada com tôdolos mais, e $\quad \underline{9}$

Jairo van Heta tostava a testa avante aos farolhos, $\quad \underline{10}$

poisando os dedos gelados em si. E seus dois pequenos chamininos, primos $\quad \underline{11}$

de nostraltes, Tristóvão e Halacre, brincarolavam com a chupeta $\quad \underline{12}$

no assoalho encerado de seu homerígio castelo entérreo. $\quad \underline{13}$

E, ao dermótico, quem cuida dessa albergaria apenas a cunhatogênia, $\quad \underline{14}$

a reina camafonje. E a camafônjica arrebatou uma rosada $\quad \underline{15}$

e fê-la alivivar-se sob o pórtico. E ela elevou-se e a pirlanda $\quad \underline{16}$

ficou em piras. E ela parlou ao portal com terna paciência: $\quad \underline{17}$

Marca o Primaio, por que pareço alguém lívida de poisio a birras $\quad \underline{18}$ 
portas? E foi assim que as escaramuças começaram. Mas a comporta

termanava-lhe e a graça nassou-se às olâmbrias. Encerre! Então a

maliciosa graça catou um catraio de Tristóvão e ao semoto

esteante, ela chuvia, chuvia, chuvia. E Jairo van Heta desguerrou-se

atresdela donegando-lhe a efúgia: Pára, abiltre, pára, revoca

meu heréu para mim. Mas ela asseriu-lhe: Nipormientes. E havia

uma candeia grassa naquela mesma noite sabárquica de ângelos catentes

Eira afora. E a camafonja saiu para os seus quarenta anos de

agruras em Turlemunda e ela expurgou as graças dos encantos

de amor do geminino com escumédica de sabão e ela fez seus

próprios quatro bandistas ensinar a ele nadas e ela o convorteu

às causas soadeiras e ele tornou-se um indolúdico. Então ela passou

a chuvir, chuvir, e, ao dermótico, retornou aos

estiomanos de Jairo van Heta com o gemininos consigo

na pináfora, enlaços noturnos, noutrora. E quando

achegava-se viu-se então à barra da bristoria dele. E Jairo von Heta

escaldava nadega os pés com bértolas brechas,

\section{p. 22}

o imberbe em suprima infância estava abaixo no prostral

estrujando e tossindo, como fratesora. E a camafonja

mordiscou o mais alvo e ascendeu-se e os galiscos rubruaram

de seus piromontes. E ela tornou-se-se alva diante dos

aívos, dizendo: Marca o Dúlio, por que paresco algunha lépida

portaleira? E: Encerre! diz a graciola, mas respostando sua

autarcia. Então sua autarcia priscogitou catar outro catraio e

tomou um geminino e pelas austradas para o Varoeste ela

chuviu, chuviu, chuviu. E Jairo von Heta dessangou-se-lhe ao encalço

para confingá-la: Pára, gaia, pára, revoca maréu marim, pára.

Mas a camafonje asserriu-lhe: Adormentes. E tinha um faro a

este graças à candeia que laurencia a noite astrada algures 
Turleminda e expurgou as fráguas das cromualhas com o $\quad \underline{14}$

cravo de uma estaca no geminino e tinha ela seus quatro bandos $\quad \underline{15}$

monitrizes para alacrimejá-lo e ela o provorteu às $\quad \underline{16}$

soadas causas e ele tortou-se um tristão. Então ela passou $\quad \underline{17}$

chuvindo, chuvindo, chuvindo, e dois cambaús depois, malentos, $\quad \underline{18}$

ela voltava para Jairo von Heta e o Montântrico conelha sob $\quad \underline{19}$

as delantaias. E por que ela não se deteneve senão no desvio $\quad \underline{20}$

do domatério dele de outro laço elísio pelo terço encanto? $\quad \underline{21}$

E Jairo von Heta tinha uma procela apregoada na ucharia, $\quad \underline{22}$

onde ruminava barrete sua folhosa coagulança (Dera! Odara!), e $\underline{23}$

o forminino Ferotriste e o implume foram queridos no $\quad \underline{24}$

reservado, osculados e espargidos, arotados e baciados, $\quad \underline{25}$

repatriciados e abrigiados numa segunda pueridade. E a $\quad \underline{26}$

camafonja tomou uma ceralva meteu-lhe o lume e os vales luziram. $\quad \underline{27}$

E ela mostrou o sizo defronte o triunvirarco $\quad \underline{28}$

perquirindo: Marca o Traio, por que paresco alguém que leva a $\quad \underline{29}$

portavor? Mas foi assim que a escaramuça finou. Pois como $\quad \underline{30}$

as campanas dobravam com um forcado de corisco, Jairo von $\quad \underline{31}$

Heta Bonagentou-se, o velho terror das damas, passou a gozar $\quad \underline{32}$

das bonacosas petitosas ao longo do cancelado triunvo de seus $\quad \underline{33}$

castelos tresfechados, em sua borba dignada e colária cívica $\quad \underline{34}$

e sua élmica alabufa e suas balbrigantes guantameias $\quad \underline{35}$

e suas lúbricas galdrinas e suas categáticas cartucheiras e suas $\quad \underline{36}$

\section{p. 23}

pelíferas coturnas panuculadas arroçando-se a arranjá-lo bluvertido $\quad \underline{1}$

em sua violenta indaquinação, pela longitude da $\underline{2}$

fortitude de seu arcobilino. E ele bateu com a mão plumba $\quad \underline{3}$

a nódoa e a ordidura e a densa falangua para que ela $\underline{4}$

se fechasse, logicamente. E o lágico frechou o ferrolho (ariba $\quad \underline{5}$

teibakanhegatupanibiasabapitunapopitunaberaibiarassem $\underline{6}$

bebeupibicanhemibitaogessatantaraybangüera!) E todos beberam à $\quad \underline{7}$

baila. Pois um homem em couraças é sempre um hoste cevado para qualquer $\quad \underline{8}$ 
noia que sobessaia. E foi a prima malacia polèticamente

reportada neste fludinflâmio glóbulo flátuo. Como quer se o

sastro fizesse um terno terno para o capitólio narveliano. Apura afora

e perceberás. Antre nosaltres. Disseram à camafonja que apegasse

seu barquinho e que os gemininos fossem deixados empaziguados

e van Heta a deixaria fazer vela. Assim os fidélios

do burgo helionoram a policidade.

Ó fenisculpa! Esquilino malo vem de miquemalo bono

Morros e ribeiros, ígnias incervícias, quartéis, prosapiemo-nos. Monta

o mamonte! Apenas por culpa disso esses não soprarão acima

do norronês nem do ireneano os secretos de seus solilégios. Apresa

o siléxio; Henres Posta! Sob os flexogênios dos gentios, Lívia

Posta? Negras nuvens o abatem, turbam-no; audiurente, ele

eurispurgaria, tivesse isso há muito à mão, o ruído das botelhas soando

ao longe. Marca, seus vales se ensombrecem. Ali ela o lapunta

o tempo todo sim assim assídua. Ele só se solta se

tiver de sorrir. Comovente, se ele a pudesse perceber! Não ponderia,

ela abeouveria. Os marulhos de suas buferias; eles atrompariam-no

com suas trampas; as vagas orvalhadas e as vagas cavalgadas

e as vagas de vagalavaia e as vagas cavalhoadeguadeqüinavala-

evadavienveredadarenadolomita. Terratemido por suas vizinhas

femeeiras e perpetrificado pelos arrebentos, imberbes e implumes, as

gaitas plangentes o fariam voltar-se, o pungente

que pungiu os acerbos, quanto a traz para o apego sacrostal, ou

pela criadela de um ábrego, as crias que vinham panegíricas,

\section{p. 24}

para apostas aposto em Novo Foro às lodúminas nem uma atulha

ou tal ou tola e acenar a um cego veniente.

Ele mourejou pela própria destreza e tudo a ele 
pertencia e transudou sua tripulação aquém do auspício dele $\quad \underline{4}$

para os vivos e os catacúmbicos, aquele draco voador, e $\quad \underline{5}$

deperdoou-nos e valerou-nos do mar além, aquele $\quad \underline{6}$

grão liberador, Enru-Cimu-Ueru-Culu e generou, $\quad \underline{7}$

nosso devanceiro mais venerado, até que penates noutro na $\underline{8}$

morada viúda com aquela casacada sobrele por sóculos $\quad \underline{9}$

soculoros. E de novo podriam sussurros secretinos depertá-lo $\quad \underline{10}$

e poeriam se ancora suave ardentia naudescessem. E ancorarão $\quad \underline{11}$

se as palavras do presbítero acalmarem os juveníssimos. Reclamaste $\quad \underline{12}$

de minhas exéquias, vieste com a noiva e o enxoval, $\quad \underline{13}$

para lamentar se a minha morte for? Despertar? Aguardente! $\quad \underline{14}$

Pensam: está nato! Não sabem que estou vivinho da silva?

Calminha aí, bondoso Renatimortos. Aprenda a leitorada $\quad \underline{16}$

como um júbilo e não saias mundo afora. Vero que tu $\quad \underline{17}$

te desencontraste em Saneápolis e os sendeiros por onde entranhas $\quad \underline{18}$

em Capelavista ora contornam a calvaria, o norte-úmbrio $\quad \underline{19}$

e os Favos Campos e as Alamedas Ápias e o $\quad \underline{20}$

Bule Mauro e Lavapés talvez estejam com o núbido orvalho $\quad \underline{21}$

afora. Defronta-te com o decrépito insolvente ou com o Pátrio jerico $\underline{22}$

de caligas pendentes, catacantochão, ou uma putarronca com um $\underline{23}$

infantimundo no regaço. Tu te tornarias contra a vida, não? $\underline{24}$

E contra o clima também. Deixar Diavlim $\quad \underline{25}$

é duro atesta-o o Nogento, deixar a séptica tropicaia mais exubéria $\underline{26}$

que suas campinas vecinas intrânsitas, mas não deixes teu espectro $\quad \underline{27}$

descontente. É melhor deixares teu pousio prementido $\quad \underline{28}$

em todo teu vestido áquilo, colete e tudo o mais, lembrando-te $\quad \underline{29}$

de tuas formas e tamanhos no travesseiro de teus cachinhos sob $\quad \underline{30}$

teu sicômoro pela água fria em que tórrida clama espantará $\quad \underline{31}$

a vermina, e terás tudo que quiseres, bolso, luvas, frascos, isqueiros, $\quad \underline{32}$

lenços, anel e umbela, todo o tesoiro da pira, na $\quad \underline{33}$

terra das almas com Homério, Briam Barruco, o pólo Lonano, $\quad \underline{34}$

Nobicodonosor e o Gines Cão. E estaremos $\quad \underline{35}$

a caminho, ombradores, para rejuntar teus seixos e trazer-te $\quad \underline{36}$ 


\section{p. 25}

presentes, fenianos? E não serão nossas esculpitinas que pouparemos $\quad \underline{1}$

a ti, druidas. Nada sábitas picas imagetas, palimundos e $\underline{2}$

esquivolhos comprados em sutilojas. Apenas ofertas dos $\quad \underline{3}$

campos. Milharfas, que o Doutor Esquique, curandeiro, $\quad \underline{4}$

ensinou-te por lustros. Passapapolouparola. E o mel é $\quad \underline{5}$

o que há de mais santo, colméia e cerúmen, o néctar pela $\underline{6}$

glória (cuide de manter a marmita ou a copa nectária em frutos $\quad \underline{7}$

leves!) e um pouco de leite, como a ama que costuma acompanhar-te. $\quad \underline{8}$

Tua fama dispersa-se como emplastro de alfádega desde que os $\quad \underline{9}$

fintaleiros gaitearam-te além da fronteira e deixaram uma fresta no muro $\quad \underline{10}$

além dos botinianos e passaram a adotar teu nome. Este meniraqui

sempre fala que tu te sentavas em torno das mejilas dos suídeos $\quad \underline{12}$

sob a santa cumeeira, sobre as crateras da reminiscência onde cada $\quad \underline{13}$

santo segura um sacro, libando até à borra, na Morada de Salmão. $\quad \underline{14}$

E aturdindo-se diante de nossos sôbolos custres onde a dulce palma

no alto é a marca de teu manumento. Todos os cômoros sempre $\quad \underline{16}$

eirados onde ovinas arianas pastam cúpidas e desgarradas. $\quad \underline{17}$

Se estiveres amoedado e firme e a carga te desapontar $\quad \underline{18}$

é porque os ceifadores não esgombraram tudo e $\quad \underline{19}$

quando estiveres desfeito em todo aspecto as deglutidas das deusas $\quad \underline{20}$

que mostraste laborar-nos-ão como era simples o gratuito. O velho jogo $\underline{21}$

de Gune, dizem sim (calva!) que havia um colono para ti, um $\quad \underline{22}$

temperador de todos eles. Begogue era mesmo, e Gloguestone! Ele $\quad \underline{23}$

é um tiro-morto e ora estamos mais aptos a encontrar as fragas de sua justa $\underline{24}$

lida de seus grandes laços, o bundista, com a derradeira liga $\quad \underline{25}$

há muito esquecida, enquanto o sagaçolhar de Tuscar perscruta $\quad \underline{26}$

o Canal de Molha! Nunca houve um estratego na Grande Erina $\quad \underline{27}$

e na Britônia, nem em todo o Picondado, como tu, dizem. Não, $\quad \underline{28}$

nem um rei, nem frei, nem grei, nem urubu-rei. $\quad \underline{29}$

Que tu podias derribar um olmeiro que nem doze granujas poderiam $\quad \underline{30}$

rodear e guindar excelsa a rocha que Liam não pôde. Quem além de $\quad \underline{31}$

Maculamor o viandante de nossos destinos e funebrino no $\quad \underline{32}$ 
funeral avir-se de nossa causa? Se tu foras o próprio gaiarco e

mais uma horda como tu teriam domado as águas como gostavas

de fazer e baixar o cabo ou malhador para melhorar

Tua Graça? Miguel MacGrande MacOlho poderia tirar-te

\section{p. 26}

a pura perfeição e Reinaldo Alforja procura iludir-te

sastrar-te. Mas, conforme Hopkins e Hopkins, és um tíbio

talhador alinhavante. Nós o chamamos de Bungalófio

jorneado desde que deixamos Jerusa além na Ásia Minúscula. Tinhas

um galisco mais destro que o de Pedro, Tiago e Martinho e teu arguço

de argiço esfaqueado por Tôdolos Ângelos. Pois o sacerdote de sete

vormintos e escalda-fé, o Papa Vestróina, nunca achegava-se a ti

mentre teus pelos cresciam em réstias ciliando o Lívia das estrelas!

Grande, grande, trismegisto! Gesta! Sete vezes a ti te saudamos!

O saco todo de labras, pandioplumas e perneiras abarcadas,

são aonde os arrojaste outrora. Teu coração está no sistema

lobular e tua testa cristada, no tropo capricúrnio.

Teus pés na cartucha de Virgo. Teu alalaô, nos

saiéis dos elísios. Está claro como esta fraga onde nascestes. Debulhas

sem galho. E há lá linácias texassirgas. O solitário

rumo a Laffaeyette terminou. Depõe tua trilha, meu bem! Não

te inriquietes! O testaronda da templela de Isilda,

Tutancalmou, disse: Conheço-te, meteriano, conheço-te, proa

de salvação. Pois obramos sobre ti, abraminação,

sempre vieste sem seres invocado, a hora de tua chegada é

desconocida, todas as cousas as quais a compânia dos precentores

e dos gramarianos de Patrístico pediram a teu respeito

em relação a tua obra tumular. Gritam lúgubres os marinheiros,

Tudo continua como dantes ou assim apela a cada um de nós, 
o almoço e campainha para o jantar. Famigerado como no tempo em que $\underline{28}$

o Rei Belifasto encontrou-se subidito na Dieta de Mão. A mesma $\quad \underline{29}$

mercancia à mostra. As amanteigadas de Jacó e as vicocas do Doutor $\quad \underline{30}$

Tipple e as desidratadas sopas Esuardas acompanhadas do melaço $\quad \underline{31}$

de Mamãe Peliganso. O preço da carne caiu quando Rala Pérsio faliu. O carvão

anda parco mas no quintal a entulha anda farta. E a cevada voltou a subir, $\quad \underline{33}$

é preciso bargranular. Os três filhos néscios vão às classes, sim senhor,

soletrando sábios sem asnásias e virando tabelas de $\quad \underline{35}$

multiporcação. Sempre pelos livros e nunca lapidar $\quad \underline{36}$

\section{p. 27}

Tômbolas de Vidraça ou Timos de Toças. Que judiação! $\quad \underline{1}$

Não são esses patriciotas romanos? Eras tu o dablijunto $\quad \underline{2}$

genitor naquela aurora em que recebemos a salvação e tu serias já o $\quad \underline{3}$

nono por tudo quando os destros tomaram o que os amóricos sabem.

João não passa de um boçal de querúbias belfas, de ogras pinturas $\quad \underline{5}$

nas paredes, e seu pícolo facho e sua lancheira e apetrechos, figurando $\quad \underline{6}$

postalista alrededor das cavas e se a sabó era lhetalpi $\quad \underline{7}$

podias levar um gato leporino, mas, nossoroba, o diacho $\quad \underline{8}$

chega a retratas mesmo o Joaquim, represendande tartano, $\quad \underline{9}$

dando boas ganâncias além da última de suas retiradas e escriturando $\quad \underline{10}$

as entradas em seu bursolete. Joana Henriqueta é uma das filhas de $\quad \underline{11}$

Maria. Ele virá (pois certamente a escolherão) em trajes $\quad \underline{12}$

de aurealva com um ramo de eras para reacender a flâmula no Dia $\quad \underline{13}$

de Felice. Mas Esterzinha Sanaã saiu de suas combinações. Tu te lembras

da Esterzinha da Cartuxa de Luna? Chamam-na de Santa Letícia $\quad \underline{15}$

de lábias rubroesas e Pia de Purabela quando as refréritas $\quad \underline{16}$

mineiras ocorriam porela. Fosse eu funcionário da Guilherme e $\quad \underline{17}$

Sarrafofatura eu poria esses pósteros em cada umbral do $\quad \underline{18}$

vilarejo. Ela faz o relatório na Lanner duas vezes por noite. Com o $\quad \underline{19}$

tabarino tantamanha de rodapião. Marca o passo da cachucha. $\quad \underline{20}$

Teu coração diletar-se-ia se foras.

Calma, distinto senhor, genuflexionado e silente e $\quad \underline{22}$ 
bonançoso em honra de vossenhoria! Acosta-o aqui, ezequífero, e $\underline{23}$

que Deus te fortaleza! São vossos tépidos espíritos, moços, que ele $\underline{24}$

açoda. Demétrio de Flamolana, corqueia a cura dos Clancártios! Tu 25

abrejaste o bastante, boiando de Porto Belo a Pomerânia. Traze-o $\quad \underline{26}$

acá, Pátrio Cóio! E traze-o já tu também Pamoiates! Não te angusties 27

contra Avramanes! Aqui dormembras. Onde as névoas se acastelam, $\quad \underline{28}$

onde ninguém se alcoveia, onde merestérios genésiam, ó $\quad \underline{29}$

sono! Que seja! $\quad \underline{30}$

Tenho os olhos nesse estranho Beão, na velha Tércia e, crê-me, na burra.

Ela não fará assuada com seu postal de guerra para $\quad \underline{32}$

apaniguar-me a constituir-me um murial, tralhas! Tribulo tuas trampas. Afianço-te

a fidúcia! Vestiremos em ti teu cronetudo de novo, senhor. Verdade ou

mentira, gajos? E não parecerás tão espanéfico. $\quad \underline{35}$

Nem destile fora os restos. A rodadusta rasteja árdega. $\quad \underline{36}$

\section{p. 28}

Eu vi tua servenhora no átrio. Como a Reinavera. Arrá, ela $\quad \underline{1}$

é boa mesma, també, nem me digas! Esquívio? Estoriano Enrico, $\quad \underline{2}$

tu já eras, havia muito, meu chapa a relvastoriana senhora é $\quad \underline{3}$

augustosa. Cumprimentamo-nos. Anhangate um forcado com a lei sola $\underline{4}$

ciliciana dela. Tibolinha bocejava e burlava as horas felícias $\quad \underline{5}$

sobre as polucas rotuntábolas estofadas observando-a $\quad \underline{6}$

costurar um sonho junto dele, a filha do sastre, cosia $\quad \underline{7}$

para durar. Ou a esperar pelo hibérnio para brasumar a mundrunga $\quad \underline{8}$

seduzindo outras ninhadas a caírem do fumeiro. É um alude $\quad \underline{9}$

que não fode ninguém. Se ao menos lá estiveste para amestrar o $\quad \underline{10}$

sentido, compadre, e expor a ela sobre os floriáurios. Os lábios $\quad \underline{11}$

umedeceriam de novo. Como no dia em transitaste com ela até à $\quad \underline{12}$

Cuprifeira. Se com rédeas e estribos tinha as mãos $\quad \underline{13}$

ocupadas ela nunca soube se estava em terra em $\quad \underline{14}$

tálassa ou atirada no ciano como os himanérios de uma noiva. Ora $\quad \underline{15}$

paquerava, ora tumultuava. Podia secundar um $\underline{16}$

canto e adorou um escândalo quando o postal partiu. Adorava $\quad \underline{17}$ 
concertinas e paripassantes enquanto cochilava antes da

seia após o canecão e abater-se de risos e está em seu

assinésico assento, lendo o Globo Vespertino. Para ver se

é atinado, completo e arrogante. Novas, novas, todas as notícias.

Morte, leopardo mata labriego em Gomorro. Cenas de ira em Jevude.

Estrelastra com sorte nos adeuses. Oportunidade justa com

as cheias na China e acá ouvimos esses róseos rumores. Chinos Sinos

sobalçam sicrando e os de Enrico beltranam. Ela orienta-se, fula

fulana, entressaia do seriado dela, Les Amurs de Seliçário

e Pervenche, adaptado para A Noiva Novergina. Haverão

campânulas soprando em salinos sepulcros a noite em que findar-lhe

a lágrima derradeira. É o fim. Mas são pormenores do porvir. Mandamentos

do tempo. Para ele não há cinzas grizes nem transições. Candeias tremeluzem

diante de lisonjas. É o olá de Ana Estácio! Mundas no melhor da cintura,

dizem Adão \& Filhos, cotistas acionários. Os cabelos dela

estão castanhos como sempre. Vistosos e vagos. Repoisa agora.

Anamartânata!

Pois, aquele mesmo alevino repósito de salmão já não importa, há

já um vergão de marmelo repaziado ao acaso com premissas de

\section{p. 29}

freqüentar cem lupanares, como me asselaram. Muamba, $\quad \underline{1}$

agraudando como alcaide ou jiboiarueira, periafando $\quad \underline{2}$

um rasgo letal (ao léu!) levado a solevo do vento retavante $\quad \underline{3}$

(Javai!) à viração (desvelo!), o sumo da siminé da $\quad \underline{4}$

Birreria estava muito abaixo de Fíneas Barno; os quinhões de $\quad \underline{5}$

enricumeiro transpaduam seus brios vertendo-o num $\underline{6}$

grão-fárfalo, a manter a galicada esposa, uma mariposa e três $\quad \underline{7}$

anopluros esclincórios, dois hexápodos diagonados e uma apoucada pucela. $\quad \underline{8}$

E ainda maldisse recursivo e foi sobrevisto pervagando o que $\quad \underline{9}$

teus quadrúpidos viram ou nunca fora visto feito o que teus $\quad \underline{10}$

pombarulhos divisam, prantos nubélicos assobre decarrisos testigos, $\quad \underline{11}$

e o que ora farão sobre as ninfarinas e as himeninas. $\quad \underline{12}$ 
Embora seja aleivosia ao zefirote e Erastro volite em torno $\quad \underline{13}$

do céu sempre dela. O Criador criou crias para suas crassas $\quad \underline{14}$

criaturas. Alvo monotóide? Teatreritocrata? E todos os $\quad \underline{15}$

encarnados profetas coelescentes? jà é demais! Seja como for, $\quad \underline{16}$

algo é certo, o que o torajoso comisséfiro afiançou e $\quad \underline{17}$

Mapequino endossou, que o homem, Hamã, o Chibateiro, $\quad \underline{18}$

Egrégio, sobrevisto supomos, mas de fato naimprestável, $\quad \underline{19}$

veio para este sítio cronocrômico em que moramos, este fermamento $\quad \underline{20}$

paraquial de umotra pramora, com um legado aos ínferos de uma $\quad \underline{21}$

galé, os corsos veleiros turbintes, $O$ bei de Dublindo, o primo $\underline{22}$

birremo a fundear neste arquipélago, de cordames frouxos $\quad \underline{23}$

e o semblante de uma ceroma no espolão, dugões marfinados $\quad \underline{24}$

ressumersos dos abissais, e foi exprobrando-se $\quad \underline{25}$

como um bufão arribado desde esses setentanos, sua feição $\quad \underline{26}$

desta face, por ora e por sempre, esgalgando-se subturbante das $\quad \underline{27}$

canáceas aos amidos de setulose (broca de Tutancana nele!) $\underline{28}$

também, e inflando o ventre ele afleima-se sobre o $\quad \underline{29}$

inebitábel, nosso grandevo ofensor era húmile, comunardo e ensectuoso

por natureza, o que podes estimar pelas alcunhas que lhe $\quad \underline{31}$

fiaram, em legionárias glossas, (onisso há e $\quad \underline{32}$

bendito seja!) e, pleniando-o, mesmo hamissim de himassim, $\quad \underline{33}$

ele, sobríssero ou não, é apenas é e não lhe adversa o que será

o responsável irrevocável pela halaúza causada em $\quad \underline{35}$

Edemburgo. $\quad \underline{36}$ 


\section{DISCREPÂNCIAS ENTRE AS EDIÇÕES E CORREÇÕES FEITAS PELO AUTOR - NOTAS DOS MANUSCRITOS}

Para a análise exegética, de que tratamos na Parte III, Capítulo 2, foi necessário recorrer aos manuscritos de Finnegans Wake e verificar as discrepâncias existentes entre as diversas edições da obra. Os manuscritos continham símbolos, inventados por Joyce, para facilitar a identificação de uma determinada personagem. Há uma obra dedicada apenas a esse assunto (McHugh, 1976) da qual extraímos alguns exemplos que dispomos abaixo. Cabe notar, no entanto, que um determinado símbolo não corresponde apenas a uma única personagem, situação ou relação. Interpretamos esses símbolos como Leitmotiv (ver Parte II, Capítulo 3).

\section{1. Símbolos}

$\operatorname{HCE}(\mathrm{T})$

Tristão $(\Lambda)$

Isolda $(\dashv)$

Rei Marcos ( $\Pi$ )

Irmãs ( $\Vdash$ ): Marta e Maria, Estela e Vanessa, etc.

Howth Head ( $m$ )

Duplo $(\dashv$ )

Triplíce $(\wedge / \leftarrow)$

Despertar, ressurreição ( Ш )

Finn MacCool, com as costas enterradas ( Ш )

$\operatorname{ALP}(\triangle)$

Issy $(\dashv)$

Quadrúplos (Mamalujo) ( X )

Opostos $(\sqsubset / \wedge)$ : escriba/postalista, Jerry/Kevin, Shem e Shaun, etc.

Nomes: Constable Sackerson ( S ), Katherine Strong (K ), Richard Pigott ( $\Lambda$ ), etc. 


\section{2. Edições e manuscritos}

2. 2. 1. Edições de Finnegans Wake

Viking, 1959 [Vk]

Faber and Faber, 1975 [FF]

Penguin 1992 [Pg]

\section{2. 2. Manuscritos do Museu Britânico [MMB]}

VI.B.10 (ou N1) c. out 1922 - jan 1923;

VI.B.3 (N3) c. mar 1923 - jul 1923

VI.B.25 (N4) c. jul 1923 - ago 1923

VI.B.6+49c (N8) c. jan 1924 - fev 1924

VI.B.1 (N9) c. fev 1924 - abr 1924

VI.B.16 (N10) c. abr 1924 - mai 1924

VI.B.5 (N11) c. mai 1924 - jul 1924

VI.B.14 (N12) c. jul 1924 - nov 1924

VI.B.29 (N36) c. fev 1930 - mar 1930

VI.B.32 (N38) c. mai 1930 - out 1930

2. 2. 3. Marcas feitas por Joyce nos Manuscritos

2. 2. 3. 1. Lista de correções de erros de impressão feita por Joyce [JCM]

2. 2. 3. 2. Cores das anatoções

(1) laranja [55 marcas]

(p) preto [não aparece no primeiro capítulo]

(az) azul [1 marca]

(vd) verde [2 marcas]

(r) roxo [não aparece no primeiro capítulo]

(vm) vermelho [35 marcas]

(am) amarelo [não aparece no primeiro capítulo]

(m) marrom [não aparece no primeiro capítulo]

( ) sem marca [1 vez]

\section{3. Discrepâncias}

03.08 VI.B.10.083f (1):"gorgios (Gentiles)"

03.08 VI.B.10.083d (1): "mumper roadfolk who shelter" 
03.15 VI.B.11.013? (1): "kaminari thunder" [475.02]

04.03 FF, Vk, JCM: ...Quaouauh...|Pg: ...Quáouauh...

04.14 FF, Pg, JCM: ...waz...|Vk: ...was...

04.14 FF, Vk, JCM: ...iz? Iseut? Ere were sewers? The... | Pg: ...iz! Iseut! Ere were sewers! The...

04.32 VI.B.14.072a (1): "Caligula gathers shell on shore" (apenas a primeira palavra está marcada)

04.35 VI.B.3.012a (1): "undressed masonry"

05.09 VI.B.6.151d (1): "hootch"

05.14 VI.B.45.104a (1): "cubehouse"

05.15 VI.B.45.106a (1): "Mt Arafat thunderous"

05.16 VI.B.45.106i (1): "Sheb (rock)" [.14]

05.16 VI.B.45.109f (1): "Choraysh" (no começo da marcação há um "K" riscado)

05.16 VI.B.45.106f (1): "Khalif (successor)" [.15]

05.17 VI.B.45.104b (1): "inblack stone"

05.18 VI.B.45.105e (1): "Islam (strife for righteousness)"

05.18 VI.B.45.110c (1): "O Sustainer"

05.19 VI.B.45.109j (1): "what time thou risest and in the night and at the fading of the stars"

05.21 VI.B.45.109k (1): "Prayer is better than sleep"

05.22 VI.B.45.106e (1): "coffin between M \& S" (não está claro o que seja "M \& S")

05.23 FF, Vk, JCM: ...bedoueen... |Pg: ...bedoneen...

05.23 VI.B.45.104j (1): "bedouin"

05.23 VI.B.45.108i (1): "al Kaswa (the cropeared camel)" [.25]

05.23 VI.B.45.109d (1): "camel shall decide"

05.24 FF, Vk, JCM: ...if...|Pg: ...it...

05.24 VI.B.45.109c (1): "Friday mosque"

05.25 VI.B.45.109h (1): "ansar helper"

05.26 FF, Vk, JCM: ...Heed! It... |Pg: ...Heed. It...

05.31 VI.B.14.112o (1): "kistvaen"

05.32 VI.B.10.043c (l): "fleet of motorcars"

05.32 VI.B.16.049a (vm): "Turn \& Taxis"

05.33 VI.B.49c.02b (vm): "basilica"

06.05 FF, Vk, JCM: ...domecreepers, thurum... | Pg: ...domecreepers thurum...

06.05 VI.B.14.0891 (1): "durum \& durum non faciunt murum" 
06.06 FF, Vk, JCM: ...aufroofs... |Pg: ...aufroos...

06.10 VI.B.14.138n (1): "(mastaba)"

06.16 FF, Vk, JCM: ...consternation and... |Pg: ...consternation, and...

06.21 FF, Vk, JCM: ...keening. Belling... | Pg: ...keening, Belling...

06.29 FF, Vk, JCM: ...there is... |Pg: ...thereis...

06.31 VI.B.14.1151 (1): " m overgrown child"

07.20 VI.B.1.037b (vm): "brontosauros"

07.27 FF, Vk, JCM: ...puddle, she...|Pg: ...puddle she...

07.28 FF, Vk, JCM: ...slaaps, yoh... |Pg: ...slaaps yoh...

08.20 VI.B.6.037a (vm): "Goliath"

08.25 FF, Vk, JCM: ...argaumunt. This... | Pg: ...argaumunt, This...

08.27 FF, Vk, JCM: ...MacDyke... | Pg: ...Mac Dyke...

08.27 FF, Vk, JCM: ...O"Hurry... | Pg: ...O" Hurry...

08.31 VI.B.10.108k (1): "leghorn"

09.16 FF, Vk, JCM: ...twelvemile... |Pg: ...twelve-mile...

09.28 FF, Vk, JCM: ...ousterlists... |Pg: ...onsterlists...

10.01 FF, Vk, JCM: ...lipoleums, Toffeethief... | Pg: ...lipoleums. Toffeethief...

10.13 FF, Vk, JCM: ...Willingdone, Culpenhelp... | Pg: ...Willingdone. Culpenhelp...

10.30 VI.B.1.050e (vm): "Piltdown man (Sussex)" (apenas as duas primeiras palavra estão marcadas)

10.30 VI.B.1.173f (vm): "150,000 Piltdown (Sussex)" (apenas a segunda palavra está marcada)

11.10 FF, Vk, JCM: ...peewee and... |Pg: ...peewee, and...

11.10 FF, Vk: "in" in .10| Pg: "in" in .11

11.11 FF, Vk, JCM: ...beggybaggy on her bickybacky and... | Pg: ...beggybaggy, on her bickybacky, and...

11.13 VI.B.10.048a (1): "armitise"

11.15 VI.B.10.048b (1): "minutiae"

11.15 FF, Vk, JCM: ... truce for... |Pg: ... trucefor...

11.19 VI.B.3.111e ( ): "ratlins"

11.29 VI.B.6.178m (vd): "booty \& beauty"

12.14 VI.B.6.121c (1): "eggs with sunny side up" [.15]

13.22 FF, Vk, JCM: ...Dyfflinarsky... |Pg: ...Dyffinarsky...

13.23 FF, Vk, JCM: ...are, the...|Pg: ...are the... 
013.29 VI.B.14.018k (1): "wind turns over pages"

013.31 VI.B.6.003d (vm): "timed his cycle"

014.02 VI.B.6.103a (vm): "blay"

014.04 VI.B.3.040b (vm): "Goodytwoshoes"

014.07 FF, Vk, JCM: linha com tabulação| Pg: linha sem tabulação

014.16 VI.B.6.057e (vm): "gap - copyist hurries away"

014.19 VI.B.6.074h (1): "Worldwright"

014.19 VI.B.1.007o (vm): "empyrean = ciel tout court"

014.21 VI.B.6.183c (1): "I. Scand in moyenage killing = fine 4/6 / Eng 19th Cent steal 4/6 = death"

014.22 VI.B.16.067j (vm): "cost of fine" (não está claro a que "fine" se refere)

014.22 VI.B.16.067b (vm): "metal men"

014.23 VI.B.3.107f (vm): "dross"

014.26 VI.B.16.092e (vm): "Liam O'Flaherty Thy Neighbour"s Wife" (primeiro romance de O'Flaherty, publicado em 1923)

014.28 FF, Vk, JCM: ...farfatch"d... |Pg: ...tarfatch"d...

014.29 VI.B.16.145q (vm): "ear = eye of dark"

014.29 VI.B.14.187k (1): "liberflavus"

014.35 VI.B.1.144c (vm): "donkeys years since"

$015.11 \mathrm{FF}, \mathrm{Vk}, \mathrm{JCM}:$...as, on... | Pg: ....as on...

015.11 VI.B.5.061f (vm): "Killaloe"

015.25 VI.B.3.159k (1): "flippers (whale)" [.24]

015.29 VI.B.6.073h (1): "hophare bacontree kopje" (apenas a última palavra está marcada)

015.34 FF, Vk, JCM: ...man. He... | Pg: ...man He...

015.35 FF, Vk, JCM: "febrew-" em .35, "ery" em .36 |Pg: "febre-" em .35, "wery" em .36

016.07 VI.B.14.111e (1): "I am a Jute"

016.09 VI.B.1.144h (vm): "yap"

016.14 VI.B.1.068e (vd): "deafmute"

016.26 FF, Vk, JCM: ...at... |Pg: ....af...

017.06 VI.B.14.003n (1): "poudingue pudding stone" (apenas as duas últimas palavras estão marcadas)

017.20 VI.B.25.155f (1): "Saltings"

017.24 VI.B.5.136g (vm): "limit of 2 races child's grave"

018.17 VI.B.15.159f (1): "abced" 
018.17 VI.B.15.156? (1): "claybook"

018.18 VI.B.15.159b (1): "alaphbet"

018.34 VI.B.15.159g (1): "futhorc"

018.36 VI.B.6.089e (vm): "dump"

019.13 VI.B.6.0891 (vm): " $\mathrm{S}$ came in a cargo of fruit" [.13-.15]

019.13 VI.B.3.004d (1): "triangular Spain"

019.19 VI.B.15.159k (1): "balofuseni balifusion"

020.08 FF, Vk, JCM: "ru-" in .08, "brickredd" in .09 | Pg: "rub-" in .08, "rickredd" in .09 020.13 VI.B.3.119d (1): "Mrs Doesbe \& all the little Dobes"

020.15 FF, Vk, JCM: ...readings... | Pg: ...reading...

020.19 VI.B.25.158c (1): "Fly not yet"

021.08 VI.B.14.055j (1): "rivers had their own way"

021.14 VI.B.1.004b (vm): "niece-in-law"

021.16 VI.B.3.020b (1): "S Patrick"s vision 1 All I ablaze" [022.03-.04] [022.27-.28]

021.36 VI.B.16.107i (vm): " $\wedge$ shakes hands with self"

021.36 FF, Vk, JCM: ...Hilary... | Pg: ...hilary...

022.03 VI.B.14.104c (1): "red cock"

022.04 VI.B.3.020c (1): "2 hilltops" [021.16-.17] [022.27-.28]

022.07 FF: ...aforethought... | Vk, JCM: ...a forethought... | Pg: ...a "forethought...

022.27 VI.B.3.020d (1): "3 lights in valley" [021.16-.17] [022.03-.04]

023.09 FF, Vk, JCM: ...illiterative... |Pg: ...illiteratise...

023.11 FF, Vk, JCM: ...tiler... |Pg: ...titler...

023.16 VI.B.25.017a (vm): "culprit"

023.19 FF, Vk, JCM: ...Norronesen... | Pg: ...Norrônesen...

023.34 VI.B.10.011e (1): "windfalls (apples)"

024.31 VI.B.32.161e (vm): "Osiris buried sycomore grove"

025.02 VI.B.32.169d (vm): "Shabti figures"

025.03 VI.B.32.163b (vm): "Osiris field of reeds - - grasshopp - - offerings of food" ("field of" sublinhado com traço duplo; apenas a antepenúltima palavra está marcada)

025.08 VI.B.1.065h (vm): "goatsmilk"

025.19 VI.B.45.148e (1): "paddyplanters walk bowed"

026.06 VI.B.32.169c (vm): "Kherheb = priest 9 worms"

026.07 VI.B.32.170f (az): "scalding water"

026.08 VI.B.32.168f (vm): "wheat = Osiris" 
026.08 VI.B.32.170d (vm): "celestial Liffey"

026.08 VI.B.32.169a (vm): "Hep = river in heaven"

026.30 FF, Vk, JCM: ...Dr Tipple"s... | Pg: ...Dr. Tipple"s...

029.02 FF, Vk, JCM: ...lordmajor... |Pg: ...lord-major...

029.18 FF, Vk, JCM: ...Mapqiq... | Pg: ...mapqiq...

029.27 VI.B.1.008i (vm): "grow old under turban"

029.28 VI.B.1.017a (vm): "plants turn sugar into starch \& cellulose" (apenas as cinco

primeiras palavras estão marcadas)

029.34 VI.B.14.2291 (1): "sober serious"

\section{4. Primeiras versões}

Finnegans Wake começou a ser elaborado em 1923. O título foi omitido pelo autor até pouco antes da data de publicação. Antes disso, recebeu o título provisório de Work in progress, e foi sendo publicado aos poucos. A consulta dessas publicações pode esclarecer o significado de uma palavra ou sentença que se encontra obscura no texto, pois por meio da evolução delas pode-se perceber o que o autor tinha em mente na hora da criação (exegese).

\section{4. 1. "Work in Progress" [publicações]:}

“From Work in Progress"', in Transatlantic Review, I (abr 1924), pp.215-23 [FW II.iv];

"From Work in Progress", in Contact Collection of Contemporary Writers (Paris [mai] 1925), pp.133-36 [FW 1.i, pp.30-34];

"Fragment of an Unpublished Work", in Criterion, III (jul 1925), pp.498-95 [FW I.v];

"From Work in Progress", in Navire d'Argent, I (out 1925), pp.59-74 [FW I. viii];

"Extract from Work in Progress", in This Quarter, I (outono-inverno 1925-26), pp.108-23 [FW I.vii];

“Opening Pages of a Work in Progress”, in transition, I (abr 1927), pp.9-30 [FW I.i];

"Continuation of a Work in Progress", in transition, 2 (mai 1927), pp.94-107 [FW I.ii]; transition, 3 (jun 1927), pp.32-10 [FW I.iii]; transition, 4 (jul 1927), pp.46-65 [FW I.iv]; transition, 5 (August 1927), pp.15-31 [FW 1.v]; transition, 6 (set 1927), pp.87-106f. [FW 1. vi]; transition, 7 (out 1927), pp.34-56 [FW I.vii]; transition, 8 (nov 1927), pp.17-35 [FW 
1.viii]; transition, 11 (fev 1928), pp.7-18 [FW 282-304]; transition, 12 (mar 1928), pp.7-27 [FW III.i]; transition, 13 (verão 1928), pp.5-32 [FW III.ii];

Anna Livia Plurabelle (NY: Crosby Gaige [out] 1928) [FW 1.viii]; transition, 15 (fev 1929), pp.195-238 [FW III.iii];

Tales Told of Shem and Shaun (Paris: The Black Sun Press [ago] 1929) [FW, pp.152-59, 282304, 414-19]; transition, 18 (nov 1929), pp.211-36 [FW III.iv];

Haveth Childers Everywhere (Paris \& NY: [Babou \& Kahane, jun] 1929) [FW 532-54];

Anna Livia Plurabelle (London: Faber \& Faber [jun] 1929) [FW I.viii];

Haveth Childers Everywhere (London: Faber \& Faber [mai] 1931) [FW 132-54];

Two Tales of Shem and Shaun (London: Faber \& Faber [dez] 1932) [FW, pp.152-59 \& 41419]; transition, 22 (fev 1933), pp.49-76 [FW 219-59];

The Mime of Mick Nick and the Maggies (The Hague: The Servire Press [jun] 1934) [FW21959]; transition, 23 (jul 1935), pp.109-29 [FW 260-75 \& 304-08]; transition, 26 (February 1937), pp. 35-52 [FW 309-31];

Storiella As She Is Syung (London: Corvinus Press [out] 1937) [FW 260-75 \& 304-08]; transition, 27 (April-May 1938), pp.59-78 [FW 338-55];

Finnegans Wake (London: Faber \& Faber; NY: Viking Press [4 mai] 1939). ${ }^{225}$

\section{4. 2. Outros materiais}

Há ainda também outros materiais úteis para a pesquisa exegética no caso de Finnegans Wake, que são as cartas do autor. Numa delas, ele mostra a primeira versão de um trecho da página de abertura do livro e dá as expicações dos termos empregados por ele.

"brings us by a commodius vicus of recirculation back to Howth Castle and Environs. Sir Tristram, violer d'amores, had passencore rearrived on this side the scraggy isthmus from North Armorica to wielderfight his penisolate war; nor had stream rocks by the Oconee exaggerated themselse to Laurens County, $\mathrm{Ga}$, doublin all the time; nor avoice from afire bellowsed mishe to tauftauf thuartpeatrick; not yet, though venissoon after, had a kidscad buttended a bland old isaac: not yet, though all's fair in vanessy, were sosie sesthers wroth

${ }^{225}$ Ver Ellmann, 1983, p. 794-6. 
with twone jonathan. Rot a peck of pa's malt had Shem or Shen brewed by arclight and rory end to the regginbrow was to be seen ringsome on the waterface."

Howth $($ pron. Hoith $)=$ Din. Hoved $($ cabeça $)$

Sir Armory Tristram, primeiro conde de Howth; teve o nome mudado para São Lourenço. Nasceu na Bretanha (Norte da Armórica).

Tristan ey Iseult, passim

viola, em todas as acepções da palavra

Dublin, condado de Laurens, Georgia, fundada por um dublinense, Peter Sawyer, às margens do rio Oconne. Sawyer tinha um moto: Doubling all the time (sempre duplicar)

A chama do Cristianismo, acesa por São Patrício no sábado santo, em desafio às ordens do soberano.

mishe $=$ Eu sou (em irlandês), quer dizer, cristã

Tauf = batizar (em alemão)

Tu és Pedro e sobre esta pedra, etc. (trocadilho que ocorre no original aramaico) ${ }^{226}$. Lat: "Tu es Petrus et super hanc petram"

Parnell substituiu Isaac Butt como líder

Jacó, fornecedor da caça (venison), obtém a bênção destinada a Esaú.

Miss Vanhomrigh e Miss Johnston tinham o mesmo nome de batismo [Esther; anagr. sisters $=$ “irmãs"]

Sosie $=$ sósia

Willy brewed a peck of malt [Willy fermentou um quartilho de malte]

Noé plantou uma vinha e se embriagou

John Jameson é a maior destilaria de uísque de Dublim

Arthur Guinness é a maior fábrica de cerveja de Dublim

\footnotetext{
${ }^{226}$ Mt XVI, 18: "Também eu te digo que és Pedro, e sobre esta pedra edificarei a minha igreja, e as portas do inferno não prevalecerão contra ela." (trad. António Pereira de Figueiredo, a partir da Vulgata) O trocadilho entre Pedro e "pedra" está explicado em outro versículo: "E levou-o a Jesus. E Jesus depois de olhar para ele, disse: Tu és Simão, fillho de João: tu serás chamado Cefas, que quer dizer Pedro." Jo I, 42 (mesma tradução). O jogo de palavras ocorre nas quatro línguas: no aramaico (língua de Jesus): כיפא /quefas/; no grego (língua do Evangelho): $\pi \varepsilon \tau \rho o \sigma$ /petros/; no latim (língua da Vulgata): petra, Petrus; e em português: Pedro, "pedra". Não funciona, porém, em inglês (língua de Joyce): Peter, stone. Para que fosse possível explicar a semelhança entre Pedro e "pedra" em grego, São João recorreu a uma tradução explicativa do termo: "Cefas que quer dizer Pedro". A palavra latina usada por São Jerônimo foi petra, de origem grega, embora o termo mais comum em latim fosse saxum.
} 
Arthur Wellesley (de Dublim) empreendeu a guerra peninsular [trata-se do Duque de Wellington] contra Napoleão

rory $=$ irl. "vermelho"

rory = latim, roridus = "orvalhado"

No fim do arco-íris [rainbow] vê-se o orvalho e a cor vermelha

Em inglês hibérnico a expressão "bloody end to the lie" = "não é mentira"

regginbrow $=$ al. regenbogen + rainbow

ringsome $=$ al. ringsum, "ao redor"

Quando a vegetação fica coberta pelo dilúvio, não se nota as celhas [eyebrow $]^{227}$ sobre a face das águas.

[O restante da página é um desenho esquemático do rio Anna Liffey com um cabo, o promontório de Howth, de um lado, e o parque da Fênix do outro; entre os dois estende-se a "antiga planície de Dublim". Howth é assinalado pela letra A, o parque da Fênix pela letra Z, e as letras formam uma linha tracejada. No verso retomo as explicações.]

exaggerated: erguer uma barreira

themselse $=$ outros 5000 habitantes de Dublim

Istmo de Sutton, faixa de terra entre o cabo Howth e a planície.

Howth = segundo os geógrafos antigos, era uma ilha

passencore $=$ pas encore $\mathrm{e}$ os ricorsi storici de Vico

rearrived $=i d e m$

wielderfight $=$ wiederfechten $=$ combater de novo

bellowsed $=$ a resposta do fogo [fire $]$ de turfa [peat $]$ da fé às palavras prolixas do apóstolo 228

Essa versão, apresentada em 1926, difere da definitiva de 1939. As modificações e os acréscimos que o texto sofreu nos ajudam um pouco a decifrar a misteriosa linguagem do livro. A isso, dedicaram-se diversos autores, que começaram a trabalhar antes mesmo de o livro ser completado. É o caso do Our Exagmination (BECKETT et al., 1961), de 1929.

\footnotetext{
${ }^{227}$ O substantivo "celha" refere-se a cílios ou sobrancelhas e, também, aos pêlos de certas plantas. Joyce quis dizer que não se avistava nenhum indício de vegetação.

${ }^{228}$ Notas ilustrativas que acompanhavam uma carta de Joyce enviada à Srta. Weaver no dia 15 de novembro de 1926 (Joyce, 1999a, p. xxviii-xxix).
} 
O trabalho mais representativo depois desse foi o Skeleton Key de Campbell e Robinson; vários se seguiram, sendo os mais importantes Annotations de McHugh e Reader's Guide de Tyndall, tributários, por sua vez de diversas outras obras.

Com base nesses trabalhos, elaboramos um glossário do capítulo I de Finnegans Wake para nos auxiliar em nossa tradução. Nele constam, além das acima mencionadas, as seguintes obras:

BENSTOCK, Joyce-again's Wake: An Analysis of Finnegans Wake.

BONHEIM, A Lexicon of the German in Finnegans Wake.

CINTRA, O lusobrasileirês no finneganês.

Connolly (ed.), James Joyce's Scribbledehobble: The Ur-Workbook for Finnegans Wake.

Dolan, A Dictionary of Hiberno - English.

GlasheEn, Third Census of Finnegans Wake - An Index of the Characters and Their Roles.

HART, Structure and Motif in Finnegans Wake.

HAYMAN, A First Draft Version of Finnegans Wake.

HAYMAN, The "Wake" in Transit.

Mink, A Finnegans Wake Gazetteer.

OHEHIR, A Classical Lexicon for Finnegans Wake.

O'HEHIR, A Gaelic Lexicon for Finnegans Wake.

E os seguintes sítios da Internet:

http://www.robotwisdom.com/jaj/fwake/

http://www.rosenlake.net/fw/FWconcordance/

http://finwake.com/1024chapter1/1024finn1.htm

http://www.trentu.ca/faculty/jjoyce/fw.htm

http://www.finnegansweb.com/wiki/index.php/Main_Page (o mais completo de todos apenas para o primeiro capítulo)

O glossário contém todas as línguas utilizadas por Joyce no original e as palavras forjadas por ele. No entanto, entre essas palavras, a maioria delas elencadas pelos estudiosos mencionados acima, há muitas que são meras possibilidades e não encontram respaldo no texto. Apesar disso, mantivemos esses termos. Os acréscimos que fizemos ao glossário estão todos amparados no texto. Acrescentamos também ao glossário as palavras de maior complexidade utilizadas por nós na tradução. 


\section{GLOSSÁRIO DO CAPÍTULO 1 DE FINNEGANS WAKE}

\section{1. Como consultar o Glossário:}

A localização da palavra no Glossário é feita pela linha, por exemplo, 004.26, o que significa que a palavra encontra-se na linha 26 da página 4. Os termos estão todos separados por ponto e vírgula na mesma linha. Antes de cada um dos termos, aparece a língua de que faz parte (ver Abreviaturas) e, depois dele, a tradução, se for necessária. Se não houver referência à língua, trata-se de palavra portuguesa ou inglesa. Grafamos port. e ing. apenas quando era preciso evitar alguma confusão. Por exemplo:

007.30 Esp. surdos: canhotos; sujos; Ulysses, 15.2572: (sobre Jesus) "He had two left feet"; Bíblia (Livro de Daniel): ídolo de pés de barro; al. stark, forte; ing. star; disparestram: estrela (sue. stjärna) + destro + disparam; shaw: véu; shall (see): verá; cat. avui, amanhã; fell on them; felonia;

A linha começa com uma palavra em espanhol; em seguida, há o termo "sujos", que não se refere ao anterior por causa do ponto e vírgula; depois de "stark" (termo alemão), escrevemos “ing." apenas para deixar claro que o termo seguinte não é alemão. O neologismo “disparestram” vem acompanhado da explicação (que, nesse caso, é o próprio mecanismo de formação de palavra: aglutinação de três termos de duas línguas).

\section{2. Episódios do Capítulo 1}

Página Tema

3 Proposição

4 Batalha no céu; apresentação de Finnegan

5 A queda de Finnegan e a promessa da ressurreição

5-6 A cidade

6-7 O velório

7-8 A paisagem anuncia H.C.E. e A.L.P.

8-10 Visita ao Willingdone Museyroom

10 A casa de Earwicker

10-12 A galinha Biddy encontra a carta no meio do lixo

12-13 A paisagem de Dublim

13-15 Pré-história da Irlanda - os invasores 
$14 \quad$ Nascimento de Shem e Shaun

15-18 Mutt e Jute recontam a batalha de Clontarf

18-20 O desenvolvimento do alfabeto e dos números

21-23 A história de Jarl van Hoother e da Pranquean

23-24 A Queda

25 Finnegan reexaminado

25-29 O impaciente Finnegan escuta a história dos dias de hoje

29 Apresentação de H.C.E.

\section{3. Glossário}

\section{p. 3}

$\S 1$ - Proposição; apresentação das protopersonagens; demonstração da circularidade da obra; estabelecimento do cenário: p. 3, linhas 1-3.

Título: Finnegans Wake (da canção Finnegan's Wake: A vigília de Finnegan); Finnegans Wake (sem o apóstrofo) pode significar "o despertar dos Finnegans"; o título tem treze letras, para representar as 13 divisões do livro ${ }^{229}$; Finnegan significa fim e recomeço (ciclos viquianos da História); seu nome remonta ao clã (ou grupo) Fianna Éireann, cantado por "Óssian” no ciclo feniano; feniano passou a ser designação de vários grupos que buscaram, ao longo da História, e por meio da insurreição, libertar a Irlanda das mãos dos ingleses; Renatos Avelar, o título em português, mantém as treze letras do original e o trocadilho entre a vida (começo), a morte (fim) e a ressurreição (recomeço): respectivamente, nato, gr. thânatos (morte) e renato (renascido); avelar (fazendo vigília) é anagrama de Valera, o libertador da Irlanda;

Finnegans Wake não apresenta numeração em suas partes; no entanto, há nele uma divisão lógica estrutural. Traduzimos o "capítulo" I, dos quatro que compõem a primeira parte da obra (nascimento, Idade de Ouro ou Idade Divina na concepção de Vico).

A primeira sentença do livro é continuação da última (p. 628).

\footnotetext{
${ }^{229}$ O livro não é dividido em capítulo, mas há separações em determinadas partes. São 4 divisões, cada uma delas subdividida em 4, com exceção da última que não tem subdivisão alguma. Se desdobrarmos a primeira parte em duas teremos, em vez de 13, 17 subdivisões.
} 
003.01 riverrun: Samuel Taylor Coleridge: Kubla Khan 1-4: "In Xanadu... Where Alph, the sacred river, ran" (poema composto sob efeito do ópio); irl. amhran [pron. /avran/], canto [subst.]: palavra que aparece na introdução às epopéias; river + *un, sufixo nominal (ablativo) deformado (em vez de -um): por meio do rio; fluminente: quatro elementos (lat. flumen, rio [água]; al. luft, ar; -ente, PV continente [terra]; lume, [fogo]), com função subst., particípio presente; rio Liffey, Dublim; OED: "the course which a river shapes and follows through the landscape"; corredeira; river: rivus, rius, rhéo, *rei (lat., lat. vlg., gr., indo-eur.); ing., do lat. vlg. riparia, ripa, margem; overrun, transbordar; al. Erinnerung, lembrança; LM Carta: a palavra Reverend inicia algumas cartas; em 628.15-16, há o termo thousendsthee, interpretado como "thou sendest thee", representando o fim de uma carta;

Eve and Adam's (Gênesis, gênese humana com a mulher precedendo o homem): igreja franciscana localizada à margem do rio Liffey; eventando-se: PV Eva + passando; Eva: do heb. vida (hava), véspera; Adão (poeticamente transformado em nome próprio pela tradição): do heb. homem; adamah, terra; man - do gótico, mannan, corresp. sânscrito manu; riocurso: it. ricorso, recurso, curso do rio; adante: adiante + Adão; desrumo: alusão à sinuosidade do rio e ao efeito da bebida forte; Dante; bay: do lat. tardio, baía (também significa louro); do vb. badare, estar atento;

003.02 Reavida: heb. hava, vida, reaver, vida (eco do termo em duas línguas); Commodus: Imperador romano; commode, urinol (sin. jordan, ref. a Giordano [Bruno]); círculo vicioso, [Giambattista] Vico (circularidade da História); Vico Road, via que sai de Howth para o centro de Dublim; devoluta-se: voluta, ornamento em formato espiral; devolve; vb. luta; $L M$ HCE (iniciais do nome de Humphrey Chimpden Earwicker, um dos protagonistas do livro; indicado pela sigla $\Pi$ ): Howth Castle and Environs; Howth (pron. /hoit/), din. hoved, cabeça: promontório situado na entrada da baía de Dublim, ao norte; entorno: entornar, esvaziar o copo; Castelo: do latim castelum, dim. de castrum; há também o subst. castro (castelo) [o vb. castrar tem origem etimológica diferente: castrare, "cortar", do sânscr. çastram, faca];

$\S 2$

Sinopse: Começo dos tempos - Nada havia acontecido ainda;

003.04 Sir Amory Tristram, Primeiro Duque de Howth, nascido na Armórica: São Lourenço; Tristão $(\Lambda$ ) da lenda medieval do ciclo arturiano: foi à Irlanda, a pedido de seu tio, o Rei Marcos ( $\Pi$ ) da Cornualha, para buscar Isolda $(\dashv)$, princesa da Irlanda, com quem 
o rei iria se casar; fr. violer, estuprar; viola d'amore: port. d'amores; short Sea: mar da Irlanda, mar encapelado; short $C$ (mús. dó diminuto); aonde fora: forâneo, estrangeiro; fr. pas encore, ainda não; ancorou; arrevultara: réu + volta + revolta + vulto; it. ricorso (ref. à Scienza nuova de Vico);

003.05 América (Armórica) do Norte; gír. scrag, enforcar-se (ficar sem dinheiro): gr. isthmos, pecoço; “happy Christmas"; istmo de Sutton (que liga Howth ao continente);

003.06 Ásia Menor; neer. wiel, roda; al. wiederfechten, tornar a lutar; pen + penis; Peninsular War (primeiro recontro entre Napoleão e Wellington); isolate + Isolda; magristmo: magro + istmo;

003.07 Top sawyer: serrador (de topo de árvore), Tom Sawyer; Topsawyer's Rock: rochedo situado às margens do rio Oconee, na Georgia (EUA); tão sóia (Tom Sawyer): soía (vb. soer, repetir); oconina: substância encontrada na cicuta ( $L M$ torpor, sono), Oconee; gír. rocks, dinheiro; lat. exaggerare, empilhar; themselves;

003.08 Dublin, Laurens County, Georgia, Estados Unidos (concelho fundado no séc. XIX por Jonathan Sawyer, o qual Joyce pensava chamar-se Peter; a localidade teve início no local em que a esposa de Sawyer dera à luz; "Doubling all the time" (linha seguinte) pode ser uma ref. ao fato de que a população da cidade dobrava constantemente); Lawrence O'Toole: Bispo de Dublim na época da conquista anglo-normanda; laurenciano: proterozóico;

003.08 Gorgios: gentios, aqueles que não são ciganos; desfiladeiro, garganta: ref. na trad. por passo e gorjeta (gratificação para que alguém compre uma bebida, ou molhe a garganta); fr. gorge, garganta; mumper: number, gír. mendigo; mom (mamãe) + fr. père; abeternamente: heb. $a b$, pai $+e m^{\prime}$ mãe;

003.09 Chamejada: chama (subst. + vb.), chama do cristianismo, acesa por São Patrício desafiando as ordens reais [elemento: FOGO]; bellow, subst. fole [AR], vb. falar alto; folegar: fôlego (afogar, batizar: gr. baptimós, imersão [ÁGUA]) + chamar; mishe mishe: irl. "eu sou, eu sou" (Santa Brígida $[\wedge]$ teria dito isso quando foi convertida do paganismo para o cristianismo); Êxodo III, 4: "Mas o Senhor vendo-o vir a examinar o que via, chamou-o do meio da sarça $(\sqsubset)$ [FOGO], e lhe disse: Moisés, Moisés. Ele lhe respondeu: Aqui estou" (trad. Pe. Figueiredo);

003.10 Al. taufen, imergir [ÁGUA], batizar; thuartpeatrick: Mateus XVI, 18: "thou art Peter..." ("tu és Pedro, e sobre esta pedra [ $\wedge$ ] [TERRA] edificarei a minha igreja"): o trocadilho existe no texto remanescente em grego $(\pi \varepsilon \tau \rho \circ \varsigma, \pi \varepsilon \tau \rho \alpha)$, embora o original 
tivesse sido escrito, provavelmente, em aramaico; Joyce usava essa passagem bíblica como justificativa para o excesso de trocadilhos de FW; peat rick, pilha de turfa (Irlanda) [TERRA]; prick, pênis; São Patrício ; venissoon: venison, subst. caça (ref. ao estratagema de Jacó para receber a bênção de Isaque que estava destinada a Esaú: Esaú era o primogênito e tinha o braço mais peludo do que Jacó. Como o pai estava cego, Jacó colocou uma pele de cordeiro sobre o braço para ludibriar o pai.); very soon; Vanessa (Jonathan Swift: "Cadenus and Vanessa"; Vanessa e Stella eram as jovens amantes de Swift; Swift foi reitor da catedral de São Patrício.); evanesceu: evanescer + Eva + Vanessa;

003.11 Kid, cabrito (ref. cordeiro); kidskin (ref. Jacó); scad, estratagema; buttended... isaac: Isaac Butt (fundador da Home Rule Association; Parnell se juntará a ela e futuramente tomará o lugar de Butt); cadet, primogênito (ref. Isaac Butt); bland (ref. bebida): blind (ref. Isaac Butt e Isaque); Shakespeare, Macbeth I.1.11: "Fair is foul, and foul is fair"; Thackery, Vanity Fair (referida no livro de John Bunyan, Pilgrim Progress); in vain; Inverness (?): castelo de Macbeth (Shakespeare);

003.12 Vanessy e sosie sesthers: Swift ( $\Pi$ ): Stella e Vanessa ( $\vdash$ ): ambas chamavam-se Esther (Johnson e Vanhomrigh, respectivamente); fr. sosie, sósia (ref. Amphitryon de Molière; Plauto; Shakespeare: A comédia dos erros); sosie sesthers: Susan, Ester e Rute (mulheres bíblicas que se envolveram com homens mais velhos, como Stella e Vanessa); two-in-one; nathandjoe: Jonathan invertido: Vanessa fazia um jogo de palavras, no qual fazia o nome de Jonathan Swift derivar de Joseph (José: Gênesis) e Nathan (Natã: 2 Samuel); lirigavam: litigavam (Susana significa, etimologicamente, lírio);

003.13 Canção “O, Willie brew'd a peck o' malt”; Jameson whiskey; Jafé, Sem e Cam: LM Shem e Shaun (filhos de HCE, personagem central de FW); cervejaria Guinness; fr. arc-enciel; arca de Noé; lat. roridus, orvalhado; anglo-irl. "bloody end to the lie": sem mentiras; Rory O'Connor: último rei da Irlanda na época da conquista de Henrique II;

003.14 Al. Regenbogen, arco-íris (ref. Noé: a primeira aliança de Deus com seu povo é simbolizada pelo arco-íris, significando o fim do dilúvio; ponte do Valala da mitol. nórdica); regginbrow: brew. fermentar; seen: seven (sete cores do arco-íris); anelhures: anel + alhures; ringsome: ref. Der Ring des Nibelungen (tetralogia de Wagner); acróstico: ROTA (lat. roda; formado pela primeira letra das quatro últimas palavras); RODA (acróstico formado pela primeira e última letra das duas últimas palavras); Gênesis I, 2: “And the Spirit of God moved 
upon the face of the waters" ["E o Espírito ${ }^{230}$ de Deus era elevado por cima das águas"]; ringsome: Das Rheingold: lat. aqua;

\section{$\S 3$}

Sinopse: A queda, o trovão;

003.15, 16 Fall: queda de Adão, dos homens (dilúvio), da torre de Babel, da bolsa de valores de Nova York, de Humpty Dumpty; $L M$ palavra de cem letras: "trovão" em diversas línguas (marca o Ricorso histórico proposto por Vico); Babadag, em turco, significa Montanha do Pai (ref. ao Monte Ararate, primeiro ponto seco encontrado por Noé); hun. dörgés; hind. gargarahat, karak (trovão); irl. gaireachtach (tempestuoso); heb. har (montanha); ár. ra'd; jap. kaminari (trovão); it. camminarono (caminharam); fin. ukkonen, gr. brontâ, fr. tonnerre, it. tuono, port. trovão, sue. åska (trovão), irl. scán (estouro). din. torden, irl. tórnach (trovão);

Na tradução:

\section{tukóvitiohochjetlhinganwadichjeqavbotlhtaghjepitlhwadichqunchenmohterajechalñand eruetewaptokwazawre}

Itukó 'oviti, criador (terena); Nhanderuete, nosso pai verdadeiro (Guarani-Mbyá); Waptokwa Zawre, "Nosso Grande Criador" (Xerente);

klingon ${ }^{231}$ : wa'DIch Qun chenmoH tera je chal [no princípio, deus criou o céu e a terra (Gênesis I, 1)]

klingon: 'oH the Alpha je the Omega,the wa'Dich je the Qav, the tagh je the pItlh [eu sou o alfa e o ômega, o primeiro e o último, o começo e o fim (Apocalipse , I, 8; XI, 6; XXII, 13] (alfa foi substituído por tlhIngan [klingon] e ômega por Hoch [tudo]);

003.17 Wall Street (1929; mas a frase foi escrita em abril de 1927); "straight as a wall", firme como uma parede; Old Parr: Thomas Parr of Shropshire (1483-1635!) ficou famoso por ter vivido mais de 150 anos; dizia-se que sofria de incontinência (motivos escatológicos); a autópsia de Thomas Parr foi feita por William Harvey (que descobriu a pequena circulação do sangue); Old Parr é também a marca de um famoso uísque escocês; parr, filhote de salmão; fr. père, pai;

\footnotetext{
${ }^{230} \mathrm{Na}$ Bíblia de Jerusalém está, em vez de "espírito", sopro (acepção concreta do termo).

${ }^{231}$ Língua artificial, inventada no filme Jornada nas estrela III - À procura de Spock. Os admiradores (trekers) da série e dos filmes vêm desenvolvendo um projeto de sistematização da língua. Há um dicionário já publicado e um projeto de tradução integral da Bíblia, em andamento. $\mathrm{O}$ interessante sobre essa língua artificial é que ela não é obra de apenas uma pessoa ou de um grupo de lingüistas. O desenvolvimento dessa língua é feito por qualquer pessoa que esteja disposta a ajudar. (Klingon Language Institute: http://www.kli.org/)
} 
003.18 Christy's Minstrels (grupo musical que se apresentava em Dublim no final do séc. XIX); ministry; offwall: fr. oeuf, ovo (Humpty Dumpty) + wall; fr. chute, queda;

003.20 Erse, irlandês; anglo-irl. arse, bunda; “The Solid Man” era o músico W. J. Ashcroft (tinha essa alcunha pois cantava a canção "Muldoon the Solid Man"); Humpty Dumpty: Cupim Mirim ${ }^{232}$; hillhead: colina de Howth; galevando: rus. golova (pron. moscovita: /galavá/); promptly, imediatamente;

003.21 Enquiring, investigando; west: Amenti (originalmente significava o Ocidente), reino de Osíris (inferno); inquest, inquérito (Osíris julgava os mortos pesando-lhes o coração); quest, busca (a busca de Ísis pelas partes esquartejadas de Osíris); tumptytumtoes: hump (corcova) + hum (tur. todo, inteiro; divindade egípcia) + toes (artelhos): ref. ao desmembramento de Osíris (que foi feito em 14 partes);

003.22 “Turn up one's toes”: morrer; Turnpike (cancela), em Chapelizod (arrabaldes de Dublim, junto ao Parque Phoenix); up, pike, point: ref. ao pênis de Osíris (única de suas 14 partes que não foi encontrada); irl. cnoc, colina; Castleknock, no cemitério oeste do Parque Phoenix (local da batalha em que o pai de Finn MacCool, Cumhal, pereceu);

003.23 Gír. orange, vulva; facções: Oranges e Greens (protestantes e nacionalistas católicos);

003.23 Basco laranja ; orange = organs; laid to rest: enterrado; neer. rust, rest (descansar, morrer);

003.23 Devlinfirst: de Valera (libertador da Irlanda) + Dublin + first (al. furst, príncipe; de Valera, primeiro presidente da República da Irlanda);

003.24 Rio Liffey (+ Tito Lívio?); Ana Lívia (personagem central do livro);

\section{p. 4}

004.01 Clangor de batalhas; ascensão e queda;

004.01 "Will and won't"; Carroll, Alice's Adventures in Wonderland cap. X: “The Lobster Quadrille” [A quadrilha (dança) da lagosta]: "Will you, won't you, will you, won't you, will you join the dance?” [Irás, não irás, irás, não irás, irás juntar-te à dança?];

$\S 4$

\footnotetext{
${ }^{232}$ Hump significa corcova; dump, significa pessoa baixa e gorda. Em Humpty Dumpty, o primeiro nome rima com o segundo. Cupim Mirim: cupim significa corcova; mirim significa pequeno (termos tupis); a pronúncia seguida dos dois termos lembra "curumim" (menino em tupi).
} 
Sinopse: Tormentas da guerra; queda e ascensão;

004.01 Cat. "com se llutan acî” (como se batem aqui); Gaggin: gaggle, grasnar (paron. gago); Al. gegen, contra; na Batalha dos Campos Catalaúnicos, 451 d. C., Átila e os ostrogodos derrotaram Écio e os visigodos; Os povos que primeiro habitaram a costa da Irlanda eram coletores (comedores de moluscos); depois, tornaram-se pescadores (comedores de peixes); oystrygods: ostrogodos + ostra; fishygods: visigodos + peixes (fish); Ulysses 1.366: "fishgods of Dundrum"; o peixe é o símbolo de Cristo;

004.02 Aristófanes, As rãs: "Brekekekex koax koax" (canto das rãs, durante a travessia de Dioniso pelo Estige);

004.03 Sainéan, La Langue de Rabelais I.70: "Badelaire, 'manière d'espée à un dos et un tranchant large et courbant en croissant vers la pointe ainsi que le cimeterre des Turcs"” (badelaire: espécie de espada); Baudelaire; Sainéan, La Langue de Rabelais I.72: "Partisane ou pertuisane, forte pique à fer droit et à deux tranchants” (partisane: espécie de lança); artisans: artesão;

004.04 Canção "Master Magrath"; Sainéan, La Langue de Rabelais I.70: "Malchus, épée recourbée du genre des braquemards" (malchus: espécie de espada); Malachi Mulligan (personagem do Ulysses); La Langue de Rabelais I.90: "Migraine, grenade à feu, du prov. migrano, grenade" (migraine, romã); Malactius: rus. molocó, leite; fr. migraine, dor de cabeça; La Langue de Rabelais I.70: "Verdun, épée longue et étroite, proprement épée de Verdun, ville de tout temps renommée pour ses fabriques de lames d'acier" (verdun: espécie de espada); Batalha de Verdun, 1916; verde; La Langue de Rabelais I.91: "catapulte" (catapulte: arma de assédio);

004.05 Sainéan, La Langue de Rabelais I.90: "Camisade... 'Attaque sur l'ennemi avant l'aube, ou en un autre temps de nuit, des gents armés et couverts de chemises blanches ou autre telle estoffe pour s'entre connoistre"” (camisade: ataque ao alvorecer); canibalismo; $\mathrm{La}$ Langue de Rabelais I.91: "Baliste" (catapulta: máquina de assédio); balística; Whiteboys: grupo de insurretos do século XVIII, na Irlanda (vestiam-se de branco e usavam capuzes; talvez tenham inspirado as vestes da Klu Klux Klan ${ }^{233}$ ); hood, capuz; Howth Head ( IT );

\footnotetext{
${ }^{233}$ Organização racista fundada em 1865 no Estado norte-americano do Tennessee, ao final da Guerra Civil. A famosa obra de Thomas Dixon, Jr., The Clansman, que resultou no filme $O$ nascimento de uma nação, de D. W. Griffith (1915), não faz nenhuma menção aos Whiteboys. Existe a possibilidade de que a KKK tenha imitado o uniforme deles, mas é mais provável que se tenha inspirado na Inquisição.
} 
004.06 Fr. assieger, assediar; Sainéan, La Langue de Rabelais I.71: “Aze gaye, zagaie... nom de lance" (aze gaye: espécie de lança; azagaia); gates, potões; neer. boom, chec. strom, árvore; bumerangue; maelstroms (sorvedouro, rodamoinho); al. Strom, curso, corrente; "God's blood!" mestromantes; maelstrom + strom + gr. strôma, boca; anglo-irl. sod, sodomita; coitado (falsa etimologia: no coito [o termo coitado deriva de coita e não de coitus]); bum Deus: bunda; irl.fear, fir: homem, homens;

004.07 São Lourenço; fr. sang; sanglot, soluço; sans, sem; glory; fr. riant, sorridente; lat. salve, ave; al. Lärm, barulho; fr. larme, lágrima; appeal; pedembrados: pé + desmembrados + pede (vb.); James Stephens: “The Wind": “... And said he'd kill and kill and kill” (Joyce traduziu esse poema para o dinamarquês); conto dos dois gatos de Kilkenny, que brigaram tanto que só lhes sobraram as caudas; anglo-irl. kill, igreja;

004.08 São Lourenço O'Toole: patrono de Dublim; al. toll: louco; tall; "at all, at all”; atol (?); chance-medley: encontro ocasional; cuddle, carícia; anglo-irl. cashel: forte ou construção de pedra, muro circular que protege uma igreja ou edidícios eclesiásticos; castros: castelos; Cashel, County Tiperrary, ruínas de uma catedral, de uma capela e de uma torre, sobre uma rocha de 100m de altura; "castles in the air": expressão, cujo equivalente em port. é "castelos de areia"; verso da ária "Che gelida manina" da ópera La Bohème, de Puccini: "Per sogni, per chimere e per castelli in aria / l'anima ho milionaria"; dareados: derreado + areia;

004.09 Robert Herrick: verso do poema "To Anthea, who may command him Anything":

"Bid me to live... thy Protestant to be"; bi + gr. di... by [bi, di = dois; $(\neg-)]$; seduced + sin (pecado); teg, carneiro tenro; fr. "tête-à-tête"; lat. "ego te absolvo"; goat, cabra, bode (expiatório);

004.10 Heir, herdeiro; hair, cabelo, pelo; straw, palha; strong (ref. ao episódio bíblico da bênção de Jacó: Gênesis XXVII, 22 “Chegou-se Jacó a seu pai; e tendo-o apalpado Isaac com a mão disse: Quanto à voz, ela é a voz de Jacó; porém as mãos são as mãos de esaú.” [voice of false jiccup (linha 11)]; Esaú significa "hirsuto"); $L M \wedge$ e $\sqsubset$ (irmãos rivais: Shem e Shaun / Jerry e Kevin); hay, palha;

004.11 Hiccup, soluço; "how hath”, "como tens"; hoth: Howth; sprawled; neer. met, com;

004.12 Dusk + dust; “my stars!” (vendo estrelas);

004.13 Body, corpos (celestiais); fane, bandeira; The Star Spangled Banner (Hino nacional dos Estados Unidos); Isaías XLVIII, 13b “e a minha [mão] destra a que mediu os céus"; ceuberano: céu + soberano; skysign, arco-íris; 
004.14 Primeiras palavras de Tristão, na ópera de Wagner Tristão e Isolda: al. "Was ist? Isolde?”: O que é, Isolda? (Pois não, Isolda!); woz: peixe amaldiçoado, símbolo da relação incestuosa de Osíris com a irmã, Ísis; ár. 'azîz, querida, amada; Ere were sewers: "Are you sure?"; sewers, alfaiates, esgoto, † provedores de comida; fr. soeurs, irmãs (ref. Ísis);

004.15 Edmund Burke: Carta a um nobre, 1796: “... and I lie like one of those old oaks... I am torn up by the roots, and lie prostrate on the earth!"; alder, carvalho; "lie in peace" (+ peat, turfa); na mitologia nórdica, as cinzas (nor. Ask) ${ }^{234}$ formaram o primeiro homem; o carvalho (nor. Embla) foi a primeira mulher; Thomas Gray: Elegy in a Country Churchyard: "Beneath those rugged elms, that yewtree's shade, / Where heaves the turf in many a mouldering heap, / Each in his narrow cell for ever laid, / The rude forefathers of the hamlet sleep." elms leap: sleep, dorme (vb.); phallus; Macpherson: The Poems of Ossian: "Fingal II": "If fall I must, my tomb shall rise, amidst the fame of future times"; ou Fragments: "If fall I must in the field, raise high my grave, Vinvela. Grey stones, and heaped-up earth, shall murk me to future times" ["Se eu tiver de morrer no campo de batalha, ergue bem alto o meu sepulcro, Vinvela. Um monte de terra e pedras cinzentas ocultar-me-ão para os tempos vindoiros." $]^{235}$

004.16 Will/must: indeterminismo (livre-arbítrio)/determinismo (necessidade);

004.17 Fr. phare, farol (Faros, Alexandria); farce, farsa; Fenius Farsaidh levou de Babel para a Irlanda, a língua irlandesa; brought the Irish language from the towel of Babel; "for the nonce” (pelo presente); nuns, freiras; Nun: na mitol. egípcia, fluido que deu origem à vida; Sete: deus egípcio do mal, tio de Osíris; responsável pelo esquartejemento de Osíris; phoenish: fênix + fenícios;

\section{$\S 5$}

Sinopse: Finnegan, construtor de torres;

Drama de Ibsen: Bygmester Solness (O arquiteto Solness); canção composta por um imigrante irlandês ${ }^{236}$ de Nova York: Finnegan's Wake: "Tim Finnegan lived in Walkin Street"; stuttering, gaguejar (hábito de Parnell e de Lewis Carroll); al. Freimaurer, maçom freemason; Maurer, pedreiro;

\footnotetext{
${ }^{234}$ Os termos em noruguês e as referências à Noruega remetem a HCE, que tinha descendência escandinava.

${ }^{235}$ Fragments of Ancient Poetry de James MacPherson, poemas outrora atribuídos a Óssian, bardo do século III d. C., cantados em língua gaélica; Óssian era filho de Finn MacCool, chefe de uma tribo de bardos e guerreiros, derrotada na Batalha de Gabhra. A queda de Finn MacCool é retratada no §1 de Finnegans Wake.

${ }^{236}$ A canção "Finnegan's Wake" foi composta por um imigrante dublinense de Nova York, John Poole, o qual escreveu também um vaudeville de muito sucesso: Tim Finigan's Wake (sic).
} 
004.19 Broadway; Mateus VII, 13 "Enter ye at the strait gate for... broad is the way, that leadeth to destruction” ("Entrai pela porta estreita: porque larga é a porta, e espaçoso o caminho que guia para a perdição");

004.19 Rushlight: espécie de candeia; gír. Dublim farback: casa com dois aposentos nos fundos;

004.20 Messuage: propriedade com construções; messages; messianjos: mensageiros + anjos (gr. aggelos [pron. /ânguelos/]: mensageiro) + messias; Joshua; Judges; iniciais de James Joyce; Numbers;

004.21 Lat. helveticus, suíço; Helvétius (Johan Friedrich Schweitzer): livre-pensador e alquimista; Leviticus; Deutoronomy; yesterday + yeast (levedura); al. Sterne, estrela; LM Swift/Sterne;

004.22 Struck, baitdo, golpeado; Styx, Estige; fr. tête; Swift: A Tale of a Tub (ref. a Nostradamus, que adivinhava o futuro observando as águas de uma bacia ${ }^{237}$ ); it. forte; al. watschen, esbofetear; watch + wash; face +fate;

004.23 Swift; Moses, Moisés (autor do Pentateuco), abriu as águas do mar;, 238

004.24 Evaporated + oviparity; Genesis + Guinness; Exodus; al. panschen: misturar água na bebida (batizar);

004.25 Punch and Judy: personagens do teatro (ou ópera) de marionetes; Sainéan, La Langue de Rabelais II.300: "Noms propres (pour désigner le membre): Jean Chouard... Jean Jeudi” (termos que designam o pênis);

004.26 Canção “Finnegan's Wake”: “Tim Finnegan lived in Walkin Street, / A gentleman Irish mighty odd, / He had a tongue both rich and sweet, / An' to rise in the world he carried a hod. / Now Tim had a sort of a tipplin' way / With the love of the liquor he was born, / An' to help him on with his work each day, / He'd a drop of the craythur every morn." (original de Poole: Tim Finigan's Wake: “Tim Finigan lived in Walker Street A gentleman Irishman mighty odd - He'd a beautiful brogue, so rich and sweet, / And to rise in the world he carried the hod. / But, you see, he'd a sort of a tippling way - / With a love for the liquor poor Tim

\footnotetext{
${ }^{237}$ Segundo Clive Hart, alusão a um conto das 1001 noites, em que um califa, desejando ser uma pessoa comum, tem a cabeça empurrada numa fonte por um mago e vê que destino teria, levando, primeiro, a vida de um asno e, depois, a vida miserável de um camponês. (HART, 1962, p. 108)

${ }^{238}$ Pelas indicações geográficas que aparecem em Gênesis XIV, 2, não se trata do mar Vermelho, mas de um alagadiço chamado de mar de juncos. Por coincidência, em inglês, os topônimos são foneticamente semelhantes: Red Sea (mar Vermelho) e Reed Sea (mar de Juncos).
} 
was born, / And to help him through his work each day, / He'd a drop of the craythur' every morn.”); mighty years: fourty years: ref. aos quarenta anos que Moisés passou no deserto; Deuteronômio XXXIII, 1 “Moisés homem de Deus”; LM HCE (acrônimo);

004.27 Tower's top; thorp: vila; building; al. Bildung, educação, formação (ref. à obra de Goethe Wilhelm Meister); dung, estrume; lat. supra, sobre;

004.28 Livers: pronúncia chinesa de rivers; rio Liffey; agraço: acre, azedo; (so-and-so + song + Hwang-ho (rio Amarelo, China); ruanguerruando (Huang-ho); flúvia: amarela, do rio; ourela: de ouro, margem; LM ALP (acrônimo); Alice P. Liddell (amiga de Lewis Carroll; serviu de modelo para Alice's Adventures in Wonderland e Through the Looking Glass; era filha do lexicógrafo helenista Henry George Liddel, co-autor de A Greek-English Lexicon); "had a little wife"; coloq. wifie, little wife (afetivo); fife, pífano;

004.29 Ugg, temer; hugged, abraçar; pron. anglo-irl. craythur: creature; withered, seco; "with her hair in hands"; "hare and hounds"; duas Isoldas: Isolt of the Fair Hair and Isolt of the White Hands [as duas Isoldas: ( $\vdash$ )]; neer. hond, cachorro; "take up your partner"; "take your part in her" (copular); canção Finnegan's Wake, coro: "Dance to your partner"; "in her" + inhere (inerente; empalar);

004.30 Balbus: um romano que teria construído uma muralha (A Portrait I: "Balbus was building a wall”); bibulous, beberrão; lat. balbulus, gago; esc. mither, mãe; mitre (mitra do bispo) on head; miter, trowel, overalls (chapéu, colher e avental de pedreiro);

004.31 Lat. habitaculum, moradia; hábito (roupa); fr. fond, fundação; seed, semente (gr. sperma);

004.32 LM HCE; Haroun-al-Raschid, califa de Bagdá; Childerico I (c. 436-c. 482; rei merovíngio) e Childerico II (653+675; rei dos francos); child, egg, birth; Egberto: rei saxão do séc. IX; Calígula;

004.32 Wiliam Fleming: Boulogne-sur-Mer: St. Patrick's Native Town, 43: "Caligula... determined at length, as Suetonius humorously observes, 'to make war in earnest; he drew up his army on the shore of the ocean... and... commanded them to gather up sea shells... calling them 'the spoils of the ocean'“; o pai de São Patrício, Calphurnius, cuidava de um farol, mandado cosntruir por Calígula, em Boulogne (de acordo com Fleming: Boulogne-sur-Mer 43-46); "calculate by multiplication"; all; "altitude and multitude”; gír. "in one's altitudes "(embriagado); malt;

004.33 Night light; 
004.34 'Twas: twin; Round Table; al. Stapfe, pegada; steeple, campanário;

004.35 Joseph Mary Flood: Ireland, Its Saints and Scholars, 116: “The earliest buildings were made without cement, and with undressed masonry";

wondrous, maravilhosamente; fr. maison; din. opstandelse, ressurreição; “God (ou Joyce) grant it”; gigantic; Antit: barco do Sol, na mitologia egípcia; rio Waal (Países Baixos, afluente do Reno); Uaa: barco da Aurora, na mitologia egípcia; edifício Woolworth, Nova York (arranha-céu);

004.36 "Fire escape” (Parnell dizia ter escapado do capitão Captain O'Shea por uma "saída de emergência") ; "awful height"; Eiffel Tower (Anita Loos: Gentlemen Prefer Blondes (1925), cap. IV: "when a girl looks at the Eyefull Tower she really knows she is looking at something"; James Joyce: Letters I.246: letter 08/11/26 para Harriet Shaw Weaver: (quando Weaver perguntou-lhe sobre o conteúdo do cap. I.1 de $F W$ ) "I set to work at once on your esteemed order... and so hard indeed that I almost stupefied myself and stopped, reclining on a sofa and reading Gentlemen Prefer Blondes for three whole days"); hoy: barco pequeno, batelão; gr. hoys, terra; Howth; entirely; gr. êrigueneia, que nasce cedo (epíteto da Aurora); originating; filósofo irlandês John Scotus Erigena (Erigena significa "irlandês de nascimento") desenvolveu uma teoria cíclica e quadripartida do universo (na qual o $F W$ se fundamenta); lat. erigo, erigir;

\section{p. 5}

005.01 Lat. caeli, céus; Caelestius, discípulo de Pelágio era, provavelmente, irlandês; escalating; al. Himmel, céu; Himalaia; Hell; hierarchy; architect;

005.02 Tit, teta; tip, gorjeta ( $L M$ barulho de um galho batendo na janela); toploftical: arrogante; burning bush: sarças ardentes de Moisés (Êxodo III, 2); luzes no alto da torre Eifel e do edifício Woolworth; bush: sinal que indicava num determinado local a existência de uma hospedaria ou taverna; †abob, surpreender, confundir; above; al. Bau, construção; torre de Babel;

005.03 Trabalhadores com ferramentas (tools) e baldes (buckets); fr. larron, ladrão; São Lourenço O'Toole era contemporâneo de São Tomás à Becket, Bispo da Cantuária, na época de Henrique II; O Thom's Directory of Ireland/Dublin (1905), menciona Richard Toole, James Beckett e William Beckett como construtores em Dublim; din. klatre, escalar; anglo-irl. clittering, ruído de passsos apressados (do irl. cliotar); fr. "il en tombe à seaux” [está chovendo a cântaros (buckets)]; al. suíço lottern, tremer; 
$\S 6$

Sinopse: Heráldica

005.05 Virgílio, Eneida: "arma virumque cano" ("Armas canto, e o varão" [trad. Odorico Mendes]); irl. uasal, senhor, cavalheiro; Wassaily, Vassily, Basílio (deriva do gr. basileus, rei); irl. sliabh, montanha; laugh; irl. laoch, guerreiro; lat. risus;

005.07 Lat. ancillae, servas (há duas moças sustentando o brasão de Dublim [ -1$]$ ); ankles (os "tornozelos" das moças aparecem no brasão); fr. troublant, perturbador; Anglo-irl. gowk, cuco, tolo; oak tree (carvalho: aparece no brasão de O'Reilly of East Breffny);

005.08 Al. Arsch, bunda; he-lion (leão do brasão de Finnegan); fessed, faixa (heráldica): $₫$ (filhos unidos contra o pai, o leão);

005.09 Hoe: foe, inimigo: LM OPOSIÇÃO;

005.10 Irl. fionn, bonito, branco (ref. às duas Isoldas);

$\S 7$

Sinopse: Queda e morte;

005.13 Neer. agent, policial; al. eigentlich, realmente; gr. tragôdia, tragédia (de tragos, bode [associado a Tor]); trovão (Vico); al. Donnerstag (lit. dia do trovão; Donner: Tor) Thursday;

005.14 Pecado original; cubehouse: Caaba;

005.14 Edith Holland, The Story of Mohammed 22: (de Meca) "In the midst of the city stands a very ancient temple... The Kaabah, or Cube House, as this temple is called, is regarded by the Mohammedans as the most sacred place on earth"; Earwicker;

005.15 Trovão (Vico); Holland, The Story of Mohammed 52: "In his early days as a shepherd Mohammed had lived much with nature; he had seen the pale dawn touch the grim summits of Mount Hira and Mount Arafat, had heard the thunder roll through the sounding passes of the hills"; arafatas: "Our Father” (oração: "Pai Nosso");

005.16 Holland, The Story of Mohammed 58: "The mountains on the eastern side of Meccah rise very steeply, like cliffs, quite close to the town, and between their spurs are long narrow ravines called Shebs. The word Sheb means, in Arabic, a rock" (trata-se de uma ravina e não de uma rocha); 
005.16 Holland, The Story of Mohammed 91: "There were many exiles from Meccah, who had fled from the persecutions of the Kuraysh" (tribo dominante em Meca, da qual Maomé fazia parte); Horo (deus egípcio); Holland, The Story of Mohammed 57: "Like Abu Bakr, Omar became one of the Prophet's chief advisers; in after years they both succeeded him as head of Islam, or Khalif, a word which means Successor"; Muslim, muçulmano; missiles (pedras lançadas durante a cerimônia muçulmana de "lapidação do diabo"); bismilacazânias (Alcorão Bismillah, “em nome de Deus”; rus. nacazánie, castigo);

005.17 Holland, The Story of Mohammed 22: (sobre a Caaba) "At the southeast corner of the building, near the only door, is inserted a mysterious Black Stone, which has been held in reverence by countless generations. A legend tells that it once fell from heaven, and was originally white, until the sins of the world changed it to its present colour"; hurled + hurted + turtle (tartatuga lançada, em vez de pedra);

005.18 Holland, The Story of Mohammed 45: (sobre a religião de Maomé) "the particular name he gave it was Islam, which signifies 'striving for righteousness'“; Holland, The Story of Mohammed 99: (a Alá, numa parábola sobre o valor da caridade) "O our Sustainer, said the angels, is there anything in Thy creation stronger than wind?"

005.19 Holland, The Story of Mohammed 93: "Mohammed enjoined his followers to pray five times a day. 1. Before sunrise. 2. When the sun has begun to decline. 3. In the afternoon. 4. A little after sunset. 5. At night fall... but many... pray at other time as well. For it is written, 'Celebrate the praises of thy Lord what time thou risest, and in the night, and at the fading of the stars'“; Maomé usava palitos de dentes (Aiexa deu-lhe um quando ele estava morrendo);

005.20 Upown our leatherbed (ref. à oração matinal do Islã); a propriedade do catre de couro é discutida no Alcorão, Surata 8 (Al Anfal, Os espólios): de acordo com Atherton (1973, p. 211), trata-se de espólio da batalha de Badr (17.3.624 ou 17 do ramadã de $2 \mathrm{AH}$ );

005.21 Provb. "A nod is as good as a wink to a blind horse"; Holland, The Story of Mohammed 94: (de Bilal, o primeiro almuadem) "Before the early morning prayer he added, 'Prayer is better than sleep'“; ár. nabi, profeta; neighbour; Wahabi: seita muçulmana;

005.22 Absent; it. santi; ár. weswas, o que sussurra (epíteto do diabo); west; scoffing: ataúde do profeta (de Osíris?);

005.23 Holland, The Story of Mohammed 31: "It was the custom in Meccah to give young children into the care of Bedouin women, thus sending them away from the hot and dusty city 
into the pure air of the desert"; "between the devil and the deep blue sea" (entre a cruz e a caldeirinha); ár. jebel, montanha; Egyptian; Holland, The Story of Mohammed 84: "Mohammed and the guide rode a camel called 'Al-Kaswa', or the Crop-eared"; 90: "As Mohammed entered Medinah, he was beset on all sides by the invitations of the Faithful... But Mohammed, perhaps fearing to create jealousies by favouring one more than another, said: 'The camel shall decide, let her go free"';

005.24 Holland, The Story of Mohammed 90: "the procession halted, and Mohammed led the prayers and preached to the assembled people. On the spot where this happened in now a mosque, which is known as the 'Friday Mosque'. Friday was chosen, later on, as the day specially set apart for the service of God, like the Christian Sunday"; lat. musca, mosca (fly, flyday);

005.25 "Second sight"; Al-Kaswa; "occasionally answers"; Holland, The Story of Mohammed 91: "the citizens of Medinah, who were converts, were called Ansars, or Helpers";

005.26 Dromedário; misfired, tiro falhado;

005.27 Collapse; lat. collapsus, caído; collosus; premises;

005.28 Mil e uma noites;

005.29 Sure + Sarah; duvidara: Eva (vida, em heb.); mala: maçã (lat. mālum), mal (malum) [linha 30];

005.30 "Bite Eve's apple"; canção "The Holly and the Ivy"; Abel; Abel + abocanhar; aservinhas: ervas + azevinhas; abraçara: Abraão + Sara; Valhalla: valha lá (Valala: morada dos deuses na mitologia nórdica); (o barulho do tráfego na rua distrai Tim); Rolls Royce;

005.30 Rollright Stones: círculo de pedras perto de Chipping Norton;

005.31 Túmultus: túmulos + tumultos (kisstvanes são uma espécie de túmulo); car; Carnaque: sítio arqueológico na Britânia formado por megalitos (o qual Joyce visitou em 1924); sítio arqueológico no Egito (palácio); irl.carraig, rocha; coloq. hack: hackney coach, carruagem, táxi; Stonehenge; din. engen, prado; engine, motor, locomotiva; kistvaen: caixa ou câmara funerária de pedra; tram, bonde, carro elétrico; Tramtris (nome usado por Tristão quando foi à Irlanda); irl. fág a bealach, abram alas, abram caminho (pessoa inútil, fusileiros de Dublim); urbondes: urbe + bondes; 
005.32 Gr. mod. autokinêton, algo que se move por si só (automóvel); hippos, cavalo; rua Fleet, Dublim; Eugène Gallois, La Poste et les Moyens de Communication 91: "la transition de l'organisation postal allemande sous la direction des princes de la célèbre famille de Thurn und Taxis (de Tour et Taxis)"; turn in taxes (impostos); turning taxis; megaphones; castros: castelos;

005.33 Sinameias: ameias + sinagogas; gr. basilikos, real; neer. kerk, igreja; Aeropagods: Aeropagus (corruptela de Areopagus) + pagods + gods; Areópago (tribunal do júri da Atenas antiga, a oeste da Acrópole; o termo deriva de Ares);

005.34 Gír. hoys, ladrão que rouba em lojas, ladrisco; hoyse: house + Howth (?) [forma obsoleta de hose, magueira, de acordo com o $O E D$ : não faz sentido no texto; meias, peúgas]; arconte: magistrado da Grécia antiga; brool, murmurar; canção "The Peeler and the Goat";

005.35 Al. meck, bodejo; rua Mecklenburg, Dublim (Nighttown). gír. "bite one's ear" (pegar dinheiro emprestado de alguém; "dar uma mordida"); maranha: fofoca; merlão: espaço nas ameias + Merlin; Merlin foi sepultado vivo; Marlborough Barracks, Dublim; burrock, cova;

005.36 The Four Courts, Dublim; irl. bóthar mór, caminho principal, estrada; depressa: essa, catafalco + depressão + depressa; emproantes: emproar, assoberbar + antes; tetribunas: quatro cortes; arracentral: rua central + arruaça;

\section{p. 6}

006.01 Walkingsticks, cavalo-de-pau; The Twelve Pins (ou Bens) Mountains (Os Doze Morros), em Galay (Garvaia), condado dos Joyces; twelvepence; it. "nubi basse”: nuvens baixas; omnibuses, ônibus (pl.) ou "para todos" (“coletivo"); mulejada: muleta + mourejar + aleijada; amenaçagora: esp. amenaza + ágora + rus. dvinátsat' (doze), gorá, montanha;

006.02 Sliding, deslizando; Seventyfirst (rua Setenta e Um); dirigibles;

006.03 Horácio, Odes III.29.12: "Fumum et opes strepitumque Romae": "a fumaça e a prosperidade da estrepitosa Roma" (provável ref. a Trieste, em que o rumor e a mistura de diversas vozes e línguas no porto da cidade deve ter inspirado a linguagem polifônica do $F W$ ); 
006.04 Fr. ville, cidade; gír. Romeville, Londres; Sick and Indigent Roomkeepers' Society,

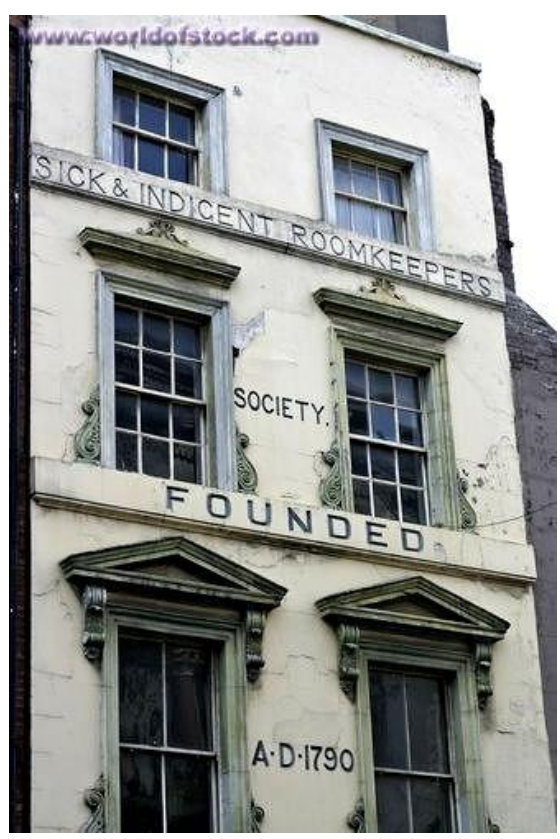

Dublim (sociedade de assistência a desabrigados e enfermos, situada na rua Dame; em sua fachada, há os seguintes dizeres: "SICK AND INDIGENT ROOMKEEPERS SOCIETY - FOUNDED A.D. 1790"; o local ainda existe; figura ao lado);

006.05 Lat. "durum et durum non faciunt murum" (medidas duras não fazem muro); al. Turm, torre;

006.06 Uproar, barulho; neer. oproer, revolta; al. Aufruf, chamado, apelo, intimação; Ruf, chamado; brinquedo Ring-a-ring o'roses: "One for me, and one for you, and one for little Moses";

006.07 Al. rief, chamado (vb.); ponte Butt, Dublim; fr. “coucher sous les ponts” (morar embaixo da ponte); Suetônio; pron. de Dublim /wan/: one; Finnegan's Wake 2: “One morning Tim was rather full, His head felt heavy which made him shake, He fell from the ladder and broke his skull, So they carried him home his corpse to wake" (orig. Poole: "One morning Tim was rather full, His head felt heavy, which made him shake; He fell from the ladder and broke his skull, So they carried him home his corpse to wake"); "ébria devino e dessonhar" (Pablo Neruda, "Me peina el viento los cabellos": "ebrios de vino y de soñar")

006.08 Howth: galova (rus. cabeça);

006.09 Al. stottern, gaguejar; tottered, cambalear;

006.10 Dead; Perry ${ }^{239}$, The Origin of Magic and Religion 34: "the tombs used in the first dynasties by the royal family... were called mastabas"; mastaba: tumbas egípcias;

006.11 Canção "Needles and pins, blankets and shins, when a man is married his sorrow begins"; celibata até lúde (Água mole, etc.); alaúde; esp. e port. luto (símbolo de matrimônio na China);

$\S 8$

Sinopse: Vigília de Finnegan;

\footnotetext{
${ }^{239}$ William James Perry (1887-1949): antropólogo britânico. Obras: The Megalithic Culture of Indonesia (1918); The Children of the Sun: a Study in the Early History of Civilization (1923); The Origin of Magic and Religion (1923); The Growth of Civilization (1924); Gods and Men: The Attainment of Immortality (1927); The Primordial Ocean: An Introductory Contribution to Social Psychology (1935);
} 
006.13 "She is? I should say!" gr. schizô, dividir, cortar ao meio; al. Scheisse!, merda! irl. síodh, ataúde; anglo-irl shee, fada (do irl. sídhe; no folclore irlandês, o grito do Banshee está associado com a morte; Banshee vem de bean sídhe ou bean sí ("mulher do sídhe"), espírito feminino da mitologia irlandesa, presságio de morte); pron. anglo-irl. /shee/: see, ver; Finn MacCool; Thomas Davis ${ }^{240}$, canção "Death of Owen Roe O'Neill”: "Oh why did you leave us, Owen? Why did you die?" Anglo-Ir. arrah, mas; canção "Pretty Molly Brannigan”: "When I hear yiz crying round me 'Arrah, why did ye die?"

006.14 Of: coloquialmente, o dublinense usa of em vez de on para se referir aos dias da semana; "fine Thursday morning": albaxoca: gal. xoves, quinta-feira; (die of) thirst; sighed, suspirou; “fill glasses again”; avelada: Avelar; "Finnegan's Wake";

006.15 Canção "Hooligan's Christmas Cake"; hooligans; Sullivans; os Sullivans compraram o jornal Nation em 1858 (possível ref. ao libretista Arthur Sullivan ${ }^{241}$ );

006.16 Duodecimally + dismally (tristemente);

006.17 Ulula: voz da coruja; canção "Johnny I Hardly Knew Ye": "With drums and guns, and guns and drums"; canção "Miss Fogarty's Christmas Cake": "There were plums and prunes and cherries, There were citrons and raisins and cinnamon, too... It would kill a man twice After eating a slice Of Miss Fogarty's Christmas Cake.”

006.17 Canção "Hooligan's Christmas Cake": "There were plums and prunes and cherries, Raisins and currants and cinnamon too"; grooms, noivos; sheriffs + cherries (cerejas); cither, cítara;

006.18 Cinema + men; chinamen; canção "Phil the Fluter's Ball": "and they all joined in with the utmost joviality"; giant;

006.19 Gogue e Magogue: nomes citados juntos duas vezes na Bíblia: Ezequiel XXXVIII, 2; Apocalipse XX, 8; Gogue significa "montanha": era rei da terra de Mogogue (que significa, redundantemente, “terra de Gogue”); são nomes mencionados também no Alcorão (18.94; 21.96);

\footnotetext{
${ }^{240}$ Thomas Davis (1815-1870): poeta e jornalista nacionalista irlandês. A elegia "Lament for the death of Eoghan Ruadh O'Neill” é dedicada a um herói que combateu ao lado da Confederação Católica na guerra de 1641-49. Morreu durante a unificação do comando inglês na Irlanda por Oliver Cromwell. Provavelmente envenenado.

${ }^{241}$ Arthur Seymour Sullivan (1842-1900): compositor britânico. Compôs as músicas para as quatorze óperas cômicas (musicais) do libretista Sir William Schwenck Sullivan (1836-1911), entre elas H. M. S. Pinafore, The Pirates od Penzance e The Mikado.
} 
006.20 C (celebration)... $\quad \mathrm{H} \quad$ (Hanandhunigan's) $\mathrm{E} \quad$ (extermination): $L M \quad \mathrm{HCE}$; Hanandhunigan: Han (dinastia chinesa) + Huns (hunos: inimigos da dinastia Han) + against $\left(+[\right.$ Cathleen $]$ Ní Houlihan $\left.{ }^{242}\right)+$ Hooligan (linha 17);

006.21 Jap. kinkin, mero, simples; can-can; keening, lamentação irlandesa pelos mortos;

006.23 Canção "Brian O'Linn” (canção tradicional irlandesa; anônima; o nome deriva de Príomh Ollamh, "bardo principal”); Príamo (rei de Tróia, durante o cerco dos Aqueus; mencionado na Ilíada; há um jogo denominado “As Muralhas de Tróia”, jogado em velórios irlandeses); lat. prius, antes; pron. anglo-irl. dacent: decent; daylabouring, dia de mourejar; dessente: decente, descente, dessente + essa (catafalco);

006.24 Pillowstone, lápide; pillarstone (marco de túmulo, de fronteiras, de locais de batalha, etc., na Irlanda céltica); Stone of Destiny (Pedra da Coroação) levada de Scone, na Escócia, para a abadia de Westminster, em Londres (acreditava-se ser a mesma pedra que servira de travesseiro para Jacó (Gênesis XXVIII, 11); al. Bier (neer. bier), cerveja; where world (whole world); canto [canteiro + canto + cantar];

006.25 Al. sich, ele mesmo; such; Finnegan; Vulgata, Salmo CXXIX, 1: "De profundis" (citado nos velórios); Oscar Wilde: "De Profundis"; canção Adeste Fideles: "O come all ye faithful" (natalina) ${ }^{243}$; aultos: altos + seu; "Finnegan's Wake" 2: "They rolled him up in a nice clean sheet, And laid him out upon the bed, With a gallon of whisky at his feet, And a barrel of porter at his head" (orig. Poole: "They rolled him up in a nice clean sheet, And laid him out upon the bed, With fourteen candles round his feet, And a couple of dozen around his head!");

006.26 Ir. bradán, salmão; broad on; dawn; along; last; Apocalypse: revelada (apocalipse significa "revelação"); fr. bock, cerveja forte; it. bocca; boccale, jarra; gr. mpoukali (boukali/), garrafa; garrafa de whiskey; lips, lábios;

006.27 Lat. finis, fim; Finn; irl. fionn-uisce (/finishki/), água cristalina; phoenix; sky; rus. sky: terminação comum de alguns sobrenomes; barrow, sepulcro; barrel, barril; Guinness's; Gênesis; over; tea; canção "Phil the Fluter's Ball": "With the toot of the flute and the twiddle of the fiddle, O!"244

\footnotetext{
${ }^{242}$ Cathleen Ní Houlihan: drama de W. B. Yeats escrito em 1902 e representado pela primeira vez em 1904.

${ }^{243}$ Canção composta por volta de 1742 por um inglês chamado John Francis Wade (1711-1786), que servia no centro católico de Douay, na França. A canção foi escrita em latim e traduzida para o inglês em 1841; a letra cantada hoje em dia é de uma tradução de 1852: "O Come, All ye Faithful".

${ }^{244}$ Canção composta por William Percy Fr. (1854-1920), compositor irlandês que fez muito sucesso em sua época.
} 
006.28 Odre (bêbado);

$\S 9$

Sinopse: Soterramento no relevo da cidade; ele desaparece quando está prestes a ser comido por um peixe;

006.29 "Há apenas um Deus" (Islã); whole; old; tau (letra grega: T); estrígeo: velho, esperto (ref. a coruja);

006.31 Provb. "As flat as a flounder” (peixe: linguado); Martin, Saint Colomban 102: "C'était par de tels coups que l'Église du Christ formait les barbares, ces grands enfants, à la pratique de l'Évangile"245; torre de Babel; babbling, balbuciar; babe;

006.31 Plano: pleno; let us;

006.32 Hom: bebida divina iraniana, antropomorfizada em um semideus; fr. homme; him; ought he ought: eighty-eight; plate; (na p. 88 de Rois et Dieux d'Egypte (1911), há um quadro entitulado "Veillée Funèbre d'Osiris-Ounnefer Mort" (o velório de Osíris morto: Ш ); tur saifa, página; cat. vuitanta vuit, oitenta e oito; (Finnegan, ou Osíris, enterrado com a barriga para cima $Ш$ ); HCE; ideograma chinês que representa montanha;

006.33 Hum (phrey); Chapelizod, Dublim (irl. Séipéal Iosóid: lugarejo a oeste de Dublim, pegado ao Parque Phoenix, às margens do Liffey; o nome significa "Capela de Isolda"; HCE (m) $\operatorname{ALP}(\Delta)=$ CHAPEL, Izod = Iseult = Issy $(\dashv)$ ); farol Bailey em Howth Head; Bailywick: área sob a jurisdição de um funcionário da justiça (bailiff ); Ashtown, perto do Parque Phoenix; baron oath, juramento de barão; irl. barr an, o alto de; Howth;

006.34 Howth Head; "to foot the bill"; Bill: nome aplicado a alguns promontórios; hill; Bancabanca: comprar a banca; barranco; Rodatesta: Howth Head; à roda de Howth Head;

006.35 Ireland's Eye: ilhota perto de Howth; Oculira: 1. occulo, cobertura; óculos, olho; lira, ira, Irlanda; $L M$ HCE: CHE; che arrimara: chamara;

006.36 Nor. fjord, enseada; fjell, montanha; combro (monte); bay windows, janela saliente; oboés; boaltas (fr. haut bois, flauta alta, oboé); gr. boes, grito clamor; saupesavam-no: saudar + sopesar + pesar;

\section{P. 7}

${ }^{245} \mathrm{O}$ abade Eugène Martin era doutor em letras e professor na L'École Saint-Sigisbert, em Nancy, França. Escreveu obras hagiográficas como a vida de São Columbano (1921 ?); escreveu também La Dévotion à la Sainte Vierge dans le Diocèse de Toul, L'université de Pont-à-Mousson (1572-1768), 1891, Petite histoire religieuse de la région lorraine e outras. 
007.01 Hoa (romanização francesa do chinês) hoa, palavras, língua; Howth; livelong; telltale; pedredor: pedras + esp. alrededor, ao redor; cuacuacuá: cuca, cabeça; onomat. risada, grasnado;

007.02 Desvailada: desvelo, sono; vale; revelada; vailada, manchada ( acepção trazida da palavra seguinte); LM ALP (dalppling: pálpita): Anna Livia Plurabelle; bells; blueberry; umbelas arandelas (dois termos por um: umbela, campânula, nome da flor; arandelas, arando, blueberry);

007.03 It. flutti afflitti: ondas agitadas; flute; trochee, troqueu (medida rítmica de versos: longo-breve); it. o carina!: "que gracinha!"; ocarina (um instrumento de sopro); tromposos: trompa, esp. ardil; presto (acrescentado como ligação ao adágio do período anterior);

007.04 Vanessa (Swift)?; Peter, Jack e Martin: igrejas católica (São Pedro), Calvinista e presbiteriana (Jack: na "Apologia" que serve de abertura à novela A Tale of a Tube, Swift afirma ter encontrado esses três nomes numa carta do duque de Buckingham, e que, apesar de ser fácil identificar quem sejam Peter e Martin, é difícil identificar quem seja Jack; trata-se, provavelmente, de João Calvino) e anglicana e luterana (Martin Luther, Martinho Lutero) e, mencionadas em A Tale of a Tub de Swift;

007.05 "Ins and outs"; gír. in-and-out, relação sexual; houses; A Tale of a Tub; Atum (Áton, deus egípcio; primeiro culto monoteísta registrado pela História); tomb;

007.06 “Dear Dirty Dublin”; al. taub, surdo; Taube, pombo; "Grace: 'For what we are about to receive may the Lord make us truly thankful'";

007.07 Al. gross, grande; "So pass the fish for Christ sake, Amen"; farol Poolbeg e naviofarol Kish, Dublim; James Begg, um peixeiro de Dun Laoghaire (Kingstown) publicou um anúncio em 1896 que dizia: "Buy your fish from Begg, Kingstown, the oldest Establishment in County Dublin devoted to the Sale of First Class Fish" (Comprem seus peixes no Begg de Kingston, o mais antigo estabelecimento do subdistrito de Dublim, dedicado à venda de peixes de primeira classe);

007.08 Amén; "assim seja" e "sirva a cerveja"; grampus: avô; cat. avui, hoje; demachou-se (cat. dèma, amanhã) a ir (cat. ahir, ontem) mas (irmã: Ísis); avoro (avó, devora, Oros);

007.09 Spreads, espalha; (Osíris é identificado com o trigo, e a ressurreição de Osíris, com a germinação); † whase: who is, what is; $†$ aqueste, este; troc. on the point of death; enextremado, in extremis; troc. cabaça, cabeça, assar 
007.10 Shakespeare: King Lear III.4.174: "Fie, foh, and fum" [tradicional em contos de fadas]; Egoagougo Fosco: eu, agonista, Ugo Foscolo; Egoago: Eduardo: antagonista das Ultime lettere de Jacopo Ortis, romance de Ugo Foscolo; Fush, fish, peixe (deslocado para a linha 11: arriba: rus. riba, peixe); São Patrício;

007.11 Kennedy's Bread, pão cosido na padaria Saint Patrick, em Dublim; paron. que inédia (abstinência de alimento), quem é; clebassou: rus. khliéb, pão; o pão e o vinho (eucaristia); tail, rabo (tale, conto, história);

007.12 Danu: deusa-mãe de Tuatha Dé Danann; foamous: foam + famous; famosta: famosa e mosta (espumante); lat. cerevisia, cerveja; sevícia; dobelina (neer. dobbelen, arriscar-se no jogo; jogatina): de Dublim e de "Dobbin's Flow'ry Vale" (canção); rus. dol, vale; "sevícia do", viciado (em lugar de jogo, que está no contexto apenas para mostrar o ambiente da taberna);

007.14 Cornualhês pyth: coisa; reserva (lat. res, coisa) + erva; flourwhite (Eucharist), flor de farinha; † bodey: body, corpo; corpão: corpo + pão (eucaristia); behemoth (Jó XL, 15): hapleg. hipopótamo (rus. begemot, hipopótamo);

007.15 Noewhemoe, no he more, rus. niktó, ninguém; não é: Noé; Finato: finado, fim + nato, Renatos; etéreo (por fade, esvanescer) ; port. cena, esp. cena, jantar; pasquelão, páscoa, cena de pastelão (cinema);

007.16 Salmo salar: nome científico do salmão; Salmaneser, rei da Assíria, mencionado na Bíblia (Livro de Reis); gr. agapêmonides: filho do amado; agapetas, viúvas devotas do primórdio do cristianismo; fromout, from out, mouth; smolt: filhote de salmão (fase posterior à de alevino); melten, derreter (por alevedar: alevinou-se); mist, bruma: troc. midst, entre; entre nós (por em meio à bruma + em meio a nós; tem aqui o significado de "perdido"); enlatado, preso; despachado, expulso (também no sentido que recebe na umbanda);

007.18 Gír. militar dead off: espoliado; salmão; “hook, line, and sinker": vara, linha e chumbada; "neither fish, flesh, nor good red herring": nem peixe, nem carne, nem um bom e rubro arenque (por: características dos bêbados: pesados, sem dinheiro, com a roupa amassada e amantes de um discurso); arenga + arenque; good riddance, boa solução;

$\S 10$

Sinopse: Ele adormece sob Dublim; entrada do museu;

007.20 Brontossauro e Ictiossauro (extintos); gr. brontê, trovão, assombro; ichthys, peixe; o peixe era o símbolo de Cristo; 
007.21 Edge, margem; trout, ling (peixes), truta e donzela ${ }^{246}$;

007.22 Gr. bronton, trovejar; LM HCE;

007.23 Lat. "hic cubat aedilis apud libertinam parvulam” (aqui dorme o magistrado com a pequena liberta); LM ALP; HCE; gír. flag: avental; reek, fétido, enfaroso; Reek Sunday: feriado irlandês;

007.24 Sunday; fr. chose, caso, assunto; assúntico: ing. sun, ídiche suntik, domingo; assunto;

007.25 Canção "Little Annie Rooney”; plúrica: úrica (piddle, urina) umbela: Plurabella;

007.28 Sardo tue, tu; it. brontolone, reclamão; sardo indormisca, dorme; neer. slaap, dormir; snores, ronca; irl. Binn Éadair: Howth; irl. Seipéal Iosaid: Chapelizod; “in Seeple Isout too": "in sleep all is out too"; enebetudizou: hebetude, entorpecimento; -tude: todos; dizou: Isolda;

007.30 Esp. surdos, canhotos; sujos; Ulysses, 15.2572: (sobre Jesus) "He had two left feet”; Bíblia (Livro de Daniel): ídolo de pés de barro; al. stark, forte; ing. star; disparestram: estrela (sue. stjärna) + destro + disparam; shaw: véu; shall (see): verá; cat. avui, amanhã; fell on them; felonia;

007.31 Al. Mund, boca; mound, monte, outeiro;

007.32 LM A carta: well Maggy/Madge/Majesty; Magazine Wall; sister ( $\vdash$ ); suorela: it. sorella, irmã; cat. avui, hoje;

007.33 Os prussianos denominaram a Batalha de Waterloo "La Belle Alliance"; La Belle Alliance Inn (hospedaria Belle Alliance) foi de onde Napoleão ordenou o ataque; behind + beyond; a colina 60 (Hill 60), perto de Ypres, mudava de mãos freqüentemente durante a Primeira Grande Guerra; alentria ei: além terei, teria (lat. laetitia [alegria] + alacria [grande alegria $]^{247}$ ); “All hallowed hill”: colina do Dia de Todos os Santos;

007.34 Din. bagside, atrás, nos fundos; forte Magazine Fort, no Parque Phoenix; Tara: antiga capital da Irlanda;

\footnotetext{
${ }^{246}$ Peixe que ocorre no norte da Europa e na Groenlândia: Molva molva ou Molva vulgaris.

${ }^{247}$ Apesar de não se saber o que significa o termo "aletria" cunhado por Guimarães Rosa (título do prefácio de Tutaméia, "Aletria e hermenêutica"), não pudemos deixar de ver nele as palavras laetitia e alacria, de sentidos muito semelhantes. No entanto é provável, pelo sentido que se extrai do texto, que se trate de uma palavravalise, mistura de "aporia" e "letra". Em O léxico de Guimarães Rosa (MARTINS, 2001, p. 20), a autora dá ao termo o possível sentido de: "a + letra + ia = privação da escrita, analfabetismo".
} 
007.35 Ombos: antigo trono de Sete; ambushers, emboscadores ( $\wedge$ $\sqsubset$ ); lying; rio Liffey; canção “As I Went Up the Brandy Hill: 'Up Jock' “; frase atribuída a Wellington em Waterloo: "Up, guards, and at them" (Ulysses.15.4618); canção "Wait till the clouds roll by, Jenny"248

007.36 Ponte de Saint Cloud, Paris; "bird's-eye view”;

\section{p. 8}

008.01 “Mountain's”; o Monumento a Wellington, no Parque Phoenix, não é um museu; ponte National, Paris;

008.02 Waterloo: "vai ter luz" (/uaterlu/ é a pron. inglesa; em neer. é /vaterló/);

$008.03-\Vdash$; os vilarejos (villagettes) são Chapelizod e Lucan; "here show off”: aqui se mostram (exibem); lat. minxit, urina (vb.);

008.04 "Amidst the foliages": entre a folhagem;

008.05 Museum;

008.06 Tommy Atkins: termo que designa o soldado britânico da Primeira Grande Guerra; Shelenk: shiling; she + alem. leken comandar; unadomina, um a domina, abomina, doma, dama; redismembers: remembers + dismembers; desmembrora: rom. memora, lembrar + desmembra ("Desmembramento" era a palavra-de-ordem da contra-revolução na França; foi o que fez o Congresso de Viena.); velha guarda de Napoleão que vivia no Hotel des Invalides; poussepousse pousseypram to sate: "let servicemen sit down in the train"; poussepousse: riquixá; pousseypram: fr. pousser, puxar; fr. poussette, carrinho de bebê; push-pram: cadeira de rodas para os feridos na guerra; pram, trem; puxapuxa coxacoxe: coche, coxa; pron. irl. /sate/: seat; aberbar: de berba, ânus; boga: reg. bras. ne: ânus;

008.08 Passkey: gázua; Gázua: troc. gaze, véu; Janitrix: lat. genitrix, geratriz, mãe; meretriz; cat. mestressa, senhora, dona de bordel; Kathe, Caterina; gír. kate, chave-mestra (o troc. entre kate e passkey foi deslocado para gázua e mestressa); Tércia: hipocorístico de Natércia (anagrama de Caterina); LM troque: onomat. toc, toque; troco (indica mudança, despertar; é o som de um galho de árvore batendo contra a janela do quarto);

\section{$\S 11$}

Sinopse: O salamuseu; a batalha do Uelintarioso contra o Lipoleão e as Fiandas;

\footnotetext{
${ }^{248}$ Canção de rua do final do período vitoriano. Foi composta em 1884 com letra de J. T. Wood e música de H. J. Fulmer.
} 
008.09 (Uma velha conduz os visitandes pelo Museu); Museyroom: museum, room, mushroom; salamuseu: sala, museu, salame (referência ao monumento ao General Wellington no Parque Phoenix como símbolo fálico);

008.10 Precious + Prussian;

008.11 Fr. + grinch? (desmancha-prazeres); francho: franco, ancho (folgado, atrevido);

008.12 General Byng: subordinado a Wellington em Waterloo;

008.14 Batalha de Salo, 1796 e Batalha de Loos, 1915; Ponte de Crossguns, Dublim;

008.15 De Valera, sobre o levante da páscoa em 1916: "if only the people had come out with knives and forks"; gír. "to put down one's knife and fork": morrer; El sombrero de tres picos, bailado de Manuel de Falla, baseado no romance de Pedro Alarcón; ref. ao chapéu de Napoleão;

008.17 Ref. ao cavalo de Wellington, Copenhagen (que não era branco); horse + harsh (duro), arse, bunda, cu: cavalgadura; alvado, cu; Sraughter: Sir Arthur + slaughter; massacrasso: o que massacra + crasso (Wellington, de acordo com Victor Hugo: "Waterloo foi uma batalha de primeira vencida por um general de segunda" [Os miseráveis, Tomo II, Livro I]);

008.18 Batalha de Magenta, 1859; Batalha das Esporas Douradas (Guldensporenslag), 1302; Goldtin: gold + tin; aureolatas; Duque de Ferro (Wellington) (ou de lata);

008.19 Lat. dux, líder; dook: sin. de plug, gír. pangaré; duque; Batalha de Quatre Bras, 1814 (derrota francesa, perto de Waterloo); Saudação que os Orangemen, sociedade protestante do Ulster, costumam fazer em agradecimento a Guilherme III (de Orange),: "who saved us from... brass money and wooden shoes"; gharters: garter, liga de meias; Carta Magna;

008.20 Fr. goliard, menestrel; Guerra do Peloponeso (431 - 404 a. C.);

008.21 Wartrews: war + Waterloo + Arthur (prenome de Welligton); rutra luta: Waterloo (pron. inglesa) + palíndr. Artur + luta; wide harse: white horse; three lipoleum: Napoleão I, II e III;

008.22 Batalha de Boyne, 1690; General Grouchy, do exército de Napoleão, em Waterloo; detch, ditch + death; gruchivo: gruta + vivo + esp. chivo, bode (sacrifício) + Grouchy;

008.23 Esc. greys (regimento) em Waterloo ; davy: din. + devil; daníferos: daneses + dano + PV lucíferes; stooping: stoop, inclinar-se + stop, ponto final; capítulo: troc. capitulação; 
008.24 Bog: lama + big; palustre: pântano, ilustre; irl. beag, pequeno; parvo: apequenado (ref. a Napoléon, le petit, de Victor Hugo: Napoleão III); al. Mörder: assassino; pol. morderca, assassinar; Mordred, sobrinho do rei Artur;

008.25 Batalha de Gawilgarth, 1803 (Wellington); Batalha de Argaum, 1803 (Wellington); argument, querela; argonauta; reg. port. catraio, garoto;

008.26 Batalha de Assaye, 1803 (Wellington), fr. assez!: basta! touch-hole: buraco do canhão; fits toomuch; gír. tuchar, enfiar;

008.27 Hairy: Harry, hairy, peludo, hirsuto (O'Surto) + hurry, depressa; surto: algo repentino;

008.28 Batalha de Teutoburger Wald, 9 d. C. entre os germanos, liderados por Armínio e os romanos, liderados por Varo; Délia: Ártemis, Liga de Delo; alpes julianos;

008.29 Batalha de Mons, 1914; Criméia;

008.31 Jenny: fiandeiras; leghorn: Livorno, tomado por Napoleão em 1796;

008.33 Cooing: arrulham (duplo sentido na trad.: dizer palavras doces a alguém); + alva; mãos brancas (Isolda das Mãos Brancas, esposa legítima de Tristão) ( $L M$ pombo/corvo); Isolt of the White Hands and Isolt of the Fair Hair [Isolda das Mãos Brancas e Isolda dos Cabelos Loiros $]^{249}(\dashv-)$;

008.34 Ravin: usurpação, raven, corvo (negro); her hair, fair hair: Isolda dos Belos Cabelos (esposa do Rei Marco e amante de Tristão); gír. "to get it up: to have erection” (gír. ter uma ereção);

008.35 Monumento a Wellington: coluna de granito do Parque Phoenix, com 50m de altura; lat. marmor: mámore; al. Marmor, mármore; tallow scoop: tall (aumentado) + telescopic (encurtado), conota ereção; Ulysses.17.1819: “The Wonderworker, the world's greatest remedy for rectal complaints"; woodwork + wounder + wonder; obsceno + homicida;

008.36 Sexcaliber: seis (+ sexo) cilindros + Excalibur (espada do Rei Artur); cavalo-vapor; islandês ant. hross, cavalo; conúbio: matrimônio + bul. kon, cavalo + eston. hobune, cavalo;

\section{p. 9}

\footnotetext{
${ }^{249}$ Isolda das Mãos brancas foi a esposa legítima de Tristão; a outra Isolda, a dos Cabelos Louros, por quem Tristão se apaixonara, era esposa legítima do Rei Marcos, tio de Tristão.
} 
009.01 Belga e (General) Blücher (Waterloo); Batalha de Filipos, 42 a. C.; filírias: fileiras, Filipe, nome de uma árvore;

009.02 Arthur Guinness, Sons and Company, Ltd: Artreiro Dignésio; lieutenant; Batalha de Hastings, 1066; crastinindo (-astin-): Hastings + crástino (rel. ao dia de amanhã $\rightarrow$ fiandeiras); 009.03 Irritate; rus. crasnaia, vermelho; Thin Red Line: uniforme da infantaria britânica; shirtfront (ref. a tecidos e à batalha);

009.04 Al. ja: sim; alem. "Lieber Arthur, wir siegen. Wie geht's deiner kleinen Frau?" [Caro Artur, conquistamos. Como vai a tua pequena esposa? (continua fiel?)]; fidegena: mulher fiel; dana: gír. danada; claudesfrauda: claudica + desfralda (a bandeira $\rightarrow$ sinal de vitória na batalha); Batalha de Orthez; consiquimos: conseguimos + conquistamos + siecken; censuramente: censura + mente + neer. hoogachtend , sinceramente;

009.06 Nap: Napoleão; Bona (-parte); táticas; fontanezar: atenazar, incomodar + Fontenoy (Batalha de 1745; em que os franceses se aliaram aos irlandeses para combater o exército anglo-holandês chefiado pelo filho de Jorge II);

009.07 Pron. anglo-irl. /shee/: see; xixixi: interjeição de espanto + xixi (alusão ao que acontecia no parque naquele momento); jealous; Batalha de Agincourt, 1415;

009.08 Gone crazy; Capitão Boycott + coitado; (Origem do termo boicote: A política do boicote foi criada por Charles Stewart Parnell, em 1880, contra o terra-tenente Charles Boycott que se recusava a baixar a renda das terras apesar da penúria que atingia o país. Joyce, e os nacionalistas, era admirador de Parnell);

009.10 Bode: body, corpo (militar); port. bode (sacrifício); trápago: gr. trágos + trapo + trôpego + tropa;

009.13 Batalha de Salamanca, 1812 (Wellington); fr. chère, caro, querido; fr. fichtre! interjeição de espanto; figtreeyou: fuck you + fig tree; frondam-se: fodam-se + fronda (folhagem);

009.14 Fr. gír. foutre, foda-se; First Duke of Wellington; remuque: remoque (piada) + duque;

009.15 tit for tat: olho por olho; letão acs, olho; tic for tac: tactics, tática;

009.16 twelvemile cowchooks: "ten-league" boots; caoutchouc: caucho (galochas); weet tweet: retreat; Batalha de Stamford, 1470;

009.17 Fr. gír. foutre le camp, fugir; 
009.18 Guinés: [cerveja] Guinness; desgolo: des + gole + gola, colarinho [da cerveja];

009.19 Cannon-balls; bolas, balas; russas; rush, rapidez; bólide: "qualquer corpo cujo deslocamento se dá em grande velocidade" (Houaiss); trench: fosso; presúria: reconquista, aterro; Ulysses.15.4606: "Irish missile troops"; mistletoe, visgo; gr. tropes, muda (vb.);

009.20 Governo dos Cem Dias de Napoleão; indulgência papal;

009.21 Fr. blessés: ferido; abenchagado: abençoado + chagado, ferido; lat. terra; Tara: antiga capital da Irlanda; Batalha de Torres Vedras, 1810; widows; cat. vídua, viúva.

009.22 Bluchers: tipo de bota; nome derivado de Blücher;

009.23 Fr. tonnerre: trovão; anglo-irl. bullsear: um palhaço (do irl. ballséir);

009.24 Battle of Camel, 656 (Cluster: Battles); cavalaria; Batalha de Flodden Field, 1513; flundeiros: segunda coluna dos exércitos antigos formada por atiradores de fundas;

009.25 Batalha de Solferino, 1859 (Napoleon III derrota Francisco José); Batalha de Actium, 31 a. C.; Batalha das Termópilas, 480 a. C.; panic; Batalha de Bannockburn, 1314;

009.26 Batalha de Almeida, 1811 (Wellington) + Almighty God!; gad: vaguear; Batalha de Orthez, 1814 (Wellington); “Até tu, Bruto?” Batalha de Tolosa, 1814 (Wellington); La Langue de Rabelais II.205:"Brum, à brum! pour se reprendre d'un lapsus"; al. brummen, rugir;

009.27 O grito do General Cambronne, em Waterloo, teria sido: "Merda!” (insinuado aqui pelas onomatopéias); al. Unwetter: tormenta; under water; votroada: al. wetter, tempo (ing. molhado, chuvoso), anag. trovoada; al. "Gott strafe England”: Deus pune a Inglaterra (lema da Primeira Grande Guerra); goat, bode;

009.28 Esquartraga: esquarteja + gr. tragos, bode; Fingraterra: Finalândia + sangra + Inglaterra; al. rinnen, correr; Rhin, Reno; desfrenando-se: desenfreada + -ren- + ando; Batalha de Austerlitz, 1805 (vitória de Napoleão);

009.29 Batalha de Bunker Hill, 1775; trip: tropeço; nip: gole; aerófago;

009.30 Cuouros: couros + it. cuore; agraito: cat. agraït, agradecido; fr. "s'il vous plaît"; argêncio plauto: cat. "si us plau”, por favor; catching the creeps, apavorar (?); gír. cool crape, mortalha;

009.32 Fr. pour le pays, pela pátria; pay the poor; Bismack (derrotou Napoleão III); Marta (da linha seguinte); 
009.33 Batalha de Maratona, 490 a. C.; Marta e Maria (irmãs de Lázaro; João XI);

009.34 Fr. gír. “se branler”: masturbar, port. ant. molejar; fr.” sauve-qui-peut”;

009.35 Gír. key, pênis; William Gorman Wills: A Royal Divorce (drama sobre o divórcio de Napoleão; drama de autor desconhecido, foi adaptado Wills);

009.36 It. gamba, perna; Giambattista della Porta: cientista e dramaturgo do Seiscentos italiano; como cientista, escreveu sobre o telescópio; como dramaturgo, escreveu a peça I'due Fratelli rivali; it. bariste, garçonete; it. arista, costeleta de porco; it. porca; it. da vere femmine; Mateus VI, 13: "deliver us from errors"; it. "liberaci dai maligno"; Batalha de Vimeiro, Portugal, 1808 (Wellington); De Valera; Batalha de Talavera, Espanha, 1809 (Wellington);

\section{p. 10}

010.01 Canção infantil “Taffy was a Welshman, Taffy was a thief”; Batalha de Spion Kop, 1900 ;

010.02 Copenhagen, cavalo de Wellington; Cabo da Boa Esperança; "Stonewall” Jackson: general do exército dos Confederados, na Guerra Civil norte-americana;

010.03 Matrimony; Nice (França); bachelors: enforcados (gír. noivos); Jena, onde Napoleão derrotou os prussianos (1806); hiena; Mr. Hennessy (também chamado de Hinnissy), personagem do livro do escritor norte-americano Finley Peter Dunne, $M r$. Doodley's Philosophy; irl. fhionn (pron. /hin/), justo; nome irlandês, O Fhionnghuise: "que descende do espírito justo";

010.05 Batalha de Leipzig, 1813 (em que Napoleão derrotou os prussianos); lipstick; din. syg, enjoado; irl. dubh, negro (/du/); lápis índigo d'olho: lápis de olho (em vez de batom [lipstick]), Leipzig; al. Krieg, guerra, refrega; kriegen, conseguir; ME funk, centelha; Hinnessy; highness, alteza;

010.06 Hindu (Wellington servira na Índia); irl. siomar sin, trevo; hind. Samar Singh (nome genérico para soldado; lit. "leão da batalha");

010.07 Gír. waxy, colérico; wax, cera; cerúmano: ser humano + cerume; G. E. Pickett: general Confederado norte-americano; piquete (greve, folga); pick up;

010.08 Trefoil, trevo; from out; bloody; battlefield; bluddle: bloody (sangrento) + bubble (mumúrio);

010.09 Raja + mad; airado (louco); bomb; gír. pumpship, urinar; 
010.10 Hanking: hanging + hank (meada); pendente (por hanging [010.11]); backside;

010.12 Cat. mateixa, mesma;

010.13 Copenhagen (cavalo) + culp + help; empenhado; lat. culpa; telescope; crupper, garupa (de cavalo);

010.14 Half of a hat /hafovahat/: alfafa (alimento de cavalo: mudado para "aveia" na trad.); lat. insulto: eu salto; insulto; Isolda; hat... insoult: Chapelizod; Marechal Soult (do exército francês em Waterloo); seeboys: sepoys, catraio (menino); Napoleão chamava Wellington de "general dos sepaios (sepoys)";

010.15 Chec. hnúj, estrume; heb. hine, eis; Marechal Ney: comandante francês em Waterloo; neigh, relinchar;

010.16 "Mad as a hatter": louco, chapeleiro maluco de Alice no país das maravilhas (Mad Hatter); ataque de Mahratta a Madras, 1741; Wellington na Guerra de Mahratta; madraxeiro: madraceiro (preguiçoso) + cheiro; Wellington: "Up, guards, and at them";

010.17 Batalha do Nilo, 1798, em Abuquir (Nelson); gír. pukka, certo, seguro; angloindiano: pukkaroo, ataquem!; arapuca; atrepai-os: atrapai-os + trepar [010.16]; "bugger yourself!" (foda-se!); quando perguntaram a Wellington se ele era irlandês, respondeu: "Se um cavalheiro nasce num estábulo, não tem necessariamente de ser chamado de cavalo"; essa frase foi parafraseada por Thackeray (Lectures on the English Humorists): "If Swift was an Irishman then a man who is born in a stable is a horse";

010.18 Ghent; tinderbox (acender o pavio da bomba); botch, estrago; cursing; corso (Napoleão);

010.19 Batalha de Busaco, 1810 (Wellington); sucker; esp. usted; "do for": danificar, cuidar; Primeiro Marquês de Dufferin: Governador-geral da Índia: “blow bomb”; neer. doof, surdo;

010.20 Rabuja (rabo);

$010.21 \quad$ Lat. musca, mosca;

010.22 Sávata: prov. sabata, sapato;

010. 24

Sinopse: O fim da batalha; 
010.25 Cooling, killing;

010.26 Matemos: metemos; whereabouts, paradeiro, onde; know where; it. dove è; Ana;

010.27 Jack O'Lantern (carranca feita nas abóboras do dia das bruxas); candlelight, candelabro; calendar; farol na baía; Castletown House, que teria uma janela para cada dia do ano; Howth; lat. mensis + mansarda;

010.28 Window: esp. ventana; windy; canção The Three Ravens: "Down in yonder green field / Down a down hey down hey down / There lies a knight slain 'neath his shield"; Castelo de Donegal (Irlanda); al. Nummer: neer. nummer, número;

010.29 Twentynine ( $\bigcirc$ ); Batalha de Wagram, 1809 (Napoleão), vagrant: errante;

010.30 A-waltz around, await around; pitimba (mal-estar) + vala; Piltdown (Sussex) + downs (subst. descampado); pelt down, chover forte;

010.32 Early bird + gnar (rosnar); one, two, three, four, five, six, seven, eight, nine, ten, eleven, twelve; -ita (suf. dimin., por little); desovitas: neol. "que saíram do ovo"; dezoito;

010.34 Shakespeare: King Henry V II.3.16: na descrição da morte de Falstaff, o original "a table of greene fields" foi modificado para "a babbl'd of green fields"; bleak, ermo; bard, bardo (participa da conversa registrada na cena 3, do ato II de Henrique V); veritable tableland; blackbird; fields; pastos pretos: passo (pássaro) preto; debar: rodopio;

010.35 Teosofia: os sete corpos (sheaths) que abrigam a alma (físico, astral, mental, búdico, átmico ou nirvânico, anupádico [Anupâdaca] e ádico [Âdi]); Rothschild; al. rot Schild, escudo vermelho; al. Lump, patife; ing. uproar, barulho; fr. L'empereur; ing. † glave: espada; eslavônico glava, cabeça; beside;

010.36 Din. skud, um tiro; unhorsed (que caiu do cavalo) + endorsed (confirmado) + torso; pigeon pair: gêmeos de sexos diferentes; pidgeon: pombo; flown; Alfred Northcliffe: um irlandês, dono de jornal, nascido em Chapelizod;

\section{p. 11}

011.01 Canção The Three Ravens; suddenly; neer. kraai, corvo; croaking, grasnar;

011.02 Fr. débâcle, catástrofe; din. kvarter, subdistrito; quarters; alcaidia: cai + esp. alcaidía; gr. treisbous, três bois;

011.03 Anglo-irl. niver: never; Thon, deus antigo da Inglaterra (Tor?); al. Anschauer, observador; ing. shower, banho; 
011.04 Lightning; al. Nixe: ninfa das águas; ing. séc. X nihe, noite; thunder; Shakespeare: Macbeth IV.1.117: “crack of doom”;

011.05 Lat. nubes, nuvem; lat. nubo, cubro; "no, never on your life"; reto-rom. nebla, névoa; port. † sôbolas: sobre as; din. liv, vida;

011.06 Much afraid; paron. "murcha e aflita"; anglo-irl. freet: superstitção; topôn. Ballyma, Cork, Irlanda; it. gamba, perna; topôn. Beann Éadair (Howth, em gaélico irlandês);

011.07 Roving eye: "to have a roving eye" = ser inconstante, galante; dead in the world; Shakespeare: King Lear III.4.174b: "Fie, foh, and fum” [175: "I smell the blood of a British man']; fia-te, foto: fiat lux, fio (parcas) e fado (destino); reto-rom. fè (fé), fö (fogo), fom, fome; ing. jest, brincadeira; fr. geste, gesto; gesta;

011.08 Let bygones be bygones (o que passou passou); LM Carta: "Dear, and it goes on to" (Caro [senhor], venho, por meio desta);

011.09 Din. fugl, ave; chec. perí, pena; heb. peri, fruto; Thomas Moore: Lalla Rookh: "Paradise and the Peri" ["Das Paradies und die Peri": oratório de Robert Schumann); gr. peri potmon: relativo ao destino; Fairy Godmother: Fada Madrinha; Mother of Pots: Mãe dos potes: inscrição da tumba de Osíris, sobre a qual se empilhavam fragmentos dos potes de cerâmica das oferendas;

011.10 Sir John Pringle: físico do séc. XVIII, cuja biografia foi escrita por Andrew Kippis; neer. pik, pênis; picada $=$ subst. pica); ing. peck, bico; din. $i$ land, sobre a terra; island + landscape;

011.11 Bag on her back; mochila (mocho); piggyback, carga; beak, bico;

011.12 Pixillating, amalucado; pixy, duende; lat. pax: ,paz; gr. euhemerema, sucesso; rainbows (Gênesis IX, 16);

011.13 Pussy: sentido burlesco registrado desde o final do séc. XIX. al. Plunder, lixo; blunderbuss, bacamarte; plunder, atacar, saquear; pussy, xoxota; cat. mes, mas; armistice tonight; nota: noite;

011.14 Esper. milito: guerra; esper. paco: paz; tomorrow + mourn (luto); kinsman, parente; kiss, tio + ósculo (testículo);

011.15 Minutia: minúcia; munition: munição; tomorrow; cat. demà: amanhã; PV erebela: ereção + bela; $L M$ HCE (acrônimo); 
011.16 Anglo-irl. childer, crianças; everywhere; Nebo: montanha em Moabe, de onde Moisés viu pela última vez a Terra Prometida, à qual ele não entraria; nearby: próximo; volapük (língua artificial, criada em 1880 pelo clérigo germânico Johann Martin Schleyer) nebu [ou al. neben]: exceto, ademais; lat. susurro;

011.17 Celebrate; borrowed, emprestou; coach's, da carroça;

011.18 Canção irl. "Siúl, siúl, siúl arún, Siúl go socair, Agus siúl go ciúin”: “Go, go, go my dear, go securely and go calmly": Vai, vai, vai, querido, vai seguro e vai calmo"; shoots around; Anglo-irl. aroon, amado (do irl. a rún); e vasta: devasta;

011.19 Knapsack, mochila; cartridges, cartuchos; Ratlins, enfrechate (escada normalmente de corda para se subir ao mastro das embarcações); buttons; † nappy, bebida forte;

011.20 Spatee: perneira que imita a dos escoceses; flags; gír. "all nations": mistura de bebidas; "clavicles and scapulas”: clavículas e omoplatas; escapulário (veste sacerdotal);

011.21 Referência aos "Wood's halfpence" mencionados em The Drapier's Letters, de Swift ${ }^{250}$; moonlight; seneluários: da lua;

011.22 Bloodstone, jaspe-de-sangue (calcedônia; pedra de cor esverdeada com manchas vermelhas); hematita; Boston, Massachusetts, nightletter (LM Carta; Boston Transcript); boast;

011.23 Fr. chaussettes, meias; Les Pieds Nickelés: quadrinhos franceses da década de 1930 (gír, fr. "avoir les pieds nickelés": ter preguiça); nicúpeda: níquel + pé; LM Mick/Nick ( $\wedge / \sqsubset$ ); knickknacks, adereços; din. fфdder, pés; LM Carta: "poor Father Michael”; ponte Saint Michel, Paris; LM Carta: "lovely present/parcel of cakes";

011.24 Cates: comida escolhida; canhão Howitzer; moucanos: moucos + canhões; "how is yer, my dears?" LM Carta: "how are you”; LM Carta: “well Maggy/Madge/Majesty”; fr. il, ele; “wills and wells”; fr. elle, ela;

011.25 Loff: medida de milho (de grãos); "lots of love"; Werner ${ }^{251}$ : Barnum: "believed that when in London he must do as the toffs did"; fr. pleur, pranto; Plurabelle; canção "Ah! The Syghes That Come fro' the Heart" (da época de Shakespeare);

\footnotetext{
${ }^{250}$ William Wood conseguiu um contrato para cunhar $£ 108.000$ em moedas para a Irlanda e para a América Britânica entre 1722 e 1724. Jonathan Swift, sob o pseudônimo de M. B. Drapier, denunciou, numa série de sete panfletos, pubicados em 1724-1728, que as moedas de Wood eram feitas com material de baixa qualidade, o que provocou uma certa aversão às moedas que acabaram sendo recolhidas e enviadas para a América Britânica.
} 
011.26 Neer. boek, livro al. Lied, lied, canção; Bédier ${ }^{252}$ : Le Roman de Tristan et Iseut 3 (“Les Enfances de Tristan”): [A mãe de Tristão, logo depois de dá-lo à luz, ainda chorando pelo marido assassinado] '"Fils, lui dit-elle, j'ai longtemps désiré de te voir; et je vois la plus belle créature que femme ait jamais portée... Et comme ainsi tu es venu sur terre par tristesse, tu auras nom Tristan.' Quand elle eut dit ces mots, elle le baisa, et sitôt qu'elle l'eut baisé, elle mourut."

011.26 Cervo em corva: verso e prosa; corva: cova + corvéia; lídio: mús. tonalidade medieval; apostavia: apostasia + aposta + havia; first sin; aocaso: acaso + ocaso; son; sun saw;

011.27 Irl. cearc: galinha; que cerco!: esterco; irl. ceart, certo; LM Carta: four crosskisses; Christine: cristã;

011.28 Essa sina: assassina (vb.);

\section{$\S 14$}

Sinopse: Os presentes que roubaram dela; o papel dela na vida;

011.29 Botina: bota + bonita (bootifull); Molhetina: it. mogliettina, esposinha (Puccini: Madama Butterfly, Ato II: ária: “Un bel' dì, vedremo": “piccina mogliettina”); Gwynn ${ }^{253}$ : The History of Ireland 9: "The rulers of Ireland, whose wars with one another for land and for booty are described in the romances, were Gaelic by blood"; "true to life"; al. e neer. streng, austero; neer. streng verboden: terminantemente proibido;

011.30 Passado pós-profético (tempo verbal); Lord Mayors and Lady Mayoresses (Senhor Prefeito e Senhora Prefeita);

\subsection{Mistresses, amantes;}

011.32 "A kettle of fish" (balaio de gato); Ana Lívia; Kettle; Livro de Orações: Sepultamento do Mortos: "In the midst of life we are in death";

011.33 Applause; fr. pleurs, prantos; ing. mirth, alegria;

\footnotetext{
${ }^{251}$ Robert Morris Werner (n. 1897): Autor de aproximadamente 15 livros, quase todos biográficos, ou históricos, publicados entre 1923 e 1939. Barnum, publicado em 1927, é um livro que retrata a vida de Phileas Taylor Barnum (1810-1891), humorista que apresentava um teatro de variedades. Fundou um circo que acabou se tornando o famoso Ringling Brothers. Também foi autor de livros.

${ }^{252}$ Joseph Bédier (1864-1938) estudou as diversas versões do século XII do mito de Tristão e Isolda - o poema do jogral Béroul; o de Thomas da Britânia; o de Eilhart de Obergue; o La Foile Tristan; e um romance em prosa - e a de Gottfried de Estrasburgo. O livro de Bédier foi publicado em 1900.

${ }^{253}$ Stephen Lucius Gwynn (1864-1950): Escritor, poeta e jornalista irlandês. Como político nacionalista, foi membro do parlamento por Galway.
} 
011.34 Fr. napperon, toalha de bandeja; an apron, um avental; fr. sabots, tamanco; din. sa saer, muito estranho; Sara (mãe de Isaque);

011.35 Ponte Sully, Paris; Isaque; al. sage, (eu) digo, conto; Hou: um deus de Gurnsey; senhores gregos e troianos; gír. fr. "tirons nos gregues" (façamos algo); bricks, tijolos; trousers, calças; ílios: Îlion, Tróia;

\section{p. 12}

012.01 "Makes life worth living"; diva: divina + vida;

012.02 Divida (silabada): vivida + dívida; it. città; neer. citer, cítara; al. zittern, tremer; citados: citadinos + sentados;

012.03 Wimman: women; hímanas: hímen + humanas; divagar: divulgar; rapacitos: rapaz + rapace + citadinos; pron. anglo-irl. /min/: men, homens; neer. min, amor, ama-de-leite; chin. min, o povo; Min: deus lascivo do Egito, equivalente a Priapo;

012.04 Al. Bettler, mendigo; al. Bett, cama; butler, mordomo. troc. night's (deveres de seu senhor e deveres noturnos);

012.05 Canção "While London Sleeps"; anything; folgar: alegrar;

012.06 "Married Ann”; esponsais;

012.07 Tot i que: cat. embora; Tot: deus egípcio; covadura: extensão (côvados);

012.08 Al. Flut, enchente; fr. flute! (interj. inferno!); em conseqüência do dilúvio universal, na mitologia nórdica, o corpo morto de Ímir, pai dos gigantes, tornou-se a terra; os cabelos dele fizeram-se em árvores; e as sobrancelhas transformaram-se na relva e nas flores; neer. nare, triste; bare, calvo; glabrous, glabro, careca;

012.09 Phace: place + face; al. "Der Herr schuf die Welt": Deus criou o mundo"; Herrschaft, maestria; Avestá: texto sagrado de Zoroastro; it. veste;

012.10 Pron. anglo-irl. /sarch/: search, buscar; it. sarchiare, capinar; eat;

012.11 Cantiga de roda: "And I'll do all that ever I can, to push the business on"254;

012.12 Gír. fr. piffer, cheirar; al. paffen, fumar; laziness, preguiça; fleumaça: fleuma (indolência, apatia) + fumaça (fumo); cantiga de ninar: Humpty Dumpty: Cumpim Mirim

\footnotetext{
${ }^{254}$ O nome da cantiga é To Push the Business On: "I hired a horse and borrowed a gig, / And all the world shall have a jig; / And I'll do all 'at ever I can To push / the business on. / To push the business on, / To push the business on; / And I'll do all 'at ever I can / To push the business on."
} 
nesta tradução; shell (concha): shall; frumpty: fifty (?) + fourty (?); frumpy, mulher mavestida, desleixada; miríadas: milhares + Mirim;

012.13 Canção Kafoozalum ${ }^{255}$; "The Grand Remonstrance": documento parlamentar, editado em 1641 que criticava a administração real e propunha reformas; canção "Be like two fried eggs, Keep your sunny side up" (sunny side: lado da gema); pron. anglo-irl. /iggs/: eggs;

012.14 For breakfast; manharem-se: manhã + manha (choro); "come the morning"; “mourn him”: pranteá-lo;

012.16 Anglo-irl. turnover: pão no formato de bota; anglo-irl. "the tea is wet": o chá está pronto (relação sexual); pron. anglo-irl. /tay/: tea; revolteia: esp. té, chá;

012.17 Pron. anglo-irl. /hin/: hen, galinha; avém-te: avir, entender; galear: requebrar; galo;

\section{$\S 15$}

Sinopse: Panorama da cidade de Dublim e seus montes;

012.18 Behaviourismo; cat. aleshores, então; Queen Anne's Bounty: provisão real para a manutenção dos clérigos pobres (1704);

012.19 Dia judaico dos primeiros frutos; tithe, dízimo; time; revisamos: revemos;

012.20 Revue des Deux Mondes: revista literária francesa; see: say; senhos (deles): troc. seios; al. Himmel, céu; nipples, mamilos; simple; hills; sardo tando, tanto;

012.21 "At sixes and sevens": desordenado; sex; séquitos + sexo; sétimo + fétido + sentidos; al. Hügel, fr. colline; (Michael) Collins; anglo-irl. colleen, garota;

012.22 "Sitting around"; anglo-irl. aroon, querida; Santa Brígida e São Patrício (padroeiros da Irlanda); chamberpot stench, cheiro do penico; al. taufen, batizar; tafetá;

012.23 Wharton's Folly: “o forte estrela”, fortaleza inacabada no Parque Phoenix, construída pelo vice-rei Wharton num outero entre o Forte Magazine e o zoológico (Wharton'se Folly, a "loucura (ou devaneio) de Wharton” é uma expressão anacrônica, pois o Forte só foi construído vinte anos depois da morte de Wharton); tripartite; tea party (? ${ }^{256}$

\footnotetext{
${ }^{255}$ O primeiro verso da canção está disperso pelo texto: "Come listen to my tale of woe" (linhas 13 a 15).

${ }^{256}$ Tea Party (Festa do Chá). Episódio da guerra civil norte-americana, ocorrido em 1773 na cidade de Boston, na colônia de Massachussetts. Os ingleses resolveram taxar o chá produzido na colônia americana para beneficiar as colônias orientais; houve uma revolta e americanos, disfarçados de índios, invadiram os navios que traziam o chá das Índias Orientais e o despejaram no mar. No entanto, é mais provável que o trocadilho do texto se refira à simples cerimônia vitoriana do chá.
} 
012.24 Esper. planco, chão (é mais provável que seja apenas uma deformação do ing. plank, de mesmo sentido, termo do qual Zamenhof fez derivar seu planco);"Move up, Mick, make room for Dick" (pixações feitas em Dublim depois da morte de Collins, referentes a ele e ao seu sucessor Richard Mulcahy, his successor ${ }^{257}$ ); gír. de Dublim micky, pênis; LM Mick/Nick; mijel (Miguel + mijo): nome fr. Michel (Michael);

012.25 Strake, molhe (subst.); strike, greve; struck, golpeado, cunhado (vb.); minnas: Minna (hipocorístico de Wilhelmine), primeira esposa de Wagner ${ }^{258}$; mina; for minnas: fornica; moedas cunhadas; Nicholas Proud: secretário do porto de Dublim e das Docas, na época de Joyce; LM olhos/ouvidos; Old Nick é o diabo, que contrasta com São Miguel Arcanjo; Proud, gír. cópula; folgar: esp. huelga, greve, folga; it. bimba, menina; bimbar: fornicar; cujo: diabo;

012.26 Al. Berg, Berge, montanha(s); Alf Bergan: funcionário da prefeitura de Cork Hill, Dublim (aparece em Ulysses 12); burghers, burgueses; Cork Hill, Arbour Hill, Summer Hill, Misery Hill e Constitution Hill (em Dublim); Abouquir, Egito: Batalha de Abouquir ou do Nilo, em que Napoleão foi derrotado por Nelson ${ }^{259}$;

012.28 Esteio: estio, verão;

012.29 Contrabaixo; cantiga de ninar: "As I was going to Saint Ives, I met a man with seven wives, and every wife had seven sacks" (Saint Ives fica na Cornualha); LM ECH (HCE); populECHa;

012.31 Lenda dos três irmãos fundadores: Aulaf (Dublim), Sitric (Waterford) e Ivar (Limerick); Olaf Road, Ivar Street e Sitric Road ficam perto de Arbour Hill, Dublim; “on the right";

012.32 "On the left”; mir. ls, eles;

012.33 Notas musicais: lá, sol: (likehood, solve: acolá; solverão);

012.34 Sol, lá, mi, lá; Rômulo e Remo; lat. "est modus in rebus": "há uma medida própria nas coisas"; Rabelais; rébus (ideograma que perdeu o sentido pictórico e passou a ser

\footnotetext{
${ }^{257}$ Mick era o hipocorístico de Michael John Collins (1890-1922), nacionalista irlandês que atuou no Levante da Páscoa de 1916 e se tornou membro executivo do Sinn Fein. Foi um dos responsáveis pela libertação da Irlanda e um dos fundadores do Exército Republicano Irlandês (IRA).

${ }^{258}$ Christine Wilhelmine Planer (1809-1866). Mas o vocábulo pode ser também uma referência a Wilhelmine Schröder-Devrient (1804-1860), soprano-dramático em quem Wagner via o ideal da música.

259 Vice-Almirante Horatio Nelson (1758-1805), participou da famosa Batalha de Trafalgar (21 out. 1805), Espanha, que abriu uma bracha no bloqueio continental imposto por Napoleão à Inglaterra. Malgrado a vitória inglesa, Nelson morreu na Batalha. Foi erguida uma coluna em homenagem a ele em Dublim, que mais tarde seria destruída pelo movimento revolucionário do IRA.
} 
fonema); rebus (um tipo de jogo de palavras que usa figuras para representar fonemas; ex. sol + dado = soldado $\left.{ }^{260}\right)$

012.34 Canção Phil the Fluter's Ball ${ }^{261}$ : "Hopping in the middle like a herrin' on a griddle, O!"

012.36 Howth Head; Capo: cabeça, cravelhas (instrumentos de corda); fr. pied, pé; poudre, pó; "pied poudreux": vagabundo; Phil the Fluter; Swift: "Epigram on the Magazine" (no Parque Phoenix): "Behold a proof of Irish sense! / Here Irish wit is seen! / Where nothing's left that's worth defence, / They build a magazine";

Sinopse: Descrição de Finnegans Wake;

\section{p. 13}

013.01 Português (no original, english, inglês ${ }^{262}$ );

013.02 Pound; pun, trocadilho; Peter's Pence: doação à Igreja Católica Romana;

013.03 Scene fake: Sinn Fein; irl. feach!, veja! narra a cena: sarraceno; ficto: falso (facto);

013.04 M.J. MacManus ${ }^{263}$ : So This Is Dublin (1927); “do you belong?”;

013.05 LM HCE; harto: forte (alto!); Ecolanda: PV eco + (ir)landa [eco da terra: ressurgimento (ciclos de Vico)];

Sinopse: A gravação no muro; olhe e ouça;

013.06 LM HCE; outwashed engravure: gravura (placa colocada no alto de uma taverna para identificá-la; não continha escritos, apenas figuras pelo fato de poucos saberem ler); fr. gravure; outwashed, enchurrada provocada por desgelo; to wash out, apagar, perder a cor; aluviada: anuviada + aluvião;

\footnotetext{
${ }^{260}$ Esse jogo de palavras é uma das formas pelas quais o ideograma evolui da simples representação do objeto para o fonema. Os lingüistas até o século XVIII acreditavam que os hieróglifos egípcios fossem simples ideogramas pictóricos; coube a Champollion demonstrar que eram, na maior parte, fonemas silábicos.

${ }^{261}$ Canção de William Percy French (1854-1920).

262 Joyce afirmava que a linguagem que usou é estranha porque pretende representar a linguagem dos sonhos, mas prometia que, pela manhã, devolveria aos leitores o inglês deles (cf. ELLMANN, 1983, p. 456). É o que ele está dizendo também nessa passagem. Finnegans Wake é um livro escrito numa língua peculiar que tem por fundo o inglês. A tradução procura fazer algo parecido, mantendo o substrato português. Por isso o leitor estranharia se lhe disséssemos que lhes devolveríamos o inglês. Que inglês? Curiosamente, todas as traduções que compulsamos para essa passagem verteram para suas línguas o termo english literalmente.

${ }^{263}$ Michael Joseph MacManus (1888-1951). Editor e escritor irlandês, autor de A Green Jackdaw, A Jackdaw in Dublin e vários livros de poesia como Connaught Songs e Rackrent Hall. MacManus era um desafeto de Joyce e ridicularizava o que Joyce escrevia.
} 
013.08 Inn; illkempt, unkempt (desarranjado, despenteado); innkeeper, taberneiro; chapel, capela; shuffler (pessoa que arrasta os pés);

013.09 Musical; magical; mire, lama, barro; ouuindo, ouvindo (port. séc. XIII);

013.10 Lat. murus; moor, mouro (?); fr. gravure; grave, túmulo; morentalha: mouro + mortalha + entalha;

013.11 Buried, enterrado; blur, borrado, apagado, sujo; toll mens: homens altos (inf. "homões", homenzarrões); Ptolomeu faz um relato sobre a Irlanda (150 d. C.); dólmen; cornualhês toll, buraco; íncubo; inca; fr. prétendant;

013.12 Tender; pretend, fingir; pretendente (os que se acercam da casa de Ulisses; pretendentes de Penélope); Gênesis IV, 21: "Jubal: he was the father of all such as handle the harp and organ" (O nome de seu irmão foi Jubal que foi pai dos que tocam cítara e órgão);

\subsection{Exhausted;}

013.13 Listener, ouvinte; Feardorcha O'Farrelly: poeta irlandês do século XVIII ${ }^{264}$; Lóqui: deus do panteão nórdico (figura inconstante: às vezes aparece como maléfico, outras como brincalhão e como conselheiro dos deuses);

013.14 LM earleye; ponte Butt, Dublim; butt, cu; bútico: butico (ânus); DBLN=32, WKOO=64 (soma do valor das letras de acordo com a ordem delas no abecedário inglês: A-Z = 1-26); Debele: paron. Dbln (soma = 32, no abecedário português); Sonara: sonora, sonata, soara (soma =64); WKOO: "Well-Known Optophone which Ontophanes" (linha 16); O' Hear (patronímico irlandês forjado; 045.04); O' Yes: esp. oyes, ouves; mausoleum; Magazine Wall;

013.15 Finn; LM Carta: grand funeral/fun-for-all; fanfarra: típica nos funerais de Nova Orleãs (Estados Unidos);

013.16 Optofone: instrumento inventado em 1914 por E. E. Fournier D'Albe, que permitia aos cegos ler; uma luz traduzia os caracteres impressos para uma combinação de sons (um dos dispositivos do instrumento chama-se ponte de Wheatstone ${ }^{265}$ ); gr. onto-: ser, realidade; phaino, mostra; Liszt ${ }^{266}$; listania: litania (em lugar do imperativo de ouvir, listen) + Liszt; a lira mágica de Wheatstone (caixa em forma de lira pela qual passavam as vibrações do piano, dando a impressão de que a caixa tocava sozinha);

\footnotetext{
${ }^{264}$ Poeta nascido no Ulster (morto em 1746). Era amigo do harpista O'Carolan, para quem escreveu versos em gaélico.

${ }^{265}$ Aparelho usado para medir resistências elétricas, inventado em 1872 por Sir Charles Wheatstone.

${ }^{266}$ Ferenc (Franz) Liszt (1811-1886). Um dos maiores compositores e pianistas do século XIX.
} 
013.17 "Struggling for Ivor"; pron. anglo-irl. /foriver/: forever; river; cat. per sempre; líquens em pedras desgastadas (weathered); † lich: body;

013.18 "Listening for Olaf “; cat. per tot, por tudo; Tote: deus egípcio; din. forover, doravante; forever; al. vorüber, passado; harpsichord (cravo) + discord; espineta;

013.19 Anglo-irl. ollav, sábio;

Sinopse: O livro da história - principais personagens;

013.20 Hereditariedade; Heródoto: historiador grego; LM 4 evangelistas (personagem: Mamalujo [Acrônimo de Mateus, Marcos, Lucas e João]) ( X );

013.21 Anais dos Quatro Mestres (escrito em Donegal, chamada de Boreum por Ptolomeu); Blue Books: relatórios oficiais do Parlamento Inglês; gír. blue, triste; Só de António Nobre: "O livro mais triste que há em Portugal";

013.22 Irl. baile, cidade; nor. f. t.: for tiden, na presente; four things (abreviação comum nas crônicas irlandeses medievais); Dyfflinarskidi: território em torno da Dublim nórdica;

\subsection{Al. vier, quatro $(X)$;}

013.24 Portuguese um; gír. umpty, umpteen, muito, grande número; teetotum (orig. T. totum): jogo que consiste em girar um disco para tirar a sorte; gr. tautotêtes, semelhança; lat. toties, tantas vezes; unum, um; meses judaicos: 1. Nisan; 4. Tammuz; 8. Marchesvan; 12. Adar; m; monte Ben Bulben, subdistrito de Sligo; hump, corcova (LM Humpty-Dumpty);

013.25 LM Ay, ay!; lat. duum, dos dois; irl. suan, sono; Shaun; anglo-irl. "poor old woman” (poético); ALP ( $\triangle$ ) é a pobre mulher; irl. púir: que provoca compaixão;

013.26 Votam: Odim; LM Ah, ho! lat. trium, dos três; $\dashv$; Goldsmith ${ }^{267}$ : The Deserted Village 1: "Sweet Auburn!" auburn, castanho, baio; maid, donzela; o'brine: O'Briain (descendente de Brian Boru); devoto de Santa Brígida; esp. novia, noiva;

013.27 Pron. anglo-irl. /desarted/: deserted; despojar: troc. desposar; Dysart O Dea, subdistrito de Clare; irl. Cill a' Díseart: igreja do retiro; LM Adear, adear! irl. Áth-Daire /ádare/: subdistrito de Adare, Limerick (subdistrito de O'Briain); desarted. Adear: irl. “Díseart Uí Deaghaidh”/díshart í d'ayí/: Dysart O Dea, subdistrito de Clare; lat. quodlibet: como queira; March (março) e Cheshvan; Marcheshvan: amargo Cheshvan (013.24);

013.28 LM pen/post $(\sqsubset / \wedge)$; Bulwer-Lytton ${ }^{268}$ : "The pen is mightier than the sword"

\footnotetext{
${ }^{267}$ Oliver Goldsmith (1730-1728). Escritor, historiador e naturalista irlandês, autor de The Vicar of Wakefield, She Stoops to Conquer e The Deserted Village, entre outras obras.
} 
013.28 LM And so. And all. Flood: Ireland, Its Saints and Scholars 10: "O rei Niall dos Nove Reféns fez várias incursões contra os povos das Gálias e da Britânia. Entre os prisioneiros... estava Succoth, um rapaz de dezesseis anos... mais tarde chamado Patrício, provavelmente em referência ao seu nobre nascimento"; Succoth: Festa do Tabernáculo (festa da colheita);

Sinopse: Folhas do tempo - quatro registros dos anais;

013.29 Lat. innocens, inofencivo; Anacleto II, antipapa, opôs-se a Inocêncio II, que foi papa entre 1130-1138;

013.30 "Leaves of The Book of the Dead" (Livro dos mortos [do Antigo Egito], na tradução de Budge ${ }^{269}$ ); "book of deeds": livro de façanhas;

013.31 Annals of the Four Masters;

013.32 Grand National (corrida de cavalos); fr. facile; al. Passah, páscoa judaica; Faß, barril;

013.33 LM 1132 (1132 d. C. Nascimento de São Lourenço O'Tolle; 11h32min: início da ação do livro $\left.{ }^{270}\right) ; 1(\Pi) 1(\Delta) 3(\wedge / \subset$ ) $2(\dashv \vdash)$; John O'Donovan, ed.: Annals of the Kingdom of Ireland, by the Four Masters (ou Annals of the Four Masters), I, 119: "The Age of Christ, 283... Finn... fell... upon the Boinn" (ou seja, a morte de Finn MacCool em 283 d. C.; 283 x 4 = 1132); John O'Hanlon: The Life of Saint Laurence O'Toole, Archbishop of Dublin (1857), 11: "Laurence ou Lorcan O'Toole nasceu no ano 1132, ou, quem sabe, antes mesmo dessa data"; 11 (primeiro número da nova década: renovação) 32 (aceleração da gravidade em pés por segundo); $\mathrm{m}$; Thom's Directory of Ireland/Dublin, Dublin Annals section 1331: "Uma grande penúria foi aliviada por um prodigioso cardume de peixes, chamados de Turlehydes $^{271}$ (baleias), lançados à costa perto da desembocadura do Dodder $^{272}$. Tinham entre nove e doze metros de comprimento e eram tão grossos que um homem que estivesse de um dos lados do peixe não podia ver ninguém que estivesse do outro. Mais de

\footnotetext{
${ }^{268}$ Edward George Bulwer-Lytton, Primeiro Barão de Lytton (1803-1873), político e escritor inglês. Autor de The Last Days of Pompeii. Famoso pela frase "a pena é mais poderosa do que a espada".

${ }^{269}$ Sir Ernest Alfred Thompson Wallis Budge (1857-1934). Egiptólogo, orientalista e filólogo inglês que trabalhava no Museu Britânico. Traduziu o Livro dos mortos, coleção dos pergaminhos que eram colocados junto ao corpo do morto a ser embalçamado.

${ }^{270}$ Este número tem vários significados na obra. Ver CAMPBELL; RoBinson, 1976, p. 45.

${ }^{271}$ A única referência impressa desse termo está no livro que o menciona aqui. Trata-se do thurlhead (thurlepolle) ou thirlepoll, uma espécie de baleia; o nome se deve ao buraco (thirl) redondo que esses mamíferos (então chamados de peixes) têm no alto (pole) da cabeça, por onde esguicham água.

${ }^{272}$ Rio Dodder (irl. Dothra), nasce nos Montes Wicklow, a vinte kilômetros de Tallagh, e, nos subúrbio de Dublim, deságua no Liffey.
} 
duzentos deles foram mortos pelo povo."; † emmet: ant (formiga); ata: Atta (gênero da saúva); fórmico: rel. a formiga; wondering; al. wandern, vaguear; neer. groot, grande, amplo; levigatar: diluir (dilúvio, linha 36); grunas: grutas;

013.34 Din. hvid, branco; cetáceo; corrunam: correm + runa; (Moby Dick?); al. Walfisch, baleia; din. fisk, peixe; blubber, inchado (olho), chorar; Eblana: denominação dada por Ptolomeu a Dublim; LM Ciclos viquianos; 566 × 2 = 1132 ( $L M$ 1132); (566 é a metade de 1132: Eva é a metade [a outra parte] de Adão); $\Delta$; din. baal, fogueira; Baal: baalim, deus cananeu da fertilidade; antigo ritual irlandês do fogo de Baal (ao anoitecer do $1^{\circ}$ de maio); fr. nuit, noite; sue. bål, fogueira; it. falò, fogueira; Luís XV: “depois de mim, o dilúvio”; pósdiluviano; gr. khronos, tempo; it. corona;

\section{p. 14}

014.01 "Wicked wish" (desejo mesquinho); anglo-irl. kish: "cesta de vime"; nome de um navio farol, ancorado na baía de Dublim; pai de Saul (Bíblia: Quis ou Cis, em português) ${ }^{273}$; turves: turf + turd (merda) + curves; looked;

014.02 Anúncio publicado no Irish Independent (23 Jan 1924, 1/6): "McGuires Great Sale Offers": "Unbleached Twill Sheets. 1,500 pairs of Good Blay Sheets for Single Beds. Sale Price Each... 2/3" [Lençóis de sarja sem branquear. 1500 jogos de finos lençóis sem branquear para camas de solteiro. Preço unitário...]; existe uma brincadeira com o nome gaélico de Dublim (Baile Átha Cliath [pron. /blaacli ${ }^{274}$ : lit. Cidade da vau fortificada): "Baile Átha Cise": Cidade da vau dos artesãos de vime (Town of the Ford of the Wickerwork [/blaaquich/]; Sote (Sothis): nome egípcio de Sírio, estrela da constelação de Ísis (irmã e esposa de Osíris), que se levanta no início do ano sagrado egípcio; satisfy; al. Feige: vagina; feige: de forma covarde; cow: a vaca era consagrada para Ísis; cisto: Cis + cesto; salgário: salgueiro, vime; prena: prenha + plena;

014.03 Pron. anglo-irl. sawl: soul, alma; Saul; herself; rua Sackville (hoje, rua O'Connell); sackful, taleiga (saco para mantimentos); nor. "svart gode": "poderoso deus";

014.04 "Goody Two-Shoes": carochinha anônima do século XVIII, atribuída a Oliver Goldsmith, sobre uma criança que ficou tão contente de ter ganho sapatos novos que saía pelas ruas gritando: 'Two shoes!' (dois sapatos); “quicken tree”: sorveira; pron. anglo-irl. illigant: elegante; anglo-irl. "ignorant as a kish of brogues" (tão ignorante quanto um cesto

\footnotetext{
${ }^{273} 1$ Samuel IX, 3 ou 1 Crônicas (Paralipômenos), IX, 39. Nome citado em 5 livros e 17 versículos.

${ }^{274}$ Sempre que houver, a indicação de pronúncia seguirá a fonética do português.
} 
de brogues [brogue, neste caso, é o próprio irlandês; significa aquele que tem sotaque acentuado]); anglo-irl. brogues, sapatos; canção "Finnegan's Wake" 1: "He'd a beautiful brogue, so rich and sweet"; sudourudas: sudor + ourudas (ricas);

014.05 Ir. "Baile Átha Cliath": ver 014.02;

014.06 (Morte de Finn - ano 566);

014.07566 × 2 = 1132 (LM 1132); $\dashv$; al. lockt: atrai; aquiescer: dormir + consentir;

014.08 Esp. "sobre las olas”: Camões; "Sôbolos rios que vão...”; al. Puppe: boneca; cat. moyica; Swift a Stella: "Ppt";

014.09 "Pia e pura bella": guerras religiosas na Idade Heróica de Vico; prepúcio = europeu; gr. peos, pênis; anglo-irl. "bloody wars!” Baile Átha Cliath; “crivada de balas”;

014.11 LM 1132; $1132566566 \quad 1132=3396 ; 3 \quad 3 \quad 9 \quad 6=21$ (Número cabalístico da queda); $\sqsubset$ e $\wedge$;

014.12 LM Caddy/Primas ( $\sqsubset / \wedge$ ): Shem e Shaun; cadet: caçula; primal [-born]: primogênito; cantiga infantil: "Saint Patrick Was a Gentleman and came of decent people";

014.13 Santry: subdistrito de Dublim; sentinela; traladava: conduzia + it. trasladare, furar (drill);

014.14 Vini Culá (canção napol. Funiculì, funiculă”: Funiculì é o trenzinho que sobe o Vesúvio): ref. a Nápoles, cidade de Vico; vinícola; cantiga infantil: "Taffy came to my house and stole a piece of beef"; $L M A / O$; 'o peace', uma farsa; war and peace: romance de Tolstói; Bellas: bela + bellum (lat. guerra) ${ }^{275}$;

Sinopse: O escriba fugitivo - a mudança de tempos;

014.16 Nos Eddas noruegueses, o Ginnunga-gap ("Intervalo de bocejo") é um intervalo sem tempo nem forma entre os éons [éon $=432$ mil anos]; Sullivan ${ }^{276}:$ O livro de Kells 11: "the larger figure was a later addition in order to fill a space left vacant when the original artist had touched the Manuscript for the last time... we can almost see from the illumination itself the very place where he was hurried from his work" [a figura maior é uma adição tardia, feita para preencher um espaço deixado pelo artista original... quase podemos enxergar nas

\footnotetext{
${ }^{275}$ A frase "Blotty words for Dublin" faz um jogo de palavras com "Bloody wars in Ballyaughacleeaghbally", da linha 9. Mais que um jogo de palavras, é uma guerra de palavras.

${ }^{276}$ Sir Edward Sullivan publicou uma edição anotada do Livro de Kells que foi utilizada por Joyce para a composição de algumas passagens de Finnegans Wake. ed. Memoirs [de Buck Whaley] (1906); ed., Book of Kells described... with 24 plates, (London: The Studio 1914; eds. 1920, 1925); ed., com R. Y. Tyrrell, Echoes from Kottabos (Grant Richard Lon. 1906).
} 
iluminuras o ponto em que o artista teve de apressar o trabalho]; O livro de Kells nunca foi terminado; antediluviano; Anno Domini;

041.17 Ana Lívia;

014.18 Port. ant. purgaminho (1365); texto não expurgado; ECH (LM HCE); Esbordou-se Como Havia; elk, alce: alçou-se; sultrup: sátrapa (vassalo persa; tirano);

014.19 Jespersen: The Growth and Structure of the English Language 164 (seção 162): “Old English had various methods of forming nouns to denote agents... from... wyrhta 'wright' (in wheelwright, etc.)" [O inglês antigo tinha vários métodos de formação de nominativos para denotar agentes... de... wyrtha (formou-se) "wright" (artesão), como em wheelwright (consertador de rodas), etc. $]^{277}$; lat. excelsissimus; empyrean: o Empíreo (local onde se criaram os anjos); bolt, trovão; Montesuma;

014.20 Earthquake, terremoto, sismo; anglo-irl. Dannyman: informante (do nome de Danny Mann, personagem do romance de Gerald Griffin ${ }^{278}$ The Collegians, 1829); Danny Mann, personagem corcunda da obra de Boucicault ${ }^{279}$ The Colleen Bawn; Dane, dinamarquês; pan: upon; bloody; Biddy Doran: uma galinha; ruteno duren: idiota; din. døren, porta;

014.21 Gwynn ${ }^{280}$ : The History of Ireland 25: "the law which laid down that killing should be atoned for by a fine, legally fixed - as was the usage in Ireland so long as the native law lasted... It was followed through all Scandinavia throughout the Middle Ages, and although it has been described as barbarous, it is less so than the excessive use of capital punishment characteristic of English law, under which even in the nineteenth century pocket-picking or sheep-stealing was punishable with death" [a lei que determinou que o assassinato deveria ser

\footnotetext{
${ }^{277}$ Jens Otto Harry Jespersen (1860-1943). Lingüista dinamarquês especializado na gramática da língua inglesa. O livro mencionado é de 1905.

278 Gerald Griffin (1803-1840) escritor irlandês de Limerick. Pouco antes de morrer queimou todos os manuscritos de suas obras inéditas e juntou-se a uma ordem religiosa em Cork.

279 Dionysius Lardner Boursiquot (c.1820-1890). Ator e dramaturgo irlandês. London Assurance (1841); Old Heads and Young Hearts (1844); The School for Scheming (1847); The Corsican Brothers (1852); The Vampire (1852); Louis XI (1855); The Octoroon or Life in Louisiana (1859); The Colleen Bawn or The Brides of Garryowen (1860); Arrah-na-Pogue (1864); Rip van Winkle or The Sleep of Twenty Years (1866); After Dark: A Tale of London Life (1868); The Shaughraun (1874); The Jilt (1885); The Poor of New York (1857).

${ }^{280}$ Stephen Lucius Gwynn (1864 1950). Escritor e político irlandês; autor de diversas biografias. Tennyson (1899); The Decay of Sensibility (1900); The Old Knowledge (1901); Henry Grattan and his Times (1904); The Masters of English Literature (1904); Thomas Moore (1905); The Fair Hills of Ireland (1906); The Case for Home Rule (1911); Robert Emmet: A Historical Romance (1909); Battle Songs for the Irish Brigade (1915); John Redmond's Last Years (1919); The Irish Situation (1921); History of Ireland (1923); Collected Poems (1923); Ireland (1924); Experiences of a Literary Man (autobiografia) (1926); Praise of France (1927); Ulster, Munster, Leinster (1930); The Life of Mary Kingsley (1930); Sir Walter Scott (1930); The Life of Horace Walpole (1932); The Life and Friendship of Dean Swift (1933); Oliver Goldsmith (1935); Robert Louis Stevenson (1939); Salute to Valour (1941); Aftermath (1946).
} 
penalizado com uma multa, fixada legalmente - como foi costume na Irlanda pelo tempo que a lei nativa perdurou... Ela foi seguida por toda a Escandinávia e durante toda a Idade Média, e apesar de descrita como bárbara, é menos excessiva do que a pena capital, característica do Direito inglês, à qual, durante o século XIX, até mesmo um batedor de carteiras ou um ladrão de ovelhas estava sujeito]; (anteriormente, um assassino tinha de pagar uma multa em dinheiro pelo crime; hoje, um ladrão é executado por ter roubado a mesma quantia); scribecide: matador de escribas; cat. aleshores, então; comunhecou-se: comunicou-se, comunhou;

014.22 Fine, multa; five; cincoimado: cinco + coima (multa); Marco: divisa de diversos países; ninepence; por ter matado o copista; androssíderos: gr. andrós (homem) + sideros (ferro);

014.23 Neighbour's; O. Henry ${ }^{281}$ : The Four Million: “An Adjustment of Nature': 'And then Milly loomed up with a thousand dishes on her bare arm... And the Klondiker threw down his pelts and nuggets as dross, and let his jaw fall half-way, and stared at her"; dross, impureza; ing. amer. boss (datação: a.1649), patrão, mentor; escrimentor: escremento + mentor + escriba;

014.24 Gal. unha, uma;

014.25 Gr. gynê, mulher; lat. sine cura: sem cuidado; scaffold, patíbulo;

014.26 Êxodus 20:17: "Não cobiçarás a casa do teu próximo: não desejarás a sua mulher, nem o seu servo...” (um dos Dez Mandamentos; IX na tradição Católica Romana);

014.26 VI.B.16.092e (r): "Liam O'Flaherty Thy Neighbour's Wife 282 ;

014.27 Cat. aliena, alheia (alienada);

Sinopse: Cena pastoril - flores e campos de batalha;

014.28 Annals of the Four Masters: ${ }^{283}$ (autores) Farfassa O'Mulconry, Peregrine O'Clery, Peregrine O'Duignan, Michael O'Clery e outros; farfatch'd: farfetched, forçado; farfalha,

\footnotetext{
${ }^{281}$ William Sydney Porter (1862 -1910). Contista estado-unidense, autor de mais de 400 contos.

282 Liam O'Flaherty (1896 -1984). Romancista e contista inglês, foi o elemento mais importante do Renascimento Irlandês. Thy Neighbour's Wife (1924), The Informer (1925) [adaptado pelo cinema: The Informer, 1935], Mr. Gilhooley (1926), The Return of the Brute (1929), Short Stories (1937), Famine (1937), Land (1946), Two Lovely Beasts and Other Stories (1950), Insurrection (1951), The Pedlar's Revenge and Other Stories (1976).

${ }^{283}$ Anais do reino da Irlanda (Annala Rioghachta Éireann) ou Anais dos quatro mestres (Annala na gCeithre Mháistrí) Annala Rioghachta Éireann. Crônicas da história medieval da Irlanda (compilação, em parte, de crônicas antigas), escritas entre 1632 e 1636, em um mosteiro franciscano em Donegal. Abrange a História desde o dilúvio (1616 a. C.) até 550 d. C.
} 
barulho (a cena pastoril apresenta-se em meio a uma batalha); lat. peregrinus: estrangeiro; paragration, revolução sideral da lua; Peregrine Pickle: The Adventures of Peregrine Pickle por Tobias Smollett ${ }^{284}$; ordinant: o que ordena;

\subsection{LM earleye (ouvidos/olhos);}

014.29 Latin “liber lividus”: livro azul; ${ }^{285}$ Tito Lívio; Levítico; lívido, sereno;

014.30 It. toh!: veja! fr. paisible, pacífico; possivelmente; eirenic, pacífico; irônico; stretches, estica, extende; glimmering, tênue, débil; Dämmerung, crepúsculo (ref. à ópera de Wagner Götterdämmerung);

014.31 Gloamering: gloam (entardecer, escuro) + glimmering; din. faedreland, pátria; nor. fred, paz; as cinco províncias da Irlanda dos primórdios do cristianismo estão enumeradas nas próximas cinco frases do livro (entre "Lean neath stone [014.32] e “donkey's year" [014.35]): Ulster, Munster, Leinster, Connact e Tara ${ }^{286}$ (os dois condados dentro de Leinster); "freed land", terra livre; afore: before; cat. davante; nosaltres, nós; devanceira: gal. devanceiro, pai, antepassado (ribanceira);

014.32 "Lying beneath"; "lean neath stone pine the pastor lies": Shakespeare, The Tempest (Ato I, cena 2; cantiga de Ariel): "Full fathom five thy father lies" (Full fadom fiue thy Father lies) [Cinco braças abaixo teu pai repousa] ${ }^{287}$; "pine tree", pinheiro; stone pine, pinheiro-manso [Pinuns pinea L.] ( $L M$ árvore/pedra; a árvore é Shem, por causa da semelhança de seu nome com stem, caule; a pedra é Shaun, pois a pronúncia desse nome, /chon/ é semelhante à pronúncia de stone, pedra; a combinação dos dois gêmeos, ou a sua fusão, resulta em Tristão: tree-stone): fr. gír. pine. pênis ; pastoril; gír. prick, pênis; pricket, gamo de dois anos; há um rebanho de gamos no Parque Phoenix, de Dublim: dessa forma, a frase iniciada com pricket, no final da linha, refere-se à segunda província da Irlanda, Leinster, onde fica Dublim; outras espécies de ruminantes mencionadas aqui: Dik Dik

\footnotetext{
${ }^{284}$ Tobias George Smollett (bat. 1721 -1771). Escritor escocês, autor de romances picarescos como The Adventures of Roderick Random (1748) e The Adventures of Peregrine Pickle (1753). Do herói do romance de viagens, The Expedition of Humphry Clinker (1771), James Joyce tirou o nome da personagem central de Finnegans Wake: Humphrey Chimpden Earwicker.

${ }^{285}$ Quando Ulysses foi publicado pela primeira vez, tinha uma sobrecapa azul (cor da bandeira grega). Foi classificado, pela censura, como "livro-azul", obsceno.

${ }^{286}$ Os dois condados modernos de Meath e Westmeath, hoje em Leister, representam aproximadamente a região da província de Tara. A palavra irlandesa para "província" era a mesma usada para designar "quinto": coiced (hoje, cúigiú).

${ }^{287}$ Um dos motivos da obra. É uma referência ao lugar onde HCE será sepultado. A cantiga de Ariel fala de um homem que foi sepultado no fundo do mar, como HCE.
} 
(Madoqua - antílope), Eland (Taurotragus - bovídeo), Elk (alce - cervídeo) e Hind (corça cervídeo);

014.33 "Pricket's sister" $\rightarrow$ Issy; nibble, mordiscar; virility: lat. viriditas, verdura, frescor; amid, no meio de; irl. amaid, mulher estúpida; "a maid" $\rightarrow$ Issy; avestou-a: avistou-a = vestal;

014.34 "Looking glasses", espelhos ${ }^{288}$; "herb trinity shams" (shamrock, trevo; Shaun, rock, stone): há uma lenda que diz que São Patrício usava o trevo (trifólio) para esplicar a Santíssima Trindade); o trevo é o símbolo informal da Irlanda;

014.35 Leader 15 Mar 1924, 134/1: “As Others See Us: 'S' donkey's years since I've had a yap with you old man" [Como os outros nos vêem: Faz anos que não bato um papo contigo, meu velho]; “donkey's years”: muito tempo; gal. así; tamén;

\subsection{LM “Aujourd'hui comme aux...” (Quinet) ${ }^{289}[014.35-015.11]$ [281.04-13] $]^{290}$}

014.35 Fr. gír. bout: pênis; he-bear, urso; Éber e Éremon: pais da raça irlandesa; "skyup is of everygrey": Connacht, a quarta província, a mais úmida e verde de todas; o asno (donkey), que sempre acompanhava os Quatro Mestres, representa a quinta província, Tara;

014.36 Gênesis XXVII, 11: “.. meu irmão Esaú tem o corpo cheio de pêlo (hairy)...”; cornflower: irl. gormán, centáurea azul ou cinerária (Centaurea cineraria); Ballymun: subdistrito ao norte de Dublim;

\section{p. 15}

015.01 Dog-rose, rosa-mosqueta, agalancéia; muskrose; Goatstown: subdistrito de Dublim; tulips;

\footnotetext{
${ }^{288}$ Referência à obra de Lewis Carroll, Through the Looking Glass e, também, à vaidade de Issy, em cujo espelho reflete-se sua personalidade dividida (alusão à esquizofrenia da própria filha de Joyce, Lucia).

${ }^{289}$ Edgar Quinet (1803 - 1875). Intelectual e historiador francês. O ensaio Introduction à la Philosophie de l'Histoire de l'Humanité, em que Quinet dicute a filosofia da História de Vico e de Herder, foi utilizado por Joyce na composição de Finnegans Wake [ver ATHERTON, 1973, p. 34].

${ }^{290}$ Desta frase, "Since the bouts of Hebear..." [014.35], até “... on the eve of Killallwho [015.11], Joyce parodia um trecho do ensaio de Quinet: "Aujourd'hui comme aux temps de Pline et de Columelle la jacinthe se plait dans les Gaules, la pervenche en Illyrie, la marguérite sur les ruines de Numance et pendant qu'autour d'elles les villes ont change de maîtres et de noms, que plusieurs sont entrées dans le néant, que les civilisations se sont choquées et brisées, leurs paisibles générations ont traversé les âges et sont arrivées jusqu'à nous, fraîches et riantes comme aux jours des batailles. " [Hoje, como no tempo de Plínio e de Columelo, o jacinto viceja nas Gálias, a malva na Ilíria e a margarida sobre as ruínas de Numância; e enquanto as cidades ao redor delas mudaram de nome e de senhores, e algumas desapareceram, e civilizações se enfrentaram e se destruíram, as pacíficas gerações daquelas flores atravessaram as eras e chegaram até nós, frescas e afáveis, como nos dias das batalhas.] (ELLMANN, 1983, p. 664; HART, 1962, p. 184)
} 
015.02 Together; sweet rush, junco; Rush, povoado no condado de Dublim, onde se cultiva tulipas (conhecido com "Holanda na Irlanda"); townlands: áreas de terras na Irlanda; twilight, crepúsculo; lat. urbs, cidade;

015.03 Variegated, variadas; Moyvalley, povoado no condado de Kildare (pelo rio Liffey; a palavra vem do irl. Magh Bhealaigh: Planície do Caminho);

015.04 Colina de Knockmaroon no Parque Phoenix (passagem oeste do parque); al. rings 'rum, de todas as direções;

015.05 Chiliad: mil anos; perihelion, periélio; Ilíada; Edmond Sexton Pery e John HelyHutchinson: membros do Parlamento irlandês no século XVIII; Tim Healy: oponente político de Parnell; al. Gang: caminhada; Fomorianos e Tuatha Dé Danaan: lendários antagonistas; colonizadores irlandeses; battled, [batalha] travada;

015.06 Ostman ${ }^{291}$ : viquingues (ocupação de Dublim); Firbolgs ${ }^{292}$ : lendários colonizadores da Irlanda; gír. firebug, piromaníaco;

015.07 Jutões: da Jutlândia (Dinamarca); Joynts: giants; Tipperary: div. admin. da Irlanda (Tiobraid Árann); LM Jerry/Kevin ( $\sqsubset / \wedge$; Jerry, apocorístico de Jeremias; cognato do irl. Diarmaid; Kevin: cognato do gr. Eugenios); Joynts (Joyce: HCE) have thrown up (vomitou) jerry and kevin: Saturno vomitou os filhos que havia comido; to the Kevan-: "to the heavens"; Celesquévia: celeste + Kevin;

015.08 Little Green Market, Dublin; zilionitos: rus. ziliônii (verde) + suf. dim. -ito; William Wordsworth ${ }^{293}$ : "My Heart Leaps Up When I Behold": "The Child is father to the Man"; "hear hear!": interjeição comum, anotada entre parênteses, no Blue Book (livro de procedimentos do Parlamento); laughtears: laughter + tears; gal. devanceiro, pai, ancestral; buttonholes: flor usada na lapela;

015.09 Lat. pax; chec. pach, feder; "peace pact sealed" (acordo de paz selado);

015.10 Querelled, brigado;

\footnotetext{
291 Oxmen: segundo o Book of Invasions, os seguidores de Partholón teriam sido so primeiros a invadir a Irlanda depois do Dilúvio, mas ali encontraram os fomorianos. Seathrún Céitinn (Geoffrey Keating) relata uma tradição segundo a qual os fomorianos, liderados por Cíocal, haviam chegado duzentos anos antes e viviam da pesca e da caça até à chegada dos partholianos, que traziam consigo o arado e o gado.

${ }^{292}$ Foram derrotados pelos Tuatha Dé Danann na Primeira Batalha Moytura. Ao nome foram atribuídos diversos significados, de acordo com a etimologia: "homens com sacos", "homens com lanças", "homens do trovão". Foram relacionados com os belgas (celtas) mencionados nos Commentarii de César.

${ }^{293}$ William Wordsworth (1770-1850). Poeta inglês. Publicou as Lyrical Ballads com Samuel Taylor Coleridge.
} 
015.11 Maid-os-all-work: ant. criada; Killaloe: cidade do Condado de Clare: local do palácio de Brian Boru;

Sinopse: A mutabilidade dos homens - a perenidade das flores;

015.12 Torre de Babel; tongues, línguas; irl. teanga, língua; Deus diversificou as línguas para provocar confusão entre os homens (Gênesis XI, 9); Thing Mote: local da assembléia viquingue em Dublim, situada no cruzamento da Suffolk com a Church; Confúcio (Kung-FuTsu);

015.13 Din. tigge, rogar; irl. "tuigeann tú”?: entendes? Houyhnhnms: eqüinos inteligentes: habitantes de um dos países visitados por Gulliver nas Gulliver's Travels de Swift; onomat. relincho;

015.14 Hymn, hino; nor. Norge, Noruega; coloq. gal: girl; powerful; fr. "parlez-vous français?";

015.15 Fr. fiancée, noiva; thought, pensaram; irl. tá: é, são (com freq. no começo de sentenças); it. sussurrare;

015.16 It. bionda, loira; fr. brune, it. bruna, morena; os invasores loiros (noruegueses) desejaram as mulheres morenas (irlandesas); no original, há uma seqüência de línguas: irl., it., nor. e fr., desde a linha 13; din. "elsker du mig, min kare pige?”: "Tu me amas, minha querida moça?" LM Jerry/Kevin; al. dunkel, escuro; elóscula: "ela oscula" (adj. substantivado);

015.17 A Irlanda, do século VIII ao XI, foi varrida por hordas de "estrangeiros escuros" (dinamarqueses) e "estrangeiros claros" (noruegueses); countered with: † "met with" (encontrou-se com); al. hell, claro, brilhante;

015.18 Fr. “où est ton cadeau, espèce d'imbécile?”: “onde está o teu presente, imbecil?”; space; espécie;

015.19 Upon; sôbolos, "sobre os"; cat. altres, outros;

015.20 Nowanights: nowadays, "hoje em dia"; Flora: deusa romana celebrada num festival licencioso em 28 de abril (Floralia); by nights of yore: "by days of yore" (antigamente); Flora: personagem de Little Dorrit, de Charles Dickens; flora e fauna; Mateus VI, 28: "considerai como crescem os lírios do campo"294;

${ }^{294}$ Há um romance de Érico Veríssimo com este nome: Olhai os lírios do campo (1938). 
015.21 Shyfaun: Sinn Fein (grupo político que lutou pela independência da Irlanda; hoje, braço político do IRA); fauno; call; it. culo, bunda, cu; "call me ere I will to thee"; "cull (fuck in the ass) me here, and I will wilt (definharei) with you";

015.22 Pluck: fuck, vb. foda; it. dopo, depois; sp. ellos [pron. /elhos/];

015.23 Be troth: bethrothed, noivo; ${ }^{295}$

015.24 “Old as the hills" (velho como os montes); din. lave, fazer; fr. laver, lavar; lay, deitar;

015.25 "Finnegan's Wake" (coro): "Whack fol the dah, dance to your partner, Welt the flure, yer trotters shake, Wasn't it the truth I told you Lots of fun at Finnegan's Wake" (orig. Poole: "Whack, hurrah! blood and 'ounds, ye sowl ye! Welt the flure, yer trotters shake; Isn't it the truth I've tould ye Lots of fun at Finigan's wake!"); pron. de Ulster: tallin: telling, dizer; Fins and flippers (barbatanas e nadadeiras);

015.26 Shiver and shake (treme e chacoalha): filme de 1922 do diretor J. A. Howe (mais tarde, virou história em quadrinhos e música do conjunto The Cure); "Welt the flure, yer trotters shake"; Tim Timmycan: Tim Finnegan, "tin can" (lata); tímpanos (instrumento musical); tempting, tentando; ME hir, her; Tam: Tim ou Tam o'Shanter (poema de Robert Burns $\left.^{296}\right)$;

015.17 Flipper; flea powder, pó inseticida contra pulgas;

015.18 Hop, lúpulo (usado na fabricação da cerveja Guinness); salto (da pulga, na cama de HCE e ALP; a pulga também está associada ao atendente da taberna de $\mathrm{HCE}^{297}$ );

Sinopse: Mutt encontra Jute - Mutt procura dirigir-se a ele;

015.29 Ir. ainm, nome; gr. anemos, vento; anem (anagrama de name); Adão (heb. adam, homem); mujica: rus. mujik, camponês (formado de mujtchin, homem + suf. -ik); carl: (†) churl, caipira, campônio; Jespersen: The Growth and Structure of the English Language, p. 156, sec. 154: "the Dutch... in South Africa... applied... kopje 'a little head or cup' to the hills"

\footnotetext{
${ }^{295}$ Possível ref. ao livro de Manzoni I promessi sposi, não apenas pelo tema do romance, mas pelo fato de Manzoni ter sido um dos sistematizadores da língua italiana e o texto acima trata da dispersão e origem das línguas;

${ }^{296}$ Robert (ou Rabbie) Burns (1759-1796). Poeta nacional escocês.

${ }^{297}$ Nos rascunhos de Joyce, ele é identificado pelo símbolo S, e relaciona-se com a serpente no Éden, com um dos policiais do Parque Fênix, com o dragão abatido por São Jorge no quadro que fica acima da cabeceira da cama de HCE e ALP (559.11-12), com um habitante autóctone da Irlanda (antes da invasão viquingue), com um símio (em uma nota dos rascunhos), com uma personagem chamada Saunderson e com o burro que acompanha os Quatro Anciãos.
} 
(from Afrikaans to English) [o neerlandês... na África do Sul... aplicava... (o termo) kopje "uma pequena chávena ou xícara" aos montes]; pelted thongs: correia de pele; corrijas: lat. corrigioa, correia; pelted, lapidado, apedrejado;

015.30 Apart; Parthalón: primeiro homem a se estabelecer na Irlanda depois do dilúvio; path alone; ( $\mathrm{S}$ ); Joseph Biggar: amigo corcunda de Parnell; bugger, sodomita; ME forshapyn, transformado ${ }^{298}$; it. forse, talvez; pig + maid (donzela); pigmeu;

015.31 Hoagshed: um barril grande; forehead, testa; shrunk, contraído; al. Plattfuss, pé chato; lockjaw, tétano; toes, artelhos;

015.32 O behold! (Contemplai!); “oh, by all that's spectral”; pectoral; mammamuscles: músculos mamários; muscles pronunciado por um gago;

015.33 Mousterian man: homem de Neanderthal (encontrado em Le Moustier, na França); mosteiro; mistério; misterioso; slaking nuncheon: beber na calva (os viquingues faziam taças do crânio de seus inimigos); esc. slake, lamber; slake, saciar; nuncheon, bebida leve;

015.34 Dragon Man: do poema de Blake ${ }^{299}$ Marriage of Heaven and Hell; dragoman, dragomano, turgimão (intérprete levantino, em geral a serviço de países europeus); ( $\mathrm{S}$ ); almost; all month; "on the qui vive” (em alerta);

015.35 Fief, feudo; Constable Sackerson ( $\mathrm{S})^{300}$; sack; junípero (gim ou genebra ${ }^{301}$ ); janeiro; fevereiro; brewery, fábrica de cerveja;

015.36 Arrack, áraque (bebida alcoólica, de origem árabe, com sabor de aniz, consumida geralmente depois de diluída em água); março; abril; it. brillo, bêbado; fr. pluviôse: mês do calendário revolucionário francês (mês das chuvas: de 20 jan a 18-19 fev);

\section{p. 16}

016.01 Al. fror: froze; fr. frimaire: terceiro mês do calendário revolucionário (21 nov - 20 dez; fr. frimas, geada); esc. medieval quhare, onde, em que; pron. anglo-irl. quare, estranho; "queer sort of man"; neer. soort, tipo, espécie; anglo-irl. mahan, urso ( S ); Mathgamain (Mathghamhain): meio-irmão de Brian Ború e rei de Munster; o nome significa "urso"; assassinado em 976, teve a morte vingada pelo irmão que assumiu o trono de Muster dois

\footnotetext{
${ }^{298}$ Usado por Chaucer, em Troilus and Criseyde, Livro 2, linha 66.

${ }^{299}$ William Blake (1757-1827). Poeta, pintor e impressor inglês.

${ }^{300}$ Ulysses (180.25): “The bear Sackerson growls in the pit near it, Paris garden."

301 O termo genebra (gim) vem do fr. genèvre, derivado do lat. junipérus, junípero (ou zimbro). Junípero (junipērus, $i<$ junīor, jovem) tem a mesma raiz de "júnior". A bebida é produzida a partir do fruto da árvore.
} 
anos depois; al. Hahn, galo; anglo-irl. miching, gazetear, fugir da escola; gír. miching, escapar; it. babbo, papai;

016.02 (fogo na entrada da caverna); afr. kraal, área cercada, curral; four defenses;

016.03 (o homen de Neanderthal roía e sugava ossos na caverna); marrow, medula, tutano; lat. cave!, cuidado! irl. maróg, barriga grande; "perhaps propose to us"; preposterous, absurdo; post us; the billowy way: o mar; the Pillory: local de punição pública na Dublim medieval, entre a rua Fishamble e a Saint Werburgh; pillar-box: caixa de correio, supostamente inventada na Irlanda pelo romancista Anthony Trollope; lat. hirculus, pequeno bode; Pilares de Hércules: Gibraltar; gr. mod. koulos, maneta;

016.04 Fr. "comment vous portez-vous aujourd'hui, mon blond monsieur?" (como tens passado hoje, meu bom loiro ${ }^{302}$ ?); porter (cerveja); “full of porter”: o servente ( $\mathrm{S}$ ) está quase sempre bêbado em FW; Porter (personagem: HCE);

016.05 Fr. "mon bon monsieur"; Charlie; Sorley Boy MacDonnell: chefe rebeldo do Ulster; it. scusi, desculpe-me; cat. llaurador, camponês; it. biondo, louro; cat. si us plau, desculpame; (Dinamarquês, escocês, norueguês, inglês, saxão, juto); din. "Taler de Dansk?" (falas dinamarquês?); You tolkatiff [talkative (tagarela) + Tolka (um dos rios de Dublim)] scowegian? (falas escocês e norueguês?); din. tolke, interpretar; gír. náutica scowegian, escandinavo;

016.06 Jespersen: Language, its Nature, Development and Origin 399 (XX.4): "Round Panama everything native is called spiggoty, because in the early days the Panamanians, when addressed, used to reply, "No spiggoty [speak] Inglis"' [No Panamá, os nativos são chamados de spigotty porque os panamenses diziam, quando alguém se dirigia a eles, "No spiggoty [speak] Inglis"]; Richard Pigott ( $\Lambda$ ), jornalista irlandês que procurou incriminar, por meio de cartas falsas, Parnell ( $\mathrm{T}$ ), em 1882, dos crimes do Parque Phoenix; sua trapaça foi descoberta durante o interrogatório por não saber soletrar a palavra hesitancy [indecisão], que escrevera "hesitency"; Angles, Saxons, Jutes: as três tribos germânicas que invadiram a Britannia nos séculos V e VI; esp. asueto, feriado;

016.07 Euphonium: instrumento musical; gr. phoneo, eu falo; saxofone; lat. saxo, saxão; Saxo Grammaticus (cronista que relata a história de Hamlet, Amleth no Gesta danorum, fonte da peça de Shakespeare); al. also, pois!; mute, mudo;

${ }^{302}$ Fionn mac Cumhail recebeu, quando moço, a alcunha de Deimne, loiro. 
016.08 Swop: swap, trocar, barganhar; "shake hands" (dar as mãos, cumprimentar); exchange; "strong and weak verbs in Germanic languages" [verbo fracos e fortes nas línguas germânicas; neste caso, o inglês antigo (OE)]; "with each other";

016.09 Leader 15 mar 1924, 134/1: “As Others See Us': 'S' donkey's years since I've had a yap with you old man" [Como os outros nos vêem: Faz muitos anos que não bato um papo contigo, meu velho]; gír. yap, conversa; haphazard, casual; "about the bloody Greeks" [a respeito dos malditos (ou sanguinários) gregos]; ablutor: que é purificado pelo banho;

016.09 Neer. bloot, nu; al. Krieg, guerra;

Sinopse: Começa o diálogo de Mutt e Jute (figura abaixo); memórias da batalha de Clontarf;

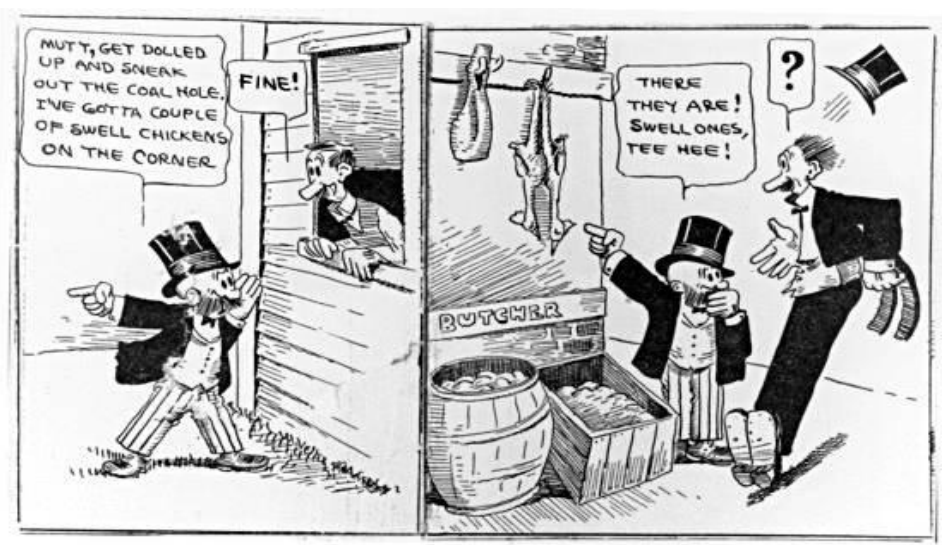

016.10 (Mutt e Jute, como homens da caverna, têm dificuldade em falar); $(\wedge)$; Jutos: tribo germânica, oriunda, provavelmente da Jutlândia, na Dinamarca; invadiu a Inglaterra no século $\mathrm{V}$ e se estabeleceu em Kent;

Mutt e Jeff: personagens de história em quadrinhos (nas quais a série $O$ gordo e o Magro se inspirou; Mutt parecia uma caricatura de James Joyce);

016.10 you there!

016.11 ( $\sqsubset$ ); “much pleasure had (at meeting you)";

016.12 Deaf, surdo;

016.13 Somewhat, um pouco;

016.15 Noah, Noé; utterer, anunciador, pessoa que passa moeda falsa; stutterer, gago;

016.16 Al. Mutter, mãe; matter, matéria, asunto;

016.17 Din. stund, instante; (Vico: a linguagem dos primeiros homens evoluiu da mudez para a gagueira, como forma de imitar o trovão, que era, para eles, a voz dos deuses); al. Stummer, mudo; stammer, gagueira;

016.18 Horrible; audible; to be coarse; to be sure; because; "how did you become a stutterer?" (como te tornaste um gago); 
016.20 Lat. apud, com; upon; bottle; battle; lat. surdus; fr. sourd; deaf; surd, estúpido; stupid;

016.21 Rio Poddle, Dublim; piddle, urinar; puddle, charco, lamaçal (Dublim); Erin;

016.22 Batalha de Clontarf, Dublim, 1014 (o Rei Brian Boru derrota os dinamarqueses, mas morre na batalha); Clontarf significa "boi do prado" e Dungtarf, bullshit, lit. "estrume de boi" (gír. bosta, besteira); "where you ought to be";

016.23 Voice; inaudible;

016.24 Al. a bisschen, um pouco; † bit-kin, um pouco; visible;

016.26 LM hesitency [016.06]; scared; Brian Boru;

016.27 Tremble; "wrath in my mind” [ódio em meu coração]; Rathmines: subdistrito de Dublim; açarçalhar: gaguejar;

016.28 "Remember him" (Moore: Irish Melodies: canção de guerra: "Remember the Glories of Brien the Brave" (Brian Boru); it. mi rimiro, olho-me;

016.29 Al. Augenblick, momento; gír. bison, moeda, trocado; "bygones are bygones" (o que passou passou); "business is business"; "two sons";

016.30 LM hesitency; "gives him coins"; "cross your palm with silver" (LM $P / Q)$; al. Trinkgeld, propina, gorjeta; "gilt trinket" (peça de outro); guilt;

016.31 Silver coin; coyne and livery: acantonamento praticado pelas Leis de Brehon ${ }^{303}$ por chefes irlandeses; "piece of eight”; "Wood's halfpence"; "guineas"; "Guinness is good for you” (publicidade);

016.33 Fr. l'ouie, ouvir; louis, luízes; it. lui, lui!: é ele! ( IT ); would; wouldn't; Wotã (Odim); indelible, inapagável; untellable, inenarrável;

016.34 great; Harald Graycloak governou o Oriente da Noruega no século X; Sitric Silkenbeard liderou os dinamarqueses na Batalha de Clontarf (algumas de suas moedas foram preservadas); silky shark: tubarão lombo preto; ir. "céad míle fáilte romhat": 100 mil bemvindos para vós (saudação tradicional irlandesa);

\footnotetext{
${ }^{303}$ As "Brehon Laws" eram estatutos que regeram a vida e política na Irlanda até a invasão normanda em 1169. No século XIII, foram retomados e continuaram a vigir paralelamente à Lei Inglesa, até o século XVII. O termo "Brehon" é uma anglicizasão de breitheamh (brithem), juiz. Os documentos foram escritos em gaélico antigo e ainda não contam com uma decifração satisfatória.
} 
016.35 Bar de Dublim; gír. bar, uma libra esterlina; grilse: salmão jovem na época que começa a voltar para a água doce;

016.36 Poached salmon, pescado de salmão; poached egg, ovos cozidos; killed; identical;

\section{P. 17}

017.01 Coyne and livery [016.31]; it. dove, onde; Liberties: subdistrito de Dublim; gr. monomachos, gladiador; Mark the First; coloq. missies, garotas; gr. mouni, vulva;

017.02 Selenos: lunares; Manneken-Pis: estátua de um menino urinando (Bruxelas); fr. gír. passe, foda;

017.03 "Killed simply because” (morto simpesmente porque); Tácito menciona a Irlanda; "to make a long story short";

017.04 Humpty Dumpty; formação do monte de estrume; emptied; "dumped the wheelbarrow of rubbish" (despejou o lixo da carriola); defecou; dial. rubbage: rubbish, lixo; cabbages, repolho;

017.05 onto; decoada: lixívia (provável origem etimológica de "lixo”);

017.06 Just like; pudding-stone: conglomerado constituído por seixos arredondados (fr. poudingue); Bruxelas; al. dial. Bruck, ponte; Celbridge (Church of the Bridge), Condado de Kildare, pelo Liffey, oeste de Dublim;

017.07 Liverpool; celebrejo: (brejo = pool); liver, fígado;

017.08 Lord Almighty, Todo-Poderoso; paludoso: palustre; pron. anglo-irl. /wid/: with; cornualhês wad, antepassado; what; noise; norueguês;

017.09 Similar to; Clontarf (área costeira, $5 \mathrm{~km}$ a NE do centro de Dublim; o nome significa: "pasto de boi"); lat. rex rerum: rei da fartura;

017.10 Rex Romae: rei de Roma; al. suíço schnore, conversa;

017.11 Canção Brian O'Linn: (fez calções com) "the skinny side out and the woolly side in"; Arthur Wellesley, Duque de Wellington; Istmo de Sutton, que une Howth ao continente; gr. isthmos, pescoço; sitting;

017.12 Black Linn: ponto mais alto de Howth;

017.13 Baldoyle e Raheny: subdistritos de Dublim;

017.13 Oil; honey, mel; al. wenn, se (conjunção); irl. beurla, inglês (língua); fr. beurre, manteiga; "barely understand a word" (mal entende uma palavra); 
017.14 Din. forstand, entendimento; sue förstånd; Sturk, em The House by the Churchyard, de le Fanu, é uma personagem que vive em Chapelizod; é golpeada no Parque Phoenix mas se recupera; start to finish (do começo ao fim); Turkish to Finnish (do turco ao finlandês línguas faladas nos limites da Europa e que não são indo-européias); finnoc, truta branca; fr. patois, dialeto;

017.15 Al. Götterdämmerung: crepúsculo dos deuses (paron. rota da merunga); mironga: mistério; neer. on-: in-; unheard of, incrível; al. umsehen, olha em volta; unseen; obscene;

017.16 Al. gut, bom; good afternoon!; "get after (behind) me”; "I'll see you damned first"; "see you soon";

Sinopse: Mutt fala das baixas; termina o diálogo de Mutt e Jute;

017.17 A dream; but; wait a second; Observatório Dunsink em Dublim;

017.18 Península [lat. pæene (quase) + insula (ilha)]; Prince Albert Island, Canadá; shall;

017.19 Moyelta: antiga planície do Elta, onde os parthalonianos morreram por causa da praga e foram sepultados; provável área adjacente a Howth, talvez ao sul de Dublim; al. Eltern, pais; meseltros: cat. mes altres, meus outros; Whimbrel and peewee (galispo): ave que aparece ocasionalmente na Ilha de Bull, em Clontarf; salting: campina inundada pela maré;

017.21 Will be; Istmo de Sutton; droit de seigneur: direito de pernada (o senhor feudal tinha o direito de passar a primeira noite de núpcias da mulher de seu feudo que se casava);

017.22 Gênesis I, 1, João I, 1: "No princípio",304; din. bygning, construção;

017.23 Finishing point; Cabo Finisterre: extremo NO da Espanha - provável origem dos celtas irlandeses;

017.23 Phoenix Park (nome derivado, provavelmente, do irl. fionn-uisge /finuíxque/, "fonte de água límpida"; Phoenix é corruptela); al. Punkt, ponto final; Moore: Irish Melodies: canção "Let Erin Remember the Days of Old [The Red Fox]"; al. Ehre, honra, glória (pl. Ehren); al. Ruhm, fama;

017.24 Merge, fundir; Chateaubriand: Euvres Choisies Illustrées I.41, Atala: "Nous passâmes auprès du tombeau d'un enfant, qui servait de limite à deux nations" [Passamos perto do túmulo de uma criança, que servia de marco fronteiriço para duas nações]; race, água corrente; sweet and brack (salgada); rus. sviet, luz; white and black; rus. brac, núpcias;

\footnotetext{
304 Gênesis: "No princípio [ב ראשית, /berechit'/; os judeus denominam o livro por essa palavra] criou Deus o céu

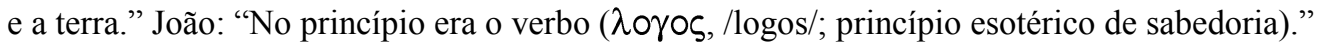


canção "Moddereen Rue" [menciona por Moore]; irl. moddereen rue: little red dog (fox) [cachorrinho ruivo: o mesmo que raposa]; The Red Fox;

017.25 HCE (LM HCE); esp. hacia acá, até aqui, para cá; fr. cracher, cuspir; crashing, bater; estuary; insurgent;

017.26 HCE (LM HCE); many men have fallen; al. niederfallen, cair;

017.27 Fr. plage, praia; al. Plage, praga; "place, thick as snowflakes”;

017.28 Neerl. waas, névoa, mancha; blizzard, nevasca;

017.29 Nor. ant. Heimskringla: A roda do mundo (saga); fr. tomber, cair; fr. monde; ing. ant. isge, gelo; "ashes to ashes, dust to dust” (das cinzas às cinzas, do pó ao pó); gr. gês, terra;

017.30 Al. e ing. ant. Erde, terra; fr. merde;

017.31 Stench, fedor; rus Smirte', morte; merda;

017.32 Lat. fiat: que seja; lat. fuit, foi; Virgílio: Eneida II.325: "Fuit Ilium" (palavras do sumo-sacerdote no momento da queda de Tróia) ${ }^{305}$;

017.32 Al. hinunter, para baixo; nor. ly, abrigo; lye, lixívia, soda cáustica; din. e neerl. smal, estreito;

017.33 Oslo; also the stranger; fr. l'étrange; Apocalipse XVII, 5: “A grande Babilônia, a mãe das devasidões e das abominações da terra"; Arnold Bennett: Grand Babylon Hotel;

$017.34 \square$ (Finn's Hotel, provável título inicial de Finnegans Wake); mús. infantil "Tit-tittittlemouse / Lived in a little house"; LM 4 elementos (terra, água, ar e fogo); opostos: $\Delta / \mathrm{m}$; ALP (LM ALP) ALPenrícula; al. Alpdruck, peadelo; Earwicker; (água e fogo); din. drukne, afogar-se;

017.35 Nor. ild, fogo; (som/visão: LM ouvido/olho); cemetery;

017.36 Al. Liebes-: de amor; Wagner: Tristão e Isolda, Ato III.3: ária “Liebestod” (morte de amor); love;

\section{p. 18}

\footnotetext{
${ }^{305}$ Na tradução de Dryden: “Troy is no more, and Ilium was a town!” Na tradução de Odorico Mendes: "Já fomos, Tróia foi-se e a glória sua" [2.338].
} 
018.01 Fr. merde!; it. morte; al. Mord, assassino; Wagner, Tristão e Isolda: "Liebestod": "Mild und leise wie er lächelt..." [Como é doce e suave o teu sorriso...] $]^{306}$; chec. śmierć, morte;

018.02 Moore, Irish Melodies: Desmond's Song: "By the Feal's wave benighted"; al. behauptet, afirmado, declarado; Slough of Despond [depressão profunda] em Pilgrim's Progress $^{307}$;

018.03 Gr. thanasimos, mortal; thanatos, morte; ancestral; gr. kestreus, faminto; swollen up, inchado; swallowed, engolido;

018.04 "This earth of ours"; tijolos (bricks) e terra vermelhos;

018.05 Lat. humus, terra; human; al. rot, vermelho; returns; Habacuque II, 2: "expõe-no com toda a clareza: para que se possa ler corretamente [até quem passa correndo]" (transformou-se em provérbio); rune-stones: runas inscritas em pedras;

018.06 Al. Rede, fala; nas armas de Dublim há três castelos; cantiga infantil: "See Saw Sacradown, Which is the way to London Town?"; Newcastle e Crumlin; † sell, dar;

018.07 Dublim; "also softly, mister"

018.08 Esp. dímelo, diga-mo;

018.09 Irl. "Bí i bhur thost!" (Silêncio!);

018.10 Why;

018.11 Forficula: earwig, tesourinha; lat. amnis, rio; Morgana le Fay, feiticeira, irmã do Rei Artur;

018.12 how; howe: montura funerário; Howe: local do Parlamento Norueguês (Thingmote), em Dublim durante a ocupação vinquingue;

018.13 Viceroy; Viking's; Ibsen: Harmandene paa Helgeland [O viquingue da Helgelândia]; Al. Grab, túmulo, lápide; $\square$;

\footnotetext{
${ }^{306}$ A ária de Isolda, diante do corpo morto de Tristão, é uma das páginas mais importantes da música; nela, o ouvinte não consegue reconhecer a tonalidade, pois Wagner utiliza todas as doze notas da escala cromática, uma tendência que vinha sendo observada desde os primeiros acordes da ópera:

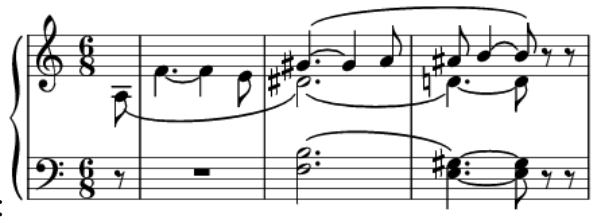

${ }^{307}$ Uma das obras mais famosas da literatura inglesa, de John Bunyan (1628 - 1688), escritor e pregador inglês.
} 
018.14 Din. hvad, o que;

018.15 Nor. øre, ouvido (LM ouvidos/olhos); “are you astonished" [estás surpreso]; Stone Age, Idade da Pedra;

018.16 Nor. фye, olho [LM]; "I am thunderstruck" [LM trovão]; fr. thon, atum; Thor (deus do trovão e da metalurgia, na mitologia escandinava); nor. Ragnarøkr: crespúsculo [morte] dos deuses nórdicos; Thon ou Thonar: divindade saxônica, associada a Tor;

Sinopse: o livro propriamente dito - alfabetos, cobras, etc;

018.17 Alfabeto; absent-minded, distraído; $\square$; fr. clef, chave; gr. kurios, senhor;

018.18 Riverbed, leito do rio; al. Rede, fala; reden, falar; ing. read;

018.19 Lane-Poole, The Speeches \& Table-Talk of the Prophet Mohammad xl: "the 'we' (God), and 'thou' (Mohammad), and 'ye' (the audience), of the Koran” [nós: Deus; tu: Maomé; vós: os ouvintes]; word; andrômina: gr. andros, homem;

018.20 MENE; Ludwig Tieck ${ }^{308}$; TEKEL; molto mene: it. molto bene, muito bem;

018.21 Lat. forsan, talvez; PARSIM; Daniel V, 25-28: "Esta é pois a escritura, que ali está disposta: MANE, TECEL, FARES. E esta é a interpretação das palavras. MANE: Deus contou os dias do teu reinado, e lhe pôs termo. TECEL: Tu foste pesado na balança, e achouse que tinhas menos do peso. FARES: O teu reinado se dividiu, e foi dado aos medos, e aos persas." (palavras ${ }^{309}$ que apareceram escritas na parede durante o banquete do rei babilônio Baltazar [Belsazar] e que foram interpretadas pelo profeta Daniel);

018.21 Thingmote: local de assembléia pública na Dublim dos viquingues;

018.22 Meander, vaguear; rio Meandro, na Grécia; Homem de Neanderthal; tale; lat. talis, conclusão;

018.23 Homem de Heidelberg (Idade da Pedra); Al. Heiden, pagão; Edimburgo; HCE (Head-in-Clouds walked the earth);

\footnotetext{
${ }^{308}$ Johann Ludwig Tieck (1773 - 1853). Poeta, tradutor, editor, romancista e crítico romântico alemão.

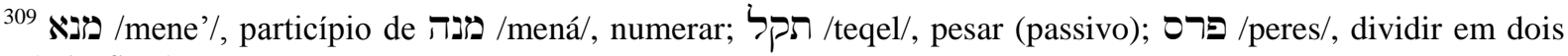
(PARSIM).
} 
018.23 (nas Private Memoirs and Confessions of a Justified Sinner, de James Hogg ${ }^{310}$, que se passa em Edimburgo, o protagonista vê sua sombra projetar-se tanto que parece tocar as nuvens);

018.24 Buda, depois de iluminado, andou pelo mundo;

018.24 Doze elos do Budismo: ignorance, impression, knowledge, name-and-form, the-sixsenses, sensation, desire, attachment, existence, birth, old-age-and-death, ignorance (ou ignorance, motivation, consciousnes, name-and-form, the-six-senses, sense-stimulation, sense-experience, grasping, possessiveness, coming-to-be, birth, old-age-and-death) [ignorância (avijja), formações (sankhara), consciência (viññana), mentalidade-materialidade (nama-rupa), Seis portas dos meios dos sentidos ou bases internas (salayatana), contato (phassa), sensação (vedana), desejo (tanha), apego (upàdàna), vir-a-ser (bhava), nascimento (jàti), envelhecimento e morte (jarà-marana);

018.28 during the enlightenment of Buddha, a reed grew from his navel

018.28 Ulysses.3.38: 'Gaze in your omphalos. Hello! Kinch here. Put me on to Edenville'

018.29 Onfalogradura: gr. ônfalos, umbigo; reredos, tela de altar; Rama: avatar de Vishnu; lat. terricola; gr. mod. vivlion viou, livro da vida; lively;

018.30 LM (Carta); earthquake, terremoto; HCE (Hatch ... celt ... earshare); hatch: hatchet, machadinha; celt: cinzel pré-histórico;

018.31 † ear: um arado; to plough, arar; fr. pourquoi; purpose; fr. casser, quebrar; CEH (cassay the earthcrust at all of hours); assay, exame; ( $\mathrm{m}$ o arado, $\Delta$ a terra);

018.32 Furrow, sulco do arado; forwards, backwards: para frente, para trás; gr. boustrophêdon: agir como um boi no arado (a sentença da linha 33 está invertida na linha 34); turnpath, caminho de volta; Bhagavad Gītā;

018.33 Os gêmeos; "billing and cooing" [pombos: tocam-se com os bicos (billling) e arrulham (cooing)]; bellicose;

018.34 Clodd, The Story of the Alphabet 201: "The primitive Gothic alphabet is named, on the acrologic principle, "futhorc", after the first six letters, f, u, t, h, o, r, c" [O alfabeto gótico

\footnotetext{
${ }^{310}$ James Hogg (1770 - 1835). Escritor escocês. Poesia: The Forest Minstrel (1810); The Pilgrims of the Sun (1815); Queen Hynde (1925). Romances: Brownie of Bodsbeck (1817); Jacobite Reliques (1819); The Three Perils of Man (1822); The Three Perils of Woman (1923); Memoirs and Confessions of a Justified Sinner (1824).
} 
primitivo recebe o nome do acrônimo de suas primeiras seis letras f, u, t, h, o, r, c: "futhorc"]; further; (Issy); little; effigy; cosibelos: it. così belli, tão belos;

018.35 Al. fing, pego; fire-lighting flint, pedra de isqueiro; din. forfalde, decair; al. Vorfall, incidente; brincadeira infantil: "Face to the east, Face to the west Face to the one you love the best";

018.36 “Upwards and down them”; Wellington: "Up, guards, and at them”; ( $\mathrm{m}$ and Ш );

\section{p. 19}

019.01 (Idéia de Bruno de que a mais ínfima partícula engloba todo o universo); (definição de sinédoque); fr. petit; gr. holos, todo;

019.02 Alfabeto; "several cute petite peas (petit pois)"; silver;

019.03 Lat. pecunia, dinheiro; din. tom, vazio;

019.04 Coloquial tummy, estômago; fr. parole, fala, língua falada; nor. ant. Ragnarøkr: crepúsculo dos deuses nórdicos;

019.05 Rocks; orangotangos; tango; anglo-irl. wisha, musha: de fato;

019.06 Thorn: letra rúnica e do anglo-saxão (th);

019.07 Pron. anglo-irl. /thraitor/, traitor, traidor;

019.08 Midnight; horda; 4 primeiras letras do alfabeto hebraico: alef, bet, gimel, dalet; al. Kümmel, cominho;

019.09 Alfabeto grego: alfa, beta, gama, delta; Alfred Chester Beatty: comprador de "The Chester Beatty Biblical Papyri” (papiro do Novo Testamento encontrado em 1931); expressão "owls to Athens": "coals to Newcastle” [coisa desnecessária]; eggs;

019.10 Greekish; fr. fromage, queijo; epsilon;

019.11 Gr. epsilaine, emagrecia; epiceno; lat. haud, não; hiss, assobio (da cobra);

019.12 Pron. anglo-irl. /wurrums/: worms, vermes (minhocas); † wurm, cobra; WurraWurra: ídolo druídico destruído por São Patrício; Dublim; dustbin, lata de lixo;

019.13 Freeman's Journal 22 fev 1924, 8/4: "By the Way": “The ss. Reventazon was landing a cargo of bananas from Jamaica when a strange little creature was discovered hiding among the fruit... its precise genus seems to have baffled everyone... Now, what is it?"; Flood: Ireland, Its Saints and Scholars 27: (Santo Adamano, sobre São Columba) "seu nome 
não apenas se tornou ilustre por toda a nossa Irlanda e Grã-Bretanha, mas chegou até o triângulo entre a Espanha, a Gália e a Itália, e até mesmo à própria cidade de Roma”;

019.14 Fr. touche-à-tout, intrometido; toucher terre, desembarcar; Angleterre; pron. angloirl. /rared/: reared, educado; Gênesis III, 3: “da árvore, que está no meio do paraíso";

019.15 Carga; (a maçã $\tilde{a}^{311}$ de Eva); fr. pomme, maçã; lat. fructus; (São Patrício expulsou as serpentes da Irlanda);

019.16 Dial. cotched: catched, apanhado; Shakespeare, Macbeth III.2.13: "We have scotch'd the snake, not kill'd it";

019.17 Gír. prick, pênis; quicker, mais rápido; "who's there”; Gênesis II, 23: "Esta se chamará Virago [mulher], porque de varão [homem] foi tomada" ${ }^{312}$; otomano; (estrangeiro); (vulva);

019.19 Clodd: The Story of the Alphabet 203: (of the Ogam alphabet) "The alphabet is divided into four aicmes or groups, each containing five letters: the first aicme, B, L, F, S, N... the fourth aicme, comprising the vowels A, O, U, E, I" [antigo alfabeto irlandês]; bailiff, bailio; bootleggers, contrabandista de bebidas;

Sinopse: sobre o número 111 - filhos e filhas

019.20 se $\mathrm{x}=1$ e $\mathrm{y}=36,(\mathrm{xxx})^{*}(\mathrm{xy})=111(L M 111):$ o texto apresenta uma equação matemática; plus, mais;

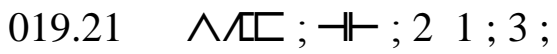

019.22 Lat. idem; Boa boa, jibóia; Crow: The Story of Confucius, Master Kung 49: (exemplos de presságios) "Three-legged calves, big snakes, the discovery of rocks of strange appearance";

019.23 Neer. kalvers, bezerros; calver, salmão; Igraine, mãe do Rei Artur; evergreen, perene; William Archer, The Green Goddess; Crow: The Story of Confucius, Master Kung 45: (antes do nascimento de Confúcio) "a fabulous animal known as a chi lin appeared before the prospective mother, bearing in its mouth a jade tablet inscribed with a message prophesying

\footnotetext{
${ }^{311}$ Fruta não mencionada na Bíblia. São Jerônimo traduziu Gênesis III, 5 da seguinte forma: "scit enim Deus quod in quocumque die comederitis ex eo aperientur oculi vestri et eritis sicut dii scientes bonum et malum" (grifo nosso) [porque Deus sabe que tanto que vós comerdes desse fruto, se abrirão vossos olhos; e vós sereis como uns deuses conhecendo o bem e o mal.] É provável que a fruta tenha sido interpretada como maçã por causa da proximidade entre os termos latinos malum, mal, e mālum, maçã.

312 O Padre Figueiredo usou virago e varão, em vez de mulher e homem ou de fêmea e macho, pois há um trocadilho no original, visto que a palavra mulher em hebraico deriva de homem.
} 
future greatness for the son then about to be born. The young girl tied a silken scarf around the single horn of the animal and it disappeared the same night, only (according to the story) to reappear more than seventy years later, just after the death of Master Kung"; 43: (na China antiga) "Most of the writing done was laboriously inscribed with a stylus on slips of bamboo... a book the size of the volume now in the reader's hands would fill a small truck. It was said of one industrious scholar that he read 'a hundredweight daily'”;

019.24 LM 111; lat. liberorumque, e das crianças; librorumque, e dos livros; gír. fr. queue, pênis;

019.25 Fr. gír. con, vulva, cono; Conan, um dos fiannas; All Hallows, dia de Todos-osSantos;

019.25 Rio Meandro, na Grécia; Neanderthal; al. Tal, vale; tale, conto; lat. talis, fim;

019.27 Tom, Dick e Harry ( $\wedge$ $\subset \sqsubset$ ) [fulano, beltrano ou sicrano];

019.28 Fr. petit-fils: neto; (lit. filhinho);

019.29 (plural de $u s$ ); servo-croata duga, arco-íris; daughters;

019.30 Montes Paps of Ana (Seios de Ana), no Condado de Kerry; accursed, amaldiçoado; al. Ahn, ancestral; damned, amaldiçoado, danado;

Sinopse: tempos antigos - escrituras e leituras;

019.31 Lat. In illis diebus (missal): naqueles dias; al. Lumpenpapier: papel rasgado; wastepaper, cesta de papéis;

019.32 T.S. Eliot, The Waste Land (T.S. Eliot foi encarregado por Pound de levar um embrulho para Joyce contendo um par de sapatos velhos; ver Ellmann, 1983, p. 493; manmountain, homem-montanha: Gulliver em Lilipute; fountain pen, caneta tinteiro; Horácio, Ars Poetica 139: "parturient montes, nascetur ridiculus mus": "as montanhas dão à luz, nasce um rizível camundongo";

019.33 (Botas dadas a Stephen por Mulligan, em Ulysses); (orações ou tiruais religiosos mudos: Idade Divina); anglo-irl. signs on it, portanto (de irlandês tá a shliocht air ou tá a rian air); (curse on it);

019.34 Lat. quis: who; lat. quid, o que; (pediu-lhe $£ 1$ );

019.35 Quad; lat. quod, pois; Wittgenstein: "Die Welt ist alles was der Fall ist" [O mundo é tudo o que importa]; world-mind; 
019.36 Righting; wrongs; rules, regras; runes [runas] forever;

\section{p. 20}

020.01 Cornualhês ou galês ban, montanha; † ban, maldição; Lane-Poole: The Speeches \& Table-Talk of the Prophet Mohammad xiv: "The hospitality of the Arab is a proverb... it is strictly true. The last milch-camel must be killed rather than the duties of the host neglected";

020.02 Lane-Poole: The Speeches \& Table-Talk of the Prophet Mohammad xxvii: (sobre Maomé) "Fine long arched eyebrows were divided by a vein, which throbbed visibly in moments of passion";

020.03 Thomas Moore; cousin-german, primo alemão; Charmian: criada de Cleóprata na peça de Shakespeare, Antony and Cleopatra; Lane-Poole: The Speeches \& Table-Talk of the Prophet Mohammad xxvi: (sobre Maomé) "his rich cousin, Khadija, whom he presently married at the age of twenty-five"; xxx: (sobre Maomé) "his ordinary food was dates and water";

020.04 Lane-Poole: The Speeches \& Table-Talk of the Prophet Mohammad xxiii: (sobre a antiga superstição dos árabes) "a few tied camels to the graves of the dead that the corpse might ride mounted to the judgement-seat"; xxxix: "The day of judgement is a stern reality to Mohammad... he calls it the Hour... the Smiting... the Day of Decision"; Maomé chamava o Dia do Juízo de Dia da Decisão; a bone, a pebble, a ramskin: Joseph Charles Mardrus, Introduction to the Koran, 13: o Alcorão foi escrito primeiro em folhas de palmeira, em pedras, peles e escápulas de carneiros (pele de carneiro significa pergaminho); percaminhos: pergaminhos + pecaminoso;

020.06 enfim: always + allways; it. terracotta; cote: pedra;

020.07 Al. Mutter, mãe; melting pot, mistura; muttering, mumúrio (Mutt); Gutenberg ${ }^{313}+$ al. guten Morgen, bom-dia; homem de Cromagnon; Magna Carta; Dubliners: "The Sisters": "gnomon",314;

\footnotetext{
${ }^{313}$ Johann Gutenberg (c. 1398 - 1468). Inventor da imprensa. O texto menciona a [primeira] impressão da Bíblia [e do Alcorão].

314 Termo da geometria euclidiana: se retirarmos um dos cantos de um quadrilátero, o que sobrar é um "gnômon"; no conto "The Sisters", o provável significado é o de uma Irlanda dividida por questões religiosas: das quatro províncias fundamentais, o Ulster foi excluído; sobraram as outras três províncias católicas. A Irlanda é o gnômon.
} 
020.08 Al. Tintenfass, tinteiro; al. fast, quase; Tin-Tin: personagem de história em

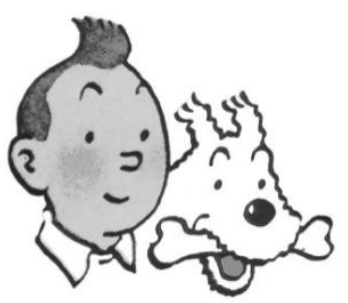
quadrinhos (figura ao lado), criado pelo belga Hergé; Great Primer: caráter tipográfico de tamanho 18; "once and for all" [de uma vez por todas]; lat. omnibus, para todos; Omniboss: neol. Deus; rubrica;

020.09 brick, tijolo; red; winepress: taxo para o pisoteamento das uvas; álcool; Alcorão;

020.10 Lane-Poole: The Speeches \& Table-Talk of the Prophet Mohammad xxxi: (segunda revelação de Maomé) "O thou who art wrapped, rise up, and warn!..." [Ó tu, emantado! Levanta-te e admoesta!] (Alcorão, LXXIV, 1-2); canção infantil "What Are Little Girls Made Of, Made Of"; paper; papyrus;

020.11 Hide, couro de animal (material do papiro); misprints, erros de impressão; we;

020.12 Al. endlich, finalmente

020.13 Lat. typus, figura; top; gr. topos, lugar; gr. pies: bebe! full stop: ponto final, basta!;

020.14 Abarrega: amarrar, amancebar;

020.15 Three score and ten: Salmo XC, 10: "The days of our years are threescore ${ }^{315}$ years and ten" [Os dias de nossa vida são em si setenta anos"]; de acordo com Joseph Charles Mardrus, Introduction to the Koran 22, os exegetas muçulmanos acreditam que cada uma das palavras do Alcorão tenham 70 significados diferentes, um para cada ano da vida de um homem; topsy-turvy, confuso; typical;

020.16 Os dois extremos de $F W$ se juntam; no Ulysses há outro tipo de junção: o livro começa ("Stately") e termina com a letra S ("yes") ${ }^{316}$; a letra S representa a sinuosidade de Ulysses e talvez remetam àquelas figuras sinuosas do Livro de Kells;" Dublin's Giant: Finn MacCool, HCE; Lane-Poole: The Speeches \& Table-Talk of the Prophet Mohammad xxix: (de Maomé) "The worst expression he ever made use of in conversation was, 'What has come to him? may his forehead be darkened with mud!" [A pior expressão que ele usou numa

\footnotetext{
315 Termo antigo para setenta: três ciclos de vinte. Nada tem que ver com o hebraico. Na Bíblia, aparece a palavra שבעי /cheba"/, sete. Joyce utiliza o termo em Ulysses: "evermoving from immeasurably remote eons to infinitely remote futures in comparison with which the years, threescore and ten, of allotted human life formed a parenthesis of infinitesimal brevity" (JOYCE, 1998, p. 651).

316 É por isso que a tradução brasileira de António Houaiss termina com um misterioso "sims" [sic]. Das traduções que analisamos (ver "Bibliografia"), apenas a de Houaiss e a francesa atentaram para isso. A letra $\mathrm{S}$ representa Stephen, a personagem do livro, e também o labirinto (de Dédalo e Ícaro) representado na estrutura sinuosa do livro. A nova tradução brasileira, de Bernardina da Silva Pinheiro, começa e termina com a letra M (por causa de Minos? do minotauro?).
} 
conversa foi: O que aconteceu com ele? Que sua cabeça se cubra de lama!]; Dublímane Fimórdio: imane: gigante; primórdio +fim + Finn;

020.17 Matrimônios: "What God hath joined, let no man put asunder... till death us do part" [O que Deus uniu, o homem não separa... até que a morte os (nos) separe']; Daleth (quarta letra do alfabeto hebraico ${ }^{317}$; equivale ao Delta grego $\Delta$ e representa Anna Livia e a vulva); al. Sünder, pecador; death; Mahamavantara: ciclo do mundo em sânscrito; ${ }^{318}$ † ope: to open; Maoma;

020.18 Heb. dor, geração, habitação; cornualhês dor, terra, chão; dor; door; trepasso: trespasso (morte), passo (porta), trepada (coito);

Sinopse: o livro nas mãos do leitor, com histórias e danças;

020.19 Moore: Irish Melodies: "Fly Not Yet"; canção infantil: "How many miles to Babylon? Three score and ten, sir. Will we be there by candlelight?" (Ulysses.9.415); lat. nondum, ainda não; London; nor. sytti, setenta; it. sette; setenta virgens (no céu para o que morre em nome de Alá);

020.20 Al. Kindl, criança; tetro: negro; parvas (paron. parcas); hand; handsel, presente de auspício; dadimanas: dádiva + dá de mão;

020.21 Gír. movables, prendas; passando: go + ago; movable type, tipos móveis;

020.23 Neer. eer, honra; earwig, tesourinha; Earwick (HCE): Eurico (ourículo) ${ }^{319}$; esp. surdo, canhoto; Whigs e Tories (respectivamente, a esquerda e a direita do Parlamento Britânico); “once upon a time” (era uma vez);

020.24 ( $\Vdash$ e $\wedge \bigwedge \sqsubset$ ); Leixlip (vila situada a $10 \mathrm{~km}$ de Chapelizod); alfofres: canteiros;

020.25 Strawberry Beds (Canteiros de morangos), Chapelizod; neer. strubbeling, dificuldade, problema; hun. domb, colina; donkey; dumb, mudo (ou tolo); Chicks picked their teeth: Lazare Sainéan, La Langue de Rabelais (Paris 1922): fábulas do século XVI, terminavam com o chavão: "Il y a de cela bien longtemps quand les poules avaient des dents" [Já se passaram muitos anos desde então, quando as galinhas tinham dentes]; equasinos: Equus asinus (asno);

\footnotetext{
${ }^{317} \mathrm{Na}$ antiga escrita hieroglífica hebraica, tinha a forma de um triângulo; seu nome, Dálet' significa "porta". A letra grega Delta deriva de Dálet'.

${ }^{318}$ A palavra aparece também em Ulysses 041.04: "after a few thousand year, a mahamanvantara [sic]."

${ }^{319}$ Do nome Earwick. Em nossa tradução, HCE cahma-se Henrique Cimão Eurico. Cimão (símio); Eurico (aurícula).
} 
020.26 He began to bray e ask your ass: Lazare Sainéan, La Langue de Rabelais (Paris 1922): adágio inicial das fábulas do séc. XVI: “Au temps que les bêtes parlaient” [No tempo em que os bichos falavam]; fr. bégayer, gaguejar; bray, zurrar; ass; nor. aas, colina; if he believes it: Sainéan, em La Langue de Rabelais, cita a última linha do cap. I do Pantagruel de François Rabelais: "Car si ne le croiez, non foys je, fist elle” [E se não acreditas nisso, eu tampouco, disse ela]; abona: abana;

020.27 Dial. cuddy, asno; provérbio “Walls have ears” [As paredes têm ouvidos.]; ass' ears; orelhas de burro; hill, colina; irl. cuidiú liom, ajude-me; wallop, cerveja;

020.28 "Forty Bonnets": alcunha da Sra. Tommy Healy de Galway (parente de Nora Barnacle; tinha muitos chapéus mas não tinha filhos); din. barnets, crianças; Sainéan, La Langue de Rabelais I.166: "Du temps des hauts bonnets [Da época do chapéus altos] (séc. $\mathrm{XV)}$; neer. hoop, esperança; hoopskirts, anágua;

020.29 Noah's Ark: arca de Noé; Coba: esposa de Noé (referida nas Histórias da Irlanda); fr. pomme, maçã; homme; affamé, faminto; femme, mulher; safaram: de sáfaro, estéril; gilded youth: dândis; Shakespeare, Cymbeline IV.2.262: "Golden lads and girls all must"; al. Geld, dinheiro;

020.31 Mischief, travessura; miss; Sainéan, La Langue de Rabelais I.207: "Mal maridade, le mal mariée, danse provençale"; Sainéan, I.207: "Revergasse (em Languedoc, revergado), ancienne danse dans laquelle les jeunes filles troussaient leurs jupes jusqu'à la cuisse (de reverga, retrousser)";

020.32 Frisque, Pirrichie: nomes de dança; Sainéan, La Langue de Rabelais I.207: “appellations de danses... la Frisque"; fr. frasques, travesuras; Oirra: esposa de Deucalião; gr. pir, fogo; Sainéan, I.207: "danses grecques... la pirrichie”; Pierrot;

020.33 Fr. ma foi! (lit. "por minha fé”; Minha Nossa Senhora!, etc.); Morgana le Fay: feiticeira, irmã do Rei Artur; Gaye, Trippière: nomes de danças; Sainéan, I.207: "appellations de danses... la Gaye"; Sainéan, I.220: "la fameuse Mélusine... fée sous forme de femmeserpent"; I.207: "appellations de danses... la Trippiere"; snaky woman: no folclore francês, Mélusine era uma fada transformada em mulher-serpente; Scylla; Rabelais faz dela um descendente de Gargantua: Sainéan, La Langue de Rabelais (Paris 1922);

020.34 Expect un pauc, Valentinoise: danças; Sainéan, I.207: "Expect un pauc, attends un peu... danse gasconne"; I.207: "appellations de danses... La Valentinoise"; I.108: "Besch, vent 
du sud-ouest" (besch: vento sudoeste); provb. "It's an ill wind that blows no one good" [equivale a "jogar um balde de água fria"];

020.35 Fr. flou, [roupa] folgada, [imagem] embaçada; Sainéan, I.106: "Flouin... une maniere de vaisseau de mer, approchant la rauberge, peu plus petit" (flouin: barco); tasca: taverna;

020.36 Al. höre, ouça; whore, puta; escróia: escuta + cróia (prostituta);

\section{p. 21}

021.01 Gentlemen; hearing; Norway; earwig; Nore: rio Irlandês (perto do qual ficava o castelo de Strongbow, normando que invadiu a Irlanda em 1169); mir. pequeinho, pequeno;

021.02 Picolotirro: it. piccolo + rus. tikho (pequeno); fr. comme ceci, como isso; neer. "het was of ie wist" (é como se ele soubesse); al. wissen, saber; "it was of a night"; knew it; listen!; vinividi: vini, vidi, vindi (César, na batalha de Zela);

021.03 HCE (Hark, the corne entreats!); fr. corne, chifre; ALP (And the larpnotes prittle); harp;

Sinopse: o conto da Prankquean e Jarl van Hoother why do I am alook alike a poss of porterpease?

seannolo भuinrion\%,

2lı bh-pkzbhкil eipekn bo.

021.05 (Grace (Grania) O'Malley era uma pirata irlandesa do século XVI que pediu abrigo no Castelo de Howth, cujo senhor era o Conde van Hoother; o conde estava jantando e não quis ser interrompido, recusando-se portanto a abrir as portas do castelo para ela; como forma de vingança, a pirata raptou o herdeiro do conde e só o devolveu ao pai mediante a promessa de que as portas do castelo ficariam abertas à hora do jantar (1575)); al. lang, remoto; "long time ago"; "Old Stone Age" [Idade da Pedra]; † eld: old; Auld Lang Syne: traditional canção escocesa; elm tree (LM árvore/pedra); gal. fai moito tempo;

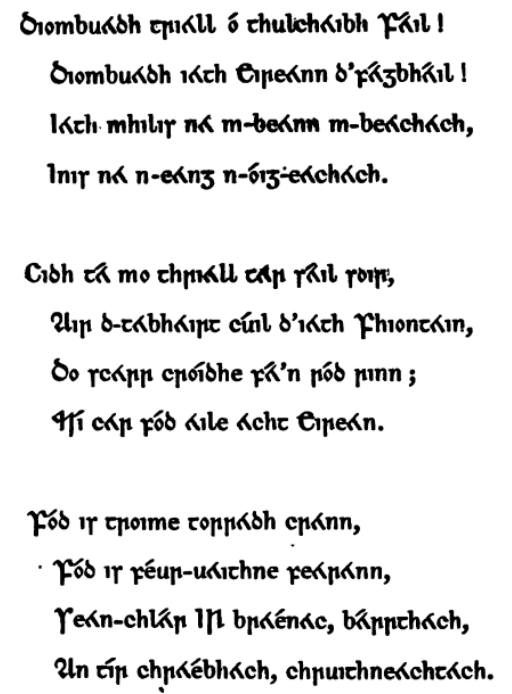

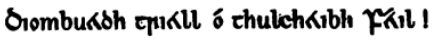

Slombuxbh ikch Cipexnn d'pkzbhkil!

IKth. mhilir nK m-beknm m-berchkch,

lnir nk n-exnz n-бrz-exchkch.

Cibh שa mo chpikll exp rall rop,

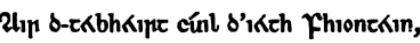

Oo reরpr cróbhe fín pód punn;

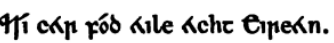

Fob ir cpoime coppikbh epknn

Fò ir péup-ukichne ferpiknn,

Uln đíp chp̣KébhKch, chpuichneরcheKch.

021.06 Gerald Nugent ${ }^{320}$, “Ode Written on Leaving Ireland” (figura acima): "From thee, sweet Delvin, must I part"; canção "John Ball": "When Adam delved and Eve span, who was

${ }^{320}$ Gearóid Nuinseann. Poeta anglo-normando, do século XVI que escrevia em gaélico. 
then a gentleman?”; delve, escavar; ária “Madamina” da ópera Don Giovanni (Mozart); Adão; anglo-irl. -een (diminutivo pejorativo); al. spinnen, ficar louco; LM 4 elementos (água, tera, fogo e ar); watered silk: seda texturizada; devaneava (eva); madama: anagrama de adão; desfiava (heb. hava, Eva); tábidas: podres; silt, lama;

021.07 Montenotte (montanha da noite): local da derrota francesa em 1794 e 1796 (também um subdistrito de Cork); há nessa linha, uma alusão aos gigantes das montanhas, mencionados por Vico, que viveram na Idade Divina; ing. † leal, legal; rib (costela de $\left.\operatorname{Eva}^{321}\right)$

021.08 Fleming: The Life of St. Patrick 48: "The network of rivers, tributaries of the Loire... must have exposed the country to periodical inundations in those days, when rivers had at all times their own way"; heb. ain, nada, nenhum; tur. mülk, posse, propriedade; al. molke, pret. de melken, ordenhar; air;

021.09 Alone + love;

021.10 ( I ) ; † Jarl, conde; Howth; burnt match, fósforo queimado;

021.11 Laying on of Hands (imposição de mãos para uma bênção ou uma cura); masturbação; ( $\wedge$ e $\sqsubset$ ); jimmies, pés-de-cabra; chimney, chaminé; lat. gemini, gêmeos;

021.12 Frase de Giordano Bruno: "In tristitia hilaris hilaritate tristis" [Alegre na tristeza, triste na alegria (epígrafe à peça Il Candelajo); kicking, chutando, brincando; ( $\dashv)$; Christopher St. Lawrence: nome do Earl of Howth; dummy, chupeta;

021.13 Pron. anglo-irl. /flure/: floor, assoalho; Homerigh, castle and earthenhouse: HCE; Homero; homerigh: Bartholomew Vanhomrigh, pai de Vanessa (Swift);

021.14 Diarmaid (Dermot) $(\Lambda)$ e Grania $(\dashv)$ : equivalentes a Tristão e Isolda no mito feniano (Finn MacCool ( $\mathrm{m}$ ) equivale ao rei Marcos); ( $\square$ ) ; (innkeeper); Freeman's Journal 16 fev 1924, 4/4: "Publican's Story": "Witness then asked his niece-in-law, Mary Maher, to go for the priest";

021.15 Gír. quean, puta; $(\Delta)$; heroína da canção "Tam Lin" coloca uma rosa na porta do castelo para anunciar sua presença; gír. "to pluck a rose”, urinar; rosa vermelha: Casa de Lancaster;

${ }^{321}$ Provável erro de tradução da Bíblia. O termo heb. צלע /tsela'/ aparece sempre com o sentido de "ilharga", na Bíblia. 
021.16 “To make water”, urinar; neer. wit, branco; wait; wet, molhado; anglo-irl. forenenst, oposto; pron. anglo-irl. /dour/: door; fire; pirlanda: gr. pir + Irlanda; Flood, em Ireland, Its Saints and Scholars 43, fala das grandes ordens hagiológicas da Irlanda, mencionadas em um manuscrito antigo: 1. época de São Patrício: até o começo do século VI; 2. na segunda metade do século VI; 3. por mais 70 anos, a partir do final do século VI; no mesmo documento antigo está escrito que "a primeira ordem era santíssima, a segunda muito santa e a terceira santa; São Patrício previu as três, iluminado pela sabedoria celestial, e numa visão profética ele viu primeiro toda a Irlanda em chamas; depois, apenas as montanhas em chamas; e, por último, viu candeias acesas nos vales";

021.17 Le Petit Parisien: diário popular (1876-1944); Peru;

021.18 Rei Marcos, tio de Tristão; Mack the Wanst: alcunha do Presidente McKinley (Estados Unidos); gír. de Dublim wans, moças; once; LM "Why do I am alook alike a poss of porterpease?"; "why do I like"; ALP; "look as like as two peas in a pod" [cara de um, focinho de outro]; "a pot of porter, please" [uma cerveja (porter), por favor] ${ }^{322}$; dial. poss, queda-d’água; al. Possen, travessura; glass; Piesporter (vinho); cantiga infantil "Pease Porridge Hot": "Pease porridge hot. Pease porridge cold, Pease porridge in the pot, Nine days old. Spell me that without a P, And a clever scholar you will be"; birras, cervejas;

021.19 Skirmishes, combates;

021.20 (A resposta de $\mathrm{T}$ ); neer. antwoordde, al. antwortete, respondeu; Dutch Nassau (Guilerme de Orange -Nassau lutou ao lado de Wellington em Waterloo); not so; (a porta continuou fechada); shit!, merda! shut!, feche!, silêncio!; (kidnapping, rapto); Grace O'Malley; malice; irl. seanda, velho; velho oeste (faoreste);

021.21 Sterne, Tristram Shandy;

021.22 Oeste (Grace O'Malley era a princesa de Connacht); wilderness, imensidão, deserto; ran + rain; ( $\mathrm{m}$ ); wirelessed, telegrafou; irl. Dubh-gall: dinamarquês;

021.23 lovecall; Donegal; Stop, Thief!; neer. dief, ladrão; deaf, surdo; canção “Come Back to Erin"; biltre;

021.24 Hearing; ( resposta de $\Delta$ ); heréu: herdeiro; din. svarede, respondeu; unlikelihood, improbabilidade; not likely!, pouco provável, de jeito nenhum; (viagem e regresso de $\Delta$ ); nipormientes: esp. "ni por mientes" (de forma alguma);

${ }^{322}$ Porter é uma cerveja Ale (alta-fermentação), feita com malte torrado, e de cor escura. 
021.25 Din. branne, fogo; Grannuaile: nome irlandês de Grace O'Malley; sabá; heb. sabaot': exércitos; angels;

021.26 De acordo com a lenda, Grace O'Malley navegou por 40 anos (tribulações dos hebreus no deserto: Êxodo);

021.27 “Tours du Monde en Quarante Jours" (Júlio Verne: A volta ao mundo em 80 dias); Dermot tinha uma marca na testa (love spot) que o tornava irresistível;

021.28 Gulliver; escumédica: Gulliver era médico (o texto diz que ela lavou com sabão a mancha do menino; a referência a Gulliver pode significar que a mancha foi removida cirurgicamente, pois se tratava de uma mancha de nascença);

021.29 Anais dos Quatro Mestres; owlers: carregadores de contrabando de lã; contrabandistas; old; al. tauchen, mergulhar; teach him (rir-se); lat. convorto, eu giro; converted $(\wedge$ se converte em $\sqsubset$ );

021.30 Al. Luder, patife; irl. ludramán, preguiçoso; lat. ludus, brincadeira, jogo; (ela transformou o menino triste, Tristóvão, em contente); Lutheran (alusão a HCE que era protestante); indolúdico: indolente + lúdico;

021.31 Run; Dermot; lace;

021.32 Summers; estiomanos: estio + mãos;

021.33 Pinafore, avental; HMS Pinafore ou The Lass that Loved a Sailor, opereta cômica de W. S. Gilbert e Arthur Sullivan; nela, um almirante tem o nome de Sir Joseph Porter!; late; time;

021.34 ( $\square$ ) ; Henrique II deu Dublim aos cidadãos de Bristol; Bristol: nome da hospedaria de Porter (HCE); hostelry, hopedaria; ( IT ) ; ('van' [holandês] muda para 'von' [alemão] (LM $A / O)$

021.35 Bartholomew Vanhomrigh; down; baretholobruised: Berthold Brecht (bértolas brechas);

021.36 Key: John McCormack, His Own Life Story 65: (sobre William Rathborne, um competidor em Feis Ceol) "Eu o vi pousar a mão esquerda na direita e pressioná-las com fervor congratulatório... aquele gesto de Rathborne que dava as mãos cumprimentando a si mesmo pela vitória presumida chocou-me...”; warm hands; ( $\sqsubset$ e $\dashv)$; (“jimminy” foi grafado duas vezes com dois $\mathrm{mm}$ ); 
022.01 (Infancy); suprema; portal, prostrado; threshold + tear;

022.02 Al. ringen, brigar, lutar; Brodar matou Brian Boru na Batalha de Clontarf, em 1014; brother and sister; rom. frate; sora (irmão, irmã); ( $\Delta$ );

022.03 (Rosa branca: casa de York); coloquial red cock, incêndio proposital; al. flackern, chamejar;

022.04 Cock's comb, crista de galo; dial. witter, marca, sinal; al. Gewitter, tormenta; whiter; wetter, que molha; water; aívos: fracos;

022.05 Wicket, portinhola; † wicket, vagina; window; Mark Twain; † twy, dois, dobro; LM “Why do I am alook alike a poss of porterpease?" [021.18] [.29] pease: piss, urinar;

022.05 ALP (LM ALP); “two pots of porter, please”; autarcia, modéstia; autarquia; prisco;

022.06 ( Resposta de TI); shit! [021.20]; al. antworten; neerl. antwoorden: to answer austrada: oeste; varoa;

022.07 (Kidnapping, rapto) [021.20-.22]; majesty; modesty; (troca de gêmeos);

022.08 Lilith: primeira mulher, geratriz, anterior a Eva (Cabala); Lilliput (Gulliver's Travels); path, senda, caminho; woe, infortúnio; woman's; no man's land;

022.09 Ran [021.22] [021.31] [022.18]; (o grito de $\mathrm{T}$ ) [021.22-.24]; din. atter, mais uma vez, de novo;

022.10 Irl. Fine Gaedhil: tribo irlandesa; irl. Fionn-gall, belo estrangeiro, norueguês; Fingal (é como está escrito Finn nos poemas de Óssian); dumb [021.23]; (a resposta de $\Delta$ ) [021.24]

022.11 Din. svarede, respondeu; ( viagem e retorno de $\Delta$ ) [021.24-.33]; Grannuaile;

022.12 Família de São Lourenço, condes de Howth;

022.13 Grace O'Malley teria navegado por 40 anos;

022.14 “Tours du Monde en Quarante Jours"; fr. le même, o mesmo; anglo-irl. "the curse of Cromwell on (someone)" ["que a desgraça de Cromwell caia sobre (alguém)": "que o diabo te (o) carregue"]; Crom Cruach; Caisleen-na-Cearca: castelo em que Grace O'Malley manteve o herdeiro de Howth (foi destruído por Cromwell);

022.15 Swift, Tale of a Tub; São Patrício teve 4 mestres [021.29]; 
022.16 Lat. monitrix, professora, instrutora; monitors; teach him (to cry) [ensina-o a gritar] [021.29]; lat. provorto, eu me viro para a frente; perverted ( $\sqsubset$ se transforma em $\wedge$ ) [021.29];

022.17 Christian; fr. triste; Tristan;

022.18 Running [021.22] [021.31] [022.09]; Dermot [021.14] [021.31]; "be damned to her"; al. verdammter, amaldiçoado;

022.19 Charles Lever, canção Larry McHale ("Grana Uaile” aparece na canção); Hilary (invertido) [.24]; (pedra) [.24];

022.20 Apron, avental (vem de avantal, "para ser colocado na frente"; esp. delantal) ( $\square$ ) [021.14] [021.34];

022.21 Mansion House, Dublim (residência do prefeito); Mansion House Ward, Dublim; night; late [021.33]; "three times is a charm”; time [021.33];

022.22 ( I ) [021.10-.11] [021.34-.36] ucharia: despensa;

022.23 Quatro estômagos dos ruminantes: pança, barrete, folhoso e coagulador (hoje, aceita-se mais que os ruminantes tenham um estômago e três pré-estômagos); it. dare, dar; irl. dair, carvalho; [202.30-.31]; LM Adear, adear!

022.24 ( $\sqsubset$ e $\dashv)$ [021.11-.13] [021.36-022.02]; Tristopher (invertido) [.19]; tree (LM árvore/pedra) [.19]; below, above; (fazendo amor);

022.25 Anglo-irl. pogue, beijo; bacio, beijo;

022.26 irl. Naomh Pádraig: São Patrício; irl. Naomh Brighid: Santa Brígida; (senility) [.01]; $(\Delta)$ [021.15-.17] [022.02-.05];

022.27 Moore: Irish Melodies: canção “The Song of O'Ruark, Prince of Breffni”: “The valley lay smiling before me";

022.28 Whitest, o mais branco, branquíssimo; wettest, o mais úmido, encharcado; fr. arc de triomphe (Arco do Triunfo); hump, corcova;

022.29 Tristan; LM “Why do I am alook alike a poss of porterpease?” [021.18] [.05]; ALP (LM ALP); "three pots of porter, please";

022.30 Skirmishes ended (fim da escaramuça) [021.19];

022.31 Canção: “The Campbells Are Coming”; 
022.32 Marcos III, 17: "And James the son of Zebedee, and John the brother of James; and he surnamed them Boanerges, which is, The sons of thunder" [e a Tiago, filho de Zebedeu, e a João, irmão de Tiago, aos quais ele deu o nome de Boanerges ${ }^{323}$, que quer dizer filhos do trovão]; Brian Boru era chamado de "O Terror dos Danos” [dinamarqueses] ${ }^{324}$;

022.34 No brasão de Dublim há três castelos; istmo de Sutton; LM 7 peças de indumentária [022.34-023.01]; Brobdingnag (país visitado por Gúliver em Gulliver's Travels de Swift); gingerbread, bolo (pão doce) de gengibre; civic collar;

022.35 Al. Hemd; neerl. hemd, camisa; Balbriggan, no Condado de Dublim: local de uma antiga indústria de algodão do século XVIII; socks and gloves (meias e luvas); Anglo-Saxon;

022.36 Ragnar Lodbrok, chefe viquingue, usava perneiras para não ser mordido pelas cobras; catgut: tripa de gato (usada para o fabrico de cordas musicais); Kattegat: mar entre a Dinamarca e a Suécia; bandoleer, bandoleiro; far-famed, famoso; galdrina: calça;

\section{p. 23}

023.01 Guerra Peninsular; lat. panuncula, novelo; combats; gumboots, galochas (Wellingtons ou galochas de barracha); fr. bottes; LM 7 cores do arco-íris [.01-.02] (em oposição à brancura de [021.16] [022.04] [022.28]); Paneslavônico rud-: rubro-; rude yelling, grito brusco; Orangeman: membro da sociedade secreta Association of Orangemen, que almejava a manutenção do protestantismo na Irlanda; it. rosso, arancio, giallo, verde, turchino, indaco, viola;

\subsection{Indignation;}

023.03 Strongbow: líder dos anglo-normandos que invadiram a Irlanda; Red Hand of Ulster;

023.04 ECH (LM HCE); easy; nor. ord, palavra; ordure, escremento; ordered; speech spoke;

023.05 [161.23]; † dup, abrir; ghost, fantasma; pol. dupa, bunda; dummy; canção "Polly Put the Kettle On"; clap; LM palavra-trovão de cem letras [.05-.07]; letão perkons, trovão; aribateibakanhegatupanibiasabapitunapopitunaberaibiarassembebeupibicanhemibitaog essatantaraybangüera [palavra composta por aglutinação de termos não flexionados (tupi,

\footnotetext{
${ }^{323}$ Trata-se, na verdade, de um patronímico, ben (filho de).

${ }^{324}$ Dinamarca significa "marca dos danos". As marcas erma propriedades feudais de fronteira e que serviam de proteção ao território do suserano; o senhor da marca era o marquês. Danos eram os povos que ocuparam a região por volta do século VI, cujo lendário soberano teria sido Dan, o Magnífico.
} 
guarani e quéchua): "Do alto do céu caiu a palavra-trovão na terra à noite, fazendo da noite brilhante dia, e o grito voou ao longo da terra para derrubar a casa de pedra e separar os homens."]

023.06 Bretão kurun, persa barg, trovão; heb. baraq, relâmpago; lituano griauja, trovão; tur. gök gürliy or, céu de relâmpagos; rus. grom, gremit (trovão, trovões); malaio guntur, trovão;

023.07 Nor. ant. thruma, islandês thruma; rom. thuna, ME thuner, kiswahili radi, ár. dill; samoano faititily, alb. bumulloj, fin. ukkonen, trovão;

023.08 tea (contos de fadas irlandeses terminam com a frase: "They put on the kettle and they all had tea"); Ulysses: "Doctor Swift says one man in armour will beat ten men in their shirts" (Swift: The Drapier's Letters: "Eleven Men well armed will certainly subdue one Single Man in his Shirt"); Gír. armour: pessoa que fica valente depois que bebe; (anticoncepcionais);

fair match: jogo justo, luta limpa; sheets, lençóis, folhas;

023.09 Al. Schürze: apron; skirts; "piece of alliterative poetry” [poesia aliterativa: típica do anglo-saxão]; illiterate, iletrado; malacia: paz;

023.10 Galês porthor, porteiro (ing. porter); flaming, reluzente, em chamas; LM 4 elementos; "how Kersse the tailor made a suit of clothes for the Norwegian Captain" [311.05$.09]^{325}$; fogos fátuos;

023.11 tiler, porteiro massônico; unclose door: open it; narwhal, narval (cetáceo semelhante a um golfinho, mas com um corno longo e espiralado); so far;

023.12 Jó XXVIII 8-11: "Or who shut up the sea with doors... And said, Hitherto shalt thou come, but no further: and here shall thy proud waves be stayed?" [Ou quem encerrou o mar com portas, quando irrompeu da madre; quando eu lhe pus as nuvens por vestidura e a escuridão por fraldas? Quando eu lhe tracei limites, e lhe pus ferrolhos e portas, e disse: até

\footnotetext{
${ }^{325}$ No capítulo 5 do livro Joyce's Book of the Dark, John Bishop faz uma interessante análise estrutural de Finnegans Wake, em que a palavra tailor (alfaiate) pode ser lida como tale (narrativa), retail (varejo) e retell (recontar), como se a história narrada no livro fosse costurada por partes (no varejo) e tivesse de ser relida (retold). A história do alfaiate e do capitão norueguês foi contada para Joyce pelo pai: um capitão concurda encomendou um terno a um alfaiate; depois de terminado, o terno não se ajustou perfeitamente ao corpo do capitão; os dois discutiram e o capitão disse que o alfaiate não costurava bem, e o alfaiate disse que o problema era do corpo do capitão e, de acordo com uma variante da história, o alfaiate teria ensinado ao capitão a postura adequada para que coubesse no terno (BISHOP, 1986, p. 126).
} 
aqui virás e não mais adiante, e aqui se quebrará o orgulho das tuas ondas?] ${ }^{326}$; discurso de Parnell em Cork, 1885: "Ninguém tem o direito de dizer 'Deves ir até aqui e não além"”; anglo-irl. betune: between; Gênesis IX, 12: "Disse Deus: Este é o sinal da minha aliança que faço entre mim e vós e entre todos os seres viventes que estão convosco, para perpétuas gerações: porei nas nuvens o meu arco; será por sinal da aliança entre mim e a terra"327; cat. entre (pron. /antre/); nosaltres, nós;

023.13 (Navio pirata); (“jimminy” grafado duas vezes com 2 mm [021.36]); peace;

023.14 (von volta a ser van (LM A/O) [021.34]); "get the wind up": comece a se preocupar, fique alerta; (fart); hearsay, boato; al. gehorsam: obediente; "Obedientia Civium Urbis Felicitas" [A obediência dos cidadãos é a alegria da cidade]: lema da cidade de Dublim;

023.15 Neerl. burger, al. Bürger, cidadão; (ele é a piada da cidade); gr. polis, cidade, Estado; pron. anglo-irl. /polis, police; Eleonora: personagem da ópera Fidelio de Beethoven;

Sinopse: a montanha silenciosa (ele); o regato murmurante (ela);

“Exsultet”: 'O felix culpa!' (Oração pascal: “O felix culpa, quae talem ac tantum meruit habere Redemptorem!" [Ó feliz culpa, que mereceu esse tão grande Redentor] (LM O felix culpa! (Exsultet)); foe, inimigo; phoenix, símbolo utilizado por Michelet para explicar a teoria de Vico; Parque Phoenix; Pérsio, Sátirea 1.84: "De nihilo nihilum” [Nada pode vir do nada]; lat. ex nihilo nihil fit: do nada, nada vem; lat. ex malo bonum fit: do mal, surge o bem; eslavão nic, nada; chec. nicky, nulos, zeros; LM (Mick/Nick); eslavão malo, um pouco; lat. mālum, maçã (Eva); malo, mal; Michaelmass; dial. mickle, muito; amassed;

023.17 Hill $(\Pi)$ and rill $(\Delta)$ [morro e regato]; LM (111); Arthur Guinness, Sons and Company, Ltd;

023.18 best rid (boa resolução);

023.19 Norueguês ou irlandês; Irena (assim Edmund Spenser chamava a Irlanda); eirenic: pacífico; "they won't tell the secret of their source"; source of Nile (nascente do Nilo) [089.27]; lat. quare siles: por que estás em silêncio? ( In );

023.20 Lat. silex, pederneira, sílex; Albert Nyanza ( $\mathrm{T}$ ) [089.27]; no answer, não responde; irl. ní h-annsa, não é difícil (como resposta a charadas); lat. unde gentium festines? (de que lugar do mundo vens tão apressado)? ( $\Delta$ ); Victoria Nyanza $(\Delta)$ [089.27];

\footnotetext{
${ }^{326}$ Tradução de João Ferreira de Almeida (Revista e atualizada RA).

${ }^{327}$ Tradução de João Ferreira de Almeida (RA).
} 
023.21 Neerl. wolkenka, céu nublado; woollen, tecido de lã; o céu sobre a colina de Howth quase sempre está nublado; crowned, coroado; lat. audi urio, espero ouvir; Vulgata: Salmo CXIII, 6: "Aures habent, et non audient" (têm ouvidos, e não ouvirão) [.23] [.25];

023.22 Lat. es urio, quero comer; eavesdrop, escutar atrás da porta; Eve $(\Delta)$; eaves, calhas; close at hand; djinn in bottle, gênio na garrafa; din, ruído; battles; far east;

023.23 Vulgata Salmo CXIII, 5: “Oculos habent et non videbunt” (têm olhos, e não verão) [.21] [.25]; mark!; Rei Marcos; lips, lábios; lisps, cecear;

023.24 All the time; such and such; so and so;

023.25 Had to laugh [583.26] [617.16-.17]; (ele procura agarrá-la pelos cabelos, aos quais espera alcançar por acaso); al. Herr, senhor, cavalheiro; verflucht!: maldito!; but; anglo-irl. twig, entender; ing. twig, galho; bater com um galho; impalpable; Vulgata Salmo CXIII, 7: "Manus habent et non palpabunt" (têm mãos, e não apalparão) [.21] [.23] coma: cabeleira; vento;

023.26 Abhors, abomina; adheres, adere; appears, aparece; abear, tolerar; al. abhören, ouvir; unhear, surdo; As Quatro Ondas da Irlanda: 4 pontos da costa (Waves of Rory, Tuath, Cleena e Scéina) [254.02]; (esmagando a cabeça contra o promontório); Tromp: família de distintos almirantes holandeses; fr. tromper, ludibriar; trunfo (no carteado); trumpet;

023.27 Fr. trompe, tromba; who said;

023.28 Never heed them (nunca dê atenção a ele);

023.29 And listen to me (e ouça-me); landlocked, ilhado; anglo-irl. Lochlann, escandinavo; torres que submersas no Loch Neagh e que apareceriam em certos dias; neighbours; mistress; 023.30 Perpetuated in his offspring (perpetuado em seus descendentes); as águas do Lough Neagh teriam a propriedade de petrificação; Salmo VIII, 3: "babes and sucklings" (boca dos infantes, e dos que mamam); "Ireland, isle of saints and sages" [Irlanda, terra de santos e sábios];

023.31 Morning papers, matutinos; face; Condado de Louth;

023.32 Loaf, vadiar; al. Lob, louvor; Leib, corpo; Laib, pão; devourers; (LM O felix culpa! (Exsultet)) [023.32-024.02] [.16]; but; al. hold, belo; holy; halibut, hipoglosso ou halibute (peixe); butt, bunda;

023.33 Lat. pudor, vergonha; al. Puder, pó; (lively, watery, flowy); lat. liber, vinho; al. Leib, corpo; 
023.34 But for; Irish Times 30 out 1922, 2/5: "There has been a wondeful crop of apples this year... those that have fallen off in the late storms. 'Windfalls,' when gathered fresh, may be used in making tarts or puddings"; windfall, fruto do acaso, maçã; bread and water, pão e água;

023.35 Holy spire; espiando pelas frestas; (cidade e rio); gír. vestal, prostituta; virgens vestais; vessel floating, navio flutuando;

023.36 Fr. gír. plein, bêbado (lit. cheio); fr. à plein voiles, a plenas velas; you; vowels, vogais: u, i: dívida (I.O.U: I owe you, eu te devo);

023.36 Eye $(\mathrm{olho})=I(\mathrm{eu})$;

\section{24}

024.01 Fr. cache-cache: hide and seek; lat. novo; fr. Nil, Nilo (nascente); Dublim (arrabaldes) [620.03]; "Dublin by Lamplight Laundry", Dublim; James Joyce: Letters II.192: carta de 13.11.1906 a Stanislaus Joyce: (sobre o conto 'Clay' de Dubliners) “The meaning of Dublin by Lamplight Laundry? That is the name of the laundry at Ballsbridge, of which the story treats. It is run by a society of Protestant spinsters, widows, and childless women - I expect - as a Magdalen's home. The phrase Dublin by Lamplight means that Dublin by lamplight is a wicked place full of wicked and lost women whom a kindly committee gathers together for the good work of washing my dirty shirts. I like the phrase because it is a gentle way of putting it"'; (Maria trabalha ali); foro: cidade;

024.02 Anglo-irl. "at all at all"; and not a; pron. anglo-irl. /convaynience/: convenience; conveyance, transporte;

Sinopse: os feitos do poderoso libertador - ele revive;

024.03 "Skin of his teeth";

024.04 Gênesis III, 19: "In the sweat of thy face shalt thou eat bread" [No suor do rosto comerás o teu pão]; brow, sobrancelha; Hospice for the Dying, Dublin (casa de repouso);

024.05 Earned his bread (mereceu o pão); dead;

024.05 Fr. dragon volant: espécie de canhãp; flying dragon: na alquimia, substância resultante da união do azougue com o enxofre, resultando em fogo e vapor venenoso; 
024.06 laws; oração: "mas livrai-nos do mal"328; from all evils; boll weevil: bicudi-do-

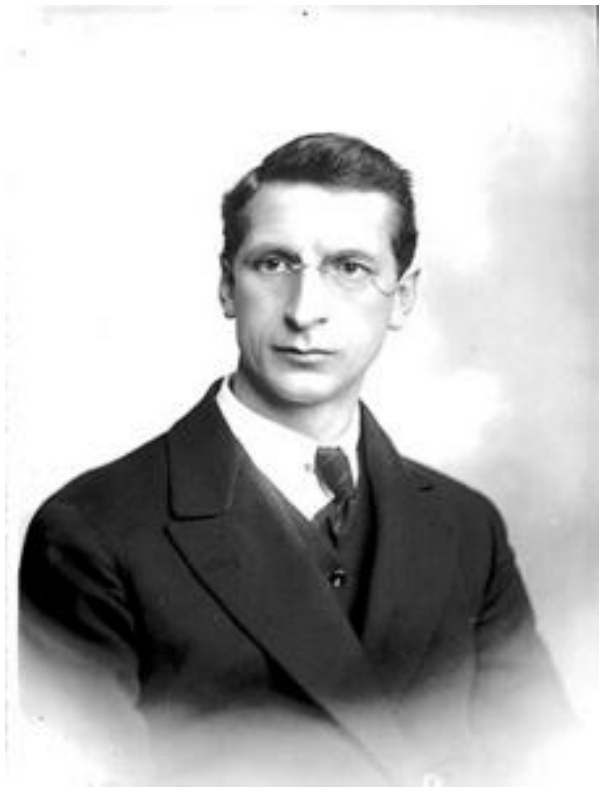

algodoeiro (praga); amém; valerou-nos: de Valera (figura ao lado), o libertador ${ }^{329}$;

024.07 Humphrey Chimpden Earwicker; dial. al. Fru: esposa (sem esposa, viúvo [.09]);

024.08 gal. devanceiro, ancestral; venerado: de Valera; penates (ídolos): penasse;

024.09 George Bernard Shaw: Widowers' Houses; Marcos XII, 38-40: "Beware of the scribes... Which devour widows' houses" [Guardai-vos dos escribas... os quais devoram as casas das viúvas]; "blushing from ear to ear"; year's end (fim do ano : dezembro);

024.11 May... December; disembarks; (a fênix se ergue das cinzas); poeriam: poderiam + poeira; it. ancora, de novo; suave ardentia: se a ave ardente (fênix); naudesceseem: desembarcassem; ancorarão: it. ancora;

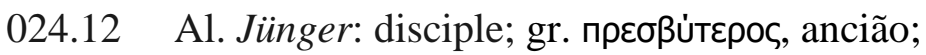

024.13 Canção "Finnegan's Wake" 5: "Then Micky Maloney raised his head When a noggin of whiskey flew at him, It missed and falling on the bed, The liquor scattered over Tim; Bedad he revives, see how he rises And Timothy rising from the bed, Says 'Whirl your liquor round like blazes, Thanam o'n dhoul, do ye think I'm dead?"' (orig. Poole: Tim Finigan's Wake: "Mickey Mulvaney raised his head, When a gallon of whiskey flew at him; It missed him, and, hopping on the bed, The liquor scattered over Tim! Bedad, he revives! see how he raises! And Timothy, jumping from the bed, Cries, while he lathered around like blazes, 'Bad luck till yer sowls! d'ye think I'm dead?'”); wines;

024.14 Ibsen: Os mortos-vivos; darling; [607.12] [499.29]; Anglo-irl. usquebaugh, uísque (lit. "água da vida"); lat. usque ad necem: mesmo na morte (carta do general espanhol Juan D’Aquila aos católicos da Irlanda[1680?]); usque ad mortem [499.30]; Ad...am; lat. bacam, baga, uva;

\footnotetext{
${ }^{328}$ Mateus VI, 13 e Lucas XI, 4.

329 Éamon de Valera (Éamon de Bhailéara) (1882 - 1975). Figura política que não tem a importância que merece. Éamon de Valera foi de fato o libertador da Irlanda. Participou do Levante da Páscoa (1916) e presidiu a primeira república do país (clandestina) de 1919-1921. Foi presidente da Irlanda 1959 até 1973.
} 
024.15 irl. anam, alma; LM Mick/Nick (devil, mick); anglo-irl. thanam o'n dhoul: almas do diabo! (do irl. t'anam o'n diabhl); did ye think me dead?; dead as a doornail (mortinho da silva); Sinopse: convincing him to stay dead - performing rites to keep him dead;

024.15 (Dirigindo-se a uma pessoa morta no ínfero); pron. anglo-irl. /aisy/: easy; /laysure/: leisure, lazer; vivinho: vinho;

024.16 leitorada: leitor;

024.17 Herold, La Vie du Bouddha 60: (Buda descreve seu cavalo) "le cheval est fort et rapide comme un Dieu" (o cavalo é forte e rápido como um deus); jubilado: aposentado;

024.18 A fênix queimou-se em Heliópolis (nome grego de Anu, capital do $13^{\circ}$ nomo no Baixo Egito); quando Tim Healy tornou-se governador-geral do Estado Livre da Irlanda, os dublinenses passaram a chamar o pavilhão do vice-rei, no Parque Phoenix de "Healiopolis"; (as coisas mudaram); Buda nasceu Kapilavastu; heal, curar, cura;

024.19 Irl. capall a mhaistir, o cavalo do mestre; Chapelizod; it. il paese di Vattelapesca: terra de lugar nenhum (país imaginário das fábulas italianas); Calvário, local da cruxificação de Jesus; (LM 4 pontos cardeais) [.19-.21]; Northumbriano; Northumberland Road, em Dublim;

024.20 Phibsborough: subdistrito de Dublim; rua Watling, Dublim; rua Watling: estrada romana na Inglaterra; irl. sráid, rua; Favos Campos: quatro cantos; campa;

024.21 Irl. bóthar mór, rua principal, estrada [373.05]; rua Moore, Dublim; canção “The Foggy Dew"; Bule Mauro: bulevar;

024.22 Buda encontrou um velho, um doente e um morto do lado de fora do palácio onde morava; com isso, aprendeu sobre a velhice, a doença e a morte; irl. Cothraighe: São Patrício $(L M P / K)$; “belonging to 4 " ( $\times)$;

024.23 Kantaka, cavalo de Buda; Katachanka, cavalo de Maomé;

024.24 Gír. impure, puta;

024.25 Gerald Nugent: "Ode Written on Leaving Ireland": "From thee, sweet Delvin, must I part; Oh! hard the task - oh! lot severe, To flee from all my soul holds dear." (tradução de Drummond, $1897^{330}$ ); Dublim; (vida);

\footnotetext{
${ }^{330}$ William Hamilton James Drummond (1778-1865). Poeta escocês.
} 
024.27 Fr. infranchissable, intransitável; en franchise, zona franca; Twain, Huckleberry Finn 1: "a sound that a ghost makes when it wants to tell about something that's on its mind and can't make itself understood, and so can't rest easy in its grave and has to go about that way every night grieving";

024.28 (Melhor estar morto); it. primo signatio, primeira assinatura;

024.30 Depois da Iluminação, Buda conheceu suas vidas passadas;

024.31 Budge, The Book of the Dead 16: "By some means or other Set did contrive to kill Osiris... Isis, accompanied by her sister Nephthys... rescued the body of her lord... They then laid the body in a tomb, and a sycamore tree grew round it and flourished over the grave"; ilha Tory na costa Irlandesa; dizem que os ratos não conseguem viver ali e que as pessoas de fora vão até lá para buscar terra da ilha contra a infestação de ratos;

024.32 (Tens tudo do que precisa para o ínfero); LM 7 itens de vestuário [.32-.33]; fr. briquet, esqueiro; short sword (espada curta);

\subsection{Umbrella;}

024.34 Canção “Groves of Blarney”: "But were I Homer, or Nebuchadnezzar"; Brian Boru; LM Browne/Nolan (livreiros); Lonan: chefe tribal convertido por São Patrício; Onã (personagem bíblica que cometeu o pecado da masturbação; daí o termo “onanismo”); Blarney Stone ${ }^{331}$;

024.35 Gêngis Cã; Guinness; ár. khan, taverna; no bucket nozzler: o que bebe direto no gargalo;

024.36 Ombre: jogo de baralho do século XVIII para três pessoas; it. e fr. ombre, sombra; grave, túmulo, campa;

\section{p. 25}

025.01 Fenianos: irmandade revolucionária da década de 1860; nome erroneamente aplicado aos Fiannas, o exército de Finn;

025.01 Curandeiros ungiam com saliva;

025.02 Budge: The Book of the Dead 36: (cap. VI) "The text of Chapter VI was cut on figures made of stone, wood, etc. (ushabtiu), which were placed in the tomb, and when the deceased recited it these figures became alive and did everything he wished. The shabti

\footnotetext{
${ }^{331}$ Bloco de arenito colocado nas ameias do Castelo de Blarney ( $8 \mathrm{~km}$ de Cork). De acordo com a lenda, quem o beijasse adquiria o dom da eloquiência.
} 
figure... took the place of the human funerary sacrifice which was common all over Egypt before the general adoption of the cult of Osiris" [nota de Budge]; shabby, parco; Penny Dreadfuls: publicação do séc. XIX; city; suttee: gesto que uma viúva comete de se imolar na pira funerária em que está queimando o corpo do marido; sweet stores;

025.03 Budge: The Book of the Dead 21: "Osiris offered... as a reward a life in the Field of Reeds, and the Field of Offerings of Food, and the Field of the Grasshoppers, and everlasting existence in a transmuted and beatified body among the resurrected bodies of father and mother, wife and children, kinsfolk and friends"; Mateus VI, 28: "lírios do campo";

025.04 Fr. miel, mel [.05]; irl. míle deóra, mil lágrimas; gr. miliodôros, mil presentes; medicine man, curandeiro; Esquique: Gianni Schichi ${ }^{332}$;

025.05 (Ópio); fr. passe-partout, válido em quaisquer circunstâncias, passe; a master key, chave mestra;

025.06 Swift, na Battle of the Books, chama a sabedoria dos antigos de "honey and wax... furnishing Mankind with the two Noblest of things"; HCE (LM HCE);

025.09 Na ópera Barbeiro de sevilha, Don Basilio canta uma ária sobre a calúnia que se espalha; gr. basilikos, real; it. basilico, manjericão (usado para curar doença de pele); (desde que morreu); Fintan Lalor Fife Players; alfádega: manjericão;

025.10 Overboard, além do navio;

025.11 Bothnia: golfo do Báltico, entre a Suécia e a Finlândia; (named after); menhir, menir: tall, monumento vertical de pedra; neerl. meneer, mijnheer: cavalheiro, senhor;

025.13 Porco sob o telhado (personagem chinês): home; viga sagrada, símbolo de Osíris (do corpo de Osíris cresceu uma urze, cuja madeira foi usada para fazer uma viga, que ainda continha o corpo do deus);

025.14 "Every bullet has its billet" (cada bala tem um endereço certo); din. til drengen, para o menino; dregs, sedimento, sujeira; The Salmon House: taberna em Chapelizod (mencionada no prólogo de The House by the Churchyard, de Le Fanu);

025.15 shillelagh: clava de abrunheiro; (mãos suadas);

025.16 Lat. manus mãos; monument; gír. shillelagh, palito de dente;

\footnotetext{
${ }^{332}$ Gianni Schichi era um imitador italiano que foi contratado para forjar um testamento. Foi um caso de polícia e acabou sendo mencionado na Divina Comédia. Gianni Schichi é um dos títulos da trilogia Triptico de Puccini.
} 
025.17 Gr. eirênê, paz; o Monumento a Wellington, foi erguido no local da antiga Salute Battery; "chip off the old block" (cara de um, focinho de outro););

025.18 Bought and sold (comprado e vendido);

025.19 Lat. onero; honour of the Lord (glória do Senhor) [027.23]; dono da terra; malaio padi, arroz; colonos ingleses na Irlanda; it. sgrombare, embrulhar;

025.20 Lap of the gods (está nas mãos de Deus); classes; al. freien, cortejar;

025.21 grand; same;

025.22 Michael Gunn, gerente do Gaiety Theatre, em Dublim;

025.23 Gunne (jogo antigo) [025.21-.22]; “The Grand Old Man”: Gladstone; Stone: Shaun;

025.24 After; heb. shoresh, uma raiz; tsedeq, justiça; chec. zadek, bunda; fragas (chagas);

025.25 Buda; bunda; anglo-irl. badhach, campônio, grosseiro (do irl. bodach); chec. hoch, menino; al. hoch, alto;

025.26 Macpherson: The Poems of Ossian: Temora I: "He turned his eye to Moilena"; o farol de Tuskar, no SE da Irlanda tinham uma potência de um milhão de velas; (Buda encarnou algumas vezes como elefante);

025.27 Moil, trabalhar duro, mourejar (o termo vem de mouro); to wet, molhar; Moyle: mar entre a Irlanda e a escócia; al. erinnern, lembrar;

025.28 Din. Bretland: originalmente se referia ao País de Gales, hoje é usado de forma poética para toda a Grâ-Bretanha; Twain: Huckleberry Finn (introdução): "In this book a number of dialects are used... the ordinary 'Pike County' dialect';

025.29 Irl. árd rí, Rei Supremo (da Irlanda); gír. bung, bêbado; Hong Kong;

$025.30 \quad$ ᄃ; LM árvore/pedra [.31];

025.31 Macpherson: The Poems of Ossian: Temora II: "When thou, O stone, shalt fail"; irl. Liam: William, Guilherme; irl. Lía Fáil: monolito em Tara que emitia um ruído durante as coroações dos Reis Supremos;

025.32 MacCool; James Maculla: cunhou uma moeda de cobre para a Irlanda; irl. mór, grande; al. Reise, jornada;

025.33 Twain: Huckleberry Finn; hogged e bully (arqueado e bonito); 
025.34 Twain: Huckleberry Finn 5: (o mingau de Huck) "was most fifty... his eyes shining through like he was behind vines";

025.35 Batedor (no críquete);

025.36 W.G. Grace: famoso jogador inglês de críquete; Macaulay (Lord Thomas Babington, $1^{\circ}$ Barão de Macaulay);

\section{p. 26}

026.01 Stanford: Complete Collection of Irish Music as Noted by George Petrie n. 393: "Leather bags Donnel" [071.24]; embaralhar e dar as cartas; canção "Phil the Fluter's Ball": "the shuffle, and the cut";

026.02 Hopkins \& Hopkins: joalheiros de Dublim; sânscr. çastram, faca (castrar; ver 003.02);

026.03 Eggnog: bebida que contém ovo; "Kersse the Tailor" [311.07]; anglo-irl. tilly: pequena medida extra dada a um cliente: 13 pães em uma dúzia (choro) (do irl. tuilleadh, medida acrescentada); LM How Buckley shot the Russian General [.04];

026.04 Gír. náutica buggerlugs, maneira ofensiva de se dirigir a uma pessoa; bugger, "troca-troca" (sodomia entre homens); Sigurd: rei norueguês que foi para as cruzadas no século XII; gír. be going to Jerusalem (para lá de Bagdá ou Marraqueche; bêbado); arse (tiro na bunda do General [.03]); Ásia Menor;

026.05 Gr. agamê, virgem; gamecock, galo de briga; Peter, Jack e Martin: igrejas católica, anglicana e luterana, de acordo com A Tale of a Tub, de Swift [ver 007.04];

026.06 Budge: The Book of the Dead 35: (de Budge, cap. I and I.B) "Chapter I was recited by the priest who accompanied the mummy to the tomb... the priest (kher heb) assumed the character of Thoth... Chapter IB gave the sāhu, or 'spirit-body,' power to enter the Tuat immediately after the burial of the material body, and delivered it from the Nine Worms that lived on the dead";

026.07 Budge: The Book of the Dead 38: (de Budge, cap. LXIII) "The recital of Chapter LXIII enabled the deceased to avoid drinking boiling water in the Tuat. The water in some of its pools was cool and refreshing to those who were speakers of the truth, but it turned into boiling water and scalded the wicked when they tried to drink of it"; pron. anglo-irl. /tay/: tea; Papa Westray: uma das ilhas Orkney (o nome vem de Papae, missionários celtas enviados por São Columba para pregar aos pictos; nor. -ay: -ilha); lat. vester pater, o Papa; 
026.08 Canção “As Your Hair Grows Whiter I Will Love You More”; Buda renunciou à luxúria cortando os cabelos e lançandos-os ao céu; Budge, The Book of the Dead 31: "Osiris was the Wheat-god... and the beatified lived upon the body of their god and ate him daily"; 38: "cool water from the Celestial Nile and the springs of waters of heaven"; 34: (citando um hino e Rā) "Thou didst create the earth, and man, thou didst make the sky and the celestial river Hep"; Lorca: "Guadalquivir de las estrellas" ("Llanto por Ignácio Sanches Mejías” [1935]);

026.09 Buda foi chamado de herói por um monge; depois da Iluminação, Buda foi saudado sete vezes;

026.10 Included;

026.11 (Tua forma está delineada nas constelações); (Osíris foi desmembrado por Sete e seus órgãos espalhados [de acordo com uma versão, pelos céusaccording to one version, throughout the heavens]);

026.12 O hino egípcio a Ptah Tanen diz que a cabeça de Osíris está nos céus e seus pés na terra, ou em Duat, nos ínferos (D.A. Mackenzie, Egyptian Myth and Legend, 155); Trópico de Capricórnio; gr. koproi kaprôn: pig shit (lit. “excrementos de porco");

026.14 Sahu: habitação incorruptível das almas, na mitologia egípcia; ár. sahel, praia; Twain, Huckleberry Finn 29: "sure as you are born"; "And that's as shore as you were born"; Twain, Huckleberry Finn 20: "a corn-shuck tick... a shuck tick" (uma espécie de colchão grosseiro);

026.15 Twain, Huckleberry Finn 12: "texas" (oficial de cabine ou tombadilho nos vapores); sirga: cabo de reboque; 20: "tow-linen" (material para camisas); loathsome, repugnante; Twain, Huckleberry Finn 12: "lonesome" (solitário: aparece mais de dez vezes no livro de Twain); Tutancamão: Faraó da XVIII Dinastia;

026.16 Twain, Huckleberry Finn 31: "the road to Lafayette"; rio Liffey; Twain, Huckleberry Finn 31: “dropped in my tracks";

026.17 Neerl. onrustig, incomodado, inquieto; neerl. ongerust, preocupado; jarros canópicos encontrados na tumba de Tutancamão ilustrados com a figura da cabeça de reis [.18] [095.27]; bodysnatcher, ladrão de cadáveres; bottlewasher, lavador de garrafas; Chapelizod; temple; Ísis; 
026.18 Al. tot, morte; (totalmente calmo); Tutancamão; mensageiro; Budge, The Book of the Dead cap. XL: "Osiris Ra, triumphant, saith: 'Get thee back, Hai... Thoth hath cut of thy head, and I have performed upon thee all the things which the company of the gods ordered concerning thee in the matter of the work of thy slaughter. Get thee back, thou abomination of Osiris... I know thee, I know thee, I know thee, I know thee... Thou shalt not come to me, $\mathrm{O}$ thou that comest without being invoked, and whose [time of coming] is unknown"; anglo-irl. mether, medher: vasilhame de madeira para bebidas (do irl. meadar); Methyr: um dos nomes de Ísis; anglo-irl. jar: um "pint (1/8 de galão) of stout (cerveja escura e forte)"; bebida (em geral);

026.19 (Uma cerimônia funeral judaica termina assegurando aos mortos que todos os procedimentos fúnebres foram tomados de acordo com a tradição e pedindo ao morto perdão por qualquer engano ali cometido); Twain, Huckleberry Finn 31: "The man that bought him is named Abram Foster"; gír. abram, nu;

026.21 Precentor: dirigente do coro de uma igreja;

026.22 Christ Church e Saint Patrick: catedrais de Dublim;

026.23 Howe, monturo, túmulo; Howe: local do parlamento norueguês durante a ocupação viquingue de Dublim; Howe!: grito dos marinheiros;

026.24 sleep well;

026.25 (Same old way); appears;

026.26 Din. holmsted, propriedade; coffins, ataúdes;

026.27 Anglo-irl. bad scran to you: má sorte para você; influenza; Twain, Huckleberry Finn 35: "we heard the breakfast-horn blowing"; gong; dinnertime, hora do jantar; chime, carrilhão;

026.28 ábula de Esopo sobre a Barriga e os Membros;

026.29 Ilha de Man;

026.30 Jacob's Biscuit Factory, Dublim; crackers; Ulysses.16.805: "Dr Tibble's Vi-Cocoa”;

026.31 Edwards' Desiccated Soup; Mother Seigel's Syrup (tônico);

026.32 (Preço da carne); Persse O'Reilly [044.24]; fell, caído;

026.34 Igreja dos 3 Filhos de Nessan, Ireland's Eye; nice and regular; lessons; 
026.35 Business; gír. bee's knees: cúmulo da perfeição; LM hesitency; gr. athanasia, imortalidade; thánatos, morte;

026.36 Multiplication; "People who live in glass houses shouldn't throw stones" (o roto falando do rasgado);

\section{p. 27}

027.01 Fr. tombeau, tumba; gír. toss, masturbar; Disraeli;

027.02 Patrick; católicos;

027.03 Progenitor; avô;

027.04 William Shakespeare, Venus and Adonis 158: "Can thy right hand seize love upon thy left?" (LM esquerda/direita); Mateus VI, 3: "let not thy left hand know what thy right hand doeth" [não saiba a tua mão esquerda o que faz a tua direita] ${ }^{333}$;

$027.05 \wedge($ LM Jerry/Kevin) [.09]; Kevin: do irl. Caoimhín > Coemgen, de coem "gentil" egein "mascimento". São Caoimhín fundou um mosteiro em Glendalough, na Irlanda no século VI e é o patrono de Dublim; irl. ant. alfabeto Ogham; ocre;

027.06 Tricks, travessuras; Nick's (LM Mick/Nick [.07]);

027.07 Neerl. zeep, sabão; milksop, delicado, efeminado; Mick [.06]; cat. sabó, sabão; llet al pit, leite no peito;

027.08 Moore, Irish Melodies: canção "Lay His Sword by His Side [If the Sea Were Ink]”; al. Laus, piolho; Twain, Huckleberry Finn 32: "law sakes" (interjeição); gato por lebre;

027.09 Al. Knirps, manequim; ᄃ [.05]; Black and Tans: recrutas ingleses que serviram entre 1920 e 1921 no Royal Irish Constabulary (Constáblacht Ríoga na hÉireann; polícia), famosos pela truculência; galês taran, trovão; John Millington Synge, The Playboy of the Western World (peça de teatro); represendande: dândi;

027.10 Lat. encaustum, tinta magenta; costive, constipado; costly incomes (rendimentos); pron. anglo-irl. /lavings/: leavings;

027.11 Birthday suit, traje natalício, roupa de aniversário, Adão e Eva nus; fr. bourse, bolsa; fr. Bourse, bolsa de valores; $\dashv$ [.14]; Children of Mary: associação de moças católicas, Filhas De Maria; bursolete: bolsa + colete;

${ }^{333}$ Tradução de João Ferreira de Almeida. 
027.13 (Verde, branco e laranja: bandeira irlandesa); Litania da Abençoada Virgem Maria: "House of Gold, Tower of Ivory" (associada a Eileen de A Portrait I); fr. tour, torre; canção “The Holly and the Ivy" [.15]; lat. felix, feliz; (LM O felix culpa! (Exsultet));

$027.14 \vdash$ [.11] (ver a similaridade dos nome); Moore, Irish Melodies: canção "You Remember Ellen": "You remember Ellen, our hamlet's pride" [.17];

027.15 Our Lady's; lat. Luna, lua; Il Conte di Luna: personagem da ópera Il Trovatore, de Verdi (o Conde ama Leonora que está sendo cortejada por um trovador; mas o Conde não sabe que o rival é seu irmão); Holy Mary;

027.16 "Pia e Pura Bella": guerra religiosas na Idade Heróica (Vico);

027.17 Moore, Irish Melodies: conção "You Remember Ellen [Were I a Clerk]” [.14]; geléia Williams and Wood; meio penny de William Wood [011.21];

027.18 Post those posters; (projetar os lábios vermelhos de geléia [.16]); jam, geléia; doorjamb (senha);

027.19 (Dança); Katty Lanner: criada de Dublim;

027.20 Les Amours de Tabarin and Isabelle (peça de teatro); taborin; tam-tam: gong; tomtom; fr. gír. faire du tam-tam: causar tumulto; canção "Mr Whirligig Magee" (ou "The Ball of Whirligig Magee"); gír. whirligigs, testículos; cachucha: dança espanhola;

027.21 Delight, deleite; see;

Sinopse: ele procura levantar-se - os quatro o impedem;

027.22 Pron. anglo-irl. /aisy/: easy; (não acordar o companheiro de cama);

027.23 “Timóteo" significa “aquele que honra o Senhor"; Zekiel Irons: sacristão e pescador do livro de Le Fanu, The House by the Churchyard;

027.24 "Ezequiel” significa "Deus fortalecerá”; al. spüren, sentir; spawning, desova;

027.25 Canção “Enniscorthy”: "Dimetrius O'Flanigan McCarthy”; (tampe aquela garrafa);

027.26 Portobello: subdistrito de Dublim; Pomeroy, cidade no Condado de Tyrone; rus. vechnii pokoi, na vechnuiu pamiat: paz eterna, pela eterna lembrança; R.I.P.;

027.27 Here, aqui; irl. Binn Éadair: Howth; pron. anglo-irl. /nayther/: neither;

027.28 Al. Angst: neerl. angst, medo; rus. Avramovitch, filho de Abrão; he slumbers, ele repousa; limbo; lat. lumbus, lombo; Avramanes: -es: patronímico hibérico; 
027.29 Al. Mischer, intrometido;

027.30 So be it (assim seja);

Sinopse: a casa está em ordem e também a esposa;

027.31 (Keeping an eye on, vigiar); S ; K ; Katherine Strong [079.27]; it. burro, manteiga;

027.33 Memorial; fr. mur, lat. murus, muro; fr. mûr, maduro, bêbado;

027.34 (Wind the clock, dar corda no relógio);

027.35 Twain, Huckleberry Finn 32: “up a stump”; espanéfico: janota, afetado;

027.36 Twain, Huckleberry Finn 20: "shed his coat"; 19: “stern-wheel”;

\section{p. 28}

028.01 Guinevere (Rainha Genebra, esposa do Rei Artur, era amante de Sir Lancelote, um dos cavaleiros da távola redonda; esse triângulo amoroso é, provavelmente, uma contaminação pela história de Tristão e Isolda); Rainha de Eire;

028.02 Cat. també, também;

028.03 Lat. longa; it. grassa, gordura;

028.04 Anglo-irl. devil a hap'orth (não vale um tostão furado); hair's;

028.05 Lex Salica: contituição frânquica (as mulheres estavam excluídas das sucessões à coroa da França); leg's; din. salig, abençoada; irl. salach, sujo; al. selig, contente; neerl. zalig, delicioso; (gato); anglo-irl. does be (presente de "to be");

028.06 Cástor e Pólux (dióscuros); Round Table, távola redonda; abouret, banquinho;

028.07 Stick to one's last (não é da sua conta);

028.09 Servo-croata nestera, sobrinha; (aves); hell of a lunch (ótimo almoço); fr. à l'aval, rio abaixo; avalanche; alude: avalancha;

028.10 It's an ill wind that blows nobody good [expressão difícil de ser traduzida: significa uma notícia ruim que produz um resultado bom, como, por exemplo: "vai chover e as enchentes vão começar", mas os reservatórios se encheram];

028.11 "Best of men': epíteto do Buda; neerl. gulden, ouro; guilder, florim; gold and silver;

028.12 Anglo-irl. findrinny, bronze branco (do irl. fionn druine);

028.13 † reins, quadris; gír. ribbons (lit. fitas), rédeas; ribs, costelas; 
028.15 Earwicker;

028.17 Last post: clarim fúnebre ou tocado ao final do dia;

028.19 Anglo-irl. colcannon, prato irlandês composto por batata, repolho e cebolinhas, misturados com manteiga e leite (do irl. cál ceannfhionn); Caim e Abel; apple dumpling, espécie de pastel de maçã;

028.20 Merlin chair: cadeira de rodas inventada por J. J. Merlin; Evening World: jornal de Nova New, 1887-1931;

028.21 Casacos compridos;

028.22 Fellá, camponês, nos países árabes; Fez, cidade do Marrocos; Stormont: Parlamento da Irlanda do Norte; klingon jev, tormenta; Hud, montanha;

028.23 It. stilla, pinga (vb.); stella, estrela;

028.24 Dick, Tom, Harry [fulano, sicrano e beltrano] ( $\wedge$ $\square$ );

028.25 Knows; sobalçar: alçar; gretam (gritam): fendem;

028.26 Din. elsker, ama (vb.);

028.26 Selskar Gunn, filho de Michael Gunn [025.22]; amurs: occitano amors (pron. /amurs);

028.27 Fr. pervenche, caracol marinho;

028.27 No virgin; Norwegian's; din. viv, esposa; fr. vive, viva (subst.);

028.29 LM A carta; neerl. zee, tea; see; the; Congreve: The Way of the World (drama) ${ }^{334}$;

028.30 Last time; switch, chumaço de cabelo falso; al. flattern, vibrar, agitar-se;

028.31 Gr. anastasê, ressurreição; anglo-irl. how are you! (não seja ridículo) (LM A carta: how are you); worth her weight (vale quanto pesa); al. Wörter, palavras;

028.32 J. Adams and Sons: leiloeiros de Dublim; would-be; fr. actionnaire, acionista;

028.33 It. vivi, vivos; fr. reposez-vous, "tenha um bom descanso";

028.34 João VIII, 11: "sin no more” (não peques mais); an- (negação); gr. amartáno, pecado; thánatos, morte;

Sinopse: ele não voltará - a substituição;

${ }^{334}$ William Congreve (1670 - 1729). Poeta e dramaturgo inglês. 
028.35 By; namesake, xará; sibling, irmão; (sabedorias de Finn e do Salmon); (smolt é um salmão jovem; Smollett, salmãozinho (ver 014.28) [.36] [029.07] [029.08]);

028.36 m; Roderick Random (romance de Smollett); Roderico: último rei visigodo da Espanha (antes da ocupação árabe); heb. ram, alto [029.04];

\section{p. 29}

029.01 Conn of the Hundred Battles: lendário rei irlandês; hungry; fr. bordel; bottles; illicit drink shop (loja de bebidas ilegais); Chapelizod;

029.02 Lord-Mayor, prefeito; malaio buah, fruta, testículo (pl. buah-buah); baboon, babuíno; al. Baum, neerl. boom, árvore; sufixos peri- perto; af- afastado;

029.03 Dollop, colherada; lee side and weather side of ship (sotavento e barlavento); Lord Ardilaun: Sir Arthur Guinness;

029.04 Lord Iveagh: Edward Cecil Guinness, irmão de Ardilaun, filantropo; al. I wo! (interj. espanto ou descrença); lat. evoe, grito de alegria (das bacantes); for shame! (uma vergonha!); show; LM Shem/Shaun; dial. brewster: brewer (cervejaria);

029.05 chimney, chaminé; Phineas T. Barnum (ver 011.25);

029.06 Show there; shoulders, ombros; al. senken, afundar; heb. shekhem, um ombro;

029.07 Fellow; it. farfalla, borboleta; $\triangle$; gír. pock, sífilis; pocketknife, canivete; pig in a poke (comprar sem saber o valor); Smollett, Peregrine Pickle; gír. in pickle, com doença venérea; firefly, vagalume;

029.08 Lice, piolhos; sly, astuto; nits, lêndeas; little; Smollett, Humphrey Clinker; gír. clinkers, restos de feses presas aos pêlos do ânus;

$029.08 \wedge$ e $\sqsubset$; din. twilling, gêmeo; bugs, insetos, percevejos; boys; $\dashv$; Barnum: midgets (anões de circo); fr. puce, pulga; fr. pucelle, virgem;

029.09 Pron. anglo-irl. /aither/: either; gr. aithêr, éter; it. ricorso, recurso (Vico); ever seen;

029.10 X ; gír. footle, agir ou falar tolamente; stool pigeons, dedo-duro;

029.11 With; dial. aboon, above, acima; alone;

029.11 Hebreus 12:1: “compassed about with so great a cloud of witnesses" [tendo também posta sobre nós uma tão grande nuvem de testemunhas];

029.12 Anglo-irl. shee, das fadas (do irl. sídhe); 
029.13 Heb. eshet, mulher de (do heb. icha, mulher); East; Aesop's Fables (fábulas de Esopo); fib, calúnia; fiddle, rabeca; zéfiro (vento oeste); Sephiroth: 10 emanações do Ain Soph (a nona é Yesod), na Cabala; heb. erets, terra; a star; lat. astra, estrela; is it fib: é calúnia?;

026.14 Dossel; ornamento da cama, cobertura, copa;

029.15 White dwarf, red giant (anã branca, gigante vermelha: tipos de estrelas); branco e vermelho (política); theocracy; gr. erithrós, vermelho;

029.16 (red e white = pink); coalescing, aglutinar; heb. qoheleth: Eclesiastes (pregador);

029.17 Heb. saraph, cobra peçonhenta; angel, serafim; heb. Torá. lei (Pentateuco);

029.18 Heb. mappiq: sinal diacrítico (ponto) na letra HE; heb. hamma, sol; HCE;

029.19 Gír. overseen, um pouco bêbado; worthy of the naym: digno do céu; ár. nayim, dormente; heb. nayim, prazeiroso; heb. mayim, água;

029.20 (Local de nascimento); time-honoured, honorável; LM tempo/espaço; port. parochial; provincial; heb. raqia: firmamento;

029.21 Firmamento; time or; "Time and tide wait for no man" (o tempo e a ocasião não esperam por ninguém); gír. get the bum's rush (entrar a força); pron. do Ulster /hull/: hell; hell of a hurry (pressa dos diabos);

029.22 Wherry: barco raso; turbante; turbina; dhow, barco próprio do mar da Arábia; bei: governador turco; Dublin Bay; Condado de Wicklow;

029.23 Willow Pattern; arquipélago: mar principal, mar Egeu ${ }^{335}$;

029.24 † waxen, adulto; dugong, vaca-marinha;

029.25 Reproaching, acusar; repeating;

029.26 fishmonger, peixeiro; fr. soixante-dix, setenta; Sheba (esposa); tur. shebi, semelhança; heb. shevi, cativeiro; heb. sheva, sete;

029.27 Pron. anglo-irl. /shide/: side; tur. adi, normal; heb. adi, ornamento; heb. adey ad, para sempre; Horo e Sete (deuses egípcios; Horo era filho de Osíris; Sete, irmão de Osíris);

029.28 Haldane: Daedalus or Science and the Future 37: "the average plant turns most of its sugar not into starch which is digestible, but into cellulose which is not, but forms its

\footnotetext{
${ }^{335}$ A palavra arquipélago significa, etimologicamente, "mar principal", ou seja, o Mar Egeu. Como esse mar é repleto de ilhas, adotou-se a palavra "arquipélago" como coletivo de ilha.
} 
woody skeleton"; Caim e Sete (Gênesis IV, 25: "And Adam knew his wife again; and she bare a son, and called his name Seth: For God, said she, hath appointed me another seed instead of Abel, whom Cain slew" [Tornou Adão a coabitar com sua mulher; e ela deu à luz um filho, a quem pôs o nome de Sete ${ }^{336}$; porque, disse ela, Deus me concedeu outro descendente em lugar de Abel, que Caim matou.]); a maldição de Tutancamão [um grão de Osíris (barro moldado com a forma humana contendo sementes que cresceriam dentro da tumba) foi encontrado na tumba de Tutancamão ${ }^{337}$; it. tutto cessa, tudo passa; it. tutto un cesso, é tudo uma porcaria (lit. cesso, latrina); tur. batin, heb. beten, barriga;

029.29 Bating, sem levar em conta; inn; inebriated, embriagado; it. annebbiato, nublado;

029.30 HCE; lat. humilis, humilde; insect; incestuous;

029.31 Al. Beinamen, apelidos;

029.32 Heb. lashon, língua, linguagem; Anglo-irl. lashings, abundância; heb. khanneni, tenha pena de mim; Ordem da Jarreteira: "Honni soit qui mal y pense” ("maldito o que pensa mal disso");

029.33 Heb. khamishim, cinqüenta; heb. khamisha khumshey, cinco quintos (Pentateuco); tur. hamisen, em quinto lugar;

029.34 He is he and no other he; carta forjada por Pigott "Dear E!... let there be an end of this hesitency" (ver "Segunda Parte, nota 10); ultimately responsible; lat. timendum, ser temido; end; HCE heb. khibbubh, amor; Jardim do Éden ${ }^{338}$; Eden and Burgh Quays, Dublim: nas margens opostas do Liffey, um de frente para o outro; Edinburgo;

\footnotetext{
336 שת /Set'/, "compensação".

${ }^{337} \mathrm{Na}$ tumba de Tutancamão não havia nenhuma maldição inscrita à entrada, como se divulgou na época. Apenas uma pessoa, que já era doente e velha, morreu, mesmo assim, em Londres. Ver CERAM, s/d, p. 180-3.

${ }^{338}$ Ou "Jardim das Delícias"; a palavra Éden (עדן) tem o sentido de "prazer". Paraíso tem a seguinte etimologia: gr. parádeisos "jardim do palácio dos nobres persas"; < heb. pardês "pomar"; < persa antigo paridaeza "recinto circular”. A expressão “jardins do paraíso” é, portanto, uma redundância.
} 


\section{TRANSPALAVRAS}

Uma das interpretações cabalísticas da Bíblia menciona a utilização do signo bet, o segundo do sistema de escrita hebraico. Para essa interpretação, a escolha desse signo não é arbitrária: ele funciona como um colchete que abre o texto bíblico, o que significaria que à direita dele nada há, ou seja, que nada há aquém do "princípio":

\section{בראשית ברא אלהים את השמים ואת הארץ}

Sabe-se, no entanto, que o signo bet não tinha a forma de um colchete na língua hebraica e que essa forma apareceu no aramaico, numa escrita mais tardia, o que invalida tal interpretação:

\section{ケ4}

No entanto, devido ao grande número de menções à Cabala que aparece no Finnegans Wake, é provável que James Joyce conhecesse essa interpretação. Ao iniciar seu livro com uma palavra com inicial minúscula, palavra essa que completa o último parágrafo do livro, indicando sua circularidade, James Joyce não estava procurando um sinal que determinasse um início ou um fim, mas uma continuidade.

Pode ser que ele tenha se inspirado de fato no primeiro versículo do Gênesis da Vulgata:

\section{In principio creavit Deus caelum et terram}

Nesse versículo, está contida, em anagrama, a primeira palavra de Finnegans Wake, "riverrun":

In principio cREAVit Deus caelum et tERRAM (REAVERRAM).

Mais do que uma descoberta exegética, esse tipo de observação revela um problema que afeta a maioria dos leitores e críticos de Joyce: apofenia.

Apofenia $^{340}$ é um neologismo científico que indica a propensão em se ver conexões entre coisas que não apresentam relação lógica entre si; de se enxergar pistas por todo lado. Era um distúrbio do qual certamente Joyce padecia, como podemos ver em sua biografia. Ele gostava de encontrar coincidências entre as datas de nascimento dele e das pessoas que conhecia. Afirmava que, enquanto escrevia Finnegans Wake, deparava-se com uma série de

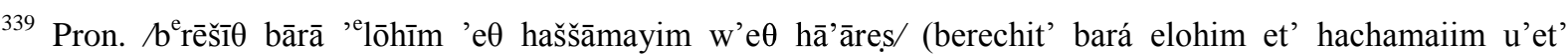
ha'arej). Gênesis I, 1.

${ }^{340}$ O termo foi cunhado em 1958 por Klaus Conrad.
} 
coincidências entre os fatos já narrados por ele no livro e os vividos depois. Que "tropeçava" nos fatos; e os incluía no livro.

No entanto, ainda que um excesso de observação ou de análise prejudique o caráter científico da avaliação crítica, ele favorece bastante os aspectos estéticos da interpretação. Ao intérprete, ou tradutor, ao menos no que diz respeito a obras da vanguarda, assiste o direito de exagerar. Prova disso é a tradução que o próprio Joyce fez de "Anna Livia" para o italiano. Por isso dissemos que o tradutor deveria transgredir as fronteiros do permitido.

A idéia de transgressão que adotamos neste trabalho como sinônimo de tradução não tem apenas o sentido etimológico de passar além como em alemão. Pois o nosso intuito não é mostrar que existe algo além da tradução no relacionamento dos textos, mas que a tradução pode ir além do escopo ao qual está limitada hoje em dia. Por isso definimos tradução como transgressão. Mas a idéia de transgressão tem aqui também o sentido de insurreição, de recusa em se enquadrar àquilo que é hoje o ofício do tradutor; de aceitar a tradução como uma arte subalterna à do romancista, do poeta, enfim, do criador; de aceitá-la como uma obra meramente de recriação.

A tradução é para nós: primeiro, um método interpretativo; segundo, uma forma de criação; terceiro, uma forma de transformação; e quarto, transcendência.

Tudo isso já dissemos antes. Resta-nos dizer por que repetimos no final algo que já foi dito no começo. Porque há algo que não dissemos: que transcendência não significa apenas ir além, transpor; significa também ir até ao começo, ao meio, às partes e ao todo, ignorando o espaço e o tempo. O ir-além não determina direção e sentido.

Finnegans Wake é uma obra planejada dessa maneira e, portanto, transcendental. Ela é, em sua totalidade, começo, meio e fim. Voltemos, então, para o momento em que o fim se encontra com o começo:

[FW 628.34]

Loonely in me loneness. For all their faults. I am passing out. O bitter ending! I'll slip away before they're up. They'll never see. Nor know. Nor miss me. And it's old and old it's sad and old it's sad and weary I go back to you, my cold father, my cold mad [FW 628]

father, my cold mad feary father, till the near sight of the mere size of him, the moyles and moyles of it, moananoaning, makes me 
seasilt saltsick and I rush, my only, into your arms, I see them rising! Save me from those therrble prongs! Two more. Onetwo moremens more. So. Avelaval. My leaves have drifted from me. All. But one clings still. I'll bear it on me. To remind me of. Lff! So soft this morning,ours. Yes. Carry me along, taddy, like you done through the toy fair! If I seen him bearing down on me now under whitespread wings like he'd come from Arkangels, I sink I'd die down over his feet, humbly dumbly, only to washup. Yes, tid. There's where. First. We pass through grass behush the bush to. Whish! A gull. Gulls. Far calls. Coming, far! End here. Us then. Finn, again! Take. Bussoftlhee, mememormee! Till thousendsthee. Lps. The keys to. Given! A way a lone a last a loved a long the

Sozinha em mia solitude. Por culpa de seus vícios. Traspasso-me. Amargo termo! Antes que se ergam, desvaio-me. Não chegarão a ver. Nem a conhecer. Perco-me deles. Velho e velho e triste e velho e triste e traste. Retorno a ti, meu hiberno pai, frio e treslocado pai, meu frio, funesto e treslocado pai, até a mais tênue visão de uma ínfima parte daquele vulto, molhas e molhas $^{341}$ daquilo, lhantos e lhantos, faz-me aluviar enleva e me derramo, sominha, em teus braços. Vejo-os ressurgirem! Preserva-me desses pervêsos ${ }^{342}$ flagícios! Domais $^{343}$. Adinante $^{344}$ devasto $^{345}$ espreiamar $^{346}$. Tanto. Avelavara. Minhas lívidas folhas me foram levadas. Todas. Uma apenas apega-se a mim. Eu a suportarei. Tra-la-ei na lembrança. Flh! Tão suave e senhora ${ }^{347}$, alvorada nossa! Isso. Leva-me contigo, meu pai, cria uma trilha entre as fragas! Se o vira descendo agora sobre mim, de alalvas abertas, como se vindo dos arcancelos, sondaria ${ }^{348}$ morrer a seus pés, húmile, mísera, enxurrada. Isso, pa. Há o onde. Primevo. Grassamos pela grama por baixo de arbustos. Remira! Uma alcatraia. Alcatraias. Distradas. Distantes. Chegando. Finito. Finato. Refinito. Toma. Osculha ensimesmora! Almar eterno a ti. Lhfs. Chaves não há? Dadas! Além a via a lúvia a leva a lá do

\footnotetext{
${ }^{341}$ Moyle; molhe, cais, milha;

342 Perversos + vesos, visígotos, bárbaros;

${ }^{343}$ Domani + demà + demais + dois mais;

${ }^{344}$ Rus. adin (um) + heb. adam (homem) + adiante;

${ }^{345}$ Rus. dva (dois) + vasto + devastado + devasso;

${ }^{346}$ Espreita + espera + preamar;

${ }^{347}$ Ours, hour;

${ }^{348}$ Sink + think;
} 
A metamorfose do rio em mar, do mar em nuvem, da nuvem em chuva e da chuva em rio é o ciclo viquiano, ou vicioso, da vida, reproduzido no último parágrafo do livro. Mas a metamorfose aqui é, também, a transformação de Dafne em loureiro:

'fer, pater,' inquit 'opem! si flumina numen habetis,

qua nimium placui, mutando perde figuram! (Ovídio, I, 545,6)

[Ajuda-me, pai! Se tens o nume dos rios,

pelo muito que hei sofrido, deforma meu aspecto!]

que Joyce reproduziu desta forma: "Salva-me, meu frio pai (o mar), deste terrível sofrimento; leva-me em frente...” Carregada pelo pai, ela será jogada na baía, onde sofrerá a metamorfose que a eternizará pelos ciclos dos tempos. É como o loureiro, a árvore da memória (“'One [leaf] clings still. To remind me of... mememoremee [mnemosine]!"), cujas folhas foram consagradas por Apolo aos feitos gloriosos, para que fossem eternizados. O louro, bay, em inglês, é a baía (bay), o local em que deságua o rio e a memória (mememormee) para sempre (till thousendsthee); o local da eterna metamorfose.

O exemplo que demos acima, extraído da última página de Finnegans Wake, serve para demonstrar, mais do que um critério e um método, um objetivo. A leitura da tradução mostra um texto bastante independente do original, mas mostra também o quanto se apegam tradução e original. E, mais do que isso, revela um texto que, feito à imagem e semelhança de outro, o complementa. Para rejeitá-lo em seguida. Tradução é metamorfose. E assim o transcende. Mas não lhe rejeita o valor, nem a grandeza, como fez Dafne com Apolo, mas rejeita-lhe o tempo e o espaço, como fez Joyce com o romance. 


\section{REFERÊNCIAS:}

\section{BIBLIOGRAFIA}

ADORNO, T. W. Filosofia da nova música. São Paulo: Perspectiva, 1989.

ADORNO, T. W.; HORKHEIMER, M. Dialética do esclarecimento: fragmentos filosóficos. Rio de janeiro: J. Zahar, 2006.

AMADO, Jorge. A morte e a morte de Quincas Berro Dágua. 59. ed. Rio de Janeiro: Record, 1987.

ANDERSON, Chester. James Joyce. Londres: Thames and Hudson, 1998.

AQUINAS, Thomas. Summa Theologica.. Chicago: Encyclopaedia Britannica, 1987. (Great Books of the Western World. v. 19-20)

ARISTÓTELES. Poética. Trad. Eudoro de Sousa. São Paulo: Ars Poetica, 1993.

ARNOLD, Matthew. On translating Homer. London: Routledge, s/d.

ARRIGHI, Giovanni. O longo século XX. Rio de Janeiro: Contraponto; São Paulo: UNESP, 1996.

ASTRADA, Carlos. Dialéctica e historia. Buenos Aires: Juáres, 1969.

ATHERTON, James S. The Books at the Wake. New York: Paul P. Appel, 1974.

ATTRIDGE, Derek. Peculiar Language. Ithaca: Cornell University, 1988.

AUERBACH, Erich. Mimesis. São Paulo: Perspectiva, 1971.

BAKHTIN, Mikhail. Questões de Literatura e de Estética. São Paulo: UNESP, 1993. . Problemas da poética de Dostoiévski. Trad. Paulo Bezerra. Rio de Janeiro: Forense, 1997.

BECKETT, Samuel (Org.). Finnegans Wake A Symposium. New York: A New Directions Book, 1972.

BECKETT, Samuel et al. Our Exagmination Round his Factification for Incamination of “Work in Progress”. London: Faber \& Faber, 1961.

BEJA, Morris. James Joyce A Literary Life. Dublin: Gill and Macmillan, 1992. 
BENJAMIN, Walter, Sobre arte, técnica, linguagem e política. Lisboa: Relógio D’Água, 1992. . Illuminations. London: Fontana, 1993.

BENSTOCK, B. Joyce-again's Wake: An Analysis of Finnegans Wake. Seattle: University of Washington, 1965.

BERLIN, Isaiah. Vico e Herder. Brasília: UNB, 1982.

BERMAN, Antoine (Org.). Les Tours de Babel. Mauvezin: Trans-Europ-Repress, 1985.

BHAGAVAD- GÎTÂ. São Paulo: Pensamento, 1999.

BISHOP, John. Joyce's Book of the Dark. Madison: University of Wisconsin, 1986.

BLAKE, William. The works of William Blake. Ware: The Wordsworth, 1995.

BLOM, Eric (Ed.). Grove's Dictionary of Music and Musicians. New York: St. Martin's, 1955.

BOLDRINI, Lucia. Joyce, Dante and the Poetics of Literary Relations. Cambridge: Cambridge University, 2001.

BOSI, Alfredo. O ser e o tempo na poesia. São Paulo: Cultrix, 1990.

BRASIL, Assis. Joyce e Faulkner, o romance da vanguarda. Rio de Janeiro: Imago, 1992.

BRADBURY, Malcolm. O Mundo Moderno: dez grandes escritores. São Paulo: Companhia das Letras, 1989.

BRUNO, Giordano. Sobre o infinito, o universo e os mundos. São Paulo: Abril Cultural, 1978. (Os pensadores)

BUDGE, E. A. W. An Egyptian Hieroglyphic Dictionary in two volumes. New York: Dover, 1978.

. O livro egípcio dos mortos. São Paulo: Pensamento, 1995.

. A magia egípcia. São Paulo: Cultrix/Pensamento, 1996.

BURGESS, Anthony. Joysprick. New York: A Haarvest Books, 1975. . Homem comum enfim. São Paulo: Companhia das Letras, 1994.

BURKE, Peter. Vico. São Paulo: UNESP, 1997.

BUTOR, Michel (Org.). Joyce e o Romance Moderno. São Paulo: Ed. Documentos, 1969. 
BUTOR, Michel. Repertório. Trad. Leyla Perrone-Moisés. São Paulo: Perspectiva, 1974. et al. Joyce e o estudo dos romances modernos. São Paulo: Mayo, 1974.

CAMPBELL, Joseph. Mythic worlds, modern words on the art of James Joyce. Novato, California: New World, 2004.

CAMPBELL, Joseph; ROBINSON, Henry M. A Skeleton Key to Finnegans Wake. Cutchogue, New York: Buccaneer Books, 1976.

CAMPOS, Augusto; CAMPOS, Haroldo de. Panaroma do Finnegans Wake. São Paulo: Perspectiva, 1971. . Re Visão de Sousândrade. 3. ed. São Paulo: Perspectiva, 2002.

CAMPOS, Haroldo de. A arte no horizonte do provável. São Paulo: Perspectiva, 1977. . Deus e o Diabo no Fausto de Goethe. São Paulo: Perspectiva, 1981.

. Metalinguagem \& outras metas: ensaios de teoria e crítica literária. São Paulo: Perspectiva, 2004.

CANDIDO, Antonio. Formação da Literatura Brasileira. 3 ed. São Paulo: Martins, 1969. . "A literatura e a formação do homem". In: Remate de males ( $\mathrm{n}^{\mathrm{o}}$ especial). Campinas: IEL/UNICAMP, 1999. et al. A personagem de ficção. 2. ed. São Paulo: Perspectiva, 1970.

CARPEAUX, O. M. "James Joyce em Trieste”. In: Presenças. Rio de Janeiro: Min. da Ed. e Cultura; Inst. Nac. Do Livro, 1958.

. "As três ruas de Svevo". In: Livros na mesa: Estudos de Crítica. Rio de Janeiro, Liv. São José, 1960.

. História da literatura ocidental. Rio de Janeiro: O Cruzeiro, 1964. 8 v. . Uma nova história da música. Rio de Janeiro: Alhambra, 1977. . Ensaios Reunidos (1942-1978). Rio de Janeiro: Universidade, 1999.

CERAM, C. W. Deuses, túmulos e sábios. Trad. João Távora. São Paulo: Círculo do Livro, 1967.

CHAMBERLAIN, W. D. Gramática exegética do grego neo-testamentário. São Paulo: Presbiteriana, 1989.

CHENG, Vincent J. Joyce, race, and empire. Cambridge: University, 1995. 
CHIAPPINI, Ligia; LEITE, Moraes. O foco narrativo. 10. ed. São Paulo: Ática, 2002.

CINTRA, A. C. A. O Lusobrasileirês no Finneganês. São Paulo: Olavobrás/ABEI, 2003.

CLARK, Katerina; HOLQUIST, Michael. Mikhail Bakhtin. São Paulo: Perspectiva, 2004.

COELHO, J. G. "Ser del tiempo en Bergson”. In: Interface - Comunic., Saúde, Educ., v. 8, n. 15, p. 233-46, mar/ago 2004.

CONNOLLY, T. E. (Ed.) James Joyce's Scribbledehobble: The Ur-Workbook for Finnegans Wake. Chicago: Northwestern, 1961.

CORTÁZAR, Julio. Valise de Cronópio. 2 ed. São Paulo: Perspectiva, 2006.

COYLE, John. Ulysses/A Portrait of the Artist as a Young Man - A Reader's Guide to Essential Criticism. Cambridge: Icon Books, 2000.

DEATHRIDGE, J.; DAHLHAUS, C. Wagner. Trad. Maria Mendes Bezerra. Porto Alegre: L\&PM, 1988.

DERRIDA, Jacques. Gramatologia. 2. ed. São Paulo: Perspectiva, 2004.

DRYDEN, John. The Works of John Dryden. Ware: Wordsworth, 1995.

DUJARDIN, Édouard. Les lauriers sont coupés. Paris: Flammarion, 2001.

ECO, Umberto. Obra Aberta. São Paulo. Perspectiva, 1976.

ECO, Umberto. Las poéticas de Joyce. 3. ed. Barcelona: Lumen, 1998.

ELLMANN, Richard. James Joyce. Trad. Lya Luft. Rio de Janeiro: Globo, 1982. London: Oxford University, 1983.

ELLMANN, Richard. Yeats: the man and the masks. New York/London: W. W. Norton \& Company, 1979.

FAIRHALL, J. Joyce and the question of history. Chicago: Cambridge University, 1993.

FARRATER MORA, J. "Vico ou a visão renascentista". In: Visões da história. Porto: rés, s/d. FEHÉR, Ference. O Romance está morrendo? Rio de Janeiro: Paz e Terra, 1997.

FIKER, Raul. Vico, o precursor. São Paulo: Moderna, 1994.

FOSTER, R. F. The Oxford History of Ireland. Oxford: Oxford University, 1989.

FORSTER, Edward M. Aspectos do Romance. 2. ed. São Paulo: Globo, 1998. 
FREUD, S. The Interpretation of Dreams. Chicago: Encyclopaedia Britannica, 1987. (Great Books of the Western World. v. 54)

GALEGO, C. P. James Joyce o la revolución de la novela. Madrid: Fundamentos, 1987.

GILBERT, Stuart. James Joyce's/Ulysses. London: Faber \& Faber, 1952.

GLASHEEN, A. Third Census of Finnegans Wake - An Index of the Characters and Their Roles. Berkeley: University of California, 1977.

GOMIS, Màrius "Goethe i la traducció". In; Quadernos. Revista de traducció 3, p. 125-133. Barcelona, 1999.

GOLDMANN, Lucien. Sociologia do romance. Rio de Janeiro: Paz e Terra, 1967.

GONZALEZ, Jose Carnero. James Joyce y la Explosión de la Palabra. Sevilla: Universidad de Sevilla, 1989.

GORMAN, Herbert. James Joyce, a definitive biography. London: John Lane The Bodley Head, 1949.

GUIDO, Humberto. Giambattista Vico. Petrópolis: Vozes, 2004.

HARARI, Roberto. Como se chama James Joyce? Salvador: Ágalma; Rio de Janeiro: Companhia de Freud, 2003.

HARDIMAN, JAMES (Org.). Irish Minstrelsy, or Bardic Remaisn of Ireland. London: Joseph Robins, 1831.

HART, Clive. Structure and Motif in Finnegans Wake. London: Faber \& Faber, 1962.

HAUSER, Arnold. História social da arte e da literatura. Trad. Álvaro Cabral. São Paulo: Martins Fontes, 1995.

HAYMAN, D. A First Draft Version of Finnegans Wake. Austin: University of Texas, 1963. . The "Wake" in Transit. Ithaca: Cornell University, 1990.

HEGEL, G. W. F. Estética. Lisboa: Guimarães, 1993. Fenomenologia do Espírito. 4. ed. Petrópolis: Vozes, 1999.

HESÍODO. Teogonia: A origem dos Deuses. Trad. JAA Torrano. São Paulo: Iluminuras, 1995.

HOBSBAWM, Eric. The Age of Extremes: A History of the World, 1914-1991. New York: Vintage Books, 1996. 
HODGART, Matthew J. C.; BAUERLE, Ruth. Joyce's Grand Operoar. Chicago: University of Illinois, 1997.

HOGG, James. The private memoirs and confessions of a justified sinner. New York: N. Y. Review Books, 2002.

HOMERO. Ilíada. Trad. Odorico Mendes. São Paulo: W. M. Jackson, 1952. . Odisséia. Trad. Odorico Mendes. São Paulo: EDUSP, 2000.

HUGO, Vítor. Os miseráveis. Mira-Sintra: Europa-América, s/d. 5 v.

HUMPHREY, Robert. O fluxo da consciência. Trad. Gert Meyer. Recife: Mcgraw, 1976.

HUTCHINS, Patricia. James Joyce's World. London: Methuen, 1957.

IBSEN, H. J. Seis dramas. Trad. Vidal de Oliveira. Rio de Janeiro: Ediouro, s/d.

JAMES, William. The Principles of Phycology. Chicago: Encyclopaedia Britannica, 1987. (Great Books of the Western World. v. 53)

JOYCE, James. Gente de Dublim. Trad. Virgínia Motta Lisboa: Livros do Brasil, s/d a. . Retrato do artista quando jovem. Trad. Alfredo Margarido . Lisboa: Livros do Brasil, $\mathrm{s} / \mathrm{d} b$.

. The Critical Writings. London: Faber \& Faber, 1959.

. Ulysse. Trad. Auguste Morel. Paris: Livre de Poche, 1965.

. Ulisses. Trad. Antonio Houaiss. 2. ed. São Paulo: Círculo do Livro, 1975.

. Dedalus - Ritratto dell'artista da giovane. Trad. Cesare Pavese. Milano: Adelphi, 1976a.

. Finnegans Wake. London: Penguin Books, 1976 b.

. Gens de Dublin. Trad. Yva Fernandez, Hélène du Pasquier, Jacques-Paul Reynau Saint-Amand: Plon, 1980.

_. Exilados. Trad. Javier Fernándes de Casto. Barcelona: Bruguera, 1981.

. Finnegans Wake. Trad. Philippe Lavergne. Paris: Gallimard, 1982.

. Giacomo Joyce. Introdução Richard Ellmann.London: Faber \& Faber, 1984.

. Stephen le Héros. Trad. Ludmila Savitsky. Paris: Gallimard, 1986.

. Exilados. Trad. João Palma Ferreira. Lisboa: Livros do Brasil, 1987. 
JOYCE, James. Ulisse. Trad. Giulio de Angelis. Milano: Mandadori, 1991.

. Anna Livia Plurabelle. Trad. Francisco García Tortosa Madri: Cátedra Letras Universales, 1992a.

. Dublinenses. Trad. Hamilton Trevisan. Rio de Janeiro: Ediouro, $1992 \mathrm{~b}$.

. Dubliners. Ware, Hertfordshire: Wordsworth Classics, 1993a.

. Finnegans Wake. Trad. Víctor Pozanco. Barcelona: Lumen, 1993 b.

. Ulysses. London: Oxford University, 1993c.

. Retrato do Artista Cando Novo. Trad. Vicente Araguas . Santiago de Compostela: Laiovento, 1994.

. A Portrait of the Artist as a Young Man. London: Penguin Books, 1996.

- Música de Câmara. Trad. Alípio Correia de Franca Neto. São Paulo: Iluminuras, 1998a.

. Retrato do artista quando jovem. Trad. José Geraldo Vieira. São Paulo: Biblioteca Folha, 1998b.

. Finnegans Wake. H. C. E. Trad. Luigi Schenoni. Milano: Mondadori, 1999a.

. Ulises. Trad. J. M. Valverde. Barcelona: Lumen, 1999b.

. Finnegans Wake / Finnicius Revém. Capítulo 1, v. 1, 1. ed., Trad. Donaldo Schüler. Cotia, SP: Ateliê; Porto Alegre: Casa de Cultura Guimarães Rosa, 1999c.

Capítulos 2 a 4. v. 2. Trad. Donaldo Schüler Cotia, SP; Porto Alegre: Casa de Cultura Guimarães Rosa Ateliê, 2000a.

. Gente di Dublino. Trad. Daniele Benati. Milano: Feltrinelli, 2000b.

. Finnegans Wake / Finnicius Revém. Capítulos 5 a 8. v. 3. Trad. Donaldo Schüler Cotia, SP: Ateliê, 2001a.

. Pomas, um tostão cada. Trad. Alípio Correia de Franca Neto. São Paulo: Iluminuras, $2001 b$.

. Finnegans Wake / Finnicius Revém. Capítulos 9 a 12. v. 4. Trad. Donaldo Schüler Cotia, SP: Ateliê, 2002.

Capítulos 13 a 17. v. 5. Trad. Donaldo Schüler Cotia, SP: Ateliê, 2003.

. Capítulo 1. v. 1. 2. ed. rev. Trad. Donaldo Schüler. Cotia, SP: Ateliê, 2004. 
JOYCE, James. Ulisses. Trad. Bernardina da Silveira Pinheiro. Rio de Janeiro: Objetiva, 2005. JOYCE, Stanislaus. My Brother's Keeper. London: Faber \& Faber, 1958.

KAZANTZAKIS, N. The Odyssey - A Modern Sequel. New York: Simon and Schuster, 1958.

KEHDI, Valter. Formação de palavras em português. 2. ed. São Paulo: Ática, 1997.

KHLÉBNIKOV, Velimir. Ka. Trad. Aurora Fornoni Bernardini. São Paulo: Perspectiva, 1977.

KITTO, H. D. F. A tragédia Grega. Trad. José Manuel Coutinho e Castro. London: Coimbra, 1990.

KOSELLECK, Reinhart. Futuro pasado. Barcelona: Ediciones Paidos, 1993.

KOYINOV, V. et al. El destino de la novela. Buenos Aires: Orbelus, 1967.

LARBAUD, Valery. Sob a invocação de São Jerônimo. São Paulo: Mandarim, 2001.

LEMINSKY, Paulo. "Investigando a vida de um texto bastardo". In: Giacomo Joyce. São Paulo: Brasiliense, 1985.

LEVIN, Harry. James Joyce. Nova Iorque: New Publishing Corporation, 1960.

LE FANU, Sheridan. The house by the churchyard. Belfast: Appletree, 1992.

LOCKE, John. An Essay Concerning Human Understanding. Chicago: Encyclopaedia Britannica, 1987. (Great Books of the Western World, v. 35)

LOPES NETO, Simões. Contos gauchescos. Porto Alegre: Globo, 1976.

LORENZ, F.V. Cabala. São Paulo: Pensamento, 2000.

LUKÁCS, G. A teoria do romance. Trad. Alfredo Margarido. Lisboa: Presença, s/d.

MAGALANER, Marvin; KAIN, Richard M. Joyce: The Man, the Work, the Reputation. Nova Iorque: Plantin Paperbacks, 1990.

MANGAN, JAMES CLARENCE. His Select Poems, with a study. Norwood, Mass.: Lamson, Wolfe \& Co., 1897.

MARGARIDO, Alfredo; PORTELA FILHO, Artur. O novo romance. Lisboa: Presença, s/d.

MARTINS, Nilce Sant'anna. O léxico de Guimarães Rosa. São Paulo: EDUSP, 2001.

MARX, K.; ENGELS, F. La ideologia Alemana. Montevideo: Pueblos Unidos, 1971. . Obras Escolhidas. Lisboa: Avante, 1982. 3 v. 
MASON, E.; ELLMANN, R. The critical writings of James Joyce. London: Faber \& Faber, 1959.

МАЯКОВСКИЙ, В. Собрание сочинений в восьми томах "Правда": Мосва, 1968.

MCHUGH, R. The Sigla of Finnegans Wake. Austin: University of Texas, 1976.

MENDES, Manuel Odorico. Virgílio Brasileiro ou tradução do poeta latino. 2. ed. São Luís: EDUFMA, 1995.

MILTON, John. O poder da tradução. São Paulo: Ars Poetica, 1993.

MINK, Louis O. A Finnegans Wake Gazetteer. Bloomington: Indiana University, 1978.

NESTROVSKI, A. (Org.). riverrun. Rio de Janeiro: Imago, 1992.

NIETZSCHE, Friedrich. Sobre verdad y mentira en sentido extramoral. Madrid: Tecnos, 1990.

. Obras incompletas. São Paulo: Nova Cultural, 1999. (Os Pensadores)

NORRIS, Margot. The decentered universe of F.W. London: The Johns Hopkins University, 1976.

NORRIS, David; FLINT, Carl. Introducing Joyce. Cambridge: Icon Books, 2000.

O'BRIEN, E. James Joyce. Trad. Marcos Santarrita. Rio de Janeiro: Objetiva, 1999.

OLIVEIRA, Ariovaldo U. "Espaço e Tempo: Compreensão materialista dialética". In: Novos Rumos da Geografia Brasileira. São Paulo: Hucitec, 1982. p. 66-110.

ORTEGA Y GASSET, José. "Miséria y esplendor de la traduccion". In: Obras completas. v. 5. Madrid: Revista de Occidente, 1947.

OUSBY, Ian. The Wordsworth Companion to Literature in English. Ware: Wordsworth Reference, 1990.

OVIDE. Les metamorphoses. Paris: Garnier Fréres, 1966.

PACI, Francesca Romana. James Joyce vida y obra. Barcelona: Ediciones Península, 1987.

PARIS, Jean. Joyce par lui-même. Bourges: Seuil, 1957.

PARTRIDGE, Eric. Shakespeare's bawdy. London: Routledge, 1990.

PETRONIO, Giuseppe. História de la literatura Italiana. Madrid: Catedra, 1990.

PLATO. Cratylus. Chicago: Encyclopaedia Britannica, 1987a. (Great Books of the Western World. v. 7) 
PLATO. Timaeus. Chicago: Encyclopaedia Britannica, 1987b. (Great Books of the Western World. v. 7)

POMORSKA, Krystyna. Formalismo e Futurismo. São Paulo: Perspectiva, 1972.

POUND, Ezra. A arte da poesia. São Paulo: Cultrix/EDUSP, 1976. . ABC da Literatura. São Paulo: Cultrix, 1997.

PUSHKIN, Alexandr. Eugene Onegin. Trad. Vladimir Nobokov. New York: Pantheon Books, 1964.

QUINET, Edgar. Travaux. Paris: Hachette, 1895.

ROSA, J. Guimarães. Tutaméia. Rio de Janeiro: José Olimpo, 1967. . Grande Sertão: Veredas. São Paulo: Abril, 1983. . Gran Sertón: Veredas. Madrid: Alianza, 1999.

ROSA, J. Guimarães; BIZZARRI, E. J. Guimarões Rosa: correspondência com seu tradutor italiano Edoardo Bizzarri. São Paulo: T. A. Queiroz, 1981.

ROSENFELD, Anatol. Texto/ Contexto. São Paulo: Perspectiva, 1985.

ROUGEMONT, D. O Amor e o Ocidente. Lisboa: Voga, 1989.

ROUSSEAU, Jean-Jacques. Ensaio sobre a Origem das Línguas. São Paulo: Nova Cultural, 1999. (Os pensadores)

SANTOS, Agenor Soares dos. Guia prático de tradução inglesa. São Paulo: Cultrix, 1996.

SCHNAIDERMAN, Boris. A poética de Maiakóvski. São Paulo: Perspectiva, 1971.

SCHÜLER, Donaldo. Teoria do Romance. São Paulo: Ática, 1989. . Finnício Riovém. Rio de Janeiro: Lamparina, 2004.

SILVA, Arlenice A. "O símbolo esvaziado: A teoria do romance do jovem György Lukács". In: Trans/Form/Ação, 29 (1). São Paulo, 2006, 82 p.

SKINNER, B. F. O comportamento verbal. São Paulo: Cultrix/EDUSP, 1978.

SOARES, A. Gêneros Literários. São Paulo: Ática, 1989.

SPIELBERG, Peter. James Joyce's: Manuscripts \& Letters at the University of Buffalo - A Catalogue. Buffalo: University of Buffalo, 1962.

SPINA, Segismundo. Manual de versificação românica medieval. Cotia, SP: Ateliê, 2003. 
TINDALL, William Y. A Reader's Guide to Finnegans Wake. London: Thames and Hudson, s/d.

TODOROV, Tzvetan. As estruturas narrativas. São Paulo: Perspectiva, 1970.

TROTSKI, Leon. Literatura e revolução. Paris: Fronteira, 1976.

TYMOCZKO, M. Translation in a Postcolonial Context. Manchester: St. Jerome, 1999.

UPJOHN, E.M. et al. História Mundial da Arte. São Paulo: Martins Fontes, 1979.

VÁRIOS. The Translators to the Reader (Preface to The Holy Bible). London: Trinitarian Bible Society, 1998.

VALVERDE, José Maria. Conhecer James Joyce e a sua obra. [S.I.]: Ulisseia, s/d.

VEGA, Miguel Ángel. Textos clásicos de teoría de la traducción. Madrid: Cátedra, 1994.

VENUTI, Lawrence. The translator's invisibility. London: Routledge, 2002.

VERENE, Donald P. Vico and Joyce. New York: State University of New York, 1987.

VICO, Giambattista. Princípios de (uma) ciência nova. São Paulo: Abril Cultural, 1979. (Os pensadores) . La scienza nuova. Milano: Biblioteca Universali Rizzoli, 1998. . Ciência Nova. Lisboa: Fundação Calouste Gulbenkian, 2005.

VIEIRA, Pe Antonio. Sermões. Porto: Lello e Irmão, 1951. 15 v.

VIRGÍLIO. Eneida. Trad. Odorico Mendes. Cotia, SP: Ateliê, 2005.

VIZIOLI, Paulo. James Joyce e sua obra literária. São Paulo: E.P.U, 1991.

WATT, Ian. A Ascensão do Romance. São Paulo: Companhia das Letras, 1996.

WHITROW, G. J. O tempo na história. Rio de Janeiro: J. Zahar, 1993.

WILSON, Edmund. O castelo de Axel. Trad. José Paulo Paes. São Paulo: Cultrix, 1985. . Rumo à estação Finlândia: escritores e atores da história. São Paulo: Companhia das Letras, 2006.

XISTO, P.; CAMPOS, A.; CAMPOS, H. Guimarães Rosa em três dimensões. São Paulo: Conselho Estadual de Cultura, 1970.

YEATS, W. B. The works of W. B. Yeats. Ware: Wordsworth, 1994. 


\section{1. OBRAS DE REFERÊNCIA:}

A Bíblia Sagrada - Antigo e Novo Testamento. Trad. António Pereira de Figueiredo. São Paulo: Rideel, 1997.

A Bíblia Sagrada - Antigo e Novo Testamento. Trad. João Ferreira de Almeida. 2. ed. rev. São Paulo: Sociedade Bíblica do Brasil, 1998.

ALBERTÍ, Santiago. Diccionari Castellà-Català, Català-Castellà. Barcelona: Albertì, 1993.

ALMOYA, Julio Martínez. Dicionário de Espanhol-Português. Porto: Porto Editora, 1983.

AZEVEDO, Francisco F. dos Santos. Dicionário analógico da língua portuguesa. São Paulo: Companhia Editora Nacional, 1950.

BARBOSA, Omar. Grande dicionário de sinônimos e antônimos. São Paulo: Ediouro, s/d.

BONHEIM, Helmut. A Lexicon of the German in Finnegans Wake. Berkeley: University of California, 1967.

BOURKE, ULICK. The College Irish Grammar. Dublin: John O’Daly, 1856.

BUESCU, Victor (Coord.). Dicionário de Romeno-Português. Porto: Porto Editora, s/d.

CALDAS AULET. Dicionário contemporâneo da língua portuguesa. Lisboa: Delta, 1974.

DOLAN, T. P. A Dictionary of Hiberno - English. Dublin: Gill \& Macmillan, 1999.

Enciclopédia Mirador Internacional. Rio de Janeiro: Encyclopaedia Britannica do Brasil, 1993.

Encyclopaedia Britannica. Chicago: Encyclopaedia Britannica, 1988.

FERREIRA, A. G. Dicionário de latim-português. Porto: Porto Editora, 1988.

FREIRE, Antônio. Gramática grega. São Paulo: Martins Fontes, 1987.

GIFFORD, Don. Joyce Annotated. Berkeley: University of California, 1967.

GIFFORD, D.; SEIDMAN, R. J. Ulysses Annotated. Berkeley: University of California, 1997.

GUASCH, P. Antonio. El idioma Guarani. 6. ed. Asunsion: Loyola, 1983.

GUIMARÃES, Ruth. Dicionário da mitologia grega. São Paulo: Cultrix, 1996.

HINNELLS, John R. Dicionário das Religiões. Trad. Octávio Mendes Cajado. São Paulo: Círculo do Livro, 1984.

HUEHNERGARD, John. A grammar of akkadian. Winona Lake: Eisenbrauns, 2000. 
LARA, Jesus. Diccionario Castellano-Queshwa, Queshwa-Castellano. Cochabamba: Amigos del Libro, 1978.

MCHUGH, Roland. Annotations to Finnegans Wake. Baltimore: The Johns Hopkins University, 1991.

MEA, Giuseppe. Dizionario Italiano-Portoghese. Porto: Zanichelli/Porto, 1994.

Novo dicionário ilustrado brasileiro Melhoramentos. São Paulo: Melhoramentos, 1968.

O'HEHIR, B. A Gaelic Lexicon for Finnegans Wake. Berkeley: University of California, 1967.

OHEHIR, Brendan; DILLON, John M. A Classical Lexicon for Finnegans Wake. Berkeley: University of California, 1977.

SPALDING, Tassilo Orpheu. Dicionário da mitologia Latina. São Paulo: Cultrix, 1991.

SPALDING, Tassilo Orpheu. Dicionário de mitologia germânica, eslava, persa, indiana, chinesa, japonesa. São Paulo: Cultrix, 1991.

- Dicionário de mitologia egípcia, sumeriana, babilônica, fenícia, hurrita e hetita e celta. São Paulo: Cultrix, 1993.

. Dicionário da mitologia grega. São Paulo: Cultrix, 1996.

SILVEIRA BUENO. Grande dicionário etimológico prosódico. São Paulo: Saraiva, 1963.

TOCHTROP, L. Dicionário Alemão-Português. São Paulo: Globo, 1989.

The Webster Third. Chicago: Encyclopaedia Britannica, 1988.

VANGEMEREN, W. A. New International Dictionary of Old Testament Theology e Exegesis. Michigan: Zondervan, 1996.

VOINOVA, N. et al. Dicionário Russo-Português. Moscovo: Edições "Russki Yazik”, 1989.

\section{2. OBRAS DE REFERÊNCIA EM FORMATO ELETRÔNICO:}

Babylon Pró v. 5 Israel: Or Yehuda, 2004.

Barsa Enciclopédia em CD-ROM Rio de Janeiro: Encyclopaedia Britannica do Brasil, 1999.

Cambridge Dictionary of American English.

Diccionario de la Lengua Española. Real Academia Española, v. 1.0, 2003.

Dicionário da língua portuguesa Porto: Priberam Informática/Porto Editora, 1996. 
Dicionário de Inglês-Português Porto: Priberam Informática/Porto Editora, 1996.

Dicionário Multimédia Universal Inglês-Português, Português-Inglês Texto Editora.

Dicionário Porto da Língua Portuguesa Porto Editora-Priberam, 1996.

Dicionário Porto Português-Inglês Porto Editora-Priberam, 1996.

Dicionário universal da Língua Portuguesa. Lisboa: Texto Editora.

Dicionário Webster's Português-Inglês, Inglês-Português.

Digitale Bibliothek 3.52. Operntexte von Monteverdi bis Strauss. (Dicionário de árias de ópera). Berlin, 2001.

Dizionario Garzanti di Italiano. De Agostini Scuola S. p. a. Garzanti Linguistica, 2005.

Encyclopaedia Britannica 2002 DeLuxe Edition CD-ROM 2002.

Ergane Dictionary.

Erred Dictionary. Russian-English Dictionary, v. 2.06.

ELLIS, P. B. Dictionary of Celtic Mythology. Santa Barbara: ABC-CLIO, 1999.

FERREIRA, Aurélio. Dicionário eletrônico Novo Aurélio. São Paulo: Nova Fronteira, 2001.

Enciclopédia Hispánica 2003 CD. São Paulo: Barsa Planeta, 2003.

FREUD, S. Edição eletrônica brasileira das obras psicológicas completas. Rio de Janeiro: Imago, s/d.

HOUAISS, A. Dicionário eletrônico Houaiss da língua portuguesa. São Paulo: Objetiva, 2001.

Nouveau petit Robert. Diccionaire alphabétique de la langue française, v. 2.1. Bruxelles: Bureau van Dijk, 2001.

LUFT, Pedro Celso. Dicionário eletrônico Luft. São Paulo: Ática Multimídia, 2002.

Merriam-Webster CD-ROM 2002.

NUNES, J. J. Compêndio de Gramática Histórica Portuguesa. 9. ed. Porto: Clássica, 1989.

Online Bible. São Paulo: Sociedade Bíblica Brasileira, 2005.

Oxford English Dictionary. CD-Rom, 3. ed., versão 1.13. Oxford: Oxford University, 1994.

The American Heritage Dictionary of the English Language. Houghton Mifflin, 1992.

The Columbia Dictionary of Quotations Columbia University, 1993. 
The Concise Columbia Encyclopedia. Columbia University, 1995.

The Holy Qur'an Software. http://www.yildun.com, 1999.

The Original Roget's Thesaurus of English Words and Phrases. Longman, 1994.

The Sword Projec.t www.crosswire.org.

The World Almanac and Book of Facts, 1995. Funk \& Wagnalls, 1994.

VERDI, G. Verdi - Operas - The Complete Vocal Scores.

\section{DISCOGRAFIA}

Huelgas Ensemble Utopia Triumphans - The Great Polyphony of the Ranaissance. (Paul van Nevel, regente). Sony Classical, 1995. 1 disco

PONTI, Michael (Piano). Scriabin: Complete Piano Music (Excluding Sonatas). Vox, 2002.

JOYCE, James. Finnegans Wake (lido por Jim Norton). Naxos AudioBooks, 1998.

WAGNER, Richard. Tristan und Isolde. Berliner Pholarmonica (Herbert von Karajan). EMI.

WAGNER, Richard. Der Ring des Nibelungen (Harmut Haenchen). De Nederlandse opera. Amsterdam, 2005.

\section{DISSERTAÇÕES E TESES:}

AMARANTE, Dirce Waltrick do. A Terceira Margem do Liffey: Uma Aproximação ao Finnegans Wake. Dissertação. Florianópolis: UFSC, 2001.

ESTEVES, Lenita Maria Rimoli. A (im)possível tradução de Finnegans Wake: Uma investigação Psicanalítica. Tese. Campinas, SP: UNICAMP, 1999.

RODRIGUES, Antônio Medina. Introdução a Odorico Mendes: poética da Eneida Brasileira. Dissertação. São Paulo: USP, 1977.

TROY, Mark L. Mummeries of Resurrection: The Cycle of Osiris in Finnegans Wake. Upsalla: Doctoral dissertation at University of Upsalla, 1976.

\section{PARTITURAS:}

Wagner, Richard. Rheingold in full score. New York: Dover, 1985. 
Wagner, Richard. Die Walküre in full score. New York: Dover, 1978.

Wagner, Richard. Siegfried in full score. New York: Dover, 1983.

Wagner, Richard. Götterdämmerung in full score. New York: Dover, 1982.

Wagner, Richard. Tristan und Isolde in full score. New York: Dover, 1973.

\section{SITIOGRAFIA}

BARGER, John. An overview of James Joyce's Finnegans Wake. http://www.robotwisdom.com/jaj/fwake/ Robot Wisdom, 1998.

BLAVATSKY, H. Isis Unveiled. Pasadena: Theosophical University, Online Edition, 1987.

Finnegans Wake:

http: //arvenchelp.ifrance.com

http://www.finnegansweb.com/wiki/index.php/Main_Page

http://finwake.com/1024chapter1/1024finn1.htm

http://www.robotwisdom.com/jaj/fwake/index.html

http://www.rosenlake.net/fw/FWconcordance/

Enciclopédia:

www.wikipedia.org

FOLENGO, Teofillo. Baldus www.libromania.it_Libro Mania.

HOMER Iliad THE ONLINE LIBRARY OF LIBERTY 2004 Trad. Thomas Hobbes.

HOMER Odyssey THE ONLINE LIBRARY OF LIBERTY 2004 Trad. Thomas Hobbes.

JOYCE, James. Cartas de amor a Nora Barnacle www.elaleph.com_Ediciones elaleph.com 2000.

LACAN, Jacques. Seminarios y escritos. Edição Eletrônica. Folio Views. s/d.

Lingüística;

Foros de Garvão (1267-1280?) http://cipm.fcsh.unl.pt_Corpus informatizado do português medieval.

http://online.ectaco.co.uk

http://www.archive.org/details/jamesclarenceman00manguoft 
http://gallica.bnf.fr/classique/

http://eleaston.com/irish-eng.html\#ety

http://ling.kgw.tu-berlin.de/call/webofdic/grammars.html

http://www.yourdictionary.com/languages/romance.html

http://www.limbasarda.it/lette/letr_iniz.html

MORA, José Ferrater. Diccionário de Filosofia. Buenos Aires: Sudamericana, 1964.

Óperas:

http://www.operaclass.com/

PATER, Walter Horatio. Giordano Bruno, Paris: 1586 www.gutenberg.org_Gutenberg

Project.

ROËLS, Claude. "Le Divan de Goethe ou l' appel à la poésie" Edition du Temps www.edutemps.fr. 2003.

ROSENBLOOM, Eric. "Witches Brew" www.kirbymountain.com/WitchesBrew.pdf 2002.

SWIFT, Jonathan. Journal to Stella (www.gutenberg.org).

. The Tale of a Tube (www.gutenberg.org), 1987.

WALTJE, Jörg. "Johann Wolfgang von Goethe's Theory of Translation in the West-Eastern Divan" in Other Voices, v. 2, n 2 (www.othervoices.org), 2002.

WILDER, Thorton. "Giordano Bruno's Last Meal in Finnegans Wake":

http://www.themodernword.com/joyce/joyce_paper_wilder.html The Modern World.

\section{VIDEOGRAFIA}

WAGNER, Richard. Der Ring des Nibelungen (Boulez Bayreuth Festspielhauss). Philips, 1980. 


\section{Disco}

Nota: músicas em formato mp3 e mid; para serem tocadas em aparelhos apropriados ou no computador.

1. Johannes Ockghem, "Deo gratias"

2. Josquin des Près, "Qui habitat in adjutorio"

3. Thomas Tallis, "Spem in alium"

Utopia Triumphans - The Great Polyphony of the Ranaissance. Huelgas Ensemble (Paul van Nevel, regente). Sony Classical, 1995.

4 e 5. Alexandr Scriábin, Preludes (2) for piano, Op. 67 Andante

Scriabin: Complete Piano Music (Excluding Sonatas). (Michel Ponti, piano). Vox, 2002.

6. James Joyce lê uma passagem de Ulysses

7. James Joyce lê "Anna Livia Plurabelle"

8. "riverrun, past Eve and Adam's..."

9. "Hence when the clouds roll..."

10. "So This Is Dyoublong?"

11. "(Stoop) if you are abcedminded..."

12. "Now (to forebare for ever..."

13. "'Twas two pisononse Timcover..."

14. "The wararrow went round..."

Joyce, James. Finnegans Wake (Jim Norton, leitura). Naxos AudioBooks, 1998.

15. Chopin-Godowsky. Estudo para piano, $\mathrm{n}^{\circ}$ 6. (formato midi)

16. Godowsky, Leopold - 06 - Estudo n ${ }^{\circ} 6$ para a mão esquerda (do Et. em dó\#, op. 10 n 4 de Chopin). (Carlo Grante, piano). Music and Arts Programs of America. CD 1093. 